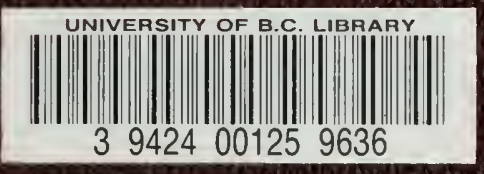

STORAGE ITEM PROCESS ING-CNE

L p 1- F 180

U.B.C. LIBRARY 


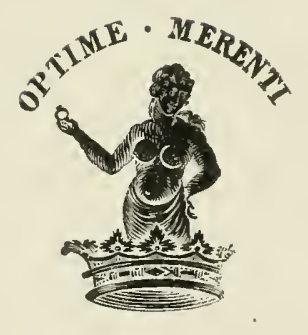




\section{THE LIBRARY}

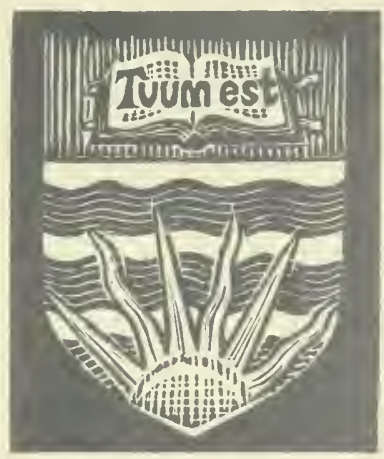

THE UNIVERSITY OF BRITISH COLUMBIA 

$-$ 



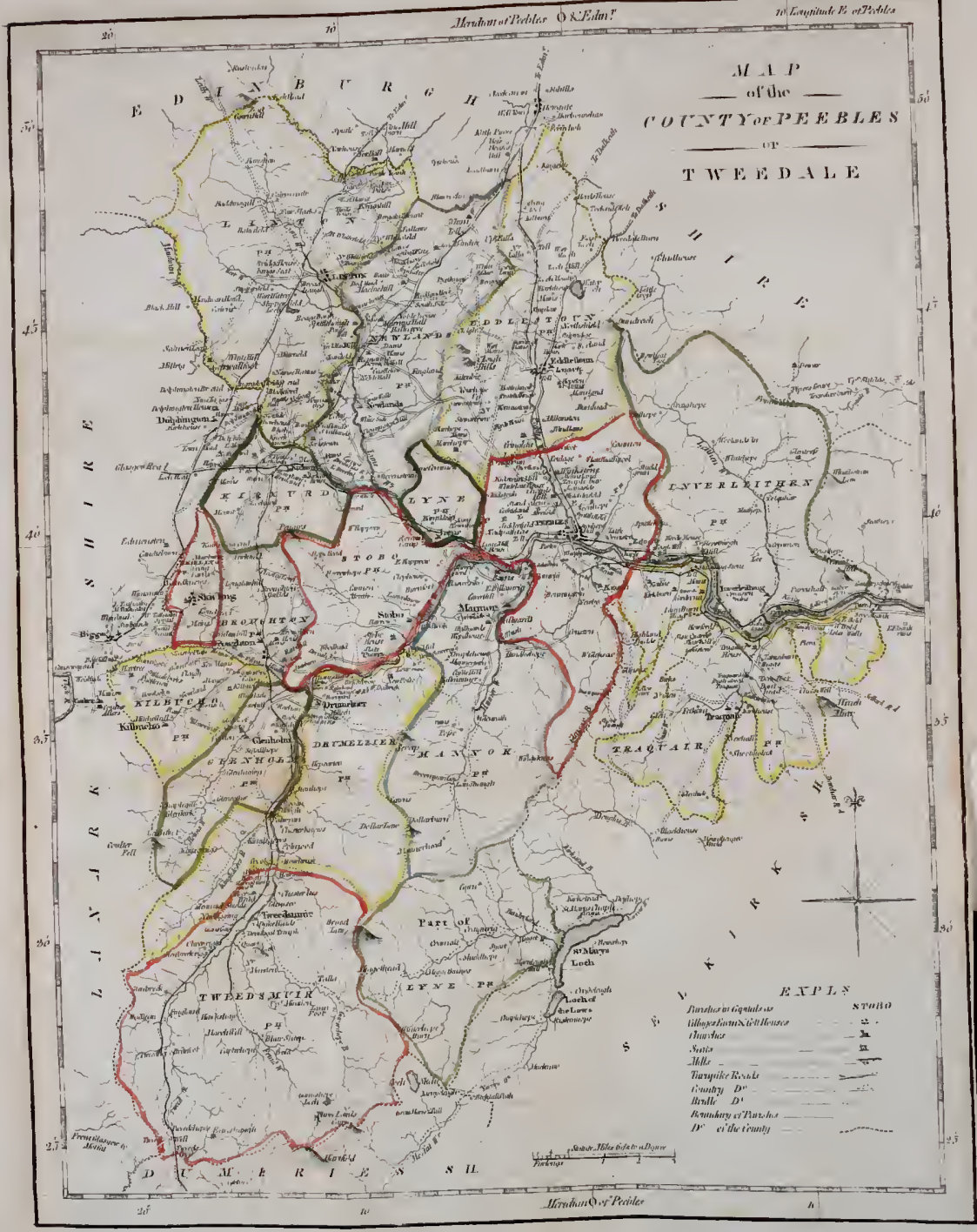




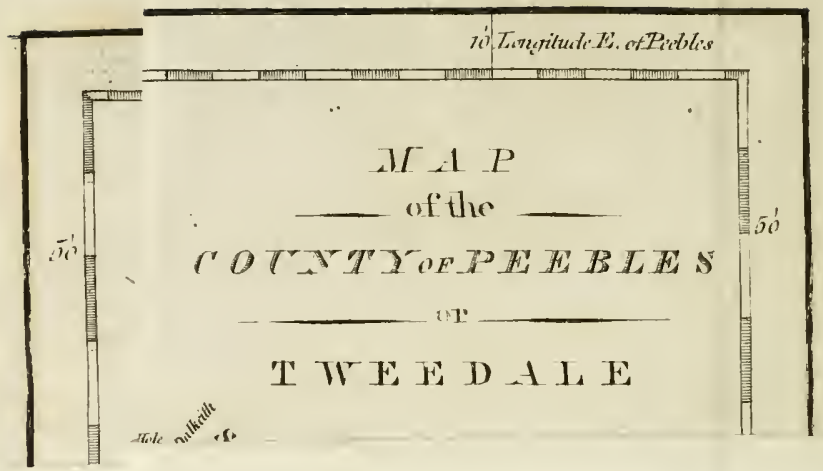




\section{GENERAL VIEW}

\section{OF THE \\ $A \mathbb{G} I \mathbb{C} U \mathbb{T} \mathbb{R} \mathbb{R}$ \\ OF THE}

\section{erunty of gecules,}

พ1Tu

VARIOUS SUGGESTIONS AS TO THE MEANS

BOTH OF

The Local and General Improvement

of

AGRICULTURE.

BY

THE REVEREND MR CHARLES FINDLATER,

Minister of the Parish of Newlands, in the County of Peebles.

With a MAP of the COUNTY, and other ENGRAVINGS.

These are Thy blessings, INDUSTRY ! rough Power!

Whom labour still attends, anl sweat, and pain;

Yet the kind source of every gent? art,

And all the soft civility of life:

Raiser of human kind! by Nature cast,

Naked, and helpless, out amidst the woods

And wilds, to rude inclement elements;

With various seeds of Art deep in the mind

Implanted, and profu ely four's around

MIterials infuite; but idle all.

'THOMSON's ALTUM:

Left to themselves, all find their level price,

Potatoes, rerses, turnips, Greek, and rice.

PuRs. ot Lit. 2. Dial.

\section{Exinburgh:}

PRINTED BX D. WUILLISON,

FOR ARCHIBALD CONSTAELE, EDINBURGH, AND T. N. IONGUAN \& O. REES, IONDON, 
Digitized by the Internet Archive in 2010 with funding from University of British Columbia Library 


\section{SIR JAMES MONTGOMERY BART.}

OF. STANHOPE,

LATE LORD CHIEF BARON OF HIS MAJESTY'S

COURT OF EXCHEQUER

$1 \mathrm{~N}$ SCOTLAND.

\section{S I R,}

BEING about to publifh an AGRICULtural Survey of the County of Tweeddale, I can think of no perfon to whom it falls fo properly to be dedicated, as to You.

Tweeddale claims you as a native, and as one of her moft ancient refidentiaries. Your long continued attention to the management of her public concerns; your readinefs to affift, with falutary advice and counfel, every individual of her fons; together with your conciliatory urbanity of manners, originating in humanity, not in artificial politenefs-have long fince ftamped you with the character, as they have gained you the appellation, of the Father of the County.

Agriculture has, to you, Sir, been particularly indebted, not only in the countenance given to the profeffion of it by your example; but alfo through your 
fenatorial labours, when Parliamentary Reprefentative for this county; in procuring for Agricultural Induftry, through legiflative interpofition, a relaxation of the cramping influence of the reftrictive fpirit of Entail. The fame liberality led you to affume an active management in the Pariiamentary Abolition of the laft remains of Perfonal Slavery which continued to difgrace your native country of Scotland.

May your Son, who has fucceeded you in the honourable ftation of Reprefentative in Parliament for this county, follow out his father's public-fpirited line of conduct, in directing his attention to thofe great objects of extenfive utility, which are fo congenial to every liberal and comprehenfive mind. Your example has impofed upon him a high degree of refponfibility to public expectation, which our knowledge of his character makes us confident he will amply fulfil.

Be pleafed, Sir, to accept of this Dedication, as a public teftimony to your public defert; as, alfo, of that fenfe of private obligation, and of private efteem, in which I have the honour to remain,

$$
\text { S I R, }
$$

Your moft obedient humble Servant,

$$
\begin{aligned}
& \text { Marse of Newlands, } \\
& \text { 10. O67. 1802. }
\end{aligned}
$$$$
\text { CHAS. FINDLATER. }
$$ 
CONTENTS, OR INDEX.

The Divifion into Cbapters and Sections, marks the prefcribed Form of the

Board of Agriculture for County Reports.

INTRODUCTION-Small advance towards a theory of agriculture-What is eftablined in practice, as to tillage; as to alternation of crops; as to recruiting the fertility of the foil-Moral excitements.

\section{THE REPOR T.}

Chap. I. Geographical State and Circumfances.

SECT. I. Situation and Extent Page

II. Divifions - - - - - - 2

III. Climate - - - - - - $\quad$ - 3

IV. Soil and Surface - $\quad-\quad-\quad-\quad-12$

Different kinds of foil $\quad$ - $\quad$ - $\quad I_{3}$

Old crofts and outfield _ $\quad-\quad-15$

Theories of the formation of foils - ib.

Surface - - - - - . 18

V. Minerals - $\quad$ - $\quad$ - $\quad$ - $\quad 20$

Nineral fprings - - - - 23

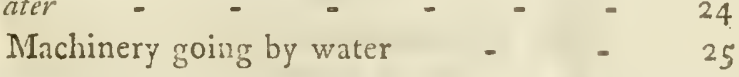

Chap. II. State of Property.

SEст. I. Eftutes, and their Managenent - - 28

II. Tenures $\quad$ - $\quad$ - $\quad$ - $\quad$ - 33

Crap. III. Buildings.

SECT. I. Houfes of Proprietors - - - - 34

11. Farmlooufes, offices, and repairs - - - 36 
(Chap. III.-Continued.)

SECT. III. Cottages - - - - - - 4 I

Furniture, victuals, and other accommodation of the labouring claffes - - ib.

No cottage mania in Tweeddale-Goldfmith's

Deferted Village-Separation of profeffions, \&c. - - - - -

Chap. IV. Mode of Occupation,

SEcT. I. Size of Farms-Actual fize

(For principles leading to proper fize, fee

Notes C \& D.)

Cbaracter of Farmers, and introduction of improved hufbandry - $\quad$ - $\$ 4$

Character of the labouring poor $\quad 59$

Management of farms-

I. Management of theep farms.

I. Do. of theep in do. - - $6 \mathrm{r}$

'Tables, explanatory of management 65

Defignations of theep - - 69

2. Do. of arable land attached to theep farms-

Do. of croft - - - 70

Do. of outfield - $\quad-\quad 73$

Enclofure of the arable part of fheep

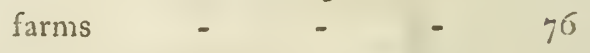

II. Management of arable farms - $\quad 80$

Do. of butter and cheefe making - $8 \mathrm{r}$

SECT. II. Rent, in money, in kind, in perfonal fervices - 86

Money and victual rents compared - ib.

Kind and fervice rents confidered $\quad-\quad 87$

Unfpecified fervices abolihed in Scotland - 88

Adfriction to mills retained-obfervations $\begin{array}{lllll}\text { on adfriction } & - & - & -\end{array}$

Åtual rent in Tweeddale $\quad$ - $\quad 94$ 
(Chap. IV.-Continued.)

Sect.III. Titbes

Table of the provifion of Tweeddale Clergy 103

IV. Poors rates (See Cbap. XV. Sect. VII.)

V. Leafes.

Effects of their duration as to the tenant's induftry - - - - 104

Effects of fifty-feven years leafes, in the eftate of Neidpath - $\quad$ - 105.

Small effect of the act of Parliament, granting a latitude, as to duration, upon entailed eftates - $\quad$ - $\quad$ - I10

VI. Expence and Profit - - - $\quad$ - 1 II

Char. V. Implements . - II

Cha p. VI. Enclofing.

Divifion of commons in Scotland, does not imply an obligation to enclofure - $\quad \$ 26$ Enclofure provided for per fe - - 128 Stone dikes, alone, fit to confine fheep - 129 Expediency confidered of total enclofure of Theep farms -
Gates

Chap. ViI. Arable Lands.

SEct. I. Tillage (fee alfo Introducion) - - 136

II. Fallowing - - - - - - ib.

III. Rotation of crops (fee alfo principles of, in Introduction; and practice of, pages 70, 7I, 85.) - - - - - - 137

IV. Crops commonly cultivated-

Green crops, for fallow - _ _ $\quad$ - 39

White do. - . - _ _ 344 
(Chap. VII. Sect. IV.-Continued.)

Ciops not commonly cultivated-

Green do. - $\quad$ - $\quad$ - $\quad$ - 146

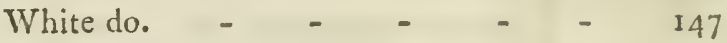

\section{Chap. VIII. Grafs.}

Sect. I. Natural Meadows and Paftures (for flooded meadow, fee Chap. XII. Sect. V.) - 149 II. Artificial grafjes - - - - - ib. III. Hay barveft - $\quad$ - $\quad$ - $\quad$ - 150 IV. Feeding - $\quad-\quad-\quad-\quad-\quad$ I5I

Chap. IX. Gardens and Orchards

Chap. X. Woods and Plantations.

Experiments on pruning, by Mr Loch - 154 Larix (alfo as fit for bedges, page 131.) - 156

Cha'p. XI. Waftes or Commons (See p. I 26.) 157

Chap. XII. Improvements.

Sect. I. Draining-

Elkington's modes $\quad$ - $\quad$ - $\quad 157$

Efex mode, as adopted at Magbiehill 158

This mode defcribed $\quad$ - $\quad$ - $\quad 159$

II. Paring and Burning _ - - 163

iII. Mamuring - $\quad$ - $\quad$ - $\quad$ - $\quad$ ib.

Lord Meadowbank's mofs compof $\quad-\quad 167$

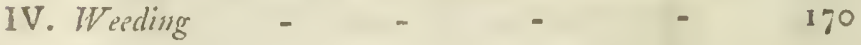

V. Watering.

Water-meadow, with a plate - - ib.

l'reduce of ditto, and expence of formation I 8 r 
C.hap. XIII. Live Stock.

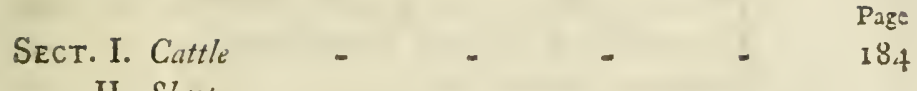

II. Sheep-

Table of numbers of, (See page 201.)

Different breeds of (for defignations of theep, fee page 69.)

Inxexpediency of dividing the high from the low paftures, for different breeds - $\quad$ i 88

Period of geftation - $\quad$ - $\quad$ - $\quad 189$

Caftration; cafting off old breeders; fmearing ; time of weaning; artificial marks, and natural characteriftic of identity; milking; fummering lambs

Food of theep; hog fence; various plants; heath and muirburn

Shelters, natural and artificial; fnow ftorms 193

Hirfeling and herding - $\quad 395$

Depofitions of fat, depending on the ground, not the breed

III. Horfes compared to oxen

IV. Hogs

V. Rabbits

VI. Poultry

VII. Pigcons

VIII. Bees

Caufes of bees, pigeons, and game animals, not thriving

Table of theep, cows, and horfes, in Tweeddale

Chap. XIV. Rural Economy.

SEct. I. Labour -

Reafons why fower of regulation of, is never

exercifed by the Juntices of Peace 
(Chap. XIV. Sect. I. Continued.

Fall of wages, in late dearths, reafon of - 204 Actual rate of wages in Tweeddale - $i b$. II. Provifions. (See alfo page 4I.) - 208 III. Fiul-

Mode of making peat - - $\quad i b$.

Chap. XV. Political Econony, as connected with, or affecting Agriculture.

SECT. I. Roads-

Syftem of management of

Probable propriety of their being placed under the management of Government - 2I2

II. Canals III. IV. $\}$ Fairs-aveekly markets-almanack of -

VI. Manufactures

VIl. Poor-

Laws protecting property, can alone create a provifion for the poor

Monks, and their charity

Scots poor's laws-inexpediency of legal reliance-ditto of laws of refidence, \&c. \&c. Tables thewing general expence, and rate of fupply

Filiation of baftards

vIII. Population-

Tables of ditto

Obfervations on the tables

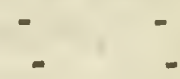

General population of the Britilh Empire $\quad 243$

IX. Corn Laws

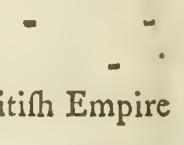

238

Colonel Dirom's publication on ditto - 245 Howlets's ditto on ditto 
(Chap. XV.-Continued.)

SECT. X. Game Laqus - - - - 248

Cafe of theep worried by dogs $\quad 2 \quad 251$

Chap. XVI. Obftacles to Improvement - 252

Chap. XVII. Mifcellaneous Obfervations.

\section{SEcT. I. Agricultural Societies}

II. Weights and Meafures

Facts added

Conclufion

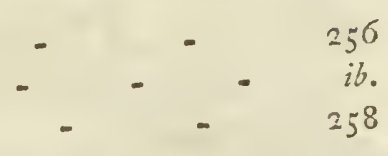

$-26 I$

\section{NOTES.}

Note A.-Explanatory of the reference of the divifion into counties and parifhes, to Civil and Ecclefiaftical jurifdictions and duties

Of the jurifdiction of the Sheriff-of the Court of Jufticiary-and of the Public Accufer - - - ib. Of the Court of the Commiflary-Juftices of Peace, and their Small Debt court - _ _ - - 267 Of Ecclefiaftical matters-qualification of clergymen, and mode of induction to benefices - _ - 268 Ecclefiaftical Courts-Kirk Seffion-their cenforial power —adminiftration of poor's funds - - - 273 Prefbytery-its Civil jurifdiction as to glebes and manfes -over fchools and fchoolmafters - - - $\quad 275$ Synod-fingularity as to powers of appeal - - 276 General Affembly-its powers as to caufes-to laws - 277 
Note B.-Explanatory of the various Scotifh tenures of property

$$
\text { of property }
$$

General view of feudal tenure 279

Difficulty of reconciling the feudal maxims of Scotifh law to any other mode of tenure, for perpetuity, than the feudal

Difficulty from regifter of fafines-of which an account is given

Hiftory of the tack or leafe-with the caufes which have led to the fuppofition of the jus delectus perfonce being of confequence

Security of Scotin tenants tenure, from acts 1449 and

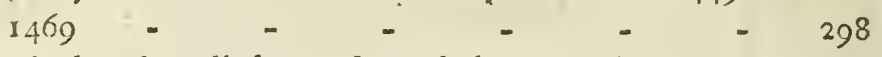

Agricultural credit hurt, through feudal notions - $30 \mathrm{I}$

Note C.-Explanatory of the origin of fmall farms 304 Abfurdity of Agrarian laws, and necellity of feparation of profeflions

Noте D.-Containing general obfervations upon the generic charater of the farmer-leafes-size of farms 308

Generic diftinctions of character, in the enjoyers and acquirers of a fortune

Farming of independent proprietors of land Do. of profefinonal farmers

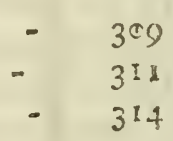

\section{Leafes-}

Confidered as to their duration

The indefinite or perpetual leafe of Lord Kames - $32 \mathrm{r}$

Leafes confidered, as to the alienable or unalienable property the tenant ought to bave in them

Difcouragement of the tenant's fixing his own capital in the foil-of his obtaining other capitals to borrow for that purpofe-and general banifhment of capital from agriculture, through the delectus perfone 
Arguments in favour of the retention of the jus delectus confidered-tenant's political principles-deterioration of the farm by worfe farmer-chance of forfeituremanners of the tenant-beggarly cultivators under middle tackfman

Leafes confidered as to the extent of the ufe of the foil in reftricted or unreftricted management

Reftrictions in Tweeddale-and proper for it

Size of Farms-

General confiderations of the conftitution of the farm Principles which dilate it to its proper fize Do. - which circumfcribe it within proper limits

Note E.-Confideration of the extenfion of the right of franchife in England, in fuperfeding the fecurity of the leafe

Note F.-Upon ufury

Note G.-Upon the unproductive claffes, and the ab-

- furdity of levelling principles

Note H.-Confideration of the effects of large and fmall capitals upon the market of grain

Of Dearth

- Monopoly

- Foreftalling, \&x.

$-$

$-$

$-\quad 35^{8}$

- Government interference, by internal regulationand of the maximum and the minimum-and individual interference for relief of the poor

$$
\text { APPENDIX, No.I. }
$$

Account of Whim, and of mofs culture

$$
\text { Apperdix, No. II. }
$$

Difeafes of theep, an efliy, with notes refcrring to Tweeddale experience 
** The Author's inexperience in revifing Proof Sheets, and the difadvantages refulting, in confequence of his diftance from the Prefs, will, it is hoped, plead his apology for the following

\section{E R R A T A.}

Page

I9. line 3 . for are, read is.

34. fecond paragraph, line 9. for he, read the.

53. lines 12. and 13 . for difunion, read disjunction.

59. line 9. for county, read country.

85. fecond paragraph, there is a reference to Note D. inftead of Note C.

36. Though the rent of the county, in the ftatiftical account, is given per parilhes, the author, in his calculation, has excluded the 3000 fheep of the Selkirk part of Inverleithan parifn; when corrected, his general inference will be found firengthened.

309. foo: noic, line 7. for enclofure, read enclofures.

343. fecond paragraph, two references to pages are left unfilled up-they are to pages 75 . and $7 \mathbf{r}$.

148. lire 9. for fuch, read much.

152. line 6. for though, read the.

185. line 2. from bottom, for forehead, rend forehand.

I93. line Io. from bottom, for to, read at.

215. Eddleftone fair-for O. S. real N. S.

242. line 15 . from bottom, for 903 , read 703 .

378. line I2. from bottom, for duty, real duties.

290. line 1.3. for old mother ancient, read our ancient mother.

291. foot note, line 2. for fteady tenor of, read fteadily announced. This correction is indifpcnfable, to exprefs the author's intended fenfe.

299. line 5. for 1446 real $I 449,-N$. B. Wherever the Scotith acts $\mathbf{I} 446$ and $I_{4} 66$ are quoted, fubfequently, let them be corrected into $\mathbf{I}_{449}$ and $\mathbf{I}_{4} 6 \mathrm{~g}$.

322. line 14. from bottom, place 2. before thefe words in italics, The Extent of the Right.

332. line 20. place 3. before thefe words in italics, The Extent of the UfE.

336. latt line, fupply a comma after fward.

340. line 5. from bottom, for mogen, read moyen-an old Scotin word from the

French, fignifying in common.

348. line II. for rife, read ufe.

302. line 3. from bottom, place a femicolon after the word preseding; and a comma after the word road. 


\section{INTRODUCTION.}

A L THOUGh Agriculture has been practifed as an art, from A the remotent antiquity, it can, as yet, hardly be confidered as ranking among the fciences, eftablifhed upon fixed and determined principles. Experience is, in all things, our only inftructor. But it is diffcult to afcertain the principles of Agriculture, through experience; becaufe, here, we callnot, as in mechanics, chymiftry, \&c. command every circumftance that is to be admitted into the experiment; and, confequently, can never determine, with exact precifion, the extent of efficacy of each concomitant co-operative caufe, in producing the refult. The wide extent of the difference of refult, produced by the differences of feafon, over which the power of man has no controul whatever, is extremely obvious; and there is no poffibility of determining how far the effect is to be afcribed to human means, or merely to the feafon, unlefs every agricultural experiment were to be conducted in a comparative manner.

In regard to the food of plants-a principle which we ought to be able to fet out with, as the foundation of the whole practice, had Agriculture attained to the rank of a fcience-no certain conclufion feems, as yet, to have been fuficiently eftablifhed. Whilft fome, perhaps, ftill adhere to the generally exploded theory of the fathers of the univerfai drill-fyltem of hufbandty, in imagining it to confift of comminuted earth, however apparently unadapted to enter their capillary refiels under any form: Whilf others place it in oils and falts; although, whes 
immediately applied, thefe fubftances feem either inefficacious or detrimental to vegetation: Others, confidering the earth as of no farther ufe, than as a fupport to retain the plants upright and firm, hold water to be the only vegetable fuftenance, or water together with air : And others, juftified, probably, by more ftrong analogies, confider it as confifting of the fubtle effuria, or other folution, of the fubftance of putrified animal or vegetable matters, adminiftered to the capillary roots or abforbent veffels of the leaves of plants, by the earth, by the air, and by rain; and tranfmuted and affimilated to their proper fubftance, by the unknown, and probably uninveftigable, powers of vegetable life.

But, though the theory of Agriculture is fo very little advanced, many parts of eftablifhed practice feem abundantly juftified by their general fuccefs.

From the earlieft antiquity, the tillage of the ground has been found indifpenfably requifite, for the purpole of deftroying ufelefs or noxious weeds, and to direct the fertility of the foil to the production of plants more adapted to the fuftenance of man and beaft-for that of pulverizing the foil, fo as to render it permeable to the fibrous roots, extending themfelves in fearch of the proper nutriment of the plant-and that of ridding foils of fuch fuperfluous moifture as is found detrimental to them, in throwing the furface into the flape that admits of the readieft defcent to water. The manipulations neceffary for thefe purpofes, together with the neceffary implements of cattle fit for labour, and the inftruments of the plough, the harrow, \&c.thefe, being fubjects more entirely under the command of man, where every thing related can more eafily be forefeen and provided for, have admitted of gradual and progreffive improvement; and, in various particulars, may have poffibly arrived at all that perfection of wiich they are fufceptible.

It has been further afccrtained, through long expericnce, that alternation of crops is highly alvantageous, in preventing the fertility of the foil from being fo fpeedily exhaufted. In this view, a claffification of crops has been formed-into thofe which are extraufing, and thofe that are aneliorating, or, at leaft, 
lifs' exhaulting. Under the former clafs are afforted what are called culmiferous, or white crops; which have few, or narrow leaves; do not thade the ground while growing; and leave the foil, when removed, in a compact, hardened ftate. 'To the latter class are referred the leguminous, or green crops; comprehending the whole tribes of peas and vetches; together with all plants cultivated for the root or for the leaves; as alfo all that are cut green for Summer food or for hay, and are not allowed to ftand till they ripen their feeds-the procefs of vegetation deemed moft cxhaufing to the foil: Thefe meliorating crops flade the foil, by their broad leaves; or pulverize it, by the expanfion of their roots; or exhault the foil lefs, by drawing more nourifment from the air; and, when remored, they leave the foil blackened in colour, and more loofe, puffy, and mellow, in confiftence. It has been found advantageous to abftain from cropping with white crops in fucceffion, and ever to interpofe a green crop betwixt the white ones. It feems not, however, perfectly afcertained, whether this advantage entirely refults from the ditlinctive difference of thefe crops, as meliorating and exharfing; or whether it may not, in part, be afcribed to the general principle (if fuch a rague conception can be confidered as a definite principle) that nature deligbts in variety. This latter fuppofition would feem, indeed, to be countenanced, from what has been alleged to have been obferved in Eaft-Lothianthat two green crops in fuccefion, fuch as turnip after beans, feems as unproductive a mode of culture, as two white ones in fucceffion. It is probably, too, upon this principle alone, that we can account for the fuperior thriving of changed feeds, and the deterioration of erery fpecies too long fown fucceffrvely in the fame ground 3 -and for the foil fometimes tiring entirely of a particular fpecies of crop to which it has been long familiarized, as is faid to be the cafe with fome Norfolk foils in regard to clover. To the fame principles, of the meliorating nature of the crop, or of nature delighting in variety, may be referred, the experienced utility of recurring intervals of patture, or what is dedigned convertible hubandry. 
Where the fertility of the foil has been exhaufted by cropiping, or where its powers of fertility have never been brought into action by culture, the application of various fubftances to the foil, under the name of manures, has been experienced to be of very great advantage. Thefe have been clafied under the two general defcriptions of enriching and fimulant; though it feems dubious, whether the claffification has proceeded upon a perfect and complete comprehenfion of their diftinctive natures. The former, confifting chiefly of regetable or animal matters, in a ftate of putrefaction, are peculiarly fuited to lands exhaufted by repeated cropping: The latter, confifting of calcarcous fubitances, fuch as lime, marl, and chalk, are confidered as beft adapted to foils whofe powers have not, by culture, been ever brought into aftion-the feptic nature of fuch fubftances tending to accelerate the putrefaction of fuch animal or vegetable matter as may fubfift in the foil, fo as fpeedily to convert them into the proper nutriment of vegetables: For the fame reafon, fuch manures may even be applied, with fuccefs, to lands in a ftate of exhauftion from repetition of crops, till fuch time as every thing putrifiable in the foil fhall have been actually putrified.

Such feems to be the general fummary of the practical principles of Agriculture; which, in particular adaptation, might be extended into a wide detail.

'To thefe general principles the Author muft be fuppofed to refer in the Report, although no explicit reference is directly exprefled.

Draining, as a part of tillage; fencing, fo as to give command of the foil for exclufive appropriation to particular ures; and theltering, by plantations of wood, for the purpofes of defending both vegetable productions and pafturing animals from the weather; - thefe, under the moft comprehenfive view of the fubject, might all, alfo, be confidered as feveral branches of Agriculture. 
Trye unity of landed eftates, in times of feudal turbulence and anarchy, being as indifpenfable to their fecurity, as is, at all times, the indivifibility of their governments to that of nations; hence, through the artificial reftrictions of Entail, together with the eftablinhed law or cuftom of the preference of Primogeniture, land has, in moft modern nations, been abftracted, in a great degree, from commerce; and large maffes of landed property have been made to ftagnate, for generations, in fingle undivided poffertion.

Portions of land, too large for the perfonal fuperintendance of the proprietor, muft be parcelled out into the occupancy of farmers, upon the principles explained at large in note $\mathbf{D}$ at the end of the Report; and, accordingly, upon the exertions of farmers, muft the improvement of the lands at large, chiefly, or almoft folely, depend.

As man, however, is not fubjected to the laws of mechanifm, like inanimate matter-nor to unreafoning compulfion, like the unreflective brute creation; his conduct cannot be regulated, or incited, upon the principles applicable to either; and recourfe muft be had to moral excitements, in order to ftimulate him to induftrious exertion.

As Tweeddale is a county, into which improvements have been all recently introduced, from counties already improved; it was agreed between Sir John Sinclitr and the Author, (when, at his folicitation, the Author confented to draw up the Report*), that it would be fuperfiuous to dwell much upon

the

- From circumfances occarring, uninterefting to the pablic, the work was not publified by the $\mathrm{B}$ sard of Agriculture, as originall? intended. The Author fent it to the Conductors of the Farmer's Magazine, who publifted fome extracts, which fecmed to excite fome demant for the publication of the whole. And to the Author's objection, that the local fale, from local interef, in fo narrow a county, for a work feemingly loca! from its title, enuld never defray the expence of publihing-the anfwer was, Publif by fubfeription, an.' we subl suppcrt you wuith a!! our iufuence. This mode was accordingly adopted. 
the minutice of agricultural practice, or implements, the detailed deicription of which night be expeeled in the Report of counties where they had been in longer ufe; and that more fpace might be allotted to the confideration of thofe moral excitements to agricultural induftry in the famer, which are of univerfal application.

The handling of the fubject, in this point of view, the Althor found more congenial to his accuftomed train of thinking. In fo treating of it, he has uniformly proceeded upon this obvious and fimple maxim, the truth of which he apprehends to be as indifputable, as its application is unirerfal, That the befl mode of infuring the invention and.profecution of the moft advaniageous meafures, is, an arrangement, wbich foall communicate, to thofe on whom their execution is devolved, a fufficient perfonal intereft in their invention and execution. To fome, We doubts not, fuch views will be confidered as foreign to the Report of a county; whilft, to others, they will conftitute its moft efiential value.

For the fake of uniformity, and of facility of reference, for the purpofes of comparifon, the fyftem of method for Reports prefcribed by the Board of Agriculture, has been adopted. "The method is not objectionable; though dificulty is expericrced in confinement to the trammels of any prefcribed method. To aroid, however, the embarrafiment arifing from the mixture of fpeculation with the detail of facts, the Author lias thrown into the form of Notes, fubjoined to the Report, various fpeculations which occurred to hin as interefting to the lubject of Agriculture at large.

For the information of Englin readers, of whom he finds a confiderable number in the lift of Subferibers, the Author lias dwelt upon fome fubjects with a minutenefs, which would have been fuperfuous in regard to natives of Scotland.

The Author returns his thanks to the numerous and refpectable Sibfcribers, who have been pleafed to patronize his work. 


\title{
AGRICULTURAL SURVEY
}

\author{
OF \\ PEEBLESSHIRE OR TWEEDDALE.
}

C H A P. I.

GEOGRAPHICAL STATE AND CIRCUMSTANCES.

SECT. I.-Situation and Extent.

' ${ }_{\text {HE county of }}$ Tweeddale, or Peebles, is fituated betwixt $55 \mathrm{deg} .24 \mathrm{~min}$. and $55 \mathrm{deg} .50 \mathrm{~min}$. of north latitude; and from 2 deg. $45 \mathrm{~min}$. to 3 deg. $23 \mathrm{~min}$. of longitude, weft from London; or betwixt $\rho_{-1}-15$ and $\circ-23$ weft of the meridian of Edinburgh. It is bounded, upon the north, by the county of Mid-Lothian; upon the eaft, by that of Selkirk; upon the fouth, by that of Dunfries; upon the wert, by that of Lanark. Its greateft length, from north to fouth, is about 30 miles; its greateft breadth, from eaft to weft, about 22. The contents, (See Statifical Tables), in Englifh acres, amount to 229,778; or in Scotifh, (at the rate of converfion, of 5 Englifh to 4 Scotifh acres), to $8_{3}, 823$ *.

Armitrong, in his Companion to the Map of Trueddale, eftimates the arable lands at one tenth of the whole. If by arable

B

- In a mountainous country like Tweeddale, the real furface may amount to a feventh or eighth part more than the plane of the bafe, as meafured for the conAruction of a map. 
is meant what is fufceptible of tillage, this proportion would feem by much too little. It is impoffible to form a probable conjecture, from any data furnifhed in the ftatiftical accounts of the parifhes, of the amount of what is actually kept in conftant or occafional tillage; as, from the very various modes of treatment which fuch lands undergo, in regard to the time they remain in pafture, during the interval of tillage, the account of bolls fown, or of the extent of crop reaped, (were thefe even accurately ftated), could give very little light into the matter.

\section{SECT. II.-Divifions.}

THE county is divided into fixteen parifhes, which are de.* fcribed, in Sir John Sinclair's ftatiftical account of Scotland, as under :

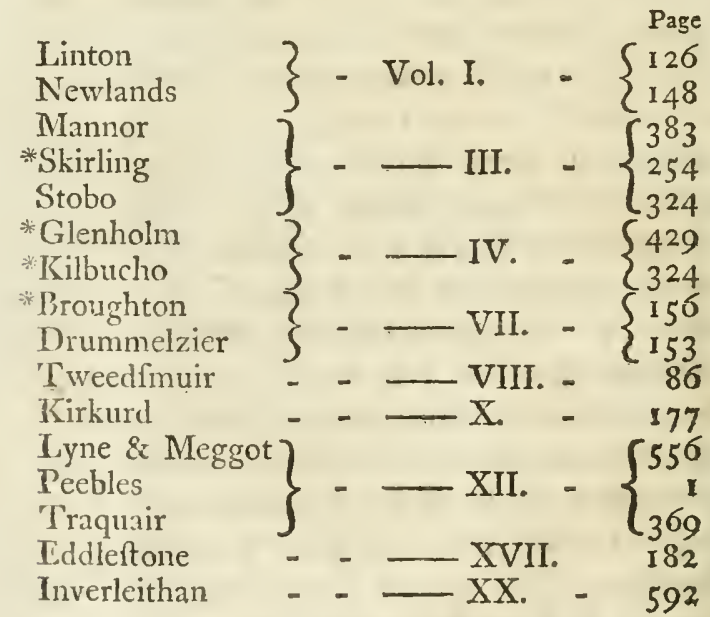

* 3 The four marked * belong to the Prebytery of Biggar; the reft to the Preßbytery of Peebles.

The divifion of Scotland into counties, refers to Civil-jurifdiction; the fubdivifion of counties into parifhes, to Ecclefiafti cal duties and jurifdiction $\dagger_{\text {. }}$

There

f For particulars, as to thefe dutics and jurifdietion, the Englifh reader may confult note $A$, at the end of the Report. 
There are two maps of this county; the one by Edgar; the lateft (which is given upon a reduced fcale in this report) by Armftrong, who alfo printed an account of 'Tweeddale, or companion to his map, in 1775 . There is alfo a topographical and botanical defcription of the county, accompanied with a collection of humorous poems, defcriptive of the manners of the times, by Dr Alexander Pennycook, proprietor of the lands of Romanno, in Newlands parifh, publithed in 1715.

\section{SECT. III.-Climate.}

THE loweft lying arable land in the county, fituated upon the fide of the Tweed, where that river leaves the county, and enters Selkirkhire, will be about 400 feet above fea-level. Betwixt 900 and 1000 feet, is probably the higheft elevation in which cultivation is attempted by the plough.

The higheft hill in Tweeddale (probably the higheft in Scotland fouth of the Friths of Forth and Clyde) is Hartfield, in Tweedfmuir parifh, upon the confines of Dumfriesfhire; its height above fea-level is, according to Armftrong, 2916 feet; that of Hartfane Broad Law, in the fame parifh', is 2850; Dollar Law, in Mannor parifh, is 2840. Armftrong, in his companion to his map, gives a variety of heights of highe?t fummits of thofe ridges of hills which traverfe the county in all directions, extending from 1800 to 2300 feet above the level of the fea. Abftracting, then, the higheft fummits, the generality of the pafture lands may be confidered as fituated at from 500 or 600 , to 1700 or 1800 feet above fea-level; or at 1150 feet at a medium.

The climate, in fuch northerly latitude and high elevation, may readily be conceived as late; and, from the mountainous nature of the country, as moift. Sown-grafs hay begins to be cut rather after the middle of July; that from natural grafs, am bout the middle of Auguft. Corn harveft feldom commences, generally, till the fecond week of September; and it is accounted rather an early harveft, when the whole is got into the Winter ftack before the clofe of Odobcr. The reapers from 
the Highlands of Scotland generally find employment for feveral weeks in Tweeddale, after the termination of the Lothian harveft; the difference being obferved as greater in favour of thefe lower ccunties in a bad, than in a good feafon.

The time of fowing, in the higher parifhes, is juft fo foon as the ftate of the weather, and of the foil, will permit. Peas and oats are frequently fown in February; it is thought tardy, at Linton, to fow even the earlier fpecies of oats much later than about the 2oth of April; rough beer, or bigg, after the middle of May; turnip, without dung, after the end of May, or with it, after the latter end of June.

The higher the elevation, the greater is the degree of moifture; and the crops are found to run more to ftraw, and lefs to corn. Early fowing is confidered as a check to the growth of ftraw, and as conducive to the more thorough ripening of the corns: The length of pod or ear, however, is found to be proportional to the length and vigour of the ftraw or haulm; and the medium, of moft advantage upon the whole, muft be attempted to be hit. Accordingly, in the lower end of the county, where (from lefs high elevation, as well as greater fharpnefs of foil) thortnefs of ftraw, and proportional fhortnefs of ear, are moft to be dreaded, fowing is deferred till two or three weeks later in the feafon, than in the higher end, where the danger moft to be apprehended, is the want of thorough ripening. From early fowing, and the ufe of earlier ripening fpecies of grain, the backwardnefs of climate is feen to be fo far counteracted, that the larveft in the croft lands around the village of Linton, (where the improved hufbandry firft became general), has, for a number of years bypaft, been finifhed fooner than in the crofts around the town of Peebles; although the difference of elevation camnot be fuppofed lefs than 200 feet. Early fowing cannot, meanwlile, be advantageoufly adopted, where the lands are not clean; elfe the weeds, more congenial to the foil and climate, will thrive fafter than the artificial crop during the cold early Spring months, overtopping and choking it.

Cold 


\section{Agricultural Survey of Peeblesflire.}

Cold eafterly winds often prevail during the Spring months: and it may be queftioned, whether we liave not, in general, nore grafs in the firft half of December, than in May. In the feafons 1794 and 1795 , froft winds continued till the latter end of June, blackening the leaves of the afh-tree, (which foon feels the impreffion); and, in low fituations, nipping down the ftems of the potato. In $\mathrm{x} 80 \mathrm{I}$, the whole potato items were laid flat with the ground, (excepting where growing in high fituations), on the night of the I Ith of June; and, in 1796, the fame thing happened upon the night of the $7^{\text {th }}$ of July. Before the lant: mentioned period, it was proverbial in Tweeddale, that there was no month in Spring, Summer, or Autumn, in which we had not experienced frof deftructive of vegetation, but the month of July.

Our Winters are rigorous; and the turnip crop is, of confequence, often loft, unlefs confumed by Chriftmas or New Yea:'s day. Cattle do not fatten upon them in their frozen ftate; it is well if they merely do not lofe flefh. In the higher parifhes, they are often frozen to fuch liardnefs, that they muft be allowed to thaw in rumning water, before the cattle can make impreffion upon them with their teeth *.

Befides the general frofts in Winter, the higher parifhes are much expofed to a fpecies of partial frofts in the end of $\mathrm{Au}$ guft and beginning of September, which chiefly affect the low-lying lands by the fides of running waters, lakes, and moraffes.

* When put into a veffel of cold water, where the procels of their thawing is more eafily cbferved, a fhell of ice, of greater or lefs thicknefs, forms itfelf alt around the furface of the turnip, like a globe of glafs, exactly fitted to its thape; upon breaking off the ice, the turnip isfound foft and fonm within it. If too nuany turnip are put into the veffel, the whole contents congeal into one mafs. In running water, the ice formed by the cold of the turnip is diffolved, as foon as formed, by the fucceffive application of new water.

I laid out a potato on the ontfide of a window to freeze all night, thawed it: in cold water next morning, and then boilcd it ; its confiftence was not impaired, bat it feemed rather infipid as to tafte.

Animal or vertable fublances, when thawed by the application of heat, gro: putrid. 
moraffes. A low creeping mift, or hoar froft (called, provincially, rbyme, or cranreugh), in a dead calm, particularly after a tract of rainy weather, is feen to fettle, after funfetting, upon lands of this defcription; which, if fucceeded by bright funfhine the day following, proves deftructive to all further vegetation. It would feem to do little damage to corns that are hard ripe ; and in regard to fome fpecies, particularly that of oats, it does not prevent their further maturation, if it attacks them whilf the juices in the ear are ftill in a watery ftate: But, in the intermediate ftages betwixt that ftate and maturity, it renders every fpecies alike unfit for feed, and of very inferior value for meal, both in refpect of quantity and quality. A particular account of this kind of froft will be found in, the Statiftical Accounts of the Parifhes of Linton and Glenholm. In the year 1784 , the crop of bigg, or rough beer, was deftroyed, through the higher parifhes, fo early in the feaion as the 17th of Auguft; and that fo completely, that I perfectly recollect to have feen it applied to the thatching of houfes in the village of Linton, unthrafhed, as it was carried. from the field, without the fmalleft apprehenfion being entertaincd of a fingle grain vegetating in the ear: In that feafon, the oat crop, which being a later grain, was not fo near maturity, fuffered but very little. In 1782 , as the froft happened much later, the beer was not fo effectually deftroyed as the oats, having reached its maturity; while the oat crop was in its moft fufceptible ftage.

It feems extremely probable, that plants, artificially introduced from a more fouthern latitude, and more benign climate, do not attain to that maturity in a northern latitude, which they reach in their native fituation: It feems equally probable, that thore plants which are native to a northern climate, and which there attain to their moft perfect ftate, are, at beft, lefs nutritious than the native productions of a more benign climate. On both accounts, it feems probable, that, in a county fituated as Tweeddale, the whole vegetable productions, whether artificial or native, fhould be of an inferior kind : and that even equal weight of the fame fpecies of grain, 
may not contain an equal quantity of nutritive fubftance; as it contains not the fame quantity of fermentable fubftance, upon which probably the nutritive quality greatly depends *. There is a difference in the quality of the grain of the higher and the lower parifhes in the county, that amounts to the difference of 1 s. $6 \mathrm{~d}$. of price per meafured boll, when the average price per boll is 16 s.

The climate of Tweeddale is not very propitious to fruit trees. The goofeberry, rafpberry, currant, and ftrawberry, are the beft fruits produced in our gardens. The rafpberry is a native, and ripens its fruit in the higheft parifhes. The bramble is a very rare plant, excepting in the lower end of the county; and I am not afcertained that it brings its fruit to perfect maturity in any feafon. The hazel does not ripen its nut to perfection in the higher parifhes, unlefs in very favourable feafons.

I am indebted to James Reid Efq. of Peebles, who has practifed phyfic, with high reputation, in the county, for near half a century, for the following Regifter of the Weather, extracted from one he regularly kept in the town of Peebles for many years.

REGISTER

* According to the calculation of Mr Ker of Kerfield, brewer by Peebles, Scots barley, on an average, yields fully one fifth lefs of fermentable fubftance, from like weight of grain, than Englifh barley. 


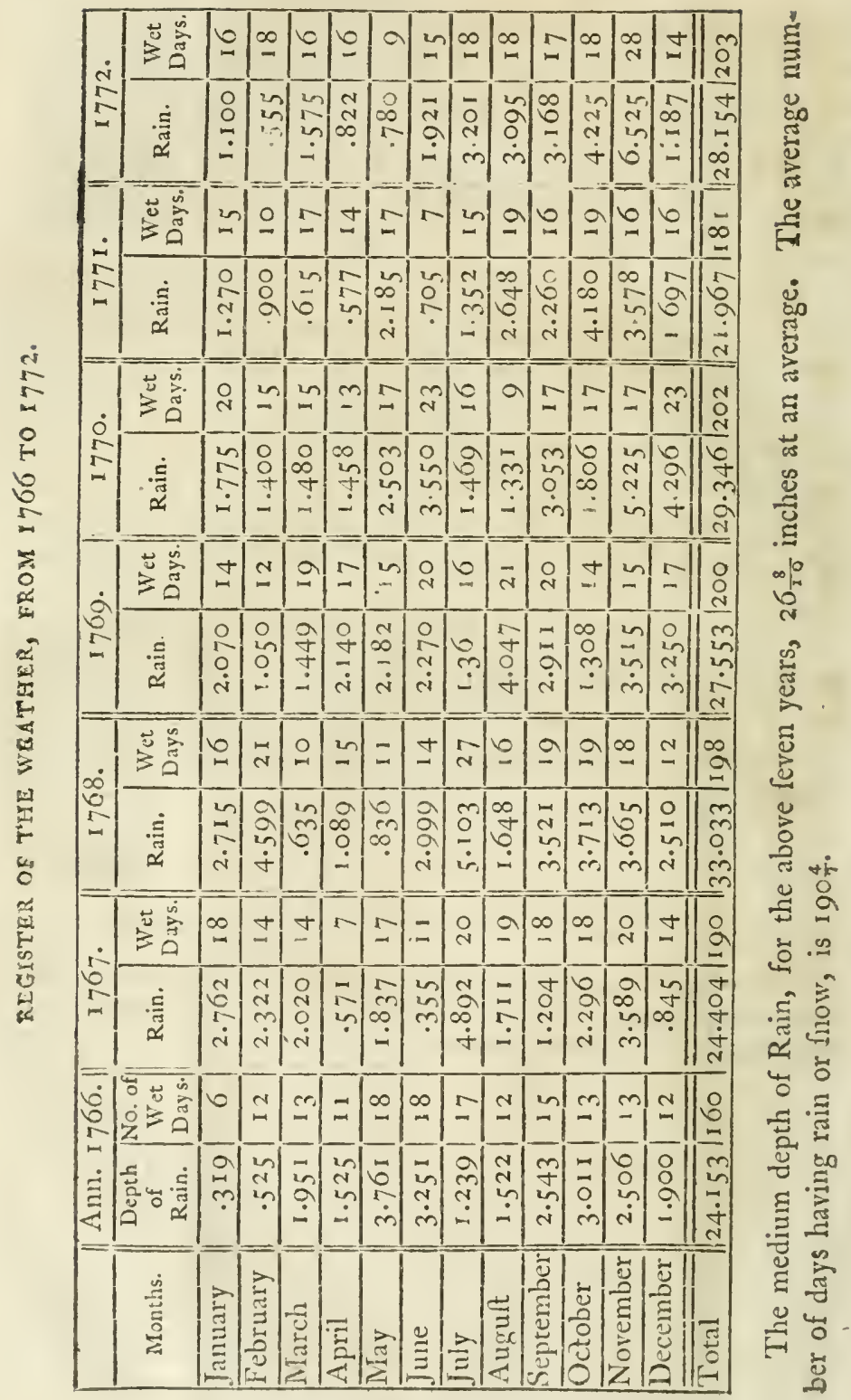




\section{Agricultural Survey of Peebles/Bive.}

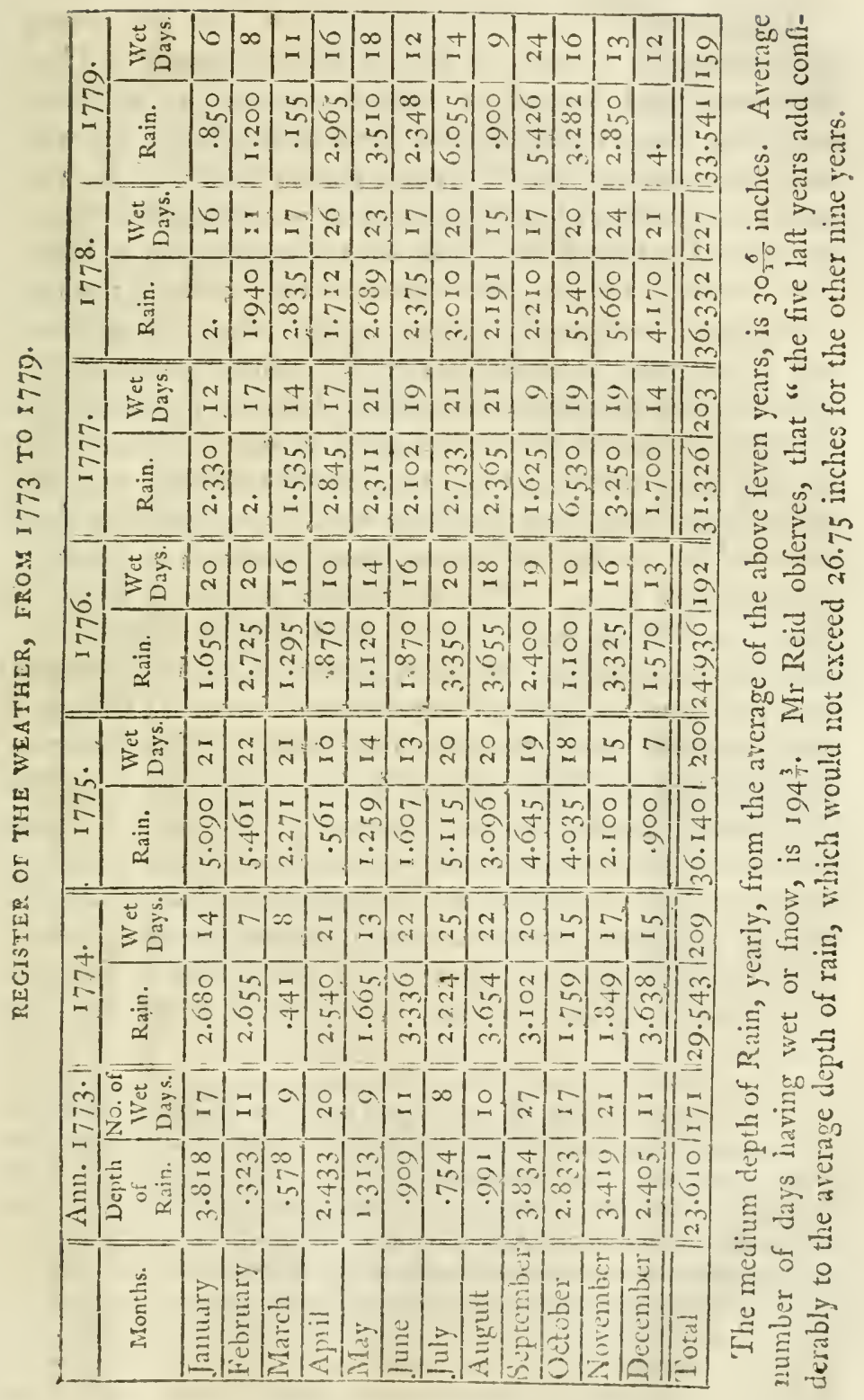


In his letter to me, Mr Reid obferves, "That the climate of Tweeddale is variable, as that of all hilly countries: That, from its midland fituation, it receives a portion of wet from both feas, though probably lefs than either fhore, yet with more days having rain from flying clouds, than even the weft coaft the quantity, however, falling in one day, often not exceeding .00I of an inch: That, from a regifter kept at Dumfries, in 1776 , the rain there amounted to 36.9 inches; when, at Peebles, it amounted only to 24.936 inches: That fnows add confiderably to the number of days mąrked wet in the regifter, in the months of December, January, February, and even March, though little to the depth of rain: That, including the fouth with the weft, and the north with the eaft, the winds blow more often from the weft, than from the eaft of the meridian, in the proportion, fometimes, as 4 to 3 ; at 0 ther times, as 5 to 4 : That the medium height of the barometer, at Peebles, is in Summer 29.2, and in Winter 29: That the thermometer has been known at $8 \mathrm{I}$ in Farnheit's fcale; and, on the 14 th January 1780 , as low as 14 below 0 : Such inftances being, however, quite unufual. He remarks, that the fituation of the town of Peebles is particularly healthful; ftanding upon a fine dry bottom of gravel, 500 feet above the level of the fea, and at the confluence of Peebles water into Tweed, the currents of which preferve a due circulation in the air, even in the calmeft weather; the eafterly fogs, which fo often overfpread the Lothians, never almoft reaching Peebles, being arrefted by the high hills to the eaftward of that town *.

* The revenue belonging to the town as a body corporate, may be confiderahis above 3001 . yearly; arifing from land rent-frem corn and four mills-from cuftom levicd eipon gonds fent to market, ne carricd through the town-from fontage allo at the bridge orer Tweed within the toun's jurifdiction, levied upon drove cattle, the moft of this kind of revenue being received from Highland cattle pafing to England. Pecules would appear to have been often ufed as a hunting sefidence by our Scotin kings. Moncy would feern to have had been coined in it; an houfe nill retaining the name of Cuinzee Nool. Large tracts of land, cxirnding on the hills for fix or feven miles downward to Gatchaup burn, would fecm to have been granted it, in property, or in right of paflurage; the rights to which are now lon, from encroachment, or through dercliction. 
In regard to difeafes, he obferves, that there are few prevalent in Tweeddale, which have their origin from damp and putrid exhalations; that bloody flux or ague feldom occur, or any putrid difeaies; and that inflammatory fevers are fometimes frequent in Spring *." In the year ${ }_{17} \sigma_{3}$, ague was extraordinarily prevalent. Since that period, it feems to have totally difappeared.

It would appear, from the Statiftical Accounts, that chronic rheumatifm (the pains, as it is provincially defigned), is frequent among old people in the lower clafies; and that flow fevers are pretty general in fome feafons, from poor feeding, bad clothing, and damp lodging: In regard to which circumftances, incident to the lower orders, Tweeddale has much im. proved, and is ftill improving t.

- The only place in Tweeddale where ague was ever frequent, was at Pirn in Inverleithan parifh, owing to a clay morafs, fince the draining of which the difeafe has not appeared. There are numerous dwellings in Tweeddale fituated in the vicinity of moffes, and of flagnant pools of mofs water, where ague is totally unknown; from whence it would appear, that the miafmatous exhalations from mols and mols water, are not of the feptic nature of thofe from clay morafs. There is, indeed, an experiment familiar to every old woman in Tweeddale, which fnows, that mofs water, even when ftagnant in pools in hot weather, is not nearly of fuch a feptic quality as ary other water placed in the fame circumftances; and it is this, that though lint will rot, if left in other water, in fuch circumftances, even for twenty-four hours only after it hath been fufficiently macerated, it may be left eight days in mods water without fuftaining any matcrial damage.

+ It hath often been matter of furprife, that no epidemic difeafes appeared after the very extraodinary alterations that the ufual foeding of the poorer claftes muft have underwent, both as to quantity and quality, in confequence of the calamitous fcarcities of 1782,1799 , and 1800 . In moft great towns, the two laft have been remaiked, from their bills of mortality, as unufually healthful; yet, undoubtedly, a very great number did not receive above two thirds of their ufual quantity of food. Surely, in ordinary feafons, or at all times in fituations of affuence, much more food is ufed than what fuffices either for health or ftrength. The return of plenty in I80I, has becn accompanied by the prevalcnce of pleurify. 


\section{Sect. IV.-Soil and Suface.}

In agriculture, as in other flibjects, terms are bandied a bout, to which, perhaps, no two that ufe them affix precifely the fame ideas. The ftrong marked diftinctions of foil, into clay, moss, and fand, appear obvious to molt people; but the different diftinctions of there, with all the intermediate diftinctions of foils compofed of thefe, together with other materials in all varieties of proportion, have not probably obtained, as yet, a fufficient number of diftinctive appellatives, to difference them properly; and, even of thofe names in ufe, perhaps, few or none have been fo accurately defined, or fo fteadily appropriated, as to communicate a very determinate fignification. It would tend much to the fpeedy diffufion of agricultural knowledge, were there fome eafy method devifed, acceffible to every farmer, in the way of fimple chymical analyfis, or otherwife, by which he might be enabled to difinguifh readily all the varieties of foil as they occur, and to refer them, under their proper defignations, to the claffes to which they belong: Writers upon agriculture would then be in poffeffion of a language generally intelligible, and be fpared numberlefs circumlocutions. Perhaps the time is not far diftant, when the fcience of Agriculture, under the aufpices of the fcientific and patriotic characters who have taken it under their protection, fhall attain to the fame precifion, in this refpect, as the fifter fcience of Chymiftry. In the mean time, I apprehend, that the terms ufed to characterife many of the varieties of foil, are very vague and unclefined; fuch, for infance, as loams, in all their varieties, moorifh foils, \&c. I confeis, I can never be certain of concciving the cxact meaning of the writer, when I read fuch terms; nor could I pretend to apply them, with any fure conviaion of exciting, in the mind of the reader, the precife idea which $\mathrm{I}$ have formed in my own.

By far the greater part of the foil of Tweeddale never was, nor probably cver will, be turned up by the plough. Of the lands under culture, there is great variety of foil; fuch as mofs, 
nools, clay, fand; mofs and clay, mofs and fand, clay and fand ; and thefe mixtures, in every variety of proportion.

$M o / s$ would feem, from its hiftory and appearance, to be a particular fpecies of foil, generated from the decompofition of vegetables fucceffively growing and decaying in ftagnant water. It conftitutes, when cut into peat and dried, a very common fuel in Tweeddale, and through the north of Scotland. It is probably convertible, by proper management, into a rich manure. It is found in almoft every hollow, upon, or among the hills, in the higher parifhes, from four or five, to ten, or everi twenty feet in depth : At the bottom of the bed, it is always of the deepeft black colour, of the moft homogeneous confiftence, and of the greateft folidity and power as fuel, when dried into peat: Nearer to the furface, it is of a lighter tobacco colour, of a more fpongy contexture, confifting chiefly, to appearance, of the interlaced fibres of plants, in a greater or leffer ftate of decay.

Befides thefe moffes in hollows, or upon dead flats, mofs is alfo found on high grounds, in the higher parts of the county, compofing a foil of from two to three or four feet in thicknefs, lying generally upon a confiderable declivity, (a circumftance rather inexplicible upon the commonly received theory of its generation), over a fubfoil, impervious to water, of fand or clay till: In its natural ftate, it is always moift; but, in courfe of repeated tillage, and of being treated with large dofes of lime, it fubfides and confolidates, and becomes more dry ; when, after the fubfoil is reached by the plough, and is raifed and incorporated with the mofs, thcfe foils are formed, which, (according to the quality of the fubfoil), I would diitinguift by the names of mofs and clay, or mofs and fand-mixtures purely artificial, and which exift not in the natural fate of the foil. Sir James Montgomery of Stanhope, iate Lord Chicf Baron of the Court of Exchequer, has cultivated more of this foil, than any other Tweeddale proprictor, upon the north-caft extremities of the parifhes of Newlands and Eddleftone; where, under his mode of management, it is brought to yield pretty large returns of the Magbiehill, or Red oat, though of inferior 
quality as to grain; and where, while laid in grafs, the largeft fized axen ever bred in Tweeddale have been reared by him *.

There is a foil pretty common on the ikirts of heath-clad hills, and on high, dry-lying flats, which has fome appearance of being a natural mixture of mofs and fand; it feems to confift of a peculiar fpecies of black earth, mixed with fand of a greyilh white colour: when turned up by the mole, the hillock appears black, fo long as it remains moift ; but, when it becomes dry, it appears as if fowdered over with the fand above mentioned: whether the black earth is real mofs, feems doubtful. It produces heath in its natural ftate; it is the pooreft of our foils; very thin; and fo loofe, as to blow with the wind in drought, after being pulverifed by the plough. When under tillage, and lying, as in general found, upon a fubfoil impervious to water, it acquires almoft a fluid confiftence in wet Winters, infomuch, that a ftrong wind will caufe the drills of turnip growing upon it to undulate perceptibly. This foil may be one fpecies of what is called moorifs foil. It abounds pretty much in Linton parifh; and, if I am not much deceived, svill generally be found above freeftone rock. The wild uncultivated thin moorifh foils which are met with in parifhes where the rock is whin, or flate, or limeftone, will, I apprehend, be found of a more folid and tenacious confiftence, and of a browner colour.

The fkirts of molt part of the hills, at the higheft elevations to which cultivation is extended, feen generally to confift of a foil of the laft mentioned kind; which appears to be compofed of a mixture of fand and clay, in various proportions, with often a mixture of gravel of various kinds; fuch as gravel of freeftone, of limeftone, of whin, of flate, and, in feveral inftances, of ironftone. From the colour, perhaps, this foil might properly be defigned bazel foil; a defignation which, I think, I recollect to have read fomewhere.

Defcending

- I have known of an American being much deceived in conceiving our mofs (from its colour) to be the fine decp black vegctable mould of the virgin foils of America. 
Defcending a ftage further down upon the hills, clay is ge: nerally found to predominate more in the compofition of the foil.

Still nearer to the bottom of the hills, where the declivity becomes very gentle, and immediately above the troughs of flat land, (called provincially, baughs), formed by the courfe of the larger waters, the foil is generally deep and fertile; being com. pofed of fand and clay, with often a great proportion of loofe ftones, chiefly of whin or flate.

The flat lands (baughs) in the troughs of the waters, particularly where fubject to be overflowed, are obferved to be, in general, of a more fandy confiftence, and the more fo, in proportion to their contiguity to the water's courfe; though, in fuch fituations, there are fome exceptions, even in favour of ftronger clay.

The old crofi lands * are comnionly found in the one or of ther of the two laft mentioned defcriptions of lands; and the foil of thefe, blackened and mellowed through repeated dunging and plough culture, may probably, with propriety, be denominated loams; varying the defignation, according to the original differences of the foil, as clay loam, fandy loam, gravelly, fiony, E. Es. Perhaps, it is proper to extend this denomination of loams to fuch foils as, in their natural ftate, bear the ftrong eit affinity to thefe artificial foils of old croft.

From the appearances of the foil, as above ftated, a theorift might be led to fuppofe, imo, In regard to the water baugksthat their fandy confintence, particularly fandy in proportion to their contiguity to the water's courfe, arifes from this_-" that the fuperior weight of the fand allows it alone to be depofited,

* Croft, or infield, iv a generic defignation, applied univerkally in Tweeddale. and over Scotland, to fuch lands as have been in nfe to be kept under conflant cultivation of cropping; receiving the whole of the dung produced from the cattle, houfe-fed in Winter, with the afhes, \&sc. from the farmer's dwelling. Land never cultivated, or only occafionally after folding or lime, is univerfally defigned auffeld. This defignation, however, refers to ploughing; fuch land never recciving the appellation of outfelu, till it is fpoken of either as plouglacd, or as absut to be fleugles. 
in this fituation, from the overflowing flooded waters; but that, in proportion as you recede from the water's courfe, the overflowing water lofes its velocity as it fpreads into a thinner body, and there depofits the more minute particles of fand, and the lighter particles of clay; which alone it was able to keep in fufpenfion to that diftance from the main ftream."

$2 d$, As to the bills, he might conjecture, "that, towards their fummits, the rain water muft run in a more diffured ftate, and with lefs monentum; and, to a certain diftance in their de. fcent, can therefore only abrade and wafh out a portion of the finer particles of clay or fand from amongt the gravel, leaving the foil which it hath run over, of a gravelly or bazel defcription: that, as you ftill farther defcend, the hills generally grow lefs fteep; whence, the relocity of the defcending water is impeded, and a depofition is made of the fine particles of fand and clay, which its velocity had hitherto enabled it to keep in fufpenfion: that, on ftill farther defcending, the various bendings of the ground throws the water together into rivulets (or burns*), where its weight and velocity, or momentum, increafing, it is enabled to walh out and keep in fufpenfion the weightier particles of fand, as well as clay, to be depofited on the banks of thefe burns when they overflow; a part being alfo delivered, as a tribute, by their main ftream, to the larger waters with which they unite, to be depolited alfo upon their baughs, in the ratio already noticed."

There are doubtlers many facts, which countenance fuch fuppofitions; it is however doubtful, if they are fo univerfal as to form a conftant general rule.

Strong examples may be found, in further fupport of that theory of foils, "which thus deduces their origin from the gradual decompofition of the riore compact fubftance of the mountains, by the action of the difierent clements, wathed

out

* The defignation of the fmalleft rill of water is a $\int_{y} k e$, or a well-franl, if from a fpring-well. If the water is of quantity fufficient to drive a fnall watcr-wheel for light machinery, it is called a burn. Larger ftriarns are called ziaters. Twecl? is our only water defigued giver. 
out by the rains, and depofited, in this manner, upon the lower grounds*." Thus, the prevailing ftone in Linton parifh is freeftone, which is everywhere found in quarries, in loofe ftones, or detachco maffes, over all the hills and moors, and beds of rirulets, at the heads of Lyne water. Now, the decompofition of freeftone fhould apparently produce land: and, accordingly, fand foil is fount to prevail more in Linton than in any other parifh of the county, with the exception of mofs, of moorith or hazel foil, in fituations as formerly defcribed, and of fome more tenacious foil, lying on limettone. Sand foil is the prevailing foil in the crofts kept under conftant rotation of cropping. The haughs, fubject to be overflowed in the trough of Lyne water, (even where that water runs through the parithes of Newlands, Lyne, and Stobo, where the prevailing ftone is whin), are, with few exceptions, of pure fand foil. The depofitions from Lyne water feem to produce the fame effect upon the foil of the haughs upon Tweed, to a confiderable diftance below their junction. The prevailing itone through the other parifhes is whin or flate, or of a mixed nature between thefe two; and the foil (with the exception, in many inftances, of fand foil, where the waters overflow) is of a more clayey, unçuous, and tenacious confiftence.

Stagnant water, as already obferved, feems, in certain circumltances, to give rite to mofs : it feems alfo probable, that, by long continued action, it may have a tendency to convert find into clay. In fome of our very fiat vallies, where the rirulets, ruming through then, have little velocity, where the courfe of the ftream, impeded by windings, keeps the adjoining lands in a conftant foaking moifture, fuch lands are, I beliere, univerfally found to confift either of mofs, or of clay morafs; generally, indeed, mofs near the fource of the ftream, and clay further down.

The higher you afcend towards the fources of the waters, mots foil is commonly found in more abundance. When the

- Townfhend, in his travcls through Spain, affirms that he could prediet the foil of ithe ralliss, from the nature of the fubftane of the furrcunding hills. 
whters are in flood, they are of a brown colour, from the clat and fand kept in fufpenfion; as they fubfide, thefe heavier matters are depofited; they gradually become black; and, for two or three days, (as the ground has been more or lefs foaked witl rain), they retain a porter-coloured tinge, from the fufpenfion, or the folution, of the more minute and lighter particles of noofs.

It has been remarked, that the hills on the left bank of the Tweed, of a foutherly or wefterly expofure, are generally more verdant than thofe of the right, though with many exceptions.

Surface.-Upon a general and diftant view, this county feems to confift of a confufed congeries of chains of mountains, running in all directions. The arable land appears only, upon internal invertigation, lying upon the banks of the waters and burns, and the acclivities of the flirts of the hills. For thefe reafons, it was found imporible to reprefent, in the map, the divifions of arable and pafture lands, or the diftinctions of foils : the arbitrary divifion into parifhes, is therefore alone marked.

In its general appearance, the county, though wild, can hardly be defigned romantic: the mountains, though high and large, and too much upon the vaft for beauty, are yet too tame for the fublime. There is nothing abrupt-nothing terrificnothing, in thort, to ftrike forcibly the imagination of the poet, or the painter ; unlefs, indeed, the feelings of a native, blunted by familiarity and repetition, fhould be queftioned, as a proper ftandard of judgement *

The

* Tweeddale has probably furnifhed the feene of fome of our favourite Scots fongs. Of the Bufb aboon Traquair, there can be no doubt: As to Trveedfide, the matter may le more problematical: Tweeddale having no exclufive appropriation of the Tweed. 'There is in the county, a Logan-loufe, alfo a Logan-burn, which, in compliment, might be called Logan-u'ater; both, probably, too infignificant to have been cclebrated in the fongs of that name. Peeblis play undoubtedly refers to fports cclebrated in the county town.

Doctor Pennycook makes a fingular remark upon the inhabitants, though I know not that it is well-founded-" Mufic is fuch a ftranger to their temper, that you fhall hardly light upon one among? $f(x$, that can diftinguifh one tune from another; yet, thofe of them that chance to hit upon the vein, may match with the fkilfullct.". 
The variety of hill, and dale, and water, might furnifh scenes of great natural beauty, or even grandeur, were it not for the almoft total want of natural wood. For though tradition reports, that a great deal of wood once grew in the county, at prefent few veftiges of it remain; and where any are found, upon the banks of the waters and fkirts of the hills, it is mere brufhwood, confifting chiefly of birch miferably tinted in growth, fome fpecies of grey willow, hazel bufhes, and a few mountain afhes, with fometimes a fringe of dwarfifi alders marking the courfes of the rivulets. It may, no doubt, be reckoned unfair to judge of what the natural wood might have been, by the remnant that now appears: The former wood may have been 'grubbed out for fuel, or to make room for pafture or the plough; and what now remains, may have bcen ftinted in its growth by the repeated cropping of the fheep: The trees, however, found in mofles, (the only fpecimens of the wood of former times), are generally, it muft be confeffed, of diminutive fize*. In the various artificial plantations through the county, the trees come to nothing in the higher parifhes, where the foil is mean, or the fituation expofed; and, of late, it is, with good reafon, coming more into prac-

tice,

* The wood moft commonly found in onr peat moffes is birch, or hazel. Oak is fometimes, though rarely found; black, heavy, and hard, like ebony. Single trees of oak, of confiderable fizc, have been found in moffes near the top of high hills.

It is pretty remarkable, that, in the moors of Carnwath parih in Lanarkfhire, adjoining to the higher parts of Tueeddale on the nosth-wert, at an elevation as tigh, and under a climate as unpropitious as any part of 'Tweeddale, molt places feem to have obtained their names from woods; fuch as Harruod or Harturood, Girlwood or Greatzood, Woodfide, Woolesd, \&c. \&c. There are no veliges of fuch woods above the furface, but abundance below the morfes. Fir (nuknown in Tweeddale moffes j is found in fome of thefe, long and ftraight, indicating its having grow $n$ in thickets. Its fibres are fo tough that they are twifted into ropes for halters and teathers: The fplits of it are ufed for light, by the name of candie f.r-Strong marks of Ercat convulfions in nature.

Some farmers have taken the hint of burying fir, for roofing, in molles, in orm der to infure its incorruntibility. 
tice, to improve poor foil by lime, and to drain the wet by ditching, or the plough, before planting. Around gentlemens houfes, where the foil is good, and where they enjoy protection and fhelter, trees thrive well; and though the uncultivated parts of the county feem no way ftriking, either for fublinity or for beauty, there are,"neverthelefs, a variety of gentlemens feats fcattered up and down, which are pleafantly embofomed in trees, and which enjoy thefe chief advantages for policy, of great diverfification of furface, and command of water.

\section{SECT. V.-Minerals.}

THERE are quarries of white freeftone in the north-eaft extremities of the parifhes of Newlands and Linton. Further weft, upon the boundary betwixt thefe two parifhes, there is a hilly ridge called Broomylees, containing quarries of a dark red freeftone, of an harder confiftence than the white, with fome feams of it which rife in flags, and which make durable pavement. Thefe are the only freeftone quarries open for fale; and from thefe, together with the white freeftone quarry of IMarfield, on the Mid-Lothian fide of the water of North Efk, the county has been, and is fupplied with thefe articles; white freeftone pavement, and ftone for ftairs or hearths, being generally brought from Hailes quarry in Mid-Lothian. The freeftone, both red and white, with a particular fpecies of the for mer, which, from its weight, would feem to contain iron, are to be found, in many other places in the parin of Linton, anú the adjoining fide of Newlands.

There are a few quarries of excellent whinfone, particularly at Editone, near the town of Pcebles; whence, probably, the town has been built. None are open for fale: There is, indeed, no demand; whin being the prevailing rock through the county: It is, however, often of either a laminous contexture, of the nature of flate, or fo interfected with cutters, as to fly under the hammer in all directions, and to be incapable of bcing drefled into a regular fhape. 
The flate of Stobo parifh has been long in repute. Befides fupplying the county, it is carried down Tweed as far as Kelfo, to Edinburgh, and through the upper ward of Lanarkfhire.

Coal and limeftone abound in the north-eaft extremities of Linton and Newlands parifles, whence the whole county is fupplied; with the exception of the parifles of Eddleftone, part of Peebles, Inverleithan, and Traquair, which more generally obtain thefe articles from the Lothians. A road, carried from Darnhall in Eddleftone parifh, to Noblehoufe inn in that of Newlands, connecting the two Edinburgh roads, would give nearer accefs, to part of thefe parifhes, to the coal and lime of the county, than what they pofiefs at prefent, to thofe of the Lothians.

The parin of Glenholm is reported, in the Statiftical Account, to burn lime fufficient for its own confumpt, probably with coal from the parifhes of Linton or Newlands, or perhaps with peat, which is, however, but a poor fuccedaneum for coal. Limeftone night be found in feveral other pariflies, but is of little value, for want of coal; it being generally accounted cheaper to carry burnt limeftone, than to carry coal from any confiderable diftance to burn raw limeftone upon the fpoto The coal is at prefent wrought no deeper, than fo far as the water can be carried off in a level; the feantinefs of population, and want of manufactures, occafioning no demand to enable the proprietors to work it in a more expenfive manner. The increafing improvement of land by lime, and the greater prevalence of fallow crops, which renders it inconvenient for farmers to fpare the time and labour formerly employed for cutting and drying peat mofs for fuel, have fo much increafed the demand both for lime and coal, that the fupply is not adequate to the demand. The prices, according to proximity to the demand and quality of the article, are as follow: Coal at Collyburn, 8d.; at Carlits, 6d. or Fit. per load of 2 crrt. *

Lime

- Formerly, licfore the formation of good cantage roads, every thing was ca:ricd upon houfes backs. Tlie bad refors to tlis gradice. 
Lime at Magbiebill, rs. Id.; at Wbitefield, 1s. 2d.; at Cariips, I Id. per boll of thells; two bolls of thells, or, at moft, two and an half, being the loading of a fingle horfe cart: Farmers carrying their own lime, carry only two bolls, and have generally nearly the fame loading as hired carts carrying two bolls and an half; the irtereft of the former bcing, to have the greateft quantity under the leaft denomination-that of the latter the reverfe.

The coal wrought in this county, is the wefterly termination of that large bed of coal which extends in a north-eaft direction through the Lothians, on both fides of the North Efk water, to the fea at Muffelburgh, in a ftretch of about fiftcen miles in length, by from feven to eight miles in breadth; and which, by Mr Robertfon's calculation, (Report of Mid-Lothian), would fuifice to fupply Mid-Lothian, at its prefent rate of confumpt, for 800 years. Ironftone abounds in the parifh of Newlands, in the range of hills running along the right of the public road as you go from Noblehoufe inn towards Edinburgh. It feems not, upon trial, to have been found fufficiently rich in yield of metal, to afford the expence of carriage to the ironworks upon Clyde, or at Carron, or at Newcaftle; though perhaps experiments may not as yet have been made, fufficiently decifive of its value. The Honourable Captain Cochrane, of the Ajax, flip of the line, erected a fmall manufactory upon his eftate of Lamancha; where, by means of a calcining furnace, and a mill with a water-wheel for grinding, this ore was converted into a paint of a dark red colour. None has been manufactured for fome years bypaft.

In thofe ages, when fcanty yielding mines could afford a profit, it would appear that gold was fearched for in the rivulets of Megget, (Statiftical Account of Lyne and Megget); and that filver was obtained from mines near the village of Linton, where remaining veftiges of old finks, or pits, ftill retain the name of Silverboles. 'The hill where thefe filver holes are, is called Leadlawe; and it is probable, before the difcovery of the mincs of Pcru, that it might be profitable to work even inconfiderable veins of Icad, for the fole purpofe of cxtracting filver 
from the lead. The value of lead would appear to have been fo far reduced, by the difcovery of the rich veins of Leadhills, Wanlockhead, and probably others, that it is now unprofitable to work inferior veins for lead; which, formerly, could have afforded the expence, for the mere filver obtained from the calcination of the lead. About forty years fince, the working of the lead veins in the hill of Leadlaw was revived, but foon dropt, as unprofitable. Attempts have been made to difcover lead worth working in other hills of Tweeddale, which have hitherto proved abortive.

Marl, or at leaft fubftances fermenting with vinegar, have been difcovered; fometimes in ftrata of hardened clay, or tough ftone of a dark blue colour, lying above limeftone rock; at other times in maffes formed by wells from limeftone, of a. petrifying nature, incrufting the fog with calcareous matter, and of a white colour: beds of it, probably of the laft mentioned origin, have been found covered with a fratum of mofs. It hath not been found but in the parts of the county in the vicinity of lime, which fuperfedes its ufe.

Chalybeate fprings, with blue fcum, iron tafte, and ochry fediment, every where abound in the parifhes of Linton and Newlands. One of thefe, called Heavenragua Well, in Linton parifh, is, I have been told, equally ftrong as the waters of 'Tunbridge. A fpring was, within thefe fifteen years, difcovered near the village of Inverleithan, containing both falt and fulphur, and faid to be of the fame nature as the waters of Harrowgate. It is confiderably reforted to ; and feveral houfes, of two ftories, have been built in the village, for accommodation. The yield of the fpring, in dry weather, is at the rate of about one chopin (Englifh quart) in the minute. Before its properties werc attended to, the place where its watcrs oozed througl the ground was much frequented by pigeons, and the fpot had obtained the name of the Pigeons Welt. 


\section{SECT. VI.-Water.}

THe river Tweed is accounted the fourth in magnitude among the Scots rivers. For feveral miles in its courfe it forms the boundary of the two united kingdoms. It takes its rife in the fouthern extremity of the county, from a well called Treedfavell, about 500 feet above the level of the fea. It runs in a north-eaft direction, till it receives thie waters of the lyne, when it bends to the ean, continuing in that direction till it: leaves the county, and enters Selkirkthire at Gatelaup Burn. Its ferpentine courfe through Tweeddale, which it divides nearly into two equal parts, is about thirty-fix miles; the whole length of its run, from its fource to the fea at Berwick, may be about 100 miles.

The principal waters falling into the Tweed, are, Ims, From its left bank, Biggar water, with its adjuncts Kilbucbo and Holms waters. Biggar water rifes in Lanarkfhire, from a bog near the courfe of the river Clyde, whofe waters, in high floods, overflow into Biggar water, and are with it carried into the Tweed; wherce the catching of falmon (which has fometimes occurred) in the Clyde, above its high falls, is accounted for. Lyne water, with its adjunct Tartb; Pcebles or EddleCone water; Leithan water. 2do, From its right bank, Mannor water; Quair water. Some other waters, falling into it in Tweedfmuir parifh, as Cor, Fruid, Tala, might, from their magnitude, be equally entitled as many of the former to a place in a geographical defcription; but there is neither actual, nor, probably, practicable cultivation upon their banks, to entitle then to a place in an agricultural furrey.

Four waters rife in Twceddale, or upon its boundaries, which do not pay tribute to the Tweed, or, at leaft, not within the county, viz. Maidwan, which divides its waters at a fulling mill on the weft fide of Linton parifh, fending the water which drives the mill to $\mathcal{T}_{\text {arth }}$, and the main fream to the Clyde; North Esk, in Linton parifh, and South Esk, iffuing from the $V^{\top}$ ater Loch in Eddleftone parifh, which join their 
freams in Mid-Lothian, and fall into the fea at Mufelburgh; Megget water, in the part of Lyne parish of that name, which. falls into St Mary's Loch, whofe outlet is Yarrow water in Selkirkfhire, which joins the water of Ettrick, and, with it, joins the Tweed a little below the town of Selkirk.

All thefe waters abound in trout, par, and eels; the lochs St Mary and Water Loch, already meritioned, together with Slipperfield Lioch in Linton parifh, abounding in perch and pike; the St Mary and Water. Lochs containing alfo, the firft, trout and eel, the latter eels, which, in certain feafons of migration, ufed to be catched in great numbers, in bafkets, at its outlet, the head of South E $/ k$ water.

Salmon are caught, out of feafon, in all the waters, and at all times, in Tweed: 'There is however no fining upon Tweed, in this county, that can afford any rent.

No water machinery of any kind has hitherto been erected in this county upon the Tweed.

I am indebted to William Brown, mill-wright in Lyne parifh, who has erected, and who keeps in repair, the greater part of the machinery in Tweeddale, for the following Itatements of the water-wheels, with the work they are employed in, which are erected upon the other waters and burns througin the county.

$$
\text { STATE, NOVEMBER 1,97. }
$$

Nuirber of Water W'beeis.

1) riving the paint-mill at Lamancha the manufactory of woollein at Inverleithan for fpinning, carding, roving, and a fulling-mill - 2 a corn-mill, malt-mill, and thrafhing-mill, at Kerfreld (N.B. the firt thrafhing-mill in the county) I fulling-mills

lint-mills

thrafhing-engines folcly

corn-mills with one pair of ftones

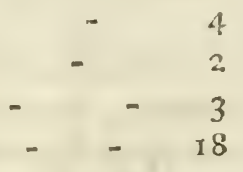

corn-mills with two pair of ftones, and a vertical

running ftone for making pot barlcy corn-nills as above, alfo thrafhing-engincs

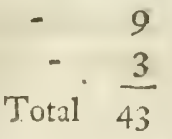


Befides the above feven thrafhing machines driven by water, either by themfelves, or along with other machinery, there were then in the county only nine other thrafhing machines driven by two horfes each, together with one for a fingle horfe, and two driven each by two men.

December 1801. The following is the Statement:

$$
\begin{aligned}
& \text { Number of } \\
& \text { Water Wbeels. }
\end{aligned}
$$

Driving the paint-mill at Lamancha

the woollen manufactory of Inverleithan, with its

fulling-mill - - - - - 2 the woollen manufactory at Peebles - - I the manufactory of felts for paper-makers at Carlips I - manufactory at Garwell-foot, or at leaft teazing and fcribling engines, and fulling - - I - fulling-mills - - $\quad-\quad-\quad-\quad 2$ $\begin{array}{lllllllllll} & \text { lint-mills } & - & - & - & \end{array}$

—_ a mill for all corns, for malt, and for a barley-mill, and a thrafhing-mill at Kerfield - - I

- common corn-mills, with one pair of millitones $\mathrm{I} 3$

__ for wheat alone - $\quad$ - $\quad$ - $\quad$ - I

- common corn-mills, with a vertical running-ftone for pot-barley $\quad-\quad$ - $\quad$ - $\quad$ - 10 ___. corn-mills with two pairs of ftones, and a vertical

ftone for barley - $\quad$ - $\quad$ - $\quad 5$ - - corn-mills with two pairs of ftones, a ftone for bar-

ley; alfo a thrafhing machine, and one of them

a ftraw cutter befides - $\quad$ - $\quad$ - 3 - - thrafhing engines folely _ _ - - - I4

Befides thefe eighteen thrafhing cngines driven by water, there are, at this date, alfo twenty-four thrafhing engines driven by two horfes each; thofe driven by hand, or by one horfe, feem difufed as infignificant. 'They are erected by all the coniderable corn farmers at their own expence-decifive of their utility. 
It would appear, from thefe ftatements, that thrafhing engines have increafed, in four years, from fixteen to fórty-two in number; and that many other improvements have been made in the machinery of mills. Two other thrafhing engines, to go by water, are in contemplation againft next feaion.

Beveled work (confidered as a great improvement in wheelmachinery, and firft introduced into Scotland, it is faid, by $\mathrm{Mr}$ Dale in his cotton-mills at Lanark, within lefs than twenty years) is univerfally adopted in the thrafhing engines, and alfo in every new erected corn-mill; the mill at Spittlehaugh in Linton parih having led the way.

In the corn-mills with only one pair of ftones, the ftones are roughed on the furface, to enable them to tear and bruife the grain, by fmall hand pickaxes. Stones, thus dreffed, ferve well for making oat-meal, which is relifhed beft when rough in the grain. They cannot grind barley or peas to that finenefs of flour which fuits the general tafte: It is therefore neceffary to have a feparate pair of ftones for that purpofe, which are dreffed on the furface with fmall chifeled grooves running in a direction from the circumference to the centre, like as in the ftones of wheat-mills; the edges of thefe grooves clip the grain like fciffars, and there is no interftice through which any of the grain can efcape, till reduced to the required finenefs of meal.

The manufactories provided with teazing and carding engines, get great employ in teazing, carding, and roving wool, from thofe who make their cloth at home; as it comes cheaper to the employer, after liberal payment to the proprietor of the machine; and the work is done better, and with lefs wafte of materials, than when thefe operations are executed by hand labour. 
CHAP. II.

STATE OF PROPERTY.

SECT. I. - Eftates and their Minnagement.

As this county confifts chiefly of hill pafture lands, producing an herbage, fcanty and poor in quality, and more fitted, in general, for rearing theep, than for fattening them; a large extent is neccfiary to conftitute any confiderable value: It may thence readily be conceived, that landed eftates are of large dimenfions; as alfo, that fingle farms mult often occupy a large extent of furface, without which, the produce would barely. compenfate the trouble of attendance and management, but could afford no rent.

Sheep farms are fometimes meafured in acres; but the meafurement affords no datum upon which to eftimate what ought to be the rent of the farm, and accordingly never enters into the. calculation of either the proprietor, or the farmer propofing to rent it in leafe. In eftimating their value, the only confideration taken into account, is, what number of fheep have ufually been, or may be kept upon the farm, with the quality of the fheep fo kept; whether fheep of a dificrent kind might not be kept to vreater advantage, fucl as fattening, inftead of breeding ftock, or vice verfa; or whether, without either fattening or brecding, lambs ought net to be bourglit in annually, to be fold off next: feafon as holding flock; or whether a mere ciminution of numbers might not be more advantageous, from diminution of the riik of death, and from the fuperiority in quality of the remaind.I, from more abundant fecting; or, in flort, whether it might be more profitable to appropriate lefs of the farm to fheep. 
pafture, and more of it to the rearing of black cattle, or to tillage.

The valuation of the county in the cefs-books, is $5 \mathrm{I}, 927 \mathrm{l}$. 3s. Iod. Scots. The grofs rent, including reut of mills, and alfo about 500 . rent from coal, lime, freeftone, and ilate, may amount to nearly 26,0001 . Sterling. Were an eftimate to be made of the free rent, the deductions would be, the provifion of the Clergy, (fee Statiftical Tables), with the building and upholding of their manfes and the parifh churches, cofting, if rebuilt, in each parifh, probably about 70ol. at an average; the falaries of the fchoolinafters, (fee Note A), with the upholding of the fchools and mafters dwelling, cofting, if rebuilt, in each parin, probably 60 or 70 . at an average. Some other deductions are not fo eafily calculated, fuch as, the up. holding of farm houfes and milis, \&x. with the as yet inconfiderable expence of poor's rates, where eftablifhed, or of vom luntary contributions for their fupport, where there are no rates.

The whole landed property may be divided among about fixty proprietors; without taking into the account a few fnall proprietors, poffefling lands to the value of 201 . yearly rent or under, around the burgh of Peebles, and fome of the villages. Without pretending to any thing like exactnefs, the proprietors may be diftributed into the following clafification:

Poficfing about, and little exceeding,

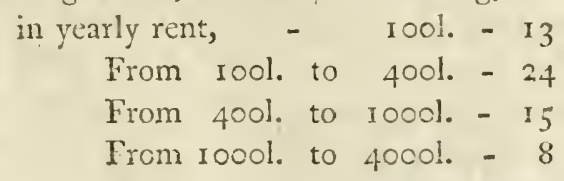

60

Of the more inconfiderable of thefe proprictors, perhaps eight or ten farm the whole of their own lands, fome of them renting other farms befides; though the farmers renting lands to the greateft extent, are not of the clafs of landed proprietors: Therc feems indeed a fecurity produced, from the certain in- 
come from landed property, where no rent is paid; which fopites induftry, and engenders indolence.

Almoft all the proprietors, who refide either conftantly, or for a sart of the feafon, farm more or lefs of their own lands, for convenience, for amufement, or even to a fomewhat greater extent; a very few, to an extent of farm that might be let in leafe at feveral hundred pounds of yearly rent. The practice, however, of taking farms into their own management, for the purpofe of letting them in leafe, at advanced rents, after high melioration, though there are fome inftances of it, is but rare among Tweeddale proprietors: Indeed, the far greater part of the lands is little fufceptible of improvement by furface culture of tillage; and inclofure, at leaft the fubftantial inclofure of ftone dikes, which need no nurfing, is as well carried on where lands are entered to upon leafe, as when in the actual occupancy of the proprietor himfelf.

About a fifth or fourth part of the lands is under ftrict entail ; befides what may be entailed by exifting proprietors, whofe deeds fhall take effect when their own confcioufnefs of the matter fhall ceafe. From a fingular circumftance, to be afterwards explained, the lordhip of Neidpath, comprehending the half of the lands prefently entailed, bids fair to become the moft fpeedily, and the moft fubftantially, improved property in the county.

Of nobility, there were lately fix who poffeffed lands in the county, viz. the Earls of Dundonald and of Hyndford, whofe lands have paffed into a different line of fucceffion from the titles; the Duke of Queenfberry, poffelling, qua Earl of March, the lordfhip of Neidpath; the Earl of Traquair, poffeffing the eftate of that name; Lord Elliebank, poffenling the barony of Darnhall, which, by entail, goes to the fecond branch of the family; the Duke of Buccleugh, whofe intereft in the county is inconfiderable.

The number upon the roll of freeholders, is generally from thirty to thirty-five, who fend one reprefentative to Parliament from the county: 'The burgh of Pcebles, in conjunction with thofe of Linlithgow, Lanark, and Selkirk, fends alfo one. 
By much the greateft part of the lands is rented by profeffiónal farmers, holding them upon leafes for terms of years. Nineteen years was, and is, the prevailing term of endurance of a leafe. The recent fpirit of improvement, leading farmers to perceive the propriety of launching out their capitals upon ameliorations of very diftant return, if only fecurity of pofferfion can be obtained till that return arrives, has raifed a demand for leafes of longer endurance; and the terms of twenty-one, twenty-five, thirty-one, and, upon the lordhip of Neidpath, three nineteens, have of late been adopted. I know not of a fingle inftance, in the county, of a liferent leafe now exifting; though, unhappily, according to the legal conftruction of the right of poffeffion by leafe, it may, under various circumftances, occur, that a leafe for a term of years may prove merely equivalent to a liferent leafe, or even that the latter may be a preferable fecurity. Grafs inclofures, perfectly fenced, being yet but rare, let at a monopoly price. They are feldom let in leafes for years, but are ufually let for the feafon by public roup or auction, and are taken by farmers for their young cattle, which eat their Winter's fodder, or by profeflional graziers or horfe-dealers: From two to three guineas per Scots acre is paid pretty commonly.

The number of farmers renting lands to the extent of from 200 to 5001 . of yearly rent, amounts to about eighty. A much greater number poffefs fmall farms, from 20 to $8 \mathrm{ol}$. of yearly rent.

Few of the fheep farms contain much lefs than 600 or 700 Scots acres; there are more that contain from 1000 to 4000 . Few of thefe farms pay lefs than rool. yearly rent. The higheft rent paid at prefent by one farmer for lands within this county, is about 600 l. yearly. One farmer who refided in this county, paid, at one time, for fheep farms, in this and neighbouring counties, no lefs than 1 7 ool. yearly rent.

The fmaller farms, chiefly arable, confift of from 40 to 50 to 100 , and, in one or two inftances, 200 acres. Two or three of thefe may pay 1001 . or $150 l$. yearly rent; the reft being rented at from 25 or 30 . to 70 or 801 . 
The following fatement, of the mode in which the lande are poffefied, (in the parifh of Linton, where there is the largeft tillage of the county; in that of Mannor, where there is only a fmall kirk town of about half a dozen houfes; and in that of the united parifh of Lyne and Megget, where there is neither village nor kirk town), will convey a tolerable idea of the whole. Perfect accuracy in the ftatement, is not, however, pretended to.

Linton Parish, (from perfonal knowledge, about the year

$$
1794) \text {. }
$$

Extent of the parifh, 25,472 Englifh acres. The whole jeariy rent, about 2,400l. Sterling.

Farmers renting to the extent of from 150 to 200l. yearly

rent

Ditto renting from 100 to $i_{5}$ l:

A proprietor farming his own lands, to the extent of what

might let at about 1501 .

A genticman renting a proprietor's houfe and parks at $75^{1}$.

Farmers renting from 50 to 1001 .

Ditto renting from 20 to 501 . $\quad$ - $\quad \ldots \quad$ - $\quad 12$

Ditto renting at about 201 . - _ - $\quad 10$

Crofters, renting one or two acres around the village of Linton, are not included in the above enumeration.

\section{Mannor Parish (from Statifical Account).}

Extent, 16,558 Englifh acres. Yearly rent, 16851 .

Farmers paying 220l. yearly rent - - - - - r

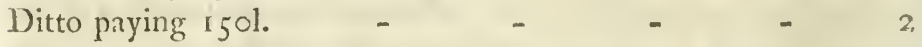

Ditto paying rool. $\quad$ - $\quad$ - $\quad$ - $\quad$ - 6

$\Lambda$ gentleman renting a proprietor's houfe and parks at $50 l$. I.

A proprietor farming his own lands, that might let at per-

haps $90 !$.

Farmers renting at from 20 to 601 . 
Parish of Lyne and MegGet (from Statiftical Account).

Extent, 16,987 acres. Rent, without including fines at entry, 9001 .

Farmers occupying large farms, one of them not refiding 6

Niller renting to extent of about $34 \mathrm{l}$. - - I

Farmer renting the minifter's glebe at 201 . - - I

Mill-wright, with a very fimall poffeffion - - I

\section{SECT. II.-Tenures.}

THE tenures, by which lands are held, may be claffed into fuperiority, property, and tack, or leafe.

Superiority is merely that nominal title to land, which confers the right of franchife. As 40ol. valuation of fuperiority confers franchife, and as, in Scotland, fuperiority may be retained, when the property of the land is conveyed away, and this fuperiority may alfo be fictitioufly conveyed in any given portions, it is evident, that, in creating votes, the fuperiority of the whole valuation, 51,927 . Scots, would give I 29 voters at the county election: As, however, the number commonly upon the roll of freeholders does not exceed 30 or 35 , it may be readily inferred, that this county has not been much difturbed by the animofities of political conteft.

Property is the valuable tenure of land, implying the full command of the fubject to all the purpofes of human life ; excepting, merely, political power, which is attached to fuperiority, and may, or may not, be attached to the property.

Tack for a term of years, is the tenure by which land is held, by profeffional farmers, from proprictors, for the purpofes of agriculture.

For a more full explanation of this fubject, I refer the reader to note $\mathrm{B}$. 
C H A P. IIf.

BUILDINGS.

\section{Sect. I.-Honfes of Proprietors.}

THERE are in the county about 30 houfes, (including all thofe in tolerable repair), belonging to landed proprietors, porfefling from iool. to perhaps $3000 \mathrm{l}$. of yearly land rent. Of this number, rather more than two-thirds may be confidered as ordinary family refidences; confifting of from 6 or 8 to 20 or. 30 fire-rooms, and conftructed upon plans confined to mere purpofes of utility, or admitting of more or lefs degrees of neatnefs, elegance, or magnificence, according to the various taftes or abilities of their refpective poffeffors.

There are five feats which have been, not long ago, or are now, the refidences of noblemen, viz. (arranging them in the order of higher up to loweft down in the county) Lamancha, Kirkurd, Darnhall, Neidpath, Traquair ; refpectivcly belonging to the Earl of Dundonald, Earl of Hyndford, Lord Elliebank, Duke of Queenberry qua Earl of March, and Earl of Traquair, none of whom refide at prefent, but the laft mentioned Earl. Properly fpeaking, threc of them only are ancient family feats, accompanying he poffeffion of the titles, Darnhall, Neidpath, and 'Traquair.

The fituation of Neidpath is, or rather was, the moft picturefque of any in the county. The houfe itfelf is, indeed, in no way remarkable; being a tower-houfe of fmall dimenfions, but with exccffive thicknefs of wall, and now ruinous. It ftands upon a rock overhanging the 'Tweed, at the lower end 
of a wide femicircular bend of that river: the concave bank is very fteep, of great height, and wooded for near a mile up and down the river, from its top to the water's edge, forming a vaft romantic amphitheatre. Upon the oppofite fide of the river, a bold projecting wooded bank juts forward into the bend; at the foot of which, lies a fmall plain, half encircled by the Tweed, fuggefting the idea of a fnug, fequeftered, fheltered fituation for an hermitage. This fcene lies about a mile above the town of Peebles, where the road, leading up the Tweed, enters upon it at Neidpath Caftle; whence it is carried along the middle of the concave bank, being cut out in the rock, and feeming to hang over the water below. To the traveller, by moonlight, the conftant fhifting of the fcenery as he moves along, with the intervening glimpfes of the water reflecting the moon-beams through the trees, gives to the whole an air of fairy-land and enchantment. I am forry to add, that the defcription no longer applies; the place having been very lately difmantled completely, by the fale of the wood. No blame, however, can attach to the prefent Noble proprietor. This fubject of regret, like many other, falls entirely to the charge of the extravagant extent of the power of entail ; imparting to the will of the dead, who have ceafed to have any further actual concern, an effect by much too extenfive, in controuling the wills of the living and interefted. When a proprietor cannot leave his landed property to the natural object of his affection, what elfe is to be expected, but that he fhould convert what of it he can into money, which the laws of his country ftill allow him to difpofe of as he pleafes? We laugh at the fuperftition of the Chinefe, in paying divine honours to the memory of their deceafed anceftors; though it is probable, this their worhip is, like that of other people, fo managed, as not effentially to interfere with their temporal interefts. But might not a ftranger to our laws and cuftoms be tempted to tax us of a more than Chinefe fuperftition, in paying to the wills of our anceftors, where they interfere fo materially with our temporal interefts, as to preclude all power of choice on our part, in fome of the moft effential parts of their manage- 
ment, an obedience more devoted and implicit, than what is generally paid even to an acknowledged Divine authority?

It would be foreign to the purpofe, and incompatible with the limits of this Report, to attempt to characterife the ftyle of the various feats of the nobility and gentry: thefe we leave to the architect and defigner of polieies, our bufinefs lying rather with the humbler fubject of the accommodation of the farmer and the cottager. I fhall juft obferve, that the mountainous nature of the country affords choice of every variety of fituation; fo that he, who choofes to expofe himfelf to every wind that blows, may frequently, at this price, enjoy a pretty extenfive profpect -of objects, however, not commonly very interefting; whilft he, who is contented to forego extent of profpect, may fnugly bury himfelf under the moft complete thelter. There are feats to be found in both extremes of fituation; though the middle ftate feems to have been the more general object of choice. I have fubjoined, in an appendix, an account of Whim, which, from peculiarity of fituation, and particularly from the cultivation there carried on, of the deepeft mors foil ever attempted to be cultivated in this county, feemed, in preference to others, to merit a particular defcription in an agricultural furvey.

\section{Sест. II.-Farm-Houfes, Offices, and Repairs.}

From various caufes, Scotland was more late in being relieved from the oppreffion of feudal ariftocracy, than her fifter kingdom; the laft act of Parliament to that effect, and for which we are indebted to our rebellion in 1745 , being fo recent as the 1748. An emancipation de jure, when obtained, proves not, however, all at once, an emancipation de facto; time is neceffary for the mind to habituate itfelf to the fentiments fuited to a new fituation; and it is but of late, if as yet, that the feelings of fecurity and independence are as univerfally prevalent among the Scots, as among the Englifh tenantry.

In former times, the Scots tenant poffeffed the fentiments and habits of the fulject of an Afratic defpot, rather than thofe 
of a free man: deftitute of that manly confidence, infpired by the confcioufnefs of fecurity in the cqual protection of law, he relied more upon the refources of his own dexterity and cunning; and the dread of being plunderel, made him cautious of difplaying fuch wealth as he poffeffed, either in improvements upon his farm, or in purchafing fuch comforts and accommodations as its profits might afford. From his contracted habits of concealment, and from the fmall degree of wealth which he had any opportunity of acquiring, the Scots tenant was contented to live in the moft miferable hovel; the poverty, too, of his landlord, who could draw little rent from a wretched tenantry, deftitute of every proper encouragement to induftry, difabling him, even had he been willing, to afford much better accommodation. Thefe hovels, fuch as they were, coft nothing to the proprietor, but were upheld for ever by the tenant; it being underftood, at common law, independent of covenant, that the outgoing tenant hould leave them always to his fuccefor, in tenontable and babitable condition: From ufe and practice, tencntable and babitable, had come to imply merely, wind and suater tight; and the common ftyle of farmhoufes admitted of little more accommodation, thin mere fhelter from the weather.

In confequence of the firm eftablinment of monarchy, and the diffolution of ariftocracy - of the abolition of heritable jurifdictions, and the fubftitution of independent Judges, unconnected with the fubjects of their own jurifliction, and having no perfonal interent in their own decifions-the fecurity of the tenantry, as well as of all the lower orders in fociety, is confirmed: General induftry has kept pace with growing fecurity; and the fituation of every rank is altered greatly for the better. In confequence of increafing icutiments of liberality among the landed gentry, of fectrity among the tenantry, and of wealth in both, the ftyle of firm-lowie's through Scotland las been much improved. Great improrements, in this refpect, have been made in 'Tweeddale, within thefe laft thirty years; Sir James Montzomery of Stanhope, late Lord Chicf Biron of the Court of Eychernax in Scothnd, Sir Jumes Nafmyth of New 
Poffo, and Mr Burnet of Barns, having been among the firft to fet the example.

In building farm-houres, it is the prevailing practice, that the proprietor pays all the outlayed money for materials and wages of workmen; the tenant performing the carriages, and becoming bound to uphold the houfes during his tack; the laft mentioned obligation having become the lefs onerous, from flate roofing having come more into ufage. In general, no ftipulation is made as to payment of intereft, for the money laid out upon the buildings; it being rather underftood, that a tenant, poffeffing ftock to occupy a farm of the particular extent, is entitled to accommodation in a fuitable ftyle. Much liberality, in accommodation of houfes, has of late been manifefted by "Tweeddale proprietors, excepting upon the eftate of Neidpath, where, in confequence of entail, the prefent proprietor, having no more than a mere liferent intereft, cannot be expected to fink money upon the fubject.

Sheep farmers can be afforded the beft dwelling-houfes; as, from their theep never being houfed, they require lefs extent of farm-offices than corn farmers.

'The beft farm-dwellings in Tweeddale, are built in a fyle fimilar, but fomewhat inferior, both as to fize, height of ceil. ings, and quality of finifhing, to the dwelling-houfes, or manfes of the clergy. Thefe latter are of the dimenfions of from 34 to 40 feet in length, by from 9 to 22 feet in breadth, within the walls; the door is generally in the middle of the front, whence you enter upon a very fmall lobby and the ftaircafe; on one hand is the kitchen, with a fmall divifion, probably taken off it, for a fcullery anil fervant's bed; on the other hand, is generally the beft room, occupying the breadth of the houfe for its length. When you afcend the ftair to the fecond ftory, the fpace above the kitchen may be equally divided, making two fmall neeping apartments; and the fpace above the beft room is uncqually divided, affording a fort of drawing room, with a fmall fleeping clofet. The garret fpace, under the roof, may be divided into a place for lumber in the one end, and the other end fitted up with a couple of beds, into what is called a 
barrack room. The farmer, having a greater number of fervants than what are needed by the clergyman, is generally accommodated with a kitchen without the dwelling-houfe, which gives more room, though his dwelling-houfe is fomewhat leis than the manfe.

The number of farm-houfes of two ftories with flated roofs, lately built, may amount to fomewhat above fifty, without including a few of that defcription, prefently occupied by farmers, which formerly were occupied by the proprietors. The two moft expenfive farm onfteads (including both dwelling and office-houfes) that have been erected in the county, are, I believe, one at Hudlefhaup in Mannor parin, by Robert Campbell Efq. of Kailzie, the other at Blythrbank in Linton parifl, by John Carmichael Efq. of Skirling: the court of the latter, for dungftead and winterers, inclofed upon three fides by the offices, and on the fourth by a wall, contains a fpace of 100 by 84 feet clear of the buildings *.

Prior to the period of improvement before ftated, the moft ufual conftruction of the better farm dwellings, was that of a long houfe of only fix feet wall in height; the apartments all upon the ground; the dimenfions about 45 by 15 or 16 feet in breadth within walls; no divifion by partitions within, but

the

* Mr Alexander, tenant of Eafter Happrew, who, upon fecurity of one of the fifty-feven years leafes, granted upon the barony of Neidpath, has built, at his own expence, a dwelling of two fories, with offices, all eovered with fate, and who generally thinks for himfelf, hás formed his court of offices into a fmall fquare, merely fufficient to contain his dung. His cattle have no accefs into this court, the offices being all entered from the outfide. The dung is toffed from the offices into this court through apertures in the walls; the urine from all the offices runs into a refervoir funk in a corner of the court; a pump is placed in the refervoir, whence, by means of wooden conduits !aid upon moveable fupports, the urine is conveyed over any part of the dung. He difapproves of the trampling of cattle upon dung, as kneading it into a folid body, and excluding the air, to the prevention of putrefaction. His winterers, upon ftraw, are fed in a feparate court, whence the dung and litter can be removed at pleafure, to be toled into the other dung-court; or otherwite lightly iaid together, for the purpofe of putrefrotion. 
the crofs partitions effected by clofe beds * fet end to end, with a paffage betwixt them. You entered at the front, where the door was placed near to one end: On the right hand, we fhall fuppofe, you had a partition of clofe beds, which cut off a fpace for a room, and, on the other hand, the fimilar partition dividing the kitchen from the paffage; turning to the left into the kitchen, a fimilar partition cut off a room from the kitchen. Thefe three apartments, viz. a kitchen in the middle; with a room at each end of it, conftituted the whole accommodation. The round-about fire fide (ftill by much preferred where there are a number of farm fervants, and certainly by far moft preferable, but for the difficulty of keeping them clear of fmoke), was univerfally in ufe in the kitchen; that is, a circular grate placed upon the floor about the middle of the kitchen, with a frame of lath and plafter, or fpars and mats, furpended over it, and reaching within about five feet of the floor, like an inverted funnel, for conveying the fmoke; the whole family fitting round the fire within the circumference of the inverted funnel. Here was placed the gudeman's refting chair, or wooden fopha, upon which he fat or reclined after the fatigues of the day, liftening, in thofe times fo dearthful of intelligence, to the news collected by the wandering beggar, or feafting his imagination upon the wonders of the lame foldier or failor who had vifited foreign countries.

SEcT.

* The clofe bed is a frame of wood, 6 feet high, 6 feet long, and 4 feet broad. In an houfe of 15 feet in width, two of them fet lengthwife acrofs the houfe, the one touching the front, the other the back walls, an entry or paffage, of thrce feet in width, is left betwixt the beds. To form an idea of a clofe bed, we may fuppofe it like a fquare-formed upright curtain bed, where the place of curtains is fupplied by a roof, ends and back of wooden deal, the front opening and fhutting with wooden doors, either hinged, or fliding fidewife in grooves. The bottom, raifed about $\mathbf{I} 8$ inches from the floor, is fparred; this is covered with fraw, above which a bag of ticken, or of fackcloth, filled with the chaff of oats, mon con:monly fupplies the place of a feather bed, with bolfter and pillows of the fame conftruction. 


\section{SECT. III.--Cottages.}

HALF a century ago, a great part of the cotages of the Scots day-labourers were built with walis of turf ; thone buttrefles, or wooden ports, built into the wall, fupporting the heavy timbers of the roof : A very few of this defeription ftill exift in this county; but the greater part are built of ftone and lime: The general defeription of the cottage of a labourer or tradefman, who keeps a cow, is, a houie of 18 or 20 feet by 15 or 16 within walls; the door is in front, clofe by one of the gables; two clofe beds form the crofs partition, dividing the fpace occupied by the family from a fpace of four feet from the gable at which you enter, where ftands the cow behind one of the beds, with her tail to the door of the houfe. There is one window in front near the fire gable, oppofite to which, at the oppofite wall, ftands the ambry, or fhelved wooden prefs, in which the cow's milk, and other family daily provifion are locked up; and, above it, lying againt the flaunt of the roof, is the /kelf, or frame, containing (helves, with crofs bars in front, to prevent the utenfils fet upon its fhelves from tumbling off from its orerhanging pofition; the fhow of the houfe depending much upon the quality and arrangement of the crokery and other utenfils piaced thus, in open vicw, upon the fielf. A cheft, containing the family wardrobe, ttanis in front of one of the cloie beds, ferving alfo for feats. The clofe beds are alfo furnifhed with a theif at head and foot, upon which part of the family aipparel is depofited, to preferve it from the duft. A wooden armed chair for the hufband, when he arrives fatigued from his labour, and a few ftools for the reft of the family, and a plunge elurn, completes the inventory of houfehold furniture; to which only a fmall bar-rel for falted flefh, and another for meal, may be added, if the family can afford to lay in ftores, and are not from hand to mouth. The cooking utenfils are, a fnall caft-iron pot, in which is daily prepared the oat meal porridire, the univerfal brealfant, eaten with nilk, or with home-brewed weak ale 
from treacle, when the milk feafon is over*; in which alf the potatoes are boiled, as the univerfal fupper, while they laft, eaten either with milk, or merely with falt; in which is aifo prepared for dinner, through Winter, potatoes dreffed with mutton-fitet purchafed for the purpofe, or broth to be eaten with bread, made univerfally with thelled barley, and kale from the kale yard, and, according to circumftances, either with or without a bit of falted mutton, to give them a relifh; the butter from the cow being all fold fresh, from the high price it. bears in fuch vicinity to Edinburgh, being the chief dependence for money to pay for the cow's Summer's grafs, and to purchafe her Winter's fodder; the kimmed milk only being ufed in the family, in the manner already ftated; or, when moft plenty in Summer, ferving for dinner broth. The next indifpenfable cooking utenfil, univerfally in ufe in every cottage and in every family in the country, is the girdle, which is a round thin plate, either of malleable, or of caft.iron, from a foot to two feet and an half in diameter, according to the fize of the family. It is fufpended over the fire by a jointed iron arcl. with three legs, called the clips, the ends of the legs of which are hooked, to hold faft the girdle. The clips is linked upon at hook at the end of a chain, called the crook, which is attached. to an iron rod, or wooden beam, called the rantle-tree, which is fixed acrofs the chimney-ftalk, at fome diftance above the fire. Upon this girdle is baked the ordinary bread of the cottager, and of the farmer's fervants, confinting of brnnocks made of the meal of peas, or of barley, but more generally of the two meais mixed together,

- Time was, when the character of not meal was greatly traduced; being accounted heating to the blood, and the caufe of cutancous difeafes, and cven of the national difeafe, the itch. It has regained its character, of late, with the faculty, as fuisacid and cooling, and is prefcribed even for cutaneous diforiters. I am inclined to date the rchoration of its charater from the publication of Smollett's Humphry Clinker; where a rational vindication of its wholefome propestics is put into the mouth of Liet:enant Lefinaliagoe. The itch lias almoft totally difappeared fince the introduction of cleanlinefs, though the ufe of oat meal is ftill pcrfevered in. 
rogether, and more rarely of oats. The meal is made into dough with water without leaven, and the dough is formed into circular cakes of from 7 to 9 inches diameter, and from $\frac{1}{2}$ to $\frac{3}{4}$ inches in thicknefs; it is then toafted firft on one fide, then the other, upon the girdle; and two or three days provifion are made at once: The bread has but a doughy tafte. The oat cake, known by the fole appellative of cake, is the gala bread of the cottager: The meal is made into dough with water, without leaven, as little water being ufed as is nerely fufficient to make the meal ftick together; the dough is then kneaded, or rolled out, as thin as polfible, into a round cake, of diameter correfponding to the fize of the girdle; the cake is then cut into four quadrants, and toafted on the girdle, alternately, on both fides, care being taken, both with cakes and bannocks, to prevent the girdle from being fo hot as to burn their furface: When the cake is fo hardened as to ftand on edge, it is placed upon an iron heater, linked upon a bar of the grate, where it toafts leifurely, till it is perfectly dry, though noway burnt; if it hath lain fome days unufed, it is toafted anew before it is eaten; it thus conflitutes a hearty fpecies of bread, of a tonic quality, to judge by the tafte; and which, by many Scotsmen in the higher ranks, is preferred to wheaten bread *. There is juft one other utenfil indifpenable to the cottager; which is, a very fmall barrel, or can, of ftone ware, to hold his falt, which he keeps in a hole in the wall clofe by his fire, to prevent its running, from the moifture in the air: He muft alfo have a wooden pail to carry water; in which his cow is milked, if he lias one; on which fuppofition, too, he muft have three cans of flone ware, or veffels of cooper's work, in which the milk is fet in the ambry to ftand for cafting up the cream.

"In the predatory excurfions of our ancentors into England, the only provifion they carried was a bag of nat meal; their only camp utenfil was the girdle; as for cosking Aen, their vay was, to boil a cow in her uwn tkin. 
I have entered the more largely into the defeription of the food of the cottager, as farm fervants are fed much in the fame way, excepting only that they may more often have broth made with flefh, and fleth, or cheefe, or eggs, more frequently for dinner along with the broth.

The moft artificial food ufed by cottagers, or farm fervants, is forvins. When oats are to be made into meal, the grain, be ing dried, is made to pafs through the mill, the millftones being fet at fuch diftance as merely to ftrip off the hufk without braifing the kernel; the hufk is then feparated by the fanners: As the grains are, however, of unequal fize, the whole is again returned to the mill, with the ftones approaching a little nearer, by which the fmaller grains are fseeled, or fhelled, without bruifing the kernels fhelled by the firft operation: The hufks, or foilling fects, are again feparated by the fanners, when the frilling, or naked kernels, are committed to the mill, with the fones fet fo near as to grind them into meal. As fome of the thells, however, ftill remain among the meal, they are feparated from it by hand fieves: Thefe fhells, thus feparated, and having the finer particles of the meal adhering to them, called mill feeds, are preferved for fowins. A quantity of them are fteeped in water for eight or ten days, according to the heat of the weather, or of the place whicre they are depofited, when they undergo the acid fermentation, to be judged of either by the fmell or tafte; they are then well wrung in the water, and the whole is decanted through a draincr into another vefiel, the drainer keeping back the hufis: After the decanted extract has depofited the fine particles with which it is impregnated as a fedinent, it is poured off; frefh watcr is poured upon the fodiment, which is well firred, and allowed to fettle for twenty-four hows, when it is alfo poured off: This wafining is intended to correct the acidity, and is repeated till the water retains only fuch fubacidity as is grateful to the pulate. When this is attained, that water is poured of, and fuch quantity of frefh water added, as, when the fediment is well firred with it, fhall bring the mixture to the confiftence of thin gruel, or cream, when a portion of it, fuflicicnt for a 
meal, (always the fupper meal), is boiled in a pot, in which it thickens; fo that, when poured into a vefiel to cool, it acquires the confiftence of a thick jeily. Againft the fuppcr hour next inght, recourfe is had again to the ftore vefiel, when the water is poured from the fediment; and it is again brought to its proper confiftence by frefh water, and the quantity needed put into the pot, Sic. fo long as the prepared ftore lafts. The fowins thus prepared, are eaten either warm with cold, or cold with heated milk. They are a food of very eafy digeftion, having fomewhat of a diuretic quality, and are extremely pleafant to mof palates. The feeds, from the different makings of meal (molders) through Winter, are preferved till the potatocs are exhaufted; when they afiord fowins, for a fupper difh, till the potato feafon comes in again. Sowins are ufed by the weavers as a drefing for linen yarn for the loom.

Subftantial labourers or tradefmen have generaliy two appartments in their cottages; the cow, flanding in a feparate tofall building ; the kitchen is formed by two clofe beds, as a paxtition, in the manner already defcribed; the room is formed by a Galafhieis partition * run acrofs the loufe. This ceconomical partition is formed of perpendicular ftandards from the ground to the ceiling, of three-fourth inch deal, from three to four inches broad, according to the thicknefs of partition required, and fet about three feet afunder: A flat board (com. monly an old door) is clapped fiat againft the ftandards on one fide; and a mafon, on the other fide, builks up the interftices betwixt the ftandards with fmall chips of thone and lime mortar, the old door keeping the work ftraight on the fide oppofite to him. At every three fcet advance in height, he lays a crofs binder of wood upon the mafonry betwixt the flandards, clofe fitted to their interval, and to. which they are nailed. Whers the whole is thus completed, the furface is fmoothed with platter lime. Partitions might be mace of this kind with fold. ing coors, and roof of lati and plafter, which might ferve the

purpofe

- I call it fo, having frift feen it ufcd at the village of Galahiells in Selkirknire. 
purpofe of clofe beds; and poor people might find it more eafy to pay intereft for the advance, than to purchafe the clofe beds, which, in this dearth of wood, may coft from forty Ahillings to three pounds each.

Cottages, as defcribed, are covered with thatch, excepting in the villages of Broughton and Eddleftone, which were rebuilt on regular plans, with flated roofs, by the proprietors of the manors, as viftas from their own manfions.

Fern is reckoned a more durable thatch than ftraw, and heath than fern. Lint is reckoned a very durable thatch, and has been reared for the purpofe; the feed, fold to oil mills, paying in fome meafure as a crop. Bafket willow might, probably, in many refpects, prove preferable to any of them. Tile is not in ufe, almoft, in this county; from a dread that it could not endure the rigour of our Winters; but chiefly from its conftant expofure to breaking in low houfes. The moft general thatch ufed, (till the two Winters 1799 , 1800 , fo dearthful of fodder, introduced the more general ufe of heath), is the ftraw of big; applied to this purpofe, as being lefs valuable as fodder: It is either fewed to the crofs fpars of the roof, by tarred twine; or the roof is firft covered with divats (fod raifed by the paring fpade) laid on, overlapping like flate, with that end only expofed which hath received a knead or glaffing by the firft entry of the paring fpade; when, after ftanding one year, the thatch, in fmall handfuls, twifted together at top, is thruft into holes previoufly made obliquely upwards in the divots by an iron-inod, dovetailed-pointed hand inftrument (called a fing), by which both operations are performed, in alternation. Heath is neither fewed nor ftinged; excepting the firt courfe along the heals of the walls, which is fewed to the fpars. It is then laid on, in courfes from gable to gable, every courfe being beat clofe with mallets, and the top either fecurcd (like other thatchings) by a ridging of fods; or, the angle of the roof being received into two deals lit at angles, and the feam of their juncture fecured by a hollowed batten of wood; a row of fod being wed (as in all! thatcings) to join the thatch to the flope of the rribles. 
A confiderable number of day-labourers and artificers are accommodated with houres in the villages, which they rent from year to year. In Linton, and in fome inftances elfewhere, they poffers them fometimes (lefs to their profit) in perpetual right of property, conftituted in form of fcudal tenure; or rent them yearly from proprietors of this defcription. When two farms, originally feparate refidences, are joined into one, the fuperfluous houfes (not occupied by the fubtackfman, to whom the theep farmer fubfets the houfes and arable land of that fheep farm where he does not refide) are let to labourers or artificers. Sometimes the labourer, or tradefman, tales ground in leafe of twenty-one or twenty-five years from a landed proprietor, generally by the fides of highways, for an houfe, garden, and cow's maintenance for Summer's grafs, or for both that and Winter's provender. He builds the houfe at his own expence, the proprietor furnifhing the price of wood, and the wages of the mafon and carpenter; and, after the expiry of the leafe, it reverts to the proprietor, who again lets it in leafe. Proprietors who refide, build accommodations for their tradefmen and labourers, for whom they have occafion; and when the lands in their occupation come to be let in leafe, the farmer accommodates independent tradefmen with fuch houfes, or lets them fall to ruin, if there is no demand for them. *

Upon the feparation of farms from their ftate of townithips, runrig, and comnonty, (to which they had been driven, fo: mutual defence, in times of turbulence), into diftinct poffefincns with feparate refidencies, the farmer, who obtained porfeflion of the farm upon which the cluftered dwellings had been erected, might have a fupernituity of houfes to difpofe of to cottagers; and in a ftate of fociety, where the iittle extention of arts and manufactures afforded few outlets to profitable employment,

more

* We have nothing of the paftorico-poetical munis in this county ; which would lead to the ereating of cottages for idlers, for whofe labour there is no de= mand, for the mere pleafure of exciting poetic ideas. Our fpare funds find fintivcient occupation in removing real diftrefs; we can afford none for the creation of sepreicntatioas of imaginary happinefs. 
more people might be found who would rent fuch houfes $c t^{\prime}$ cottages, though there was fmall demand for them as country labourers, from their finding nothing better to do: Such fitultions would be, however, deferted, when better employment occurred to their occupiers; and I doubt not but fuch ameliorations may have often fuggefted notions of thote ideal diftrefles fo graphically depicted, and to pathetically deplored, in Goldfmith's fanciful poem of the Deferted Village. The notion of whining over the defertion and depopulation of the country, is now abandoned to idle and ignorant fentimentalifts, who are left to lament, at pleafure, the lofs of thofe encianting fancied fcenes of rural content, and cottage innocence and felicity, which no man of ienfe believes ever to have had an exiftence but in the imagination of the poet.

Cottages have been built, and cottages have been deferted, ac-s cording to the local or general demand, or want of demand, for them. Amelioration of agriculture as to the fituation of farmhoufes, giving more of them to one place than there was demand for, occafioned their defertion in fuch fituations. The union of farms may fometimes alfo lave the fame effect; and the growing improvements of furface-culture may occafion a frefh demand for labourers, and of cottages for their accommodation. The old fyftem, however, of adfricting the cottager's labour, in hay time and harveft, to the farmer from whom he rents his cottage, is probably not very eligible for either party : If the cottar is bound, as was cuftomary, at low wages, or at no wages, this muft be compenfated to him in the lower rent of his houfe, or in privileges of fowing barley, lint, or potatoes, and carriage of fuel: It might be equally advantageous that every thing fhould be paid for on both fides at market price, which might diminifl temptations to evafion in performing the terms of the agreement.

The feparation of profeflions is indifpenfable to their perfcction *. 'The tradefman and labourer ought to have no more

land

* The converfe of this propofition feems alfo to hold irue; and the minute knowledge of detail fecms inconfiften: with enlarged views. It would be no rccommendation 
land, than grafs for his cow, and perhaps a garden of fuch fize as could be laboured at his fpare hours, which would be particularly healthful to thofe of fedentary profeffions. If he gets fo much land as requires ploughing for Winter's fodder, the lofs of time he fuftains, and the diftraction of application which enfues, (in hunting after farmers, who keep horfes, to plough for him, for favour or for hire, and in attending to the culture of his crops when growing), in general foon difqualifies him from carrying on the bufinefs of his profeffion with much fuccefs. Many tradefmen in this county are reduced to this fituation; being obliged, from neceffity, to bungle on in the beft way poffible. Where it is to be had, and where, from vicinity of refidence, it is equally convenient to all interefted, a grafs field, or a grafs inclofure requiring no herding, rented in common as a cow pafture, from a proprietor or farmer, is the beft accommodation in this way for tradefmen; and as for Winter fodder, to purchafe it in the market. Unhappily, however, the monopolizing fpirit of the landed proprietors, jealoufly reftricting the confumpt of the fodder to the farm that produces it, ftands in the way of this moft eligible mode of the cottager's accommodation. Indeed, except in the cluftered refidence of fome of the villages, this moft advantageous mode of having grafs cannot be attained to; but a fingle cow is grazed at the expence of an herd to attend her. Such as are not burdened with the additional diftraction of land to be cultivated for their cow's Winter fodder, have ftill, as yct, contrived to obtain that accommodation; either in the expenfive purchafe of fown grafs hay, (which the fpirit of reftriction has not yet doomed to be confumed upon the farm where

commendation of a ftatefman, that he was perfenly Rilled in the practice of wcaving; nor of a prefident of an Agricultural Board, that he could vie with a miller or a butcher in judging of the yield of grain or the weight of a buliock. The fubdivifion of labour wonld fem cartied to a sidiculous excefs, in the connitution of France; where haranguing is the exclufse privilege of one part of the reprefentation, and judging, of the other: Or, does a Frenchman, neceffarily, fi heat himflf, when the fieaks, as to be incapable of judging with difsretion? 
it grew); in that of ftraw fodder, from farms held by older leafes, unfubjected to reftricting claufes; or in that of growing corns fold by public roup, upon the termiration of leafes by conventional expiry, or the tenant's bankruptcy; as againft fuch difpofal, in fuch circumftances, the reftricting fpirit has not as yet univerfally lifted up its teftimony.

The perfection of improvement would feem to infer the complete feparation of every profeffion: The occupation of every inch of the lands by profeffional farmers; and the cluftering of labourers and artificers into centrical villages, fo completely detached from the occupation of land, as to buy even their milk, as well as every other kind of farm produce, from the farmer by profeflion; perhaps, even the profeffional carter, to be fo infulated within the bufinefs of his profeffion, as to purchafe from the farmer every article of his horfe's provender. Such a completion cannot, however, exift, but in a country rich in produce by nature and cultivation, and poffeffing a very numerous population : but it is the tendency of the efforts of felf-intereft in every individual to produce an approximation towards it, fo far as circumftances will admit. Meantime, it were idle to attempt, by political regulations, prematurely to enforce the adoption of fuch arrangements as will, of their own accord, enfue in the natural courfe of things. It were ftill, however, more abfurd, to counteract, by regulation, thefe natural tendencies towards amelioration, by forcing the land into fmall cottage poffeflions, where there is no demand for fuch minute divifion; either in yielding to the Cockney apprehenfion of that bugbear the monopoly of farms; or to the enthufiafm of fentimentalifts, wifhing to embody their poetic conceptions, by the gratuitous erection of cottages; which muft neceffarily transform their occupants, from independent labourers, paying in work for what they receive in wages, into abject dependent beggars *

C H A P.

* Sec Note C at end of volume. 


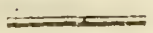

CHAP. IV.

MODE OF OCCUPATION.

Sect. I.-Size of Farms-Charader of Farmers.

Avaccount has already bcen given of the actud fize of Tweeddale farms, (pages 28-33).

That the largeft pofible difpofable produce may be raifed, at the leaft expence upon that produce, in a fhcep farm, fo as to enable it both to fend more goods, and of better quality, to market, and, of courfe, to afford moft rent to the proprietor, it ought to be of fufficient extent to admit of diftinct birfeling and kerding; in fuch a manner, that each diftinct hirfel fhould be fufficiently numerous to occupy, completely, a diftinct herdfman, without which he muft be kent, to a certain degree, idly and unprofitably. If fheep farms are either too fimall or too large for this purpofe, the public mind may fatisfy itfelf upon this head, that all fuch inequalitics of excefs or deficiency, will infallibly rectify themfelves, fo foon as agricultural ftock is fufficiently abundant, by the offer and acceptance of higher rents for fuch farms, under the moft proper conferuction, as to fize, for their most productive and moft profitable occupation,

In the courfe of the actual demand in offers of larger rent (which can alone be afforded upon the fuppofition of larger cifpofable produce raifed at lefs expence), the fleep farms in - Tweeddale have paffed through various revolutions, in regard to their fize: 
Before the extenfion of trade and manufactures affordcd fo many outlets to profitable occupation, it is probable, that, upon the death of a farmer, his children, having no other profitable occupation in view, would continue the poffeffion; either agreeing to manage it, without divifion, as a common concern; or dividing it amongft them into minute feparate poffeffions. Upon the former fcheme, their management would be fubjected to every caufe of inefficiency, originating in difcrepancy of views, or difcordance of will; upon the latter fcheme, to all the inconvenience and expence of keeping, in a conftant ftate of preparation, a refervoir (fo to fpeak) of labour, to effect what could never pay for it: to which may be added, too, the temptation, or even the neceffity, of forcing corn to grow (for maintenance of fuch fuperabundant population), in confiderable defpite to nature, and at fuch difproportionate expence of the labour of men and horfes, as, in other occupations, or more favourable fituations, might have produced a tenfold greater profit. Such unprofitable occupation, in minute divifion, or under heterogeneous difcordant management, muft neceffarily (from the offer of larger rent than it could afford) lave foon been made to give way to a more productive occupation, in undivided pofiefion, and under fingle unthwarted direction: accordingly, fuch conjunct, or minuteJy divided pofiefion, lias very generally ceafed through the county *.

In the deficiency of farming ftock, or fkill, or both ; fuperior ftock, or even fuperior fkill and enterprife, with that credit which is given to confidence, have fometines diflodged what was deficient: And, accordingly, inftances have ạlready been

* The farm in Tweeddale which had admitted of mon rife of rent, at the time it was let, is one at Inverleithan, partly arable, partly mecp paflure. It was entered to at Whitfunclay 1795 , at the ycarly rent of 3501 ; it had, in mediately before, been poffeffid by three or four tenante, in conjunet farm, lipon a leafe of nineteen years, none of whom are underftood to have enriched thẹn:felice, though thcir yearly rent was only 1251 . 
been given, of one farmer, in particular, renting, at one time, to the extent of $1700 l$. of yearly rent. But, in confequence of the more univerfal diffufion of agricultural fkill and enterprife, with the more general acquifition of farming capital, fuch monopolifts have been gradually hemmed in to an extent more fuited to their capacity of fuperintendance; in courfe of the effectual demand for farms of more manageable extent, in offers of higher rent. I fpeak under correction of the inhabitants of the county; but affert, according to my own obfervation and beft information, that, during the time elapfed fince the termination of the American war, (a period of moft rapidly progreffive improvement to Scotland), the inftances of the difunion of theep farms into feparate poffeffions, in this county, very confiderably exceed, in number, the infances of their union into fingle poffeffion.

The acquifition of fuperior $\mathrm{fill}$, in regard to productive furface culture, but particularly the greater demand for carters and carriers to perform the carriages of coal and lime, \&c. to the larger farmers, (who generally efteem it cheaper to hire their carriages from profeffionalifts, that they may attend, without diftraction, to their own profefional vocations), have raifed a demand for fmall arable poffefinons, of different, though all of fmall extent; whofe poffeflors pay their rent, and maintain their families, partly by the produce of their dairies, partly by performing the carriages of the larger farmers, or fometimes working upon the highways. The greatef number of thofe minute occupiers will be found in thofe parifhes that lye neareft to the torw of Edinburgh, and which alfo are thofe which are neareft to the coal and lime of the county; where the opportunity of difpofing of dairy produce to the higheft advantage, and the ricinity to the materials of the carriage for which there is the greateft demand, enable offercrs to come forward with an effectual denand, in offers of higher rent, for fuch minute poffeffions. MIy readers, I fuppofe, will have no hefitation in believing, that the exiltence of a couftitution of fuch minute occupancy, is not to be aferibed to any capricious principle of fentimentalifm in the Tweeddale proprietors of 
land, under whom they exift; but to the more fteady principle of their felf-intereft; to which we may apply the lines applied to the ftomach by Prior, in his Alma,

\section{- of which it is the folid froke \\ That tells our being wbat's o'clock.}

I have ventured to detail my notions of the fixed principles which uniformly operate, both in dilating farms to their proper fize, and alfo in circumfcribing them within their proper bounds, in wote $\mathrm{D}$ at the end of the Report.-I proceed to

\section{The Charafter of Farmers.}

And here I fhall juft ftate a few particulars as to the character of Tweeddale farmers, and the influence thereby produced upon the introduction of the improved Jy/em of farming; referving what $I$ would fuggeft as to the generic character of the farmer, to the note $\mathrm{D}$.

'The heep farms being the mont extenfive farms in Tweeddale, and requiring the greateft extent of capital, the ftoremafters, of courie, conflitute the noof opulent clafs, and are the moft informed. From near vicinity to markets, they generally tranfact all their own bufinefs in perfon, without interrention of a middleman; and are, by confequence, formed to labits of acutenefs, and activity in bufinefs; and have the more opportunity of acquiring fome knowledge of the world. That cuftomer would, neverthelefs, be a very fimple fool, indeed, who fhould expect to obtain a cheaper bargain, at firft hand, from a 'Tweeddale theep farmer, felling his goods himfelp, than what could be got from a middleman or forefaller; who (according to the furgeftions of anxious fear in dearths) will force the markets at his own option, becaufe he will not go without his profit. I am rather of opinion, that there is more probability the foreftaller might be obliged to relinquifh his expectations of profit, than that he fhould be able to fell the commodity to greater advantage than the 'Tweeddale farmer 
himfelf. Betwixt thefe farmers and fuch permanent cuftomers as are in ufe to buy, in wholefale, their theep and their wool, a liberal fyftem of intercourfe prevails, from a fenfe of mutual intereft; infomuch, that the goods are often bought before being feen, or fold and delivered without fixing the price.

A finilar liberality in dealing fometimes alfo takes place between the poffeftors of the fnaller arable farms and their cornmerchants. This clafs are generally, now, induftrious; fome of them confiderably enterprifing. Till of late, the habits of all the farmers led them rather to fave, than to make money; to ftudy œconomy in expence, rather than the liberal outlay of capital, in expectation of a more plentiful return. The fimall arable farmers, poffefled of lefs capital, and generally obliged, not merely to overfee, but to work upon their own farms, are neceffarily more confined than the theep farmers, in their range of obfervation, and their means of information; which feems the chief caufe of the latenefs of introduction, into Tweeddale, of improvements in the cultivation of the foil ; fuch improvements being of lefs intereft to the extenfive hill theep farmers, who otherwife, from their more enlarged opportunities of information, might have been expected to have fooner adopted them.

Both claffes, very properly, difcover a confiderable degree of tardinefs in adopting modes of improvenent introduced by gentlemen farmers, in farming their own properties. They are difpofed to confider fuch improvers as admirers of the clirious, as much as of the uffful, in farming; and are difpofed to lend but doubtful faith to the accounts of the profit of fuch fchemes; looking upon them as the mere exaggerated fatements of fervants, wifhing to curry favour with their mafters, in flattering them with the idca of the utility of their experiments, rather than as the refult of that accurate obfervation and rigorous calculation which are, in a great meafure, incompatible with the numerous avocations incident to the fiation of fuch improvers. Unlike to the political reformers of the inte feafons of dangerous fpeculation, when innoration, mercly as fuch, was confidered as improvennent; they are reluctant in relinquifhing 
relinquifhing the fure and trodden path of long experience for mere unafcertained theory, whatever brilliant profpects it may hold out. Though llow to change, they are not, however, fo bigotedly wedded to old practices, as to reject fuch improvements as have ftood the teft of repeated and unequivocal experience: And the new improved fyftem of hubandry has, accordingly, at laft, found its way into general practice.

This improved fyftem, which may, be fhortly characterifed as comprehending the ameliorating rotation by green crop fallow, and artificial graftes, had been practifed, upon a fmall fcale, by gentlemen proprietors farming for amufement, and perhaps by one or two farmers, confidered by the generality rather in the light of gentlemen farmers, near forty years ago; and many unfuccefsful attempts were fucceffively made to introduce it into general practice among profeffional farmers. In fome inftances, it was attempted, by allowing the farmer a deduction of rent for each acre kept by him under green fallow crop; a mode, in particular, adopted by Mr Kennedy of Romanno: But a practice, to which, apparently, the farmer needed to be bribed, had not the appearance, with the public, of a practice which was for his advantage; and the examples, in this way produced, met with few imitators. Others endeavoured to entice farmers from improving counties to fettle upon their eftates; very properly judging, that the example of fuch profeftional farmers would weigh nore with their fellows than that of any gentleman farmer who had no rent to pay. But, as it is extremely difficult to prevail with fuch as are fuccefsful it hone to defert their connexions for a land of ftrangers, the perfons, thus introduced, proved, in general, mere defperate adventurers; who, having nothing to lofe, fported fanciful and injudicious fchemes, at the rifk of the proprietor; till they were difmifed, after exhaufting the pockets and patience of their employers, by a continued feries of unproductive expence.

Neverthelefs, the new hubandry was at laft introduced by means of profefional example: And I have no hefitation in afcribing its prefent prevalence to the example fet by $\mathrm{Mr}$ James 
M'Dougal, farmer in the village of Linton, originally from the neighbourhood of Kelfo, and trained under the celebrated $\mathrm{Mr}$ Dawion at Frogden. Being poffeffed of only a fnall capital, but his ideas of improving farming, inferring a much more liberal outlay of capital upon equal extent of land, than what correfponded with received ufages, he entered, upon leafe, to a farm (very fmall in proportion to what would have been confidered as fuited to the extent of his capital) at Linton, in the year 1778; which farm he ftill occupies, with confiderable additions: the land, fuited to conftant rotation of cropping, being a pure brown fand foil; the hill pafture land being very thin, moorifh, or hazel foil. The arable land, intended for conftant rotation of cropping, he immediately began to prepare for the Norfolk turnip-foil rotation of four, viz. $1 / f$, Green fallow crop of turnip or potato, to which is applied the whole dung collected upon the farm; lime being alfo ufed, at firft going over, to the extent of twelve or fourteen fingle-horfe cart loads of lime thells per acre, and applied previous to fowing the turnip, and after raifing the potatoes: $2 d$, Big or oats; grafs feeds being fown with the crop, at the rate of 10 lb. of Dutch red clover, 2 of white clover, and about a buthel of rye grafs per acre: $3 d$, A crop of hay; the after growth either cut for green houfe-feeding, or paftured: $4^{t} \mathrm{~h}$, Red oats; when the rotation begins again with green crop fallow. At the fame time, he conmenced a fpecies of improvement, till then almoft cqually foreign to the practice and the notions of either landed proprictor or farmer, in fallowing, liming, and, where attainable, dunging alfo his outfield hill pafture; for the purpofe of fowing it off with grafs feeds, for theep pafture, with the very frift crop. For a while, his neirlibours could hardly be ferioufly perfuaded that he farmed at his own rik; conceiving of him rather as a mere agent for tive proprietor: Rut, being convinced of their mifali, and witneffing his fuccess, they, at length, began to think of becoming profelytes to his fytem. The example firt firred smongeft the fnall arabie dairy farmers; from the obvious adrantage feen to refult to the dairy, in configuence of the nore alym ! 
ant green houfe-feeding thus procured for the cows, by cut grafs for Summer and Autumn, and by turnip through Winter, befides fown grafs hay for the Spring months : and a practice, radically founded upon the fame principles, may be now confidered as univerfal.

In the extenfive uninclofed hill theep-farms, the dairy is neceffarily a matter of trifing import, from the next to impofibility of appropriating a diftinct walk to cows: The new fy [tem was, therefore, looked upon with indifference by the ftoremafters, till about the year 1786 or 1,87 . When M'Dougal applied his turnip to the purpofe of feeding fheep of the native breed of Tweeddale, which, for a while, it was fuppofed, would not take at all, to the eating of turnip; they were cheaply inclofed upon the field by nets, their horns (with which this fpecies are liberally provided) being fawed off, to prevent their entangling in the inclofing nets, an operation feeningly attended with no rifk or detriment to the animal *. The theep farmers now faw clearly the advantage to be derived from a practice, which (by enabling them to prolong the feed of their caft-off breeding ftock through part of the Winter, inftead of hurrying them to glutted markets, as formerly obliged to do upon the failure of the grafs), put it thus in their power to obtain a better price; and that, not only by procuring a longer range of marketing feafon, but alfo from the additional improvement made upon the carcafe of the animal. The advantage was equally obvious, of thus fecuring a certain quantity of regular fupply of hay for their holding ftock in Winter ftorms. As might be readily expected, the example, when it once took effect, was, by much, more rapidly diffufed amongft this clafs: Infomuch that, I have the beft reafon to believe, there is not now a fingle fheep farmer in Tweeddale, who has land fit for the purpofe, or length of leafe fufficient to make it

worth

* They are cut off, within an inch of the 1kull, by a hand faw : Cautery, formerly ufed, is now omitted, the lofs of blood being no greater than what is deemed falutary : It is judged moft fafe to perform the operation when the weather is frefh and cool. Where wooden flakes are ufed inftead of nets, there is $\mathrm{mo}$ need of cutting the horns. 
worth while to alter his practice, that has not already reduced, or is not reducing, his croft land, at the leaft, under a fyftem of management correfponding to the principles of the aforementioned rotation of four *. Farther than the corn lands adjoining to the farm houfes, and eafily herded, becaufe always in fight, this fyftem cannot be carried with any degree of convenience; nor even thus far, without confiderable inconvenience, whilf the lands remain uninclofed.

In the diffufed population of the county, each individual is diftinctly recognized, and the check of mutual obfervation has a ftrong influence in producing regularity of morals, an influence unhappily awanting in great towns, where the cluftered population renders the individual indittinguifhable; making them the refort of the profligate for concealment, and the feminaries of every fort of corruption. The prevailing characteriftics of the lower orders in this county are, fobriety, induftry, and a fenfe of religion; with the exception of a few infances of perverfion of principle, occafioned by the introduction of the French philofophy, and thofe, too, chiefly confined to the county town. A good many, who have not married early, or who have got thrifty wives, and families not very numerous, have a little money faved. Shepherds, kept by their vocation at a diftance from temptations to focial expence, are generally wealthy for their itation; and the competition of their capitals, fometimes procures the divifion of large farms. Bating ficknes, accidents, families more than ordinarily numerous, and fuch other circumftances as may produce ftraits, without fault or mifmanagement, there fubfifts, in the generality of the lower claffes, a fpirit of independence, which revolts againft the idea of fubfifting upon charity: Happily, indeed, poor's rates are not fo decidedly eftablifhed by law or practice, but that fubliftence, not gained by perfonal induftry,

- In one of the higher meep farms of lweddale, where the plough had never been ufec', the farmer, within thefe few years, has brought into tillage ten ur twelve acres of land; induced to adopt the practice, for the purpofe of procuring turnip for carrying on his caft-cff breeders, and likewife fome hay for his beep in fnow ftorms. 
induftry, is ftill confidered as charity, and not as a right. Moft of them contrive, by their own induftry and frugality alone, not merely to feed and clothe their children in a decent manner, but alfo to give them education, fo far as learning to read: Very frequently, they are alfo taught writing, and a little of arithmetic ; though more commonly the young people themfelves obtain thefe laft mentioned branches of education from their firft earnings of wages, by attending night fchools in Winter, after their working hours. A profligate head of a family, who diffipates, in idle extravagance, the means intrufted him by Providence for the maintenance and education of his family, is a character rarely to be met with. Not only do parents endeavour to fupport their children in an independent manner, but cliildren, alfo, are feldom deficient in endeavouring to aflift their aged parents, according to their refpective abilities; and there are not awanting inftances of day-labourers fupporting aged parents paft their labour, without being indebted to any charity whatfoever.

We are apt to form unjuft eftimates of the characters of people in fituations different from our own, by referring to a wrong flandard. The fame induftry to obtain gain, with the fame penurious attention to the oconomizing of its expenditure, which would difgrace a perfon in an affuent fituation, are indifpenfably neceflary to the maintenance of refpectability of character in the poor; the want of them directly leading to abject dependence and beggary, to difhonefty and ruin. The rich are, however, fometimes apt to defpife, in the poor, as mean, thofe habits which would indicate meannefs only in a fituation of affuence; overlooking thofe manly efforts of fortitude and felf-command, which are exerted under ftraitened circumftances, in maintaining the noble fenfe of independence, and the confcioufnefs of inflexible probity - efforts to which, from the delicacy of their own elucation, they might find themfclves to be altogether unequal, but which, no doubt, are more cafily fupported tlirough force of habit. The poor, meanwhile, are equally incapable of granting fuperior latitude to the rich, in point of expence: Without inforring from it the fame pro- 
figacy, which, in their own fituation, would be the infallible refult, and not duly confidering that this greater liberality of expenditure is the caufe of independent fupport to many of the induftrious; they are fometimes apt to comfort themfelves, under a fenfe of inequalities of condition, by adopting the idea of a future retribution, upon the model of the parable of the rich man and Lazarus, generalized without limitation or reftriction.

\section{Mode of Managing Farms, with their Produce.}

Though none of the fections, in the fchedule of the form prefcribed for the Reports by the Board, would indicate a direct and continued difcuffion of this fubject, I have thought proper to introduce it, as a feparate fection, under this chapter of the Mode of Occupation; that it may be feen, under one view, to what purpoles the farms in this county are applied, and what kind of produce they yield, from which the farmer is enabled to pay his rent, and to obtain his own profit.

For the fake of diftinctnefs, this fection may be divided into two parts, I. The management of Seep pafture farms; II. The management of arable furms.

\section{Managennent of Shcep Farms.}

In fome of the large fheep farms, where the farmer does not refide, as alfo in others where he does refide, plough culture is unknown, or ufed only to a very fmall extent: The meal, for family maintenance, being bought in ; the cows and horfes, for family ufe, bcing fupported chiefly, or entirely, through Winter, upon fuch coarfe natural hay as is found upon the farm without culture, confiting chiefly of fprits; and the theep, in Winter ftorms, being either driven to other parts of the country, where there is more accefs to the pafture from lefs depth of fnow, or where fodder can be obtained; or elfe fodder being bought in to them from other places, when there is carriage accefs to the furm. 
The generality of theep farms have, however, more or lefs arable land attached to them. In a few inftances, the arable land may form the principal dependance, the fheep being rather an acceffory; or they may be nearly balanced in point of importance.

It would lead to endlefs and fuperfluous minuteners, to ftate the various proportions which the theep and the arable lands bear to one other, as to their importance in point of profit, in the various theep farms of the county. It will fuffice, to convey a general view of the fubject, fir $f$, to ftate the general management of theep in theep farms; fecondly, to fate the managemcnt of the arable lands attached to theep farms.

Fivf, Management of theep in theep farms.

Tweeddale being, in general, more adapted to breeding than to feeding, the great article of fale from the theep farms is young fheep for holding ftock; though, fince the practice has become generally prevalent within thefe thirty or forty years, of kceping fewer fheep upon the fame extent of land, probably more are fattened for the butcher, than under the antiquated practice of overfocking the pafture.

The great article of fale, formerly, from the breeding farms, was the ewe and wedder lambs, kept on through Winter, and fold in the end of the enfuing June, or beginning of July, at fourtcen or fifteen months oid, and called at that time ewe or wedder hogs. Of late, feveral fuch farms, inftead of keeping the lambs through Winter, difpofe of the lambs in June or July, at three or four months old, in the fame feafon in which they are lambed. The fale of hogs is at Linton markets, whence they are bought for the Highlands of Scotland, for the Oichil Hills in Fifenire, or for Lammermuir in Eaft-Lothian, where they are kept on to a proper age, and either fold fat, or fold for farther fattening, to the Lothian grafs parks, or to Fingland. When fold as holding lambs, they are generally bought in to the Upper Ward of Ianarkfhire, whence they are fold, next feafon, as bogs, at Linton markets, as above. A fuw, buth of holding lambs and of hogs, are difpofed of at the markets 
markets of Stag's Hall in England, and of St Bofwell's in Roxburghfhire.

There are breeding farms in Tweeddale, where (as in the farms of the Upper Ward of Lanarkfhire, juft mentioned) no breeding ftock of ewes are kept, and no lambs produced; but which buy in, annually, lambs in the end of June or month of July, which are fold as hogs, after being kept a twelvemonth.

In fome few very high lying ftormy lands, hogs are bought in annually, and fold, after being kept twelve months, as dummonds. In one or two inftances of farms of this defcription, the hogs bought in, are kept for two years; and, being then three years old, are fold off for farther feeding, under the name of old zuedders. The greater part, however, of old wedders, to be found for fale in Tweeddale, are merely thofe which are bept on, becaufe they were not in condition for the market, as hogs or dummonds.

There are a few breeding farms, where all the lambs are fold fat for the butcher; none being retained, but what fuffices to keep up the breeding ftock of ewes and rams.

There are a very few farms of fine grafs, which keep no Atock, or very little ftock, upon them, through Winter; ewes, heavy with lamb, (confifting of the caft-off part of the breeding ftock of breeding farms in this or other counties), being annually bought in, from the month of March forwards, at Houfe of Muir markets, but oftener at Peebles fair ; and the whole, both lamb and dam, fold off fat from the grafs, to the butcher; the dam being ftill farther fattened, upon turnip, afthe failure of the grafs, if the farm hath arable land attached to it fit for raifing this crop. Inclofed grafs parks are frequently depaftured by fleep after this fafhion of farming.

Befides thefe annual fales, the farnis which keep a breeding ftock of ewes, fell off; annually, a portion of their old breeding ewes, before they begin to fail with age; viz. a fourth, fifth, or fixth part, at the ages of four, five, or fix years, according to the length of time to which they preferre their vigour, which varies in diferent fams; a proportional quantity 
of ewe lambs being preferved annually to fupply them. Thefe caft-off breeders, or crocks, are fold fat from the grafs at Martinmas, or ftill farther fattened upon turnip, or for the purpofe of being fattened by turnip feeders : But farms of this defcription, which have attached to them a confiderable quantity of low arable, or meadow ground, for Winter pafture, generally give the crocks the ram, keep them on through Winter, and fell them, heavy with lamb, in the month of March, at Peebles fair, or Houfe of Muir markets : the caft-off rams, in the proportion of one to forty crocks or fo, are fold in September or October, before their flefh grows rank from rutting. It may be alfo noticed, that farms felling bogs or dumnonds, have alfo a few dummonds, or old wedders, to difpofe of ; being the rejectaneous ones kept on for another feafon.

Such are the fales of theep from theep farms.

Wool is alfo an article of fale from all the fheep farms, excepting thofe which annually buy in lambs and fell them rough, after a twelvemonth's keep as bogs. A fmall quantity is fold to Stirling, a greater to Hawick, and the greateft part to Yorkhire, for ferges, for fhalloons, for carpets, and coarfer cloths.

Sheeps milk cheefe is fold from a few of the farms; the practice of milking the ewes has, however, of late, been more difufed; the detriment accruing to the ewes being confidered as overbalancing the profit from the cheefe: The enormous price fetched of late by the cheefe, feems to be recalling the practice.

In feveral fheep farms, young black cattle, or young horfes, confitute alfo an article of fale, more conftant, or more incidental; but in none to any great extent: The fame may be faid of the produce of the dairy, and of corn.

The following Tables will convey an idea of the modes of management, and of the proportions of the fales. The proportions in the Tables are taken from known farms, though the numbers are arbitrarily chofen. 


\section{EXPLANATION OF THE TABLES.}

Ist, The ftock of breeding ewes are marked at the top of the Table. In thefe, are included the ewes going in their fecond year, or giminers, the ram being admitted to them at Nartinmas, when they are eightecn months old, excepting in two or three of the mot high-lying ftormy farms dealing in this fort of ftock. The rams are not included in the breeding ftock at the head of the Tables. In high-lying breeding farms, the proportion of rams to ewes is about one to forty; in lower lands, one to fifty. The numbers accounted for in the Tables, are merely thoie belonging to the farmer. The fhepherds have the privilege, generally, of grazing a certain quantity of theep along with the farmers, in lieu of wages; receiving alfo fix and a half bolls of oatmeal, and the grazing of a cow, with coarfe fprit hay for her Winter fodder, in lieu of victuals. Upon a fattening farm, the herd may have the privilege of keeping twenty-eight or thirty breeding ewes, with fix or feven lambs to keep up his breeding ftock; and, upon a breeding farm, perhaps fifty theep, young and old.

$2 d$, The numbers at the foot of each column, how the quantity of the fpecies in that column which are annually fold. As the practice in Tweeddale is to number fheep in fiores and odd, this mode of numbering is foliowed in the Tables. Thus,

score. od.t.

1015 , is 215 .

$3 d$, Upon inquiry, I find, that in lambs, the proportion of males fometimes exceeds that of females; and that, at other times, the fenales are moft numerous; but that, upon the whole, they are nearly equal. They are therefore ftated as fuch.

$4 t h$, The holding of a farm, is the number falved or frneared at Martinmas. The old breeders that are to lamb the enfuing Spring, arc marked at the head of the Tables, as the holding ftock; but to thefe may be added the number of the ewe- 
lambs, accounted for in their column as fet apart for breeders, making allowance for death.

5th, In regard to the numbers fold, (as marked, foot of each column), it may be remarked, that there are always a certain proportion rejected by the large wholetale purchafer, which are either fold at inferior price, or kept on another feafon, as before explained. 


\section{TABLE I.-BREEDING FARM.}

Holding 4 I fcores 5 odd of Breeding Ewes, and felling out Wedder Hogs.

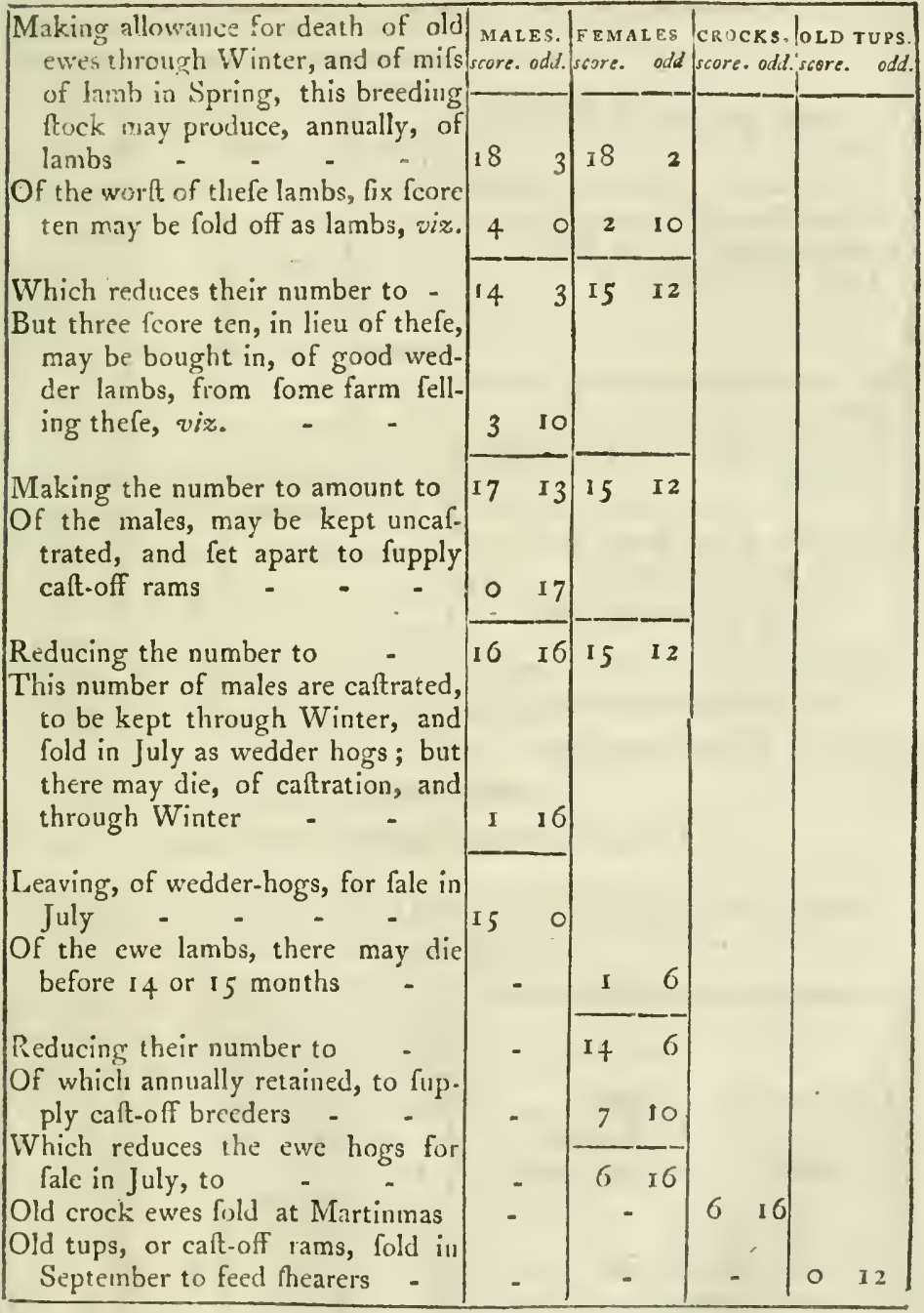

The numbers annually fhorn may be fifty fcores: Six fleeces meraging a flone of 23 lib. Englith, the wool not wafhed. 


\section{TABLE II.-BREEDING FARM.}

Breeding Stock, 40 fcores of Ewes, and felling Wedder Lambs.

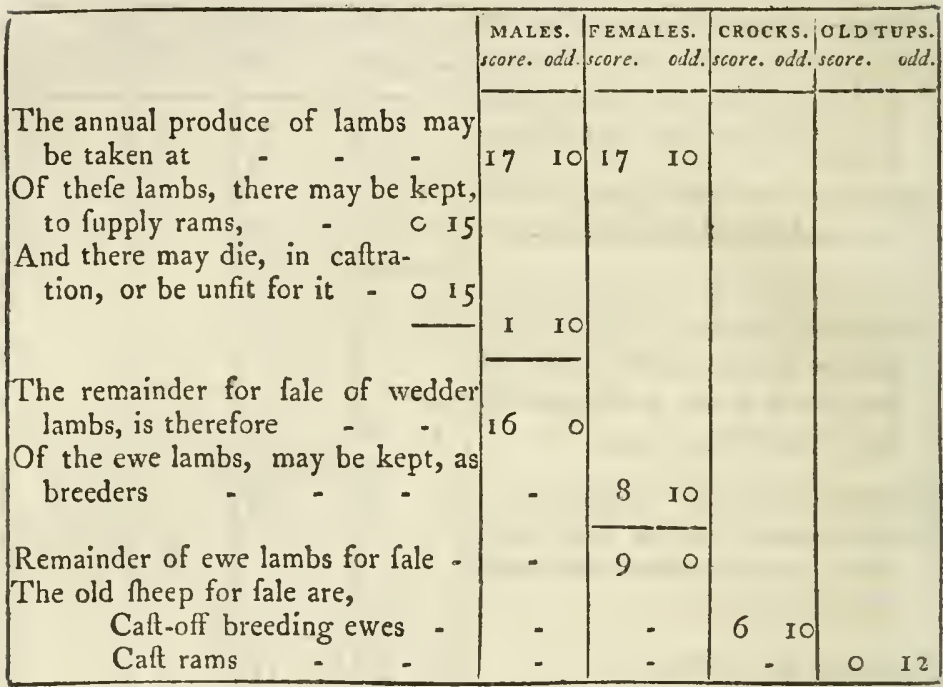

Number fhorn annually, forty-eight fcores; fix fleeces, unwafhed, averaging a ftone.

\section{TABLE III.-BREEDING FARM.}

Breeding Stock, 50 fcores of Ewes; the Lambs and Crocks all fold Fat.

\begin{tabular}{|c|c|c|c|c|}
\hline . & $\mid \begin{array}{l}\text { MALES. } \\
\text { score. odd }\end{array}$ & $\begin{array}{l}\text { FEMALE } \\
\text { score. OC }\end{array}$ & $\begin{array}{l}\text { crocks. } \\
\text { score. add }\end{array}$ & $\begin{array}{l}\text { OLD TUPS. } \\
\text { score. odd. }\end{array}$ \\
\hline $\begin{array}{l}\text { Annual produce of lambs } \\
\text { Ewe lambs kept for breeders } \\
\text { Tup lambs kept to fupply rams - }\end{array}$ & $\left|\begin{array}{cc}22 & 10 \\
I & -\end{array}\right|$ & $\begin{array}{l}22 \\
11\end{array}$ & & \\
\hline $\begin{array}{l}\text { Remainder fold fat } \\
\text { Old crock ewes fold fat } \\
\text { Old caft.off rams }\end{array}$ & $\left|\begin{array}{ll}21 & 10 \\
& -\end{array}\right|$ & $I^{1}$ & 9. & 15 \\
\hline
\end{tabular}

Number annually fhorn, fixty-two fcores ten; five and an balf fleeces to the ftone, unwalhed. 
In regard to thofe farms where lambs are bought in annually, to be fold out next feafon as hogs; or, where hogs are bought in, to be fold next feafon, or next again, as dummonds or old wedders; or, where ewes heavy with lamb are bought in, both lamb and $d a m$ to be fold out fat the fame feafon; their œconomy is fo very fimple, as to need no illuftration. It may be juft obferred, that the rifk of dying is greateft in lambs kept over Winter, to be difpofed of as hogs, one in twenty being the common average of deaths.

In felling theep, the Tweeddale practice is, to give one to the fcore, without payment; fo that, when theep are fold, for inftance, at 10l. per fcore, they are not paid for at the rate of Ios. a head, but at the rate only of 9 s. $6 \frac{1}{4} \mathrm{~d}$. In dull markets, an additional theep is fometimes given, without payment, to the hundred; and fometimes one alfo to the parcel, \&x. 'This practice, introduced from facility in the feller, that the advantage may go with the buyer, is ftill perfevered in ; perhaps, from the vanity of the ftoremafter, that he may boaft of a good price; or perhaps, that the nominal may be taken for the real price, in a way of deception, which, however, deceives nobody. The cuftom only introduces confufion and perplexity into the account, and had much better be laid afide.

Before proceeding to ftate the management of the arable part of theep farms, I thall explain the Tweeddale defignations of theep, according to thcir fex and ages.

\begin{tabular}{|c|c|c|c|}
\hline \multirow{7}{*}{$\begin{array}{l}\text { 1. From the time they are lambed, in } \\
\text { April, till the enfuing Martinmas that } \\
\text { they are fmeared or falred, they arr } \\
\text { defigned - } \\
\text { 2. From their being falred at Martinmas, } \\
\text { till next July that they are thorn - } \\
\text { 3. From this thearing till next July, when } \\
\text { they are fhorn for the fecond time - } \\
\text { 4. From that tirce till next July, when } \\
\text { they are horn for the third time - } \\
\text { 5. From that time ever after }\end{array}$} & \multicolumn{3}{|c|}{ DESIGNATIONS OF } \\
\hline & MALES. & FEMALES. & CAST \\
\hline & Tup Lambs & & \\
\hline & & Ewe Hogs. & Wodder Logs. \\
\hline & Tups. & Gimmers. & nds. \\
\hline & $\begin{array}{l}\text { Tups } \\
\text { Tups }\end{array}$ & & \\
\hline & & & \\
\hline
\end{tabular}

N. B. The caft-off breeding cwes, when fold at Martimmas, are defigned fack eques, or crocks; when fold heavy with l.mil in March, they are defigned great croes. 
Second, Management of arable land attached to fheep farms.

In ftating this management, it nay be proper to diftinguifh the arable land into old croft, and outfill. (See Note, foot of p. I5.)

Croft.-Around all the dwellinghoufes of theep farms, which have been long occupied as refidences, there is generally found from ten to thirty acres or upwards of old croft; i. e. land which, for ages, has been kept in conftant culture; receiving, in rotation, all the dung collected from the cattle houfe-fed in Winter, \&c. The rotation obferved on this croft, was, univerfally, and, in a very few inftances, continues ftill to be, r. Big, with the dung; 2. Oats; 3 . Pcas: no green fallow crop, nor artificial grafies for hay; the only hay from this croft being procured, by allowing a ridge or two of the third under oats to remain untilled; when the roots of the couclgrafs, \&c. never killed by fallow, produced a fpontaneous crop. As the land was ever full of grafs roots, the theep derived confiderable benefit from picking up thefe roots from the ploughed land, in barren early Spring months. This indeed was the only fenfible objection brought by the adherents to the old fyftem, againft the introduction of the new.

When potatoes came to be planted in confiderable quantities, which was our firft improvement upon the old fyftem, a part of that third intended for peas (our ameliorating crop under the old fyftem) was affigned to the potato; and when the potato was cultivated to fuch extent as to occupy one half of the peas third, it is evident, that, by intershanging the places of the peas and the potatoes at the fecond vice of the rotation, the whole croft, in courfe of two rotations, or in the fpace of $f i x$ years, would be clcaned; at leaft in fuch imperfect manner, as can be effected by potato fallow; where, from necefity of more early planting, the land cannot admit of fuch previous cleaning as with a turnip crop.

Since the introduction of the turnip and fown-grafs hufbandry, this old croft is, we may now fily univerfally, kept under rotation, upon the principles of the Norfolk rotation of four, viz. I. Green crop fallow of turnip, and part of potato, with 
all the dung; 2. Barley or Big, and fometimes Red Oats, with grafs feeds; 3 . Hay; 4. Oats, or fonetines Big, when the demand is great, anfwering tolerably well with one furrow upon light land. Where there is fuficiency of arable land for the purpole, it is evident, that, by thus applying dung only once in four years, the farmer may add to his crofts an additional brèak, equal to one third of what he could formerly conmand by his dung; particularly when we adivert to his additional power of enriching his land, by eating the tumip crop upon the ground with his fheep, inftead of being obliged to difpofe of them in glutted markets, upon the failure of his pafture; this ability of the farmer to take a longer range of marketing, tending allo to keep the market price of meat more fteady and equable to the confumer.

If the land is of that fuperior quality, as to admit of a rotation of five or of fix after one dinging, it is evident, where there is land lying fit for the purpore, that a quantity of additional land may be taken into the rotation; extending, in the firft cafe, to two thirds more; in the fecond, to double of what could be commanded by his dung, under the old fyftem of the rotation of three. The five-courfe rotation is very commonly adopted, where there is fufficiency of land, and the foil of confiderable richnefs; viz. I. Green fallow crop, with the dung; 2. Big, with grafs feeds; 3. Hay; 4. Oats; 5. Peas. The fand foils are, however, commonly kept in rotation of four only; being accounted too poor to bear a more extended rotation, and being alfo found unpropitious to peas, the only other ameliorating crop in ufe, in the altemation of white and green crops. A rotation of fix is fonctimes, but very rarely, attempted; though I am inforned it hath been found to anfwer by Sir James Montgomery of Stanhope, upon fome of his very fuperior land in the old crofts of Stobo: This fix-courfe rotation may be, I. Green fallow crep, dinged; 2. Big, or Barley, with grafs feeds; 3. Hay; 4. Onts; 5. Peas; 6. Oats : Or, r. Green fallow crop, with dung; 2. Oats; 3. Peas; 4. Big, with grafs feeds; 5. Hay; 6. Oats; or fome fuch mode of alternation, as fhall include grcen crop fallow, 
and artificial graffes, with the conftant interchange of white and green crops. It is probable, no land in Tweeddale can, with advantage, be fubmitted to fuch fevere courfe of cropping; unlefs the hicep farmer were to confine his green crop fallow entirely to turnip, and (facrificing the theep in a great meafure to the foil) to confine the fheep eating the turnip, in all weathers, upon the turnip field. But the greater part of the fheep farms have not fufficient extent of proper arable land fo: rotation fields, to render their poffeffors very folicitous about dung; of which article they have often a fuperabundant quantity for their rotation fields, in confequence of the nuinber of young black cattie they rear and keep through Winter, upon the coarfe fpontancous hay of the farm. In their turnip feeding of fheep, they therefore look more to the improvement of the fheep, than the benefit of the turnip field: the fheep are accordingly, in many inftances, never confined, but have liberty to range at large over the whole turnip field, and to retire, when full, to dry beds, where they chufe, or to the fog, when they wifh for varicty of food. I think there can be little doubt, that the sheep muft, in this way, thrive much better than in any other; yet it mut be confefied, that it is a moft unceconomical mode of expending the turnip crop: the fheep foon wound every turnip of the field, by their bite, after which, the turnip can ftand no ftrefs of weather. If the fheep are not to be confined upon fucceffive portions of the field, it would be expedient to inclofe the field from the theep, and, by having one fide of the inclofure moveable, to admit them to the turnip by little at a time. Unlefs upon the very light dry fand foils, the fneep are materially retarded in their thriving, by being confined upon the turnip field when the weather is wat.

The firt improvement introduced, according to prefient remembrance, into Tweeddale nheep farming, was, the diminution. of numbers; by which, the numbers kept were rendercd fupeyjor in quality, from nore abundant feeding, and the rifk greatly diminifled, of death, and of difeafes originating in poverty. The laft great improvement was, the turnip and fown grafs hifbandry, through which, fheep and arable farming have been rendcres. 
rendered mutually fubfervient to each other; the acceffion of dung, from the fheep feeding upon the turnip, enabling the ftoremafter to enlarge, or keep in higher order, his crofts, or rotation fields; his turnip and his hay enabling him to difpofé of his crocks in better order, and with greater extent of market, and alfo fecuring for his holding ftock a certain degree of provifion; when their pafturc is blocked up by fnow ftorms. Such, however, is the excefs, in Tweeddale, of the quantity of mountainous theep pafture land, above that of the arable land, that it is queftionable, whether the whole arable land woult fuffice, under any proper rotation of culture, to afford an extent of turnip crop equal to the feeding of the old theep annually fold, or a full fufficiency of hay, annually, to fupply the holding ftock in a Winter ftorm; even fuppofing the whole arable lands to be attached entirely to fheep farms; or that the fheep and arable farmers fhould, in their interchange of traffic, bring their interefts to the operation of a copartnery.

Outfield.-In moft of the fhcep farms, befides the old croft, tracts of arable land are found, of greater or lefier extent, and lying fo flat, or upon fuch gentle declivity, as to be eafily acceffible to the plough. Where thefe lands are fo fitunted, as to give little interruption, while under crop, to the theep walks, they are occafionally brought into tillage, after folding of theep or black cattle, or after lime.

Ewes, where nilked, are folded, nightly, for convenience of milking, for fix or feven (formerly eight or ten) weeks after the middle or latter end of July that the lambs are weaned. A fmall flock, upon a narrow range of pafture, may be folded, nightly, through the whole of Sunmer, without inconvenience; as they have no diftunce to travel from the fold to their pallure, in going and retuming. Where a part of the ewes and lambs of an extenlive fheep farm, are fittened upon enclofed and iniproved pafture, on the tiune farm, it is confidered as cren adrantageous to take them off their paftere every night, to a cons tiruous fold; as this prevents that diligut wheh they fect to the purts of their patture upon which they have lain. 'The black eatle, which are not houfed thron hamer. (which, i: 
fome farms, comprehends the whole, in others, only thofe not giving milk), are folded, nightly, to prevent their damaging the growing corns, from Whitfunday, till the end of September or October, that the corns are got of the ground.

The folds are confructed upon a part of the outfield grafs ground, intended to be broken up for tillage. The enclofure is made of fod-dikes, at the expence of about 3 d. the running rood of 6 Scots ells; whins are inferted below the coping fod, to make the fence more formidable. Left, in a large range of fold, the folded cattle thould frequent a particular part of it, enriching it with their dung, while the remainder of the fold re. ceived little or no dung; it is judged preferable, to have trio or three folds for the black cattle, and two or three for the fheep, according to the time they are folded, to be occupied in fucceffion; rather than to enclofe the whole fpace intended to be ploughed, in a fingle fold at once; by, which means, the land would not be fo equally teathed (dunged). After harvent, the fod dikes of the fold are levelled, and the land ploughed; or, where lime is alfo added, the lime is laid upon the furface before ploughing "; when a fucceffion of three or four crops of oats are taken, according to the richnefs or poverty of the foil ; after which, it is left to cover itfelf with grafs fward, as nature thall direct; ftable loft grafs feeds being fometimes fown with the laft crop, to bring it fooner to grafs. After the whole of the outfield has been gone over in this manner, what was, firft refigned to grafs, is again reforted to; being ready to undergo a fecond courfe of the fame treatment. According to the number of crops taken, after this mode of dunging, the farmer has thus, yearly, under crop, triple, quadruple, or even quintuple, of that quantity of his outfield, which he can fold in a feafon.

If the farmier finds that he hath more outfield in his farm, than he can thus teath, by folding, during the currency of his leafe, and judges that it would yicld him more profit under crop, than in pafture, he has then recourfe to lime; liming,

upon

- As an improvement, the lime is laid upon the furface, fometimes, in the beginning of Winter, previous to the Spring, when the land is folded, 
upon the fward, as much as he can overtake in a feafon; and, with no other manure than the lime, taking, perhips, four or five crops of oats, then one of pcafe, which, in fome meafure, fecures a fixth one of oats; when it is configned to nature, to gather fwrard for pafture. Very weighty crops, to the above extent of number, have been reaped, in this way, from outfield of tolerable foil, wubich bad never before been either ploughed or limed: Upon attempting, however, to make it undergo the fame treatment, by a fecond liming, even after it had lain in grais for fourteen or fifteen years, the experiment has been found unfuccefsful; and teathing by folding, not liming, was judged the manure to be thenceforward depended upon for crops.

Barbarous as this method of treating the outfield may appear, it is not eafy to fuggeft a better mode, fo long as the fe outfields Ball remain unenclofed. To improve thefe comparatively fimall portions of arable land to be found in extenfive fieep farms, and to lay them out under rich pafture, would produce no perceptible advantage to a large fheep flock, to whom it would only yield a few mouthfuls a piece, and whom, by the enticement of its fuperior fweetnefs, it would only diftract from the coarfer pafture on which they muft depend. It would be idle, to forego the fubftantial advantage of crops, for an inconfiderable quantity of fuperior pafture, which would be detrimental, rather than advantageous; unlefs, by being enclofed, it could be diftinctly appropriated to fuch a number of animals as it would fuffice to feed fully, whether theep for the butcher, or çows for the butcher or for the dairy.

Outfield land, exhaufted by fuch treatment, efpecially after liming, is, no doubt, of lefs valuc than in its original ftate; i. e. in refpect of the profit that can be derired from it, by fubjecting it to fuch exhauftion: Otherwife, it may univerfally be confidered as improved; inafinuch as the lime brings a fpontaneous white clover into the fward, much preferable to the rufhes, lieath, or other courfe grafies which are native to the foil previous to its receiving lime. At all events, why fhould anxiety be manifefted, as to lant alone, againft reaping advantages which cannot be obtained a fecoul time to the like ex- 
tent? Why preferve a value, always in mere poffibility, without ever realizing it? A coal mine never to be worked, is, furely, cqually ufelefs as an exbaufed coal mine. The value, thus abftracted from the outfields, is not all loft to the identical farm to whici they belong; being transferred, in fhape of dung, from the outíclds to the crofts, through the acceffion to the dunghill, from the great adidition of fodder from the outfields, confumed by cattle in the farm ofices: The profit, meanwhile, from the crops, augments the capital of the farmer; in whofe hands, from the aconomy adhibited in its application, it is capable, under proper encouragement, of being more effective of agricultural improvement, than in any other hands; it may be fo employed upon that very farm; or if, from fimilar caufes, it is everywhere fimilarly augmentch, its operation will come round, although the identical farmer fhould not lay it out upon that identical farm whence he derived it.

Were all the arable lands of fheep farms completely enclofed, fo that the famer might have the opportunity of appropriating his improved pafture, exclufively, to that precife number of cattle which it would fufice to feed to the full, there can be no cloubt, but that it would then be more profitable to lay down the outficks in rich pafture, after moderate cropping, than to exhauft them. It might then be eligible, to throw off the whole of the prefent crofts in pufure, which, in that ftate, might pay cqually weli as under crop; and to convert an equivalent part of the prefent outfield into croft or rotation fields; which, by receiving all the dung collected from the farm ofices, together with the accelion from fheep eating the turnip upon the ground, mirht foon be rendered equally rich as the old crofts of the farm *

The greateft improvenent of which Tweeldale is fufceptible, is, to render fleep farming and arable farming mutually fubfervient to cach other, by fuch a fcheme of enclofure: The great aclulition

* 'To lhis fyllem of manarement, the farmers upon Cotnit Lockhart's cftate were boun! down, at the liaf Icafing out of his lands in the Upper Ward of Lanarkhirc, alont fie years agn. Tenants on mexpircel lesfes foon followed t!e

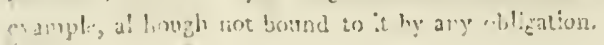


addition of dung, from the nheep feeding upon turnip, and through various methods of mere folöing of them, might add greatly to the extent of the lands kept in rotation tillage, as alfo to the quantity of their return; whilf the improved pafture, and the turnip crops, would enable the farmer to fell the whole, or part of his difpofcable fhecp, (according to the proportion of his arable to his hill land), in higher condition, anl at an higher price. Farther than the arable land, enclofure could be of little or no advantage to fheep farms, for reafons to be explained under the article $\beta$ secp $*$.

But

* John Loch, Efq. of Rachan, whofe property conffis of a fmall round hill, holding about a dozen or fourteen feores of breeding ewes, and of a more confidesable extent of arable land, of excellent guality, all of which he farms limfelf, has, for upwards of twenty years bypaft, been fetting an example of the reciprocal fub. ferviency of theep farming and tillage, to the mutual advantage of both. He Flaces great dependence upon the folding of his heep, both for bringing land into tillage, and alfo for the improvement of his pafture.

In his letter to me, he obferves, that he took the hint of improving land upon a large fcale, by meep folding, from obferving the luxuriancy of the crops produced in the way of folding fheep, common in the conutry; and that, hitherto, the profecution of the practice, upon a more extended fcale, has anfwered his warmeft expectation. Finding the fod dikes of the country troublefome and expenfive, he got flakes of foreign wood, each ten feet in length, and in fuch number, as to enclofe abont four fifths of a Scots acre at a time. His whole flock of fheep were, nightly, brought from his hill, and folded up.n his land intended to be bronght int stillage, from the end of May, till the end of Oenober; the fiake fold bing fhified ro new ground every 10 or $\mathbf{1} 4$ days in wet weather, and once in three weeks when the weather was dry. Wherce it may be concluded, that about 8 Scots acres would? thus be annually manured by his flock; or at the rate of thirty fhcep to manuring one acre.

In this manner he brought much of his arable land into tillage, for which he had accefs to procure manure in no other way.

He has fometimes got ploughed, before Winter, a part of the land intenced for theep-folding the enfuing Sumner; and alfo limed it in time, to have the lime effete before folding the Meep: Upon this part, which the Beep were folded firt upon in Spring, he had the opportunity of iowing lroarlcaft turnip, after the flocep wcre removed, which turncd out a half crop; abd were eaten by the fiecp, next spring, upon the field, in time to have the land fo reated, plowned along with the reft of the folded land for a crop. This he conficers as a rery great ingrowmest; as land fo treated, not only reccives a thecp tcathing, in common with ite

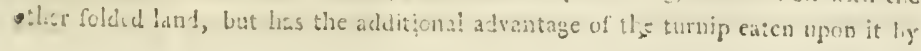


But who, it may be afked, are the proper perfons to carry on fuch fchemes of extenfive enclofure? The anfwer we would be inclined to give, upon experience of what has been effected on the lordfhip of Neidpath in Tweeddale, is, Tenants, at their own expence, upon moderate rents; and with the fecurity, from their leafe, of thrice ninetecn years poffeffion of the farm.

Proprietors, not practical farmers themfelves, are but ill qualified to judge of the proper plan of enclofure, to render the farm productive; but of this the tenant is a competent judge, becaufe to this alone he directs his attention. The proprietor confults often elegance, $\mathcal{E}_{c}$.; the tenant only ufe. The proprietor cannot drive a hard bargain; and there muft be a want

the fheep, previous to its being fubjected to a crop of corn. The ploughed land he confiders as yielding a drier bed to the folded theep than the grafs land; and, when it hath been limed, the paddling of the fheep's feet, mixes the lime more intimately with the foil, than can poffibly be effected by the operation of the harrow.

Having brought into proper order the greater part of his outfields by means of folding, and having laid out, in grazing parks, what is not intended to be kept under confant rotation cuiture, he has now lefs occafion to fold his fheep upon new land intendel to be cultivated. He, however, finds the folding to be the bent mode of recruiting his improved pafture, deftroying the fog, and invigorating the grafs. The turnip ficlds, upon his rotation lands, he finds moft profitably expended, when eaten upon the ficld with theep. And as his hill is now all enclofed, and fubdivided with ftone dikes, he is in no rik of intermixture; fo that he can attempt difierent breeds of theep. He has found the Cheviot breed to anfwer well, and is now croffing that breed with the Sonth-Down. He tells me, he is entirely of the opinion of the old writers, "that a fock of fieep is the mont powerful arm, either for bringing land into culture, or for preferving it in the moft highly productive condition."

Although Mr Loch informs me, that, to judge by the price at which he difpofes of his theep, the continued folding is in no way detrimental to them; it would neverthelefs be cxtremely abfurd, to extend his practice to widely extended ficep farms. Ilis fmall flock can, without long travel, be eafily conducted, daily, from his comparatively fmall extent of hill land to their fold, and back again, without much fatigue, or interruption of the time of pafturing. The cafe widely diffirs, in both refpects, as to an extcnfive hirfel of 50 or sco fcores of theeps frafturing, when at eafe, feattcred orer miles of muuntain. In fituations fimilar to his own, !n fy ftcm ean be better than Mr Loch's. The fame fy ftem, as to the fattening part of his fincep, is aronted by Mr Charles Alexander, upon his extenfive farm of Laficr Jiapineiv. 
of œconomy in the whole of his expenditure: The very fame capital, under the rigidly reconomical application of the tenant, would effect almoft double the execution. The tenant, even upon a nineteen years leafe, would be willing to pay intereft for enclofing capital: If, however, the enclofures are laid out with a view to tafte, more than utility; or if the capital advanced is over proportioned to the work executed, the tenant can lefs afford intereft, and the proprietor has paid difproportionately for the extent of melioration accruing to his farm.

Perhaps, the moft ceconomical fcheme of enclofure, which a proprietor could adopt, would be, to give his tenant a charte blanche as to enclofing, when he finds him judicious, thriving, wifhing for enclofure, and willing to pay common intereft for the capital advanced : that he fhould entrift the direction of the enclofures entirely to the tenant, in the certainty that they nlall be conducted fo as to add the moft productive value to the farm: that he fhould alfo impower the tenant to contrast with the undertakers, who, as he pays intereft, will therefore adhibit his ufual ceconomy in the advance of capital. Upon fuch a fyftem, it might be prudent in a proprietor to borrow money for the purpofe of enclofing, however unfafe fuch practice has hitherto been accounted in the agricultural improvements of proprietors; as he might be certain his tenant would never call for an advance, for which he is to pay 5 per cent., unlefs upon the well-founded profpect of its yielding himfelf 10 or $15 \%$. Indeed, a great part of the lands in Tweeddale cannot be brought to their proper productive value, by improvement of culture, till enclofure is more generally extended. When this thall be effected, improvements of their value may

be

* Money funk in agricultural improrements, is not like money launched out upon mercantile enterprizes; it cannot be recalled all at once, but mercly in annual returns; and probably not in this way, till after a confiderable lapfe of time. Proprictors borrowing money for fuch purpofes, fhould know well from whom they borrow. Moncy-broking, conveyancers have an evident intereft in fhifting fecurities as oftcn as poffible, from the profit arifing to them from drawing up wew titles of fecurity, the expence of which falls upon the bonower. Such is the cafe in Scotlind. 
be extended, both to the arable lands and to the fheep. It is, however, fubftantial, immeriately ufeful, ftone-dike enclofure, that the 'Tweeddale fireep farmer ftands in need of ; and for this alone would he confent to pay intereit. Hedges, he confiders as mere vexatious baubles, which can never, in any degree, prove a fence for Tweecidale fheep. Confidering, indeed, the variety of foil that muft be encountered in any extenfive fcheme of enclofure, it were abfurd to fuppole, that every part of it was fit to rear thorns. In fo far as my obfervation extends, there is not to be met with, even in the richeft foils of Tweeddale, one hundred yards of continuous hedge, fufficiently fencible againt any defcription of pafturing animal. I now proceed to

\section{Managenent of Arable Firms.}

By arable farms, I would be underftood to mean fuch farms as do not depend upon theep, but upon tillage; although there are few of them that do not keep a few theep of the long-tailed, large, fine-wooled, Englifh breeds, which are eafily confined to narrow ranges; neither pofleffing that uncontroulable propenfity to roam at large, which is proper to our native wild fheep; nor the fame contempt for hedges as a fence: Thefe fheep pafture along with the cows, are often houfed in Winter, and are called pets; a defignation applied to every kind of fheep kept in this ftate of domeftication.

There are few of thefe farms entirely arable, though fome are.

A confidcrable number of them are monly enclofed with hedge and ditch, which, with conftant repairs by paling, makes a tolerable fence. As thefe farms often extend into the plains, and have the arable lands of theep farns interpofed betwixt them and the fheep; this circumfance gives protection to the hedge enclofures, which, being thus defended from the affaults of their more formidable enemies from without, more eafily fuffice to confine their more peaceful inhabitants within.

'Thefe farms are of fmaller fize, and of lefs extent of rent, than the flecp farms, as alleady montioned. 
The ftaple articles of their produce are the dairy articles of frefh butter, thimmed milk cheefe, new dropt calves, with old cows fold off, in calf, or fat, and fometimes young cows or oxen; corn alio and hay; with, incidentally, a young horfe bred from the plough mares; and, where they are kept, the pet lambs, or old pet theep, fold fat.

Frefh butter, fent weckly to Edinburgh, by weckly carriers, is the chief dairy product to which attention is paid; and with good reafon. To deal in fatted veal, excepting, incidentally, at the fcarce feafons; or in any cheefe, but what is made of the milk, after abftracting the cream for butter; would be to relinquifh the advantage we poffefs, of vicinity to the beit market for freth butter, and to place ourfelves on a level of conpetition in the market, with counties the moft diftant from the capital *.

- Benter is all made from cream. Great care is taken to preferve the milk from impurities. A milk-houfe muft be cool, but free from damp, and adnitting of the circulation of air. The milk veffels, generally of cooper's work, are wcll wafhed, every time the milk is taken out of them, in boiling water; and are carefully fcrubbed, with a rubber, or hard brufh made of the fmaller twigs of bea:h; fome adding a little falt during the fcrubbing, others a little quicklime, to neutralize the acid imbibed by the veffel from the milk. The milk is poured from the milking pail into thefe veflels, where it is to remain for cafting up the criam, through a fieve of fiannel, or of fine brafs wire. According to the heat or coolnefs of the weather, it is alluwed to ftand for 36 or 48 hours, before the cream is fkimmed off; the cream is put into a feparate veflel, where it is collected for the weckly churning. The churn ufed, is the barrel-churn, with moving breakers; though, of late, a fquare box, with a fliding lid, and moring breakers, which can be taken out at pleafure, is getting into ufe, from the greater facility of cleming it. The cream, when put into the churn, is paffed through a canvafs bag; and, in Mert, every precaution is thes lifed, to preferve the milk free of every taint, and of the admixture of all extraneous fubftances. Alout jo years ago, very little attention was paid to cleunlinefs; and, after the butter was taken from the churn, a large knife, hacked faw-ways on the edge, was repentelly pafled through it in all dircetions, that hairs and other impuritics misht be remored, by their adhering to the ragged edge; this practice, then univerfal, was called buing the bitter.

Of all animal concoctions, that of the converfor of the aliments into milk, feems to produce the leatt change upon the oiginal nature of the alinent; and 
The parifhes chiefly abounding in fmall arable and dairy farms, are thofe neareft the capital, as Linton, Kirkurd, Newlands, Eddleftone, and Peebles; Newlands being probably the beft adapted for the dairy, in confeguence of more abundant fhelter for mill-cows, from the more abundant artificial wood plantations. The town of Peebles confunes a confiderable quantity

the quality of the milk and butter depends very much on the natuse of the food given to the cows. The butter of cows, fed in Winter upon carrots and hay, differs very little, either in colonr or richnefs, from that made upon Summer's grafs feeding. There feens, indeed, to be a particular congruity betwixt the juice of carrots and milk; infomuch, that the expreffed juice of rafped raw carrots, put into the churn along with the cream, gives to Winter butter, not only the colour, but a confiderable degree of the rich tafte of buttcr from grafs: It, indecd, prevents the butter from keeping fo long fweet. The difagreeable tafte given to milk and butter, frnm turnip fecding, is generally corrected, by putting into the milk veffels, along with the new milk, a fmali quantity of faltpetre, either in powder, or infufed in water.

The 1 kimmed milk is made into cheefe; the milk being immediately curcled, fo foon as the cream is taken from it, after being warmed to the heat of ncw milk; when, if the dairy yields a fufficiency at one fkimming for a cheefe of the fize required, the curd is immediatcly committed to the cheefe prefs; if not, the curd is preferved, and mixcd with the curd from the milk next limmed. The whey is ufed inftead of water, for making the oat-meal porridge, to the confiderable faving of meal, (a faving produced $t$ ) a greater extcnt, by ufing milk for the fame purpofe in Winter, when there is not finfiency of milk for cheefe-making), and the refidue is given to pigs; fometimes, inftead of uater for drirk, to weaned calves for lolding flock; and fometimts to new weaned foals. A fort of rery mean checfe, is fonctimes made from butter milk, but none for fale; when kept tiil moulder? (which foon happens), it acquires a particular high aromatic flavcur, exceclingly grateful to fume palates.

In the fhecp farms, where theeps' milk chcefe is made, the whole milk of the cows upon the farm is mixed with the thecps' nilk. The butter, during this period, being ill tafted, is kcpeto be mixed with the tar for fmearing the fleep; and the milk is afterwards made into cheefe. There are, by confequence, very few farms where cheefe is made of entire heeps' milk; and, from the various proportions of the admixture of cows' milk, there are few articles in commerce, paffing under one common denomination, of which the qualitics are fo various as thofe of theeps' milk cheefe.

The yearning, or runnet, ufcd for curdling the milk, is commonly the ftomach of a calf, well falted, along with the curd found in it, and dried: When abont to be ufed, it is cut into fmall picces, (fome only ufing the flomach, and throwiag 
quantity of dairy produce from the farms in its neighbourhood. The medicinal well, with the woollen manufactory, begun at the viliage of Inverleithan, may, in time, raife a confiderable demand for dairy produce, from the farms in the parifh of that name, and in that vicinity.

The

3way the curd, which is often rancid), and put into a can, with a ftrong pickle of falt and water: When it hath Ateeped fo long, that the l:quor, upon trial, is found to have acquired the ycarning quality, the liquor is carefully decauted from the fediment, and bottled up for nfe; when fiefh pickle is poured upon the ftomach, fo long as it is found capable of givinz out this quali:y to the pickle. Inftead of the ftumach of a cali, fome ufe, with fuscefs, the ftomach of an old cow, falted, rolled up hard, and dried; the fomach of a hare, or of a lamb, are found to anfwer; and perhaps the fame property is to be found in all fomachs, incenched, in early life, to digen milk: What appears fingular, the infide fkin of a hen's sizzard, cleaned, falied, and dried, is found to poffés this quality; perhaps, it is a property belonging to every kind of ftomach. Several regetables are 11 fed, in aid of the forach yearning; I have made trial of decoctions, of all difierent ftrengths, of one pointed out to me, as of high character, but could not find that, of itfelf, it had the fmalleft tendency to curdle milk. The quantity of the ycarring liquor necellary for a given quantity of milk cannot be afcertaince ; evcry paiticular ftomach yielding a fronger or weaker impregnation to the pickle in which it is infufed; and the houfewife being not unfrequently difappointed, in finding that no yearning quality whatever has bcen imparted. If chymical analyfis were applied to runget, perhaps fome fuccedaneun might be found out, which would produce the effict with certainty, and, at fume time, prevent the bad tane often communicated, hy Romach rumet to the cheefs.

Suect-milk cheefe, i. e. cheefe macle of the whole milk, withont ab?racting the cream, is not made for fule in this county; hut only for private family ufe. The theory of preferving all the richnefs pofible, to cheefe of this defcription, feems to dcpend upon the following facts, which feern abundantly afcertained in experience : Ino, That cream is evaporable, in a derree of beat not very intenfe; as appears from the equal prornefs, both of the chcefe and of the whey, when the milk is too much heated before putting the yearning to it: 2do, Tisat the aths fon of the cram to the curd part of the milk is but firbt; as appears from the riclners of the laft drainings of the whey, which, in whole milk cheefe, are very rich crean, if the curd is too hard wrought by the hand, or if it is too hard prefled at firf, immediately mpon its being committed to the cheefe prefs: $3^{\text {iio, }}$, That the whey, if not fuon feparated, fpeedily contracts the acid, and then the putrid fermentation in the cheefe; making the cheefe fvell, tainting its foull and tafte, and rendering it unfit for kceping.

Hence, the propricty is indicated, Imo, Of yearning the milk as cool as may be: $2 d e$, Of moderate working of the curd by band, in extracting the whey; to. 
The erident advantage to the dairy, to be derived from the improved fyftem of hufbundry, led fpeedily to its adoption (as already obferved) in farms of this defeription. The milk-cows (generaily feeding to from 25 to 30 ftones Dutch of carcafe, when fold mocierately fat to the butcher) are much fed in the houfe, during mid-day heat, and over night, in Summer, tipon clover cut green; which adis greatly to the dung bred upon the farm. The turnip crop is given to the milk-covs, and the young ftock in Winter. The plough horfes are alfo much fed on cut clover in the houfe throngh Sunmer, when hard worked; as they can thus fill their bellies very fpeedily, and have more time for work: When at pafture, they generally feed with the milk-cows; or fometimes, when they come hungry from the yoke, they are teathered (i. c. confined by a long rope, faftened to their halters, with a ftrong wooden or iron

gether with a regulated preffure, moderate at firn, and gradually increafing, when it is put into the cheefe-well, and fubmitted to the checfe-prets *: Or the Ayrnire practice, of taking the curd repeatedly from unde: the cheefe-prefs, and Aicing it into fimall pieces, which are expoted, at each operation, mpon a ficre, for draining and drying by the air; that, thus, the aqueons particles of the whey dripping of, or exhaling, the cream, beenning dry, may continue adhering to the curd, while undergoing the laft more fung confog hating prefure.

The eneral time of prefure, bccaufe fuiting the practice of daily chcefe making, without the experse of double apparatue, is 24 heurs.

Seme houferives falt their cheife in the curd; others, by nubbing falt upon the fin of the cleefe after it is made; others, hy putting the cleefe in pickle, which is thought to extrakt fome of its richurfs.

A fact, faid to he cftablithel in experience, is the ground-work of fome family receipts for making very lich whole milk cheofe, viz. That a fmall quantity of the whey taken of, made boiling hot, and ponted tpon the remainder, caufes the curc iuftantly to corfoliciate, and cxpel the whey, the cream part, meantine, renaining united with the cond; the mans of curd is then lifted from the whoy, and plunged into the colitef fpring water, which congeals the cream, from its licyufaction by the heat; it is then put into the cheeli-wall, and fubmited to tise prefs.

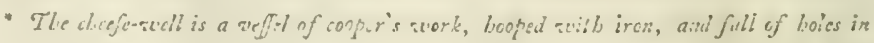

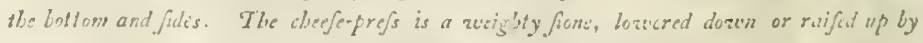
a lever, or by a forewe; ar a fmall zucigit, wutis advantuge of a long levir prefing dozin

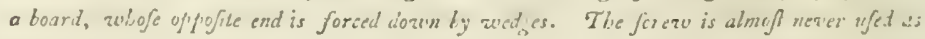
a preffing furce; and is improper, as is does not, of itfalf, followe "'p its ativentage. 
jin at the other end of the rope, winch is fuck frm into the ground) upon patches of fuch coarfe grafs as they would reject when full fect.

A confilerable number of thefe fams are of too fmall extent, to give fufficient occupation, at ail feafois, for the horfes and fervants necefiarily kept upon them: The farmer, therefore, lets out his fervants and horfes, and often himfelf for hire, in carrying coal, peats, lime, flate, ftone, \& rc. \& rc.; or in labouring the ftill fmaller poffeffions of day-labourers or artificers, who occupy land for the mere maintenance of one or two cows; or in working upon the public roads. Indeed, a number of them are merely taken with a view to fuch occupations. (Sce Note D.)

For the moft part, thefe arable farms are held in leare inmediately from proprietors: A few are lield in fubtack from tenants. When a theep farmer takcs in leafe a fheep farm, which formerly had been a farmer's refidence, but where he does not intend to refide, he geirerally fubfets the houfes and croft-lands of that farm; referving to himielf the right of Winter downfail for his theep, which, if rigoroully cxacted, would be an effectunl bar to their improvement.

Where the arable farms are all equaliy fit for plough culture, through their whole extent, and properly fubdivided by inclofure, the whole is regulurly cultivated; pafture forming a part of the fyftem of rotation, and the general principles of rotation culture, alrcady muntioned, being obferved. For inftance, to begin with the breaking up of what is in pafture; accorling as the rotation admits the field to hare lain for a longer or fiorter time thisler palture, one crop of oats and one of peas, or two of oats and onc of neas, are taken; then turnip fallow with dlung; then barley with grafs feeds; then hay; then patture for a longer or fhorter periol. If, however, the land is not all equally fit for either pafture or tillage-if, for inftance, a particular fielt is more convenient for paiture than the others, from contiguity to the loufes; from being beft watered; from being lefs fit for tillage, on account of fteep declirity, or of wetnefs, or of poverty of foil-or if, as is oft- 
times the cafe, the beft arable land is alone inclofed by a fingle ring-fence, without fubdivifion, the reft of the farm lying open: In theie cafes, the open uninclofed land, that which is leaft adapted to make a return in tillage, or that wich, in other refpects is moft convenient for the purpofe, are refigned to permanent pafture: The perpetual tillage land being cultivated, if light or fandy, under a four-courfe rotation; if of better confiftence, under that of five; and, in fome very few infances, under that of fix, as already lefcribed.

\section{Sect. II.-Ront, in Money, in Kind, in Perfonal Services.}

Although victual rents may be mof equitable in making provifion for perpetuity, as being lefs fubject to rariation in value, at diftant periods, than money rents, yet, for the thort endurance of an ordinary leafe, money rents are certainly preferable, both for the proprietor and tenant. They prevent all difputes, as to quality, in the payment; or intrigues, as to friking the market price, upon converfion: 'They prevent alfo, the irremediable inconvenience incident to victual rents; of doubling or trebling the rent againft the tenant, in an year of fcarcity, when he is leaft able to bear any addition; or of diminifhing the value, in the fame proportion, to the proprietor, in an year of plenty. Money rents are alfo by much the moft eligible, as interfering, in no degree, with the tenant's management, but allowing him to turn his ftock and induftry to whatever mode of culture he fincls molt profitable; whilf rents in kind, in carriages, or other perfonal fervices, are, from this interference, extremcly injulicious. In rery long leafes, it might be eligible, that a part of the rent fhould be payable according to the rate of victual; calculated, however, not from year to year, but always upon the average of perhaps the immediatcly preceding eight or ten years, in order to avoid the exccfive incqualities of price that take place from feafon to feafon.

In Tweeddale, the proportion of rent paid in kind, or perfonal fervice, 'is very trifling; the more enlightened among the proprietors, cntirely relinquifhing all rent of this fpecies. In cafes 
where the proprietor refides, (the practice being, however, often continued from mere blind adherence to old ufage, even where he docs not refide), out of an idle anxicty of being fecure of accommodation in certain articles, or perhaps from fome filly conception, that the farmer will fet no value upon the wrork, and the time he can fpare from his farming operations, or upon fuch produce as can be raifed from his ofals; a fmall proportion of kind rent or fervice is exacted, in addition to the money rent ; fuch as, neal and bacon from mills, poultry, and the carriage of fuel from all forts of farms. The leaft reflection would, however, convince any one, that all fuch articles might be obtained equally cheap, without, as with, an obligation to furnifh them. The tenant's varying views and practice, through the courfe of his leafe, are the only proper meafure of the time and labour he can fpare from the farm; and thefe he will furely be ready to hire to the proprietor, as cheap as to any other: The tenant's experience can alone afcertain the extent of produce which may be raifed from his offals; and this produce the landlord can always purchafe at its market price. If either time and labour, or offal produce, are impofed beyond this extent, they come dear to the tenant; and this dearth muft fall ultimately upon the landilord, as the lefis rent, proportionally, can be afforded. If the landlord wifles to have fecure accommodation, at fuch expence, he can always command it volustarily, by offering a price equally high. As a fum equal to the diminution of etherwife afforiable reint, from neglect of farm, and wafte of its produce, by the exacticin of labour and time and offal prochction beyond their proper extent, coukl at all times bribe the tenant to the fame extent of negligence and of wafte-the only difference confiting in the tenant's being paid before (in diminution of rent), or offer (in excefs of pricc), for the negligence and the wafte; - - in ittuations where particular accommodations cannot poffibly be obtainced for hirc or price, it may be more cxcufeable to fecure them by obligation: Vie ouglit, however, to be certain that they cannot otherwife be had, as undoubtedly crery thing can be had cheapeft from the profefional fuminer. In regurl to 
poultry, in particular, it may be remarked, that the reficerts proprietor can generally rear them himfelf, at much lefs expence than his tenant: For, as the tenant's houfes are in great nart low roofed, and covered with thatch; and as growing corn crops, with his barn-yard, are in clofe contiguity to his dwelling, which admits not of policy; the damage fuftained by poultry, in treading down growing corns, and deftroying the thatched coverings of the houfes, and the corn ftacks, may foon amount to more than what they can produce of profit, from picking up offals that would otherwife go to wafte: But the flated roofs, and grais lawn of the proprietor, fecure him againt fuch damage.

By act of Parliament 1748 , the arbitrary unfpecified fervices of ufe and wost, an obligation to which was inferred at common law, though not exprefled in the leafe, are all abolinhel. They would feem, formerly, to have furnifhed a pretext for endlefs vexation and oppreffion of the tenantry; even fo far as to devolve upon them moft of the public taxes impofed by Parliament upon the proprietors of the land. No preftation is now exigible from the tenant, but what is exprefsly ftipulated in his leafe; with exception of fuch legal burdens as are already, or thall be directly impofed upon bim by act of Parliament; and alfo, of his adtriction to the mill.

The permanent legal burlens, impofed upon the tenantry by act of Parliament, in their capacity as tenants, are, the one half of the poor's rates, where fuch rates are carried into effect; the one half of the falary of the parochinl fchoolnafter; alfo, a cerm tain number of days labour upon the public roads, proportioned to the number of labourers and horfes kept upon the farma burden which (from the experienced inefliciency of compelled labour) is now almoft univerfally commuted into moncy payment, by authority of l'ariament, in the fpecial acts obtained by the different counties, for making and repairing their roads by the money they are impowered to collect in toll; the commutation being affented accorling to the ploughs kept, or the valuation of the lands in the cefs-books; and the money arifing from it, being generally applied to by-roads, now that the public roads are uphele from a diflerent fource.

The 
The burden of adfriction to mills (called in Scotland thirlage) infers an obligation upon the tenant, to grind his grain at that particular mill to which the lands he occupies are thirled; i. $e$. which poffeffes the exclufive privilege of manufacturing the grain of thefe lands.

It feems not improbably conjectured, that, in former times; the Great Baron obliged all his tenants upon the barony, to bring their whole grindable produce to his mill, (not only as the narrow-minded mode of obtaining indennification for the expence of erecting it, but) as the bet method of both afcertaining and collecting his rents, which were moft probably paid in kind, and in proportion to the produce. The proportion retained at the mill, in name of multure, might therefore include, not only the price of manufacture, but the whole of the victual rent: Accordingly, the territorial bounds of an adftriction are generally commenfurate to that of a barony ; and the extent of thirlage is frequently ftill found to reach to the whole of the grindable corns. In confequence of the introduction of money rents, and of the alienation of lands from baronies, in all the varieties of private bargain, the thirlage of lands to mills is found. exifting under all modifications of extent, both as to the proportion of produce which the mill has the exclufive right of manufacturing, and alfo as to the proportion retained, as multure, or price of manufacture.

In Tweeddale, the rate of thirlage varies in both refpects: The moft narrow extent of adftriction reaches to all the oats ufed in oatmeal by the farmer's fanily and fervants upon the farm; and the broadeft (the only other extent I believe in the cournty) reaches to all the grindable corns upon the farm, with the exception only of what is confumed by the horfes, and of the feed fown upon the farm*. 'The corns of beer and of peas'

- The broacket adfriction leaves an option to the farmer (after having manufacturcd as much as is judged equal to the confumpt of his family and fervants) of difpofing $\mathrm{cf}$ the remainder in an unmarufactured fate, upon his paying to the mill a proportion fomewhat inferior to what might have bcen exactcd upon manufactur: ing it (called dry multure), amonnting to alonk a whe ats thenticth part of the ฤuantity difnofed of. 
were probably introduced into culture, of a date much later than that of the eftablifhment of thirlage; and this is probably the reafon why, even under the broadeft adltriction, reaching to all grindable corns raifed upon the farm, thefe two fpecies of grain are pretty generally underftood to be cxempted from the adftriction-a circumftance which I have known to lead to the prepofterous fowing of beer, where oats would have been more profitable.

The rate of multure exacted at the mill, is, in general, mont moderate where the extent of adfriction is moft narrow, and higheft where the extent of adfriction is broadef-correfponding, it would feem, to the remanence of the lands under their original conftitution in regard to thirlage, or to the prevalence of the notions of emancipation in the bargain of their alienation. Thefe rates of aditricted multure vary in this county from a $25^{\text {th }}$ to a $21 \mathrm{nt}$, and even a 16 th part of the quantity manufactured: A certain proportion of meal is alfo paid for the ufe of the kiln in drying the grain, though there is, indeed, no thirlage to kilns, and it may be dried at home; and a finall due, in meal, eftablifhed merely by ufage, and therefore lefs defined, is paid to the under miller, under the name of knavefsip. Where the highent rate of adftricted multure is due, the proportion paid for the drying and manufacturing procefs, is fuppofed to amount to about a $I 4$, th part of the quantity manufactured : But in cafes where there is no adfriction, the multure is univerfally a $32 \mathrm{~d}$ part; and the whole quantity exacted, for both drying and grinding, is reckoned not to exceed the 28 th or 27 th part, which may therefore be confidered as the real market price of the mainufacture of grain.

Thirlage not only fubjects the tenant of the thirled lands to an higher rate of multure, but alfo to various other burdens and vexations. If the mill to which he is adftricted fhould be out. of repair - let his demand be ever fo urgent, or his grain in ever fuch rifk of being fpoiled, he muft allow the miller a proper time for reparation (fome fay fix weeks from the time of application) before he is entitled to go elfewhere for fervice. The thirled tenant is fubjected to many occafional fervices, from which 
which the free tenant is exempted; fuch as, the upholuing of the water dam dike; the upholding, frequently, of mill fanners and mill freves, and the carriage of milltones, when needed: he furnifhes fuel for drying his grain ; he tranfports his grain to and from the mill-furnifhings provided for him by the miller at free mills; he attends alfo at the drying procefs, fifts his own meal, and performs the greater part of the mot laborious work; in all of which, his time and labour (in reality, or at leaft in probable imagination) are not well hufbanded.

Adfriction is, in principle, abfurd. In every employment, of which mere pecuniary emolument is the object, the only ftimulant to induftry, excellence, and integrity, is that neceflity of pleafing cuftomers, in order to fecure their cuftom, which arifes from free competition: But adftriction (implying an excluinve right to employment, whether the performance thall, or fhall not, give entire fatisfaction to the employer) completely removes this ftimulant. What check can the adfricted tenant have over the manufacturer of his grain, when the latter knows that the tenant cannot withdraw his employment, however diffatisfied with the execution, nor have recourfe for any damage but what can be legally inftructed? How is it polrible, legally to inftruct damage from negligence or improper manufacture, or from unneceffary and expenfive wafte of the tenant's time in attendance, or from difhonety in resard to the yield of grain, which it was impofible to afcertain, but from the return at the mill? The tenant muft evidently lye much at the mercy of the manufacturer of his grain, which may be productive of confiderable real wafte, if not from difhoncty, at leaft from that negligence attendant upon fecurity of cmployment-productive, alfo, of much imaginary oppreffion, which, of itfelf, is probably the worft of grievances. In farms where the adftriction extends to all grindable coms, it acts, like the Englifh tithe, as a direct tax upon agricultural induftry, increafing in proportion to the increafed productive vilue of the lands, to the improvement of which, no fhare of the capence has becn contributed. 
Where land adfricted to a mill is thrown into grazing, it is generally underftood that no multure is exigible: Adfriction, therefore, can yield but a precarious rent. Suppofe an adftricted farm, where the adftriction reaches to the oats ufed as meal by the farmer's family, has been poffeffed, for time immemorial, by one family; but that, in courfe of a demand for fmall conveniency farms, by people living by other profeflions, it fhall hav been divided into twenty diftinct tenements, feparately occupied by as many different families; and that the population it hath now to fupport is ten times more numerous: thali the adfriction, in this cafe, continue to be reftricted within the extent of oats ufed as meal by the fingle family originally poffing the farm? or fhall the adfriction receive a tenfold extenfion, and be interpreted to reach 10 oats ufed as meal by the wobole of thele farmers fanilies? We may alfo reverfe the fuppofition to the unition of farms; and here, alfo, a fair field is opsned for litigation, to decide whether the adfriction thall be contracted to the quantity of meal confumed in the fingle fanily now poffefling; or fhall be continued at the extent of confumpt of the whole families originally poffefling the diftinct farms before they were united. Does the adfriction, in thort, continue always of the fame invariable value? or, is it, thus, liable, from the various occupation or management of the adtrifted lands, to be increafed, to be diminifhed, to be annihilited?

It is furely to be expected, that an uage, fo abfurd in principle, and fo vexatious and litigious in its application, will not long be fuffered to exift under an enlightened Britifh Legiflature *.

Where the privileged mill and adfricted lands both belong to the fame proprietor, one flould think the interference of the l.egiflature in no way neceflary; it is, indeed, furprifing, that, in all fuch inftances, the good fenfe of the proprietor has not led him to emancipate his tenants from fo prepofterous a bon-

dage ;

* The above was written in 1796 or 1997 . Sec the reafon for not alering it, in the :ublecguent foot note. 
dage; though I know but of few inftances where fuch liberality has been difplayed. Where the mill and aditricted lands are vefted in different proprietors, it is not, indeed, to be expected that the adfriction fhould be given up without a proper equivalent : It were furely, however, a matter of no great difficulty for the Legiflature to confer a right of forcing a fale of the adfriction, under fome fpecified method, by which the price might be regulated, and the claims of all having intereft might be adjufted. Why not let the whole be referred to juries, acting by appointment, and under the authority of the Judge-ordinary of the county ?*

What

- An ad, to enforce the commutation of thirlage into an annual payment in grain, according to the award of a jury appointed by the Sheriff of the county, or the Sheriff of the county where the mill is fituated, if the fervient and dominant tenements are in different counties, was obtained in $1799 .-$ The above is retained as originally written, as the reafons of obtaining an act, are the fame that fhould lead to embrace the privileges of it. By the act, no tranfient poffeffor can apply for the commutation during his tranfitory interent, the application being only competent to perpetual proprietors.

I have heard, as yet, of no inftance of an application for the benefit of this act; which may be one example, ont of many, thowing that a grievance, which feems opprefive fo long as we enjoy no method of redrefs, feels lighter fo foon as we have it in our power to rid ourfelves of it when we will. The fume obictvation is probably fornewhat applicable to tithes in England: The tithes of the clergy are exclaimed agaiuft, becaufe the clergy, as a corporate body, can neither fell nor commute them: The tithe in the poffstion of the laity does not feem to have occafioned fich clamour. Yet it is frange that lay impropriators nill contirue to pofiefs, perhaps, an extent of tithe egual to that of the clergy. Their bcing empowered to fell, probably diminifhes the anxiety to purchafe. Perhaps, ton, without a compulfory act to enforce a fale at preicnt value, it might be diffcult to agrce upon a price with the holders of a property which progreffively increafes in value with the progreflive improvement of the country, without any expence of culture.

Till uniform precedents are cftablinted, juries mily be fomcwilat at a lofi to afcertain the value of an adftriction. It is evident, that the adfriction is worth the excefs of the adfricted inulture above unadfricted nulture, to the whole extent of the adfriction : But is it worth no more? If it is worth nothing more, then, on fuppofition that the rate of mulure were the fume under ad?ricion as at free mills, the adfriction is work nothing, and libery can af ard no puthafo moner. 
What farther remains to be obferved, under this fection, relative to rents, may be very thortly ftated.

The ditrefling fcarcity of fodder, occafioned by the extremities of cold and wet in feafon 1799, and of drought and heat in that of 1800 , occafioned fuch an extraordinary mortality or flaughter of all cattle ftanding in need of Winter fodder, that the great diminution of black cattle gave an extraordinary rife to the value of fheep. Some few farmers, who have, of late, taken theep farms in leafe, (unaware, certainly, that the rife of

fheep,

The following hiftorical account of mills in Tweeddale, from $\mathrm{Mr}$ Cliarles Alexander in Eafter Happrew, 1 think worth preferving.

It would appear, that a confiderable number of corn mills, formerly exifting in Tweeddale, have been allowed to fall to ruin. This would feem readily accounted for, in the following manuer: That, formerly, the lands were fubdivided among a greater number of proprietors; that, from a grudge at feeing the multures from the grain of their lands obtained at other peoples mills, each fmall proprietor was anxious to eref a mill upon his own lands; and that, through fuch fhort-fighted calculation, mills were foon multiplied to an extent far exceeding any demand for their employment: That, meanwbile, in order to obtain rent adequate to the expence of their erection (though without any juft calculation of the lofs that might otherwife accrue in fecuring it), heavy thirlages were had recourfe to, both as to the extent of grain which the tenants were compelled to manufacture, and alfo as to the rate of multure, or price of manufacture; perhaps, too, from a filly conception of thus cunningly catching rent from the tenantry, in a way they might lefs grudge, from its being lefs apparent; as in the cafe of lind and carriage rent. But, as thefe fmall properties were gradually bought up, and united into large eftates, the reafons no longer fubfifted which had given $n$ rigin to this multiplicity of mills: The greater part were therefore lèft to go to ruin, one only being preferved for each eftate; the fly mode of eatching rent, in a way fuppofed lefs apparent, lcading, however to the continuation of the thirlage of the tenantry, to the old extent, and at the fame rate of multure. This revolution, having produced no advantage to the tenantry, as to extent of thirlage or rate of multure, has alfo, in many inftances, fubjected them to the additional inconvenience of diftant or incommodious carriage to the fingle mill upon the eftate to which they have been transferred; inftead of being accommodated, as formerly, with mills at their own doors.

It is probable that no real lofs of rent would be incurred, were all fich proprictors, by gencral confent, to emancipate their tenants entirely from thirlage; and to let thcir mills for what thcy would bring, on fuppofition of the tenants being at liberty to go where they plafed, for thorter dilfance, or for better fervice: r.taters woult cone rende, ard the luf, on one hamb, woubd be rezaind on il.e oiticy. 
Theep, within thefe few years, to more than a third above their ordinary value, can only ftand till the deficiency of black cattle is fupplied by breeding), are fuppofed to pay at the rate of from five to fix fhillings for every fheep's grafs. Previous to this, the rent of breeding theep farms was fuppofed to average at rather better than three fhillings per head of the ftock kept on the farm ; that of hill-feeding thecp farms at about four fhillings, or four and fixpence.

Arable lands are fometimes let by meafure. The croft lands round the villages, may let at from thirty to fifty flillings per Scots acre; thofe around the town of Peebles from forty to fixty fhillings. Thefe may be confidered as mere conveniency rents. Arable farms, according to quality, in this county extremely various, may yield from fix or feven, to twenty or twenty-five fhillings, per acre. The higheft rent per acre ever paid for a farm, of fuch extent, as that its management conftitutes the fole occupation of the farmer, is that given of late for one in Inverleithan parifh, which the proprietor himfelf had improved, and is fifty fhillings per acre.

The rent to the landlord is almoft all that the tenant pays for his land. He pays neither tithe nor land-tax. The half of fchoolmafter's falary, a trifle of itfelf, (not amounting to one halfpenny upon the pound rent), though exigible, is almoft never exacted. Poor's rates are fellom impofed, except in trying cafes, fuch as, the dearths of crops 1799 and 1800 ; and, in thefe feafons, I believe, the poor's rates did not exceed, in any parifh in Tweeddale, 4 per cent. upon the rent, or 2 percent. i.e. $4 \frac{1}{4} \mathrm{~d}$. upon the pound of rent to the tenant. Statute labour, commuted at 8s. 4 d. upon the rool. Scots of valuation, cannot, in Tweeddale, amount to more than $3 \frac{3}{4} \mathrm{~d}$. upon the pound of rent. Excepting window-duty, and the tax on riding and. farm horfes, the above are the only kind of compulfatory taxes exigible from Scots tenants.

The whole rent of the county has been already ftated (from: the Statiftical account) as amounting to about 26,0001 .

In the Statifical Tables, fubjoined under the article Pop:lation, it appears, that the number of theep held in the county 
amounts to 112,800. Suppoling, therefore, three-fourths of thefe breeding farms for holding ftock, and each theep paying three fhillings-Inde, 84,600 theep, paying at three fhillings a head, rent - - - - L. 12,6900 o 28,200 dc. paying at four fhillings a head, do. 5,144 0

\section{Rent from fheep L. $17,834 \circ 0$}

The cows, young and old, are in thefe Tables

fated at $437^{3}$; or, as fome of thefe are in

the Selkirkthire part of Inverlcithan parifh,

fay only 4300 . Suppofe thefe can pay, over-

head, of rent, at the rate of 1 l. ros. each;

hence

$6,450 \quad 0 \quad 0$

Rent from fheep and cows L. 24,284 ○ 0 The remaining 17161 . of rent may be fuppofed to be made up, from horfes reared above what fupplies the breeding ftock; and from grain fent to market, above what fupplies the confumpt of the farmers families and fervants.

The average rent per Englin acre through the county, would appear to be confiderably under half a crown.

The facts founded upon above, are chiefly collected from the ftatiftical accounts. But various interefts might prevent accuracy of ftatement in various articles. I hould fufpect the rents are ftated low.

\section{SECT. III.-Tithes.}

The Clergy of Scotland are fupported upon fixed fipends or falaries, modified out of the tithes of the lands, by the Court of Seition.

The medium falary of a clergyman, I have underftood to lave been formerly eftimated at 601 ; belides a houfe, and a glebe of land, confifting, at an average, of near ten acres.

The Court of Seffion had not, from its original conftitution, any jurifdiction in the matter of tithes and ftipends; but, by act of f'arliament 1707 , a commiffion was delegated to it from 
the Scotin Parliament, for the purpofes of valuing of tithes, of plantation of kirks, and of augmenting the ftipends of the Clergy. It was at one time conceived, that, fo foon as the Court had fulfilled the purpoie of this commifion, in augmenting the clergyman's living in any parifh, its power expired in that inftance, and it had no right of future interference for the fame purpofe of augmentation. In courfe, it was an eftablihed maxim, that, without a frefh commifinon from Parliament, the Court could grant no fublequent augmentation to livings which had been augmented by it lince 1707. In confequence, however, of a change of views in the Court, as to the extent of this Parliamentary commiffion, as alfo of the public opinion in regard to the flendernefs of the Clergy's provifion, the Court has, within thefe ten or twelve years bypant, departed from its ufual maxims, and has fhown a willingnefs to grant augmentations, whenever necefiary, wherever there are funds for the purpofe.

The Clergy have not been backward in embracing this $f_{a-}$ vourable opportunity; and it is believed that, immediately, if not already, the medium of Scots ftipends will reach to rool. or 100 guineas, befides the dwelling-houfc and glebe.

The livings of the Tweeddale clergy have all received augmentations, fince this change of maxins; with exception of that of Kirkurd, where the teinds have been all valued in money, and are all exhaufted in payment of the prefent ftipend.

The power of valuing, and for ever fixing the value of his teind, at a certain rate, howfoever much the lands may be fubiequently improved in value, is a great privilege to the Scots landholder. Frad it been made a rule (as in the late act for conmutation of thirlage), that the teind hould always be valued in an annual payment in grain; though the fund, out of which the Clergy were to obtain their provifion, could not have increafed in proportion to the improved producion and value of the lands; neither could it have fuffered a diminution in value, from the depretiation of money. As, howerer, there is nothing to prevent the valuation from being efimated in mo- 
ney, landholders lave, by this means, not only obtained the juftice of being at full liberty to improve the productive value of their lands, in the certainty of reaping to themfelves the whole profit of their improvements; but they have obtained an iniquitous advantage, in having a perpetuity fixed in a manner which renders the bargain of gradually increafing advantage to them, and of proportionate increafing difadvantage to the other party*. The Scots landed proprietor is, at any time, entitled to raife a procefs before the Court of Seffion for the valuation, and alfo, if he choofes, for the fale of his teind; when, after proof of the free rent of his lands, the tithe is eftimated at one fifth part of the proven rental ; and the decerniture of the Court fixes it for ever at this precife extent, however much the lands may afterwards increafe in value. The free part of this tithe (that is, what is not already appropriated to the clergyman) is payable by the proprietor to the titular of the teinds; but as it is to the titular a precarious fund, being fubject to the future augmentations of the living of the clergyman of the parifh, the proprietor can compel the titular to fell it him, at nine years, or at fix years purchafe, according to different fpecialties. When an augmentation of ftipend is grant-

* In the cafe of the augnentation of the ftipend of Lamington, the Court of Seffion feemed to manifeft an intention of redreffing this incquality, arifing from the privilege of raluing tithe in noncy, by finding that fuch a valuation did not freclude them from allucating fipend in grain. It would have fulfilled every view of equity, had the Court, in allocating grain, eftimated it as exhauffing juft as much of the money-teind as would have fufficed to have purchafid it at the date of the valuation. If fuch was ever the maxins, it was not perfercred in; for, upon a reclaiming pcition, though the Court adhered to the maxim of their having power to allocate grain where teind had been valued in money; yct they found, that grain, fo allocated, hould be entimated as exhaufing the tcind at the rate of I 5 s. per boll. This procedure fecms to be confidered as a precedent for ali fimilar cafes: But upon what naxim it may be founded, fuperior to mere faeility of compromife, it is diffcult to gucfs. Whare mere compromife is allowed to take place of general principles, it is very apt to betray us into inconfiftency. In the fame fpirit, where graiu is allocated upon money-teind, the proprictor may rid himfelf of the victual, hy making a furrender of his whole moncy-tind, if only be makes his option within the years of preferiptioss. 
ed, the titular of the teinds of the parifin can allocate to that purpofe, in the firft place, the whole frce teind of fuch proprietors as have not purchafed their teind from him: when thefe are exhaufted, the remainder of the augmentation falls, pari paJu, upon the tithes which have been purchafed from the titular and thofe of his own lands, if he has any within the parifh.

Important as is the privilege of the valuation and purchafe

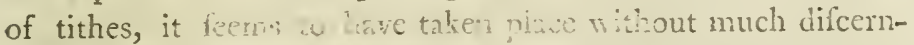
ment of, or vin iv, its acirantwon conieguences. At the Reformation, the patrimony of the Church, coiffias of the church lands, with the tithe of all other lands, was fiz $\frac{1}{4}$ upon by the Crown: it was foon lavifhed away upon the favouites of the Court, by James the Sixth. Charles the Firnt, upon his acceffion, amongft other devices for raifing money, bethought himfelf of recaliing the improvident grants made by his father, of the property that had belonged to the Crown: and, accordingly, in the firft year of his reign, he raifed a revocation and reduction of all thefe grants. The grantees (who, in the cafe of tithes, were called titulars of the tithes) being, however, found too powerful a body to be rafhly attacked; and they, on the other hand, being apprehenfive that the King might uitimately fucceed; the affair ended in a compromife, in which it vas agreed to fubmit the whole to the King's arbitrationaffurance having, no doubt, been previoully obtained, that he would not abufe the power thus giren lim to cut and carve for himfelf. Proprietors of land who had obtained none of the fpoils of the Church, and had felt no temporal benefit from the Reformation, (it being of no moment to them ih hether they paid their tithes to a layman or clergyman, if indecd the latter were not more eligible in point of moderate cxaction), were alfo allowed to reprefont their clains, in the arbieration, in regard to the tithes of their own land - a meafure probably adopted to ftrengthen the hands of the King in dealing with the titulars. In 1629 , the King pronounced his decreet-arbitral upon the whole matters fubmitted to him: In which he fatisfies limfelf with an annuity to be paid him fiom cach fpe- 
cies of tithe-an annuity which has never been collected fince I674; appointing alfo commifioners to value the tithes, for the purpofe of afcertaining his amnuity, which was to be a proportional part; and fixing a fifth of the free rent as the proportion which was to be held as tithe: Enpowering alfo every proprietor of land to compel the titular to accept of the annual value fixed, infead of levying the corpora of tithe; or to fell the tithe altogether, upon the terms already mentioned. 'Thefe decreets of the Fing were confirmed by the Scots Parliament in 1633 , and commiffioners were by it appointed for carrying them into effect: Thefe commifions were renewed from time to time; and the laft commiffion, before the Union, and confequent extinction of the Scots Parliament, was granted, as be. fore noticed, to the Court of Seffion in $570 \%$

Scots lancholders feem to have been flow in apprehending the value of this privilege conveyed to them. I an affured, that few of the more ancient procefles of valuation of tithe feem to have been raifed at the inftance of the proprietors; but at that of the commifioners, for afcertaining the King's annuity; or of the titular, to afcertain the furplus teind he was entitled to receive. From the barbarifm of the country, it is likely, few proprietors entertaincd any conception of their rents rifing in confegrtence of improrement.

Conftiutions, apparently opprefive, are often more fo in appearance than in reality; fuch, in ail probability, is the cafe with the tithes in England. 'To the Scots landholder, privileged as he is, it may appear hard, that the tithe of the Clergy thould rife upon hin, in confequence of improvements made folely at his expence, and to which they have contributed no fhare. As, lowever, the clergyman will, doubtlefs, in general, find it convenient to live upon good terms with lis parifioners, it is prefumeable that he will ordinarily confent to accept of a very eafy compofition. The farmer (wio, in tuling his lafe, rnuft, no doubt, nake allowance for the polible exaction of the whole tithe) will, therefore, always ind himfulf eafer, winder the moderate compofition of the wergynu, than he could have done under the proprietor, 
fuppofing there was no fuch thing as tithes; becaufe the latter lies under no reftraints of this nature, to prevent him from exacting full rent for the whole value of the fubject. Thus would it feem probable, that tithe fo far operates to the encouragement of the farmer, in preventing him from being difabled to carry on his improvements by a rent racked to an exorbitant fretch: But the inprovements which fuit a farmer, upon any proper length of leale, are of equal importance to the increafe of the produdive powers of the foil, as thofe longer-figited improvements of more diftant return, that are fuited to the more permanent intereft in the fubject, of the perpetual proprietor. Without doubt, the clergyman, as well as the proprietor, expects to reap where he has not fown; and, upon a renewal of leafe, will look for a rife in compofition, as the other will for a rife of rent, proportioned to the increafed value of the fubject; though improved entirely by the proper outlay of the farmer's capital, and though neither have contributed one farthing to the improvement. If, however, the lands thall have, meanwhile, been improved in productive value, it muft be a matter of fmall concern to the public, whether he who reaps the immediate benefit fhall be a foxhunter or a preacher. Extraordinary things are alone thought worth reporting; and the inftances of oppreflion of the farmers by the Clergy, which reach us in. Scotland, candour muft therefore difpofe us to conlider as the exceptions from the general rule. Such feems to be the favourable view of this fubject. But when it is confidered that neither landholder nor farmer can, at beft, have any farther fecurity for a favourable compofition obtained, than the uncertain incumbency of the compounding clergyman, with the-prefumeable good difpofition of his eventual fuccefior the difadvantage to improvement muft ftill appear very confiderable.

Were an arrangement fettled by law, under which the Englifh tithe could be impartially valued-without the odium of rigorous exackion attaching to the Clergy-at fame time preventing the poffibility of fraud and chicane, doubtlefs pretty prevalent at prefent; it cannot admit of question, that the re- 
venue of the Clergy would, in the firt inftance, be very greatly augmented *. And it feems to be as little doubtful, that, upon fixing the value of the tithe, the rapid progrefs of improvement, on removal of this incumbrance, would foon much more than indennify the expence of the immediate rife in the value of the tithe.

It is prefumeable, that, in the event of the agitation of fuch a meafure, Martin will avoid the infatuation of his bro. ther Jack; who, in the intoxication of applaufe for his zeal, in tearing, from the coat given by his father, the meretricious ornaments affumed through evil perfuafion of brother Peter, tore ftuff and all, to tatters, fo as hardly to leave himfelf wherewithal to cover his nakednefs: And, that the equity of a Britih Legilature will no more confent to give, without proper equivalent, the property of the poffeffor of one tenth, to the holder of the other nine, than to give the property of the holder of nine tenths, gratuitoufly, to him who poflifies one. The character of injuftice is invariable, whether practifed upon a larger, or a leffer fcale.

Grain, or lands, conftitute the only permanent values upon which to fettle annuities for perpetuity. In the view of pub. lic utility, it feems, however, very inexpedient, that the income of individuals, compofing a corporate body, flould arife from lands held in property by the corporation: The exifing individuals having but a liferent, or even thorter intereft in the fubject, no improvement of it is to be expected from then, but fuch trifling ones as coft little expence, and inmediately repay; none of thofe moft important ameliorations, of expenfive outlay, and of diltant return, which fuit thofe alonc, whore property is exclufively perfonal, alienable, and tranfmiffible.

* I underftand, that, in feveral of the reports of Englith connties, this angmentation of the tithe is ftated as the great objcotion againf a commutation; it muft cerrainly, then, be very laxly exacted. Pcrhaps thofe who are molt clamorous for a commutation, flatter themfelves witis the profpef of an unfair valuation. 
IABLE, SHEWING THE PROVISION OF TWEEDDALE CLERGY.

The victual part of the ftipend, generally one half oatmeal, and the other, beer in grain, is herc converted at the rate of $15 \mathrm{~s}$. per boll. The glebes are valued at 11. per acre, Scots; that of Peebles at 21. Excepting where they can, without inconvenience, be kept in grafs, the pofiefion of a glebe may, however, be confidered as confituting an article of expence, rather than of profit, to the clergyman: as, when kept under tillage, a preparation for labour muft be maintained in readinefs, of which the return of produce from fuch a fmall poffeffion cannot defray the expence. The money tipend includes from $3^{\text {l. to }} 5^{1}$. allowed the minifter for the expence of adminiftering the facrament of the Lord's fupper, called communion clements. No valuation is put upon the minifer's manfe or dwellinghoufe.

\begin{tabular}{|c|c|c|c|c|c|c|}
\hline \multirow[b]{2}{*}{ PARISHES. } & \multirow[b]{2}{*}{ PATRONS. } & \multicolumn{5}{|c|}{ PROVISION OF THE CLERGY. } \\
\hline & & & Toney & $\begin{array}{l}\text { Bolls of } \\
\text { rictual. }\end{array}$ & $\begin{array}{l}\text { Aires Siots } \\
\text { in Glebe. }\end{array}$ & $\begin{array}{l}\text { Whole Value } \\
\text { of Tiving. }\end{array}$ \\
\hline Linton & D. of Queenfocry & & $\begin{array}{|cc|}5 . & d \\
t .3 & 4 \\
\end{array}$ & 110 & $x 3 \frac{1}{2}$ & $\begin{array}{rrr}\text { I. } & \text { s. } & \text { d. } \\
\text { I5 } & \text { I } 3 & 4\end{array}$ \\
\hline Newlands & Do. & 64 & 001 & $9^{6}$ & 16 & 14800 \\
\hline Lyne \& Megget & Do. & 104 & $3 \quad 4$ & 二 & I 4 & $12 x \quad 34$ \\
\hline Broughton & Do. & $5^{6}$ & 00 & 48 & 22 & 11400 \\
\hline Glenlo!m & 110 & $4^{6}$ & 134 & $9^{5}$ & 9 & $127: 34$ \\
\hline Twecdimair & Do. & 75 & 00 & 48 & 10 & 12100 \\
\hline Urummelzier & Du. & 74 & 20 & 74 & 10 & .39120 \\
\hline Mannor & 10. & 91 & 3610 & - & 24 & 1351610 \\
\hline Pceble: & Do. & 100 & 0 이 & 64 & 6 & 13000 \\
\hline Inverleithan & Do. & 10 & I8 6 & $65 \frac{\pi}{2}$ & 10 & 1.3010 \\
\hline Kirkurs & Mr Casmichael & 70 & $0 \quad 0$ & - & $\mathrm{JP}$ & xy 00 \\
\hline skirlug & $\mathrm{D} n$ & .0 & I1 & 80 & 8 & 113110 \\
\hline Kilhueho & Col. Nintenn & 5 & $0 \quad$ & 80 & 11 & 12600 \\
\hline Eddleftone & Lond Elliousk & 68 & 170 & 10 & 25 & 15.3170 \\
\hline Traquair & The crown. & .58 & 169 & 86 & $11 \frac{1}{2}$ & $1.306 \quad 60$ \\
\hline Stobo & Sir Ja. Montgomeny & 68 & 09 & 6.4 & $2 I$ & $\begin{array}{ll}33 & 0 \\
\end{array}$ \\
\hline$\overline{\text { Total }}$ & -1 & IIIO & $\mid 1 I 4$ & $(y) 3 \frac{x}{2}$ & 230 & $\overline{2000} \sqrt{3} 10$ \\
\hline
\end{tabular}

Several of the Duke of Queenfbery's patronares are fold. The parifhes of Glenholm, Kilbucho, and Broughton, are annexed together, as the incumbencies tinall ceafe. 


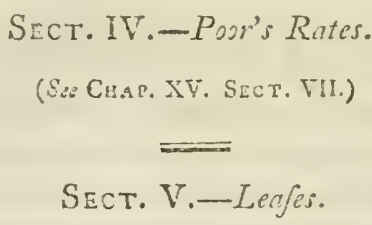

Some political writers have a?cribed the early and fourifl. ing ftate of farming, in Eingland, to the wide diffifion of the right of franchife; which, by creating a mutual dependence of intereft betwixt the landed proprietor and the farmer, caufes the intereft of the latter to be more attended to ; rendering the fecurity of a leafe of the lefs importance. Whether this feeming adiantage may not be counterbalanced by other difadvantages, appears to be very quentionable *. As the Scots farmer poffeffes no tie of this nature, his fole fecurity of tenure, to excite his induftry, muft be founded in the legal or con. rentional obligations of his leafe; which renders the leafe of fuch importance in Scotland, that its proper, or improper conftruction may be well conficlered as the primary fource of good or bad hubandry.

More general obfervations upon this fubject, I have refered to note $\mathrm{D}$ at the end of the Report. In this place, I fhall confine myfelf to the ftatement of the different effect of leafes, in this county, as fimulants to the tenant's induftry, in raspect of their duration, as experienced in fact.

We poflefs, indeed, in this county, no very extenfive range of experience, as to the comparative effect of leafes of different endurance, in exciting the occupying tenant to improvements of permanent duration, and of expenfive execution; though, from a fingular occurrence of circumftances, our experience is probably nore enlarged than that of many other counties.

No very permanent or expenfive improvements, have ever, with us, been made, upon the fhort fecurity of the leafe for nineteen years. One farmer, upon the farm of Stevenfon, in Newlands parifh, under this fecurity, planted about two acres 
of firs, as a fell, or Alelter, for his fheep; which continues to be of very great advantage to the fucceeding tenants of the farm. 'The moft confiderable exertion ever yet made, upon fuch Mort fecurity of pofieflion, is that of Mr Scot, a farmer upon the eftate of Traquair: He has cut off from his fheep hill pafture, by a head-ilyke of ftone, better than feventy Scots acres of land, fit for tillage, at his own charges; and has reduced the whole into an high fate of cultivation, by the turnip and fown grafs hußbandry, after clearing it of ftones, at very confiderable expence. The example, however, of this tenant, cannot be interpreted into a precedent, for expectation of what may be effected upon the fecurity of tacks of fo thort endurance; becaufe his fituation is, in fome refpects, fingular-he is the $f(r f$, in that quarter, who has difplayed fuch fpirited exertion, and may, of courfe, have received fome few favours, to which he is fo well entitled; and may have entertained, not unreafonably, a reliance for a preference, againft the next letting of the lands.

But the greateft exertions, out of all comparifon, that have ever yet been excited among the Tweeddale tenantry, are thofe that have enfued upon the fecurity of the fifty-feven years leafes granted upon the lordhip of Neidpath, about the year 1788 *. Although the tenants were obliged to advance

fines

* This eftate is under frict entail; and as it does not remain in the prefent poffeffor's family, he has no farther intereft in the fubject, than to draw from it all the money it can yield him. The late leafes were offered, at the then prefont rents, for fifty-feven years; upon condition of paying a graf $\int u m$, or fine, at entry, proportionate to the advance rent that might otherwife have been expeded. The tenants confulted Counfel, as to the powers allowed by the entail; when it was found, that it contained no claufe diredty reftrictive of the duration of the leafes that might be granted; though there was a later claufe referring to a refrieting one, which night thence be inferred to have been intended, though omitted; but nothing to indicate the extent of the reftriction feemingly intended. The tenants accepted the leafes, upon the opinion given them, that entails were, in their interpretation, friffifimi jur is, in which nothing could be infersed by implication beyond what was directly expreffed.

The late decifion of the Houfe of Peers, in the cafe of Trilicoultiy, in which it was found, that the hic of entail in poffefion was not debarred from even the $a b$ - 
fines at entry, (here defigned grafunis), which, by curtailing the tenant's ftock, difabled him, fo far, from carrying on improvement; yet (as credit could eafily be obtained, where needed, upon fecurity of leafes of fuch long endurance; difencumbered, as they were, from their very length, from all the abfurd embargoes upon agricultural credit, originating in the deprivation of the power of alienating the leafe, which is effential to the Gothic right of delectus perfone, fuppofed inherent in every proprietor of land), a fpirited ftyle of improvement immediatcly commenced; which, for expence of outlay, and diftant profpect of return, were (according to any ideas we had been accuftomed to conceive) fuited only to perpetual proprietors of land; and not at all to be expected from tem. porary poffeffors upon expireable tenures.

Almoft all of them have already built to themfelves, at their own expence, commodious dwellinghoufes, mottly of two ftories, and covered with flate; and alfo farm offices, in feveral inftances, of extenfive range, and including thrafhing machines, and covered in the fame manner. Plantations of wood have been made, as fhelters for the theep. Mr Murray, in Newlands parifh, has, for this purpofe, inclofed and planted from eight to ten acres upon his farnus.

Moft fubftantial improvements have been alfo executed upon the arable part of the farms of this cftate. Mr Symington, in Peebles parifh, has cut off from his theep hill pafture, on the farm of Edftone, by a head-dike of ftone, upwards of an hundred Scots acres of arable land; which he is fubenclofing into feparate fields, as each portion flall, by culture, be brought into a ftate worth feparate enclofure. Mr Gray, upon his farm of Lyne, in the parifh of that name, has completely fallowed, cleared

folute alienation of that eftate, mcrely becaufe the reftriction againf alicnation was not duly inferted in the refolutive claufe of the entail, (although directly expreffed in the prohibitory and irritant clanfes of that deed), would certainly feem, a fortiori, to render the fecurity of thefe long leafes unquentionable. The hardihip of entails is thus rcdreffed in particular iuftances, by refufing them legal fupport, upon any fpccious pretext. A geveral law would prevent the expence of particular applications, 
cleared of ftones, and fubftantially enclofed, in feparate divifions, by ftone dikes, five diftinct fields, confifting of about fiftecn Scots acres each; to be kept in conftant rotation of tillage, under a courfe of five flifts, viz. turnip fallow, barley with grafs, hay, oats, peas; thus enabling himfelf to render his theep and arable farming mutually fubfervient, by fattening of his caft breeding ftock upon the turnip, to the great enrichment of the foil; or to connect the dairy to his theep farming, from the abundant green feeding to his cow's, of clover cut green in Summer, and of turnip in Winter *. Mr Alexander, another farmer upon this eftate (already mentioned in the note, page 94.) in the farm of Eafter Happrew, parifh of Stobo, befides building a flated dwellinghoufe of two ftories, with a convenient court of farm ollices, all likewife

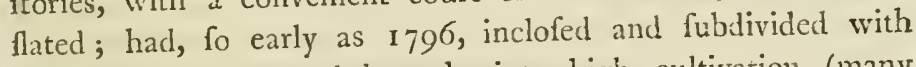
with ftone dikes, and brotight into high cultivation (many acres having coft at the rate of 30 s. per acre for clearing away ftones, befides thofe ufed for building) no lefs than one hundred and twenty acres of arable land; an exertion, at leaft, equal, if not greatly fuperior, to any that has ever yet been made, in this county, on any one farm, in the fame fpace of time, by either farmer or proprietor: This was part of his fcheme, fince followed out, of inclofing one hundred and fifty Scots acres, fubdivided into ten feparate inclofures of fifteen acres apiece, intended to be kept under a conftant rotation of tillage, which admitted of recurring intervals of pafture $t^{\circ}$

From

* Mr Gray's land, which he interded to inclofe, being encumbered with earthfaft ftones, he, at firft going orcr, gave every field a complete bare fallow with lime, without any green crop; that, by repeated crofs-ploughings, he might be enabled to difcover every ftone which obftructed plonghing: thefe were blown to pieces by gunpowder. The encloing went on at fame time with the fallowing; the ftones, with which the land abounds, being ufed as part of the ma terials of the ftone dikes. His farm containing much low land, he finds profit in buying in theep to cat his turnip crop, rather than in fattening his own offcaft breeding ewes; which are kept on, through Winter, and fold, great with lamb, in the Spring.

t The farm of Eafter Happrew was a breeding Theep farm, of middling ex sent, in refpect to the number of lixep kept upon it; but containing, in its lower 
From the ceconomy necefiary to fuch extenfive undertakings, the ftones ufed in enclofing were chiefly gathered from the land; which, being rounded in courfe of repeated friction by the plough, ftand net fo firm in building, and occafion need of more frequent repair. Thofe, howevcr, who take a view of the many fimfy attempts at enclofure, by hedge and ditch, through the county, will not be much difpofed to difapprove of the ftone dikes apon Eafter Happrew. Our propenfities, in Scotland, feem to lead us to extravagance in the expence of

parts, a great extent of fiat land, and land of firch gentle acclivity, as is eafily cultivateable by the plough.

Before Mr Alexander's occupancy of this farm, it was managed in the ufual Ayle, already pointed out in defcribing the mode of occupation in peep farms.

Encouraged by his fuperior length of leafe, Mr. Alexander immediately faw the advantage of launching into a fcleme of farming, inferring more extenfive outlay of capital, and a mere diftant period of return, than what was any way fuited to the interelt of a farmer, upon the tranfitory fecurity of a nineteen years leafe; and which, of courfe, was unprecedinted in the accu?tomed practice, formed in confonance to the vicws fuited to this fhurt, but ufual, tenure of the farmer's poffertion.

He detcrmined upon a fyftam that hou'd make his theep and arable farming mutually fubfervient to cach other; and which, properly to accomplih this object, inferred an extenfive enclofure of ethe araite part of the farm.

His original fcheme was, to fatteg all the beep reared uan his farm, by the means of improves palture or turnip fediug, upon the low arabie parts of the fulm; inflead of difpoling of them, as they were formerly wont to be difpofed of, for holding flock: In Mort, to feed all thit he rcared upon the farm, and: to rear all thue lie forl, whether flucep or black cattic. In this way, his hill heep were to be bronght to that fupcrior value thcy would pofts, when difirofe' of

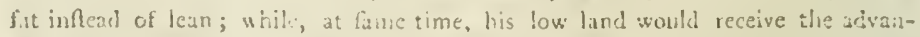
tuge of the dung, wrine, and paddling of his neep fed upon the turnip telds;

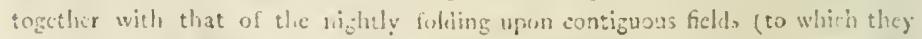
could be earsicd from, and fr m which they could be remitted to their palture with little internption) of his ewes and lambs feeding, through Sunmer, upin his improed pafure parks. A nonibir of bullocks were alfo to be annually brod, in order that the cant, of proper sge, miglit be lionfe-fer wich turmip; while the

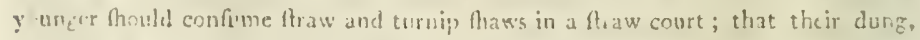
ingether with that of the other houfed labouring or milking cuttle, wight be

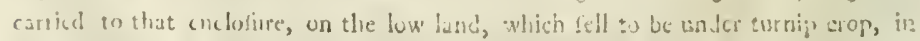
the courfs of the rotation. 
means, difproportionate to the ultimate profit to be obtained: Witnefs the canal, made previous to the trade, betwixt the Fritlis of Forth and Clyde, upon a fcale that has admitted of the paffage, without unloading, of a fivip direct from Sweden; which, for many years, yielled I per cent. to the fubfcribers, and was at laft finined by aid from Government. Inclofure

The rotation propofed, was that of ten hifts, correfponding to the number of the inclofures, viz. Int, turnip with dung; $2 d$, barley (or oats on the wildeft ground), fown down with grafs fecds; 3 d, hay; 4 th, 5 th, 6th, 7 th, pafture: $3 \mathrm{~h}$, oats; 9 th, peas; Ioth, oats; or (if it fiould be found more eligible), after the hay, to have the 4 th, 5 th, $6 \mathrm{th}, 7 \mathrm{th}, 8 \mathrm{th}, 9 \mathrm{th}$, pafture; the Ioth, oats; when the rotation re-commences. A fcheme, too, was laid down for bringing into culture, fuch parts of unenclofed arable outichl, contiguous to the enclofure, as lay on fuch feeper declivity as made it inconvenient to carry dung to it in carts; and this was by folding upon it, with the fheep fceding in the enclofures: The land to be fo folded, is ploughed the year before folding; and, early in Spring, is crofsploughed, and reduced by the break-harrow, then ploughed again, and fmoothed with the common harrow; a broad border all around being referved unplonghed, to afford fod for building the fold dike : After being cunged by the folded thees, it receives a fourth ploughing, when it is fit to be ridged for fowing drilled turnip. Mr Alexander informs me, he divides this fold into three ciftingt parts, by dike or wooden flakes; the two firf parts are teathed, in time to produce the one very good, and the other middling turnip; the laft is ton late of teathing to be fown for turnip, but in fine preparation to be fown out, the fucceding feafon, with oats and graffes, along with the two parts which carried the turnip: If he can get it accomplithed, thefe folds are limed either before the admifion of the fleep, or the fowing of the turnip, or the fowing off in grafs: and the fame general principles of rotation are adopted in thefe lands, as in the enclofed land.

When Mr Alexander commenced practing upon this fyftem, he brought down anuually a certain portion of his bill ewes with lamb, and fattened both lanb and dam upon the artificial pafture of the enclofures; teathing fome of the outfield as above; or (when he began enclofing) teathing what was to be next enclofed, (which, in part, was but outficle), by folding them upon it. A fpring crop of late Lown turnip upo: part of this teathed land, put it in his power to have the next year's portion of ewes for fattening earlicr tupped; as, from thefe fpring turnip, they had food to bring then in milk, before the fpringing of the grafs; one inprovement in agriculture thus always facilitating the fitcceding ones. Whilf he continucd to fecd his own hill theep, he kept always the lumbs of his rery youngent ewcs for brceding liock; as the oliter, being lof reflefs, and having more milk, fed both themfelves and their lambs beter, under confinenent of exchofure; it is anufual to retain the laubs cf youncen cues for brecling nock, becaufe their 
is but the mean to impart command of the foil for converfion to agricultural improvements: If the expence of the execution of the mean fhall deprive us of the power of accomplifhing the end, our county proverbial ftory will become applicable;-of the boy who bad got a penny, and laid it all out in the purchafe of a purge to keep it in.

Such, then, are the exertions which, in this county, have been excited, upon the fecurity of the fifty-feven years leafes. From the agricultural report of Berwickfhire, it would appear, that this pattern county of Scotland has alfo owed its fuperior improvement chiefly to the ftrenuous and oconomical exertions of the tenantry, under the excitement of the fecurity of leafes of long endurance.

In fo far as I can obtain information, we have had no experience in this county, of the effect of the thirty years leafes, which,

lambs are always of lefs fize; but $\mathrm{Mr}$ Alexander perfuaded himfelf, from anatomical reafons, as well as from analogy to what takes place in the human fpecics, and other animals, tlat, though the firft-born of the mother is the leaft, as an infant, this prevents it not, at mature age, from attaining to the ufual fice of the animal of that fpccics.

Such are the general ontlines of Mr Alexander's practice. He writes me, that, of late, he has altered, in fome refpects, his original fyftem. His rearing bullocks, being kept on improved pafture in Summer, did not Winter fo well upon ftraw as thofe from coarfer Summer pafture; he therefore now buys in winterers to carry on to, or half fed beafts, for immcdiate Winter houfe-feeding upon turrip. He fays he has alfo begun, fo far, to alter his fyftem as to fheep: He retains his former black-faced breed for his hills, but is getting a finer wooled kind for his low improved pafture; and thefe two breeds he kecps perfeetly diftinct: The kind he has chofen for his low pafure, is a mixture of the Mugg with the Bakewell, which he looks upon as the handfoment fhecp of any he has feen introduced into the country; the experiment is, however, but newly hegun. The gmatity of land annually teathed by 300 ewes with their lambs, paftured in the enclofires on improved pafture, and folded on the ontficlds, as above cxplained, was cight acres; and the profit of their dung, eftimated from the crops it enabled him to procure, in a fituation where no dung could otherwife be procured, he cftiinates at the ratc of 25 , annually from cach theep.

A ten courfe rotation of this kind, upon land, too, of which a great part had to te bronght from a ftatc of nature, at a great expence; together with cnclofing, entirely at the farmer's expcnce; all this conftitutes a fchcme of farming which Mir Alexander thinks lic could not have adopted, confiftently with lis intereft, ipon a leafe of fher:er cndurance than the threc ninetecn years. 
which, by act of Parliament, roth of his prefent Majefty, proprietors of entailed eftates are empowered to grant, upon condition of the total enclofure of the farm on the part of the tenant. In many infances, the fee-fimple of the farm might not defray the expence of the enclofing; or the expence might be altogether difproportionate to fuch additional benefit as is reaped through means of enclofure; or enclofure (as in Carfe lands, where there is no pafturing of cattle) might be of prejudice; or univerfal enclofure might be ufelefs, though partial enclofure might be highly advantageous. In the act, no modification is allowed, any way equal to the variety of differences that may occur; which, indeed, it is imponible to forefee, and provide for; and, for which, a proper modification of the general principle could alone be fettled, with propriety, by a Jury upon each particular cafe. Tenants, in mont cafes, it is faid, prefer a nineteen years leafe, with its ufual legal privileges, upon entailed eftates; rather than fubject themfelves to the legal preftations, fo often inexpedient, which they would be fubjected to, upon embracing the advantageous duration of leafe held out to them by this act. After fome inquiry among men of bufinefs, I have heard of few inftances of leafes taking the benefit of this ftatutory latitude. The bill, I have underftood, met with fuch clamorous oppofition from eventual expectants upon entails, that its fupporters were obliged to compromife the matter; and to content themfelves with what they could obtain, fince they could not obtain all they could have withed. If it is thought expedient, that, in this inftance, public utility fheuld interfere in counteracting the cramping influence upon improvement, produced through the policy of entail, it would feem that this act would need to undergo a revifion; elfe it muft continue, as it hath hitherto remained, in a great meafure nugatory:

In a country already imprọved, where the tenant enters upon immediate acivantages, without necellity of great advance of capital; leafes may, with lefs inconvenience, be of fhorter duration: But in a county like Tureeddale-where fo little, till of late, hath been done-where fo very much remains to be 
done, to carry improvement to its attainable height; particu. larly in rendering theep and arable farming mutually fubfervient, by means of fubftantial enclofure, as well as of furface culture; long leafes feem indifpenfable. Fifty-feven years may probably be more than neceflary, though thirty might not be fufficient; unlefs, indeed, we were to fuppofe fuch permanent improvements to be univerfally executed by the proprietors; which few of them could attempt, without borrowing money, which they wonld fcruple to rilk; and none could execute, but at almoft double expence at which they could be executed by tenants having fufficient intereft in the execution.

\section{SEct. VI.-Expence and Profit.}

IT hath often been obferved, that agricultural calculations are extrensely fallacious. In regard to moft of them, the prefumption is, that the refult is the firft thing determined, and that the data of the calculation are then fabricated to give that refult: The variations in the extent of crop, according to difference of feafons, with the variations in price both of corn and cattle, from the varying rate of markets, allow of great latitude of aflumption as to the data; without incurring danger of offence to probability: Befides, without any direct intention to deceive, farmers are apt to be betrayed into extenuation of their profits, from anxiety to conceal then ; whilft projectors, for the creciit of their fchemes, and proprietors, indulging flattering imaginations of the value of their lands, are mifled into exaggeration; even the reporter of a colinty, through a confined fort of patriotifm, is tempted to give importance to the place of his nativity, by magnifying the value of its produce. Pofferfing, myfelf, fmall knowledge of fuch details, and aware of fuch multitudinous caufes of deception; I have judged it unneceffary, either to fabricate detailed ftatements myfelf, or to procure fuch fabrications from other hands; in the conviction, that, notwithntanding the appearance of accuracy which they exhibit, nothing certain is to be learned from thens. 
If any one choofes to make calculations of the value of the produce of theep farms, in order to afcertain what rent they may afford; the data of fuch calculations are laid before him, in the tables already given, of the produce, and application of the produce, of theep, in theep farms, of different defcriptions. And if he confiders the rates of price, as they exifted at the end of the American war, whofe effect feemed to be the depreciation of every article of farm produce; or as they exifted during this war, which feemed as much to augment their value-if, in particular, he attends to the extravagant enhancement of the price of theep in the feafons $\mathrm{r} 80 \mathrm{I}-2$, apparently occafioned by the diminution of the breed of black cattle, through hunger or the butcher, in confequence of the extreme dearth of fodder of crops 1799 and 1800 ; he will then find a latitude of fuppofition in refpect of prices, to the extent of difference of more than two to one. For example, he may ftate the price of the wedder hogs of Table I. at any price, from 7 s. to I 5 s. apiece; the caft-off breeding ewes, if fold to the butcher, or for farther feeding, at Martinmas, from 6s. 8d. to 16s.; or, if kept through Winter, and fold heavy with lamb to the grazier, from 8s. to Il. 4s., the wool from 2s. 6d. to ros. per ftone. The price of wedder lambs in Table II. might, in fame way, be ftated at from $3^{\text {s. }} 6 \mathrm{~d}$. to $8 \mathrm{~s}$; ; the ewe lambs, from $3^{\text {s. }}$ to 7s.; the cant-off breeders, and the wool, at the fame prices as in Table I. In Table III. the fat lambs, from 4s. 6d. to 103.; the cant-off breeders, at MTartinmas, from 8s. to I8s.; wool, from 4s. 6d. to izs.

Having, from fuch ditis of what has been, afcertained what will be the probable price of the produce of the farm during the currency of the propoied leafe; our calculator's next bufinefs will be, to thate the charges that fall againft the produce; and thefe are, the intcreft of the capital advanced by the farmer, the gurrest expences of management, together with that remuneration to the farmer, above the mere intereft of his capital, which may induce lim to take the trouble of managing its application himbif, rather than le mit it to anether who would 
pay him interef for it, without putting him to any manner of trouble.

The capital advanced, in all breeding farms, is the purchafeprice of the breeding ftock, at Whitfunday, the conmon and proper term of entry to the farm. As the bringing of ftrange fheep into a farm, particularly from better and more fheltcred pafture, to what is poorer and more expofed, is ever attended with rifk: As even, in many farms, ftrangers are apt to take difeares which are not incident to the natives: $A s$, in every defcription of farm, fheep, habituated to the ground and its boundaries, are eafily kept upon it, without need of ruch moleftation from the fhepherd's dog - a circumfance which, for the firf year, will make the farm fuffice to graze a confiderably greater number of theep that have been bred upon it, than of frangers brought from another farm: For thefe different reafons, the intrant tenant is willing to pay at the rate of ten or twelve per cent. more of price for the holding ftock of breeders upon the farm, than any other defcription of purchafer could afford. The intrant tenant would be willing to give that price for the whole ftock of breeding ewes (excluding merely the hogs retained to fupply the ftock), which a grazier could afford for the ewes of full growth, and in full vigour; that is, for the Itock, exclufive of the hogs, the gimmers, and the crocks. Thus, the ftock of farms (Tables I. \& II.) might be eftimated, with the latitude already noticed, at from about 9 s. 6d. to 11. 8s. apiecc; and the hogs retained for keeping up the ftock, from $8 \mathrm{~s}$. to $17 \mathrm{~s}$. The ftock ewes of Table III. at from I Is. to 305 . ; and the hogs, generally bought in as lambs upon fuch farms, at the fame price as thofe of 'Tables I. \& II. In Table I. the ftaple difpofeable produce being hogs, and the time of marketing them being the beginning of July, the outgoing tenant muft make bargain with the intrant, to allow them to remain upon the farm from Whitfunday, the term of entry, to July; or the intrant muft purchafe them at a price-fomcwhat inferior (fay by from $6 \mathrm{~d}$. to Is.) per head cheaper, than what may be fuppofed will be the market price at the marketing feafon. In regard to all thefe farms in the Tables, as the bargain for the 
ftock is generally made fome months previous to Whitfunday, the ewes are all fold under infurance of their being pregnant, and a fmall deduction of price is allowed in every inftance that fhall afterwards occur of mils of lamb. The deduction for mifs of lamb is not, however, confiderable; becaufe the price fetched by a barren (or yeald) ewe at Martinmas, will, from her fuperior fattening, prove little inferior to what is fetched, upon the whole, from both a dam and her lamb for the feafon; the dam fattening lefs, from the exhauftion of fuckling her limb. If there is no arable land upon the farm, family maintenance ought to be ftated to capital advanced, for the period intervening betwixt the term of entry and the commencement of the fales from the farms, as marked in the tables; as alfo, maal for the herdinen, the reft of their fee being paid in the privilege of grazing a certain quantity of theep along with the mafter's. If there is arable land attached to the farm, a feparate account may be opened for it; the family maintenance may be charged againft it ; and will accordingly fall to be ftated to account of capital advanced for one year and an half, or till the fecond Martinmas after entry to the farm, when the intrant reaps his crop.

The current charges to be ftated againft the annual returns, where there is no arable land, are, maintenance for the farmer's family; meal, at the rate of $6 \frac{1}{2}$ bolls of oat meal per aimum to each, for his herdfmen, the reft of their maintenance being compenfated by privilege of grazing a cow, and her Winter's fodder, from coarfe natural hay of the farm; amount of falving (or fnearing) with tar and butter, at the expence of about 4d. each; the expence of feeding the fheep, when neceffary, in fnow ftorms, at the rate of about $\mathrm{I}_{4} \frac{x}{4}$ pound Englinh weight to each fheep through the 24 hours; marketing expences, and allowance for incidents.

After deducting thefe current charges, together with double intereft for the capital advanced, to compenfate the tenant's perfonal trouble for employing it himfelf, infead of lending it out at intereft, with an allowince for tear and wcar, and 
for infurance, the remainder of the produce fhould go for rent.

'The herdfmen, as obferved, are allowed, in general, to graze fo many fheep along with the mafter's, in lieu of money-wage; thus fecuring their diligence, by giving them a common intereft in the concern, as copartners; though, in this way, there is a temptation to make all the incidents of mifs, or death of lambs, fall to the fhare of the mafter. The common extent of this allowance is, upon farms of the defcription of Tables I. \& II., the grazing of from 45 to 50 , including the hogs retained for keeping up the herdfmens ftock; and in the defcription of Table III. from 30 to 35 , hogs alfo included. The Tables fhow the ftock kept by the mafter.

The proportion of produce from the fheep, to that from the arable lands attached to the fheep farms, varies in every farm. In the greater part of Tweeddale fheep farms, the produce of the arable part, is accounted little enough to be allowed for family and herds maintenance, or a few more of the current charges; and the rent is expected to be paid folely from the produce of the fheep. 
CHAP. V.

I M PI. EMENTS.

OUR improved implements being all derived from more earIy improved counties, in the furveys of which they are defcrib ed, it would be fuperfluous to enter into minute defcriptions of them in a report of 'Tweeddale.

Plougks, ufed for land eafily tiller, are, within thefe few years, almoft all of the conftruction introduced by Small, with knee'd coulter, and curred mouldboard, fuch as is recommended by Dalkeith Farmers Society, and double muzzle, to temper the direction, and regulate both the breadth and depth of the furrow-lice. The Scotifs plougt, of a light confruction, is preferred for lands abounding in ftones; its fuperior length of heach rendering it lefs liable to be joftled from its direction. This fame plough, of froing and weighty conftruction, is allo preferred for tearing up coarfe lands from a ftate of nature, when covered with heath, bent, whins or fprots; in which cafe, oxen are commonly conjoined, in the draught, to horfes. The Scotifh plough, with mouldboard of ftraight deal, may probably anfwer nearly as well as any other, in land which is covered with firm fward, and where the furrow-llice turns over continuous, and without crumbling to pieces; but, in funely pulverized foil, it can hardly be expected to cifict more than merely pufhing the earth to one fide: In fuch foils, the curvature of Small's ploughh, continued from the rery point of the fock to the cxtrenity of the mouldboard, fecms indifpenfabie to make the plough carry on the fourfold operntion of ahtiruting 
the furrow-lice, raijing it up clean, removing it to one fide, and reverfing it, to expofe a new furface to the air.

Cleaning ploughs, of various conftructions, are ufed for urefling drilled crops, on green crop fallow; fuch as, the one with double mouldboard, for fetting up the earth to the drills. Very commonly, both proceffes, of paring earth from, and fetting it up to, the drills, are performed with a fingle mouldboarded plough; no doubt, with confiderable lofs of time in the latter procefs. We have a paring plough, of very light conftruction, with a right-hand mouldboard fixed, and a lefthand one, which can be taken away at pleafure; which laft one is alfo provided with a regulator, to fet it at a greater or lefs width, when the plough is ufed as a double mouldboarded plough. 'Two inftuments, for reverfe purpofes, are, thus, œconomically comprehended in one, though the latter purpofe may be a little more imperfectly performed. We have feen, in the neighbourhood, a double plough, with two diftinct coulters and focks and mouldboards, (the two mouldboards placed, the one on the right-hand plough, upon its left fide; the other, on the left-hand plough, upon its right fide-fo as to turn their furrows againt one another, into the interval betwixt the two ploughs.) It goes in the interval betwixt two ridges, and muft evidently appear a very imperfect inftrument, liable to be impeded by a very fmall ftone or clod fticking betwixt the mouldboards, at the hindermoft ends, where they muft neceffarily approach very near to each other. We have heard, but Lave no experience, of another kind of double plough, which goes along a fingle ridge, paring both its fides at once, and throwing the earth off to right and left, the crop upon the middle of the ridge efcaping in the interval betwixt the two ploughs. A defcription, with a figure of this plough, is given in the Scotifh Farmer's Magazine, No. IV.-(a work which feems to be ably conducted; promifing to be of great ufe in diffeminating the knowledge of practical agriculture, particularly as, I am informed, its extent of circulation has already far cxceeded the hopes of its molt fanguine fupporters.) A new mode of paring the drills of turnip fields with a fingle mouldboarded 
plough, lately fallen upon by Mrr James MPDorgal at Linton, formerly mentioned, may probably fuperfecle, as to that fallow crop, the ufe of both thefe kinds of double plotghs. He pares only one ficie of the rilge, going as near as may be to the plants with the plough, and throwing the furrow-flice (overhapping and overwhelming the untouched weeds) clofe to the foot of the plants upon the ridige on the right hand. The operation is reverfed, at next going over the field. The inconvenience of obftruction incident to the firft mentioned double plough, cannot here occur; and the inconvenicnce of paring both fides of a ridge at once, ariing from too much expofure to drought, is alfo equally aroided; while, at fame time, this half-paring fufiices equally well, and, in fome refpects, bctter than the whole paring, in equal time, performed by the double plough. Sir George Montgomery of Magbiehill, (who is curious in agricultural inftruments), has introduced a paring plough, upon the principle of the Dutch hoe, which, at one operation, cuts the weeds in the bottom of the furrow betwixt two ridges, paring or fcraping alfo the fides of both.*

A draining plough, of his own invention, has been fuccersfully ufed by Mr Sanderfon upon his fmall theep farm, which he rents near the village of Linton. It is drawn by fix horfes; and, by means of one coulter defcending to the left from the beam, and of another coulter (or wing, like the cutting wing of a peat fpade) rifing up to the right from the fock, it cuts, and clears out, at once, a drain of two feet by eighteen inches. It might be of great ufe in many fheep farms, in draining foft boggy lands, where its operation would not be obftructed by ftones. The miner, a kind of draining plough, has, very lately, been introduced by Sir George Montgomery. It hath a very ftrong beam, into which is fixed a long and ftrong coulter, to clear, in part, a pantige for the fock ; which is a pointed piece of caftiron, of about fffeen inches in length, round, about the thick-

neis

* In No. X. of Farmer's Magazine, an acconnt of a plough, with a coulter rifing upward from the fock, is given, which promtes mucl: adrantage as a paning plought. 
nefs of a man's arm, and comected by a ftrong broad bar of iron to the beam. It is drawn by fix horfes. It is intended to follow in the furrow after another plough, the fock going deep in the till, and forming, as it goes along, a conduit-pipe for the pafiage of water. Rven fuppofing the conduit, fo formed, not to remain for any tine permeable by water, the very breaking of the till, fo as to allow more water to lodge in it, muft conftitute a very confiderable improvement in thin foils, upon a retentive till bottom, as, in this way, fuch foils may receive and hold more rain-water, without poaching; nor will the moifture be fo fuddenly exhaled, as to caufe them cake in drought.

Drill-sloughs, (or Barrous), for fowing turnip-feed, all agree, now, in this part of their confruction, that the feed is made to pafs from a covered hopper, down a fpout, at the back of the coulter, into the rut made in the ridge by the coulter; thus fecuring the feed againft both wind and rain in time of fowing. The machine runs upon two wheels; and, in one kind of confruction, the wheels are made faft to the axle, which pafies through a brafs nut, in which the hopper terminates, from whence the feed is received into dimples in the axle, which, as it tums round, delivers it into the fpout fixed to the back of the coulter. In another conftruction, the feed is put into a tin canifter with fome fmall holes in it, which is hung over a funnel comnected with the fpout; and a piece of foring iron, attached to the canifter, is ftruck by the fortes of one of the whecls fucceffrvely as the wheel turns romin, in order to flate out the feed. In the finft conftruction, the feed is fometines apt to be bruifed betwixt the iron axle and the brafs nut, and to clog up the dimples; the laft confrect:on is more fure in forving, and is getting moft into ute. A very fimple drilling fower, for fowing larger feeds under furrow, is defribed in No. VI. of the Farmer's Magazine; it is fixed to a furemoft plough, dropping the feed into the furrow made by it; two other ploughs follow after; fo that every third furrow is fown. 'Flis drill-forver has been thus 
thus fatisfactorily ufed, this Spring, by Captain M'Kay of Scotfton, and Mr Loch of Rachan, in fowing peas.

Rollers are ufed of folid ftone, or of folill wood, generally beech or plane: Some gentlemen have had them of a hollow cylinder of caft-iron: They are fometimes in two pieces, upon a common axle, to prevent heaping of the earth in turning. Harrozss, in ordinary ufe, are the commoni ones mentioned in the report of Mid-Lothian. Break-barrozus are ufed, with teeth of fquare iron, the corner of the iron going foremoft. Flat coulter teeth, drawn edge foremoft, have been ufed; but they do not feem to be confidered as of the beft conftruction, as, when the harrow is driven from its direction, by obftructions, (fo often occurring in the land to which it is applied), the flat fide of the teeth coming to be oppofed to the draught, creates a refiftance almoft infuperable:

One-borfe coup carts are almoft tiniverfally in ufe. The common calculation is, that doible-horfe carts carry a load in proportion to that of one-horfe carts, only as three to two. As it takes but one driver to manage two one-horfe carts, it is evident that, with thefe, he could carry a load as four, while, with two horfes in a double-horfe cart, he could only carry a load as three : not to mention the additional eafe to the horfes, which muft be both well broke and filfully drove, when acting in concert in the double-horfe cart, in order that they may thare equal fatiguie.

The fraiv-cutter, confifting of an iron wheel, turned round by a handle, which is provided with fteel knives fcrewed into its periphery, and with rollers which feed in the ftraw to be fubjected to the operation of the knives, whofe motion is alfo produced by the fame handle, has been recently introduced from England by Sir George Montgomery; as alfo, a very fimple machine for cutting Swedifh turnips far hor:es.

Fanners, a winnowing machine, faid to be an invention of Papin a Dutchman, are univerfally ufed through Scotland; it is believed to be but of late, if this machine is, as yct, fo univerfal in England. No farmer in Tweeddale, renting to the extent of 201., or even lefs, is unprovided of fanners. The 
machine, even under the late dearth of wood, colts not above 21. I0s. Its principle is, the whirling round, with great velocity, four flat boards or vanes fixed to an axis within a wooden frame, by means of a handle and multiplying wheels. The current of air thus gencrated, is confined by the frame, which covers the vanes all round, with an exception of an opening for admitting air, and directs the current to the further end of the frame, which is open. Meanwhile, from a hopper fixed upon the top of the frame with a loofe bottom, (which is agitated by the motion of the machine), the grain falls down through the frame, before the current of air ; the chaff is blown out at the further end of the frame; the lighter grain goes over a partition into a receptacle; and the heavy grain, which the wind cannot force over the partition, falls nearly perpendicular into the bottom of the frame, whence it is difcharged by an aperture for the purpofe. Before the introduction of this molt ufeful machine, much time was loft at the barn, and at the mill, in waiting for the natural wind, to feparate the chaff from the corns, or the hufks from the ftripped kernel. Every barn was provided with two doors, oppofite to each other, to admit the wind, which, in thefe latitudes, is moft generally from the weft; and cuftom has continued this fafhion of conftruction, though its reafon has ceafed. The Englifh practice of cleaning grain, by tofling it from a thovel, the heavieft flying fartheft, and the chaff and lighter grain falling at a nearer diftance, feems not to have been adverted to. By every corn-mill, a knoll top, on which the kernels were winnowed from the hufks, was defigned the freeling-bill.

When fanners were firft introduced, upwards of 40 years 2go, it is faid that fome of the diffenting clergy lifted up their teftimony againft fuch profane innovation; as marking a miftruft in Providence, in thus fending for a wind of our own, and not waiting for a commiffoned wind. It muft be confefted, that a fimilar religious prejudice has, in this country, been oppofed to the practice of inoculation for the fmall-pox: It has not militated againft the cow-pox; becaufe that pox is not look- 
ed upon as a difeafe, and the infertion of it is, in courfe, confidered as an indifferent act.

The number of fanners in Tweeddale is nearly $35^{\circ}$; they are now an appendage of all the thrafhing-machines.

Thrafbing-Mills.-The number of thefe, as already obferv$\mathrm{ed}$, have greatly increafed, amounting at prefent to 18 going by water, and 24 driven by two horfes each. Though the arrangement of machinery can render the fmalleft power equal to the overcoming of the greateft refiftance, by multiplying proportionally the velocity of the agent's motion, over that to be ultimately communicated to the patient; yet, where a given refintance is to be overcome, and a given velocity is at fame time to be preferved, no fuch aid can be derived from mechanical contrivance; but a ftrong acting force is indifpenfably neceffary. Such is the cafe in the thrafhing-mill; in regard to which, the moving power can probably admit of littlc aid from contrivance, excepting merely what may be given it by the diminution of friction. The only other contrivance I have ever yet heard of, which promifes to give aid to the moving force, is one mentioned in the Addenda to Dr Douglas's Report of the Counties of Roxburgh and Selkirkfhires, page 369 ; and that is, the placing of the fwitchers, or beaters, upon the drum, in a line, crofling, at a fmall angle, that of the drum's axis, inftead of being placed parallel to it, as has hitherto been their pofition. This will certainly diminifh the refiftance of the ftraw to the ftroke of the fwitcher; inafmuch, as the fwitcher, inftead of ftriking, at once, the whole ftraw prefented to it over the fwitching-ftock by the rollers, will ftrike it all in fucceffon; and will thus meet with a comparatively finall refiftance, from the frmall portion of the ftraw ftruck at once, in each inftant of this fucceffion: The advantage will be the fame as that of drawing $a$ froke, in cutting with a fabre, or in thaving with a razor. If the fame number of fwitchers are applied to the drum as in the prefent conftruction, but placed allant, fo as to occupy, each, the precife place of the diagonal drawn betw: $x t$ the oppofite ends of two fwitchers, lying parallel to the axis of the cirum, as in the prefent conftruction; it is evident, that the above flated 
advantage would be perfectly gained: And, at fame time, as there would be no intermiffion between the ftrokes of the fwitchers (the ftroke of the following fwitcher commencing at one end of the drum, in the very inftant that the ftroke of its predeceffor had finifhed off at the orher end); it is alfo evident, that the motion of the machine would be perfectly equable and continuous, without intermiffion or fhake. One objection I have heard ftated to this conftruction is, that the flanting fwitchers would have a tendency to propel the ftraw before them to the farther end of the rollers, and to create additional refintance, by collecting it there into greațer thicknes : An objection which,.. feemingly, might be removed, by forming notches in the prom jecting bars of the fluted rollers; the notches in the one bar being always placed oppofite to the unnotched part of the one next to it. After all, the equability of the motion may, probably, be confidered as a matter of tafte, more than of real ufe ; otherwife, the diminution of the velocity of the ftroke, by its gradual flanting application, would (from the proportional diminution of the refiftance) admit of the redrefs of greater multiplication, from the confruction of the multiplying wheels-fo as to attain to nearly equal velocity in the beat, from the fame moving force: whilf, at fame time, the equability of motion might be preferved.

Intelligent practical mechanics are the beft judges of thefe matters. Nor would I have prefumed to ftate the above fuggeftions, had not the improvement been ftated, in the Report alluded to, as the invention of a practical mechanic.

The fpeedy diffulion of fuch an expenfive machine, in fuch a poor county as Tweeddale, to the difference of from thirteen to forty-four in the fpace of three years, may be juftly held as a decifive proof of the great utility of the invention. The extent of yield of grain, from this mode of thraning, above what is procured from thrathing by flails, I have underitood, from thofe well acquainted with the fubject, to amount to the odd's of one in twenty; and that the wages of the labourers required to aflift, when the machine is at work, amount to no more than what would have been neceffary to merely winnow by the 
fanners the quantity of grain made entirely fit for market by this operation of the machine; and that, upon a farm of any confiderable extent, the amount of this faving of hand-labour would readily repay the whole of the capital funk upon the machine, in the fpace of three years.

The thrafhing-machine is probably the moft ufeful invention ever introduced into the mechanical fart of farming, next to that of ploughing with two horfes without a driver: And the profit, like that of every other invention by which increafe of product, and diminution of expence is procured, muft ultimately tend to the increafe of the value of lands. I am forry to be informed, that the ingenious inventor, Mr Andro Meikle, has not been able to derive fuch advantage from his invention, as is in any way adequate to his remuneration; being, like moft great mechanics, fo abforbed in his favourite contemplations, as to be incapable of paying that attention to his intereft which might enable him to turn his talents to his own advantage.

Time was, when inventions for facilitating labour, through -mechanical contrivance, wexe looked upon, by labourers, with an evil eye; as tending to deprive them of employment and of bread: Political reafoners have alfo declaimed againft them, as tending to diminifh population. Thefe prejudices feem to have nearly vanifhed; it being univerially underftood, that fuch inventions can never come to be generally alopted, but in proportion as they are found to enrich their employers, in faving the outlay of capital, or in rendering the outlay more productive : But capital, faved or augmented by the addition of product, can yield no revenue to its proprietor, till it is confumed, in form of wages, by productive labourers-like, as ftraw cannot be converted into dung, till it has nafed through the bellies of the catter. 
C H A P. VI.

E N C L O S I N G.

IN hearing of the meafure, agitated in England, of a bill for general enclofure, it furprifes a Scotfman, when he is informed that the bill is intended for the purpofe of dividing into feparate diftinct properties, the lands held at prefent in conjunct property and poffeffion: $\mathrm{He}$ is led, neither by the law's nor the practice of his country, to confider the enclofure of commonlands, as infeparably connected with their divifion : He is therefore difpofed to interpret enclofure in a metaphorical fenfe, as implying the mere ideal enclofure of the divided lands within the comprehenfion of feparate property. If in Scotland, as in England, actual eaclofing were neceffarily to follow upon divifion; this incurred obligation to enclore, would have proved, in general, an abfolute bar to all application for divifion; as, in moft of cafes, the fee-fimple of the commonties to be divided, would not have fufficed for the expence of feparate enclofure.

There are, in Scotland, general laws relative to divifion, folely; by which, upon application to the Court of Seffion, from any of the parties having intereft, a divifion, according to refpective intereft in the fubject, proceeds, after a manner both fimple and unexpenfive. But no obligation to enclofe refults from the act of divifion: there are feparate laws for enclofure; and to thefe, recourfe may be had, when the intereft of thofe concerned thall fuggeft to them the propriety of fuch a meafure.

The Scots ftatute for divifion of commonties, is of the date of 1695 ; and for enclofure of feparate properties, the ftatutes, 
enforcing ftraighting of marches, and mutual expence of marchdikes, are of the earlier dates of $166 \mathrm{I}, 1669,1685,1686$. As the Union of the two Crowns, and confequent intercourfe between the two nations, has fubfifted of fo much longer date than the earlieft of thefe ftatutes, it is furprifing, that the one nation thould have borrowed fo little from the inftitutions of the other.

Almoft all common-lands in Scotland have been divided; and, in few years, the poffeffion of land in common property, will be a fpecies of tenure unknown. I know of none fo held in Tweeddale; with the exception of a fmall piece of muirground in the parin of Eddleftone; as alfo of fome few acres of village green, never ploughed, lying around fome of the villages, and the town of Peebles; upon which the houfe-fed cows and horfes are turned out for airing, and the children enjoy their out-of-door fports, and wathed clothes are dried, \&c. \&c:-Cateris paribus, a village green is a ftrong determining circumftance of preference in choofing a fite for a boardingfchool.

But, though commonties may be divided, and every fpecies of conjunct property in land (fuch as fervitudes of pafture) may be feparated, upon fetting apart an equivalent in land for the value of that fort of poffeffion of it which is given up; the law of Scotland has recognized no neceffary connexion betwixt divifion and enclofure *. The parties dividing, may enclofe,

- The droit de parcour, or right of common hirfelling of cattle, to pafture in common at certain feafons, (a right complained of under the old rerime of France, as totally incenfiftent with every propofal of improvement of breeds), is unknown almolt in Tweeddale, and will foon be totally abolifned over Scotland. Winter herding las been enforced by laws of the fame date as thole referred to in the text. The proprietors of hill land pafurazes would appear to have often obtained, through mere fufferance and cuftom; the right of Winter downfall for thcir hecp, upon low lying contiguous araile lands, belonging to other proprietors; a cuftom which eafily crept in, when there were no Winter crops of grafs, turnip. \&c. upon the low lands, worth preferving.

In a cafe of this kind, at the village of Linton, where the right of Winter downfall was interpreted, ia praetise, as inforring "Lhat there was no obligation 
clofe, if they will; but are not necelfitated to enclofe, as ari implication from the divifion.

Whatever may be the cafe in more fertile counties in Scotland, a claufe, rendering inclofure a neceftary confequence of divifion, would, in many inftances, prove an effectual bax againft any application for divifion.

Where enclofure is wanted, it is provided for, by fpecial act for that purpole, that the conterminous proprietor hall bear one half of the expence of the march-dike, prefumed to be mutually beneficial: And this aid may be obtained by application to the Sheriff of the county, who is alfo authorifed to ftraight marches. Upon fuch application, thefe advantages of mutual aid are invariably obtained; excepting in fome fpecified inftances, where the other party is conceived not to have equal, or equally permanent, intereft in the enclofing, and where the enforcing of this privilege would be a hardhip; unlers that other party, ipfo facto, fhews that it is no hardfhip, by taking advantage of the march-dike in making enclofures of his own - when, though not originally bound, he binds himfelf by his own deed, and is liable to action of recovery.

'epon the proprietor of the dominant tenement, to herd his fneep from any Winter crop upon the fervient one; and where (from extention of the analogy of pafturing upon the grafs of the (tubbles) it was alfo inferred, that the dominant proprictor had a right to all the grafs growing upon the fervient tenement, even in Summer; " the proprietor of the fervient tenement brought an action before the Court of Seffion, for a declarator of the extent of this right of fervitude; which, after fuch interpetation, condemned his land to a comparative fterility, by excluding cvery attempt at the improved hufbandry. The Court found, that the rominant proprietor could not (through mere toleration of the other party of a practice whiln it did him no damaze) eftablith a right deftruetible of all farther improvement of the other's fubject; they found the dominant proprietor obliged to' herd his cattle from all Winter crops upon the fervient's lands; alfo, from all fown erafs, for $t$ wo years, both in Winter and Summer: So that, for a rotation of four or fice fifts, to which it is applied by the villagers who rent it, the lands are as effectually proteded by this decifion, as if they were completely encloied by a fence.- Such is the farour flown to iraprorcment by the Scots law and its interpreters, - The safe is tont of Chatto $v$. Lockhart, decided about twelrc ot foure tecll years $3 \mathrm{~g}$ 
It might, indeed, probably, be a difputeable point, how far a permanent proprietor, from fuch advantage being taken of his march-dike, might be entitled to compel a mere liferenter to pay half its expence; to which he could not otherwife be compelled.

In the cafe of a liferenter enclofing, it might alfo be difputeable, how far he could compel a conterminous perpetual proprietor to bear half expence of march-fences. It may be refufed on the one hand, upon the maxim, for moft part juft, that there can be no obligation where it is not mutual: It may be contended, on the other hand, that the law, impofing half expence upon a conterminous perpetual proprietor, has refpect merely to his permanent intereft as fuch; and thar, his intereft being ever the fame, it fhould make no difference, in the eye of law, whether he is called upon by one having a perpetual, or merely a tranfient intereft; particularly, in point of utility, in the cafe of unalienable corporation lands, whofe fituation, in refpect to his lands, cannot alter, and which could not therefore, otherwife, have ever a chance of being enclofed.

The penalties decerned by law for trefpafs upon inclofed lands, are perhaps more fevere than neceffary in certain cafes: their over-proportioned feverity prevents their fo frequent exaction, whilf their effect in terrorem may be the more pow. erful.

The only enclofures to be depended upon, for conining our Tweeddale breed of theep for fattening, (particularly, when it is alfo neceffary to exclude thofe which are upon coarfer fare and fhorter allowance on the outfide), are ftonedikes. The ftone enclofures generally ufed in this county, for that purpofe, are what are called Galloway dikes. 'They are of dry ftone, built firm, fmooth, and folid, till about $3^{\frac{3}{2}}$ feet from the ground, when large projecting ftones are laid acrofs, upon which a conical cope is erected, compofed of ftones, laid with fuch interftices as can be feen through; but, at fame time, clofely locked together: the whole height of the dike is generally five feet: the cope, from its tumbling appearance, intimidates every fpecies of animal; whilf, from its loofe 
contexture, it can be executed at lefs expence of materials. Thefe dikes are built at all prices, faccording to the eafe or difficulty of procuring ftones, or, as they are built at the expence of an eafy proprietor, or of an intelligent and Barp farmer $)$, from, perhaps, four thillings to ten fhillings per rood of fix yards, building and materials both included.

In feparating hill fheep-walks of flock fheep from the arable part of fuch theep farms, fences of the above defcription are the only ones which promife to give the fmalleft fatisfaction. In effecting this purpofe, it muft be confidered, that a great variety of foils muft be encountered; and that, though thorn hedges may be reared upon old croft foil, or what naturally has the appearance of loam, or upon rich clay foil; yet they cannot be raifed upon fand foil, mofs foil, moorifh, or hazel: the probability is, therefore, that in very few places will the hedge ever grow to the ftrength of a fence; and there is allo a certainty, that, let the hedge grow fo as to prove a fence againft any other fpecies of cattle, it will never prove a fence againft a Tweeddale fheep; when tempted by a ftrong incitement to break through it, they will contrive to wriggle their bodies through any interftice that gives admifion to their heads; and as, in fuch efforts, the wool is torn from the theep, fo the theep obtains ample revenge upon the hedge, as its wool will infallibly canker and deftroy the beft grown hedges. Inflead of lelps-meet, hedges and Tweeddale fheep are mutual plagues and curfes; they are confidered by Tweeddale Theep farmers as mere vexatiocis baubles: and certainly more money has been unprofitably thrown away, in this county, in attempting to make fences of thorn hedge, than upon any other abortive attcmpt at improvement. The fheep farmers upon Neidpath, cuclofing at their own cxpcnce, have univerfally had recourfe to Galloway fone dikes, in cutting off their arable land from the fhecp hill pafture; and even for the fubdivifions of the arable land, fo cut off, thefe dikes are almoft univerfally employed; although, in many inftances, the foil may have been perfectly fit to carry thorns to their full growth. Such men will certainly. be heid adequate judges of the moft profitable 
profitable outlay of their own money; and their practice I Ahould be inclined to hold as decifive of the general expediency.

Live hedges are unqueftionably a much more beautiful fence than a dead ftone wall; they alfo afford more fhelter; the ditch alfo, upon the face of which they are planted, acts as a drain: As, however, they are utterly inadmiffible as fences, where Tweeddale theep are concerned, thefe advantages muft be obtained by other means. Trees, in a few years, rife above the reach of theep; and, probably, the moft fatisfactory mode of obtaining both thelter, beauty, and draining, in the enclofures on theep farms, would be, to drive ditches parallel to the ftone fences, at fuch diftance as to admit a ftripe of planting; the fide of the ditch next the planting to be faced up with the fod raifed in forming the ditch, and what is taken out of the ditch (vernacularly the deeds) thrown behind this facing, to fupport it; the top of this facing to be defended by pegs, or paling, without which, no earth fence is in any degree a fence againt Tweeddale fheep: Such a fence, with a few repairs, might proted the trees till above reach of the theep.

It may be noticed, as a proper piece of oconomy practifed by the Neidpath farmers, in their enterprizes of enclofing, that they never enclofe till the field is, by culture, brought into a ftate worth enclofing, fo as to yield immediate intereft for the enclofing money. They therefore enclofe in that feafon when the field is in preparatory fallow; by which means, the ftones removed from the field aflift in building the dikes, faving both materials and carriage; and the enclofure is of profitable advantage the very firft year of its crection.

In fituations where ftones are at a very great diftance, it might probably be ineligible to attempt at all the enclofure of the arable part of fleep farms. Perhaps, in fuch fituations, beech hedges might be more feafibly attempted, than thofe of thorn, from a few indications in Tweeddale of the hardinefs of that plant. The larix, to judge from their appearance, in our wood plantations, feems remarkable for thriving, better than any other tree, in 
poor foils and expofed fituations. Some trials are juft now making, of applying them to enclofure. They are planted upon a border, in two rows, at eighteen inches diftance betwixt the rows, and the fame diftance betwixt plant and plant; the plants of the one row placed oppofite to the intervals betwixt the plants in the other row. A double ditch, with the bank betwixt the ditches fown with furze (rubins), might probably anfwer, in fome degree, for the purpofe of a fence. As to the objection of the thedding of the feed, this might be obviated, by conftant application of the fcifars, a clipt whin having probably no more tendency to produce feed, than a clipt hawthorn; the thick matting of fmall lateral twigs, produced from clipping, alfo protecting the roots from the action of fevere frofts *. I know of no plant fufficiently aquatic, to promife to become a fence in undrained mofs. Probably mofs muft be kept in a middle ftate, betwixt wet and dry, in order to raife any vegetable production. When laid up in a bank, with double ditch and hedge, thorns will thrive for an year or two, fo long as the bank retains moifture; but when the bank becomes dry, (and it will become fo dry, that, in Summer's drought, it would burn down to the water's edge, almoft, in the ditches), the thorns decay and foon die. Of this, we have had fome experience in this county.

In the fmall arable dairy farms, thorn hedges are more admifible as a fence; becaufe they are protected from the wild fheep of the hills, by the interpofition, generally, of the arable part of the fheep farms betwixt them and the fheep; and the tamer animals of the dairy are by no means fo impatient of reftraint. Confidering the variety of foil which muft be gone through, (a circumftance not eafily avoidable in conducting a thorn

* In the fevere Winter of $1779-80$, when the violence of the froft dentoyed mont of the whins, I perfectly recollect, that the whin buthes upon the north end of the Pentland Hills near Edinburgh, which furvived the frof, were the luw matted bufhes which had been cropped over, both fides and top, by the Theep. The fheep may thus inftruct us in the proper management of the whin, as the afs did the ancients in the management of the vine. 
thorn hedge enclofure), the probability of its never becoming fencible in many parts of its courfe, together with the continued care and attention of probably fix or feven years, before a thorn hedge will become in any degree a fence, even in our beit. foils, it is not furprifing that the Tweeddale tenantry, in general, manifeft that reluctance they do againft becoming bound to protect, and rear, and leave them fencible, upon a leafe of nineteen years. There is good reafon to conclude, that the thorn fences which have thriven beft in Tweeddale, are thofe which the refident proprietor has taken entirely under his own protection, even while the lands were under leafe, without en. trufting them to any obligation inpofed upon the tenant.

The enclofing of the arable part of theep farms, in order to render theep and arable farming mutually fubfervient, is the chief improvement of which this county is fufceptible. In regard to the expediency of enclofing the bill pafture of fheep farms, the following is the refult of information or reflection.

A mere ring fence around the boundary of an extenfive Theep farm, could not fave the fmalleft expence of herding*; not even although only one kind of theep (hogs for inftance) are kept upon it, and where, of courfe, the whole flock go together in one body (or $\operatorname{bir}(\varepsilon l)$ : Becaufe, even under this moft fimple mode of occupation, the grafs of the low parts of the farm muft, at one feafon, be faved (hained), for provifion for the Winter months, after all fpringing of grafs has ceafed: As allo, becaufe, through the Spring, Summer, and Autumn, the fheep muft, at different periods, be kept more to one divifion of the grounds than another; in order that all the varieties of graffes, fpringing at their different feafons, in all varieties of foil, and of elevation, may be all confumed in their proper feafons, fo that the full benefit of the whole may be reaped. Far lefs could a mere ring fence fuperfede any necefrity of herding, in an extenfive breeding farm, where various kinds of theep are kept, afiorted into different flocks or hirfels, according to

their

- I fpeak not hare of a mere park, in which ewes and lambs, or wedders, are fittened through Summer, and none, or very few, kept in Winter. 
their kinds. Were even a diftinct enclofure formed for each diftinct hirfel, (againft which there would, too, be often unfurmountable objections), this would ferve no purpore, for the reafons juft ftated; unlefs there were alfo fubdividing enclofures, comprehending each diftinct fpecies of pafture; as the theep would often rather linger upon the fweeteft pafture, however bare, than betake themfelves (without the compulfion of herding) to lefs palatable, though more abundant food. It would be giving too much credit to their inftinctive difcretion, to fuppofe them capable of the felf-denial of making any refervation of Summer's food for their Winter's provifion.

From all this, it appears that a fcheme of fuch complete enclofure of theep farms, as would fuperfede herding, even fuppofing the fcheme of fubdivifion in itfelf otherwife unobjectionable (which is a problematical fuppofition), would require fuch multiplied expence, as the advantage gained could never repay.

A pafture enclofure, to ferve occafionally as an hofpital, and to confine the rams till the proper feafon of admiffion, would, however, be advantageous in every theep farm.

It appears improbable, that a demand for the enclofure of the mountains of Tweeddale, fhall ever arife for any other purpofe than its fubferviency to fheep. Were we, indeed, to fuppofe the population of Scotland to arrive to the fame extent as is attributed to China, by the moft exaggerated accounts, (a fuppofition not ablolutely impoffible, bating accidents of war, famine, peftilence, inundation, fansculottes maffacre, or the final diffolution of the mundane fyftem); it may fo happen, that the demand for even the meaneft productions, that can in any way tend to the fupport of human life, may lead the hand of induftry, with propriety, to extend itfelf to the minute furface culture of the higheft Tweeddale mountain; were it even merely to meliorate the quality, or augment the quantity of produce of crow-crops and bilberrics. Till fuch an xra arrive, it would be abfurd, in point of private intereft, and ruinous as to that of the public, to kick againt the pricks, in throwing away ftock upon cultivation fo little productive; while there remain 
remain fo many fubjects of cultivation, capable of yielding fuch returns of profit, as might fpeedily accumulate into new capitals. The enclofure of the arable farms, and of the arable part of theep farms, may give profitable occupation to the whole agricultural capital that fhall arife in Tweeddale, for more than half a century to come.

Gates.-Larix, from its toughnefs and incorruptibility, requiring lefs weight of wood, and, confequently, admitting of diminution of expence in the fupporting gate-pofts of mafonry, has been lately ufed by John Lock, Efq. of Rachan, in gates, for theep enclofures, of exceeding light conftruction, 


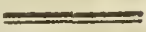

C H A P. VII.

A R A B L E I. A N D S.

\section{SeCt. I.-Tillage.}

THE two-horfe plough, directed entirely by the ploughman, without a driver, was introduced, about thirty years ago, into this county, and the practice has become univerfal in all lands of eafy tillage. Very ftrong land, or coarfe land newly broken up from its natural ftate (of, perhaps, heath, furze, bent, or rufhes), are tilled by four horfes, or four oxen, or by two horfes and two oxen, and with a ftrong Scots plough. Mofs foil, when deep, is generally tilled by oxen alone. The cattle are univerfally yoked two a-breaft.

In fome inftances of ftcep declivity, a furrow flice is turned over by the horfes going down hill, the plough returning empty to the top of the afcent.'

\section{SECT. II.-Fallowing.}

COARSE land, broken up from a ftate of nature, is fometimes left unftirred for twelve months, to allow the fod to rot, and is fallowed with bare fallow, and limed the enfuing feafon. Mofs foil, when fallow comes round in the courfe of cropping, is not unfrequently fallowed with bare fallow, to allow opportunity of frequent and deep ploughings, in order to make the mofs fubficle and confolidatc, and to incorporate it thoroughly (for that purpofe) with the dung and lime laid upon it, and with fuch of the fubfoil as can be reached and raifed by the plough. Deep clays (of which there is little in the county), unfit for turpip or potato crops, may alfo be fallowed barc. 
Ail land, fit for thefe crops juft mentioned, are fallowed with them, as green crop in drills. Land of this defcription, intended for fallow, is ploughed from the ftubble as foon after harveft as poffible: If foul, it is clean ploughed, that all the roots of the weeds may be loofened : If it is clean, the very old Scots practice of ribing, is now beginning to be revived; that is, the furrow raifed by the plough is turned over upon an equal fuperficies of land, left firm-a practice feemingly worth attention, as, by this mean, a furface is expofed to the action of the froft, greater than that prefented by clean ploughing, in nearly the proportion of three fides of a cube, to two fides of a triangle, of equal altitude, and upon the fame bafe. It feems to be a good maxim in tillage, to plough rather fhallow for all the fucceffive crops that enfue after manuring, in order to keep the manure near the furface; and to plough deep, in Harveft, the land to be fallowed the enfuing Summer, that new foil may be expofed to the Winter's froft.

\section{Sect. III.-Rotation of Crops.}

AFTER what hath been faid upoin this fubject (p. 70, $7 \mathrm{r}, 85$ ), it may be fufficient here to obferve, in general, That the admiffion, or non-admiffion, of pafture into the fyftem of rotation (where the whole farm is under regular rotation of culture), mult depend upon the means of procuring dung-whether it muft be made by cattle kept upon the farm, or whether it can be otherwife procured, without necelfity of keeping cattle for the purpofe.

Near a great town, fuch as Edinburgh, there is always fuch high demand for pafture for milk cows and horfes, that no mode of culture (except the raifing of gardcn ftuffs or nurfery) can compete with pafture in point of profit. At a little greater diftance, a large quantity of land may be kept under conftant crop, without intervention of pafure in the rotation; the dung procurable from the town fuperfeding the neceffity of keeping catthe to produce dung: In fuch fituations, there may be no neceffity for heeping any cattle, except. labouring horfes, and cows, 
for the mere fupply of the farmer's fanily; thefe may be main tained, through Summer, on green houfe feeding; and no pafture may be needed, but fome fmall patch for mere airing for health to the cattle. At fuch diftance as precludes the purchafe of dung from a great town, cattle muft be kept, in order to create it. If there is hill land, fitter for pafture than aration, that may be either paftured in its natural ftate, or niay be improved and laid down in permanent pafture; and the low land may be kept ander confiant rotation culture, without neceffity of the intervention of pafturage. If the land is all equally fit for aration, it would be, probably, moft advifeable to cultivate regularly the whole, admitting pafture into the fyftem of rotation; as this is probably, the beft mode of preventing the land from tiring of thofe crops to which it hath been too long familiarized *. In a farm of this latter defcription, fuppofing it divided into equal breaks, it might be a curious queftion, to afcertain how many of thefe breaks it would be neseffary to have at once in pafture, in order to fupport fufficiency of cattle (fuppofing they could not be got elfewhere) to yield dung fufficient to keep the reft under crop? or whether, if cattle can always be got to purchafe fron: mere pafturing counties, the cattle bought at harveft, fufficient to confume through Winter the ftraw and turnip produced upon the farm, would yield fufficiency of dung to keep the whole farm under conftant cropping, without the in tervention of pafture?

From very limited, and not very accurately obferved experience, I have been led to imagine, that a cow of about 25 ftone Dutch in weight, though even houfed nightly in Summer, and fed alfo in the houfe in mid-day Summer heats, will not produce above 12 or 14 fingle-horfe carts of dung annualIy; and a plough-horfe, much of whofe dung is neceffarily loft at work, about the fame quantity. Now, 50 or 60 fuch cart

loads

- In Norfolk, where the cultivation of clover has bcen of fuch long ftanding, we hear of fields fo tired of clover, that they will not now produce it. About, perhaps, 30 years ago, Meffrs Stodhart and Prentice, in the parin of Pcttymain, in Clydefdale, introduced the culture of potatoes upon a large feale: Thair comaios return was then 80 bolls, per acre-it does not now excced 40 . 
Loads are but a moderate dunging for one acre under green fallow crop: four fuch animals would, therefore, dung one acre annually; or four would keep four acres agoing under a rotation of four, needing one acre only dunged each feafon. This ftatement pretends not to any thing like accuracy; but fuch feem to be the nature of the data upon which fuch calculations thould proceed.

Sir George Staunton informs us, that through the whole 'route of the embaffy to China, along its eaft fide, by the Yellow Sea, to Pekin; and thence to Canton, through the greatert length of the empire in the interior ; the whole country, fo far as the eye could rach, was found under crop, without the leaft intermixture of pafture; and that animals feemed rarely ufed, even for the purpofes of tilling or carriages. It is a curious queftion, how the lands were kept in heart, without animals to yield dung : for the crops were obferved to be univerfally luxuriant. Sir George, from information and conjecture, fuggefts irrigation, mixture of the foils of different fields, and human excrement, as the means of manure. What becomes of the ftraw of their crops? Is it choppel, or otherwife comminuted, and mixed with meals or roots, to pafs, in this fhape, through the bellies of the lower orders? or are they littered with it? An agricultural furvey of China would form a moft interefting work. They furely cxcel the Europeans in practical agriculw ture, as much as they arc inferior in moft other things.

\section{SECT. IV.-Crops commoniy cultivater.}

THE crops falling under this defcription, are; finf, the meliorating green crops of turnip, potato, peas, artificial grafies; fecond, the exhaufting white crops of oats, bigg, barley.

Turnip and potato are chiefly ufed as the green-fallow crop. The land allotted for fallow, which is generally ploughed immediately after harveft, is, after re rated ploughings and harrowings in Spring, laid into ridges, the crowns of which are at the diffance of from two and an half to three feet of diftancs 
from each other; dung is then emptied from carts into every third furrow, in fmall heaps (or butches), five or fix of fuch hutches being contained in a fingle-horfe cart; the dung is then fpread by a three-pronged fork (or grape) from the hutch, along the furrow in which the hutch lies, and the furrow on either fide.

For turnip, the ridges are immediately fplit by the plough, which reverfes the pofition of the furrows and ridges, covering up the dung in the furrow's, and making the ridge occupy the former place of the furrow. The feed is immediately fown upon the frefh mould by turnip barrows, formerly defcribed. The feed is not raifed in the county, but purchafed in the thops. The turnip are white, red, or green, topt. The red probably grows to the largeft fize, but the green feem more hardy; whence the propriety of part of each; the firft for a bulky crop to be firt confumed, the other for food later in the feafon*. From two to three pounds weight of feed are fown upon a Scots acre; the abundance of plants being reckoned the beft fecurity againft the devaftations of the fnail or fly. The firfi culture they receive, is to thin the plants in the row, by handhoes; and the fooner this operation is performed, fo much the better; the weeds are then often hidhed down, in the intervals betwixt the rows of plants, by the hand-hoe; the fides of the ridges are then pared by a paring-plough drawn by one horfe, and the earth afterwards fet up to the plants by a double mouldboarded plough. A great part of this culture, while growing, has of late been nuch fimplified by $\mathrm{Mr}$ James MrDougal in Linton. Immediately after the plants are fingled in the row

(which

- The frequent lofs of turnip crop from feverity of Winters, is introducing fift the practice of pulling all the turnips about Martiunas, laying them up in long narrow ridges, and covering them (as they are to be coufumed fooner or lister) with merely their own thaws, or with a flight covering of turf : fo preferved, they are found to feed well throus the whole of Arril-which will render tie fardinefs of kinds of lefs confequence. Turnip may thus be raifcl even on nili" cos, as they may be taken off before the Winter rains, without iujury to the lamel. 'The fusws aud roots are both cat of when the turnips are pul'ed. 
(which he is careful to have executed before the weeds in the intervals of the ridges have come to any fize), he pares one fide of all the riliges, taking care fo to temper his plough that the furrow thrown from it overlaps, and whelms up all the weeds in the interval, and is lail clofe to the plants upon the righthand ridge; after an interval futficient to rot the buried weeds, he pares the other fide of all the ridges, laying the furrow as before; and this operation he repeats fo long as the plants will admit of the paffage of the plough without injury; nor does' he fet up the earth to them at all. It is evident, that, under this mode of management, the plough, in paring, can be carried much nearer to the plants; as, on one fide of them, the earth is firm; as alfo, that the plants are much lefs expofed to drought, than when they ftand with the earth pared from both their fides at once. In the fheep farms, the turnip is appiied to the feeding of caft-off breeding ewes; in arable farms, to the milk cows, or rearing ftock, or feeding off-caft cows, or fometimes bullocks. The Ruta baga, or Swedih turnip, is coming into repute, as the fureft Spring food: its cultivation is the fame as that of the common turnip; cnly they are fown in the beginning of May, while the common are fown in the latter end of May, or befơre the middle of June. They promife to fupply the great defuleratuni of fucculent Winter food to laft till the grafs feafon. Laft Spring my own crop of them, pulled early in Winter, topped and tailed, and laid up in a ridge upon the furface of the ground, and thatched with rufhes, ferved as food to milk cow's till the 1 ith day of June; very few of them being damaged by keeping.

For potato, the land is prepared and dunged as for turnip. The potato fets are then laid upon the dung, and the ridges are fplit by the plough to cover the potato; or, fometimes, the field is juft harrowed acrofs for this purpofe. A late practice is, to cover them with a garden-rake; then to cover them further by a flight plough, paring off one fide of all the ridges; then, after forne time, by another paring off the otker fide of all the ridges; with the intention of thus covering them flightly with loofe earth, fo as not to exclude fo totally the in- 
fiuence of the air, fun, and dew, as is apprehended to bo done by fplitting the ridges at once, and thus covering the potato deep by two furrows compreffed againft eacli other by the action of the plough + . If the horfe is made to walk upon the top of the ridge in covering the potatoes, this prevents the earth from being compreffed upon them by the trampling of the horfe. Juft before the plants appear above ground, the land is generally harrowed: when they diftinctly appear, a furrow flice is taken from both fides of the row of plants by the plough, and the plants are cleared of weeds by the handloo; and, as foon as pollible thereafter, the earth is laid up by the double mouldboarded plough to the plants, and then drawn clofe to their ftems by hand-hoes *. The time of planting potatoes, is as early as may be in the month of April : on this account the fallow given with potatoes is more imperfect than that with turnip, there being lefs time for preparatory cleaning before the infertion of the crop. The feed apparently moft in requeft, from being moft prolific, is the Apple or fonadab potato; it is a round-haped potato with light purple clouds upon a white ground; it is very lately introduced, 1 do not know whence; and perhaps its fuperior prolific quality depends merely upon the principle which caufes every change of feed to be an improvement: When beat, after boiling, it is faid to produce more meal from the fame meafure than any potato hitherto known. rams are fometimes planted for cows and horfes; it feems a late plant, and pro. bably is therefore lefs nutritious than the common potato, which we can ripen to perfection. Hays are affuredly moft nutritious when cut before the ripening of the plant: in this refpea,

+ By following this method, I had a crop, in the unfavourable feafon 1795. fully cquali to that of the very favourable feafon 1794 .

- It is of importance to be cypeditious in the operations of the plough, left the tendrils thrown out by the plant fhould be torn by its action: from not at a tesding to this circumftance, I ruined a moft promifing crop in 1793. The ploughman, in the laft operation of the plough, obferved the bottom of the furt :97 fn:inkled with torn tendrils, appearing as magcots. 
refpect, however, roots bear, more probably, an analogy to corns. I know not if this analogy holds in every refpect; in that cafe, abundance of root, like length of ear, thould depend upon ftrength of ftem, which is promoted by late fowing; but fuperior ripening, accompanied with lefs ftrength of ftem, and proportional diminution of bulk of root and of grain, fhould be promoted by early fowing; and each fituation fhould ftrike the medium that beft counterbalances the difadvantages to which it is moft liable. Early potatoes are raifed in gardens : it feems particular, that this plant fhould bear neither flowers nor feed. It is needlefs to defcant upon the ufefulnefs of potatoes, fo univerfally acknowledged, as food for man and beaft. As the curl is hardly known in Tweeddale, a good number of potatoes are annually difpofed of for feed to the Lothians.

Peas are fometimes fown upon part of the break intended for green crop fallow: They are very feldom drilled; indeed the rapid growth of the plant will admit of very little horfehoeing. When the farmer cannot reach his whole fallowbreak with turnip and potato, for want of dung; he fows peas upon the refidue, without dung; and next feafon gives that part a little fpring-fallowing with dung, in preparation of being fown out with bear and grafs feeds along with the part that had carried turnip and potato: At next return of fallow, he takes care to turn that part, which had bore peas, into tirnip and potato. Peas are moft generally fown upon outfields, (as mentioned page .): They conftitute a regular crop upon rotation land, where the rotation contains five or fix hifts, (page .) In the higher parihes they are a very uncertain crop. They are fown in February, March, or April; and are frequently fown under furrow. Two kinds only are in ufe; the Peebles pea, of a grey colour, fpeckled with dark Spots; and the Mragbielsill, a ftill earlier kind, of much the fame appearance, and growing lef3 to furaw: A ftill earlier kind was picked out by myfelf from a field of Magbielill peas, by marking the earlieft bloffomed italks, (the way in which $\mathrm{M}$. Montgomery of Magbiehill, father to Sir James Montgomery of 
Stanhope, late Lord Chief Baron of the Court of Exchequer, is faid to have difcovered the Magbiehill). The experiment hath been ftill further profecuted by Mr Aitken, proprietor of Callends in Newlands parifh, who has difcovered two kinds in thefe peas; one kind with ftraw of a purpleifh cait, with naughty fhort pods; the other longer podded, with ftraw of a yellowifh thade.

In proportion to the earlinefs of ripening, all our kinds are refpectively lefs abundant in ftraw; but this deficiency is partIy remediable by late fowing: In fome of our foils and fituations, there is no danger to be apprehended from deficiency of luxuriance in ftraw, however early the kind, or however early the fowing; there, this earlieft kind of pea is advantageous : In different fituations, where peas are ufed as an eke to the turnip and potato fallow crop, the adoption of this early kind might afford time for fome preparatory fpring-fallowing of the ground, previous to fowing.

\section{Artificial Grafjes. (See Char. VIII.)}

Second, White crops in common ufe.

Oats, always fown after clover, upon rotation land under rotation of four thifts, and fometimes with grafs feeds after green crop fallow; or in a rotation of fix hifts, after peas; and the only grain cultivated upon outfields, bating fometimes the interpofition of peas. Of this grain, we have three diftinct fpecies.

The Blainfie, or Tucedfide rubite, is the lateft, and is found to fuit the loweft lying parifhes better than any other.

The Carnquatb is about ten days earlier than the laft, and grows to ftraw, in thin poor foils, better than any other fpecies. It is procured from the high lying noor farms in the parifh of Carnwath in Clydefdale; the beft from Barbacblec, in Whitburn parin. It is (proportionally to the bleaknefs of the fituation and poverty of foil it grows in) a long, thin-bodied, ill-filled oat, with a baird or azun.

'The Magbiebill, earlier, by eight or ten days, than the laft. It was introduced, from Ayrthire, in the beginning of laft cen- 
niry, by Mr Montgomery of Magbiehill, in Newlands parifh, father to Sir James Montgomery of Stanhope; and has continued, without degeneracy, in the upper parifhes of Tweeddale. It is more fhort and plump, on equal land, than the two preceding; and is hence known by the name alfo of barley oat, impofed upon it from its figure. It was introduced into Roxburghhire, by Mr Dawfon of Frogden, about fifteen years fince, and there obtained the name of red oat. It is eafier fhaked than the two preceding fpecies; though, in fact, feldomer thaked, from being oftener cut down before the fetting in of the equinoctial ftorms. It fuits not the lower parifhes, where, from tharpnefs of foils and drier climate, thortnefs of ftraw is apprehended. In the higher parifhes, it is fown upon deep mofs, or reclaimed clay morafs, where there would be danger of other fpecies lodging; in dry land, it is never fown, but where the ground is in good heart, as upon clover lea, or after turnip and potato fallow.

Rough beer, or big, is reckoned the beft grain to fow along with grafs feeds in rotation lands; it is fometimes fown under furrow, though rarely. - Blended beer, that is, a mixture of rough beer and of barley (fo common in Fiferhire), is not ufed in this county. The hiftory of this practice is curious: It would feem, that, by the intermixture of the farinx of thefe earlier and later ripening fpecies, the whole field ripens at one time, probably in the intermediate period of the ripening of each of thefe grains. Captain Mackay of Scotiton carefully picked out fome of the barley from a field he had of blended beer; and this barley he finds more early than any other barley the has fince procured for feed. Experiments ought to be made in regard to this fubject; as, 1 . Whether barley and big, when fown together for the firtt time, would ripen equal3y, as the blended beer does in Fifenhire; or whether it requires fucceffive growing together, to accomplinh this interchange of properties? 2. It might be worth afcertaining, by the experiment of feparating the two grains, whether the peculiarity each had attained in growing blended together, would zemain as a permanent diftinction? Alfo, whether the big had 
gained, in improvement of quality, from laving obtained fomewhat of the latenefs of barley; and whether the barley had degenerated fomewhat to the inferiority of big, from having had imparted to it fomewhat of its quality of more early ripening?

SECT. V.-Crops not commonly cultivaied, or in fmall quantity, are, of green crops.

Beans, fometimes tried in drills, but quite difufed, from the impoffibility of faving them in our wet harvefts.

Tares, fometimes a few fown as green food for horfes: The purpofe, however, is more certainly fecured by cutting part of the hay field very early, that the fecond crop may come in before the general fpringing of the aftermath of the hay field.

Cabbages, fometimes ufed as part of the green fallow crop.

Carrots muft be fown fo early, and muft confequently be fo much overtopt by weeds, before they appear through the ground, that little preparatory cleaning can be given to the land before fowing; and the fubfequent weeding muft be a very tedious labour. For thefe reafons, as alfo from the difficulty of raifing them in froft, they feem unfit for a general fallow green crop. If any, induced by the rhodomontade defcriptions of their profit, to be found in books of agriculture, were to choofe to rifk them as a crop, it feems probable, that the fecureft mcthot of rearing them, would be to fow them (as has been fuggefted to me by the venerable Countefs-Dowager of Dundonald) upon land that had previoufly carried a crop of drilled turnip with dung; preparing the land, by merely fplitting the ridges, and fo wing them on the top of the new ridge formed by this operation. At $\mathrm{Mr}$ Henderfon's, in Kirkurd parifh, I have eaten butter, in Winter, from the milk of cows fed upon carrots and hay, which, for richnefs of colour and of tafte, feemed to come nothing: Short of that made upon grafs in Summer.

Lint is fewn, in inconfiderable quantity, and merely for family ufe, upon land previoully fallowed, along with grafs fceds; or on clover lea. The 'Truftees premium (whether from the good fenfe of the farmers, or from fome new meafure as to 
the locality of its diftribution) feems not now to have the effect of making it be fown, as a gambling fpeculation *.

Of white crops, thofe not commonly cultivated, or not to any great extent, are,

Wheat, not cultivated, in the higher parifhes, for want of climate; nor, in the lower, as too exhaufing to the foil.

Rye ufed formerly to be fown on the outer ridge of cornfields next to dwellings, to defend them from poultry, which would appear to difike the grain. None is now fown, even for that purpofe.

Potato crops may arerage between thirty and forty bolls per acre, (nineteen or twenty ftone per boll, feventeen and a half pounds to the ftone). Sixty bolls per acre is held a very great crop.

Turnips

* A bounty, or premium, feems ufeful to induce the trial of fomething new. If, upon fufficient trial, it is found protitable, it wil! force its own way. If it cannot fand upon its oven legs, why tempt people to what is umprofitable, in fetting them a-gambling for a prize? More than twenty years fince; I was apprifed of the following incidert :-At a time when the Truftees for encouraging arts, manufactures, \&c. held out a premium to encourage the growth of lintfed, the mirifter of Humby, in Eaft Lothiar, was in ufe to fow lint upon land in his farm, which was in fit condition to have carried wheat; finding tlat, from the premium of one filling per peck allowed by the Truftecs for feed, when adjudged fit for the purpofe by their appointed judges, and from the gd. per peck, the teal price given for it at the oil mills, the only markct where there was a demand for it, he could, upon the wholc, make more from his crop of liutfecd, than what he could obtain from a crop of wheat. As for the lint itfelf, it always was difpofed of, unmanufactured, as thatch, to the villagers of Ilumby.

A patent for a new invention has this in it, preferable to the encouragement of a bounty or premium, that the public have nothing to tempt them to put in ufe the practice, but the profit fousd to refult from it. Every thing has two handles. The profpcet of obtaining the advantages of a patcnt, may give great cucouragement to the genius of invention: But when it is confidered that this reliance, after one invention hath been fallen upon, has a tendency to forite all farther effurts at invention in him who has thus flown himfelf poffefted of a genius for it; perhaps the effect of patents may appear more ambiguous. Patents can never be apr,lied to agricultural praktice, which cannot, like thofe of manufacture, be proved in fecret; they would tend only to encourage invention in the conftruction of ncw implements of hulbandry, 
Turnips may feed towards fourfcore Tweeddale theep per acre, from Martinmas till Newyear's day; or may feed a couple of bullocks, of thirty ftones each, Dutch weight, for between three and four months, if the crop is tolerably good.

Big or Barley, fown always upon well-dreffed land, may average eight bolls per acre over the county.

Oats, where fown as part of rotation, may produce nearly the fame return as bcer. Confidering, however, the poor returns from fuch of the lands upon which this grain is fown, the average of return over the county may probably not exceed four, or four and a half bolls per acre.

Peas, as they are not fown in fuch quantity, upon poor foil, as oats, and are pretty much difufed in the higher parifhes, may probably average about fix bolls per acre in their return.

The above ftate of returns is, however, mere vague conjecture. 
C H A P. VIII.

G R A S S.

Sect. I. - Natural Meadows and Paftures. (See p. 85.)

ENGLish meadow, or dry land in natural grafs, which is conftantly faved for hay, receiving every fecond or third year a top-dreffing of dung, is unknown in Tweeddale: Scotin farmers would confider fuch a mode of obtaining hay, as very unœconomical, and would expect to obtain it much more advantageoufly from land kept in rotation tillage. Scotifh meadow bay is obtained only from wet boggy land; confifting (according to the nature of the foil, difference of degree of wet, or difference of expofure) of coarfe fprot grafs, or graffes of finer quality.

\section{Sect. II.-Artificial Grafes.}

THESE conftitute the Scotifh dependence for hay, entering into every improved fyftem of rotation culture.

They are fown in Tweeddale, gencrally with barley or big, though fometimes with oats, upon land that had previoufly carried a green fallow crop. Where the land is dry, and of free mould, and well defended, lefs feed is neceffary; becaufe lefs of the feed and fewer of the plants perifh, than where the foil is ftiff, or inclined to wet, or open to the trampling of cattle in Winter. In the firft cafe, about a bufhcl of Englifh rye grafs, with ten pounds weight of Dutch red clover, fuffice for a Scotifh acre; in the laft, nearly a burhel and an half of the former, 
with fourteen or fifteen pounds of the latter, are requifite. When pafture conftitutes part of the rotation, fome pounds of white clover, and of rib grafs, are added; a part of the rye grafs, and of the red clover, being kept hack*.

Hill pafture grafs receives little improvement, except the accidental one received from the refrefhment of the tillage, inftituted, with a view to corn, after lime or folding, as already fpecified in pointing out the treatment of the outfield arable land of theep farms. This fort of tillage is beginning, however, to be modulated into a greater correfpondence with the interent of the fubfequent pafture. In outfields, of clay or mofs foil, at 1000 feet elevation, wet from the continual moifure of the air, alternate oats and natural pafture are the only admiifible modes of cultivation.

\section{SECT. III.-Hay Harvef.}

THE harreft of meadow hay commences at Lammas ; fometimes interfering, towards its conclufion, with the commencement of corn harreft: That of hay, from fown grafles, about the middle of July.

- According to Captain Mackay's experience at Scothon, in Newlands parih, yeilow or bop elover did not grow at all; neither when fown upon old croft land, of deep free foil; nor when fown on light free foil, to the extent of $8 \mathrm{lb}$. per acre, Forlffire for (fold under that name in Edinburgh feed hops, and feerningly a culmifernus grafs, that is natural to our beft leas) produced, with him, upon the laft mentioned foil, a tolerable crop of hay; lut, for two or three ycars that the field was continued in palture, every fpecies of cattle feerncd to naufeate the two or three cxperimenting ridges bearing Yorkmire fog; or, at leaft, fo much to prefer the other graffes of the field, that thefe ridges had to be cut for hay, from among the fect of the pafuring cattle. He tried alfo, upon a field of the fame fort of foil, in a fmall patch of the fied, a fpecies of elover called coul grafs (very fimilar in appearance to the red clover, with a dark green leaf, which grows fpontaneoufy under our hedges); it yielded a very weighty firf cutting of hay, feemingly very palatable to horfes; the aftermath was inferior to that of the reft of the field, r,robably from the exhauftion of the roots in the weighty firf growth. In fubfequent pafture, all animals fuemerl fousd of the cow grafs; and it remaincd an yea? of two louger in the cround, than the Dutch red clover. 
In making hay from fown grafs, every precaution is taken to prevent the exhalation, or wafhing out of the juices, by the un, air, or rains: It is therefore never, nowv, fpread ont (or teaded); but lies fome time in the fwath, which is alfo turned whole; and, in this ftate of unbroken fwath, is found to thoot off the rain: It is then put up in large cocks, and thence into tramped ricl-s, (that is, ricks built by a perfon who ftands upon the rick in building it); whence it is carried, at convenience, into the Winter ftack, or fold to the confumer. It is faved with all that precaution againf exhalation, or fermentation, which an apothecary ufes in curing his medicinal herbs, to prevent walte or degeneracy.

In making meadow hay; from the more advanced period of of the feafon, and more foft and fucculent nature of the grafs, oppofite maxims of management are adopted; and every advantage, of tcading before the fun and wind, is taken, in order to procure as much drynefs, as will make it keep in the Winter ftack.

Heating the hay in the Winter ftack, would be confidered as a deterioration, except in regard to fprot hay, for the purpofe of making it more eafily chewed.

The aftermath of clover is fometimes ftacked with dry ftraw for fodder.

Almoft no farmer, now, cuts hay for two fucceffive years from his field of fown grafs.

\section{SECT. IV.-Fieding.}

Turis is applied to feeding crock theep, or to the milk rows of the dairy; a few bullocks are alfo fed upon them, befides the caft-offs of the dairy. Potatoes are very much given to horles. A finall quantity of hay is always reterved in the arable dairy farms, for new-calved cows in Spring, though the greater part is foll. The provident theep farmers feil no hay, till their fleep are enfured againft Winter ftorms. Peas ftraw was the great feed of theep in forms, till fuperfeded by lay; 


\section{I52 Agricultural Survey of Peeblespire.}

it was always accounted our beft fodder, for horfes working hard in Spring; there is either a prejudice, or experience, againft giving it to cows. Oat-1traw is our next beft ftraw fodder. Straw of big is dangerous for horfes, exciting inflammation; though this tendency feems corrected by potatoes. It is given to milk cows eating turnip; though chaff of beer, fteeped in boiling water, is the great dependence of cottagers, for their new-calved cows in Spring. 


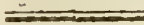 \\ C H A P. IX. \\ G A R D N S, ORCHARDS:
}

THERE are three hot-houfes in Tweeddale; at Whim, Kirkurd, now Caftlecraig, and Darnhall ; another is begun at Kingfmeadows, and aniother probably in contemplation at Kailzie. A botanic garden, with fuch exotics as could live in our climate, either in the green-houfe or open air, was kept up by the late Sir James Nafmyth at New Poffo.

In hill countries, great heat is often produced, in particular fpots, from reverberation. The reflection from a rocky hill upon the garden of Pirn, in Inverleithan parifh, is the reafon that, in that garden, two crops of peas, fit for the table, have been often fucceflively raifed in one feafon from the fame plot of ground. I do not however imagine the gardeners' boaft, in fome better climates in Scotland, could there be exhibited, of fowing peas, reaping their produce, fowing this produce, and having eatable peas from that fowing, within the feafon: 


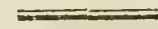

C H A P. X.

WOODS AND PIANTATIONS.

The natural wood is inconfiderable. (See article Surface.)

The extent of artificial wood, I am apt to think, may amount to rather more than two thoufand acres; but my data can afford room for only vague conjecture.

'The practice of fallowing, lining, and laying the ground in proper ridges, where neceflary for draining, previous to planting, has been fometimes tufed; and ought probably to be ufed more frequently. From various quarters, I am affured that it contributes aftonifhingly to the quick growth of trees, to keep the earth around them in cultivation of fallow for a fucceffion of years. This practice might be worth inflituting, in plantations in the immediate vicinity of houfes erected in fituations that have not the immediate advantage of ready grown fhelter of trees.

The following facts are afcertained in experience by John Loch Efq. in his plantations of Rachan. Trees, when not deprived of their lateral branches by pruning, naturally grow with their boles of a conical form, correfponding to the general outline figure of the whole tree: After ceafing to grow fo faft to height, the top gets gradually rounded, from the dropping off of the under branches through rottennefs, occafioned by the overfhadowing of the upper branches: After this period, the bole advances lefs in girth at the root, but more in girth towards the top, lofing more and more its conical fhape, and approaching nearer to a cylindrical form. For experiment's fake, he carly pruned a parcel of trees in the plantation, by 
rubbing of the lateral buds as they beg:m to fhoot: Thefe trees are at prefent, and have been, for many years, of a cylindrical form in the bole, from the root up to thofe lateral branches which had not been difplaced; whiln thofe, of like age, which had never been pruned, ftill retain their boles of a conical Thape. Hence, one of two conclufions feems necefiarily to follow : either, firf, that the upper part of the boles of the pruned trees has been accelerated in growth, without retardment of growth in the under part of the bole: or, fecondly, that the upper part of the boles has mate merely, or little more than, the ordinary advance; whilft their under part has been retarded, from the abftraction of the branches, whofe office it is, probably, to attract the fap in greater quantity to the parts of the bole contiguous to their infertion. From the general appearance of the pruned and unpruned trees, the laft conclufion appears the proper inference. Whence, it would appear, that pruning is unfavourable to the growth of trees; at leaft, in fo far as to prevent them from attaining to the fame content of folid wood in the bole, in equal time.

From Dr Anderfon's reafonings, (in the third volume of his Agricultural Effays), it would neverthelefs feem probable, that, in order to obtain good wood free of notches, the arrangcment of nature muft be followed in plantations; that the trees muft be planted fo thick, as that the exclufion of air muf fpeedily prune off the lower branches, in making them die and drop through rottennefs; or, if not fo thick planted as to produce this effect, that they fhould be timeoufly pruned.

In one part of Mr Loch's plantations (where the furface foil is very poor, producing but dwarfifh heatl, and incrufted with a white coloured lichen, as with a leprofy), it is evident (from the firs, in which the length of each year's growth is feen, in the length of bole intervening betwixt the off-fets of lateral branches), that the trees had at firft languifhed, whilft their roots were confined to the ungenial furface foil ; but that, apparently, upon their roots piercing into a fubfratum of bettcr mould, they had taken on more vigorous growths. 
The Rachan plantations exhibit a Atriking inftance of beauty, incidentally obtained as an acceffory, where utility was purfued as the primary object-the moft fatisfactory mode, furely, in which it can be obtained. In picking out the good foil, worth improving, from the bad, and in enclofing it, the bad was, of courfe, enclofed; fo that no farther expence was incurred, in planting up the bad foil, but the mere purchafe and infertion of the trees: And fuch, happily, is the fituation of the grounds, that the plantations are difpofed in all the wild irregularity of nature.

The greatent extent of healthy thriving plantation is, perhaps, to be found at New Poffo, and at Stobo, upon the oppofite fides of Tweed, in Stobo parifh; where the foil or climate feem. peculiarly favourable to the growth of trees. There they hardly contract mofs, fo incident to trees in the upper parifhes.

Larix has been experienced to thrive better than any other wood, upon our pooreft foils, and in our moft expofed fituations. We have itrong proofs of its fuperior durability in paling, cven of the fhort age of twenty years growth. It is be come a favourite tree. Hitherto, it has been thinly interfperfed among other trees in plantations; and, from fo fpeedily overtopping all others, it is wind-waved, for want of thelter. This has lately introduced the practice of planting them by themfelves, in thickets, that they may fhelter one another. 
CH A P: XI.

WASTES OR COMMONS.

(See Enclosing, Page 126.)

CH A P. XII:

IMPROVEMENTS.

SECT. I.-Draining.

THE generality of the cultivated foil in Tweeddale, being light, draining is not of fuch general indifpenfability, as in counties of more retentive foil: The greater part of it, too, lies upon fuch declivity, as affords a ready defcent for the furface water. Where neceffary, draining has been generally ata tempted, either by open ditches, or by covered drains, pretty deep and wide, filled with ftones, at fuch expence and difficulty of procuring materials, as precludes any great extenfion of them : It thus attempted, often, at great expence, and, not unfrequently, to very little purpofe.

Elkington's mode of draining, as defcribed in Mr Jehnfton's book upon that fubject, viz. "the tapping of the (fuppofed) resfervoirs in bills, by boring anger boles into them, fo as to procure a free iffuc for their waters, which are received into, and earried away by, proper ditches, prepared for their reception; preventing, thus, the water from oozing out, from want of proper vent, in all directions, over the edges of thefe fuppofed refervoirss 
fervoirs, through large tracts of fuperincumbent furface, and wetting the land, to a great extent, below:" As alfo, his mode of draining land-locked bogs, from whence there is no outlet for the. water, "by boring through the impervious frata, in the bottom of the bor, upon which the water refts, into fuch pervious frata as may (very probably) be found to exift below." Thefe compendious modes of draining (when they thall be perfectly underftood) promife to be both the moft extenfively ufeful, and the leant expeninve, that can poffibly be adopted, in all cafes to which they thall be found applicable. In all the fuppofed cafes put by Mr Johnfton (in regard to the pofition of the ftrata, and of the receptacles where the water fupplying the fprings is contained in hills), the remedies fuggefted muft infallibly prove effectual: The fuppolition, however, of the exiftence of fuch bowl-hapect cavities, where the water overflows the edges of the bowl all around, and which, inftead of being allowed to overflow the edges, might all be drawn off by an auger hole, bored into the bottom of the bowl, would, it is feared, be feldom found realized in the hills of Tweeddale; where the ftrata more generally affume an oblique polition, than one any way tending to horizontal. It is evident, that the practitioner, upon this method, muft ever proceed merely upon fuppofition; which may or may not be realized. Long experience would feem neceffary to enable him to form probable conjectures.

But, beficles that wetnefs, arifing from water-refervoirs in liils, and from collections of water in land-locked bogs, there are many tracts of land kept in an inferior ftate of production, from a thin furface foil incumbent upon a till impervious bottom; where, from the incapacity of the foil to abforb any confiderable quantity of water, the land is put into a poachy ftate by cvery heavy thower of rain. Mr Johnfton (in his account alreally quoted) has given a moft perfpicuous and well reafoned defcription of the modes adopted in England (particularly in the county of Efrex), to remedy this evil, by means of a very weconomical fpecies of covered drains.

Sir Gcorge InIontgomery of Magbiehill introduced this mode of draining, in 1797 , with noft complete cfice, in his parks 
of Sunnyfide, in Newlands parifh. The foil of thefe parks was of that thin, black, moorin nature, upon a retentive till bottom, already defcribed (p. 14.); fo poachy, in Winter, that, when pulverized by fallow, it, in Winter wet, prefented no more refiftance to the foot of the pafienger (which plumped down to the fubfoil), than what would have been prefented by a-bowl of rice and milk: Even when in pafture, and the furface firned by grafs fward, the parks were extremely fubject to Winter poaching; and, upon the fecond or third year of pafturage, the furrows betwixt the ridges ufed to be completely grown up with rufhes. The firft park, drained after the method defcribed by Mr Johnfton, had been paftured one year previous to the draining procefs: In an hour or two after the hearieft rains, a horfe may now gallop over this, without almoft leaving the impreffion of his feet; and the rufles, which were beginning to take poffeffion of the furrows, have literally all perifhed for want of moifture: I have, indeed, never obferved fuch a total change of the nature of any foil. The moderate expence of the execution, would feem to render this mode of draining an undertaking fuited to the tranfitory intereft, in the foil, of even a tenant upon a leafe of nineteen years; provided, at leaft, he is not fubjected to the rifk of forfeiture, during its currency, from the injudicious retention of the delectus perfone, through the confructible, or expreffed conditions of the leafe. The expence would, in few inftances, excęed thirty fhillings per Scots acre.

Inftead of detailing the practice at Sunnyfide, it may be of more ufe to ftate, in general, the mode of forming thefe drains; and the general principles of the practice.

The ceconomical mode of forming theie drains, is, Firft, to open up a trench by the plongh where the drain is to be drawn, throwing off a furrow flice to either hand, in going and returning; if the plough is not ufed, the carth muft be dug out by a common garden fpade, one fpading deep. Secordly, Another fpading is dug out by a fpade, I 2 inches deep, and 3 inches in breadth at top, tapering to 5 inches in breadth at bottom; this fecond frade is provided with an iron wing upon its g.aff, by 
which the digger, ftanding on the furface, forces it with his foot into the ground, it being impoffible for the operator to ftand within the narrow trench, previoufly formed by the common garden fpade : the mouldery earth, falling from this fecond fpade, is cleared out by a correfponding fhovel, which, for the reafon already afligned, is bent a little upwards in the neck. Thirdly, Another fpading is taken out of the trench, thus formed, by a fpade (furnifhed with an iron wing for the foot, a little farther up the (haft) of 16 inches in depth, and $3 \frac{x}{4}$ inches in breadth at top, tapering to $2 \frac{x}{4}$ inches at bottom: This fpade is formed very ftrong, and rounded confiderably in the back, to afford the better prife; and is, in fhort, pretty fimilar to the inftrument ufed in this county, under the name of the foot-pick, or pick-ax for the foot: The mouldery earth, falling into the bottom of the narrow rut formed by this third fpade, is then fcraped out by an iron fcoop, attached to a wooden thaft; the fcoop is like to the one half of a tube divided longitudinally, or to the boring part of an auger or ruimble; it is about a foot in length, $2 \frac{\mathrm{T}}{2}$ inches in width at the neck, tapering to $1 \frac{8}{2}$ inch at the mouth; its iron neck is bent, fo that the fcoop forms an angle of about 45 degrees with its fhaft, enabling the operator, ftanding with a foot on each fide of the trench, eafily to fcrape out, and throw afide, all the loofe earth from the bottom of the rut.

The bottom of the drain, fo formed, fhould be 26 , or, better, 30 inches below the furface.

The drain is then ftuffed with wood prunings, cuttings of liedges, weedings of fur plantations fplit, or with heath or whins, or with flraw or rufhes; which two laft, when ufed, are directed to be twifted into ropes, of the fize of a man's arm, and three fuch ropes to be put into the drain, one fingly, the other two along-fide of each other. The ftuffing is put in, in fuch buik, as to Rick faft before reaching the very bottom of the rut, fo as to leave a pafrage of 2 or 3 inches clear at bottom, for paffage to the water; though, when the materials are of loofe contexture, this is of Jefs confequence; the water percolating through their intertices, and finding always more room from that decreafe in bulk, which enfues upon the decay' 
of fuch perifhable materials. A perfon, with the fcoop, goes immediatcly before the one putting in the ftufling, to fcrape out any loofe ftuff that may have tumbled into the rut. It is almoft fuperfluous to mention the propriety of beginning the operation of ftuffing, at the head or higheft part of the drain.

The ftuffing being put in, and, if it is of very open materials, a little ftraw or rushes being laid a-top, to prevent earth from running through it-and the drain being ituffed to the height of ro inches, or a foot, from the bottom-the earth taken from the drain is returned above the ftuffing; care being taken to lay the moft free and loofe earth immediately upon the ftuffing, that the water, oozing from the foil, may find ready admiffion into the drain: For this purpofe, the ftuffing is fometimes covered with fand or gravel.

Where the drains are conducted in the fame direction with the declivity of the field (that is, ftraight up and down), they will draw water laterally to the diftance of two yards and an half from their fides, in very retentive foils; and, by confequence, they ought to be made parallel to each other, at every five yards diftance. They are, in no foil, found to draw to a greater lateral diftance than three yards and an half; and, of courfe, ought never to be placed at a greater diftance than feven yards afunder. The lefs declivity fuch drains have, they are, in Effex, accounted the more permanent; becaufe, where the water has a quick run, it is ready to abrade earth from the fides, or raife it from the bottom of the rut, fo as to occafion obftructions. On this account, where the land lics on a fteep declivity, it may be proper to carry the drains floping acrofs the declivity, in order to diminifh the velocity of the run of water; in this cafe, the drain can only catch the water from its upper fide, and can draw none from the other file; though, perhaps, it may draw to double diftance from land above it, than from land upon the fame level; fo that, probably, the drains need not be made more frequent in this direction, than when the courfe of the drain follows the natural decline of the field, and, of courfe, draws from both fides. 
Drains of this kind, ftuffed merely with ftraw, have been known, according to Mr Johnfton, to laft twenty years, with'out exhibiting the fmalleft fymptom of decay; and it is not known how long they may ftill endure. Stuffed with brufh. wood, they have been known to laft forty years, with little or no repair. It is judged, that frefh cut green branches are the moft durable ftuffing, particularly thofe of the willow and the beech. Stones are confidered as the very worft of ftuffing for fuch drains; as, whenever an obftruction is once formed, it muft remain: Whereas, when the ftuffing is of wood, heath, ftraw, rufhes, \&c. everi when fmall obftructions are formed, new vent is foon found for the water, in the vacuities formed by the decay of the ftuffing materials.

Where a drain is obftructed, the water rifes to the furface, inmediately above the obftruction; and the remedy is, either to clear out the drain at the fpot, or, which is eafier, to cut a new drain from above the obftruction into the next drain.

When obftructions become fo numerous, as to require the field being drained anew, the approved method is to conduct the new drains, fo as to cut acrofs the old ones, making them alfo a littie deeper; by which means, the field is more effectually drained than at firft. In cutting acrofs thefe drains, the whole ftufing has been found entirely confumed; but the earth fo perfectly arched over the place originally occupied by the ftuffing, that the paffage for the water remained clear, and the drain was found (in the Effex phrafe) to bleed freely.

Thefe drains can only prove effectual, where the rut, form: ed by the lift narrow fpade, is cut into an impervious till bottom; as, where the bottom is of fand or gravel, the water efcapes from the rut, to rife again in fome other part of the field. Where there are only partial fpots of this open bottom, the Efrex practice is, to conduct the water in the rut over thefe open-bottomed patches, in a pipe formed of puddled clay.

The whole drains of the field may be conducted, either into a receiving open ditch, at the bottom of the field, or into a covered drain : in the laft cafe, this receiving drain flould have a flagged or caufewayed bottom, "built fides, and covering flags. 
In very fliff clays, the furface water might be incapable of percolating into fuch drains; in which cafe, crowned ridging is the only remedy.

In fheep-wralks, never intended to be ploughed, fuch drains, formed much more fhallow, and ftuffed or covered, by merely inverting the furface tirf, might often be of effential benefit.

\section{SECT. II.-Paring and Burning.}

VERT little ufed in this county; apparently ruinous in thin foils; might be ufed advantageoufly, in deep mofs foils; were it not that not one feafon in ten gives drought enough for the operation, and that the preparatory fteps (in cafe of failure) would be very obftructive to other modes of culture.

\section{SECT. III.-Manuring.}

Teatbing, by folded theep or black cattle, has already been noticed.

The other manures ufed, are, the dung of cattle from the farm-houfes, lime, compott of lime and mofs, or of lime and fcourings of ditches*.

Dung of cattle collecied in farm-offices, feems too little attended to, in regard to the moft proper mode of ftoring it up, for proper fermentation, and for prefervation. The dungftead is often found fituated upon a declivity, allowing the juices to run off; or upon a bottom of loofe gravel, unfecured, by caufeway, above clay, to prevent the juices from being abforbed; or fo placed, that the rain water from the roofs of the houfes runs into it, and from it, warhing out and carrying away the foluble and moft nutritious particles of the dung. Little confideration feems paid to the principles, that, too Y 2 much,

- In a comparative experiment of Captain Mackay's at Scotiton, betwixt the effects of the pure dung of cattle and thofe of compoft of fcourings of ditches with lime, both applied to old croft of deep rich loam, the refult turned out in favour of the compoft, for three or four fucceflive crops. Perhaps in fuch foil there, might be much matter for the lime of the compolt to convert into vegetable food, 
much, as well as too little moifture, and too much exclufion of air by over confolidation, as well as the too free admifion of it, are all equally unfavourable to a proper fermentation.

Lime is, ftill, fometimes, injudicioully applied to the fward immediately before ploughing, fo as to fall to the bottom of the furrow when the field is ploughed; the practice of letting it lye upon the fward for an year or two before ploughing, that it may incorporate with the grafs roots, is however more approved: It is generally efteemed beft to apply it, new flacked, in its higheft ftate of pulverization, to fallow previoully harrowed fmooth; then to harrow in the lime after it is fpread, and afterwards to plough the land with a fhallow and narrov furrow.

Whether, upon land kept in conftant rotation culture, it is beft to lime fully at once, or to lime flightly at fhort intervals, feems not well decided in this county.

'The theory of lime feems not at all well underftood: And it would feem prudent, to keep the theory ftill open, that it may be accommodated to fuch facts as fhall prefent themfelves in experience, rather than fhut it up definitively, to their exclufion-the common effect of theory when embraced as complete, and adhered to with bigotry * . That its cauftic alkaline inature, when applied quick, hould diffolve the fmall feeds in the foil, or the live roots, converting their oils into foap foIuble in water, and fitted to enter the capillary vefels of the roots of growing regetables, feems contradicted in experience. Lime, fpread quick upon growing plants, never has been found to diffolve them: whence then thould it be fuppofed defructive of the organization of live roots? In drying pickled

* Without forming a theory, knowledge would be a mere procefs of memory, and would confint of a mere lumber load of disjointed, unconnceted faets, ineapable of inference or application. It is wifely ordered, for the increafe of uffut knowledge, that mau thould delight in fyftem; and Mould in general feel a mental want, till the facts which have reached his knowledge are fyntematically arranged; rubon, alore, he can fay, that he underfands or can explain. Every thing, however, las its cxtremes: fyftematic inference ought never to be implicitly truftcos, vithout verifying its conclufions by experience, where attainable. 
pickled wheat, by dufting it with quicklime, more of that fubftance is furely brought into contact with the grains of wheat, than what can be fuppofed to fall to the Thare of the feeds of weeds in the foil, even upon a ftrong liming: and why Thould what is found beneficial in the one cafe, be fuppofed noxious in the other? Or, if this is fuppofed one of its principal effects, beat unburnt limeftone, or flacked lime become neutralized or effete by the reabforption of fixed air, fhould at leaft be incapable of producing thofe effects; though it would appear doubtful whether its effects have not been obferved equally good, when applied in thefe ftates, as when applied in its quick or cauftic alkaline ftate.

From a large tract of land in Lyne parifh, which had never been at all cultivated, the farmer reaped a long fucceffion of weighty crops of oats, after liming. Upon a renewal of lcafe, he thought he might apply to this land for a repetition of the fame crops, upon a frefh application of lime. He limed a part which had lain in pafture for fourteen years; but his crop was worth nothing: And he is convinced, that no return is to be expected from this land, but by the application of dung, in teathfolding or otherwife.

In a field in the parifh of Skirling, which was fuppofed to have been limed long ago, the tenant had recourfe to complete fallow, as a preparation for laying down in grafs. The field was limed upon the fallow; and a few ridges were left unlimed, in order to obferve the difference. No difference was obfervable in the crop laft feafon, nor is obfervable in the grafs this Spring.

Thefe facts feem to indicate, that lime fertilizes, by acting upon pre-exifting materials in the foil; whether, by neutralizing acids inimical to vegetation, and thus removing obftructions impeding the operation of its vegetative powers; or whether, by ftimulating, by direct influence, thefe powers into action.

In Dr Anderfon's effays on lime, as a cement and a manure, fome experiments are detailed, which would indicate its effects as a manure. And many years ago, I recollect to have heard 
facts, adduced by a Mr Smith (which occurred in lis improvement of the eftate of $\mathrm{Mr}$ Glafsford, the great Glafgow merchant) and by Mr Pitlo, (as refults occurring to him in improving farms of Sir William Cunningham's of Livingfton), which feemed to point to the fame conclufion.

Whatever may be the jut theory of the modus operandi of lime, its application muft be found, in general, advantageous. in this county, as may be inferred from the increafing demand for it among the farmers.

From fome experiments we have heard of in Yorkfhire, it would appear, that lime laid upon grafs, without being mixed with the foil by ploughing, had no perceptible effect. At Magbiehill in this county, a grafs park was limed, without being ploughed, to the extent of three times the rate of ordinary: liming; to the very great improvement of the grafs, and proportional increafe of the rent.

The common rate of liming, near to the limekilns, is from twenty to twenty-five bolls of fhells, or from ten to twelve fingle-horfe cartloads per Scotifh acre: though, at the remoteft diftance, where the fhells (carriage included) coft from four fhillings to four Shillings and fixpence per boll, even the low. rate of fifteen bolls of fhells per acre, is found evidently beneficial upon unreclaimed land newly broken up. Incieed, at thefe difances, the foil is found, generally, more light and fharp.

MIos is fometimes applied, even in a raw ftate, and frem. dug, to light foils, apparently with good effects. I have feen, it thus applied at Blyth, in Linton parifh, in fupplement to teathing, upon the ends of ridges, over which the fold-dike enclofure could not be conveniently extended.

Some burn it, after drying it, in open fire; alleging that. the fire only difipates the aqueous moifture, and ufe the afhes fo procured. Others burn it in a fmothered fire, keeping the flame from burfting out, by the addition of wet mols, frefh dug, to prevent the efcape of volatile particles.

It is very commonly made into compoft with lime, with or without a proportion of the dung of cattle. Made into compoft 
poft with lime alone, it would appear, from Lord Meadowbank's experiment, of very little value.

Mofs, in fome Englin counties, would appear to conftitute a moft powerful manure, even when merely dried, pulverized, and fown on the field by the hand. It may, no doubt, vary in quality, in different fituations; and is probably of fuperior quality, in proportion to fuperiority of climate. We are led fo to judge, in comparing the aftonifhing returns from moffes cultivated according to Smith's recent method, in the low-lying county of Ayr, with the effects produced in this county, by a fimilar mode of treatment, which hath long been practifed, with very little advantage, by Sir James Montgomery of Stanhope, at the Whim.

From Lord Dundonald's experiments, mofs would appear convertible into very rich manure, when treated with fuch fuperabundance of alkaline falts as thall fuffice, not only to difengage the acid, by which the large portion of oil contained in it is bound up, but alfo to convert that oil into foluble foap. Lime is our cheapeft alkaline fubftance; and yet Lord Meadowbank experienced no valuable refult from the mixture of mofs and lime in compoft ; although Smith's improvement of mofs in Ayrhire, feems to depend upon the large application of lime to mofs foil, drained with fhallow drains, fo as not to dry it to withering. It is afcertained alfo, by late experiments, that the alkali of potafhes is obtained, in incomparably greater quantity, from almoft every fpecies of weed dried and burnt, than from the burning of wood, whence alone it was in ufe to be procured. His Lordhip's brother, the Reverend Janies Athol Cochrane, has, this feafon, been inftituting a variety of experiments upon mofs, as a manure, and for other purpofes, at Lamancha, in this county; the refult of which will probably be laid before the public.

Lord Meadowbank, in his publication, December I801, recommends the following method of forming compoft of mofs, the good effects of which he conceives as fufficiently rouched from lis fix laft years experience of its application. 
Let a row of cart loads of new made dung be laid out along the crown of a dry ridge, on which the midden is to be formed, clofe to one another: Let two rows of mofs be then depofited, one on exch fide of the row of dung. The midden is then thus formed: The workman begins at one end of the rows; he throws forward fo nuch from the rows of mois as fhall make a bottom of fix inches thick; he then throws, upon this bottom, dung, from the dung row, to cover it ten inches thick; then, above this, fix inches of mofs; then four or five of dung; then fix more of mofs; then a thin layer of dung: He then covers the outward end, and the two fides, with mofs, and lays on mofs a-top till it is raifed to the height of four feet, or four and an half. Having thus completed this part, he proceeds, as before, till the whole is formed. Afhes of coal, peat, or wood, fhould then be fpread over the top of the midden, at the rate of about one cart load to twenty-eight carts of compoft; or, if thefe are not be had, about half the quantity of finely powdered nlacked lime.

The mofs ufed thould be thrown out of the mofs-pits weeks or months before being depofited for the midden; that, by draining and drying, it may not check the fermentation intended to be produced, through its excefs of preffure, or of moifture. Care muft be taken, for the fame reafon, not to fet a foot upon the compoft when making up. And if the dung ufed has little litter in it, frefh weeds, potato fhaws, \&c. or even fawings of timber, muft be alded in making the compoft, to keep it open.

In mild weather, feren carts of common farm dung is fufficient for twenty-one of mofs. In proportion to the cold, more dung is necefiary for proper fermentation. In Summer, the fermentation may come on in ten days, or fooner; it is apt to exceed, and to firefang the materials; a ftick fhould be kept in it, to try the heat; and if it arifes to near blood heat, it fhould either be watered, or turned over, when frefh mofs may alfo be added. It fhould thus remain untouched, till three weeks before ufing; when it fhould be all turned over, upfide down, and infide out. This compolt is equal, weight for weight, 
to the beft dung." When the mofs is ufed raw, it flould be laid upon the midden lumpy, to admit air.

Nore experiments ought to be made in regard to a fpecies of manure fo frequently obtainable in this county.

Urine of catile, till of late too much neglected, is now more atterided to: It is collected by earth laid down to abforb it (as are alfo the juices ruming off from dungfeads); or it is received into a pit furnifhed with a pump. Mir Stewart, at Efhields, a farm below Pcebles, belonging to James Hay Efq. of Hayfon, collects the urine in the way laft mentioned, and applies it to the land by purting it into a puncheon, furnifhed, at the lindernoft end, with a pipe, terminating in a large rofe like that of a watering pan; the puncheon is fixed upon a wheel carriage, drawn over the field by one horfe, and the urine from the rofe befprinkles to the breadth of nine feet; fo that an cighteen-feet ridge is watered in the going and returning of the carriage. He obferves, "That as urine is of a fcorching quality, it is unfafe to apply it to any growing crop, in great heat or drought; fo that, in general, it is unacivifeable fo to apply it, after the moith of May: That it ought not to be applied to any land in Winter, from its being fo eafily wafhed away by rains; and never, on wet lands, earlier than the month of March; and then, only in dry weather: That it may be laid upon fallow, at any time when it is dry enough to abforb it readily: That, in dry warm weather, it is advantageoufly lais upon ciunghillo, particularly thofe of compoft."

The modes of applying ding have already been explained. Perhaps the mode of applying it, in top drefing, has not been attended to fo much as it deferves. This mode is feldom practifed, except for pafture parks, with compoft; or with cornpoit or alles, to forward a fecond growth of clover.

If well prepared dung were fpread upon crops in a grosuing fate, in Spring, it would feem probable that every nutritious particle, wafled in by the rains, would be greedily abforbed by the roots, norv in an astive bibulous fate: But when manure is ploughed in, it feems probable that much of it is placed too deep, to be reached by the plants; and, particularly, 
when it is ploughed in before Winter for a Winter crop, that much of thofe juices, diluted by Winter rains, paffes by the roots, without being appropriated by them, which they would have readily abforbed, if in an active vigorous ftate of growth. If fuch application were ufed, when the weather is not as yet fo hot as to occafion evaporation, or when the plants fo far cover the foil as to prevent it; it feems feafible to fuppofe, that a much lefs quantity of manure would produce a much greater effect. This mode of application feems to be ufd, to much advantage, in feveral Englifh diftricts. I have had occafion to obferve, this Spring, great fuperiority of effect from afhes harrowed in with the feed ; probably the effect may not be lanting.

\section{SECT. IV.-Weeding.}

THE larger weeds only (fuch as docks, thiftes, and muggwort) are pulled from the corns. Lint alone is carefully handweeded. Green fallow crops are weeded by hand and horfehoeing. In an experiment of hand-weeding oats, by James Reid Efq. of Peebles, at the expence of about a crown per acre, the additional return, above the yield of the unweeded. part of the field, was eftimated at about one boll per acre : the fallow green crop cleaning hufbandry being then, however, fcarcely in practice, the difference would be the more remartable. Hands could not be procured to carry on this operation to any great extent; and the new hufbandry feems, in a great meafure, to fuperfede its ufe.

$$
\text { Sect. V.-Watering. }
$$

FORMERLY this fpecies of improvement feems to have been pretty much in practice, in the parifn of Dolphington, in the contigurous county of Clydefdale. It feems to have fallen into difufe, probably from never having been fcientifically conducted.

In the year 1797 , a float meadow, and a catch meadorv, wcre formed upon the farm of Kirkhoufe, in Traquair parifh, 
(bclonging to the Duke of Buccleugh, and rented by Mr Currer), by Mr Stevens, the perfon fent to Scotland for that purpofe by the Board of Agriculture.

The fuccefs attending the watering, in thefe inftances, has diffufed the practice. A farmer, on 'Traquair eftate, has got one executed by Stevens, which is flooded by the water of Quair ; being contented to lay out the principal, and to forego the intereft, during the currency of his tack, upon condition of being reimburfed the principal at the expiry. Robert Campbell Efq. has had one formed at Kailzie, to which he is intending to make additions; and feveral more are in contemplation.

I find no better way of explaining the fubject, than by inferting the following account and plan, which I fent to the Farmer's Magazine, and which is inferted in No. X. That account was chiefly fuggefted from what $I$ had found in a pamphlet, publifhed by $\mathrm{Mr}$ Wright in $1798-99$, lipon the method of floating land in Gloucefterfhire. I have added notes, from what occurred from the perufal of a pamphlet of Bofsell's, in Dorfethire, publifhed in 1790 .

\section{Explanation of the Plates.}

\section{Plate I.}

Fig. 3. reprefents a float meadow, under irrigation; the dark inading reprefenting the water.

When the hatch of the water dam-dike * (marked $\mathrm{H}$ ) is lifted up, the water runs in the natural channel of the river; when the lateh is flut, as reprefented in the figures, the natural channel is laid diry below it, and the water runs laterally along the main feeder + in the direction of the arrows, and is from it diftributed into the floating gutters $f(g g g g)$, which

* Where thele is but one ontlet (or thoroug $b$ ) in the dam-rlike, the dam-dike is defigned, by Bofwell, a faice. Where there are more than one outlet or thorongh, with correfpouding hatches, the dam-dike is defigned a were.

t The main feeder is defigned, by Bolwell, the lnead main.

$\$$ Bofwsll difigns the ploating gutters trenclus. 
are formed along the crowns of the ridges into which the mest dow is arranged, overflowing on both fides of faid gutters, and running down the fides of the ridges into the furrows os drains $\&$ betwixt the ringes $(d d d d)$; which drains difcharge

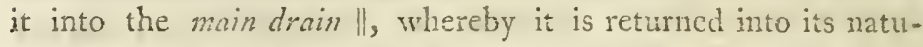
ral channel at the foot of the meadow.

The marks $(0 \circ$, or $\Delta \Delta)$, and the tufts, in the main fecder and the floating gutters, denote-The jirft, obfructions (called bends by Bofwell) made by flakes, or fods, or ftones, in order to raife the water, and make it flow over from the main feeder into the floating gutters, or from the latter over the panes; the fecond, notches cut in their fides, with a fimilar intention. If, however, the main feeder and floating gutters are properly conftructed at their firf formation, thefe fupplementary aids will be, in a great meafure, unneceffary; for the main feeder ought, sit its entrance, to be of dimenfions juft fufficient to admit the quantity of water which is to be conveycd to the meadow; and gradually to contract its fize as it goes along, in order that the water, for want of room, may be forced into the floating gutters, dribbling alfo over every point of its own fides: The floating gutters ought to be formed after the fame model, that, by their primary conftuction, the water may, in like manner, overflow their fides through their whole courie. That as little as polible of furface nay be taken un in unproductive water courfes, a fimilar mode of confructicn muft be adopted in the drains; they ought to be narrow, neareft to the main feeder, where they receive little water; and to cliverge, in proportion to the greater quantity of water they lave to carry, as they approach nearer to the main drain: 'This laft is, for fimilar reafon, fimilarly confrueted. In the three plates, this node of confruction is made obvious to the eye.

The

S The furrow drains betwixt the ridges, Dofwe!l defigrs trench srains; and the piece of grafs furface, nuer which the water floats, fying betwiat each trens.' al' trent's draiv, he defizns a pane.

If The main drain is called, ly Bofwel!, tail drawn. 
The meadow, in this plate, muft be conceived to lyc in a regular and very gentie flope, from the main feeder to the main drain.

Fig. I. and fig. 2. prefent a view of the ridges cut acrofs, with each its fecding gutter $(g)$ upon its crown, with two difcharging drains $(d d)$ along their fites. When tirey are formed in grafs land, with the intention of preferving the grafs fward whole for immediate watering, they may, mot cheaply, though more roughly, be formed, as reprefented in fig. I.; the floating gutter being morely bulked up into its proper fhap, by the foil and fward taken from itfelf and from the receiving elrains, in forming them; wolen, the depofitions of fediment from the floating water, will gralually fill the fhoulders of the floating gutter, up to the dotted line, moulding the ridge at length into the fliape of fig. 2. Were it not for the greater expence, it would be better to make them of the fhape of fig. 2 . at their original formation. It comes more cheap, though it occafions more delay, to plough the land into proper ridges, and, after complating the formation by the fpade, to fow it off with grafs feeds, and to delay the flooding till the fward has attained to a proper confiftence *.

In the formation of the meadow, particularly if the declivity is very fmall, care fhould be taken to lofe as little as porfible of the level, in the main feech and floating gutters, by giving them fuch fmall defcent as fhall barely fuffice to make the water run ; in order that the greater defeent may be afford. ed to the water, down the fides of the ridges from the floating

gutters

* It would appear probable, frow fome experiments in Twecdlale, that water adnitted over recently fown artilicial grafes, makes the land throw then ont. Pcriaps, indeed, fufficient carc had not been taken to let the water off as readily as it came on : Upon fuppofition, however, that natmal grafes would prove more hardy, an intelligent farmer in Dunfyre parth, thire of Clycleflale, wiso is forming a water meadow, propofes to take a crop of nats, after a filf rongh formation by the plongh; then to lat the land lye in panture one feafon, for the further eftablinment of the natural grafs roots; then to plough into the full fhape, affifting the formation by the fpadc, and to take a fecousl ctop of outs; after which, either to water immediatcly, or pantuic another acafon, is the fward fhall or thall nes anpear to have a proper confiftence. 
gutters to the receiving drains; that thus the water may float over the grafs panes, with the greater rapidity, and in more quick fucceffion-the principles upon which fuccefsful watering, in a great meafure, depends *.

The narrower the ridge is formed, the greater defcent can be given from the gutter on its crown to the drain in its furrow, fo as to make more water pafs, in a given time, over the grafs-bearing pane; but, at fame time, the more furface muft be unprofitably occupied in unproductive gutters and drains. A balance medium mult be attempted betwixt thefe advantages and difadvantages. Mr Wright exprefies the opinion, "that the breadth of the ridge ought never to exceed eleven yards, nor to fall fhort of eight.' Mr Bofwell is not explicit as to the breadth of ridge; he, however, incidentally, in treating of the formation of a particular defcription of meadow, in dry ground, mientions ten or twelve yards: In general, he obferves, that, upon light channelly or fandy foil, the breadth of the ridges may be extended, and more meadow may be watered by lefs power of water ; and that, in firong clay, or moffy (corky) foils, more water at a time, and longer continued, is requifite; and the ridges muft be narrower: In thefe laft foils, the heavier and more rapid the body of water which is made to pafs over them, fo much the more of beneficial effect is to be expected; unlefs, indeed, the current is fo unmanageably rapid and weighty as to endanger the tearing of the fward.

It is evident, from the infpection of this plate, that, if the meadow has been properly formed according to the foregoing defcription, the hatch $(H)$ is no fooner lifted up, than the water refumes its natural channel, and the meadow becomes immediately dry; its figure immediately freeing it of all furface water,

\footnotetext{
* In a meaclow, formed Spring 1797 , by Mr Talbot of Penrick Calle, the defeent of water, in the floating gutters, is at the rate of one inch in nine yards; and of two inches in one yard, over the fides of the ridges; the diftance betwixt the floating gutters and receiving drains being five yards, or the whole brealth of the ridge ten yards. 'This formation, Mr Wright commends as wearly perfec; though, in refpect of breadth of ridge, he prefers that arlopted in the Duke of nedford's mcadow, where, froun more abusdant water, it is fixect at eight yards
} 
water. To prevent the pofibility of any water getting into the meadow, when intended to be laid dry, Mr Bofwell takes notice of the trunk; which may be a $\log$ of wood bored like a pump ftalk, and is buried under ground at the entrance of the main feeder; one end (which is fhut with a hatch or plug when the meadow is to be flooded) opening in the bottom of the main feeder, the othcr into the channel of the river below the hatch (H). The fame effect is produced, either by prolonging the firft floating gutter into the main drain, with a hatch to fhut it, at proper diftance from the main drain, when the water is turned upon the meadow; or by carrying up the firft drain to the main feeder, with a hatch to thut it when the meadow is under water, and to be raifed up when the meadow is laid dry.

The convenier: contrivance of the ruay-pane, noticed by $\mathrm{Mr}$ Bofwell, may here be explained.

Suppofe, then, the meadow of this plate I. to be enclofed, on one fide by the natural channel of the river, on the other three by hedge and ditch, with the ditches next to the meadow, and the herges on the other fide of the ditch; it is evident, that advantage may be taken of the ditches, at the head and foot of the meadow, for the main feeder and the main drain; and that the ditch on the fide of the meadow oppofite to the channel of the river, may ferve the purpofe of the leffer drain $(d)$ on that fide. Bofwell has no objections to this ufe of any of the ditches, but to that of the head ditch, for the purpofe of a main feeder: Not only would the roots of the thoms breed obftructions in the main fecder; but, which is of more difadvantageous confequence, rats and moles, working in the bank, would make holes in it, by which the water would be carried off. To remedy this, befides other advantages, Bofwell advifes the forming of the main feeder parallel to the head ditch, but at the diftance of a lalf ridge, or pane, below it *. This pane is formed to llope properly from the main fecder into the head ditch, and is floated immediately from the main feeder. This pane is called the way-pane; becaufe carringes for carying off

- Or at fuci diltance as ha!l futóce to torn $x$ hay cart. 
the hay arc admitted upon no other part of the meadow; which faves the damage that would accute from wheels croffing the floating gutters and fmaller drains; the hay, in making, being all carried up, in courfe, to the edige of the main feeder.

This meadow is all flooded at one time; or, as Bofwell exprefles it, by one turn of water.

\section{Plate II.}

This plate reprefents a float meadow, lying in different declivities: It may be floated all at once; or, if the water is deficient, at all times, or, in time of droughts, any one, or any two of the three compartments into which it is divided, may be fingly watered, while the remainder is kept dry: It is a meadow with three tums of water.

In this meadow, it is fippofed that the ground rifes from the natural channel of the river up to (F I.), which is a feeder with its correfponding floating gutters $(g g g g)$; and thence defeends to the hollow along which is conducted the drain (D I.), which receives the witer from the leffer drains $(d d d)$, and difcharges it into the main drain. It is fuppofed, that the ground rifes again from ( $\mathrm{D}$ r.) up to the fecond feeder ( $\mathrm{F}$ 2.), and thence defcends to the hollow, along which is conducted

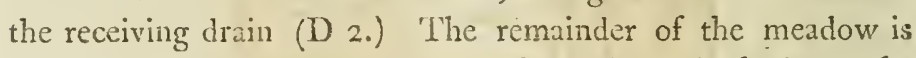
fuppofed to lye in a regular flope, from the main feeder to the main drain, or laft mentioned receiving drain. The letter $(r)$, in this and the former plate, marks a fmall rut or gutter, formed by a fpade or triangular hoe, for conducting water to places upon which it does not appear to fcatter regularly.

The hatch upon the river's natural channel, and the one upon the feeder ( $F$ 2.), are reprefented as thut; and, confequently, the natural channel, together with that part of the neadow which is floated from the feeder (F 2.) as dry. 'The hatches, upon the fee?cr (F r.), and upon the main feeder, are reprefented as drawn up; and, confequently, the two parts of the meadow, floated from them, are reprefented as under water. 
I'INU].STEIS STRVE:

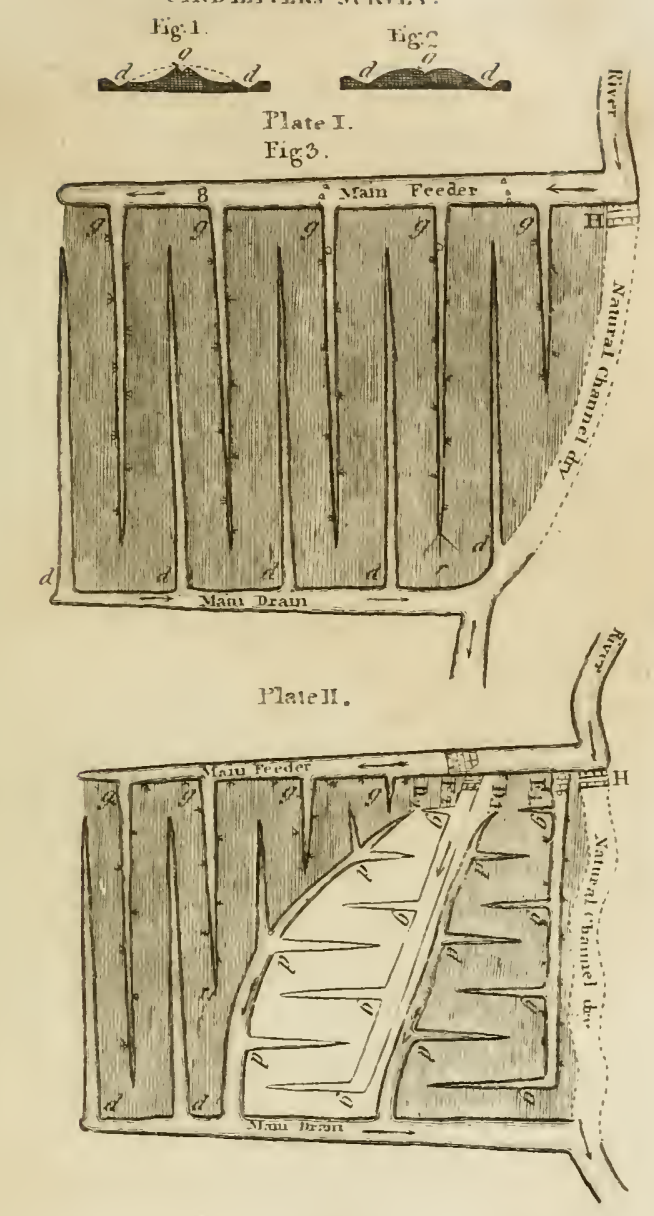

puspe s.-

i'la:e IRT.

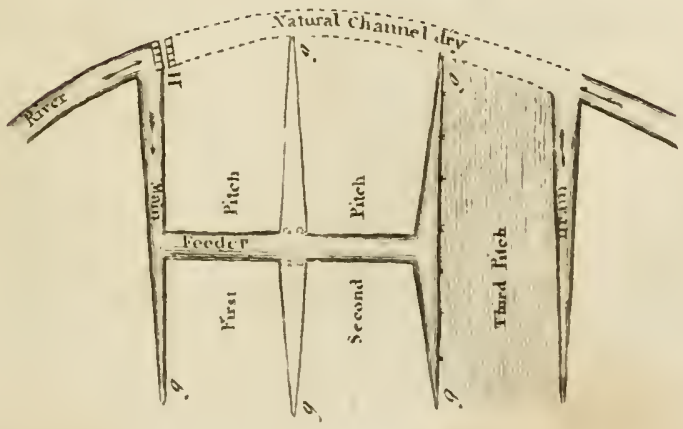


In the conftruction of float meadows, the floating gutters die away to nothing within four or five yards of the main drain; the water from the extremity of the gutter eafily fpreading over that fpace; or, where ready to collect into a firam before falling into the main drain, being made to fnread properly by the fmall ruts marked $(r)$ : The fmall receiving drains, for like reafon, may be made to die away before reaching the feeders. This is reprefented in the plan.

In forming meadow, Gloucefterfhire flooders make no account (according to Mr Wright) of the original quality of the foil or fubfoil; the meadow will, in all cafes, come in time to be equally good; the goodnefs depending entirely upon the quality of the water, which foon creates, of itfelf, foil enough for the plants. The fubfoil is of no account, whether pervious or impervious to water; as it is found (after fufficient time for the water depofiting fufficiency of fediment), tliat the watcr difcharged by the main drain, is, in every meadow, nearly equal in quantity to that admitted by the main feeder, any apparent diminution being no more than what might be fairly attributed to evaporation, from fuch an extent of furface, without fuppofing any of it to have funk through the foil *. If, however, there are fprings in the meadow, thefe mutt bo carried off by underdraining; for every meadow mult firt be thoroughly drained, before you can drown it to good effect.

Ufed water is confidered as of very little ufe; hence, meadows formed below another meadow, to be watered by the fame water that hath, immediately bcfore, watered the meadow above, are confidered of very inferior value. Hence arifus the propriety of making the watered panes narrow; as, even in meadows where the ridges are the not narrow, the part of

$$
\text { A a }
$$

* Mr Bofwell takes notice of a meadow of thin moorifu fuil, npon an inpervious bottom of clay till, watered from a fring near to iis lource. It. proved perfedly barren : When the meadow was laid dry, a ycliowilh-coloured watcr cozed throngh the fril (probably from ochry imprectnation of the fubfoil): It was sovered witl chalk and other manures, and 211 to no purpofe: At kongth it witj thorouglaly underdraized, when it imm diat. ly becume probustive. 
the pane neareft to the floating gutter bears more grais than the parts farther off; becaufe the former firft filter the water, and tranfmit it ufed, in fone degree, to the latter: 'The balance of difadvantages, however, forbid too great narrowing of the panes, that fufficiency of productive furface may remain unbroken.

Even fimple clear water, taken off for the meadow near to the fource of the fpring, and w!here no extent of furface is wafhed by rains to render the water turbid even in the wetteft fealon-even fuch water enriches meadow; with the exception, probably, of fprings impregnated ftrongly with minerals, which might prove deftructive to vegetation: The beft effects are, neverthelefs, to be expected from waters draining a good extent of fertile lands, or receiving the drainings of great towns.

Water is fuppofed to act both as an enricher, and as a Winter frelter to the grafs plants. In the former view, the quality of its depofitions will afcertain its value; though (as eren the water from a fpring enriches, and as this too is detericrated by being $u(e d)$, it is not improbable that pure water, in filtering through the grafs, undergoes fome kind of decompofition; in the courfe of which it is deprived of fome vegetable pabulum, which the plants of grafs affimilate to their own fubftance, and which it cannot again render out in the fame quantity, to the plants it next paffes over in fucceffion*. As a mere Winter folter, water hould have the fame effects, ufed, as $u n-$ ufed. For both purpofes, it would appear eligible that the water thould cover the panes in a fheet of one inch of thicknefs; and moving in a fucceffion, of the quicknefs given by a defcent of two inches to the yard, from the edge of the float-

- By Count Rumtord's experiments on food, particularly in making foups from regetables after long boiling, it would appear that water properly decompofed forms a chief article in animal nutrition. Six or feven ounces of a mixture of peas, potatocs, and barley, weighed dry, will, after long boiling with fufficicncy of water, furni?h food for twenty-fonr hours to a hard working man; although it is ccrtain, that a man perfestly idle would abfolutcly ftarve upon fuch an allowance, if adminiftered to him under any o:her form, and thongh he thould drink along with it the lame quantity of wates. 
ing gutters, upon the crown of the ridge, to the edge of the drain along its fides. To cover the meadow with a heet of water exceeding an inch and half in thicknefs, would, it is fuppofed, rot out the roots, from the too entire exclufion of the air: for the fame reafon, the water mult, at longer or Thorter intervals, be turned off the meadow, that the plants may get air. Confidering the depth and rapidity of water required in floating, a confiderable command of water is necefo fary for no great extent of meadow. It is always better to contract the extent of meadow, than overftretch the power of the water.

\section{Plate III.}

This plate reprefents catch meadow for the fide of a hill, or Ateep declivity. It is called catcb, becaufe, when the whole is watered at once, the water, floating over the uppermoft pitches ${ }^{*}$, is catcled in the floating gutters, which diftribute it over the inferior pitches $\dagger$.

The lateral horizontal feeding gutters, which fcatter the water over the firf and fecond pitikes, are reprefented as fhut by fods, or ftones, \&c. (8); and, confequently, thefe firft and fecond pitches appear dry: The whole water is reprefented as paffing down the main feeder into the loweft floating gutter; whence it floats the lowef, or tioird pitcl, and is received into the drain at the foot of the meadcw, to be returned by it into the natural channel.

When the whole is to be floated at once, the obftructions (8) are taken from the lateral floating gutters: obftructions, meantime, are placed in the main feeder, immediately under the floating gutters, to force the water into faid gutters: thefe obftructions muft not, however, entirely cbfruct the main feeder, but mut allow fcme am fod water to proceed to the lower pitch-

es.

- I am fufpicious that the word fiteb is here improperly ufed : I believe a pircb of work is the technic floater's phrafe to denote the portion of a meadow watered by one turn of water. It may anfiser well enough here as a reference to the plate.

$\dagger$ Meadow watered by water catched fum a sigher lying meadow after havine

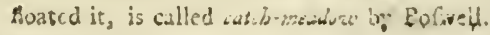


es. The breadth of the pitckes, in catch meadow, I have not found afcertained; they may, no doubt, confiderably exceed that of a pane in a float meadow; becaufe, from the more rapid defcent of the water over the ground, it may run farther, without being fo much impoverifhed by fo much fhorter continued $u f e$.

Bofwell propofes a different form for catch meadow. The main feeder, in this plate, he carries on, along the hoad of the meadow, and down the fide oppofite to that bounded by the water's natural courfe. Drains, of fimilar form to thofe marked $(d d d)$ in the two preceding plates, but of larger fize, are drawn, in the place occupied by the floating gutters of this plate, with their fmaller end approaching near to the natural channel, and diverging towards (in order to difcharge themfelves into) the main feeder, on the oppofite fide of the meadow. Hatches are placed upon the main feeder, immediately below its turn down hill, and immediately below the dircharging mouths of each of the drains. If you chufe to water the firf pitch by itfelf, fitut the hatch immediately under the turn downwards of the main feeder; the water then accumulates in the horizontal part of the main feeder, and it floats over its bank upon the firft pitch: meanwhile, all the other hatches being opened, the water floating over the firft pitch, is catched in the firft drain below it, and difcharged into the perpendicular part of the main feeder. To water the fecond pitch by itfelf, open the hatch immediately below the turn downwards of the main feeder, and thut the hatch upon the main feeder immediately below the diverging mouth of the drain lying under firf pitch; the water then runs along the main feeder, without floating over, till it comes to this thut hatch; when it runs up the drain along the head of fecond pitch, overflows its fides, and waters that pitch; and, the hatches below being opened, the drain at the foot of fecond pitcls difcharges the water into the main feeder. By this ingenious contrivance, the feeders and drains ferve the double purpofe of drains and feeders, into which they are alternately converted.

Catch meadow, on the face of hills, is not fo much prized as float meadow upon flat lying laud. 
Bofwell propofes, as advantageous, the formation of land into water meadow, even qubere there is 120 perennial run of water; if, only, it be fo fituated, that, in wet weather, the drainings of any large tract of cultivated rich land can be collected into a main feeder, and brought over it. This he calls watering by land floods.

After what has been fuggefted, as to the formation of water meadows, nothing more feems requifite, on this part of the fubject, but the explanation of Rafter Levelling. When meadow is formed from grafs land, preferving the fward, inequalities of fmald account are equalized by this mode: The fimall heights are deeply rutted by the fpade into narrow parallel ftripes; one ftripe is taken out, and another left remaining, alternately; thofe left, are beaten down by the heel or a mallet; thofe taken out, are chopped and fpread in the little hollows, and beaten down: The levelling thus proceeds in double ratio; the heights being lowered down, and the hollows elevated.

Watered meadows are expected to yield, firft, a Spring feed, coming in by the middle of March, or beginning of April: 'This may be paftured till the beginning of May. If a crop of hay is next intended, the pafturing muft ceafe then; as, if continued for a fingle week in May, the hay would be suined in quality (according to Wright); as it will be foft, woolly, and unfubftantial, like a crop of aftermath. Second, The pafture having been eaten quite bare, the meadow is watered for a few days, (the fewer, in proportion to the heat of the weather); and, in fix weeks or fo, a crop of hay will be in readinefs for cutting. Third, After the hay is remored, the water, again turned over the meadow, for a few days, will produce a crop of aftermath, for pafture or for green houfe feeding: A fecond aftermath, or even a third, is proctired, fonetimes, in the fame manner.

The Spring feed, raifed by the Winter watering, is a wholefome food for every kind of pafturing animal. No fact, howeyer, is betser afsertained in agriculture, than, that paf- 
turing ßeep on grafs, raifed by Summer watering, infallibly rots them. They muft never, therefore, be allowed to tafte the aftermath; unlefs it has been allowed to grow after the hay crop, without watering.

In Scotland, it is not to be expected that watering will produce either fuch early, or fuch abundant vegetation, as under the fuperior climates of Gloucefter or Dorfet hires.

One general rule in watering is-never to admit the water, when there is growth upon the meadow, fit for either pafture or cutting, as the fediment of the water would make the crop naufeous or uneatable - and to admit the water at the time the meadow is quite bare.

Another general rule is, to proportion the continuance of the water upon the meadow, to the heat of the weather, continuing it longeft when the weather is coldeft. In hot weather, too long watering is faid to produce a fcum of a whiteifh colour, which is deftructive of vegetation; and whofe cure is, inftantly to lay dry. Hot foil needs fhorteft; cold, longert watering.

The meadows ought to be eaten bare in the middle of October, that they may receive the benefit of the water from the firft floods after Summer, which muft neceffarily have the richeft depofitions; and this firft flooding may be continued for five or fix weeks.

In November, December, January and February, the flooding may be continued; firft, for five or fix weeks at a time, and then, gradually for lefs fpace at a time, with intervals of Jyjing dry gradually increafing. From Michaeimas to Candlemas, no flood fhould be allowed to pais, without its waters being thrown over the meadow, to obtain the fediment. In Scotland, the watering may probably be continued through March.

That the benefit of the water may never be loft, it is proper to have a meadow with different turns of water; or feparate meadows, to be alternately watered, and laid dry. This is alfo peculiarly advantageous in procuring an uninterrupted fucceffion of aftermath palture, or green houre feeding.

By continued courfe of watering, meadow is not only fertilized for grafs, but enriched for tillage. 
A Scotin farmer is aftonified at the accounts of the return of meadow, as ftated by Mr Wright. For inftance, in South Cerne in Gloucefterfhire, the rent obtained from one of the beft meadows, per Scots acre, for five weeks pafture from the fecond day of April; amounted to no lefs than 5l. 9s. $\frac{3}{4}$ d. The fubfequent hay crop amounted to 230 'Tweeddale ftones per acre, at 22 Englion pounds to the ftone, befides the after foggage, whofe value is not ftated. The number of cattle maintained per Scots acre, for the above five weeks pafturing, amounted nearly to feventeen wedders, one and a fourth cow, together with one colt.

The average value of meadow in Dorfethire, is ftated, by Bofwell, at a much lower rate. Meadow's are let, by themfelves, at from $30 s$. to near $3^{l}$. per Scots acre; or, if the crops are let feparateiy, the Spring feeding till the int of May is let at about 12s. and the aftermath at from I2s. to I $8 \mathrm{~s}$. per Scots acre; the price of the hay crop varying, according to crop and markets, from 11. 18s. to 3l. 5s. per Scots acre.

The expence of forming water meadow, cvery thing included, Bofwell eftimates at from 5l. to 7 l. 10s. per Scots acre, according to the favourable or unfavourable predifpofition of the grourds.

In high lying theep farms, where the returns from tillage are not adequate to its expence, water meadow feems to promife a mode of obtaining an early Spring food for ewes, and Winter fodder for milk cows, and horles kept for carriage of fuel and riding, at a cheaper rate than, in fuch fitnations, they could any other way be procured. Mr Anderfon has, I underftand, introduced watering in his Meep farm of Cramalt, in the high lying parifh of Meggot. Our Scotih experience is as yet too limited, to decide upon, 


\section{H A P. XIII.}

\section{I, IVE S T O K.}

\section{SeCT. I.-Cattle.}

THE average fize of milk cows may be about twenty-five fones Dutch weight, when moderately fat. The farmer endeavours to fuit the fize of his cows to their pafture. He efteems it much more fafe to have them under, than overfized.

Irr Mackie, in his fecond letter to Colonel Dirom, relative to the corn laws, obferves, that fmall animals take on fat more readily than large ones, in proportion to their feeding, for two reafons: firft, Becaufe the furface of the bodies of fmall animals is much greater, in proportion to their folid contents or weight, than that of large ones; and, as fat is moftly depofited upon the furface of the body, they have, confequently, a larger fpace to lay it upon: fecondly, Becaure the mufcular fibres of fmall animals are lefs tenfe, and more eafily admit that fat, which, in the fattening procefs, infinuates itfelf into the interior veficles of the mufcular fibres. He takes notice of a comparative experiment of fattening large and Imall oxen upon turnip and hay; in courfe of which, it was found, that each large ox ate double of what was confumed by the fmall one. When both were fold, the large oxen fetched 12l, each of price, and each pair of fmall ones 161. 
Mr Loch of Rachan fpeaks highly of a breed of cows he has got from Kyle, recommended in Colcnel Fullarton's Report of Ayrthire.

Mr Stewart has a breed at Efheilds, picked up in Berwickthire. Two kinds of them he withes to propagate as ftock: The one, of a dark red colour; face, breaft and legs, white; horns fmall, long, and well fet; bones fmall for their weight; body round; legs fhort, but well fet on them: The other, of a paler red colour, with more of white; the bones fmall alfo, but not fo handfomely fet, nor the horns fo handfome. The firft, are the muft kindly feeders; the fecond, the beft milkers: the firft, when fattened, of fuperior beef; the fecond, yielding moft tallow.

It feems probable, that a great range of well obferved experience is ftill necefiary, before any thing very decifive can be pronounced, as to the indications in black cattle, that prognofticate fuperiority, as to the diftinct properties of feeding or milking.

\section{SECT. II.-Shecp.}

There feems to be no clear tradition, nor even plaufible conjecture, as to rwhen, or whence, fheep were firt introduced into this county, or whether the prefent breed are indigenous, or from another country. There is, indeed, an obfcure tradition, that, previous to the introduction, or general prevalence of theep in the parith of 'Tweedfmuir, the farmers in that parifh paid their rents, by grazing, for hire, through Summer, the oxen then generally ufed by Lothian farmers for their Winter ploughing.

The native Tweeddale breed, which has continued the fame as far back as memory or tradition extends, are all horned, with black faces, and black legs, and coarfe wool. Their fhape, to which alone attention has been paid in felecting the breeders, is compact, fhort-coupled, flort-legged, round-bodied, with a rifing forehead; in fhort, poffelling thofe qualities, which, in every other fpecies of animal, has hitherto $\mathrm{Bb}$ bec!! 
been confidered as indicative of kindly feeding and eafy keep *.

Sir John Sinclair, to whom his native country ftands highly indebted on various accounts, has, feemingly with great propriety, recommended the Cheviot breed, as the beft adapied of any known fpecies of fine-reoled freep, for high, bleak fituations. They are in the courfe of being fairly tried in Tweeddalc. Nothing, however, decifive can as yet be faid in regard to the experiment.

They are hardy and vivacious, and no more liable to difeafes or death, than our native kind; excepting, merely, in a fevere feafun, at the time of lambing, when the lambs are more ready to perifh from inclemency of weather, being more naked at the time of birth.

Their longer back, longer legs, lower forehand, and more lank fhape, would indicate their being lefs kindly feeders: they are acknowledged, indeed, to be fo, by thofe who are propagating that kind. It is pretty generaily fuppofed, that the lands, which would fuffice to maintain fifty fcores of the native breed, would maintain only forty-five fcores of the Chevivi; and that, not from fuperior weight of carcafe, but mere unkindlinefs in feeding.

There is no judging, as yet, of the profit from the fales; as the price has not, as yet, come to its level. Whilf the rage for this fpecies of improrenent continues, and till once the country is fully ftocked, the ewe lambs draw a pretium affectionis for breeders; and even the wedder lambs draw the fame kind of price, on account of the wool, from thofe whofe farms are adapted

- Mr Stewart, upon Mr Hay of Hayfton's farms of ERields, or Hayfton, has bronght our native breed to bring lambs in January; from the very plaufible notion, that they will feed their lambs at lefs expence than any other breed yet known, in that very expenfive feaion of kceping. The practice was once very profitable; hut, as in all firoilar cafes, the fuperior profit attracts capital to the fame employment, till the profits are beat down, by competition, to the Icvel of that obtaincil in other employments; the only diffence remaining, being that which confifts in natural advantages for the practice; for which, proportional rent muft be paid againd a ncw leifo. 
adapted for carrying on this kind of ftock fleep. Nieanwhile, an adequate price is not obtained from the Edinburgh butcher, for the fkins and wool of the lambs, or old theep difpofed of to him; becaufe he contracts with a dealer, through the feafon, for the fkins of all the fheep he finall kill, at an average price; and he camnot, as yet, fay before-hand, what number of fine fhins he flall have in his parcel. He reckons the carcafe inferior, both of lamb and mutton.

Fine wool, like every other article in comnerce, muf fall in price, as it becomes leís fcarce. There is, too, no reafon, in the nature of the thing, why fuch as can afford it, fhould not give a proportionably higher price for delicate mutton, as for fine wool; it being juft as reafonable to wifh to be delicately fed, as to be foftly clothed: Nor is it perfectly afcertained, that the mutton of the Cheviot breed comes up to the acknowledged delicacy of that of our native breed.

It remains, then, as yet, to be determined, by fair experiment, whether, in point of profit, the acknowledged fuperiority of the black-faced breed, in regard to feeding and carcafe, and the lefs rifk of death of lambs, fhall furpass, or equal, or come fhort of, the acknowledged fuperiority of the Cheviot breed, in regard to wool. The experiment will be completely tried; and, if fuccefsful, the change of breed will be as completely effected: For the Tweeddale farmers are certainly as much fet upon their own intereft as any other clafs of men, when, only, it is clearly afcertained to them where thcir intereft lies.

In regard to agricultural improvements, the higher ranks of fociety are ready to difplay too much of the fpirit which animates the democrats of the day; their notions of improvement, lantily embraced from mere partial views of the fubject, muft be inftantly adopted, and erery ancient fyftem muft be ovcrturned, to make way for them; their ablinat reafonings, it priori, muft he implicitly conficled in ; paft experience is unworthy of attention, and future experience not worth wating for; imnovation is Ifurm; a coutious renitency againt change,

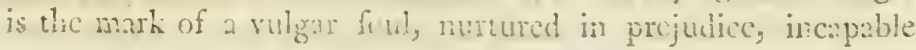


of mental energy, and of directing itfelf by the polarity of rea* fon *. The fame zeal leads, in both inftances, to the fame difregard of veracity; and the report of an infuriated reforming gentleman farmer, as to agricultural facts, deferves as little credit, as that of a democrat in regard to public events.

In gentlcmens parks, different kinds of fine-woolcd fheep have been kept; particularly the Bakewell breed, with long combing wool: 'The South Down have, of late, been adopted, by Sir James and Sir George Montgomery, at Whim and Magbiehill ; and by the Countefs Dowager of Dundonald, at Lamancha. Their wool, though lefs in quantity, may, from fuperior price, render them equally profitable with the Bakewell; while their fmaller fize would indicate their flefh to be more delicate, though not comparable to that of the black-faced breed.

The idea which has been fuggefted, of dividing, univerfally through this county, the high lying coarfe pafture from the lower and more fine, appropriating the former to the coarfer wooled, and more eafily kept breeds, and the latter to the lefs kindly feeding, but finer wooled, would be found inadmiffible; the coarfe-wooled kinds requiring lower pafture for Wirter. Even where old wedders (the hardieft of all theep) are kept, there muft be varieties of pafture, to fuit the changes of feafon.

The period of geftation, with theep, being twenty-one weeks, the general term of the admifion of the tups to the ewes is the $22 \mathrm{~d}$ November; fo as that the lambing may commence by the i8th of April. In lower fituations, where the grafs fprings carlier, the tup is admitted perhaps ten days fooner. Except-

" Mr Chatto of Mainhoufe, near Kelfo, at one time, followed farming as a profeftion. When he commenced practice, fraight ridyes were the order of the day; every one was branded, as prejudiced to antiquated abfurd cuftom, who had not ftraight ridges, at all events: He, too, therefore had his ridges ftraightened. He has affured me, however, that of all other criors in farming, he never fo heartily repented of any one, as of fraightening ridges in wet land; the formes high crowns, now levelled, remaining for years perfeetly barren; and the old fursows, now flled us, being conrerted into mire. 
ing in two or three very high-lying farms, the tup is admitted to the gimmers, as well as to the older ewes. According to the poverty or richnefs of the pafture, and confequent more enlarged, or more circumfcribed fpreading of the fheep in their feeding, one tup fuffices for forty, or for fifty ewes: And no more than what are neceffary are kept of fuch an unprofitable ftock. An enclofure would feen: highly neceffary in every fheep farm, in which to confine the tups for fome weeks, previous to their admifion to the ewes, in order to fuperfede the awkward contrivance of a cloth fewed over their bellies, which. though it prevents the premature impregnation of the ewes, does not prevent exhauftion-not to mention the excoriating efiect of the confinement of the urine.

The lambs intended for wedders, are caftrated as late as cair be hazarded, that they may fhow better in the forehand, and in the born*; but early enough to avoid the great Summer's heats, which would render the operation dangerous: The u. fual feafon is fome time in June. 'Thunder or froft, immediately after the operation, are both highly dangerous. The mode of operating is this: One perfon, commonly a maid-fervant, holds up the lamb, with its back againft the holder'; breaft; the operator, ftanding before the lainb, cuts off a part of the fcrotum with a tharp knife, then fqueezing out the tefticles, he catches them betwixt his fore-teeth, and draws thenz away, with all their veffels attached to then.

Lambs are not fhorn till the fecond July from their being lambed.

The

* It feems odd, that caftration Mould prodice fuch uppofite effects in the bull and the ram, increaling the growtl of horn in the former, and diminifhing it in the latter. This is one, of various inftances, in which analogy does not holit. We muft have recourfe to analogical reafoning, in fabjects inaccefible to experi. ence: It is, however, idle to reft upon analogy, where we have accefs to confirm or annul the conclisfion by experiment. That like events thall take place in like circumfances, is the fundamental principle of all reafoning, as to caure and effc尺 ; but circumftancer will appear alike, upon a fuperficia! vic's, where a witf

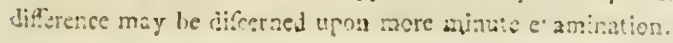


The breeding ewes are calt off at the ages of four, five, or fix years; requiring, proportionally, the retention of a greater or lefs number of lambs, annually, to keep up the ftock. Sometimes particular ewes will fhew fymptoms of failure more early, or will retain their vigour longer than any of thefe allotted periods: Their ftate is examined once a year, and is judged of by the appearance of their eyes, and the condition of their tecth, when thofe to be caft off are liftinguifhed by fome vifible mark of keel (an iron ore which makes a red mark) or of tar. It is judged beft to caft them while yet in full vigour, as they draw the better price. From the retained name of crocks, or decript, the old practice had been different.

The theep are all fmeared, or falved, at Martinmas, with a mixture of tar and butter: twelve Scots pints (twentyfour Englifh quarts) of Norway tar, with one and a quarter ftones ( $16 \mathrm{lb}$. of $22 \mathrm{oz}$. going to the ftone) of Orkney butter, fuflice for fifty lambs, or for fixty fmeared for the fecond time: The fame tar, with a ftone and an half of butter, fuffice for eighty older fheep. The young fheep require more tar, in proportion, in order to kill the vermin, to which they are more fubject. Smearing is farther judged neceffary to keep the wool in better quality, and in greater quantity; as, alfo, for a defence againft cold and wet. It, no doubt, difcolours the wool; and the reprobation of this long-conftituted practice, furnifhes a theme for declamation to our ignorant, inexperienced, revolutionary, reforming farmers *.

About the beginning, or towards the middle of July, the lambs, intended for hoiding ftock, are weaned; when they reccive

- Mr Loch of Kachan ouferves, that a fmear, which fhall, at cnce, fhoot the rain, kill vermin, and defend the wool from the withering effect of weather without difcolouring it, feems to be, hitherto, a defideratum in fheep farming. He propofes a fmear compofed of butter, train oil, and turpentine.

He informs me, that, ten or twelve years ago, on obferving a recommendation to that chict from tise Wool Socicty, he clothed fixtcen of his flock, from the neck to the tail, with cerecluths of a foot in breadth, as a fubftitute for fmearing: But, at Mcaring time, the woul below the cloths was fo padded and glued together, by the vifid clummy perfpiration from the animals body, as to be goos for nothing. 
ceive the artificial marks to diftinguifh to whom they belong; which are, the farmer's initial, ftamped upon their nofe with a hot iron, provincially defigned the birn; and alfo marks cut into the ear with a knife, defigned lug mark. Head mark, or, in other words, that characteriftic of individuality ftamped by the hand of Nature upon every individual of her numerous progeny (and which we learn fo readily to difcern, in all thofe fpecies with which we are moft familiarly converfant) is, however, efteemed, by every theep farmer, as the moft certain and unequivocal mark of the identity of a fheep : It is a mark with which no coincidence can take place (as in artificial ones), through either accident or purpofe. An intelligent fhepherd, whofe perceptions are fharpened by habitual attention, can readily diftinguifh every individual of his flock, independent of any artificial mark; juft as he could recognize a fellow fervant, upon perfonal acquaintance, whether he were drefled in a long, or fhort, or black, or white coat, or wore no coat at all. A perfon, remarkable for his quickneis in diftinguifhing theep, has been known, for a wager, to put threefcore of ewes and lambs, of a flock he had never before feen, all higgledy-piggledy, into a houfe, and immediately to go in hinufelf, and to turn them all out one by one; firft, a ewe, and then ber ozun lamb, without committing a fingle miftake; although the only means required by him, to enable him to difinguifh fo accurately, was to be allowed to obferve them for half an hour quietly feeding, cach ewe with her lamb alongfide of her, previous to their being driven into the houfe *.

After

* It is exceedingly probable that the individual, in every fpecies of animals, is perfectly diftinguifhed from every other individual of the fame fpecies, by characterific marks of individuality: Ilow elie, indced, could mates diflinguilh cacl other at the pairing feafon? Rut, from want of habitual and minute atieniom, the general remblance alone frikes us; whilit the minute differences efcape on: obfervation. To one unaccuftomed to fheep, is Twectidale flock (all of one mike of body, and fame texture of wool, all horncd, with black faces and legs! woulh, upon a curfory view, appear as perfectly alike, anel equally undictinguithable from onc another, as a fluck of crows. I queftion not but a crow herd wonlit fion

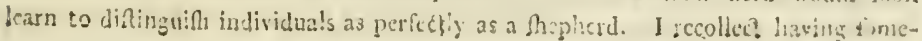


After rearing the lambs, the ewes were wont to be milked for fix or feven, or even to the length of ten weeks. The practice is, in fome farms, totally difcontinued, to prevent weakening the ewes; where continued, it is ufed in moderation.

The lambs, for holding ftock, immediately upon their being weaned, were in ufe to be fent, often to great diftances, to be fummered (as it is called) for fix weeks, upon barren heathy land, in fome cold, bleak fituation; from a notion that fuch rugged treatment had a tendency to harden their conftitution. Very violent tranfitions of this nature, from the moft palatable and nutritious of food, the mother's milk, to fuch unpalatable, innutritious, and hardly digeftible pafture, are, however, now generally condemned. The lambs are indeed fent to the higher parts of the farm, whofe graffes are, at this feafon, in their highelt ftate of perfection; care, however, is taken that their food thall be both copious and palatable. Meanwhile, fome better and lower lying pafture is faved (bained) for them, for their Winter's provifion : what is thus hained, is called the bog fence. Formerly, the hog fence was referved exclufively for the lambs, which were admitted to it at Lammas; but, from the obfervation made in farms fo fmall, as not to admit feparation of hirfels, that the hogs were much lefs fubjec to the ficknefs (a difeaie often exiremely fatal to hogs), it has, of late, come pretty much into practice, to allow the old theep and the hogs to pafture indifcriminately together.

The earlieft fpringing food of theep, is a plant, bearing a white cotton head upon its feed-ftalk, vulgarly defigned Mo/fcrop: It begins to fpring about Candlemas, if the weather proves frefls: It grows in mofies. Dravu-ling fucceeds it, in the month of March; fo defigned, becaufe the Iheep feize, tenderly,

where met with a remark, that a painter, in drawing a foreigner, is much more apt to hit off the gencral national appearance, than the individual refemblance. For this reafon, county reports might be beft made up from the reports of two, a forcigner and a native; the finf for the eneral features, the latior for minuto difilicuess. 
tenderly, with their teeth, the part of the plant appearing above ground; and, inftead of biting it over, they draw up a long white part of the plant from a focket under ground. The lateft fpringing plant is beath, which yields its flower to the bee, after all other flowers have decayed. A proper fucceffion of earlier and later fpringing heath, is a matter of eflential confequence in moft Tweeddale theep farms, (and indeed in all fineep diftricts where heath abounds), in order that the range of this fpecies of food, in its moft eatable ftate, may extend through the greateft poffible portion of the feafon. This fucceffion is obtained by burning a certain portion of heath, each Spring, before the rifing of the fap; fo as to have heath. upon the farm, of one, two, three, or four years growth from the root. As in all plants of a fhrubby nature, the heath plants moft recent from the root, fend forth their thoots moft early in Spring, and the oldeft later in the feafon. When the game laws were, of late, altered, by protrading the commencement of partridge fhooting, in favour of late corns, it is pity but the legal feafon for muirburn had alfo been prolonged, in favour of the theep. There is not one year in ten, in which the proper quantity of heath can be burnt within the time limited by law, which extends from Michaelmas to the end of March: Burning in Winter has been found deftructive of the heath, in fome inftances of trial. Old heath, or whins, or broom, are the great refource of fheep in Winter fnow ftorms, as they kcep the fnow afloat, and allow the fheep to come to the grafs growing about their roots. I have never heard of any attempt to cultivate any of thefe plants for fleep, but whin and broom.

Prejudices continued long in Tweeddale againft artificial melters and Winter feeding for fheep, upon fuppofition that they rendered then too lazy to dig the frow with their feet, in order to come at their natural food: Both thefe prejudices have nearly vanifhed, being expelled by experience. Trees are, in various inftances, planted for fhelters. It would be for the intereft of every proprietor of theep farms, to encou.

$\mathrm{C}$ c

rage 
rage the farmer to rear fhelter of trees, by allowing him the weedings of the plantation, and becoming bound to pay the farmer, at the rate of perhaps $8 \mathrm{~d}$. or Iod. apiece for every tree left ftanding at fpecified diftances, at the expiry of his leafe: Such an intereft communicated to the farmer, would give the moft effectual fecurity for the protection of the trees. Shelters are alfo procured by buildings, enclofing a fquare open area in the middle, furnifhed with hades on every fide. Stells (that is, circular fpaces of area, proportioned to the fize of the flock, enclofed by a five or fix feet wall of ftone or fod, without any roof) were the primeval thelters invented by our forefathers: The circular figure of the building caufes the drifting wind, in fnow ftorms, to wheel round it, without rifing over it, and depofiting the fnow in the calm region within. The theep are fed, in Winter ftorms, with fuch provifion as can be procured, under the trees, in the thades, and within the circles: Even where no feeding is adminiftered, much advantage refults to the animals from mere defence againft the weather; and they are much the more alert in fearching for natural food, fo foon as the ftorm ceafes. The mode of acting of the fheep, gives a pretty certain indication of the weather to be expected: Upon the near approach of a fnow ftorm, thofe accuftomed to helters, are obferved to make for their thelter: Upon the near approach of thaw, their prefentiment leads them to be lefs induftrious in digging the fnow for food, as if confcious that fuch labour was no longer neceffary.

When fnow drift unexpectedly arifes, and the depth of fnow on the grounds prevents the polfibility of driving the fheep to Thelter, the herdfmen gather them together in a body, and kcep them in conftant motion, that they may tread dowis the fnow as it falls, and may not be whelmed up by it. The natural helters are the leeward fides of bills of Aiep declivity (or frrait bields); a calm is formed immediately under their brow, where the drifted fnow is depofited and accumulated, whilft the flseep reft, unmolefted by it, farther down the hill. 
When thaw comes, the fheep are carefully guarded againft refting upon thefe bields, where they formerly found fhelter; as the heat of the earth, melting the under furface of the accumulated fnow under the brow of the hill, caufes the wreath (called, from its figure, a combed sureat/3) to flide down in a body, like an avalantbe in the Alps, crufling to pieces every thing it meets in its courfe; the very weight of the wreath, when long accumulated by drift-winds blowing from the fame quarter, expofes the theep to the fame rilk, in their bields, even in time of froft.

The proper birfeling and berding of the fheep, in clafing them into diftinct flocks or hirfels, and in allocating to each flock its proper walk for the different feafons of the year, are matters much attended to. A proper management in thefe refpects, is held as the diftinctive mark of fuperiority in theep farming.

The principles of hirfeling are, to clafs into feparate flocks fuch theep as are endowed with different abilities of fearching for food; and to have all that are in one flock, as nearly as poffible, upon a par, in this refpect. For inftance, ewes far gone with lamb, or fuckling their lambs, muft not be claffed with theep unclogged with fuch incumbrances, who would always get the ftart of them in running to the beft bites. Hogs, too, thould be kept feparate from the older theep, who would intimidate them; and muft alfo be provided, if poffible, with more delicate and more plentiful food; though, as already obferved, this advantage to the hogs is now beginning to be in fome meafure relinquilhed, on account of the diminution of the rifk of their death refulting from their pafturing in common with older theep-whether this diminution of rilk arifes from prevention of over eating, or is owing alfo to fome other undifcovered caufe.

The principles of herding are, to allocate, to each particular flock, feparate walks upon the farm for each feafon of the year; fo as that all the different kinds of herbage may be completely ufed, in their refpective proper feafon, and a fufficien- 
cy be left, in a proper eatable fate, for Winter provifion, after all fren fpringing of grafs is over *.

Such are the general principles kept in view, in regard to hirfeling and herding: Their proper prabical application depends upon profefional fkill ; or may be neceffarily determined by the peculiar circumftances of the farm, which may render it necefiary to be contented merely with what is practicable; inftead of what would be more eligible. In very fmall fheep farms, hirfeling cannot be attended 10, the minutenefs of each diftint hirfel, into which they muft fall to be claffed, being unable to afford the expence of feparate herdimen.

* Many isielligent farmers are of npinion, that the whole of hirfeling and herding refolves itfelf into the fimple principles following, viz. to have no more frock upon the farm, than what can be abundantly fupplied with food; to keep the whole pafture in its hightn eatable natc, by fhifting the focks gradually over the whole in fucecifion, fo as that none of it Ball have fprung to feed-ftalk, or fiall have withered or rotted, before the fheep are admitted to it; and, that after having eaten up what they have been laft admiticd to, they fhall aluays have another fpace in readiness, which thall have lain racant for perhaps three weeks, and no more than three wecks, for frofhening and taking on a new growtlr; and, that as to Winter provifion of grafs, after all fpringing of grafs has ceafed, it is in vain to think of fupplying this, by refering a part, till it has growil withered, rotten, and uneatable; for that faid referration would have done them more gond by putting it previounty into their bellies and unon their backs, when it afforded nourifhing food, than by prefenting it to them in Winter, wheo unpalatahle, innutritive, and wiwholefome. The dependence of shecp againft fuffering in the unproductive manths of Winter, muft be chicfiy fough in their good halit of body before Winter fets in; as then they munt depend, for immediate food, upon finch faniy picking as ean be got from heath, whins, or hardy coarfe graft:s, which they rejected in summer, and which fland through Winter; and hay in frow- forms.

They accoust nothing nore scceffary, in regard to feparation into diftinet hirfels, than to kecp the lambs, afecr weaning, spon the lower part of the pafture, fon Auzutt till Deember; afier which, all gn mixed over every part of the farm till March, when the heavy ewes are feparated from the barren micp, and fced, with tivit lambs, upon the lower pafture, till the time that this pafture is again fet afis: for the new-weaned lambs. They judge, th at more derends, in preventiun of foclenes, upon the grafs being always in an catable thate, than upen mixit $z$ the old with the young facep upon the hog fence. Where a brecling farm felis werider hogs, the havy exes are uorn off in Spring, the hoge getting the low gersunds to fit th:om fooner for the market 
It is a fact afcertained, that fat theep, from farms of different qualities in Tweeddale, fhall appear equally fat to the handling of the butcher; yet the one kind fhall yield perliaps one third more of tallow, in proportion to weight of carcafe, than the other kind. Here, the locality of the depofition of the fat depends upon the panture, and not the breed. May there not be fufpicion of quackery, in the reports of breeders, as to the propenfity of peculiar breeds to depofit fat on particular quarters?

\section{SECT. III.-Horfes compared to Oxen.}

WHERE arable farms are of fufficient extent to admit of fubdivifion of labour among the labouring cattle; fo as that a fufficiency of heavy, flow work, requiring mere frength and fteadinefs, could be entirely appropriated to one clafs; whilf another clafs could always be employed in work requiring chiefly agility and expedition; it would then, evidently, be advantageous to keep two diftinct fets of cattle, for thefe diftinct fets of operations. But as almoft none of the Tweeddale farms are of fuch extent as to admit of this diftinct appropriation of different kinds of labour, cattle muft be kept which will equally anfwer all kinds of labour. In this view, the horfe will be found a much more univerfal animal than the ox: and the horfes fitteft for Tweeddale, muft be fuch as poffefs a confiderable degree both of ftrength and of mettlc.

The breed of horfes has been confiderably improved, fince the introduction of two-horfe ploughs.

Oxen, once univerfally ufed in all kinds of tilth, are now as univerfally laid afide; a fact clearly decifive of the inutility of ufing oxen for labour. Could the farmer, by ufing oxen inftead of horfes, fend more produce to market of beef or corns from his farm, would any thing elfe be neceflary to induce him to adopt the change? An interen may not be purfued when it hath never been clearly feen; but nothing will induce the dereliction of an intereft, already feen and reaped, but the difcovery of a fuperior interent arifing from a differ. snt management. 
The fubftitution of oxen for horfes in labour, is, never thelefs, the theme of popular declamation; and it would not be at all furprifing, if fome of the wife city committees, fitting in profound inveftigation of the caufes of the high prices of provifions, thould bethink themfelves of applying to the Legiflature to enforce this fubftitution by compulfion. We would rather recommend it to them, to get over their prejudice againt the ufe of horfes fleth as food: No defcription of pafturing animal will take on flefh more fpecdily than the horfe; and, if his flem fhould become palatable, he would be, in this refpect aifo, much more œconomically kept than the ox. We have heard of dogs having been ferved up at table, in this country, after the manner of Otaheite: It would be much more patriotic, to introduce the Tartar falhion, of eating old horfes well fattened: Indeed, after overcoming the repugnance arifing from the hideous and difgulting appearance of that undiftinguifhingly voracious and fcrophulous-looking animal, the fow, repugnance to the flefh of horfes would appear a mere prejudice of education-like the prejudice againft potatoes entertained, according to Count Rumford, by the Bavarians, which obliged him to introduce them by Iteaith, as an article of food, into the poors-houfe at Mu. nich.

\section{Sect. IV.-Hogs.}

SwrNe are kept at corn-mills, and upon the offal of dairy farms: There is a prejudice againt the ufe of their flefh, which is daily giving way.

\section{SECT. V.-Rabbits.}

THer are found wild in the fand-hills of Linton parin ; fometimes kept tame in houfes; but are not an article in commerce. Some of the fand-hills juft mentioned, might probably be converted, with advantage, into warrens. 


\section{SECT. VI.-Poultry.}

THEY are impofed fometimes as kind rent. The town of Edinburgh feems not, as yet, fufficiently rich to afford fuch 2 price for poultry, as would render it profitable to apply the whole produce of a farm to the rearing of them as its ftaple article of fale. Thofe fold to Edinburgh, are, therefore, only in fuch quantity as can be reared from the mere offals of the farmers barn-yards; or as are foolifhly impofed beyond this extent in kind rent.

\section{Sect. VII.-Pigeons.}

There are few pigeon-houfes, and, I believe, none that yield rent. It is a general complaint, that they do not thrive; which is, upon the whole, no lofs; the farmer fuffering the lefs from the privileged depredations of this protected animal.

\section{Sect. VIII.-Bees.}

Мucr, of late, has been faid of their polfible product; and they are probably not fo much attended to, in Tweeddale, as they deferve. If the country, however, were ftocked with then to the utmoft poffible extent, it might be queftionable, whether the diminution in produce of beef, mutton, wool, hides, and tallow, from the impoverifhment of the pafture, would not more than compenfate the return in value, from the increafed production of honey and of wax. Were the depredations of the bee confined to the flowers alone, which are unpalatable to pafturing animals, from the wife provilion of Nature for the prefervation and propagation of feeds *, the

range

* Mr Loch of Rachan, in his letter to me, incidentally takes notice of this wife arrangement of the inflinet of paflusing animals. He obferves, that they will bardly touch the fes-ftalks of plants, as if confsious of the sonfequences; but 
range of the bee would lefs interfere with the pafture of other animals : But the bee feems equally fond of the rich exfudations from both buds and leaves; the abftraction of which may probably leave the plant more barren of the proper nourifhment of cattle.

The improvement of agriculture, from thinning the number of weeds producing their flowers and feeds at various feafons of the year, has a tendency to diminifh the range of food, both for game animals and for bees: The number of the former has, accordingly; been obrerved to be diminifhed; and, by like reafon, the land may have been rendered incapable of fupporting fuch numbers of the latter: The fame reafon may account for the want of thriving in pigeon-houfes.

that, when plants are cut and given to them in this fate, they will readily eat what they would otherwife have rejeeted; as if confcious, that the fame reafon for sefraining, now, no longer fubfifted.

As reafoning of their own does not furely lead the beafts to fisch wife practical conclufions, the regulation of their inftinct may certainly, not unreafonably, be afcribed to a Supreme and Beneficent Intelligence, that created, and that governs the unirerfe-a doctrine which, it is to be hoped, we may be allowed to maintain, without imputation of folly; whatever may be decreed by any pragmatical, felf-fufficient Affembly concerning it ; whether by the appel nominal, or the reckoning of their nofes; or whether by acclamation fimple, or the ftrength of their vociferation. (Written in I796.) 
TABle of Sheep, Black. Cattle, and Horsts, in Tweeddale,

The Numbers from the Statifical Account, fupplied from equally good information, where deficient. There is joined, an account of the horfes, as in 1797, obligingly communicated by Mr Brunton, County-Ślurveyor.

The acres in each parifh are from Armftrong: As he fays he converted them at 700 to the mile, I have reduced them to the proportion of 6.70 .

\begin{tabular}{|c|c|c|c|c|c|c|c|c|}
\hline \multirow{3}{*}{ Names of Pariffes. } & \multirow{3}{*}{$\begin{array}{l}\text { Conients in } \\
\text { Acres Eng- } \\
\text { lifp. }\end{array}$} & \multicolumn{3}{|c|}{$\begin{array}{l}\text { From Sir Fobn Sincluir's } \\
\text { Statiffical Accounts. }\end{array}$} & \multicolumn{3}{|c|}{ Workingborfes. } & \multirow{3}{*}{$\begin{array}{l}\text { Total } \\
\text { borfes. }\end{array}$} \\
\hline & & No. of Sheep & Conus & Horfo & \multirow{2}{*}{ Liable } & \multirow{2}{*}{\begin{tabular}{|} 
Not li- \\
able in \\
tax.
\end{tabular}} & \multirow{2}{*}{$\begin{array}{l}\text { Sadille- } \\
\text { borfes. }\end{array}$} & \\
\hline & & 100.9 & a cotes. & & & & & \\
\hline Linton & 25,472 & 10,000 & 4601 & 130 & 89 & 10 & II & I IC \\
\hline Newlands & 16,604 & 3,000 & 700 & 230 & I 33 & 13 & 23 & 169 \\
\hline Kilbucho & 6,135 & 4,000 & 140 & 50 & $4 \mathrm{I}$ & 9 & 10 & 60 \\
\hline Kirkurd & 6,053 & 2,000 & 200 & 70 & 33 & I I & 12 & 56 \\
\hline Lyne \& M & 16,988 & 10,500 & I 18 & 33 & $\mathrm{I} 5$ & $=$ & 5 & 20 \\
\hline Skirling & 2,633 & 4,000 & 150 & 75 & 37 & 7 & 4 & 48 \\
\hline Broughtor & 4,261 & 2,200 & 200 & 80 & 39 & $=$ & 4 & 43 \\
\hline Mannor & $16,55^{\circ}$ & 8,700 & 190 & 85 & 46 & 7 & 9 & 62 \\
\hline Drummelzi & 21,714 & 5,000 & 300 & 50 & 29 & $\mathrm{I}$ & 10 & 40 \\
\hline Glenholm & 8,283 & 5,000 & 150 & 60 & 31 & 3 & 6 & 40 \\
\hline Traquair & 15,808 & 10,000 & 200 & 98 & 68 & 12 & 16 & $9^{6}$ \\
\hline Peebles & 16,649 & 8,000 & 500 & 200 & 108 & 26 & 20 & 154 \\
\hline Tweedfmuir & 21,376 & 15,000 & 80 & 35 & 11 & $=$ & 3 & 14 \\
\hline Stobo & 11,456 & 5,000 & 190 & $8 \mathrm{I}$ & 29 & 6 & 51 & 40 \\
\hline Eddlettone & I9, 428 & 8,400 & 620 & 193 & 94 & 15 & $\mid 12$ & 121 \\
\hline Inverleithan & 20,361 & $15,000^{*}$ & 180 & 92 & 37 & II & III & 59 \\
\hline Totals & 229,779 & II 5,800 & 4378 & I 5062 & 840 & I3I & $16 ́ 1$ & 1132 \\
\hline
\end{tabular}

* About 3,000 of this number of theep are in that part of this parifh which lies in the contiguous county of Selkirk; probably alfo 6 horfes, and I a milk cows. 
C H A P. XIV.

RURAL OECONOMY。

\section{SECT. I.-Labour.}

Justices of the Peace have powers veited in them for the regulation of wages, as alfo of the price of provifions. They, however, very wifely, refrain from interfering in matters which can alone be properly regulated by the courfe of the market.

The demand for labour, as for every other marketable article, neceffarily varies according to circumftances; and the price muft, of neceffity, be regulated by the proportion betwixt the exifting quantity of the article and the demand. Where capital, and profitable employment for capital, abound, in proportion to the population, the demand for, and confequent reward of labour, will, neceffarily, rife to the higheft rate; but the reverfe muft, as neceffarily, enfue, upon the oppofite fuppofition. If, in the former cafe, it thould be attempted to lower the wages of labour below what the demand can afford, the competition of employers, poftefted of capital, would lead them to break through, or evade, all fuch regulations. If, in the latter cafe, it thould be attempted to raife wages above what the demand can allow, the competition of labourers for employment would beat them down, avowedly 
or fecretly, to their natural market price*. And the only effect of fuch nugatory regulations, mult iffue in the occafioning of more or lefs embarraffment, in the contrivance of evafions to efcape the penalties of their contravention. (See Note F, at the end of the Report.)

The unremitting effort of the generality of individuals to better their circumftances, occafions the accumulation of capital; and the wages of labour rife in proportion to this accumulation. The increafing of wages tends to diminifh the further accumulation of capital; were it not that the more cafy circumftances of the labourer cncourage marriage and population, and, by multiplying the number of labourers, tend to beat down their wages, through their competition for employment. Acting and re-acting, thus, mutually, upon each other, alternately, as caufe and effect, accumulation of capital, and increafe of population, would proceed, hand in hand, in an interminable progreflion; were it not that external and internal war (a ftate fo natural to man, as to have made the art of mutual deftruction furnifh, at all times, and everywhere, the bu-

finess

* Indeed, in this way alone, conld the exifting capital in employment be equally diffufed among the labourers of a country, fo as that each fhould receire his proper fare of it, in proportion to his willingnefs and ability to work; if it were pofible to carry into effect any regulations raifing wages to an higher rate, the infallible confecuence muft be, that the diftribution of the aforefaid capital would be confined to a fmaller number of labourers, and that the remainder conld get no employment, and munt therefore fithfilt on charity. But if the charity comes excluively from the pockets of thofe poffeited of capital, the capital, thus hrortened, is able to employ fill fewer at the regulated rate: If it comes, in part, from the employed labourers, it is to them all one whether this diminution of wages arifes from their giving it in charity to the idle, or from its being taken from them through the competition of the induftrious. In the reign of fansculstim in France, it might have been tlought, that the raifing the wages of labour wenld have been the primary object of Government; and yet, during the height of its prevalence, the exccfive low rate of wages, compared to that of Britain, was then heid out, in the French Affenblies, as a ground of confidence, that France would soon carry off the manufacures of Britain. In fact, the capital of that conntry was fo exhanfted by confifeation and requifition, to fupport the profigacy of her Eyrants, and the mad fehemes of her Government, that funds did not exift to fupport labour, cxecent at the very lowch rate of recompenfe. 
sinefs of a particular profeffion--a profeffion, too, whofe relative virtues have ever been held in the higheft celebrity) may ever, at fhort intervals, be expected to intervene, to the thinning of population, and the perdition of capital: A vicw of human nature, noft lamentable, but, at fame time, ludicrons; and which will ever be found to correfpond to reality, fo long as man continues what he is-a reafoning, rather more than a rational animal win the cool fpeculations of the clofet, $j u f$; but, incapable of ating up to the maxims of juftice, fo foon as his paffrons aroufe hin to action. Or, fhall we efteem the acquifition of the warlike virtues cheaply purchafed, at the premature expence of a few lives, through glorious toil and honourable wounds; which, otherwife, might have quietly terminated in the fuffocation of defluxion? Or fhall we prefer the poets golden age of inmocence and inactivity, when men had little elfe to do, but to bafk in the fun?

The rate of wages experienced a fad reverfe, from the deficiency of funds for the employment of labour, through the fcarcity of the crops 1799 and 1800 . Litile difference took place in the nominal or money rate of day's labour; but there was lefs employment; and employers preferred giving the higheft accuftomed rate of money wage, without fumifhing victuals in the houle. 'The great competition for the privilege of eating at difcretion, at the rife of the inafer, without iggard io the price of victuals, caufed a prodigious declenfion (even to the amount of one half) in the moncy wage of fervants to eat in the mafter's houfe. Since the return of plenty, from the abundant crop of $180 \mathrm{r}$, wages are again rifing; though they have not yet attained (by pe:haps a fourth) the exifing rate previous to the ycars of fcarcity.

Before that period, the yearly money wage of a good ploughman, getting lis victuals, lodging, and wahing, in the mafter's houfe, had, within fix or eight ycars, rifen from fix or feven to ten or twelve pounds. If he was married, he had, perhaps, twenty flillings lefs of moncy wage, and, in lieu of vidvals, $6 \frac{1}{2}$ bolls of oat meal, and the Summer's and Winter's, 
maintenance of a cow for kitclen * ; or, in place of the cow's maintenance, ninepence or tenpence, weekly, for that purpofe: The mafer furnithed him alfo with a houfe, with carriage of fuel, and as much lanel for potatoes, beer, or lint, as the dung from lis cow and athes would manure; the ploughman's wife, in recompenfe of thefe privileges, affifting the mafter, without any wage but her victuals, in time of hay and corn harveft. The fmallnefs of 'Tweeddale arable farms, admitting little of fubdivifion of labour, it is generally necellary that the ploughman fhould be fit for all work, as fowing, mowing, ftack-building, thrafhing, \&sc.

The money wages of a female country fervant, living in the mafter's houfe, had arifen to twenty-five, or even thirty-five fhillings, for the Winter half year ; and, in Summer, to forty, or (where there was long ewe milking) to fifty-fix fhillings. Some of the moft robuft young women do not engage themfelves for the half year after Whitfunday, that they may have the opportmity of gaining two diftinct fees, the one for ewe milking, and the other fubfequently for harvett work.

Ewe milking (now more and more difufed) commenced formerly about the latter end of June; the lambs being more early weaned, that the more cheefe might be obtained: It feldom, now, commences till the beginning or middle of July; continuing, in fome few places, nine weeks, but more generally confined to fix. The farmer needs additional female fervants for the ewre milking. Six or feven fcores of ewes are allotted to each milker. The milking is a fevere fervice: Very little time can be allotted to fleep during the night, as the ewes muft be milked over night, when confined to the foid, and in the morning, before they are again put out to pafture; and the time of their detention in the fold is fhortened as much as porw fible, that they may have time to feed through the day. As the ewe milkers muft, alfo, milk the cows upon the farm, and perform the tafk of fpinning, each, ten cuts of worfted from

roved

- Kitcken (in Latin, obfonium) fignifics any thing caten alomg with bread, There is no Englifh word equivalent. 
roved wool daily, they find but little time for fleep in the day time. The milking fold is an inclofure of fod dike, with whins inferted below the coping fod, to prevent the ewes from breaking over it. At one fide of the dike, is erected a pen (bought), by fod dike, or paling of wrood, inclofing an oblong fquare, open at one end, and of a breadth to admit all the milkers ftanding fide by fide. Into this bought, as many ewes as it can contain are drove in at a time; when the milkers entering, prevent the ewes from getting out, and immediately proceed to bufinefs: Each milker feizes the ewe neareft to her by the haunches, drawing it backwards till it ftands with its hinder legs ftraddling acrols the milking pail; fhe then, with both hands, feizes upon the teats, and milks, by fqueezing them betwixt the firft joint of the thumb, bent in, and middle of the fore finger: when milked, the ewe is turned out behind her, the herd taking care that the milked ewes fhall not mix with the unmilked, upon their efcape from the bought. From the pofition of the ewe, whatever drops from her falls into the milking pail; the folid refufe is feparated, by draining or depofition, but no chemical procefs is in ufe to feparate the dilute; and probably the peculiar pungency of the cheefe is partIy owing to the falts in the urine. Before the fineep are florn, the cheefe is peculiarly dark in colour, and has a peculiar baute gout, from the freat, or other matters from the wool (called eik), mixing with the milk: this is cheefe made under the zuool. In regard to flieeps milk cheefe, as in regard to moft other viands, it conduces little to the appetite of the gueft to pry into the fecrets of the kitchen. This cheefe is in great requeft, and of high price, from its increafing fcarcity; which will reJrefs itfelf, when the price becomes fo high as to render it advantagcous to the farmer to facrifice the animal's advantage to the increafe of its cheefe. When old, the cheefe is accounted one of the beft flomachics. The wage of ewe-milking amounts to about half a crown weekly, with board; the farmer's wife allowing, alfo, to each milker a piece of coarfe cloth, called a ewe-milker's brat, to cover her before, to prevent her 
clothes being fpoiled by the tar and other filth adhering to the wool.

A woman fhearer, hired through harveft, gets from twenty to twenty-five fhillings, with board; a man, from twenty-five to thirty. When a track of wet weather feems fet in, they are difbanded till the weather fhall clear up : In wet mornings, or fingle wet days, they are detained at board, and employed in twifting ropes for binding on the coverings of the ftacks. Days wages for thearing neceffarily vary, more from the variety of demand for the work, than thofe of any other labour; women receiving from eight to fourteenpence, with victuals; and men from a fhilling to twentypence. Shearers hired at a fixed fum for the whole harveft, with to perform the moft work in the leaft time, but are lefs careful as to the mode of execution; thofe hired by the day may more readily be made to perform the work with exactnefs, but have not the fame intereft in performing much: A mixture of both kinds feems preferred; the mutual example correcting the faulty tendencies on both fides.

Piece-work would always come moft cheap, were it not for the rifk of faulty execution, in cafes where its mode cannot be fpecified in the bargain. Undertaken by the piece, fold dikes of fod coft threepence per rood of fix Scots ells, ruming meafure: Ditches, from eightpence to a fhilling per rood, according to the fize of ditch, and nature of the foil. Mowing of grafs, from two to five fhillings per Scots acre, according to the ftrength of crop, or its ftanding ftraight, or being warped by the wind. Thrafhing, about fevenpence per boll, with victuals. A ftout labourer, working by the piece, will carn from fixteen to twentypence a day, without victuals.

When victuals are furnifhed, days wages are, for mowing grafs, from fourteen to fxteen pence: For more ordinary Summer's work, from tenpence to a fhilling: For ordinary Winter's work, eightpence or ninepence. Wromens ordinary wage for Summer's outwork, not of a prefling nature, like that of harveft, fuch as gathering wceds, hand-hoeing, \&ic. is fourpence with, or eightpence without victuals. There is very little agricultura! 
gricultural employment for women in Winter. With victuals, a tailor's wage is tenpence: Other handicrafts, as in MidLothian.

Ploughmen and thepherds are hired for a whole year; women fervants half yearly, except fuch as referve themfelves for ewe-milking, and for harveft work. The old ftyle is obferved in the terms of entry to, and removal from fervice. Uniformity would, here, be eligible, as well as in weights and meafures.

\section{Sect. II.-Provifions.}

To what has bcen obferved on this fubject, under the article of Farm Houles and Cottages, it may be added, that, in fheep farms, the flieep dying of difeafe are ufed as flefh mcat, under the defignation of traik.

\section{Sect. III.-Fuel.}

In the higheft lying parithes, near the fources of the waters, peat of mors is the only fuel ufed. The beft peat, (being the moft folid, black, lafting, and yielding the ftrongeft heat), is that which is found in thallow beds of mors, lying generally upon a declivity: it is commonly not above fourteen or eighreen inches, or the length of a peat, in deepnefs, after removing the furface foil with the roots of the heath or ling growing on it, (called the tirling of the mafs): As the digger ftands upon the furface, and prefles in the peat-[pade with his foot, fuch peat is defigned foot-peat. Other peat are procured from deeper now mofles of various qualities; and as, in digging, a paftage is made to drain the water from the bottom of the mofs, and a perpendicular face of the nofs laid bare, from which the digger, ftanding on the level of the bottom, digs the peat, by driving in the fpade horizontally with his arms; this peat is, therefore, defigned breafl-peat. The peat-fpade is furnifhed with a triangular cutting mouth, as alfo, with a cutting wing on the right fide, both of well-tempered metal, to cut the half decayed wood found mixed with the mofs; the wocden Maft termi- 
sates at the end near the iron, in an oblong fquare fhape, on which the peat refts when lifted up. The operator begins to the left, and works to the right. He begins by turning the fpade back uppermoft, that by its wing he may feparate the one fide of the firf peat from the folid; reverfing the fpade, he at one pun drives it in to the whole depth of the oblong part of the fhaft, the wing cutting the fecond fide of the peat. By a jerk of the thaft, the end of the peat breaks off at the point of the fpade; it is raifed up, and carefully turned of upon the ground; it is taken up by the women wheelers, (burlers), who lay a number of them upon a wheelbarrow without fides, and lay them down, fide by fide, upon fome contiguous dry ground. Two hurlers commonly fuffice to fpread the peat dug by one man. When the peat have become fo hardened by the drought, that they will ftand on end, they are placed on end three or four together, and leaning againft each other; this is called footing the peats. After this comes the operation of wind-rowing, or the building them up in narrow heaps, or fragments of dikes; in which ftate they remain till carried home and put into a Winter ftack, which is covered with fod to defend it from rain. 
C H A P. XV.

POLITICAL OECONOMY, AS CONNECTED WITH, OR AFFECTING AGRICULTURE.

\section{SECT. I.-Roads.}

THE landed proprietors of every county are, certainly, the clafs moft fit to be intrufted with the management of the roads; which act upon the agricultural improvements, in which they are fo nearly interefted, like oil upon the wheels of a machine. 'They have mof leifure; may be expected to have more enlarged views, and liberal fentiments; and are nore habituated to beflow labour and pains upon fubjects whence they derive no immediate pecuniary advantage: They are fometimes apt to be deficient in energy. In narrow counties, where all are more intimately conneacd, the public advantage is too ready to be facrificed, in fome degree, to mutual accommodation; which, when yicicled to from facility, in one inftance, is claimed in others upon the preccient. Infances are not awanting, in this county, of the public road, from this caufe folely, being carricd in a zig-zag direction, inftead of the ftraight one; or over fteep acclivities, inftead of around them. It is well obferved by the Rev. Mr Handyfide, in his ftatifical account of the parih of Lyne in this county, "that the beft mode of conducting the direction of roads would be, for the truftecs of each county, to commit the direction of their roads to the determination of thofe of another county.'

Syftems, begiming where nothing previous exifted, are often more eafily carried into the beft effect, than the reformation of arrangements originally bad. 
About the middle of laft century, the time when the general views of the utility of good roads had reached this county, and made tumpike acts be applied for, the public road to the capital was eked up out of private roads, made chiefly to fuit private conveniency; and, of courfe, fubjected to fuch deflections as might be expected, where private accommodation was the principal, and that of the public rather a by-riew: They were narrow; they were often dreffed up, like avenues or private approaches, with tall hedges and plantations of wood. From want of energy to require, or of difintereftednefs to offer facrifices of private convenience and advantage ; or perhaps, too, from a doubt how far the inexperienced return from tolls could afford to pay indemnification of the private lofs incurred, in breaking through exifting inclofures, in order to give the public road its proper width and direction-From fuch reafons, it has happened, that the moft public road of the county (the one lcading from Edinburgh, by Noblehoufe, to Moffat, Dumfries, and Carlife) is, for about feven or eight miles of its courfe, fo completely thaded by high walls, and hedges, and wood plantations (its breadth, alfo, often not exceeding 15 or I 8 feet), that neither fun nor wind can find accefs to dry it : Repairs, more expenfive than the return of the toll (though ligher than any in the Lothians) can afford, are but barely fufficient, therefore, to prevent it from becoming an impafiable, rotten bog; and every fliow-drift chokes it up completely. A prepofterous propenfity feems, indeed, pretty prevalent, of placing wood plantations along the fides of public roads; though, furely, moft proprietors need be at no lofs to find other fituations, where they might be of equual benefit as fhelter, without detriment to the road, by overfhadowing it, or to the traveller, by giving a lurking place to the robber.

The roads through Tweeddale are made, at an average, at about 801 . per mile. Various fchemes have been aclopted as to upholding. In the upper diffrict, where there is moft repair, and moft wear, from the conftant heavy carriage of lead from J.eadhills, an apparently reconomincil mode was chofen, of letting the upholling to fmoli nccupiers of lands upon the rond ficles; rio, 
who, it was thought, might give the neceffary repairs at $b_{y}$ kours: 'Thefe by-bours, however, feldom occurred; the money was confumed by people, from whom it was impofible to recover it, and the roads neglected. 'They have, of late, been let to a profefional undertaker at more expence, and probably with fomewhat better effect.

The ftatute labour is commuted at eight fhillings per rool. Scots of valued rent; which the landed proprietors pay in to the county collector, along with their cefs, having recourfe upon their refpective tenants.

Befides the roads marked upon the map, a road, from the Peebles road at the foot of Tarth water, carried over that water by a bridge, and ruming up the weft fide of Newlands water, to the Noblehoufe road, and thence to the Linton road, would be of great utility in giving ready accefs to coal, lime, and freeftone, to a confiderable diftrict of country lying below. Another road from Darnhall to Noblehoufe Inn, connecting the Edinburgh roads by Peebles, and by Noblehoufe, would open the coal, lime, and freeftone of the county, to Eddleftone and Peebles parifhes. A communication to Weft Lothian might be of ufe, by the pars of the Pentland-hills, named Cauldfane-fap, connecting the Linton Edinburgh road with that from Edinburgh to Ayrihire. An ufeful road has been lately fet on foot, by fubfcription, from Traquair, fording Tweed, and carried up Leithan-water ; opening a communication to the Lothian coal and lime, to the parifhes of Traquair and Inverleithan.

In regard to all matters, that will naturally be undertaken through a fenfe of intereft, by individual exertion, and at private rifk, it is fafe to leave them upon this footing, without Government interference. But though, in a certain degree, the committing of the management of the roads to the landed proprictors of the refpective counties, wears the afpect of intrufting it to thofe who have the moft intereft in the proper execution of the truft, yet various confiderations would indicate the propriety of the whole roads and tolls being placed under the immediate management of Government : For, granting that Go- 
vernment expenditure is always lefs conomical than any other; ftill this difadvantage would be more than counterbalanced, from the advantage of employing the military, in time of peace, with very little expence above their ordinary pay. It might be expected, upon this fytem, that general views would more fteadily prevail over partial confiderations; and that the fuperplus of funds, from tolls upon roads of great recourfe, might be applied to roads of lefs recourfe, which the funds from their tolls cannot afford to make, or uphold, fufficiently. An inflexible arrangement of management wolld, however, need to be laid down, fenced by the fame facrednefs that guards the fyftem of the finking fund. The heightening of the tolls would be an obvious and eafy mode of taxation, which, if regulated as at prefent, by weight of carriage, would fall heavicft on the poor.

\section{Sect. II.-Ganals.}

For thefe the country is too mountainous, and its produc. tions of too little value: None exift in fact, nor are in contemplation.

Sect. III. \& IV.-Fiors-Weekly MIarkots.

THE Peebles Tuefday's weekly market formerly fupplied the manufacturing weft country with meal from the fouthern corn counties. The canal betwixt Forth and Clyde having openest the Lothians to the weft country, there is now a very inconfiderable quantity of meal difpofed of at Pecbles market; the fouth country farmers, who frequented it, now carrying their corns to Dalkeith, and returning with coal or lime; for both of which they depend upon the Lothians. It is needlefs to take notice of fairs which exift now only in name, and where no bufinefs is donc.

The following, I believe, is a very exact lift of the fairs, in this and other countes, whoc Tweeddale famers tronfact bufiners. 
IAIRS IN TWEEDDALE.

\section{Toun of Pecbles.}

1mo, Fafenferen fair. Held upon the firft Tuefday of March, N.S. Ewes great with lamb are fold by character, without being flown. It is the great market for feed corns, fold by fample, or often by character; alfo the chief fair for fervants, for the year, or half year, fucceeding the enfuing Whitfunday.

2do, Beltyne fair. Held fecond Wednefday of May, N. S. Stallions are fhown; fervants are hired; farm fales of outgoing tenants are advertifec.

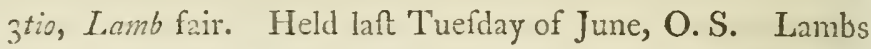
for holding, fold by character, without being fhown; wool alfo by character; but, when Linton third market falls upon the fucceeding clay, the bargains are feldom completed till the parties have met again at that wool fair.

4to, St Andrervs fair. Held laft Tuefday of November, N.S.; called alfo Siller fair, becaufe the chief or only bufinefs is, the payment of bargains upon credit from the preceding fairs.

'Two other fairs are fometimes ufed as dates of payment in bills, though no fair is held, viz. Rjte fair, laft Tuefday of October, N. S.; and Hock fair, firft Tuefday of September, N. S.

\section{Lintons.}

There were five markets, continuing week after week, upon Wednefdays: Molt of the bufmefs is now tranfacted at two of them, riz.

Second I inton market. Held third Wednefday of June, O.S. Wediter and ewe hogr fold and delivered upon the market grununds; alfo a few dummonds and old tups; lambs for holding, foll by charader. The fhecp come to the market sround easly on the 'Tuelday, and are gencrally all fold off that evening. 
evening. This is the principal market for Tweeddale holding fheep.

Third Linton market. Held Wednefday the week following; though, as at the fecond, the bufinefs of felling the flieeps is all tranfacted on the Tuefday erening. The Welnefday is the great market for coarfe vrool, of the black-faced or Linton breed; all fold by character; from Tweeddale, Upper Ward of Ciyderdale, part of Dumfrieshire, of Selkirkfhire, and the lilly parts of the three Lothians. Shearers are hired for the enfuing harveft.

\section{Skirling.}

I mo, May fair. Held firft Tuefday after the 26 th of May, N. S. or upon that day of the month, when it falls on that day of the week. Yeild cows for grazing, with a few milk cows, are thown, fold, and delivered.

2do, Fune fair. Held firft Wedneflay of June, O.S. One of the greateft fairs in the fouth of Scotland for a fhow of working horfes: 'The rate of this market generally determines the price through the feafon. A few milk cows.

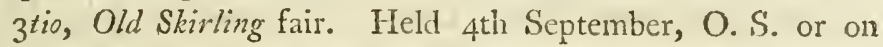
the Monday after, when the day of the month falls upon Sabbath. A pretty extenfive fale of horfes; alfo of black cattle, partly fat, partly young, for lolding.

\section{Eidlefone.}

Edellefone fair. Held $25^{\text {th }}$ September, O. S. or on Monday, if that day of the month falls on Sabbath. Chiefly wintering young black cattle; oxen for draught; and a few fat cattle. Servants hired for the half year fucceeding enfuing Martinmas.

\section{Broughton.}

Brouglaton, fair. Held nime days after Eddleftone fair, ol oil Monday, if the ninth day falls upon Sabbatp. Cheefe fold in wholefale by character. Servants hired for the TVinter half jear: 
FAIRS IN MID-LOTHIAN.

House of Muir narket. There are three, weekly, for ewes great with lamb, fhewn, fold, and delivered upon the grounds : 'The only confiderable one is held upon the laft Monday of March, N.S.

FAIRS IN CLYDESDALE.

\section{Carnath.}

Ino, Inilfwimer Fair. Held firlt Thurfday of July, N.S. A great thow of horfes; milk cows; grazing cattle; a few fat cattle.

2do, Lacurie's (St Láurence's) Fair. Held fecond Wednefday of Augut, O.S. The fale is, of liorfes, of lambs for holding, and fat cattle.

\section{Biggar.}

Imo, Midfummer Fair. Held firt Thurfday of July, O. S. Lambs for holding; a few milk cows; a few horfes.

2 do, Old Biggar Fair. Held firlt Thurfday of November, O.S. Fat black cattle, chiefly; a few winterers; rather more horfes than at the former. Lint is allo retailed, at leaft in fuch fmall quantities as may ferve a family's Winter fpinning.

\section{Sanark.}

St Fames's Fair. Held laft Wednefday of July, O. S. A great market of lambs for holding; probably, the greateft thow, in the South of Scotband, of year old horfes: Thefe are bought generally to the Weft country, are worked very early, but gently, and well fed; and are returned, when full grown, to the great Skirling horfe market. Wool is retailed.

Befides the above fairs, a confiderable number of Tweeddale hogs, and older fheep, are annually fold at the fair of Stagfhall Dank, in England. 
Lambi for holding are alfo fold at St Bcfivell's fair, in Roxburghfhire. Held i 8 th July, N. S.

Fat lamb is weekly fold in the Edinburgh market, through Summer, from the end of June till the end of September; alfo, crock ewes, fed upon grafs, or farther carried on upon turnip, from Martinmas till New-Year's Day. Butchiers from Glafgow buy probably more of the black cattle, fed on turnip in this county, than the Edinburgh butchers, notwithftanding of the greater proximity of the latter; owing to the greater riches and population of that country of manufacturers.

A few black cattle, fat, or for feeding, are bought or fold at All-Hallow-Fair in November, in Edinburgh.

Such meal as is fold from that part of the county lying above Peebles, is "fent weftward to Biggar weekly Thurfday's market. Meal-dealers in Kirkurd, Newlands, and Linton parifles, buy at Pecbles, and tranfport to Birgar; and often buy grain at Leith, to be manufactured at our mills, and fent to Biggar. Oats, from the higheft lands, ripened, or rather withered, to be fit for keeping, by the froft, which would betray themfelves if made into meal, find a market in Edinburgh, for the ufe of horfes.

No fiars of grain are ftruck for the county; the reference of price of beer is made to the Mid-Lothian fiars.

'The borough of Peebles, as is probably the practice in more boroughs, claims a preference in its own weekly meal-market, and allows no ftranger to purchafe till the town is firft ferved; a reftriction which, like all fuch reftrictions, has a tendency to difcourage the refort of buyers and fellers. In the dearth of r799, the Magiftrates attempted to fix the price of meal; while it was rapidly rifing, they would allow only laft market day's price: As might have been forefeen, no meal came to market, but what was damraged, fo as to be worth nothing more, elfewhere, than the town's allowed price. Whether through mere coincidence, or from caufation, the influenza was morc mortal at Pecbles, than common in the combry. Boroigh Magitrates muft often adopt mobbifn mewires, liowswer contrary to their own conriction. 


\section{SEct. V.-Commerce.}

Excepting that in meal, already noticed, there is little o: ther commerce, but mere retail trade.

\section{SECT. VI.-Manufactures.}

AN woollen manufactory was fet on foot at Inverleithan, by Mr Brodie (better known by his extenfive iron-works in Shropfhire, and his hip hearths), who is a native of, and proprietor in the county: The houfe confints of four ftories, containing all kinds of machinery, and driven by water. Cloths are made of all colours, from 27 to 30 inches in breadth, and (before the laft great rife of wool) at from Is. 6d. to 6s. per yard. The iron-works have been, of late, a fo much morc profitable concern, that the woollen has been leis attended to.

It is furprifing, that no manufacture of coarfe woollen has, been eftablifhed at the village of Linton; where there is water to drive machinery of confiderable weight, abundance of lime, freeftone, coal, and peat; the diftance from Edinburgh about I 6 miles, and the accefs a turnpike road.

A Linton weaver, Alexander Alexander, has lately erected a manufacturingr houfe, with water machincry, upon the Norti Etk, on the lands of Robert Brown Efq. of Newhall ; he fupplies fereral paper-mills with felts, made of the coarfe Tweeddale wool; and propofes, as capital, and credit, and rent for the commoditics, increafe, to extend the manufacturing to that of ferges, and fuch other fuffs, as coarfe wool is adapted to.

A manufacluring houfe has very lately been fitted up at Peebles for narrow cloths: And, there, two or three individuals had occafronally done a little in the lame line, in the intervals of their cmployment by cuftomers; carpets and flannels, and fome cotton goods, being manufuctured upon the fume fytem. Noft of the looms in 'Tweetdale are, however, cmployed in working to private cuftumers; though fome coulthmtly, and others occafionally, are emrloyed in wearing li- 
nens for the manufactories in Edinburgh, or cottons for thofe of Lanark or Glafgow. There are in Peebles a few ftocking looms.

SECT. VII.-Poor.

$\dot{A}$ society muft have become rich, before it can make liberal provifion for the fupply of its poor.

In a fociety of favages, fuch as thofe of America-fubfifting upon mere natural produce-by the chafe, by fifhing, or upon fpontancous fruits and roots-without appropriation or culture of the lands; without domeftication of animals, which are perfecuted in hunting, to the danger of extermination-an immenfe tract of territory is neceffary to fupply fubfftence to a very inconfiderable tribe; which mutt be traverfed, with the utmoft exertion, by each individual, in fearch of the means of his own perfonal fupport. In fuch a ftate, where the moft laborious exertions of each, in the maturity of ftrength, are often requifite to fecure even a fcanty perfonal fubfiftence, it is not to be expected, that proper provifion can be made for thofe who are paft their labour, or for thofe who have not attained to it: Accorlingly, the unirerfal provifion for the aged is, to knock them in the head; unpromifing infants are put to death, as an effectual mean of preventing them from becoming burdenfome; and even thofe deftined for prefervation, are deferted in feafons of unfuccefsful hunting, and turned over to the mercy of the wild beafts\%. The imperious paramount calls of

* Such is the harpy fate of favage liherty and equality, to which the ditsiples of the new plitufoply of Rourtati would have us to revert, by abandoning all the inftitutions of civilized and indaftious fociety--Sie a formor by the cirthor, upon liberty and equality.

The expofure of infants is allowed by law, alfo, in the highly cultivated empire of China. Among favagen, the want of culture prevents the earth from fupporting its full complement of population. In Chira, the population would feem in have increafid to an extent bevoul what the territury can fupport, under the highen degree of culture. War, fumine, or peltitcnee, wou!d ficm necaffary to the reticf of China; if it cannet nifourthen itfelf of its erer fopulation hy coloniz:tion, to which its prefent maxim: of Covernuent would aprear ad ar?e. 
felf-prefervation, fteel the heart againit the feelings of humani. ty, which it would be fuperfluous to indu!ge towards eliftreffes, which there are no means of relieving. The adnirer of the favage ftate may exclaim, 'If you find, there, no palaces, you will find as fcw hofpitals:' 'Thicre can, indeed, exift no funds for the erection of either the one or the other : every esertion being required to enfure merc felf-prefervation, there is no leifure for the purfuits of either fcience or humanity.

The fundamental laws, enfuring relief to the poor, are thore which enfure the acquifition of wealth-thofe which fociety muft adopt, when man, relinquifhing his ftate of favage liberty and equality, where all have like right to all, betakes himfelf to the cultivation of the earth, and the domeftication of animals, from whence all civilization, implying leifure and fecurity of fubriftence, muft originate. They are the laws of appropriation, the fources of never ceafing inequalities of condition: Laws which encourage induftry, by holding out to the induftrious, the fecure profpect of rcaping the fruits of his labour, in afcertaining to hin the undifturbed perfonal poffeffion and enjoyment of that fubject, to which his induftry has been attached, and in which it hath become infeparably inherent; together with the power of transferring it to defcendants, or other natural objects of his affection-a power indifpenfable to the excitation of an induftry of farther profpect, than of mere liferent provifion-effential to the accummulation of capital, and to the prevention of its diffipation, in the fame lifetime in which it was created *.

Man was formed for action, and that the active talents of each might be called fortl to exertion, every one's particular intereft is left to his own management: For, though man is alfo benevolent, a continued intermeddling interference in the concerns of others, would, to his own confcioufnefs, as well as to his neighbour's feelings, appear the height of impertinence. To rejoice with thofe that do rejoice, without envy or malignity, conftitutes a character amiable to others, and delightful to the

: Sce the author's fermon on liberty and eq̨uality. 
the pofieffor ; but for active benevolence, the calls arc only orcafional. To fecure to all a fair field for the exertion of individual incluftry, by enforcing, impartially to each, the lawrs of juftice, afcertaining and protecting property in its full exercife, is, in general, the utmolt range to which bencrolence, under a fenfe of common intereft, can extend its active exertions with propriety. Such univerfal protection of all, by all, being obtained, a fente of feparate intereft will, generally, beft acconsplifh every otlier purpofe that benevolence could. fuggeft. Cafes will no doubt occur, as exceptions to the general rule, where individual interef camnot be profecuted or defended, or where individual diftrefs cannot be relieved, by individual exertion; and in thefe, the humane and benevolent ought ever to be ready to aflift. The human conftirution is formed in wonderful harmony; the principle of felf-intereft pofiefles, at all times, the energy of a paffion; whilit benevolence is only a dirnofition, in readinefs to be rouzed into the paffons of indignation, or of fympathy, as cafes of oppreftion, or of diftrefs, thall arife, which call for our active interference.

To fuppofe that benevolence, of itfelf, will or ought to lead to the inceffant accumnlation of funds, out of which diftrefs may be relieved as it occurs, would be, to lay a firefs upon this principle, utterly difproportioncd to its habitual energy: And the fecure profpeet held cut to felfifmers, will be found the nnly means of creating funds for the purpofes of liberality. In this fenfe may the law, protecting property, be callad ou $\int$ choolmager to bring us to Chrift. Thofe trained to habits of acquiftion and accumulation, may indeed often prove deficient in liberality; but they are the founders of the clafs born to independence, more apt to difipate than to accumulate, but, in general, more liberal : And thus, through varieties of chancter, the lame purpofes are naxiy produced, which night, in a better manner, be obtained, were tach individual charader mone properly balanced.

The monks, who profelled to renounce entire! this wotli for the next, inftead of confering the active duties of ire, as

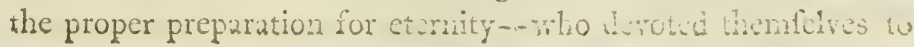
colitacy, 
celibacy, and to a life of poverty, to be fupported folely upon alms-in confitence with their general profeflion, thcir par. ticular row, and their own practice, were led to fet light by induftry, of the moft powerful incentives to which, they were deprived by their risles: They, profeffedly, interefted not themfelves at all in induftry, or that augmentation of population which may enfue upon increafe of indtiftry; they trenched upon the time of the indufrious by religious feftivals; they fung forth the praifes of almfgiving, in which they had fuch an immediate intereft; and fo celebrated this particular difplay of benevolence, as if it comprehended the whole of Chriftian charity: Infomuch, that the word clavity, without farther explanation, is apt, from habit, to convey the idea merely of alms; though, undoubtedly, of all benevolent exertions, this is the moft equivocal, even as to the accomplifhment of its own end. * When thofe prefefied beggars and alms-preachers had become rich, through pious donations, given them in their own name, or as common almoners, who diftributed the charity of other people; from fellow-feeling, and regard to confiftency, they were profufe in the indifcriminate diftribution of alms: and monafteries became the refort of idlers and fturdy beggars, who preferred the refource of alms, to that of their own induftry. $t$ A crowd of idle profligates were thus relieved from the neceflty of indufry, to which they might happily, otherwife, have been compclled by ftarving; and their fubfiftence ultimately roned as a heary tax upon the induftrious part of the community; which, of itflf, might liave been accounted a good political reafon of the reformation.

Upon

- We have fermons upon alms, by clerzymen of high refpedability, in which eno much of the fpirit of monkifm is difplayed-where, too, the appropriation of the land and water, and other fubjects of human inctuftry, feems invidioufy glanced at, as ufurpations upon the common rights of man-where, alfo, the rich fecm advifed to divide with the poor, in the way of almfgiving; left the ufurpation, $\mathrm{cx}$ inting through fufferance, thould he terminated by infurrection. All this favours Alongly of the favage-Ante cuthufiafin of Rouffeau.

+ Townfend, in his Travels through Spain, attributes the general want of induftry, in a great meafiri, to the indifcriminating alms of the monafteries. 
Upon the abolition of monafteries, at the rcformation, the fame difficulties occurred in Scotland, as in other reformed countries, in regard to making provifion for the really poor; as alfo for curbing the licentioufnefs of thofe fout iallers, who, together with the really poor, had depended for fubfiftence upon monaftic alms; but who now inundated the ftate, and lived by depredation. The evil feems, indeed, to have attained to fuch an alarming height, that fome of the moft ftrenuous affertors of liberty in the Scotifh Parliament, thought it neceffary to propofe, that the whole mentlicants, indifcriminately, fhould be enflaved, and their fervices adjudged to fuch mafters as would confent to maintain them, for fuch work as they could compel them to perform. This idea feems, in fome frape, to have been adopted by the Legiflature; as appears by various acts of the Scotifh Parliament; in which magiftrates are empowered and enjoined to apprehend forners, maifierlefs men, fturdy beggars, \&c.; and to adjudge their fervices, for different periods, to fuch as would accept of and maintain them. Indeed, the Scots acts chiefly refer to fuch defcriptions of poor.

There are a great number of Scots acts of Parliament, renewed from time to tine, enjoining affefiments for the poor, together with the building of parifh worhhoufes, in which they were to be put to labotir. Thefe acs, either from their contradifory nature rendering them incapable of execution; $0 z$ from want of intereft in, or compulfitor upon, thofe who fhould have exccuted then: were, in fait, never executed at ail. Excepting, indeed, in great towns, where, from the number of the poor, their labour might be fuppofed fomewhat adequatc to the expence, the crection of workhoufes would have inferred confiderable expence, without profpect of indemnification. As defuetude is, in Scotiand, underftood to abrogate law, and ought ever, in mutable man, to he comfrued into dereliction of purpofe, thefe laws may be confidered as obfolete. The eril of flurdy begging has, in a great degree, cearcd-haring been configned to the remedies of farving, or thic gallows; and the real poor have been erer laft to depend, chient, upm roluntary clarity, without any $\mathrm{l}$. 1 provition- mobality the 
beft footing on which the matter can reft, both as to the poos and their providers. From the enormous extent to which poor's rates have arifen in England, it is probable, that great caution will be ufed in attempting to organize this fubject, as to ScotInnd, into any very ftrictly defined legal fyitem.

The poor, generally, through Scotland, have hitherto been fupported by voluntary contributions, given in at the church door on Sundays, and other donations; together with a few fmall ftated perquifites, fuch as, from 2s. 6d. to Ios. for the we of a finer or inferior pall, or mortcloth, at burials; from one to two fhillings for proclamation of banns of marriage; befides, in fome cafes, from the intereft of money mortified by charitable perfons, Thefe funds are adminiftered by the Minifter and Kirk-Sefion (fee Note $\Lambda$ ); fometimes, by allocating penfions from time to time; fometimes, in a manner, left ellirely to the difcretion of the Minifter, leaft the fixing of penfrons hrould beget a reliance to relax induftry. From the increafe of diffenters, and the too prevailing cuftom among the opulent, of abfenting themfelves from church, it is probable, thefe funds may not long fuffice; when recourfe muft be had to parochial affeffments. Such equal afleffment is alfo preferred by many, as it reaches erery one; whilt, upon the fyftern of voluntary contribution, the burden is rolled over upon the Iberal, and the avaricious efoape: Though, certainly, if the eftablifhment of poor's rates leads, necefarily, to fuch enormors expence of poor's eftablifhment, as has enfued in England, the liberal had better bear the whole of the prefent expence, fix times toli, than incur their fair proportion of the then rate.

Though the ftatute poor's laws in Scotland may be confidered as obfolcte, from difufe; there is, neverthelefs, a confuetulinary law for poor's rates, though feldom, and never general3y, acicd upon (fee Note $A$ ): And it would be well, if the necefity of aeting upon it could altogether be fuperfecled. Untike to funds employed in productive labour, which reproduce themelves, together with a profit, funds, employed in fupport of rice peor, atc altogether ammihilated. If an individual, or as 
focicty, are poffeffed of funds fufficient to maintain an hundred perfons for a twelvemonth; fuppofing thefe hundred fupported, idle-the fund perifhes in the ufe, and is no longer in exiftence: If, however, it had been applied to the fupport of an humdred, as the wragges of prodluctive labour, in agriculture, trade, or manufacture, it is equally evident, that fuch labour would, at the ent of twelve months, have replaced the fund, with a profit that might be added to it, which might enable it, for the enfuing twelve months, to fupport an hundred and ten or twenty-affording, thus, additional fubfiftence for an increafing population. Were the whole funds of fociety devoted to alms, and confumed in idlenefs, mankind would foon revert to the favage ftate, having nothing for fubfiftence but natural produce; and the one half might repeatedly eat up the other, before population was reduced to that limited number which natural produce would fuffice to fupport. It feems ridiculous, therefore, conftantly to ring the changes of commendation upon charity, in the fenfe of almfgiving, as if it comprehended the whole of what was commendable in neighbourly practice; and to confider the conduet of thofe, who lay out their funds in the employment of productive labour, which replaces them, together with a profit, as immeritorious, if not in fome degree immoral; when the good of mankind fo evidently requires, that no more funds fhould go to perdition, than what are abfolutely neceffary to relieve fuch diftrefs as cannot otherwife be relieved; and that the greateft quantity poffible thould be applicd to the employment of productive labour + .

When the fupport of the poor is enforced by a compulfa. tory tax, and a maintenance can be claimed as a right, and not a favour, the mame of application is removed *: And if the maintenaince is any way equal to the wages of laborious induftry, an irrefifible temptation to pretence of poverty and G $g$ inability

i Sce Noic G.

* In dearth I 795, a finall afiffment of poor's rate was impofes, for the firth time, in Ncwlands; and 1 found that many came to claim a fiare of the mathey of the gentismon, whu, otherwifs, yould haya made no application. 
inability is held out: So foon as funds are thus provided, at bundance of candidates for their confumpt wilt prefent themfelves; nor is there any certain criterion to diftinguifh the valuntarily from the neceffarily poor. Nothing requires fo little encouragement to make it thrive, as idilenefs; to which poverty, in two cafes out of three, may be confidered as a fynonime. Through frugality, in the days of youth and ftrength, a fund of fupport might often be provided againt the infirmities of old age; but the fecure profpect of otherwife obtaining fucl provifion, fuperfedes the neceflity of fuch faving.

Where poor's rates have been regularly eftablimed in Scotland, they have, from thefe caufes, been continually upon the increafe + .

Where poor's rates are eftablifhed, they neceffarily bring along with them laws ftrictly defining refidence; that it may be afcertained on whom the burden of the poor's fupport falls. Thefe laws, as enacted in England, have been, by fome, confidered as originating in a humane regard for the poor, and to indicate

† Compare the expence of Yarrow, in the ncighbouring county of Selkirk, (Statifical Account, vol. yth, page 509), where rates hare been eftahlifhed for a confiderable period, with that of the parihes of Linton and Newlands in Tweeddale, where, till the laft feafons of dearth, there were neither poor's rates nor fix. ed penfions. Ciateris paribus, the poor are proportioned to the population; they are fuppofed alfo to abound moft where there are villages. Linton contains a village of 300 fonls; there is no village in Newlands, or in Yarrow. Throwing away odd numbers, the population of Yarrow was $\$ 200$; that of Linton and Newlands 900 cach : The expence in Yarrow ought to have born a proportion, therefore, to that of Iinton, or of Ncwlands, as four to three. In Yarrow, how. ever, in 1732 , the rate, for one year, was 120 l. beficles the collections and otlies funds: This fum, too, mult have been all cxpended; as pon's rates are generally laid on to anfwer penfions priorly allocated. But even including the dearth of winter $1795-96$, the yearly expence in Newlands and in Linton had not exccesed 361 . cach; nor $3 \mathrm{I}$. for an average of five years. The clergyman obferves, in his Report above quoted, ' that the ponr's rates were moderate at their commenecment, cuing to the fimcll number of penfioners:' an obfervation which furely needs no commenit. In the deasths I792-1800, I have been informed, that the poor's rate in Yarrow amounted, annually, to about 4201.: In Linton, and in Newlands, thic expence amounted only to about Iool. annually; poor's rates being then affeffed; in the two latter parifies, ih aid of the ordinary funds. 
the mode in which they may obtain a fettlement: By others, with more appearance of probability, they have been looked upon as obtained upon the principle of felf-defence, in order to get rid of every avoidable burthen. In Eugland, it would appear, that no perfon coming to a parifin is allowed to fettle there, Icft he thould acquire a refidence, and eventually be. come a burden, unlefs he can produce fecurity for his cven. tual maintenance to an extent that no indultrious labourer, having only his own labour as his fund of fupport, can procure. Induftrous labourers are thus confined as prifoners within the precinds of the parin which gave them birth; they are debarred from carrying their induftry to fuch places as have a grcater demand for labour, and where higher wages might be obtained; or, if they have acquired a new refidence, they are prevented from retiring, in the feafon of age and infirmity, to fuch friends and relations as might footh and comfort them; and, by performing many little offices of good will, wubich could not be procured from frrangers but for bire, might make their maintenance come far more cheap. The fuperplus of labourers, in one diftrict, cannot be difburthened upon another, where a greater demand for labour hath arifen; nor the necefity of the latter be relieved from the fuperfluity of the former; the litigations inftituted to eviot refidences, with the expence of the removal of paupers to their proper reficlence, cofting more, too, in every litigated infance, than what the fupport of the fubject of litigation would colt in any Scotin parifh. (See Smith's Wealth of Nations, Book I. chap. $x$. part fecond, and third particular.)

From the moderate expence at which the poor have hitherto been fupported in Scotland, laws of relidence have very feldom become the fubject of litigation: Otherwife, there are laws of confuetude, (at leaft, admitted by general acquiefence); as, that three years actual refidence, without being beholden to any poor's fund, conftitutes a legal refidence to a grown perfon; and, that birth conftitutes the fane to a child. But there is no authority in Scotland that can remove a flout labourer from a parin, to prevent his acquiring a refidence; 
and no pledge againft his erentual maintenance can be requires? either from himfelf, or from his lat parifn where he had refidence: he muft be confidered as what he is, and not in pro. fpect of what he may become. 'Till the great increafe of the expence of maintenance occafioned by the dearths of 1799I\$oo, I have heard of few inftances of litigated refidence. Indeed, it would appear preferable, in general, to cupport whatever poor happen to refide in your parih, if fuch rule fhall be univerfally adopted, than to incur the expence of le, gal eviction of refidence in any infance. Eren under an expenfive poor's eftablifhment, fuch as that of lingland, it were probably preferable to adopt this rule as law, than to fubject the labouring part of the community, and the public at large, to the opprefive reftraints, inconveniences, and difadvantages, that refult from the law's of refidence.

In Scotland we have no office-bearers under the defignation of overfeers of the poor and ckurch-quardens. If thefe oflice-bearers, who feem to have power to aflefs for the poor, are not themfelves liable to the tax; or if they receive emolument proportioned to the fum they thus place under their own adminiftration, it were not furprifing fhould they be w1ceconomically liberal at the expence of other people. In the contradictory Scots acts of Parliament, (all, roo, of equal authenticity, the fubfequent always homologating the whole of what went before), the power of compulfitor, as to the poor's provifion, is fometimes lodged in the Sheriffs of counties, in the Comminfioners of Excife, in Commifioners appointed by the Kirk-feflions, in the Kirk-felions themfelves, in overfeers appointed by the Juftices of Pcace, or the heritors with advice of the Kink-fefion. By the cuftom acquiefced in, it is the heritors who impofe the tax, when recourfe is had to rates: and, as they bear the one half of the impofition, their tenants, who bear the other half, are in the iafe hands of thofe who have a common concern*. The minifte:

- In a fmall parifb in Clydeflale, berdering upon this county, where the zreaser past of the lands bcicng to one propictor, to whom the cther heritors generaily. 
minifter and kirk-feffion are the ufual adminiftators; but are refponfible to the heritors for their adminitration: 'The adminiftration is not confidered as a voluntary fervice, for which hire may be exacted; it is rather held in the light of a fort of profefional duty. 'The poor's funds are, therefore, virtually, both impored and adminittered, at no expence, by thofe who bear the burthen. Little liable as fuch a fyftem would feem to the polfibility of abufe; yet fuch, it would appear, is the propenfity to idlenels, alias poverty, when any fecure profpect of provifion is held out to it; that, as formerly obferved, wherever poor's rates have been regularly eftablifhed in Scotland, they have increafed that poverty they vere meant to cure.

Faulty as our confuetudinary fyftem may appear in various refpects, it is highly queftionable, whether that man would in fact benefit his country, who thould attempt to organize it into a more regular flape.

In burghs, poor's rates are laid on like other taxes, aco cording to ftented fubfance. In the country all is laid upor proprietors and poffefiors of land, by the rule of the valuation of the lands in the cefs-books.

The Scots poor's acts, having chiefly relation to the poor from idlenefs, enjoins their apprehenfion, and the adjudging of their fervices to thofe that would accept of them; and, from the act 1672 downwards, (as it would feem they could not be difpored of by the former provifion), enforce and reinforce the erection of work-houfes, or correction-houfes, in all the principal towns, into which all the poor from their adjoining counties fhould be collected, and where they hould be compelled to labour. Under firere penalties, the Magiftrates are enjoin-

generally delezate their powers as to public encerns of the parih, it was found neceffary to eftablin a poor's rate during the late deaths. This proprictor fent meffages to the tenantry of the parith, that, as feveral of them were elders of the firion; and as all refided, and knew the fituation of the poot; and"as, likewife, they had to pay the orie hali of any afferinent iurpofed, he knew nobody fo fit to manage the bufinefs as themfelves: He defired them, therefore, to mict with

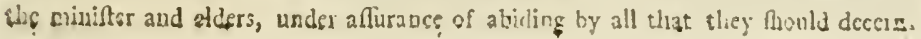


ed to erect fucl houfes in thirty-two towns fpecially defigned in the act. The heritors of the parifhes in the counties attached, for that effect, to thefe towns, are enjoined to levy affeffments, one half payable by the proprieto:", and the other by the poffefior of the lands, for the purpofe of paying to the Iragiftrates at the rate of two Millings Scots, fer diem, for each of the vagrants fent by them to the correction-houfe for the firft year of their refidence, and of one fhilling Scots per diem for the next three years; the Magiftrates, meanwhile, having alfo the profits of the work of thefe vagrants for thefe faid four years, as alfo, for feven years thereafter, as an indemnification for the expence of erecting thefe correctionhoufes. After the expiry of faid eleven years, the acts make ro farther provifio:1. It would appear to have been prefumed that the vagrants confined in them would, by that time, have acciuired fuch habits of induftry, that they might fafely be fet at large upon the public. In thefe acts, however, the poor unable to ruork, i. e. the real poor, are left to be fupported by the voluntary contributions at the parifls kirk: So that the mode confuetudinarily now acopted for affefling poor's rates for the real poor, is borrowed from that part of the Scots acts which relates folely to the provifion to be made for fending idle vagrants, able to work, to thofe correction-houfes where they were to have been compelled to labour.-(Dr Aiderfon bas given a good viere of the Scots poor's laws, in bis periedical publicetion, called the Bec.)

In a very few inftances, sucrk-boufes, as thcy are defigned, have been erected in great towns, in conformity to the letter of the Scots acts, for the reception of the real poor unable to suork, who have been maintained hitherto by voluntary collections at the church doors, and other voluntary donations. In Edinburgh, the preffure of the two recent years of dearth and fcarcity has led to the obtaining of a fpecial act of Parliament, empowcring the impolition of a poor's rate, when neceffary, to the extcnt of 10,0001., for the fupport of the unable, and the occafional relief, in fuch feafons, of thofe whofe work cannot reach the whole of thejr maintenance. 
That there is a poffibility of maintaining the poor more cheaply, when collected together into alms-houfes, will appear evident to every one who has attended to the difference, in cheapnefs, of common mefing, compared to feparate eftablifisments. But, though phyfically poffible, it has been found morally impracticable to mess the poor at even the fame degree of cheapneis in alms-houfes, as that at which labourers, receiving no charity, do, in fact, maintain themfelves upon their diftinct feveral eftablithments. From Dr MrFarlane's Inquiries concerning the Poor, publifhed in $\mathrm{r}_{782}$, it appears, that, even in Edinburgh (where the poor's houfes are managed by the moft rcfpectable inhabitants, and are reckoned to be upon a better footing than thefe of moft other countries), the average annual expence of each individual, in thefe houfes, came to from 4.1. 45. to 4l. 10s.; whilt, upon the fame average, the annual earnings of a tradefman, after deducting houfc-rent, amounted to no more, for food and clothing to himfelf and family, than I 5 l. per annun; which, allowing the computation of only three children to the family, falls to be divided among five individuals, allowing only of ${ }_{3}$ l. for the maintenance of each. Such is the wafte that may be cxpected, when perfons live at the expence and rilk of other people : fuch the exertions and frugality which fpring from natural affection, and the honourable pride of independence.

To think of maintaining begsars cqually cheap as indippendcnt induftrous labourers maintain themfulves, is feemingly in vain: Yet, the expenfive maintennace of the firft, is an oppreffion of the laft. (See foot-note, p. 203.)

'The expence of erecting and fupcrintending ahns-1oufes, can, at all events, oniy be afforded in great towns: "ithey are inacimiffible in country parifles, where the pornkation is thin. Lven in great towns, it is queftioned, whisther the poor might not be more cheaply maintained in their own hutes, (when left to difpofe of fuch abilities as they poffers, in fuch lines of fmaller induftry as they fhall find out for themfelves), iv the antitance of occafional charity, diftributed according to ned and defort; when, having a lefs certuin dependence, living rore it thri: 
own rifk, and having the entire property of fuch earnings as they can obtain, by fuch induftry as they are capabie of exercifo ing, a greater degree, both of ceconomy and of induftry, would be enfured; and they would alfo be more happy in their own fcelings, when freed from the monotonous irkfomenefs of confinement, and from the languor of want of an employment immediately and perfonally interenting. A very accurate fyftem of fuperintendence of the moft refpectable inhabitants (fuch as was enforced, in Edinburgh, by the neceffity of the cafe, in the calamitous feafons 1799-1800) would need, however, to be kept up, to this effect. But men of bufinefs are too much occupied in bufinefs; and thofe of wealth and leifure are too bufied in illuftrious idlenefs, to find leifure for occupations of obfcure ufefulnefs.

Could work-houfes be put upon the footing of thofe of Count Runford at Munich; fo as that the poor might have refort to them for work fuited to their feveral abilities, without compulfion; might obtain the full ordinary wages of fuch work as they can execute, to be entirely at their own difpofal; and wholefome food afforded them at the cheapef rate at which it can be afforded in the way of cooking in common, after the mot ingenious contrivances for the conomizing of fuel and of labour, and of fuch fcientific cookery as gives the greatef quantity of nourihment from the leaft quantity of raw materials; there is little queftion but that the expence would come far cheaper, than upon any fyftem of compelled labour under confinement, and where the whole profits of the work performed goes to the bencfit of the work-houfe.

The following 'Tables, from the Statintical Accounts and other information, will fhow the eafy rate at which the poor are inaintained, where so regular poor's rates are eftablifhed; and will alfo convey a general notion of the mode of the adminiftration of the poor's funds. 'The 'Tables are from the books of the treafurers; in which are marked every mere occafional fupply, under accicicntal diftrefs from ficknefs, \&c. as well as the nore regular fnpilies in cites of permanently par- 
tial or total inability to work. Gratuitous charities from well difpofed neighbours, in articles of maintenance or of clothing, do not appear in the books, nor in the tables. No fuch gratuitous charities would be given under a compulfatory fyftem of regulations, leaving nothing to be determined according to private apprehenfion of need or defert. 


\section{T A B L E I.}

Showring the annual average expence of the Poor, in the three parifhes of Linton, Newlands, and Kirkurd. 'There are no poor's rates in either of thefe parihes. In the two firft, the fettling of fixed penfions has been carefully avoided, left fecurity fhould relax indufrious exertion; though, no doubt, in cafes of extreme old age, \&c. where the circumftances of the pauper were evidently feen to admit no liope of change, the fupply given comes to be, in practice, nearly as equal and regular, as if a fixed penfion were allotted. In the laft, fmall penfions may have been allotted; though never to the extent of excluding dependence upon occafional voluntary relief. In the two firt, the poor have been made to depend upon the difcretionary power of the parifh Minifter, as treafurer; who acts according to the occafional advice, reprefentation, \&x. of the more refpectable inhabitants in the different quarters of the parifh.

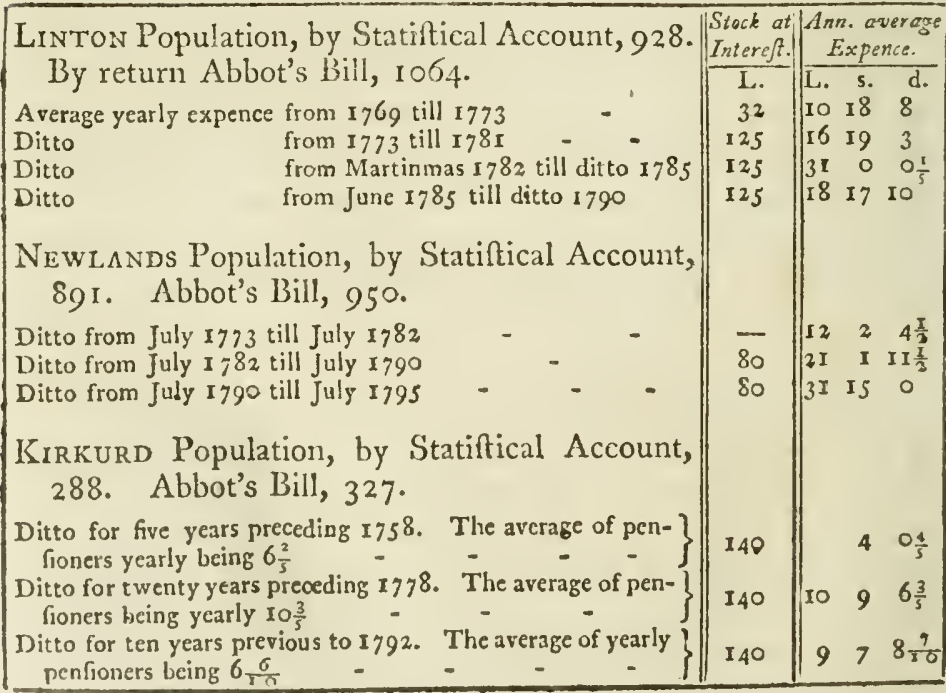




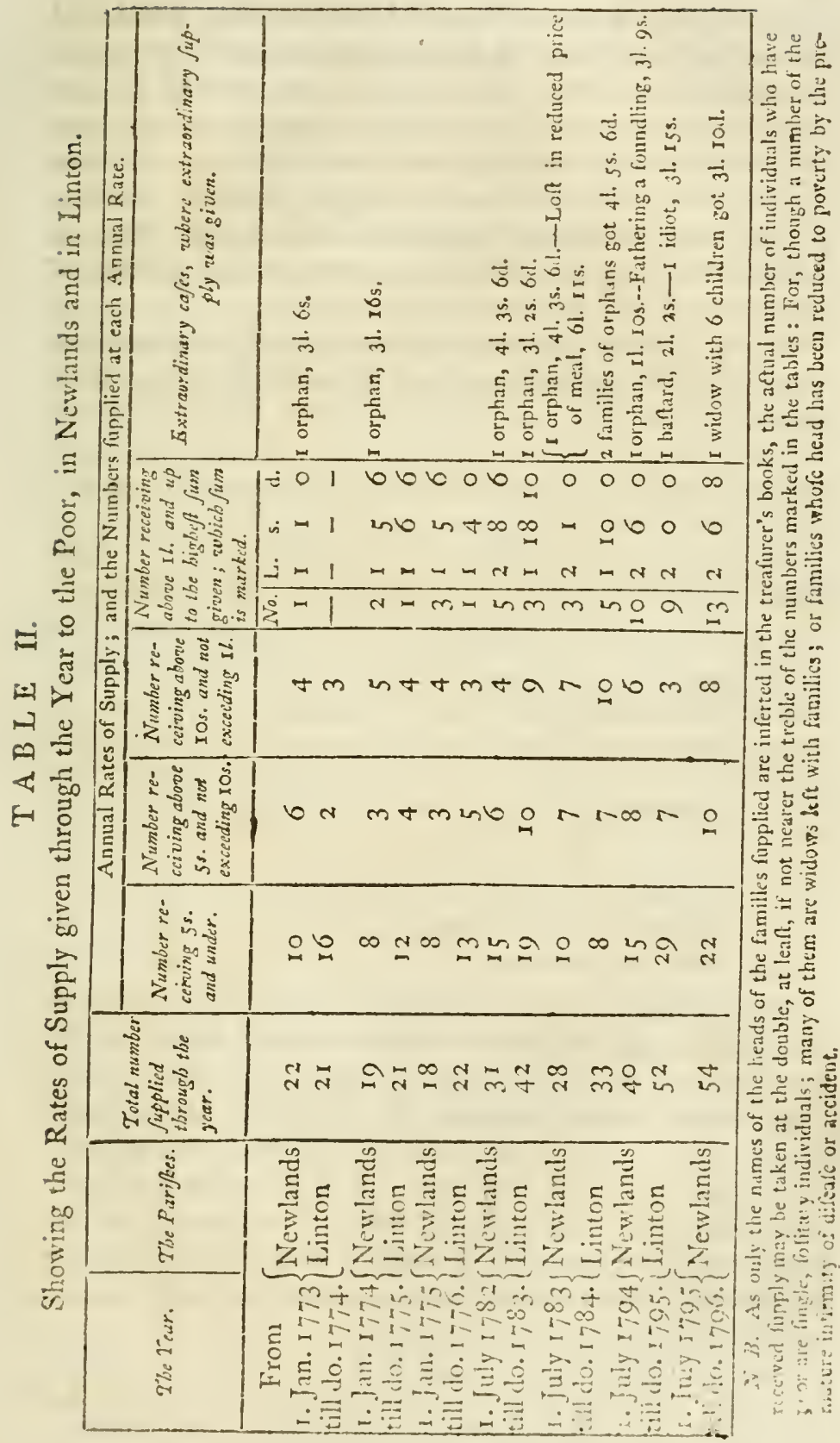


I am indebted to the Reverend Mr Forrefter, Minifter of Linton, for the following ftatement of the rates of fupply grant. ed to the poor of that parifh from January 1800 till January I80I. I am forry I cannot furnifh a ftatement of the fame kind for Newlands; as money was given to different diftributors; and though their accounts were given in to the treafurer in detail, they are entered in his books only in grofs: The annual expence, however, the number of poor, and the rates of fupply, were much the fame as at Linton.

Poor's rates were impofed in both parifhes in the two dear years; but the adminiftration was difcretional, without fixed penfions.

Expence Poor of Linton trom Jan. i 800 to Jan. i 801.

The total number fupplied was $70 .--$ The whole annuai $\mathrm{ex}-$ pence amounted to I03l. IOS.-The rate of fupply as under:

\section{RATE.}

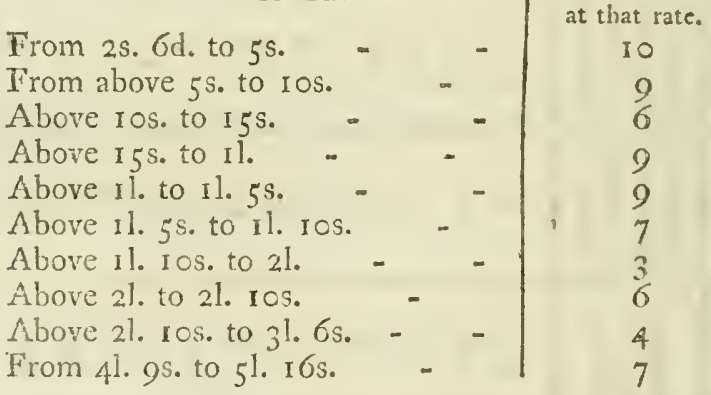

The moft ferious burdens to which poor's funds are expofed, are, orphans and old people without rclations, who muft be committed to the hireling care of frangers; in which cafes, there is much exponce incurred, for little fervice, flovenly executcl. Lven a baftard child, difownel by the father, is not a very ferious burden, if the mother is ftout and oeconomical: $\Lambda$ bout twenty-five years fince, I knew of an inftance of this lind occurring in the parifl of Linton; where the maintenance of the child, till it was fit to do foncthing for ifflf, did not cont the Surion, munally, above 40 s. 
In cares of baftardy, we are apt to be too indulgent to the weaker fex; though, undoubtedly, both culprits ought to fuffer; and neither ought, furely, to be a gainer for their encouragement: Yet, when a ploughman could gain only 61 . or 7 . of yearly wages above his victuals, I have known one of this defcription amerciated by Juftices of the Peace in an aliment of 41. yearly to his baftard child, till it thould arrive at the age of ten years. The next to ruin that would enfue upon fimilar decifions, would render them equivalent to an act of banihment, and defeat entirely their intention; beficies holding out anl irrefiftible temptation to perjury, in Scotland, where, by law, it is referred to the accufed father's oath to decile whether he is or is not the real father; unlefs, indeed, the mother can adduce prefumptire proof, from circumftances (femiplena probatio) of his guilt; when her oath is taken in fupplement of her proof.

In the dearths of $1782,1795,1799,1800$, fome parifhes bought meal, and fold it at an under-rate to their poor; others approved rather of diftributions in money; as interfering in no way to the difcouragement of the retail trade in meal; the encouragement and free competition of which, was confidered as both highly convenient for thofe tradefpeople who got no goor's fupply, and as the beft fecurity againft their being ima poled upon.

There are two or three friendly focieties in this county: In laft dearths, fome of their capital was loft, by bing embarked in the very idle, but highly popular concern of importing grain. They have all embraced the privileges of the ant of Parliament in their favour, by fubmitting to its regulations. Under the frugal management of adminiftrators chofen by the members, they promife to be of great ufe, at fmall expence, and with little rifk of mifapplication. 


\section{SECr. VIII.-Population.}

\section{POPULATION TABLE.}

\begin{tabular}{|c|c|c|c|c|c|c|c|c|c|c|c|c|}
\hline \multirow[b]{3}{*}{$\begin{array}{l}\text { Names of } \\
\text { Parifhes. }\end{array}$} & \multirow{3}{*}{ 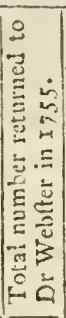 } & \multirow{3}{*}{ 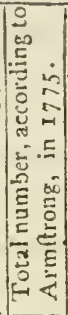 } & \multicolumn{9}{|c|}{ From Sir John Sinclair's Statifical Account. } & \multirow{3}{*}{ 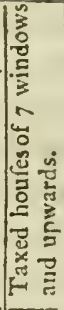 } \\
\hline & & & \multirow[b]{2}{*}{ 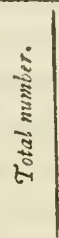 } & \multirow[b]{2}{*}{ 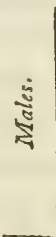 } & \multirow[b]{2}{*}{ 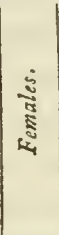 } & \multicolumn{5}{|c|}{ Ages. } & \multirow[b]{2}{*}{ 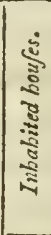 } & \\
\hline & & & & & & $\begin{array}{l}\dot{0} \\
\dot{y} \\
\dot{y}\end{array}$ & \begin{tabular}{l}
$\dot{0}$ \\
0 \\
0 \\
0 \\
0 \\
\multirow{0}{0}{}
\end{tabular} & $\begin{array}{l}\dot{0} \\
2 \\
\dot{0} \\
0 \\
0 \\
5 \\
5 \\
0\end{array}$ & $\begin{array}{l}0 \\
0 \\
2 \\
2 \\
0 \\
0 \\
5 \\
5 \\
0\end{array}$ & $\begin{array}{l}\text { : } \\
\text { हे } \\
\text { षे }\end{array}$ & & \\
\hline & & 800 & 92 & & 479 & & 6 & & 146 & 9 & & \\
\hline & IOC & 940 & 8 & & 443 & 220 & & & & o & & \\
\hline & 679 & 810 & & 371 & $i$ & I3I & & & & I & - & \\
\hline & 279 & 250 & 36 & 188 & 3 & 105 & 75 & & 32 & I & 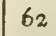 & \\
\hline & 3 & 260 & 288 & I $3 I$ & 157 & 5 & & & & 6 & & \\
\hline ggot & 26 & 167 & 152 & i1 & 8 & 2 & & & & 6 & & \\
\hline & 335 & 230 & 234 & 120 & & & & & & 6 & - & \\
\hline & 367 & 274) & 264 & 142 & & & 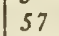 & & 3 I & 5 & - & \\
\hline & 320 & 292 & 229 & 123 & 106 & 49 & 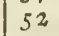 & 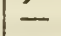 & - & - & 42 & \\
\hline & 305 & 320 & 270 & 123 & 147 & 6 & - & & $\ldots$ & - & & \\
\hline & 392 & 270 & 300 & & 16 & 76 & 72 & - & - & - & 55 & \\
\hline & 559 & 420 & 560 & 268 & 202 & 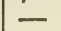 & & - & - & - & & \\
\hline & 651 & 480 & 445 & - & 1 & IIS & 88 & I 8I & 39 & 19 & - & \\
\hline & 1896 & 1582 & 1920 & - & - & 547 & 365 & 626 & 322 & 60 & - & 8 \\
\hline & 35 & 250 & 227 & - & - & {$[-$} & - & - & - & - & , & \\
\hline & & & 31 & 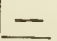 & & & & & & & & \\
\hline Mais & 8908 & 3 & $99^{2}$ & - & $1-$ & - & $=$ & $=$ & 二 & - & - & \\
\hline
\end{tabular}

Accorcing to Dr Pennycook, the population in 1755 was 8000 . In the Statifical Accounts, it appears, that the population of Linton in 1777 was 1003 . In the account of 1 .yne and Mrggot, the average population is faid to be $\mathbf{r} 60$. In the account of Mannor, after the clafification, as in the above table, the clafis. fication continues; 54 from 20 to 30 years; 28 from 30 to $40 ; 28$ from 40 to 60 ; 17 from 60 to 80 ; I from 80 to 90 . In that of Glenholm, the population is faid to be more numerous in Summer. In that of Stobo, the arrangement is; above 8 years of age, males II9, females 102. About 40 of the inhabitants, ftated above as belonging to Inverleithan parim, refide in that part of the parifh which lies in the county of Selkirk. In Yeebles parif, 22 of the tayed houfes are within the burgin, as alfo I 4 \& of the population 


\begin{tabular}{|c|c|c|c|}
\hline ले & 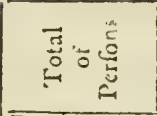 & 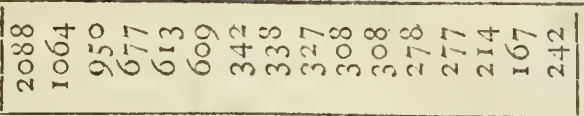 & $\mid \begin{array}{l}\infty \\
0 \\
0 \\
1 \\
1 \\
0\end{array}$ \\
\hline 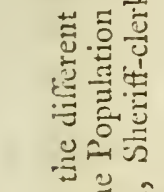 & 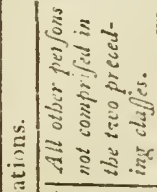 & 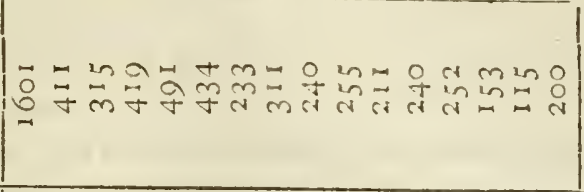 & $\mid \begin{array}{l}7 \\
\infty \\
\infty \\
i n\end{array}$ \\
\hline 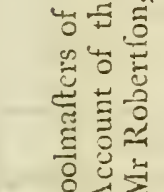 & 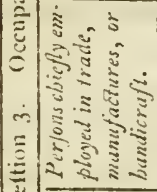 & 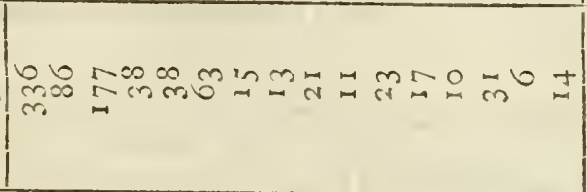 & $\stackrel{2}{\infty}$ \\
\hline 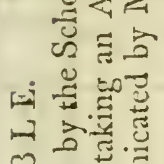 & 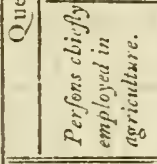 & 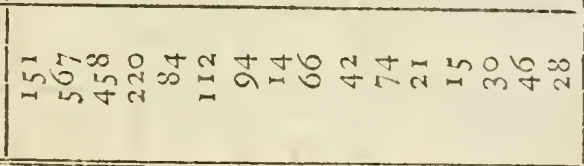 & $\begin{array}{l}4 \\
\text { 9 } \\
4 \\
4 \\
4\end{array}$ \\
\hline 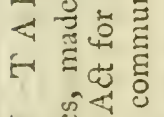 & एँ & 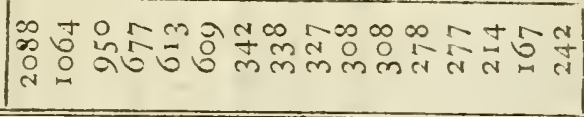 & $\begin{array}{l}\infty \\
\infty \\
0 \\
1\end{array}$ \\
\hline 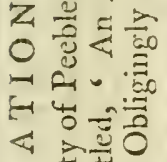 & 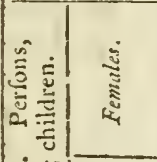 & 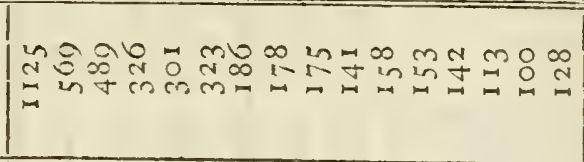 & $\int_{0}^{2}$ \\
\hline 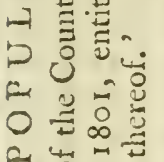 & 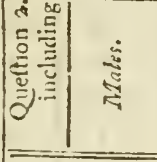 & 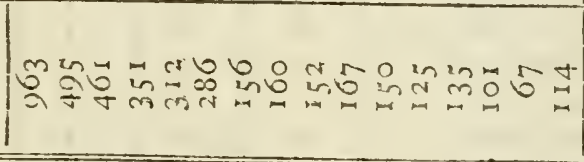 & $\stackrel{5}{\dddot{2}}$ \\
\hline 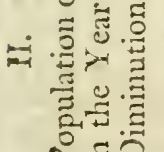 & :ב & 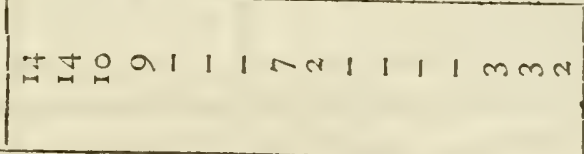 & $\sigma^{t}$ \\
\hline 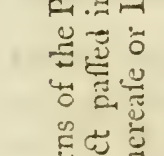 & 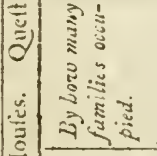 & 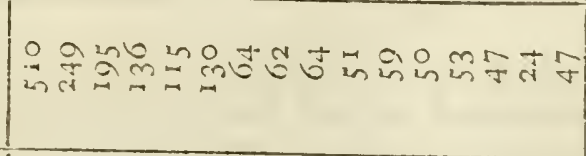 & $\begin{array}{l}i \\
i \\
\infty \\
\infty \\
\infty\end{array}$ \\
\hline 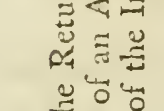 & 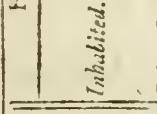 & बे & $\left\{\begin{array}{c}\infty \\
\infty \\
\infty\end{array}\right.$ \\
\hline 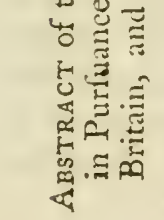 & 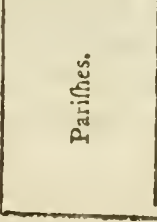 & 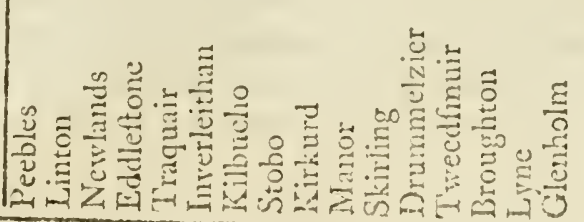 & \\
\hline
\end{tabular}


Of Taxed Clocks, Watches, and Dogs, in I797; for which am indebted to Mr. Brunton, County Surveyor.

\begin{tabular}{|c|c|c|c|c|c|c|c|}
\hline \multirow{2}{*}{ Names of Parifhes. } & \multirow{2}{*}{ Clocks. } & \multicolumn{2}{|c|}{ Watches. } & \multirow{2}{*}{$\begin{array}{c}\text { Total } \\
\text { Watcbes. }\end{array}$} & \multicolumn{2}{|c|}{ Dogs. } & \multirow{2}{*}{$\begin{array}{l}\text { Total } \\
\text { Dogs }\end{array}$} \\
\hline & & Of gold. & Of filver & & $\begin{array}{c}\text { Paying } \\
3 s .\end{array}$ & $\begin{array}{c}\text { Paying } \\
5 s .\end{array}$ & \\
\hline Eddleftone & I I & 3 & 10 & I 3 & I & I7 & 18 \\
\hline Newlands & I I & 8 & 10 & 18 & I & 27 & 28 \\
\hline Kirkurd & 5 & 5 & 8 & I 3 & - & 20 & 20 \\
\hline Skirling & I & - & 2 & 2 & - & - & - \\
\hline Stobo & 5 & - & 6 & 6 & I & 10 & II \\
\hline Glenholm & 4 & 3 & 5 & 8 & - & 9 & 9 \\
\hline Kilbucho & 3 & I & 3 & 4 & - & 4 & 4 \\
\hline Niannor & 7 & 2 & 10 & 12 & 5 & I 5 & 20 \\
\hline Drummelzier & 4 & 4 & 4 & 8 & I & 19 & 20 \\
\hline I'weedimuir & 5 & I & 2 & 3 & I & 6 & 7 \\
\hline 1.yne \& Meggot & 6 & - & 5 & 5 & - & I I & II \\
\hline Inverleithan & 7 & 2 & 7 & 9 & - & 22 & 22 \\
\hline Traquair & I I & 3 & 9 & I 2 & I & 18 & 19 \\
\hline Broughton & 2 & - & I & I & - & 一 & - \\
\hline linton & 5 & I & 6 & 7 & - & 14 & 14 \\
\hline Peebles, comtry & 4 & - & 5 & 5 & - & 20 & 20 \\
\hline Town ditto & 15 & 2 & 19 & $2 \mathrm{I}$ & 2 & 9 & II \\
\hline Totals: & 106 & 35 & II2 & 147 & 13 & $22 I$ & 234 \\
\hline
\end{tabular}

None of the foregoing accounts of the population would appear to have been made up from actual enumeration, but thole in the ftatiftical accounts, and in the return by the fchoolmafters, purfuant to Abbot's bill.

Pennycook, as phyfician to the county, had much opportunity of information, though it is probable that his ftatement is mercly deduced by calculation from probable data. The return to Webfter, I am informed, was made up from calculations, founded upon the proportion which the whole population is 
fúppofed to bear to the number of examinable perfons upon the minifter's exanimation-roll; but it is unccrtain, how far fuch lifts might have been accurately kept; and, though examinable perfons are confintered to be thofe who have attained to eight years of age, and all above that age, yet it is queftionable, how far, in every infance, fuch claffification might have been rigidly adhered to. Armftrong's ftatement, I know, in various inftances, was taken from the randon guefs of clergymen fitting at their own fire-fides, who kept no regular lifts.

The inhabitcd houfes are noticed, in eight of the parifhes, in the Statiftical Accounts; and the rate of inhabitants to an houfe, in thefe, is $5 \frac{x}{50}$. In the fame parifhes, by the return in purfuance of Abbot's bill, the rate of inhabitation is $5 \frac{x}{7}$ to an houfe; and by faid return, the general rate of inhabitation is $5 \frac{1}{4}$ to an houfe.

It is, unquentionably, a matter of great importance, that the real ftate of a country fhould be afcertained; and for this purpofe, it would be neceffary, in Scotland, that the keeping of regular regifters of marriages, births, and deaths were enforced.

In the affortment of the population of Tweeddale upon Abbot's bill, the claffes employed in agriculture, trade, manuffacture, and handicraft, are ftated at $292 \mathrm{I}$, and the nondeferipts, at $588 \mathrm{I}$, or more than double. 'The fchoolmafters would need more fpecific inftructions as to fuch affortment; otherwife, nothing can be learned from their returns-while fome, as is confiftent with my own knowledge, in this county, return, in the non-defcript clafs, the whole of the females, and the whole of the children; and others make the wives and children go along with the fathers of the families, \&rc. \& c.

In twelve of the parifhes, the proportion of males to fenales is given in the Statiftical Account; and the fcmales exceed the males by $5^{1}$; and, in proportion of the whole population in thefe twelve parifhes to this diflerence, the whole population of the cominty, by faid accounts, fhould give a difference of excers of fenales over males of $79 \frac{2}{3}$ nearly: This excefs, per ruturn suncler $A$ bbot's bill, is 412 ; but, in proportion of the whole of 
the population, per Statiftical account, to the whole under Abbot's bill, the excefs of females by the latter ought (in the above ratio) only to have been $\delta 6 \frac{x}{2}$ nearly. Could this difference of excefs in the females be owing to the abfence of males, in confequence of a ftate of war? or, are thefe great variations of the proportion, to be attributed to inaccuracies in the different enumerations? No doubt, in the twelve parifhes of the Statiftical Account, on which the above calculation is grounded, the town. of Peebles is not included; and this may make the general excefs of females over males appear confiderably lefs from the Statiftical Account, widowed females generally betaking themfelves to towns; not, however, feemingly, to fuch an extent as fhould eafily explain the great difference of excefs in the return under Abbot's bill. The enumeration under Abbot's bill was, indeed, made during the Summer half year, when the farmers cmploy more fervants, particularly female fervants; and that may have increafed the difference of the proportion of females, and, indeed, of the extent of the whole population, by the excefs of the demand for farm fervants in the Summer half year, above what is fupplied by the fpread of the Winter inhabitants of the town of Peebles, and villages, in that feafon, over the country: But this alone could not nearly account for either the excefs of the proportion of females, or the increafe of 903 upon. the whole population, in the return of Abbot's bill; not even upon the fuppofition of the returns to Sir John Sinclair having been made, generally, from an enumeration in the Winter feafon.

The fure method of obtaining an cxact enumeration is, to have it executed over the whole empire at one time; which prevents all poflibility of deficiency, or duplication of return, in confequence of migration.

Confidering the great excefs of the proportion of females under Abbot's bill, which certainly implies the abfence of a greater number of males in the army and navy, who are therefore not enumerated; and confidering, notwithfanding, the great excefs of the total population over that returned to Sir John Sinclair; it mult certainly appear, that the population of the 
county has rapidly increafed within thefe ten years bypaft. As this increafe cannot be attributed to the introduction of manufactures, it nuft be afcribed to improved agriculture; and the lamentation over the depopulation of the country, which we find in feveral of the ftatiftical accounts of Tweeddale parifhes, muft either have proceeded from mifinformation, or from partial views - it may have taken place, locally, in fome parifhes, but not upon the qubole, over the county; or apparently, (from circumftances explained p. 47,48 .) where it had 110 reality: And hence the account of farm-toruns once inhabited, and now fallen to ruins, which are confidered as the marks of a former more frequent population.

The population in Tweeddale, according to the above tables, would appear to ftand at the rate of I to $26 \frac{x}{10}$ acres; or at the rate of 24 to the fquare mile *.

The following ftate of the population has appeared in the newfpapers, as already prefented to the Houfe of Commons:-

\begin{tabular}{|c|c|c|c|c|}
\hline & & Males. & Females. & Total. \\
\hline England & - & $3,987,935$ & $4,343,499$ & $8,33 \mathrm{I}, 434$ \\
\hline Wales & - & 257,178 & 284,368 & $5+1,5+6$ \\
\hline Scotland & ot vet returned. & $734,58 i$ & 864,487 & $1,599,068$ \\
\hline p & Guernfey and Jerf & - & - - & $4,000,000$ \\
\hline & ed - & - & 一 & 80,000 \\
\hline Arn & Militia & I98,35 I & - & 198,351 \\
\hline Nav & Marines & I 26,279 & - & I 26,279 \\
\hline Sea & regiftered fhips & 144,558 & - & $144,55^{8}$ \\
\hline Cor & n board of hulks & $\mathrm{I}, 4 \mathrm{IC}$ & - - & 1,410 \\
\hline otal & - & & & \\
\hline
\end{tabular}

SECT.

* That the reader who has little accefs to books may form fome comparative notion of the relative ftates of population, I fubjoin a fate of the computed populution to the fquare mile in different countries, from 'lownfend's Travels in Spain : Rufia 5; Spain 67; Fngland ro7; France 147 ; Ifolland 272.

The population of Tweeddale appears to be nealy an one hunded apd eightyo frcond part of that of Scotland. 


\section{SEct. IX.-Corn Laqus.}

THE beft corn laws for encouragement of agriculture erer introduced into Scotland, were, the acts of Parliament 1449 and 1469 , with the gradual extenfion of the principles of thefe fatutcs, through the liberal interpretation of our Judges; affording affurance to the cultizator of the foil, of reaping the fruits of his labour and his capital, by communicating fecurity to bis tewure of polfefion. The act of Parliament I 748 falls under the fame defcription: Much alio remains in expectation from individual exertion; as an enlightened fenfe of felf-intereft fhall be more and more diffufed through the claffes of landed proprietors, and of profeffional farmers, in regard to the proper confiruction of leafes. - See note D.

In regard to the corn laws, properly fo called, the views entertained by landed proprietors and farmers feem to be, that the price of corn fhould be artificially enhanced, by conftant bounties upon its exportation, and by the prohibition or difcouragement of importation; excepting in clamant cafes of more than ordinary fearcity and dearth. And confidering how many exchnive privileges have been oltained againf thefe clafies, by merchants and manufacturers, who have fo often had the addrefs to perfuale the public at large of the coincidence of the public good with their own private views-in mowopolics of the home market, fecured to them by prohibition of the inprotation, and bounties upon the exportation of fuch articles as they deal in; together with monopolies of the honeproduced raw matcrials of manufacturc, by prohibitions of its crpostation in an unmanufactured flatc; it is not furprifing, that the former claffes thould have bethought themfelies of obsaining cxclufive privileges in countcrbalance.

If we trut to the opinion of that profound and clofe reafoncr, the author of the Wealth of Nations, it would appear, that, though lome nonopolies will cnrich niercliants and masufacinrers, at the exprnce of their fellow-fubjects, thus iniquitruffy dalarred from buying where they can be cheapest 
ferved; yet, that no fuch alvantage can accrue to farmers or landholders, from fuch exclufive pofiefion of the home market of corn: for that corn is the ftandard of value of every other marketable commodity; and that a certain quantity of corn will ever, at an average, purchafe the fame quantity of labour (fo cffential a part of the confituent price of every marketable article), proportionally to the libcral, moderate, or fcanty reward given to labour in any country, according to the progreffive, ftationary, or declining fate of its profperity. That fuch artificial enhancement of the price of corn, therefore, could be of no real benefit to the farmer or landed proprietor; for, though the farmer can afford more money rent in proportion to the greater money price he recsives for his produce, his landlord can make no larger purchafe of hone labour, or its products, in which his expenditure muft chiefly lye; as they muft all prom portionally rife in money price; nor can the farmer, for the fame reafon, extend his cultivation proportionally to this increafe of the money price of his corns; and that, by confequence, this artificial enhancement of the price of grain cannot tend to the encouragement and increafe of tillage. That, meanwhile, the heightening of the price of com heightening the wages of every manufacture, difables the manufactures of the country from competing in the market with the nanufacturcs of other countries, where wages are cheaper.

It would be much more confonant to the natural fenfe of equity, and probably not impoitic, to remove crery kind of artificial reftriction in regard to agriculture, manufacture, and commerce; and to lave every one to tum to the beft account he can, his fkill, his induftry, his capital, and his revenue, deftined to enjoyment in confumption; fubjected merely to fuch impofitions of taxation as are neceffary for the fupport of Government.

Confidcrable alarn, in regard to the declining ftate of agriculture through the kingdom, fecms to lave heen cxcitcd by the publication of Colonel Dirom upon the com laws, in $+796$.

Fron: 
From that publication it would appear, that, from the year I688, (when bounties upon exportation were firft permanently obtained, in addition to the formerly exifting reftrictions upon, or prohibitions of, importation), tiil the year $175^{\circ}$, our export. of grain gradually increafed; till it arofe to an annual average of 800,000 quarters above our imports: But that from that period (after which our corn laws ceafed to be fo favourable to export, or fo inimical to import) a melancholy reverfe took place; till at length, during the twelve years from 1773 downwards, the balance againft exportation arofe fo high, as to amount to an annual excefs of 311,176 quarters imported, above what was exported ; and from that period till $\mathrm{r} 793$, to about 546,408 quarters.

A publication fubfequently appeared in 5797 , entitled, Difperfion of the gloomy apprebenfions, of late repeatedly fuggefied from the decline of our corn trade; and conclufions of a directly oppofite tendency, eftablificd upon well autbenticated faets, by the Reverend John Howlett. The execution feems to come up to the profeffion of thic title of the work.

As 800,000 quarters was formerly the balance of exportation above importation, and the importation now exceeds the exportation by 546,408 quarters ; it is evident, that the proportion of grain confumed, to that raifed, exceeds, now, the proportion in $175^{\circ}$, by both thefe fums, or by $1,346,408$ quarters annually. When, however, fays Mr Howlett, it is confidered, that, fince 1750 , the population of Great Britain has increafed probably by $2,500,000$ *-that, in confequence of increafing wealth, the whole population are better fed-that the increafe of confumption of butcher mat has fo augmented, as that, upon a moderate computation, 300,000 more of fheep are annually killed, 60,000 of $0 x \mathrm{cn}$, and 40,000 of fwine-that the additional number of high fed horfes, now kept for pleafure, for travclling, for tranfport of commodities, above what were kept for thefe purpofes in 1750 , amounts, upon probable calculation,

* The actual enumeration has feemingly flown the increafe to be greatly abave ine sugpofition in the text. 
lation, to 400,000: And it will then appear, how very little length thefe $1,346,408$ quarters of grain would go to the fupport of this prodigious increafe, both of men and animals, which muft fubfint upon the produce of land. This greatly increafed confumpt could not poffibly have been fupported, but from a proportionally increafed production from the lands, by the improvement and extenfion of agriculture: Nor is there taken into the above account, the increafe of confumpt from the additional number or better feeding of working cattle, implied in improved or extended agriculture; nor the additional animals of the dairy, required from increafe of population; nor the increafed rate of maintenance for thofe in the army and navy.

Mr Howlett appeals to every one's experience of what he fees around him, in regard to the progrefs or retrogradation of agriculture-the feen ftate of the fact, being a much furer ground of conclufions, than the returns from the Cuftomhoufe.

He is of opinion, that corn laws cannot have any confiderable influence in any way; but alleges, that as the improvement of agriculture has continually increafed fince the Revolution, and that as corn laws (of the beft conftruction, in the 0 . pinion of the favourers of them) have, at different portions of that period, co-exifted, an opportunity is thus afforded of confounding mere coincidence with caufation: But that agriculture will be found ftill to have gone on progreffively improving, equally, during that portion of thefe periods when they are fuppofed leant, as when fuppofed moft farourable*. That if

$\operatorname{cor} 12$

* At the Revolution, life, liberty, and property were perfectly fecured; and that encouragement given to induftry, which arifes from fecurity of reaping, and unmoleftedly enjeying its fruits. Shall, then, any fuperior caufe be fought for, to account for the profperous ftate of induftry in agriculture, or any other occupation? Under fuch circumftances, is it not glaringly abfurd to fearch for the caufes of the nation's thriving, in any partial fyfem of regulations, fuch as the corn laws, which it has been found repeatedly fo neceffary to altcr and amend, and fo frequently to fufpend altogether in their exicution? Might we not almont as reafonably 
corn laws had any confiderable effect, it would chiefly appear in keeping the market price fteady and uniform : but that, even in thofe periods, when corn laws are fuppofed to have operated to the beft effict, the prices appear to have been fubject to equal fluctuation, as at any other period; as is evident, upon infpecting the tables of prices, produced by thofe who would wifh, from thence, to fhow their beneficial effects. That the price muft depend upon the feafons fent by Providence, and is but little determined by the controul of human contrivance, in the way of regulation.

\section{Sect. X.-Game Laqus.}

THE facred animals, whofe perfons are inviolable, whofe adions are fecure againt refponfibility, whofe damages can neither be prevented nor compenfated (like thofe of the human fpecies) by their punifhment, nor extirpation, nor recovery from their owners, or, rather, thofe who have the exclufive privilege of becoming fuch, fo foon as they can catch themowners, therefore, only upon hypothefis:-thefe animals, in this country, are of a kind, whofe ravages are very little deftructive. We have no deer, or wild boars, roaning at large. Excepting in a flight degree, in regard to Muirburn (page 193), we have no laws facrificing hurbandry to the accommodation of the game: We have no regulations protracting the cutting of hay, till the birds fhall be fledged; or of corns, till they fhall be fat; or prohibiting the ufe of certain manures, for fpoiling

fonably account for the fuccefs of an individual, not from his induftry, but from lis Chriftian name, or his nofe, according to the hypothefis of Father Shandy? There is furely no little degree of impertinence in the enthufiattic patronizers of the corn-law fyftem, in calling upon us to arreft our attention upon trifles of even ambizuous tendency, to the neglect of the invaluable bleffing of that freedom we crijoy. A found conlitution of body can ftand the tampering of quacks; and when vigorous liealth ftill temains, it is apt to be aferibed to the nofrum adminifscied. The fuperior founduefs of the Britifh conftitution may thrs confer unnerited credit on many an islle or unfulutary political nofirum. 
fpoiling of their flavour ". Crows, which cvery one is allowed to deftroy at pleafure, occafion much more damage to the crops, than the whole tribe of game animals put together. The only damage at all worth attending to, is that refulting from men and dogs, in purfuit of the game.

Before the high tax upon game licences, with heavy penalties for hunting without licence, the fheep, particularly upon the range of Pentland-hills, in Linton parifh, wcre much molefted, in the muirfowl feafon, by thoughtiefs, idle, apprentice boys from Edinburgh, traverfing the grounds.

In regard to the detriment of agriculture, the very worft poffible regulation, in refpect of the game, would be, to throw it indifcriminately open, with liberty to purfue it everywhere, to all without diftinction. The very beft would be, to veft in the occupying farmer, an abfolute power of preventing every perfon, without exception, from hunting over his farm againft his confent: A privilege thus granted of favour, and not held of right, would never be atufed, to the damage of farming ftock.

No doubt, thofe privileged to hunt, are commonly in circumftances to enable them to make full compenfation for any damages they may occafion; and in fuch fituations of refpectability, as would reftrain them from knowingly occafioning any damage whatfoever: Yet, without fome fuch regulation, property launched out in farming can hardly be conceived equaliy protecterl by law, as other property launched out in the bufi-riefs of other gainful profeffions. To have recourfe for damages, merely where damage can be legaily inftructed, would

$$
\mathrm{Kk} \text { nowhere }
$$

* Allifions to the old French game laws-See Toung's Tour. There are laws on the Scotifh fratute book, unrejsalcd, which prefcribe the punifhment of the lois of the right hand, for the third ofience of thooting pigeons. They may be confidered as fallen into defuctude, like other laws alfo unrepealed; fuch as, the ftatute againt fornication, in $556 \%$, by which it is ordaincd, that all perfons guilty, as well the men as the women, "tha!l be tane to the deepeft and fouleft poole, or water of the parochin, and their to be thrice douket; and thereafter banithed the faid rasa o: paruslin for ever.' 
nowhere elfe be confidered as a fufficient compenfation, for having property put in ritk at the mere pleafure of another.

Suppofe the whimfical privilege were affumed, of playing cudgel matches, for diverfion, in a glafs or clina fhop: The Thopman would furely have fome reafon to be diffatisfied with this privilege, although he had the moft undoubted fecurity of recovering all damages that might enfue; and though, frorn the nature of his wares, no damage could poffibly occur, in total fracture, or even mere fiflure, but what could, with eafe and certainty, be inftructed. In hunting, however, for example, with flow hounds in Tweeddale, where the fheep, walking wide, are naturally very wild, the mere recourfe for legally infructed damage mult afford ftill lefs adequate compenfation for the rifk; as, from the nature of the property, much damage may be fuftained, which is utterly incapable of any legal inftruction-fuch as, lofs or prevention of fat, from difturbance in their paftures-difeafes confequent upon overheating, in running through fear, or even upon fear itfelf. Here, as elfewhere, the power of prevention of unneceffary rifk is the proper and the beft fecurity. Upon the other hand, it would appear a fevere regulation to exclude the proprietor, without leave afiked and granted, from fuch rural fports as he might find upon his own grounds; which might have a tendency to prevent monied men from invelting their capitals in the purchafe, the improvement, and adorning of landed eftates. Expediences here clafh, and the fubject is confeffedly of great delicacy. Farmers, no doubt, are apprized of their fituation, and, in their calculations of difcount, muft make allowance for riks, whether more conftant or occafronal. Meanwhile, I have ftated the matter in the ftrongeft point of view; as there can be no harm in reminding hunters of the very particular fituation, in which the very valuable farming ftock of the country is placed - a circumftance perliaps too ape to be forgotten in the ardour of the chare.

Game feens now, by the laten decifions, to be confidered as property; or, at leaft, that the property of another cannot be rendered fubfervient to the ufe of ftarting game in it, or of following 
following game through it; and it is thus happily in the power of the proprietor of the lands to exclude all privileged hunters, whofe rafhnefs might render them more regardlefs of rifk upon the property of another, where they have lefs intereft in the tenant's thriving.

In the cafe of theep worried by dogs (a cafe fometines ocm curring in the country, and often in the vicinity of towns and villages), it feems not perfectly decided, whether the firf trefpafs of the dog is at the rilk of the proprietor of the theep, or of the owner of the dog. In the lateft, I believe, and frongeft decifion of the Court of Seffion, upon this fubject, the decifion went near to the eftablifhment of the general principle, - that the firft trefpafs is at the rifk of the owner of the dog. In that caufe, of a dog belonging to a tar-yard, an opportunity was given of bringing forward the matter upon the general principle, divefted of all fpecialties: But (though it was made a common caufe, I have heard, among a number of perfons keeping theep around Edinburgh) the anxiety of the parties led them foolifhly to bring forward fome vague fpecialties, tending to criminate the former character of the dog; and, though the only circumftances of this kind, either alleged or proved, amounted to no more, than ' that the dog had, fome time before, been feen looking earneftly at the theep in the enclofure, the Court, in awarding damages againft the owner of the dog, laid much ftrefs upon this fpecialty of the cafe, in order to decline the indirect eftablinment of the general principle - a meafure which our Courts of Juftice feem fly of adopting; fuch decifions amounting, in effect, to a fort of legiflation, and reqquiring legillative caution and deliberation。 


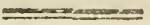

\section{H A P. XVY.}

OBSTACLES TO IMPROVEMENT.

Deficicacy of capital is the great general obnacle to agricultural improvement. Manufacturing and trading capital have had fo many fuperior privileges beflowed upon them, that more than a due proportion of the capital of the country has, thence, been attracted into trade and manufacture. Nor, if we trut to the opinion of the author of the Wealtl of Nations, can this difadvantage be counterbalanced, in favour of agriculture, by any exclufive privileges attempted to be beftowed on capital employed in this oscupation by the corn-law fyften. More full fecurity of reaping the proper fruits of agricultural fkill and capital, than what is prefently enjoyed, might certainly, however, be conferred, to the encouragement of the more extenfive invefiture of capital in farming, and to its accumulation in more rapid progreflion, were it not for prejudices of various kinds.

Prejudices, to prevalent among lanted proprietors, in regard to the cxtent of intereft in the lands communicated by the leafe to the occupying cultivator; both as to the dwration of that intereft, and alfo as to the complcte alienable property of it-Prejuciices defructive, in an high degree, of agricultural credit, and tending to prevent the tenant's fixing of even kis oren capital in the foil ; refriching, of courfe, all the more important improvements, of permanent duration, but diftant return, to tilic exertions of the landed proprictor; whofe means, 
generally equalled by his expence, feldom greatly abound, cannot fpeedily accumulate, and are necefiarily leaft efficacious in their application; - the Scots law, feemingly not as yet fufinciently difentangled from the thakles of feudalifm, giving tco much fanction to fuch prejudices. See notes $\mathrm{B}$ and D.

Prejudices in regard to the fize of farms, which would lead to remulations, on the part of individuals, or even of the public, interfering with the natural order in which the fubject would neccharily arrange itfeif; upon the principle of the $\epsilon$ ifing agricultural capital exerting itfelf iniformly to ottain that mode of its invefiture, under qubich it can be rendered moft bigh. ly productive. (See note D.)-Entails tend to obftruct the beft arrangements; beth in regard to the duration of leafes, and allo in regard to thofe exchanges or fales of property which nightit tend to render farms more productive, either as to fize, or to other circumftances of more convenient and profitable pofieffion. The little effect of the relaxation of entail, by Act, Parliament roth of his prefent Majefty, in regard to leafes, has been fpecified already (page IIr.): A power is, in that act, alfo conferred, of making cxchanges of Ind, to the extent of thirty acres; which may fometimes fuffec, but much oftener may fail to effect the purpofes of a profitable exchange. An originaily bad conftitution is not eafily rectifed.

Prejudices of the mob, which have tco much infected every legillature, in regard to the free matketing of grain; difcouraging the profetion of the com-merchant; forcing, in fome meafure, the farmer into retail trade, and depriving him of the advantage, fo profitable to every producer, of a wholefale merchant to takc off, and to pay for his produce; retuming liim thus immediatciy the capital he had advanced, with its profit; and enabling him again immediately to apply it to the peculiar bufinefs of his profetion, as a producer-and that, too, with entire and undivided attention. In time of dearth, the fe prejudices expofe both the farmer and the corn merchant, fo efrentially ufeful to him, to the defurtetion of their capitals, by the fury of the unculightenat mob.--Nor are thele mobbifl: conceptions confined entircly to the lewer orders of focicty.- 
Our ftatute book ought to be purged entirely of all laws enacted in the fpirit of mobbifh conception, which continue to give countenance to fuch abfurd prejadices ( (ee note $\mathrm{H}$ ); and the prompt exertions of the military force hould ever protect from outrage the capitals fubfervient to agriculture-the moft ufefully employed of any other. A ftrong ftanding military force is indifpenfable, both to the effecting and to the perpetuating of the civilization of any country.

The ruant of proper fubdivifion of labour, and of farming, in all their feveral branches. This want cannot be fupplied by any regulation: There is an univerfal tendency, however, to fuch completion; as every one muft find that pratice makes perfect$n e f s$, according to the proverb; and would find that he could gain more by undivided attention to one thing, could he only obtain fufficiency of employment to occupy himfelf entirely in that way. This infers, however, a plenitude both of capital and of population *.

The want of ricbnefs of foil, and berignity of climate. This is an evil which admits not of complete cure : It may be palliated; by the thelter of wood plantations; by the enclofure of arable farms, and the adoption of a rode of preparation, and of cropping of the lands, fuited to the foil and climate; as fuggefted through the courfe of the Report.

- The fubdivifion of Jabour, and exclufire application to one fpecies of work, has a natural tendency to produce the arrangement of men into cafs, as they are found in the early civilized eaftern regions; the families readily continuing to follow the occupation of their forefathers. It feemed to have produced fomething of this kind in Holland: where, it is faid, villages were to be found entirely occujied by a particular fpectes of boors, or farmers, who devoted their whole attention to the culture of lint, and its manufacture into flax, fit for the fpinning-wheel. They poffeffed 110 lands upon leafe; but hired, for a fingle feafon, from more general farmers, particular ficlds, ready drefled, for carrying a crop of lint: The profetrion of lint boor was continued among them from father to fon: I know not if they ufnally intermarried, exclufivcly, with thofe of the fame caft; or whether fuch cuftom had grown fo invariable as to have obtained the force of a law; or whether this mark of an approach to high cultivation, has furvired the irrup. tion cf the difciples of the favage-ftate philoropisy of Roufeau. 
The avant of proper modes of foring up grain, fo as to preferve it from natural decay, and from the defruction of vermin. Such an invention would more deferve a premium, than that of afcertaining the longitude with precifion, or that of dying cotton of a fcarlet colour. Grain would then continue at an equable price; the plenty of one feafon would cover the fcarcity of another; and we would hear no more of dearths. Within thefe twelve or fifteen years, we have been vifited by the brown burrowing rat, which feems entirely to have banifhed our former fpecies of black rat: They feem too cumning to be enfinared to take arfenic; at leaft when adminiftered in the way of unfcientific family practice; and our beft remedy hitherto difcovered, is a fufficiency of cats. Foxes have abundant fhelter in the numerous young plantations of wood through the county; and their depredations among young lambs are often very confiderable: A fox-hunter is fupported in the county by contribution aniong the fheep farmers. The gentlemen proprietors, out of the rogue-money collected along with their cefs, have, of late, revived the inftitution of a thief-catcher, to clear the county of fuch fturdy beggars as extort alms by intimidation.

The prokibition of the exportation of avool, by confining its fale to home manufactures, may prevent the price from rifing to the rate it might otherwife do, and prevent that attention being paid to its improvement which otherwife might be paid.

Corn lazus, as of doubtful tendency; and

Game lavus, as in fome degree detrimentad, have already been mentioned.

Bad roac's may alfo be again noticed, as weferring to this chapter, particularly the by-roads, 


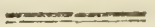

CHAP. XVII.

MISCELIANEOUS OBSERVATIONS.

Sect. I.-Agricultural Societies.

THERE are none in the county inflituted for the exprefs purpofe of formally difcufing agricultural topics: A bookfeller in the county town has fet up a circulating library; bur meets with fmall encouragement : From the thin difperfed ftate of population, the number of readers cannot be many, and thofe who do read do not read much. A monthly club, compofed chiefly of farmers, meet at the head inn of the county town, for focial intercourfe. There is a fociety of the proprietors and farmers, infituted for the purpofe of profecuting rogues, from a fund raifed by annual contribution of the members.

\section{Seст. II.-Wreights and Meafures.}

Butter, cheefe, wool, lay, are fold, within the county, by the Tweeddale tron weight; the pound confining of 23 Englith ounces, and s 6 fuch pounds going to the ftone. Butter and cheefe, fent to Edinburgh, are fold by the pound of 22 Englift ounces; if fuch pounds to the ftone.

Nical, butcher meat, put barley, are fold by Dutch weight, of $17 \frac{1}{5}$ linglifh ounces to the pound. Meal is generally retailed. in half flones, containing eight of fuch pounds, called pecks, fixtcen fuch pecks going to the boll, and two bolls going to the load; which laft is the denomination under which it is fold in wholefale, a peck being given to each load, though this praclice is 
wearing out. Barley is fold in pounds and ftones, by retail; in wholefale, it is fold in bags, the bag containing fixteen ftones.

Groceries are fold by the Englin pound of fixteen ounces.

Grain is all fold, now, by a late regulation of the Juftices of Peace, to whom fuch regulations are ky law committed, by the Linlithgow firlot; which is alfo, by law, the Itandard of scotland. The firlot is fubdivided into four pecks, four firlots go to the boll, and fixteen bolls to the chalder. Potatoes are fold by the oat firlot, with as many above the mouth of the veffel as will lye when toffed on by a fhovel: The weight of a firlot of potatoes may be abour eighty ftones Dutch weight; though, in potatoes, as in grain, the proportion of the weight to the meafure depends upon the quality of the article.

The new eftablifhed firlot, is a wooden reffel, with its fides rifing at right angles to the bottom; a mode of conftruction ins difpenfable to uniformity. In the old neafure, the fides were made to rife at all varieties of acute angles from the bottom; fo that, though they all held exactly the fame quantity of water, they varied, to the extent of difference (as I am informed by dealers) of from a 40 th to a 3 oth part, according as the lefs or greater acutenefs of the angle admitted of the eafier or more difficult paftage of the grain into its apex. Many perfons feem deeply interefted in eftablifhing the fale of corns by weight, and mot by meafure: 'There is, no doubt, a lieight in meafuring, which cannot be practifed in weighing: In other refpects, the feller, in both cafes, mult make calculation of differences of $\mathrm{va-}$ lue, in the fame weight and fame meafure of grain, according to the different qualities of the grain as to thicknefs of hus.; and its different ftates of dampnefs or drynefs. Sixteen ftones Dutch is the weight of good bigg in Tweeddale: It has been known, in favourable feafons, to weigh eighteen or ninetcen Itones; but this weight is feldom attained.

The liquid and long meafures in Tweeddale, are the faze that generally previl through Scotand. 
I Thall ftate here a few facts which have been omittcd in their proper place.

Dairy farming, as the fyftem of tenants paying rent, which is now fuch a confiderable object in the parihnes neareft to the capital, was firft practifed, in its prefent mode of accuracy, upon the farm of Wefter Deanshoufes, in Newlands parifl. Sir James Montgomery of Stanhope refided upon, and occupied this farm, while he held the office of Sheriff of the county. Sir James afterwards let the farm to Mr Thomas Stevenfton, who, in confequence of the prior refidence, found himfelf furnifhed with every accommodation and conveniency for dairy farming, in a ftyle greatly fuperior to what any landlord would, then, have thought of propofing, or the tenant of requiring. The tenant contracted with Edinburgh coffee-houfes for frefl butter; and, though with fomewhat more trouble, obtained prices fuperior to what are obtained by thofe who fell it to weekly carriers, or to Edinburgh grocers: The fame mode of difpofal is continued by his fon, who fucceeted him in the farm. Old Stevenfton throve upon this practice; and left three fons, eftablined in as many farms, in this county. $\mathrm{Mr}$ James Henderfon, in Weftmains of Kirkurd, was the next that made a figure in this fpecies of farming.

Mr George Dalziel, innkeeper, firft at the village of Linton, and afterwards at Noblehoufe inn, was the firit farmier that fowed turnip in the open fields: I believe he had a field of perhaps two or three acres at Linton, fo early as the $176_{3}$ or 1764 An innkeeper upon the London road, which then paffed by Linton to Carlifle, previous to the making of the road by Selkirk, lind many opportunities of information; and Dalziel was a man of obfervation and acutenefs. I believe he might alfo be the firft who cultivated potatoes, on a large fcale, by the plough. But the knowledge got from oral information, can never be fo accurate or complete, as what is obtained from ocular infpection of the practice. Dalziel made trials, both of turnip and artificial graffes: I believe, however, that neither were at all adopted into a regular fyftem of rotation of cropping, till introduccel 
introduced in this form by M'Dougal, as noticed (page ${ }_{5}^{6}$ ). I have reafon to believe, that the turnip hufbandry was introduced into Ayrhire, in confequence of a hint given by Mir Alexander Dalziel, fon of George, and then factor upon Lord Glencairn's eftate, to a $\mathrm{Mr}$ Smith occupying a farm near to the village of Monkton in that county; in confequence of which, Smith came to Noblehoufe, in the Summer of 1789 or 1790 , on purpofe to be inftructed in the practice of the culture of the plant when growing, in fingling the plants by the hand-hoe, and ploughing betwixt the drills. The fact, being fo recent, may be eafily afcertained. So late as the publication of Colonei Fullarton's Report, the regulated Ayrfhire practice, to which the temants were bound by their leafes, was that of three years corn crop followed by fix years grafs: and though this fyltem would appear to have been only a fmall improvement unon fome prior fyftem fill more burbarous, we find, that the honour of its invention continued to be ftill keenly contefted, as, antiently, was the honour of the birth-place of Homer.

Wooden flakes, for confining fleep upon turnip, are coming more and more in requeft: For thefe two laft years, many Tweeddale carpenters find almoft clofe employment in furnifhing them-a fign that Tweeddale fheep farmers, in feeding on turnip, do not pay their whole attention to the benefit of the nheep, as ftated in page 72 ; but are attending more to the benefit of the land. 'The flakes are each nine feet long, made of foreign fir ; and, when well painted, are, according to their more ftrong or more flight conftuction, afforded at from 5 s. to 7 s. per flake. In Autumn I80I, when the aftermath clover was everywhere fo luxuriant, an intelligent farmer, in the parifh of Dunfyre in Clydefdale, bordering upon this county, confumed his clover by fheep enclofed in flakes, as on a turnip field, to the great benefit of the land. This practice was a novelty in this neiglibourhood.

To one acquainted with this county for upwards of $3^{\circ}$ years bypaft, it conveys a pleafing idea of progreflive improventent, that the clafs of farmers, formerly ftudious of making sain mercly 
merely by faving, are now fo liberal in their outlay, even upos the mere inftruments of their trade.

It may be here noticed, that the Tweeddaic hills are generally hard and dry; that the fheep are peculiarly healthy and hardy, the rot being fcarcely known; and that, for holding stock, the heary ewes, in particular, (in which kind of ftock there is the greateft rin, from unfound paftures), fell at a price proportionally more high than that drawn for fimilar ftock from more fufpicious quarters, in proportion to the diminution of the rifk of their thriving, 


\section{CONCLUSION.}

WAS man covcred, by nature, with fur, like the bcar; were the elements fo tempered, that their influence could not injure him, or his body impaffible and unfufceptible of injurydid he inhale aliment, witl brcath, like the camelion; was the continuation of his kind provided for by the permanence, and not the fucceffion, of individuals; or, was the fucceffion procured by fpontaneous prodnction, without diftinction of fex, or the paffions originating in that diftinction -.. Upon fuch fuppofitions, there could be no call for induftry, to procure clothes, houfes, fuel, or meat; no neceffity of any kind of exclufive appropriation; no poffibility of injury, nor perception of difinction betwixt juftice and injuftice; no need of mutual cooperation, of government, or of law; - but each individual, poffefling the boafted perfection of the ftoic fage*, would conftitute a completc whole in himfelf, unconnected with, and independent upon fociety. Having no wants or defires to ftimulate his felfifh exertions, for their relief or gratification + ; having as little call upon his benevolence, in behalf of others, as unneedful as himfelf, it were difficult to conceive what could be his occupation-whether his ftate of exiftence would not be merely paftive? whether he could be faid to live, or merely to vegetate? whether his mind could turn its attention upon its own powers, or rife to objects of more fublime contemplation, witl-

- Totus in fe teres atque rotundus.

Ingenii largitor venter. 
out having the knowledge of fuch powers brought home to its confcioufnels, from their firft having had their energy called forth upon more immediate and urgent concerns?

It were endlefs to indulge fpeculation upon the confequences deducible from ideal fuppofitions. We muft take man as he is - fitted for, and deftined to action, by his great Creator-impelled, by his wants, to thofe exerticns to which their relief is entrufted-and left to become the artificer of his own fortuneimpotent, indeed, in his individual capacity; but powerful, in the co-operation of his fellows.

The profperity of man in focicty; the extent of the population that can be fupported; together with the comfortable fubfitence of that population, depend upon the improvement of Agriculture and the other Arts: and their improvement, is the joint refult of ftock, of kilil, and of induftry.

Stock is created by man, in his capacity of an hoarding animal, out of the favings of the products of his induftry.

Skill is obtained by him, as an obfervant, a recollecting, comparing, combining, inventive, and communicative beingfrom experience and information, from judgement and inference. His animal frame is happily adapted to enable him to carry into execution the contrivances of his intellect. He acquires dexterity, in his operations, from habit, in their frequent repetition: And the excellence of his dexterity, depends upon the exclufive application of his talents to one occupation; both leading to, and confequent upon, the proper fubdivifion of fabour and employment.

Induitry confifts in the unremittent and ftrenuous application of fill, dexterity, or ftock, to their proper profitable occupation. Man's excitement to it, arifes from his wants and his defires, joined to the certain profpect of being allowed to apply its products to their relief and gratification. In particular cafes, his benevolence will excite him to ftrong exertions of induftry; in the cafe of defcendants, always-if, indeed, under this modification, the motive is, with fuch ftrict propriety, defigned benevolence: In general, though it may frequently aroufe energy, it is a motive much lefs energetic, or, at leaft, by no means 
to be depended upon for fuch unvarying conftancy in its operatron as his felfifhnefs.

To afford him the certain profpeet of enjoying his acquifitions, and of tranfmitting their fecure enjoyment to defcendants, or other natural objects of his affeetion, through the protection of equal law - This is all that fociety can effect for him, to thimulate him to the exertion of induftry, to the acquifition of Akill and dexterity, and to the accumulation of ftock-This is all that can, in this view, be held out to him, in the arrangement of the terms of private contract for fpecific purpofes *.

To think of rendering him induftrious through regulation, were he not induftrious by nature; or to attempt to excite his induftry, without holding out its proper excitement, were to offer remedies to the dead. The vital powrer exifts of itfelf; remedies cannot infufe it, but muft prefuppofe its exiftence: Regulation fhould attempt nothing but the removal of obftacles to induftry.

Skill, induftry, and ftock, are mutually and equally fubfervient to each other, in promoting the productive efficacy of each. Without a certain proportion of fkill and induftry, no ftock could ever be created; or, if in exiftence, could be turned to no profitable account. Without the poffeffion of a certain proportion of ftock, fkill and induftry could not be applied but to operations of immediate return; though, in agriculture particulasly, the importance of the return is often in the direct proportion of its diftance. Without fkill, the operations of induftry muft be comparatively inefficacious. Till ftock, however, has been confiderably accumulated ; till individuals become rich; fo as to have leifure for contemplation, without neceflity of conftant perfonal application to labour, for the purpofes of immediate fubfiftence; no fkill can be acquired, no time can be dedicated to the cultivation of the fciences, to the confequent invention of machinery, nor to the difcovery and contrivance of the application of the other natural powrers to the facilitating of labour

- Sec note D. 
bour-through which means alone can induftry be rendered; to the higheft degree, productive *

Energy, once raifed, exerts itfelf univerfally. Man delights, and with reafon, in the exercife of thofe talents that mark the fuperiority of his nature; though the exertion fhould bear no immediate reference to the ends that firt called them forth to action: They become the fubjects of emulation, the fource of confcious fatisfaction, and the foundations of fame. In the words of an elegant political author- ' The fpirit of the age, then, affects all the arts; and the minds of men, being once soufed from their lethargy, and put into a fermentation, turn themfelves on all fides, and carry improvements into every art and fience.'

The fpirit of a monk dictates feclufion from the world. The fpirit of Chriftianity confiders this world as the theatre of active duties; in the proper difcharge of which, confits the beft preparation for eternity.

* See note $G$. 


\section{N $O$ IT IE S.}

\section{NOTE A.}

THE divifion into counties, marks the boundary of the jurifdiction of the Sheriff, who is the judge of the county in civil caufes, (all of which, in Scotland, are determined by the judge, without the intervention of a jury), his fentences being fubject, upon appeal of the parties, to the review of the Court of Serfion. This laft mentioned court is the Supreme Court of Scotland, from whence an appeal lies only to the houfe of Peers. It is compofed of fifteen judges, (nine of whom conftitute a quorum), and is juftly confidered as the Grand Jury of Scotland in civil caufes *.

The Sheriff is alfo the criminal judge of his county, judging, in petty crimes, without a jury; and having, as generally fuppofed, a right to judge, though feldom choofing to judge, without a jury, in crimes inferring fevere punifhment, only thort of capital + . His fentences are confidered as fubject, by appeal, to the review of the Court of Jufticiary, in all cafes of feverer pe-

$$
\mathrm{M} \mathrm{m}
$$

nalties,

* It was this notion of the Court forming the great national Jury in civil caufes, which raifed, not many years fince, the wcll-founded oppofition to the economical plan propofed, of augmenting the falaries of the judges, by diminifhing their number, and dividing thore of the aboliked places among thote to be rctained.

f Arnot, in his hiftory of Scots criminal law, obferves, that Magitrates of royal burghs have thown grcater aptitude to judze without juries in fuch caufes whin their burghs, than Sheriffs within their coustics; whence he conclujes, that prefumption is always in proportion to ignorance. It is a neceflary qualification in a Shcriff, that Le Alall have paft:d trials as an advocate before our fuprome coure. 
nalties, except where he has decerned upon the verdict of a jury. The power of the Sheriff to judge, by a jury, in capital cafes, feems to be falling, or to have fallen, into defuctude; all fuch caufes being now determined by the Court of Jufticiary, in their more permanent fittings at Edinburgh, or at their annual circuits through the country. This laft mentioned court is compofed of a Lord Juftice-General, (an office next to finecure), and of fix of the judges of the Court of Seffion; thefe fix having an additional falary, proportioned to the additional trouble of their double gown*. They judge in all capital caufes, upon the verdict of a jury, and (as has been afcertained by the rejection of an appeal by the Houfe of Peers as incompetent) in the laft refort. They are always ready to meet for difpatch of bufinets, as it occurs, at Edinburgh, during the Winter and Sunmer Selions of the Court of Seffion; and take circuits, two and two together, through the different diftricts of Scotland, for the adminiftration of criminal juftice, during the Summer vacation of that Court. Private parties are not bound over to profecute crimes. This duty is devolved upon the procurator-fifcal, before the Sheriff-court; and, upon the Lord Advocate, or his deputes, before the Court of Jufticiary, in Edinburgh, or the Jufticiary Lords, upon their circuits. They are the public accufers, and carry on criminal profecutions at the public expence. 'Tlic infitution of the Grand Jury, with whom is vefted the power, after precognition of facts, of fupprefting, or of enforcing, criminal profecutions, is unknown in Scotland, where thefe powers are vefted in the Lord Advocate alone, who has been found irrefponfible in the exccution of his office, by a decifion of the Court of Jufticiary, upon a complaint againf lim (originating, apparently, rather in the wifh to have the extent of his powers defined, than in any feeling of oppreffion) from a perfon againft whom he had intented a criminal profecution, and who was acquitted by the jury through failure of proof $t$. The inftitudion of a public accufer fcems a great. improvement

- Gown, the Scotifn name for the rube of oftict.

+ M'Laurin's criminal caŕs. 
improvement in criminal law. The inveltment of the extenfive powers of a Grand Jury, in an officer of the Crown removeable at pleafure, is apparently lefs favourable to the fecurity of the fubject; yet no feeling of grievance has been excited for more than half a century; affording one proof, among many, that Liberty, or (to fpeak more corretly) the proper circumfcription of liberty, (whence refults equal and general fecurity of life, liberty and property), is more dependent upon general knowledge and manners, and the publicity of meafures, than upon any fpecific forms that have been devifed to infure it.

The courts of the Commiffaries have alfo a county jurifdiction, extending to cafes of fcandal, probates of wills, marriage, aid divorce, \&c.; being the remaining veftige of the civil jurifdiction exercifed by bifhops courts. Unlike to other Scotifn courts, the emoluments of the judge arife not folely from an adequate fixed falary, but from weighty fines or dues upon each particular caufe; the whole expence, almoft, of obtaining juftice, thus falling upon the party, inftead of his being infured, as in other courts, againt the expence of the judge, which the pub. lic at large defray.

The jurifdiction of the juftices of the peace, is almoft every way fimilar to that of the juftices in England; with the exception, that we hardly know fuch a character as that of a trading juffice, making money of his office; whence we are apt to infer, that the nomination in England is not confined, as in Scotland, to the refpectable landed proprietors. This jurifdiction of the juftices extends, as to the powers of each, fingly, and of the whole, collectively, over the county for which they are nominated. Clafifications of parifhes into difricts, for holding different juftice courts, for the greater accommodation of litigant parties, has of late been made over Scotland, in purfuance of the late act of Parliament for Scotland, vefting in the juftices a power of judging, fummarily, and without appeal, and according to the dictates of confeicnce alone, in all caufes founded upon nicre perfonal contract or obligation, where the clain does not exceed the value of $31.6 \mathrm{~s} .8 \mathrm{~d}$. Sterling. 
To confine judges to written laws, as the rule of their judgement, is the characteriftic feature of liberty; and the expence of fornal litigation, is the price that mut be paid for liberty. To allow them to judge, at difcretion, and without appeal, bears a ftrong refemblance to defpotifn. Wherc, however, fuch power is vefted in a clafs of men, in an independent fituation, and confined to caures in which they have no perfonal intereft, and of fuch fmall magnitude, as removes every fufpicion of improper influence, the fummary juitice of the Afiatic cadi, feems, in practice, infinitely preferable to the expence and delay ever found attcindant upon formal law litigation. The litility of this mode of adminiftering juftice, has been fo apparent, after experience, that many counties in Scotland exprefied their wifh to the Legiflature, through their reprefentatives, that the powers of the juftices hould be enlarged. Their powers have accordingly been extended, by a fubfequent amendment of the act, to caufes where the claim does not exceed 5l. Sterling in value *.

The divifion of counties into parifhes, rcfers, almoft cxclufively, to ecclefiaftical duties and jurifiliction.

Every parif in Scotland is provided with a minifter (clergyman); in fome initances with two.

The minifer is prefented to the office and its cmolumcits, in many infances, by the Crown; in the reft, by fome lay patron, all of whom are gencrally extenfive proprietors of land. The perfor prefented, mutt be one found qualified for the office by the Church: And the Church, jealous of its own refpcotability, has enforced, by a number of repeatal regulations, a wery long apprenticethin, in the way of liceary and theologi-

* Barny conists might have becn noticed as annther nole of the adminiftration n: junice, hut they a:e almon univcrfally fallen into defuetude, excepting in cafc of difputes aling at public markets or fairs, uhere the bailiff of the barony, within which the fair is held, leciles the differences that may arife letween neutral perfons at the markei. The decifions of a bailiff, dependent upon the proprictor of a batony, in caufes of litigation betwecn the bescon and his own tenant, muft certainly arfear is a vey fufpicious light to independent judges, befoze whom they might eome by appcit. A juriddiction of fuch a nature cught excry: where to be lairl allic. 
cal elucation. The candidate for the minifry, after a regular courfe of univerity cducation, muft regularly attend the theological lectures of a divinity profeffor, in fome one of the univerfities, for at lealt four fuccefive feafons ; during which attendance, he muft give repeated fpecimens of his talents for public fpeaking, in difcourfes, ptiblicly delivered, upon prefcribed fubjects. Before he can obtain a licenfe from the Church to be a public tencher, he muf alfo undergo examination before the Prefbytery to which he applies for fuch licenfe, and exhibit before them fpecimens of his talents for teaching, by difcourfes on a variety of preferibed fubjects. The purity of his moral charader muft likewife be fufficiently attefted by the clergy in whofe bounds he has refided during all the ftages of his progrefs, from the commencement of his theological ftudies. When he has received licenfe to preach from the Prefbytery, he is qualified to receive a prefentation to a parifh. But, before his admillion into a benefice by the Church, he mut again undergo fimilar trials and examination before the Prefbytery within whofe bounds the pariih to which he is prefented lies.

By the old Scotifh acts of Pariament, the Church are bound to receive into the office whatfoever queliffed ninifer fhall be prefented by the Crown or other lay patron. After the Revolution, by act 1690 , the right of prefenting to racant parifhes was taken from the patrons, and rifted in the heritors (or landed proprictors), the chlers (or veitry), and the heads of familics of the parifh; wlo prefentch, or, it the tcchnical phrafe, calied the minifter to the oflicc. This ad was, howcrer, repealed, and the right of prefentation again refted in the original patrons, by an act of Qucen Anne. This act of Quecn Anne was unpopular with the lower orders in Scotland, who fecm generally to favour the right of univerfal fuffrige in the elcction of minifters * the Church of Scotland, fö a while,

fcemed

* The great bulk of diffenters from the Church of Seotland, have left it, upos: account of the mode of election by a patron, innead of univerfal fuffage. Within thefe thirty years, an election of a cirfenting miniter took place in this county, 
feemed to efpoufe the caufe of the lower orders. In order to defeat the intention of the act, they fet up the pofition, that a call was ftill neceflary, as well as a prefentation; and that a prefentee (though ftamped current as a qlialified perfon by the Church, in obtaining licenfe from it) could not be confidered as qualifed for that particular parifh to which he had been prefented, unlefs he obtained alfo a general call from the parifhioners, who alone were the proper judges whether or not his particular caft of gifts fuited their particular capacity of edification. A call from the parifhioners was therefore adopted, as a neceffary requifite to admiflion into the office, after a prefentation, had been given. To prevent jugrgling tricks of patrons, by prefenting fuch unqualified perfons to parifhes as the Church would refufe to induct, in order that they may pocket the emoluments, there are laws enjoining patrons to prefent qualified perfons within fix montlis from the vacancy, under the penalty of incurring a forfeiture, for that vice, of the right of prefenting, which then devolves to the Pretbytery : And, in one inftance

upor

upon the broadef bafis of the muft tumultuary popular clection. It was on that occafion adopted 25 a maxim, that every one robo bat a farl to be faved, hußand and wife, man, woman and child, mafters who had a permanent refidence, and fervants who might change theirs at every term, had all an equal right to vote in the election; provided only they harl arrived to the capacity of julging; the teft of their having arrived to this, being hold to be tlicir participation of the facrament of the Lord's Supper, which generally takes fhce frum the age of 15 to 18 . What mode hath been adopted in later elections, I have had leis accefs to learn.

The diffenters profofs to adhere to the articles of the Eftablifhed Clumrch, but to differ in their interprctation from the eftablifhed clergy, who are tuppofed to have relaxed from the rignur of high Calvinitm, in forming conceptions of the Supreme Bing, more amiable, and lefs tremendous, than what are fuggefted by abfolute decrees of election and reprobation. Sume difference is alfo ftated as to the mode of enforcing the dutics of morality. To ding dureng gade acorks-to vilify their importance as to man's falvation, feems, among the diffenters, to be the proper mode of exalting and doing honour to the fuprenc cfficacy of the Redeemer's sighteoufnefs. To treat morality with fomewliat more refpect, is imputed as an error to the chablifhed clergy-it is called legal dochine.

- That patrons may not be tempted to keep parifhes vacant, there is alfo another linv, by which pations are obliged, at the fight of the heritors, to apply the 
upon record, the Church, under colour of this law, refufed induction to a prefentee whom the parifhioners refufed to call, upon pretence that, by this refufal, he was evinced to be a perfon unqualificd for that particular charge; and alio, upon the affumption that the right of prefentation had thus devolved to the Prefbytery, gare induction to another, whom the Prefbytery prefented upon a call from the pariflioners. Upon a competition for the emoluments of office, by thefe two candidates, our Supreme Civil Court found, that the patron's prefentee had no right, becaule he had not received clerical induction into the office; and that the other had as little title, as he was not prefented by the patron: That, of courfe, no forfeiture of the patron's right had occurred; that the parifh remained ttill racant; and that the rights of patrons could not be defeated, nor popular election fubltituted in their room, upon any fuch pretexts. The inhability of a lay prefentation alone, to confer a right to a church office and benefice, witliout clcrical induction, was indeed thus fuftained; but it was equally manifeft, that the refufal of clerical induction to a prefentee, who had bcen famped as qualified by the Church, could not infer a jus devolutum on the part of the patron, and could only prolong the vacancy of the parifh. For thefe reafons (and probably alfo from the apparent abfurdity of fuppofing that the quaiification of fufficient talcnts and literary acquifitions was not of univerfal application, but that every particular caft of head required an appropriate particularity of adaptation), the Church has, for a long period, ceafed to obtrude the necefirty of popular election; and, though the form of a call has not yet fallen into defuetude, and has indeed been declared by the Church to be a neceffary form, the people themfelves are convinced of its being only a form, and in general very properly refufe to appropriate to themfelves a mere fomblance of popular election, where the fubfance is awanting: The prefentee is therefore clerically inducted, unlefs tenible objections are ftated, after a citation

with

vacant fipends to pious ufes; that is, to fucis works of public utility, as are not otherwife provided for by law, 
with proper inducic to that effect (called, the ferving of lis edict); againt his doctrine or moral character *.

- Thofe who are fatisfied with the previous regulations of the Church, as a fuflicient fecurity againft the admifion of improper members, adhere to the Clurch; whilf fuch as inagine their own private choice neceffary to contitute the pafforal relation betwixt thenfelves and their clergyman, join the Diffenters + .

Probably three fourths, or more, of the candidates for benefices in the eftablifned Church, obtain their purpore through a long courfe of fervice, as tutors to children in families that have intereft with the Crown, or other patrons--another courfe of clerical training, that feems ftill further to enfure both literary acquifition and propriety of conduct. Accuftomed, however, to look up to the higher clafies for promotion, the manners of candidates for the eftablified Church, are rather formed to conciliate the favour of the more enlightened part of fociety; and are lefs adapted to the tafte of the lower crders, than the mainers of thofe who look down towards univerfal fuffrage. The diffenting clergy are probably more popular with the lower clafes; and may, there, have more influence. Indeed, there

* Though I lave deferibed the mode in which church fettlements are now carried on, it maft be obferved, that there has ever exifted an oppofition party in the Church (called the high-flyers, or wild party, hy their antagonifts, who defign thenifelves, the moderate party), who infitt on the neceffity of a call. It is believ$\mathrm{cd}$, none of them w'ould wim to entablifh the univerfal right of fiffrage in all who bave fouls to be faved. The party feems, howcrer, divided in opinion; fome withing to extend the right of fuffrage to every male the head of a family; others, to refrict it to heritors and elders : others, merely to heritors, either eftimated per capiis, or in proportion to their valuation in the cefs-books. The Church, periaps nut crer wifely, has fet hor own forms in oppofition to her practice, by a declaritory luw, paffid not twenty years fince, in which the call is declared a neceffary form.

$\uparrow$ 'The rclation betwixt a chergman and his congregation, is compared, fometimes, to marriage; to the completion of witich, mutual confent of paries is nerefiry: And other conclufions are alfo drawn from this fimile, as a ground of icsuring-as, that tranlaticn to a Lettor bencfice, is friritual aduitery, \&c. 
is a fource of error, arifing from mere polition; and he that is foremoft, may fometimes be conceived to lead, when, in fact, he is only driven - as the rife or fall of mercury in the barometer is the indication of the ftate of the weather, but not its caufe.

The mediocrity of the livings in the Scotifh Church, has been confidered as favourable to the refpectability of the clerical character; confining their attempts at diftinction to the roads of literary eminence, or exemplary morals, and attention to their profeffional duties; and precluding every hope of its attainment through the oftentatious difplay of riches in expence: The equality, however, of church livings, and the next to total abfence of every chance of promotion, prefent a want of fimuhus to great exertion.

The loweft Ecclefiaftical Court, is that of the Kirk-Seflon, a court fomewhat fimilar to that of the Englifh Veftry, and which hath only a parochial jurifdiction. It is compofed of the minifter of the parifh (who is the perpetual moderator, or prefident), and an indefinite number of elders, two of whom, with the minifter, are neceffary to form a quorum*. As an Ecclefraftical Court, the Kirk-feffion exercifes a fort of cenforial power over the inhabitants of the parifh, inflicting upon delinquents the penalties of exclufion from the facraments, or the penance of public rebuke from the pulpit, before the congregation, on Sabbaths: This power, which, from its nature, is difcretionary, would feem, in former times, to have been exercifed often in a manner very inquifitorial, haraffing, and vexatious; particularly before Ecclefiaftical cenfures were deprived of all ciril peral effect: it is now exercifed with more difcre$\mathrm{Nn}$ tion:

* The elders are chofen from the lauded proprietors, or other refpe?table inhabitants of the parifi: The exifling Kirk-fefion choofe the clders, who are formally inftalled into the office by the minifter, if no objettion appears againft their moral or religious charakters, after proper citation, upen ten days indiciz, to thet effect. It is fumetimes difficult to get proper petfons to confent to become elikess. from the idea, that the charater impoics an obligation to a conduet peculiariy exempláry. 
tion; and, in moft great towns, it is not exercifed at all.: Its exercife, in country parifhes, is chicfly confmed to fornication ; their adminitration of the poor's funds making Kirk-fefions chiefly anxious in inveftigating an irregularity which may affect the furds, in bringing the maintenance of baftards upon the parifh *. In all Ecclefiafical caufes, an appeal lies from the Kirk-fefrion to the Court of Prefbytery.

Befides their Ecclefiaftical jurifliction, Kirk-fefrons are the ordinary adminiftrators of the poor's funds of the parifh; which they adminifter without any expence whatever, or any farther fee or reward, but the confcious fatisfaction, and general credit that may accrue from adminiftering well. Their adminiftration is fubject to the controul of the heritors (landed proprietors of the parin), who may, when they pleafe, infpect the accounts; and who ought to be voluntarily confulted by the Kirk-feffion, in all important tranfactions of uplifting or lending out fuch poor's money as is at intereft. Where poor's rates are eftablifhed (which feldom took place, excepting during the laft two years of dearth and fcarcity), the heritors, upon previous citation from the pulpit, meet once a quarter, or half year, with the Kirk-feffion; when (a lift of the poor being made out, and weekly or monthly penfions being allotted to

eacli)

* Clurch courts cannot, by their fentences, affen the civil rights or property of any perfon: Their power extends only to what may be called the fpiritual correction of vice, by exclufion from the facraments, till public penance is performed, or other fatisfying marks of penitence exhibited. A woman's accufation of a man, as having been guilty of fornication with her, is not liftened to, unlefs a child is produced, as a corpus delidi, fubfantiating the exilfence of the crime, and thus far giving credibility to the accufation. If, thex, the woman can prove no prefumptive circumfances, the man can repel the accufation by his oath-if She proves any fuch, his nath is not admitted. The civil law follows the fame rule, as to decerning the aliment of the child, which the Church does as to fixing the fcandal: of courfe, the prefumptive proof taken by the Church court, is often, though not neceffarily, fuftained by the Civil court. (See page 237. of the Report.) 
each *) the Kirk-feffion account for the one hillf of the money arifing, fince laft meeting, from collections at the church doors on Sabbaths, and from the poor's perquifites paid in at funerals and marriages; which fum, together with the intereft of lent money, being compared with the penfions alligned, the deficiency is made up by a parochial affeliment, the one half payable by the proprietors of the land, the other half by the farmers who occupy it: the remaining half of the money, arifing from collections and perquifites, is left under the adminiftration of the Kirk-feflion, to provide for accidental unforefeen cafes of diftrefs.

The Ecclefiaftical court immediately fuperior to Kirk-feffions, is that of the Pretbytery. This court comprelends, under its jurifdiction, a greater or leffer number of parifnes, feldom under twelve; and is compofed of all the minifters of the parifhes under its jurifdiction; each Kirk-feffion in the diftrict having a right to fend alfo one lay elder to reprefent then, who is elected every half year. In this court, all proceffes againft minifters muft originate. Its Ecclefiaftical decifions are fubject to the review of the Court of Synod.

Befides its jurifdiction in matters purely Ecclefiaftical, as to the doctrine and difcipline of the Church, this court hath vefted in it a feparate jurifdiction, in matters of a partly civil nature, in which its judgements are not fubject to the revicw of any court but the Supreme Civi! Court. Imo, Where a minifter is not provided of a glebe, or where it is dencient in quantity, they can fet off, for that purpofe, from the church lands within his parifh, to the extent of four and an half Scots acres of arable land (including the fpace occupied by the fite of his manfe, or dwelling houfe, and garden), as an arable glebe; together with as much pafture land as may fuffice (according to report of valuators) for the pafture of two cows and one horfe. They can alfo compel the heritors to buifd, or keep in repair,

the

* Sunetimes no penfions are fixed, from the dread of himplueffing indufty, $1 ; y$

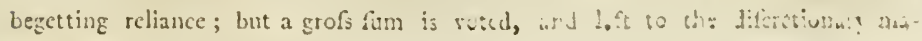
dagerapnt of th. Kitk-efiton. 
the parifh church, and the minifter's manfe and offices. $2 d s$, With concurrence of the county commifioners of fupply, they may compel the heritors of every parith to make provifion of a legal falary for a fchoolmafter *; and alfo to build an houfe for the fchoolmalter's refidence, and a fchool for teaching in. The heritors are the electors of the fchoolmafter; but his election is not valid till he is found qualified for the office, after examination, by the Prefbytery; and the Prelbytery have it at all times in their power to difmirs him, either for incapacity or immorality ; their fentences as to his qualifications being fubject to review of the fuperior Ecclefiaftical courts alone. The Prefbytery has generally five or fix ftated meetings yearly, or more, upon citation from their moderator, (chofen half yearly from the clerical members), when unforefeen bufinefs occurs. The meeting is held at the county town within the jurifdiction.

The provincial Synods are the courts next in fuperiority to Prefbyteries, holding meetings twice a year, in November and in May. Thefe comprehend a greater or leffer number of Prefbyteries; and all the component members of the Prefbyteries under their jurifdiction, are conftituent members of the Synod.

An

* The maximum legal falary cannot excced IIl. 2 s. $2 \frac{8}{32} d$. ; the minimum is 51. IIs. $1 \frac{4}{1}$ d. ; the one half is fayable by the proprietors, the other by the occupiers of the land. The fchoolmanter is almoft always conftituted precentor (the perfon who leads the finging of pfalms in church), and cleprk to the Kirk-fefion. The wrges of teaching are very low; from is to Is. 6d. per qunarter for rẹading Englifh, and not exceeling from 2 s. 6 d. to 3 s. for reading, writing, and arithmetic; the feholars, too, paying only for the precife time of attendance. The whole cmolument of the Scots parochial fchoolmafters will not, probably, at an average, cxceed twenty guincas ycarly-a rccompence, by much too fmall, for their very ufeful and noof laborinus occupation. Schools are zenerally fipplied from among young men profecuting thcir studies with a vitw to the cletical office; and, if zinere were no cliurch bersefices in profpe $\varepsilon_{\text {, }}$ there could be no well qualified fchoo:mafters in fact, as no perfon, any way decontly qualificd for tile ctfice, could ever contcut limelf with a country tchool as his u'tirations. 
An appeal lies from the Synods to the Supreme Court of the General Affembly of the Church of Scotland *

The General Affembly is the Court of laft refort. The IKing is there reprefented by his Commiffioner. It meets once a year, for ten days in the month of May, at Edinburgh. It is compofed of reprefentatives from all the Prebyteries of Scotland, each fending two clergymen at leaft, or more, in proportion as the clergy conftituting the Prefbytery thall exceed twelve in number: One lay elder is alfo fent from each Prefbytery, and one from every Royal burgh and univerfity. With the exception of the erection of new parifhes, or of afliftant charges in the fame parifh, or overtures (propofals) of new laws, every caufe Ecclefiaftical nuft originate in the inferior courts of Kirk-feftion or Prefbytery, and can only come before this zourt by appeal. The power of legiffation does not reft entirely with this court, though it here pofieffes pretty extenfive powers of controul: The power of enacting ftanding laws, is, by the conftitution, vefted in the courts of Prefbytery, to which all overtures of new laws muft be remitted for their deliberation, and without the concurrence of the majority of which they cannot be enacted. Like the Lords of the Articles, however, in the Scotin Parliament, the General Affembly can refufe to tranfimit any overture for deliberution; and can ercn refufe to enact, after a return of approbation from a majority of Prefbyteries. By fuch arrangenents has the Church endearoured to

aroid

* In regard to the power of appeal from inferior to fuperior church jucicatom ries, there is a fingularity in the conftitution of the Scotih church, to which Da parallel is perhaps to be found in any conftitution, antient or modern. Fiven al? though nope of the parties ințerefted hould feel aggrieved by the fentence pronounced, or appeal from it, it is, neverthelefs, comptent for any member of the cout which has pronounced the fentence, to bring it under tevicw of the Supcics. Court, upon his announcing his difent, and protefting for liberty to complain, if he Shall conceive either that the fentence is contradictory to matesial julitec, or fubverfive of any principle of the conftitution: The Superior Court will receire an appeal from fuch appellant, and to the cffect cither of fimply cenfuring the coure which pronounced the fiatence, of of toially reverfing the fuatence, as they hit $\therefore$ s.uৎf. 
avoid the inconveniences objected by Anacharfis to Solon's republican model of Athens, of the wife only deliberating, while fools decide. Under her cumbrous Dutch built form of republican conftitution, the church is moft unwieldy in her motions, particularly in enacting laws. The neceflity, therefore, has been apparent, of invefting the General Aflembly with the indifpenfable power of enacting overtures into interim laws, to be of force from Affembly to Affembly, till the general fenfe of the Church can be obtained; and, which is pretty fingular, fome of the moft important laws of the Church, in regard to the qualifications of clergymen, and in regard to difcipline (which laft goes to the important effect, as to the clergy, of deprivation of office, benefice, and the clerical character), ftand upon no other authority, than this interim provifory power of the General Affembly : They have, however, been fo long acquiefced in, that they lave paffed into laws of confuetude, without neceflity of frefh enactment every Affembly, according to the ftated mode of the exercife of this provifory power.

The Scots clergyman is bound to refidence; and his charge can be declared vacant, upon fix weeks abfence, without leave to that effect, obtained from his Prefbytery: He can hold only one benefice. A degree of exception, is, however, very properly admitted, as an excitement to literary effort, in regard to holding Profeformips in Univerfities; when thefe are removed at fuch fmall dilance as not to obftruct, in any great degree, the performance of parochiil duties. The ftated parochial duty of the clergy, are thofe of public prayer, and preaching every Sabfath: The prayers are never read, and fermons very feldoma cuftom which, no doubt, adnits of more animation in the fervice; fubjecting it, however, to crery variety in performance, according to the various abilitics, or accidental ftate of fpirits in the adminiftrator: The cuftomary difcourfes, are two every Sabbath, and often three in Summer. The minilter alfo adwiniflers the facraments of Baptifm (taking the father fponfor in preference to any other), and of the Lord's Supper; the latfir, at leatt, once yearly, and feldom more oftcn: He generally $\therefore$ crifies, ton, through his whole parin, once a year; and, 
next year, formally vifits, giving exhortations, both on week days: He, befides, occafionally vifits the fick; and, among the poorer claffes, generally acts, in fome meafure, in the capacities of lawyer and phyfician, as well as of divine. Marriage is valid, in Scotland, as to all civil effects, without the adhibition of Ecclefiaftical ceremonies, or the publication of banns in the church.

I thall conclude this note, by juft obferving, that the dirifion into parifhes refers alfo to the ftature labour, affeffed parochially: This fimple noode of making and upholding roads, feems the firft that has been devifed by almot crery nation, before adopting the much more preferable one of a toll, levied from the pafienger. As compelled labour turns, however, to very little account, this fervice, as well as moft other perfona fervices, has been almoft univerfally, through Scotland, commuted into money payment, at a very moderate compofition.

\section{NOTE $B$.}

As the Scots law preferves a ftrict analogy to the feudal fyftem, it may be proper, fhortly, to fate the lcading features of that fyftem; that the nature of Scots tenures of land may be rendered more generally intelligible.

Before the complete eftablifiment of the feudal fytem, the lands would feem to have been divided, in large portions, among great families, the heads of which poffefied all the rights of independent fovereignty within their own territory; iiving in a ftate of conftant hofility with one another, and incapable of union, excepting a tranfient one, under the mof refpected military leader, when national attack required fuch coalefcence, for the purpofes of national defence.

In fuch circumftances, public utility muft have foon pointed out the necenity of a permanent union of the whole ftates under one fupreme power, to which all the reft fhould be fubordinate; and that, not only for the purpofes of national defence, but for the prefervation of internal tranquility, by the fuppreftion 
of the right of private war or feuds. Such views led to the eftablifhment of the Regal power in one family, under which the other powers were united, upon terms of union more or lefs ftrict or loofe; the public advantage, as well as the private ambition of the Mionarch, both leading to the gradual extenfion of this fupreme power, that the whole force of the ftate might be thus concentrated, fo as to act with energy, either againft foreign encmies, or for the domeftic protection of its own members.

In following out thefe views, the great landed proprietors, originally independent, were all, in various ways, reduced to a military dependence upon the Crown as their fuperior; holding thence their lands upon condition of the military fervice of themfelves and their retainers, and of their perfonal attendance in the Court of the Monarch, for the purpoles of granting narional fupplies, and of enforcing the due execution of the laws * the only conftitution conformable to the manners of the times, which could give unity and confiftence to a State.

There great barons, the immediate vaffals of the Crown, afligned, by a fubinfeudation fimilar to their own mode of tenure, portions of their lands to their military retainers, as fees granted them, upon condition of their perfonal military fervice at the call of their immediate fuperior, and of homage and attendance in the baron's courts.

In thofe times of turbulence, when no fecurity could be enjoyed, but under the protection of a military head, upon coniition of military fervice, allodial, or independent property in band, could not long remain an eligible mode of tenure: And, accordingly, it may be readily prefumed, that proprietors of this defcription would find it neceffary to renounce fuch a tenure (howevér eligible it might appear in our times), by refigning their lands either to the Crown, or to fome powerful baron is fuperior, to be held thenceforward from fuch fuperior, upon the recinrocal conditions of protection on the one hand, and military fervice upon the other.

In

* IIence the origin of the Houfe of Pecrs, and thcir right of attendance fer apita, and not by seprcientation. 
In this manner, the whole ftate came, in procefs of time, to be entirely united into one mass, by a regularly connected chain of military dependence and fubordination.

At the original formation of Monarchy, it is extremely probable, that many of the great barons were in a ftate of power to enable them to make terms with the monarch, in fubjecting themfelves to him in military fubordination; and that, though, upon the perfect eftablifhment of the feudal nilitary fubordination, the tenure of their lands affumed the appearance of fiefs, or fees, for military fervice, yet their lands were never held during the mere good pleafure of the Monarch, but were, from the firt, confidered as held upon hereditary right. In regard, however, to fubordinate fees, or fiefs of land, they would feem at firft to have been held only during the good pleafure of the fuperior. But as the military chief would feldom eject his companion in war, unlefs for failure of fervice due; and would, in general, be inclined, upon the death of his vaffal, to continue his heir in the poffeffion, if fit for military fervice; or even, during the heir's minority, to accept of a fubftitute till he came of age; it would feem natural, for thefe reafons, that, in ufe and practice, fiefs thould gradually come to be confidered, firit, as poffeffions for life, and at length as hereditary; a fine, it would appear, being accepted of by the fuperior, to induce him to accept of the heir for his valfal *. Such would feem to have been the gradual extenfion of the right of property in their lands, which military vafials progreflively acquired. This extenfion of their right would fecm to have been confined to the poffeftors of fiefs of confiderable extent, enabling their owners to bring feveral retainers into the field, and themfelves to maintain fuch a rank, as put then upon a companionable footing with their fuperior. It is probable, no fuch privilege was generally granted to the poffeffors of land fees of fuch fmall extent, as compelled the por-

$$
\text { O o }
$$

feftor

* This prefert, ameunling Eenerally to double the feu-cluty, is fill retained ass a feudal cafualty, due to the fuperior upon the aceerson of an leeir. 
feffor to be the immediate cultivator of the foil, and to appear fingly in the ranks as a foldier, without any retainers under his command. Forming our judgement from inference, in a matter where few facts are upon record, we can hardly conceive how the abfurd ideas (pervading the Scotifh law, and the mode of thinking among Scotin proprietors of land), in regard to the importance of the proprietor's right of a delectus perfone, as to the leafe-lolder cultivating his ground, could have originated; excepting upon the fuppofition, that thefe more inconfiderable feofees, lant mentioned, never acquired permanent property in their lands, but werc, gradually through change of manners, moulded into mere farmers; a clafs valued by the landed proprietor, merely as conducive to his profit; and to whofe conftitution, military feudal notions have no applicable reference, but that which may have continued afrociated, in confideration of fuch an original.

As monarchy rofe in ftrength upon the ruins of ariftocracy; and a regular difciplined military force, fupported by taration, began to be fubntituted to the unmanageable mobbih miJitary fervice, for external defence, and internal police; the Crown, or Great Barons, as fuperiors, would find themfelves nothing the poorer, in difpenfing with this military fervice, for which there was no farther occafion, and were eafily induced to accept of an yearly ftu, or quit-rent, in place of it. In regard to the Crown, this commutation money of the military fervice was probabiy the earlieft form of a general land $\operatorname{tax} *$

During

- This yearly feu-duty continues as one of the feudal rights of fipcriors over the lands that hold of them. In progrefs of the right of alienation: acquired by vaffals, though this few-cluty muft ftill in form be retained, in orsler that the right may be dily confituted, in conformity with the feula! ideas of Scotih law; jet : he fer-duty came to he reducil to a mere nominal paymout, or quit-rent; and such lioldings obtaified the nanie of bincls-lioldings. When the fuperior, probably for a valuable confirieration, thus clice to emancipate his vafial, hy giving him a Hench-holding, the wit, or fyortivity of the times, was fometimes difplayerl in the xrminal rreflation retained; fuch as, the obtigation unon the vaftul, to gite fo many blafts of a horn when his fuperior hould pars his maror, to dance befere likn, to chtertain him vith a haceies, \&c. \&c. 
Ouring the aftual continuance of perfonal military fervice, a delectus perfone, or right of choice in regard to the perfon who was to be his military vaffal, was a matter of the utmoft importance to the fuperior, as a military chief. In fuch circumftances, it would have been obvionfly abfurd, that the vaftal fhould have had a right vefted in him, of fubftituting another perfon to ferve in his ftead, by the voluntary alienation of his fee; or even that the land thus given him by his fuperior, in mere ufe, and as a retaining fee for his perfonal fervice, fhould be confidered capable of being evicted, as a property, by the creditors of the vaffal. But, upon the abolition of perional military fervice, fuperiors could feel but little intereft in this matter; and, accordingly, the power of alienation was gradually affumed by the vaffal, through toleration of the fuperior. As this, however, was no doubt confidered as an higher degree of indulgence from the fuperior, than his allowance of the tranfmifion of the fief by hereditary defcent to the vaffal's heir (who feemed to have a fort of natural claim to continuance of poffeffion), it is probable this right of alienation was longer in becoming a matter of common ufage; an higher fine, too, would ever be exacted by the fuperior, to procure his confent to the acceptance of a ftranger, than what he required as a conlideration for continuing the poffefion to the natural heir *.

Whillt land was poffeffed by the vaffal, merely as a fee or benefice for perfonal nilitary fervice; till once the minor was fit for fuch fervice, the fuperior had a delecius perjonce in the fubititute to ferve for him; and the benefice, meanwhile, reverted to the fuperior, till the minor thould attain to majority, burdened only with the minor's aliment. As it was of the utmoft importance to the fuperior, that his vaffal, particularly if a female, fhould not form dangerous connexion with his enemies by marriage, the delichis perfon was therefore infer-

red

* This fine, won the alnumition of a Aranger, or fingular fucceffor, is Aill retained among the fendial cafualices due to the fuperior: One year's rent of the Libject is fonctimes cxated; but, in gencral, tipeliprs compoand for lets. 
red to convey a right of interference in this matter; and the fuperior's confent was held neceffary to the validity of his vaffal's marriage. Thefe rights over the eftates of minors, and in regard to the vaffal's marriage, conftituted the fuperior's right of alardfipip. So long as the delectus perfona continued to be founded in the reafon of the thing, thefe rights of wardfhip were cheerfully acquiefced in ; but when, upon a change of manners, and of the ftate of fociety, the fuperior ceafed to have any other than a mere pecuniary intereft in his vaffals, they came to be confidered as the fource of great oppreffion. The tutory of minors eftates came, then, to be conferred by the Crown, or other fuperior, to needy dependants, as a mears of repairing a ruined fortune; and the havock committed on eftates under tutory, feems repeatedly to have called for the interference of the Scotifh Legiflature, in acts, to prevent the commiftion of fuch abufes. The female ward would alfo frequently be expofed to grievance, in being difpofed of in marriage by the fuperior to the higheft bidder, without confulting her own choice. As the oppreflion of wardfhip came to be more and more felt, it is probable the fuperior's right would come in ufe to be compounded for in money payment; the Legiflature alfo, more and more, interfering to regulate its exercife. The final abolition of the hardfhips of ward are, in Scotland, of fo late a date, as the act of Parliament 1748.

In this manner, the right of fuperiority gradually arofe, from the circumftances of fociety, and extenfion of analogy; and, in like manner, was it gradually circumfcribed, in confequence of a change of circumftances: Till, at length, the right of the vaffal, from being held merely at pleafure, and from being ftrictly perfonal and beneficiary, came to be per. petual, patrimonial, and hereditary, every way alienable and tranfmiftible; or, in flort, entire property, fubject merely to annual feu-duty, and the other feudal cafualties.

During the actual exiftence of the feudal ftate, the fuperior alone figured in the inagination as the proprietor of the lands. 
lands *. When, however, the vaffal had obtained an hereditary right to his lands, with unreftricted powers of alienation, fubject merely to the feu-duty and other cafualties incidentally due to the fuperior; be was, to all intents and purpofes of human life, the proprietor. And the queftion came to be, "In what light the originally more important right of the fuperior fell to be viewed?" The fonorous law diftinction was invented, of dominium directum, to denote the right of the fuperior; and of dominium utile, to denote the right of the vafaltechnic defignations, which never were adopted, or have fallen into difufe, in common language; in which the right of the fuperior is called fuperiority, and that of the vaffal properity. From the impreffion of ancient ufage, the right of fuperiority has been confidered, in the eye of Scotifh law, as the more noble of the two; and, accordingly, fuperior advantages have been beftowed upon it, both as to fecurity of poficfion, and as to eafe and preference of recovery.

Amidit the ftruggles of monarchy againft feudal tyranny (the final fuccefs of which has proved the epoch of emancipation, and of the extenfion of the protection of law to the lower orders), Royal burghs (which had been gradually withdrawn by the communication of privileges from the Crown, from their dependence upon the great barons) were called upon to fend reprefentatives to the King's Court of Parliament, in order to balance the power of the Nobles, formidable to the Crown and to the internal peace of the country, and to nothing elfe. For the fame reafon, the leffer barons, holding of of the Crown as fuperior $t$, who had been excufed the fervice of perfonal attendance in the King's Court, from their inability

* Till within thefe two centuries, the vaffal is not defigned propriotor in the Scotifh acts of Parliament, but retains the defignation of tenant.

t Compofer, probably, of thofe to whom the King had feued out portions of his own perfonal domain, or of the domains of fuch nobles as had forfeited them to him by their rebellion; and perhaps, too, of fuch originally allodial proprietors as had, in their choice of a military protector, refigned their lank's in vaffalage to itie Crown, in jreference to any other military chisf. 
to bear the expence, were alfo fummoned to appear by ieprefentation; and, by ufe or ftatute, the poffeffion of lands holding of the Crown, valued in the county cefs-books at 400 . Scots, or valued at 405 . of old extent, was, and is the qualification fubjecting to the birdan (according to former notions), or entitling to the privilege (according to modern views) of reprefenting, or being reprefented.

The Crown could call upon its own vaffals to balance the power of the Nobles; it could expect no fuch fupport from the vafials of the Nobles themfelves: And, accordingly, landed proprietors, holding their lands in vafialage from fubjects as their fuperiors, were not called upon to exercife, and have not obtained any right of reprefentation. In refpect of this right of reprefentation, all lands holding immediately of the Crown as fuperior, are defigned freeblds.

In the progrefs of arts and manufactures, new modes of expence were opened up; and the funds in the hands of the great barons, formerly employed in fupporting that magnificence, which confifted in the number of military attendants, vere diverted to the purchafe of the productions of the fine arts; the fame vanity, formerly difplayed in a numerous retinue of armed followers, often leading its poffeflor to barter power for perfonal decoration, and to part with the command over men (to ufe Dr Smith's illuftration) in order to become proprictor of a pai: ot diamond buckles. 'The great barons were laid under new temptations of contracing debts, and of relieving themfelves, by felling portions of their landed property. In all feudal ftates, advantage was taken of thefe propenlities in the nobles to weaken their own power. 'The Crown ufed all its infuence in encouraging the alienation of the eftates of the nobles: And, in order that every alienation fhould furnith the Crown with a new frecholder or leffer baron, regulations were, in various countries, enacted as to the mode of inveftiture of thefe new purchafing proprietors; by which the pratice of cubmitedation, of the buyer in vaffaligge to the feller, as his, fopcrior, was prohibited; and the land fold sas mate to hold, by confocuence, immediately of 
the Crown as fuperior. Unfortunatsly, our Scotifh monarchs either overlooked the propriety of fuch regulations, or poffefled not fuficient influence to enforce their adoption: Accordingly, there is no law in Scotland preventing the disjunction of fuperiority from property. A whole property may thus be fold, whith the feller, by fubinfeudation, makes the buyer hold of himfelf; the feller, menuwhile, continuing vafial to the Crown for the lands fold. And, as this retained right of freehold from the Crown may be divided and dif. pored of, in as many portions as the valuation of the lands can afford of freehold qualifications, hence it comes, in Scotland, that mere fuperiority is fometimes alone reprefented, whilt real property enjoys no right of reprefentation.

Whe right of franchife is thus confined, in Scotland, to the great Barons or Nobles, appearing in the Scotin Parliament per capita, but, fince the Union, by fixteen reprefentatires in the Houfe of Pecrs; to the Landed Electors, often merely fuperiors, but not proprietors, who fend reprefentatives from the counties to the Houfe of Commons; and to Royal burghs, who fend reprefentatives to the fame houfe.

The Scotith law has hardly as yet been brought to recognize any other mode of holding land in perpetuity, but the feudal tenure: A mode of holding which is very expenfive, and which comes to be very opprefive in the cafe of fmall landed propertics, particularly where thefe have been purchafed for the purpore of ereating upon them expenfive buildings; as crery heir by fucceftion, and every purchafer by fale, in order to complete their titles, fo as to have the full command of thcir fubject, mun not only pay the feudal cafualties die to the fuperior from the heir or lingular fuccefor, but muft alfo be expofed to the expence of precepts of clare conflat, charters from the fuperior, and infeofment upon the charters; deeds executed upon papers or parclments paying hich thamp duties, and accompanied with formalitics of expenfive execution. Thefe decds are equally expenfive, whether the rubject be worth 20s. or 20,000l. of year?y value; and though Gow 
vernment, in the ftamp duties upon receipts, promiffory notes, and legacies, have properly apportioned the price of ftamp to the value of the tranfaction, no difcrimination of the difference in value of the fubject is made as to the famps for deeds arcertaining the titles to perpetual landed property*. In the village of Linton, where the inhabitants hold each his fmall poffefion in perpetual property, by all the cumbrous and expenfive formalities of feudal tenure (like fo many fifhing cobles moored by the anchors and cables of firt rate men of war), I have known a cot-houfe, with its kale-yard, both not worth 20s. of yearly rent, colt three times the value of the fee-frmple of the fubject, in expence of conveyance, and of making up of feudal titles, in the fpace of eighteen years; a tax upon the commerce of fmall properies in land, almoft equally opprefive as the Spanih tax of Alcavalla upon other merchandife. In cares where manufacturing villages have been erected upon ground purchafed in perpetual property, the feudal cafualties of the fuperior come fometimes to be peculiarly grievous; when, after the alienation of expenfive buildings, to the erection of which the fuperior contributed no thare, upon ground originally worth nothing, the purchafer (who probably was aware of no fuch fleeping claim) is called upon, as a fingular fucceftor, to compound with the fuperior of the ground, by a whole year's rent of his fubject. A cale of this kind was, within my own recollection, warmly litigated betwixt the fuperior and the inhabitants of the manufacturing village of Airdry, in Lanarkfhire. But, though it feemed gencrally wined, that an exemption, from the burden of feudal cafualties, conld have been admitted, in a cafe bearing no fort of analogy, even in original purpofe, to feudal practice; yet, our Supreme Court found itfelf obliged, in itrict conformity to the principles of Scotih law, to decide in favour of the claims of the fuperior.

The

- There is the fame want of diftinction proportioned to value, as to the ftamps for writien leafes. 
The fuall territories, lying within the jurifdiction of Royal burghs, are the only perpetual properties enancipated from the burdeniome formalities of feudal holding.

It were to be wifhed that fimple and unexpenfive modes of holding landed property in perpetuity, fimilar to burgage holding, were rendered more general for properties of fmall value. It might, at fame time, be very inexpedient to abrogate encirely feudal forms, however foreign to prefent circumftances, commuting the feudal cafualties upon a fair valuation, as in the cafe of tithes. In regard to properties of fuch magnitude as to afford the expence, thefe forms may be confidered as of confiderable utility; inafmuch as they are appropriated forms, to which long ufage has given a fteady and a determinate fignification-a circumftance of more importance than many feem to be aware of *

The tack or leafe, renewable at the termination of certain periods, upon paying a fma!l or mere nominal fpecified fine to the proprietor as fuperior, is the fimple linexpenfive mode of holding, which the late Lord Gardenftone has devifed for

- To allege, that a change in the forms of conveyance would prore rlinous to that refpecable clafs, who, it is faid, live as a tas upon properiy, by blotting paper in the multiplied forms of conveyancing, is very abfurd. Were we to fupfrofe the modes of holding and conreyancing reduced to the utmoft conceirable fimplicity, yet, if they were only formed of a nature fufiziently plisble to be ealily accommodated to that enclefs diverfification of rights, in a!l thcir fupporeable varieties of original conflitution, tranfmifion, and fuhtranfmifiou, for which a demand might arife in a bufy and incuftrinus ftate of fociety; a receffity woull then be created for the feparate profeftion of the conveyancer. The arrangement and cluffication of thefe rights, in all their actual and fuppofiable varieties, mult conftitute a diftinct feience; requiring, as other feiences, a clear theoretic head, to form fuch gcneral rules of practice as fhould prevent all entanglemelit and confufion. - If the expence of conveyancing were more moderate, there would be more frequent demand for the employment of the convesancer: The prefent high expence of conveyancing brings it under the rule of Dean Swift's zintlimetic of taxation, where two and two produce, not four, but one. The isme may be fiaid of ftumps, where no proportion is held to the value of the funject. The parties will often rather trult to the fecurity of mutual gocd faith, than incur the expence of a legally corfitituted fecurity. 
the feuars in his village of Laurencekirk. It is with diffculty, however, that the Scotih law (bigotted as it is to the antiquated urages of feudalifm, notwithftanding the abfurdity of forcing them into coalefcence with modern manners, to which they bear no fort of analogy) has admitted the tack as a mode of holding land in perpetuity. In Scotinh law, it is confidered as indifpenfable to the nature of a tack, that it hall have an $i h$, or term of expiry; and the want of an ifl is, in legal conftruction, an irritancy of the tack: It is alfo confructed into an irritancy, if the yearly rent, fpecified in the tack, is merely nominal and illufory, and is not fomewhat adequate to the value of the fubject. It was in order to propitiate the prejudices of old mother ancient, the Scotifh Luaw, that Lord Gardenftone devifed his tack for his villagers,-in reality a perpetual right, thougin under the femblance of an expiring one. And it is to be hoped, that our Judges, in the exercife of their nobile officium of interpreting law according to equity*, will endeavour to mollify the manners of the venerable matron, and lead her to recognize and extend her protection to this new fpecies of right; conftituted, in fact, after

* The political axiom, of the neceffity of feparating the Legifatire from the $\mathcal{J}_{4 \text { a }}$ dicial pazvers, though $\mathrm{juf}$ in general, muf yet be underftood with many grains of allowance. In the unceafing changes which the fate of fociety undergoes, laws, highly reafonable at one period, come to be inapplicable in a fubfequent one; and would be productive of much inconvenience, if literally enforced, and not equitably interpreted. But no Legiflature can, with becoming fteadinets, interfere to make new laws upon every partial feeling of grievance; nor until the old are found, uncquivocally, to be univerfally orpreflive: The equitable interpretation of the Judge is the only remedy fivited to particular cafes. Such power of difpenfing with law, would he dangerous in the hands of a fingle Judge. In England, all fear of danger is remored, by the intervention of the Jury, in civit caufes. The Supreme Cuurt of Scotland, as formerly obferved, conftitutes the Grand Jury of the nation in civil caufes; they have ever aftumed a nobile officium, in interpreting law according to equity; nor has this power ever been exerted, hut for the manifeft advantage of the fubject. Almon the whole fecurity enjoyed by the Scotifh .cuitivator of the foil, has been gradually extended to hin by liberal ftretches of our Jndges, in their equitable interpretation of law; which, is its letter, is not very favourable to his fecurity. 
after a faflion to which the has not been accuftomed; but, in the outward form of which, fuch feemly deference has been paid to her habits, by the fictio juris, or the quafi.

Some attempts have been made of forcing her to recognize the tack as a right of perpetuity, in its native undifguifed fhape, and without attempting to introduce it under cover of the wed-. ding garment of feudality. A tack for ever was fuftained (Wight againft Hopeton) in $\Sigma_{7} \sigma_{3}$. The fentence was not, however, decifive of the general principle; but proceeded merely upon the fpecialty of the challenger being debarred from the action by a perfonal objection againft bis title to challenge*. In 1760 , a tack for 1260 years was fuftained, upon general principles, by the Court of Seffion. An oppofite fentence upon a fimilar caufe, had, however, previoufly been reverfed by the Houfe of Peers in 1758 . In the uncertainty of, all human affairs, a poffeflion for 1260 years may be well reckoned equivalent to a perpetuity; and, where manufactories are to be ereeted, and the ground to be improved to its utmoft pofible extent, by the acceffion of valuable buildings, it would certainly be expedient to take advantage, either of this, or the formerly mentioned

fpecies

* From the number of judges in the Scots fupreme ciril court acting as a jury, the fame fteady tenor of uniformity of principle in their decifions, is not to be expected, as in the Englifh courts, where a fingle judge prefides and directs the decifion of juries, by his reports upon the cafe. A fugle perfon, of abilities, naturally forms a confiftent theory; and the practice confonant to it may be eftablithed into uniform precedent, from the facility with which juries will ever allow themfelves to be dirested by a judge of eftablimed integrity, and of acknowledged intellectual afcendancy. In this way, the fyftem of infurance laws has arifen, from the decitions of Lord Mansfield. Indeed, in fuch circumftances, a judge is not thy of bringing forward his general views, and, without hedging himfelf behind fpecialties, is ready, like Lord Kenyon, to lay down his general principle of decifion in each particular eafe. In a jury of judges, where no afeendancy of this $123-$ ture is acknowledged, there may be rivalry of fyntem, and a hynefs of entering into fyftematic contentions. This may be one reafon why our courts are reckoned more ready to fond their decifions upon the fpccialties of the cafe, and more Scrupulous of deciding to the eftablishment of general prineiples. To eftablifh general prineiples as to the interpretation of law; particularly where an equitable interpretation has come to be cxpedient, approaches fomewlat to the nature of giflation; and requires, no doubt, legilative caution and deliberation. 
fpecies of tack-holding, if the decifrons in their favour can as yet be fufficiently depended upon, as forming a fteady general rule of precedent.

Befides their contrariety to the accuftomed mole of holding property in perpetuity, one great argument of thofe who have attempted to impugn the validity of tacks of fuch long endurance, was, the danger of invalidating the faith of the regifter of landed property *. In how far fuch tacks might indeed affect

țhe

- It may be proper, for the information of the Englifh reader, to give, here, an account of that fingular infritution in Scotland, which gives fuch fecurity to conmerec is land, the Regifer of Safnes.

Alter a pariety of regulations in regard to protocols, or books kept by public notaries, which, in Scotland, (as at prefent over the Continent), were the only prefervatives of deeds, from whence authentic copies conld be procured, in default of the originals; and, after various attempts at fubtituting fomething better in their room, continued from the year 1450 downwards -.. At length, by aft $22 \mathrm{~d}$ of James VI. chap. I6. ancuded, in practice, by interim aets of the Court of Seffinn, (which has ever aftumed a fort of by-law power in regulating the furms of conducting bufinefs), as alfo amended by fubfequent acts of the Parlianent itfelf, the idea of a general regifer, of anthentic faith, and equally accetrible to all having intereft, for all tranfactions relative to perpettual riglits upon landed property confituted in the form recoguized by the Scots law, was fullly incorporated into the borly of the law itfelf; a fyftem, beftowing as great fecurity upon the commerce of lands, as human ingenuity conld probably have invented.

For general accommodation, particulur regifters are kept for crunties, (two or three counties being claffed tugether, and haring a commun regifer); and a general regifter is kept in Edinlurgh, in which it is competent to regiffrate deeds from any part of Scntland. In one or other of thefe, all deeds ufficting larid, us real sights, and confituted by infeofment or fafine, whether in the way of complete transfeicnce, or ncrely of pledge, nunt be engroffed verbatims. The regintation mut take place within fixty days of the execntion of the deed, withont which, the deed becomes invalid. If there are two fuch deeds of fafine upon the fame land, the one prior in execution, but polterior as to the date of regiftration, the other poltesior in execution, hut prior in regiftration; the latter hath, by law, the preference. Evety perfon wifhing to lay out money upon lasil, eitlicr in purchafe, or lcuding on mort gace, or finking it for an heritalik annuity, has accefs to confult thefe regifurs; in one crotice of which, he is cestain of ubtaining information hoov far the land is alreacly atrected by any decils of a finzilar nature. As the county regifters arc folled up, they are tranfmitted to the fidinbugh kegifter

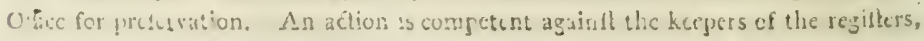

- 
the faith of the regifter-in how far this might be prevented, by enforcing the regittration of tacks, of a certain length of endurance-or, in how far fuch multiplicity of regiftration miglit not tend to inextricable confufion, of which there is already fufficient danger, from the multiplied regiftrations of titles to fuperiorities, divicied and configned for the purpofe of creating fictitious or real election votes - - - thefe are matters of difcuflion for thofe more intimately acquainted with the fubject.

There is, in Scotland, no veftige of that fimple, unexpenfive tenure of land, fo frequent in England, called copybold; excepting only the four towns of Lochmaben *. There are, indeed, lands

if the deed is not regiftered within a linited time after it hath been prefentcd: And to prevent the regiftration of deeds in any other order of priority, than that of their prefentation, a minute book is kept, in which is inferted a general defription of the deed, with the daie of its prefentation to be recorded; which minute is fubfribed, both by the prefenter of the deed, and by the kesper of the regifter, as a check againn falfitication. The judges of the Court of Stfion, too, (under what check to fecure vizilance I know not), are recuired and empowered, when they pleafe, to call for both the regifter and the miruta-book, to fee that they accord, when compared together. In Mort, by contrivance of fo many checks, this matter fems brought to all the perfection of which it is fufeptible.

This high degree of fecurity has, it is believed, fince generally known, brought a confiderable infux of Englith money into the Scotifn loan market-enabling, probably, the Scotifh merchant and manufacturer to borro:v money on fomewhat eafier terms. - - Honct John Bull, with all his puffing affectation of fupcriority, would do well, in feveral inftances, to take a lefton from his fifter l'eg.

The Athenians, as we learn from the Travels of Anacharfis, had fullen upon a very fimple idea of a regifter. A fone, on which the nature of the right affecting the land was engraved, was fet up in iome conlpicuous part of it; without which publication of the dect, it is proba le the deed was of no validity againft third parties, any more than Scotin decds unrecorded in the public re. gifter.

* Therc were, indeed, in Scotland, as in England, rentallers, or kindly tenarts, around the manfions of the great proprictors, confining generally of relations of the family, who held their lands, not by military tenure, but for very moderatc sent, in money or in kind; and who wcre in ufe to fucceed from father to fon ; the fimple evident of their title being a mate regiftration in the bools of the Lord of the Manor, without any of the expenfive formalities of the feudal 
lands of a certain defcription, in Orkney and Zetland, which, by a particular ftatute, are privileged to be held by udal (probably allodial) tenure; exempted from all the expenfive forms and cafualties of feudal holding; ' to fave' (as expreffed in the ftatute) 'the expence of renovation of rights and inieofments."

Having thus given fome account of thofe tenures by which lands are held in perpetuity, I hail proceed to make fome obfervations upon the conflitution of that temporary right of holding, by which the actual cultivator of the foil poffeffes for agricultural purpofes, namely,

\section{The Tack, or Leafe.}

This fpecies of tenure hath not obtained, in Scotland, the defignation of property, or eftate in land.

In times of turbulence, the military chief, and his armed retainer, were of principal importance, and alone figured in the imagination. The record of them has, accordingly, been more clearly preferved, and their progreflive hiftory can be more accurately traced; till the right of the former terninated

tenure. Thefe rights were in train of acquiring complete validity, from cuftom, zs in England; when their poffeffors, as in England, would have become copyEolders. Their progrefs towards confirmation, was, however, checked by the Rcformation. At this period, the lands of the Church, being feized by the Crown, vere difpofed of to court favourites; and thefe new proprictors, having no kindly connexion with the churchmens kindly tenants, univerfally ejected them-a precedent, which made all fimilar rights be immediately cal!ed in gueftion : when our law courts, after being much puzzled how to act in a cafe entircly new, at length interpretcd them, according to the circumfances of each cafe, into leafes for life, or for ccrtain terms of years; fo that they have all, long fince, expired. The rentallers of Lochmaben alone efcaped; owing to the latenefs of their fupesior's application for their ejection, which made his long acquicfecnce be interpreted into an homologation of their right to poffefs as they had porfeffed hitherto.

Many of thefe Lochmalion rentallers, we are informed (Statifical Account, Vol. VII. page 2.40), can inftruct the poffefion of their lands in their families for $5 \approx 0$ years; and may, thereforc, in puint of antiçuity, though probably net Ewillice manucrs, vie with mon of the nobles of cur land. 
in the prefent mere fuperiority; conferring only political power, but without profitable ufe of the lands; and that of the latter, in the property, or valuable ufe, with the full command of the fubject. The hiftory of the actual cultivators of the foil, of more importance than that of either, as to the increafe of its powers of production, is involved in impenetrable obfcurity: from the want of record, we can, however, fafely infer, that their ftatement was, originally, mean, unprivileged, and defpifed.

It feems extremely probable, that the lands, occupied by the military chiefs, or their more confiderable military retainers, were originally cultivated by flaves, who had no intereft themfelves in the produce, but were compelled to labour under overfeers, at no expence to their mafter, but merely that of their maintenance. But as men are not eafily brutalized into the quiet paffivity of labouring cattle; as their fuperior powers of memory, comparifon, and judgement, are apt to kindle their feelings into permanent paffions, dangerous to their tamers, in proportion to their fuperior reach of contrivance; it would feem to have been found expedient, in Scotlind, as in every other country of which we have more diftinct record upon this fubject, to admit the flave into a participation of interent with his mafter, in the produce of the foil *.

- The lands of the Romans were originally cultivated by flaves. And it i furprifing, that, under fuch a mode of culture, their agriculture fhould have fo much excelled. Having no commerce, there was no other road to wea!th and comfortable fubfiftence, but the moft accurate cultivation of the foil. 'The fuperintendance of the proprictor feems accordingly to have been fo very conftant and minute, as to palliate, in a great meafure, the evils of fuch a conftitution of cultivation. Superior accuracy of finperintendance might become equally the teft of fuperiority; as is the fame accusacy in doing bufinef, in our nanufacturing and commercial towns.

The inconveniences, howerer, of this fyrtem, made it gradually give way to 3 better: Slaves were admitted to a copartwery intereft witl the mafter: This 1 avery was firf mitigated, in their being made adforipti glesce, like the peafunts in the Northern parts of Europe; fo that they could not be tork from their families, 
To ftimulate the flave's induftry, a fenfe of interent was found a more powerful motive, than the fear of puniflment. He was therefore no more confined to his mere maintenance, but obtained the privilege of being capable of acquiring and tranfmitting feparate property of his own; and was admitted into a joint copartnery intereft, with his mafter, in the produce of the foil which he cultivated: The mafter provided cattle, feed, and inftruments of labour, and the villaine received the half of the produce, after deducting what was neceffary to replace, or repair, the ftock which belonged to the mafter. 'The villaine, lrowever, could have fmall inducement, when capital accumulated in his hands, to fix any of his own capital in improvements of the land: The fnaring of the mafter, to the extent of one half of improvements, fo effected, would have been an effectual bar to the attempting of fuch improvements; befides that, probably, the villaine's fecurity of endurance of poffeffion was not fuch as to give him affurance of even this proportion of a fuitable return. To give, then, a rational inducement to the cultivator, to launch out his own capital in the improvement of the foil, various encouragements would be given ; till the cultivation of the land was at laft brought to its prefent footing; as undertaken by farmers, properly fo called, hiring the ufc of the lands from the proprietor, at a fpecified rent, and for a time certain, and cultivating it entirely by the outlay of their own capital: The various progreffive fteps of this anem lioration of the fyftem of cultivation, is, however, nowhere diftinctly recorded.

In gradnally communicating privileges to the cultivator of the foil, it fecms reafonable to fuppofe, that the mode which would noft obvioufly occur, would be, to follow the analogy

or fold feparate from the lind: They were afterwards made ecloni partiarit, like the metaycrs of France, who cultivated by means of the proprietor's ftuck; receiving one half of the produce, after replacing the flock; and leaving the ftock behind them, upon quitting pofftfion of the land. The author of the Wealth of Natirns conccives, that the Weft Indies conld not afford the expence of unptodictive llave culture, but fur the fuperior valie of their kind of produce. 
of that mode by which the privileges of military tenants had been enlarged: And it is probable, that the profecution of this analogy, joined to the reafons already fuggefted (page 282), might lead to the adoption of the abfurd notion of the right of a delectus perfone being effential to the proprietor of the lands-a conftitution which confiderably weakens both agricultural credit and enterprize, but which is fo interwrought into our accuftomed habits of thinking, that moft of proprietors, and bufinefs-men of the law, with their feudal-ridden imaginations, adhere to it more tenacioufly than to any other article of their creed. Accordingly, we find, that, as military tenants, at firft, became tenants for life, from being tenants at will; fo, the firt notion, of giving the fecurity of independence to the cultivator of the foil, in Scotland, as elfewhere, was to give him fecurity of poffeffion for life. The liferent tack feems the firf adopted fpecies of tack-holding, rendering the poffeffor independent, his fituation refpectable, and his rights and interefts regarded: Superior privileges were accordingly beftowed upon the liferent tack; the property in this tack was, and is, confidered to be fo complete, as to imply the full power of its alienation, in defiance of the proprietor's fuppofed effential and inherent right of the delectus perfone; and, when granted to a woman, was not confidered as forfeited upon her marriage, as implying aftignment contrary to the proprietor's right of delectus, in confequence of its falling under the hufband's jus mariti; although fuch is the abfurd conftruction of Scots law, in regard. to the effect of a woman's marriage, upon a tack for definite time, to which the fhould fall heir by inheritance, or even, perhaps, acquire by perfonal contract. The period of nineteen years, feems, in Scotland, to have been confidered as equivalent to the life of a perfon of age to enter upon a liferent tack; and, from this analogy, various privileges, originally communicated to the liferent, would feem to have been extended to this fpecics of tack. As nineteen years may, however, be confidered as a favourable exchange for a liferent, this is probably the reafon why the Scots tenant feenrs to have gencrally preferred this fccurity; infomuch, that the mention of a tack, without 
fpecification of the term, in common habit fuggefted the idea of a nineteen years leafe. The privileges granted to cultivators, by legiflating proprietors, feem to have been granted flowly, with reluctance, and to no greater extent than what obvioufly indifpenfable utility required: A thort-fighted avarice withed to grafp at the fruits of the cultivation effected by the tenant's ftock, as fpeedily as pofible; even fo prematurely, as to allow no fufficient fecurity of time for their being effected at all: And the genius of law feems to have been univerfally inimical, both in modern and in antient nations, to the long duration of leafes, which feemed to keep back the proprietor from reaping the benefit of the increafed value of his property *.

When fubfequent views of utility fuggefted the propriety of tacks of ftill longer duration, they were ventured upon with timidity, as an extenfion of a fpecies of tenure, to which the genius of law was unfriendly; which, as yet, the had not recognized to that extent, and which the might be fcrupulous in fanctioning. Such tacks, therefore, fought fhelter under the form of the privileged tack of nineteen years, which had acquired an analogical ftability, and whofe talifmanic influence was thought able to protect them: The whole term meant, durt not be arowedly exprefied; but the tack was granted for two nineteens, or three nineteens of years, till the number of years propofed fhould be completed in nineteens.

Originally, the cultivator's right of poffeffion was confidered as only perfonal in regard to the proprietor, but not as a real. right

- Till the days of Juftinian, the legal term of a Roman leafe was only five years. The tenant could alfo be ejected by an heir, or a purchafer of the lands. In France, a leafe had no fecurity from law but for nine years, till 1775 ; the fecurity was then extended to twenty-feven years-Whether the ephemeral decrees of her late Affemblies, affecting legilation, have ever reached this fubję, I know not; or whether they were fo occupied with confitutions, or the forms in which bufinars was to be carried on, as to have found no leifure to do any bufinefs at all; or whether they reftrieted themfelves totally to demolition, upon the Godwinian priaciple, that cfablifhment, implying fationary ftability, was in diametric oppofi. tion to improvement, whofe very eflence confifted in an unfettled progrefion. 
right in the foit. His right, then, terminated upon the ccfin tion of the proprietor's right of property, whether by death or alienation; by the fucceffion of an heir, or of a purchafer; and the heir, or the purchafer, could eject him. By act of the Scotin Parliament, of fo early date as 1446 , he was fecured for the whole term of years fpecified in his leafe, in whomfoever the right of property night come to be vefted, whether heir or purchafer.

Originally (in confequence, probably, of the whole ftock of the farm being the property of the mafter; probably, in part, owing to the undiftinguifhing nature of the policy of barbarians, which, in other inftances, made the firft merchant of a nation, that could be feized, anfwerable for the debts of the other merchants of that nation; or a whole family punithable for the crimes of its head), the whole crop and ftock upon the farm could be at any time poinded and fwept away, to fatisfy the debts of the proprietor of the lands: And this would appear to have continued, as the law of confuetude, even after the lands had begun to be cultivated, by the outlay of the tenant's own proper capital. This change of the mode of cultivation, evidently demanded a change of the law: And, by act 1469 , the tenant was fecured againft fuch hardnip; it being thereby enacted, that the crop and ftock thould not be liable to the creditors of the proprietor, excepting in fo far as the tenant was indebted to him in rent, by the terms of his leafe.

Two fuch remarkable ftatutes, enacted at fuch an early period, and within the fpace of twenty years, fhow the early introduction, and the rapid progrefs of the change of fyftem of cultivation, from that of villainage to that of freemen, cultivating by their own proper outlay, and at their own ritk.

The act 1469 , in its literal fenfe, is indeed univerfally underftood to have gone no farther, than to fecure the tenant from being attached, in this manner, for the perjonal debts of his landlord; but is not underftood to have given him any relief, in regard to the delite fundi, or ruth dibts, for which 
the land itfelf had been pledged*. Accordingly, fo late as 1628 , a decifion appears upon record, in which the goods of the tenant are found liable for payment of annualrent, conftituted by infeoffment and fafine, in all the years and terms due to the infeoffee, preceding the date of the poinding, and alfo for the current term's rent; ' although the tenant, at the time, thall owe no rent to the proprietor, in terms of his leare.' By a liberal interpretation, however, of this act, now perfectly eftablifhed in practice, the tenant is fecured againft all debts of the proprietor, except in fo far as he is indebted to him by his tack; fo that, though the proprietor's heritable creditors may force him to pay fooner, they cannot force him to pay more than the proprietor would, or could have done.

The tenant's own property is thus completely fecured by the operation of thefe two ftatutes; in the liberal manner of their interpretation, through the nobile officiun of our Judges, in interpreting law according to equity, which has fupplied the deficiencies of our law-(See foot note, page 290). The tenant's own perfonal creditors are left, however, in a more precarious fituation; to the confiderable diminution of the extent of his credit, in enabling him to borrow money to carry on his improvements. Wherever land is appropriated, it is probable the proprietor, on leafing out his lands, has ever poffeffed, in right of hypothec, a preferance over all other creditors of his tenant, for at lcaft one year's rent, upon the crop and ftock; and it feems highly reafonable, that he who furnithes the land, which is the fine qua $n$, fhould ever enjoy this extent of preference.

There

* When a proprictor pledges his land, in fecurity of an annualrent, or of the fayment of principul and intereft of borowed money, he places the anmulrenter, or mortgage, precifely in his own fituation, according to the forms of the feudal law, as proprictors quoad bee efjicta.

He, accuritingly, fymbolically divefts himfelf of the property, by fynbolical refisuation of it into the hands of a perfon conftituted to reprefent the fuperior;

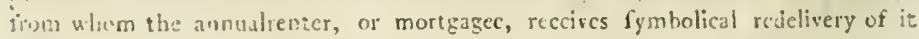
by infooffincrit. The tranfaction is atterocd by the notorial written deed, called

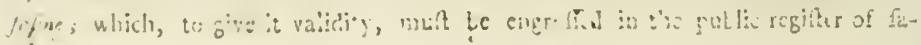
inc. 
There feems, however, no good reafon, why the fuperior, or other creditors of the proprietor in debitis fundi, Thould enjoynot only the fame extent of preference as the proprietor himfelf, into whofe place they can ftep when they pleafe, to make good their claims, which is reafonable-but an extent greater than the proprietor ${ }_{2}$ in coming before all the other creditors of the tenant, not only for one year's rent, but for all arrears of vent due by him to the proprietor, and alfo for the current term's rent. In the latter of thefe inftances, the law beftows an extent of preference upon a derivative right, greater than what belongs to the original it is derived from; and feems to have loft fight even of analogy, as well as of utility.

The agricultural credit of the cultivator is, however, lefs hurt in thefe inftances, which may occur feldom, than from that perpetual obftruction to it, which is conftituted in the refural of the law, to fupport him in the full, complete, alienable, and evictable property, which be ought to have in bis leafe; which, in many cafes that might be figured, may prevent him from freely fixing his own capital in the foil; and which may prevent others from lending theirs, from the well-grounded apprehenfion, that, if once there fixed, it may never again be withdrawn. The right of delectus perfond, which, very oddly, has been magnified into a confequence that does not belong to it, in the eye of law equally as of individual conception, obftructs the tenant's credit, by depriving him, in a great meafure, of the power of aflignment, or of fubfets. In all tacks, where affignation and fubfet are debarred by covenant in the leafe, the proprietor can prevent either; although he fhould be able to produce no reafon, but his own whim or fancy, and cannot inftruct any diminution of fecurity; or, even although he fhould have all reafonable additional fecurity offered him, which would be held fatisfactory in any other cafe. There is indeed an exception, in the cafe of tacks of very long endurance, where (as the law has never recognized, or peedily relinquithed the abfurdity of the right of tack being undefcendible to legal heirs) the proprietor, from the diftance of time, though held a very conjuror in the difien matut of frivils, is confidered as liaving re- 
nounced his delectus; from the impolibility of his knowing the characters of the eventual fucceffors, either through fimple vifion or the fecond fight: Our Supreme Court have, I am told, upon thefe principles, within thefe few years, fuftained the vaIidity of a fubfet of a tack of $3^{8}$ years. What length of tack thall be confidered, thus, upon legal principles, as implying power of fubfet, or where the point of time lies, within which the law fialt fay to that power, 'hitherto thalt thou come, and no farther,' remains hid in the counfel of our Judges, to be determined in fome future decifion. In I 79I, it was decided, that, in a tack of 19 years, it was implied, in law conftruction, without any formal ftipulation in the leafe to that effect, that the power of delectus was retained; and that the tack was zeither affignable nor fubfettable.

In fubfetting, the original tackfman is confidered as bound to the proprietor, as well as the fubtenant; whilft, in affignment, the original tenant is free, fubtituting the other in his place. In conformity to the analogy of the feudal law, therefore, as well as to the greater fecurity of the proprietor, the Scotifh law is confidered as more favourable to fubfet, than to afignation; becaufe, in fubfet, the firft tenant does not relinquilh his pofition as a quafi vafial, and the purpofes of the metuphorical delectus may be, thus, confidered as metaphorically, or analogically fuifilled, by this fictio juris, or quafi : moreover, too, the fecurity of the proprietor, fo far from being weakened, is greatly ftrengthened, in having lis right of hypothec unimpaired, and the fecurity of two inftead of one. Upon this principle, it was confidered, by our law oracle, Erfkine, that a power of fubfet was implied, in all cafes where the contrary was not directly exprefred; till the aforementioned decifion, in I79I, came to rectify our mifconceptions.

Even Erfkine allows, that, upon legal principles, an exprers ftipulation in the tack againft aflignees, both legal and volunta";', would prevent the tack from being evicted by the tenants's cre!itors: Otherwife, a tack, unaffignable by the tenant's voJuntary deed, would, accorling to him, be evictable by adjudication, at the inftuce of the tenant's creditors: Bur, even in 
that cafe, the creditors would be guilty of lefe-MIljefle towards the facred right of the delectus, were they to bring the reverfion of the leafe to a fair fale to the bett bidder: They are debarral, therefore, from fuch unhallowed and irrcierent meafures; they can only enter upon adminifration, as refponfible factors of the tenant's concerns.

The great foundation of law, conftituting, at leaft, the difference betwixt right and wrong, is public utility. When law reafoning confines itfelf to the attent of fymbolizing, in practice, ufages long fince obfolete, and whofe reafon has ceafedthough, in refpect of the exactnefs, or want of exactnefs, with which the aflimilation is effected, it may be juft or incongruous -yet, in its own nature, as it is neither true nor falfe, fo neither can it be either right or wrong. There is, however, a neceflity of fixed rules of procedure; without which, there can be no fecurity or confidence in law. Decided views of utility are Aowly evolved; and, meantime, the moft obvious rule is the analogy of known ufages.

Views of utility, however, exccpting perhaps in the inftance already quoted, fecm progreffively to have been gaining the afcendant over fyftematic law reafoning. And though the tack, in Scotiand, is ftill fomewhat encumbered by a remnant of the fhackles of feudalifm, in a confiderable degree obftructive of agricultural credit and enterprize; yet, under the benign influence of the enactments of 1446 and 1466 , with the liberal fpirit of interpretation fubfequently followed up by ous judges, the Scotifh tenant probably enjoys more fecurity than what was ever beftowed upon the actual cuitivators of the foil, either in ancient, or in modern times. Comparing ourfelves with others, more eaufe of fatisfaction will prefent itfelf, in having attained the relatively beft, than of regret, in not having attained the beft fuppofeable.

Proprietors, in their covenants, might redrefs all deficiencies of the law, in exprefsly renouncing all retention of the jus delectus : Or, fhall we fuppofe them grafping after the chances of forfeiture- or that, in their wifdom, they fhould conceive at fririted cultivation to proceed under fuch ritk? 
It might be mentioned, that the policy of entails, through the reftriction often contained in them as to the endurance of leafes, militates alfo, in a very great degree, againit liberal outlay of capital in cultivation. A feeming relaxation of their reftraint has been indeed obtained by act of Parliament, roth of his prefent Majefty. Obfervations upon that act have been made (pages IIO, III, \& 253 of the Report.)

In this Note, the leafe or tack has been confidered, chiefly in an hiftorical point of vicw. Some additional confideration of its circumftances, in the view of public utility, will be refumed in a fubfequent one. I have been much indebted for information to Rofs's Lectures on Conveyancing.

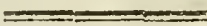

NOTE C.

WHERE manufactures are eftablifhed, an effectual demand, in offers of larger rent, will arife for fmall fubdivifions of land, to be poffeffed by cow-feeders fupplying the manufacturers with milk; or by thofe keeping poft-horfes for travelling, to tranfact bufinefs ; or by carters, who find occupation in tranfporting fuel, and the materials and produce of manufacture. Even where agriculture has arrived at confiderable improvement, fuch demand will arife, in a mere farming diftrict, from the advantage enfuing upon fubdivifion of labour; the farmer finding it cheaper to hire all his carriages from the profeftional carter, than to perform them himfelf; as he is thus allowed to apply his whole capital, with entire undivided attention, to his own proper profeflional occupation, the cultivation of the foil *.

The

- The fame argument applies to tbe retailing of meal. Conld the farmet find it edvantageous to intercept the profit of the carter, by performing his own carrlages, he needs no other inducement to make him do it. The very fame reafon would make him the retailer of his own grain. Bue the profeffional cartes cain carty cheaper, as the profeffional retailer can alfo retail cheaper tban the farmer, with whofe bither bufncis fuch occupations would obftrudtingly interfure. 
The poffefors of fuch minute tenements, cannot properly be defigned farners: they depend not upon farming, nor does it contitute their chief occupation. It marks a progrefs in improvement, when labour and employment are fo nuch fubdivided, as that their difinet branches can afford chief and prinsipal occupation to their diftinct feveral profeffionalifts. But the complction of improvement implics their complete and perfect feparation. And there is an univerfal, turemitting tendency to fueh completion; every one's intcrent neceffarily leading him to confine limfelf to that occupation, in which, through practice, his undivided attention would render him more and more expert, fo foon as he can find fufficient employment in that particular occupation, as to enable him to devote to it, exclufively, his whole time and attention; every other profeftionalift, meanwiile, engaged chiefly in fome other branch, finding it for his intereft to take his furnifhings from the former, that he may alfo, in like manner, exclufively devote himfelf to his own particular employment. In great towns, where there is fuficiency of employment in one particular line of profefion, we find, accordingly, that land is very feldom occupied by carters, cowfeeders, \&rc.; they difincumber themfelves of that interruption to their bufinefs which would arife from the cultivation of the foil, finding it much cheaper to purchafe the farm produce they need from the profeffional cultivator. For the fame reafon, merchants ciealing in the retail of corn, potatoes, hay, or other farm produce, do not take land in leafe; finding that the profelional cultivator can furnifh it to them cheaper: than they could raife it. Nor is the practice of fuch profeffonaliits, of not pollefling land, the effect of any regulation, or even public prejudice. On the centrary, as to the latter fort of profufionalits, it is the univerfal, ineradicable prcjudice of all great towns, that crery rctailer of farm produce fhould himfelf be the producer of the artick. Neither will any landlord refufe the highen rent offered him ; fo that there is nothing to prevent merchants from outbidiling profeffonal farmers, if it were nore for their intreft to produce, as well as to fell. 
So long, howevcr, as the circumftances of a fociety are fuch, as not to admit of perfect fubdivifion of employment, there will exift a clafs of fuch minute occupiers of land; not for the immediate profit derived from land, but on account of its fubferviency to other more profitable employment. It is needlefs to fay that fuch minute occupation ought to be encouraged; for, fo long as the circumfances of fociety require it, it will force its own way, from its being able to afford more rent. But it would be equally ahfurd, either unnaturally to force it into, or out of, exiftence, by inftituted regulation; it ought to be left to be fettled by the actual demand.

Inftituted regulations counteracting natural tendencies, wils ever be themfelses counteracted: And, therefore, there is very little danger to be apprehended of the introduction of a fort of general cottage-fyrtem of the occlipation of the lands-a fort of Agrarian law, of late fo much cried up. So long as fuch paftorico-poetical politicians content themfelves with attempting to enlighten the landed proprietors, in convincing them that fuch minute occupation would tend to their intereft, no harm can enfue. The proprietors of land, after liftening to their declamation, will judge of the expediency, by the ofiers of rent which are made them; and their confciences will be kept eafy as to the propriety of fuch procedure, from the confrderation, that the higheft rent can be afforded only from the higheft production raifed at the leaft expence.

Of all forced artificial regulations, the moft abfurd (condemning the earth to fterility, and its inhabitants to poverty) would be an Agrarian law, dooming the lands to fubdivifion, into equal poffeffion, among the inhabitants of every country; whether to be heid in property or in leafe. In a common pafturage, (the only conceivable mode of holding pafture lands in equal poffefion), is it poffible to imagine that any thing could be effected, in the improvement of brecds, in the prevention of intermixture, in proper ftocking of the land, in hirfeling or hercling? Among fuch puny proprietors, or farmers, having each an equal interent in the half or quarter of a common horfe, might not the animal be oftener idle tlun occupied, for 
want of agreement as to the time when, and the purpofe for which, he was to be yoled; or ftarved, before his mafters Should agree when, or whereupon, he was to be fed? Every individual being thus, in a manner, adjcriptus glebur, and doomed, per force, to be a farmer; and no one being at liberty to devote himfelf to any other profeffion; of courfe, each indiridual muft, of neceflity, become Jach-of-all-trades, and provide himfelf in every kind of furnifhing he required; and the ftrange uncouth fyftem of univerfal awkwardnets and bungling that muft enfue, may more readily be conceived than defcribed. Nothing but the continued interpofition of the moft violent regulating force, counteracting the ftrongeft natural tendencies, could ever preferve fuch an unnatural conftitution of things, for any time, in exiftence: As every fuch fmall polfeflor muit conftantly be endeavouring to difpofe of his minute poffeffion, which cannot fufficiently occupy him, which he cannot occupy to any purpofe, and which prevents him from betaking himfelf to more profitable employment, to thofe who could readily afford him more for it, than he can poffibly make of it himfelf. It would, indeed, be extremely fingular, if that fubdivi fion of labour and employment, which is the characteriftic of civilization and improvement in exery other inftance, fhould form an exception to the generale rule, in the fole inftance of the cultivation of the foil. The Agrarian foftem is, in fome fort, exemplified in the common-property lands belonging to burgh corporations; the occupation of which, by diftracting their attention from their proper profeftions, has generally the effect of beggaring the members of the corporation. It is happy for them, when they have the good fenfe, and fortunately alio can arree, to let their corporation lands, in undivided poftefion, to a practical profefional farmer. The inhabitants of the town of Peebles, in this county, poffefs lands in common property, chiefly confinting of hill pafture, but containing alfo arable land: Particular domiciles, in the town, have different proportions of intereft in this common property attached to them as appendages, the whole integer of the property being ideally confidered as confiting of a certain number of foums, and the particular 
particular intereit of each domicile being defignated by a fpecified number of thefe foums. Before thefe lands were, happily, by univerfal confent, let to a fingle farmer, the value of one foum was confidered as equivalent to 5 . yearly; withour taking into the account the lofs fuitained by the proprictors of the domiciles, in diftraction of their attention from their proper employments in the comnoin nanagement of this common concern. Now, that the lands were let to a profeffional farmer, the yearly rent divided among the proprietors, amount-

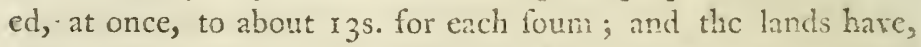
even fubfequently, been fubfet, by the original farmer, at * confiderable over-rcnt *.

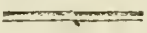

FัTE D.

Trie topics of inquiry, furgyefted in Chap. IV. of the prefcribed form of the Agricultural Reports, arc curious and inportant : viz. the proper fiae of forms ; - the generic clarainer of farmers; - the proper conftrution of the finner's lenfe. Each of them merits particular difcufion. I fhall ftate what has occurred to my reffection; If, In regard to the character of the farmer; $2 d$, In regard to the contrubion of leafes; $3 d$, In regard to the proper fize of farms.

- When a contiguous proprietor withcil, of late, to purchafe this common property land from the domiciled pioprietors of the fums, fome of the burgh politicians protefted azainft this disjunction of the foums from tic dicmiciles, $b_{\mathrm{s}}$ ? the burgh fould le defertad of its inbabiants; an opinion inetinncel by dicciuratury acts of the 'Town Cumcil, recorded iu the Town's bouks, declas ing any one ir-

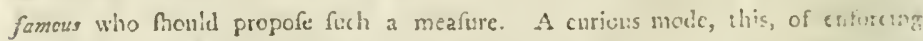
population, to preferve refpedivility to the burgh ; thengh, peil.aps, vpon a ta: with ether entails of land, intended 10 preferse confectenec : nunies-mlet:" family names, mcre!r, or as cif'gnative of rarb. 
Charater of the Fainter.

The origin of profenional farmers, as conftituing a diftinct clafs in focicty, is not to be attributed to any articial regulation of political contrivance; it is an arrangement that nut neceffarily take place, in the natural courfe of things; and that hath therefore exifted, in every age and nation, fo foon as men have emerged from the Jack-of-all-trades ftate of favagifm, and attained to any degrce of civilization. In proportion as civilization advances, through the effect, and as the additional caufe of the proper fubdivifion of employment, the proferfion of the farmer has become more and nore exclufive, appropriate, and diftinct.

In the progrefs of civilization, uncie! the protection of laws, or cuftoms equivalent to !aw, fecuring property in its acquifition, enjoyment, and tranfrnifion, two diftinct deicriptions of perfons will arife, into which every fociety may be divided; thofe whofe fortunes are already made, and thofe subo have their fortunes to nake: The firf trained to habits of enjoyment, rather than to thofe of acquifition; the fecond to habits of acquifition, more than to thofe of enjoyment: "The firft comprehending the landed and the monied intereft; the fecond comprenending thofe who liave not equal property in land, or in money, and who are willing to give rent, or intcreft, for the ure of the one cr the other, which they pay out of the profts refuiting to them from their fkiful and induftrions we of either: Thefe, again, employ under them, all manner of day-labourers, and artificers. The two clafles are deftined to be niutuily fubfervicnt to cach other : They are, indecd, mutually incilpenfible 10 cach other's exiftence*. In thofe born to opulcice and intependence, and trained up to the proper enjoyment of a fortune, the fame adventurous fpirit of enterprize, or patient induftrj, oi minute

attention

* Wothing could be more abfurd, than the Jacnbinical attempts of repicfutin:s the firft of thefe claffes as a nuifance in focirty. See fubfequent nete, C. 
attention to œconomy, in the acquifition of gain, are not to be expected, as in thofe who have their fortunes to make: And it is happily fo ordered, to preferve fome fort of equality in the conditions of men, and to give their chance of rifing in the world to thofe in more poor circumfances; otherwife, thofe in obfcure fituations, could never poflibly emerge from their obfcurity, if they had to compete againft equal induftry, joined to the advantage, of which they are deftitute, the poffeffion of wealth : But, in the ordinary routine of human affirs, poverty begets induftry; induftry, riches; and riches, when long enjoyed, and the habits by which they were obtained forgotten, leads to that prodigal profurion, which terminates in poverty; -when the rotation recommences. Meantime, men of kill and enterprize, but deftitute of capital, are accommodated with the ufe of land, or of money, by thofe poffefled of fortunes in either; whilf the latter are equally accommodated by the former, who enable then to live at eafe, by fharing with them the profits, in name of intereft, or of rent, which they were enabled to make by their induftry, through the loan or hire of money, or of land. It is not from mutual attachment, but from mutual need of each other, that thefe two claffes are fubfervient to each other's intereft: It is not from any view to the other's accommodation, that the monied, or landed proprietors, grant the ufe of their money, or land, to the man of fkill and enterprize; but becaufe, with their habits, they receive more from lin, in fharing his profits, in the 11ame of intereft or of rent, than what they could obtain, by directing, themfelves, the outlay of their monied capital, or overfeeing the cultivation of their own foil: It is not from any defire of obliging the monied, or the landed capitalifts, that the man of enterprize confents to fhare with them in the fruits of his induftry, in fuperintending the proper profitable ufe of their money, or their land; but becaufe, without the ufe of land, or of money, his tikill and induftry could be turned to 110 account. The fame obfervation is equally applicable to the mutual accommodation of thofe who cmplny labourers, and thofe who give their manual libour for hire: The former give employment to the latter, 
ter, becaufe, without their labour, ncither ftock nor land could be turned to any profitable account; and the latter, labour for hire, to the former, becaufe they necd their maintenance to be daily, or at fhort periods, advanced to them in wages; being unable, for want of ftock, to await the ultinate return of the product of their labour. The benevolent intention of mutual accommodation, is, in the general, director of nature; not in thofe who are thus mutually fubfervient to the accommodation of each other-though the practice of mutual accommodation has, by the ordination of nature's Author, a ftrong tendency to beget fentiments of mutual good-will *.

In an induftrious ftate of fociety, though the whole menbers are thus mutually fubfervient; it is not, through the fubferviency of gratuitous donation on the one hand, and fervile obligation upon the other; but through the fubferviency of the interchange of equivalent values; by which, in the midt of mutual dependence, in one fenfe, they are mutnally independent, in another.

To return, however, from this digrefinon, which, I prefume, will not be confidered as very foreigin to the fubject; the character of the independent country gentleman, the proprietor of land, ftands clearly diftinguifhable, upon the principles laid down, from that of the farmer who rents land for hire.

Independence is, no dount, a relative idea. The counitry gentleman, however, who, either wifely (in confideration of the general ftandard of wealthinefs), or foolifhly, confiders himfelf as independent, is not at all likely to acquire that character, and thofe habits, that fhall fit him to becone a very fuccefsful cultivator of the foil. From his fituation, he is laid under a refponfibility; and from the education, and habits fuited to lits fituation, he is fuppofed to poffers that libcrality of mind, and extenfion of views - that public fpirit, and difengagement from the contracted purfuit of private cmolument, which point hin

out

- The good-will produced by interchange of mutual acconmodation, $: 1 /$ is expreffed, in Latin, by one word, neceffitudo. 
out as proper to be entutited with, and as having moft leifure to manage, meafures of public concern : Ilence a variety of duties are impofed upon him, which mult neceflurily occupy a confiderable thare of his attention, if he would wifh to preferve his proper refpectability. He lives upon an income, the extent of which is publicly known; and, from the publicity of his income, a certain fuitable expence in his fyle of living, is exacted of him, by cuftom and fathion. From the numberlefs avocations to which he is thus neceffarily expofed, in the difcharge of his public duties, and in his focial intercourfe, he cannot be fuppefed to beftow that habitual and minute attention, fo indifpenfabie to fuccefsful hufbandry: That penurious attention to ali the minutice of ceconomy, which fo well fuit the profelional famer, would, in his fituation, be even degrading. Neither can he remedy thofe deficiencies, arifing from his fituation and confonant habits, by the fubltitution of an overfeer: For, admitting the latter to be as active, fkilful, and honeft, as can well be fuppofed, it is not in nature to expect from him, as acting for another's interift, and at another's rifk, the fame frenuous exertion, with the fame attention to œconony in expence, as what may be reafonably expected from the profeffional farmer, ading for his owun intereft, and at bis orun rifk; when, from proper durntion, and other fecurity of his tenure of poffefion, he is certain of reaping the whole profit of the utmolt exertion of his fill, induftry, and ceconomy, in the proper outlay of his ftock *. But, further, the funds for improvement, in the hands of the independent country gentleman, mult, in general, be extroniely limited. From the rate of living, impofed upon him by fullion, in his oftenfible fituation; from the ambition of diftinction, which even the moft prudent can harilly reftrain within the bounds proportioned to lheir means; from al! the habits afumed in an independent fituation, in which he hath bees taught to confuler it as his bufineds to enjoy, rather than to arquire; from all thefe circumftances,

- P'rutefonal farners fometimes complain of the vicinity of gentkmen imfl. sis, itu iblencis of the latter's ferrants being fouad contarious. 
ftances, his favings, from his annual revenue, can be but inconfiderable. Inconfiderable as are thefe favings, they, how ever, conftitute the only fund which he is inciined to risk upon agricultural improvencnt. He feruples to borrow money for this purpofe; becaule it is feldom found that his improvenents make a fuitable return; for, though he often does excel in theoretical knowledge, his pracical fkill nut ever come far fhort of that of the profeffional farmer: He is univerfally, too, confidered as an eafy and a lawful prey to all thofe in his employ; nor is he poffeffer of that ftrict, unremitting attention, which is necelfary to his felf-defence: His fchemes are therefore executed, at an over-proportioned expence; and, for want of practical tkill in direction, and, fill more, of œconomy in execution, his return of profit is feldom adequate to his expence of outlay*. The habits, of his ftation lead him alfo to attach himfelf to ornamental, as much as to ufeful and profitable improvements; the former being, in the univerfal mode of thinking, that ufe of money which fuits thofe born to independence; and whofe minds, in the courfe of an education fuited to their circumftances, may be fuppofed to have imbibed a relifh for the liberal arts. Even to borrow money for the purpofes-of ornamental architecture-of drefing up a lawnof placing here a piece of water, and there an artificial ruin for a vifto: Even to borrow for fuch purpofes, is not judged prepofterous; though no return of profit is, in any thape, expected.

If, cven when the mind is ftored with all the acquifitions, and the energy, that can render a ftate of independent fortune mont highly refpectable, little fuccefs is to be expected from. the proprietor's cultivation of his own foil: What can pofibly $b_{2}$ expected, when independent fortune plends privilege of worthlefs infignificance; and the power of enjoyment diplays itielf in mere debafing and Atupifying fenfulity?

S's

The

* It is proverbial in this councy, and probably every where befides, "That a Fisielional farmer might aifurd, as rent, the whole furmer's profit, raped by th:

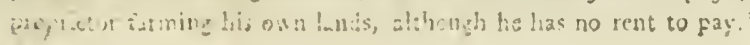


The farming moft fuited to the ftation, and congenial to the proper habits of the refpectable independent country gentleman, would feem to be great outline improvements-beneficial, not to fingle farms aione, but to a whole eftate; and in which, farmers, having intereft merely in fingle farms, will not, of courfe, fo imnediately intereft themfelves: leaving the details to be filled up by the particular profeffional farmers, who have an immediate intcreit in therr execution. The only detail farming, fuited to the independent country gentleman, is experimental farming, for the purpofes of invention, or of verification; conducted, too, upon a fcale that could involve no important confequences: That minute attention and œconomy, which would degrade him, if applied (like thofe of the profeffronal farmer) for the mere purpofes of gain, would do him credit in conducting experiments, producing refults of general utility. It is not, indeed, to be expected, that the inventions of the gentleman farmer flould be immediately adopted; nor is it fit they fhould: What is perfectly afcertained as ufeful, will, neverthelefs, fooner or later, force its way into practice.

The character of the profeffional farmer is, from the oppofite nature of his circumftances and fituation, formed in generic diftinction, to that of the independent landed proprietor.

Having to acquive, not to enjor, a fortune, his faculties are tharpened by neceffity; his whole energy is called forth, as he muft cither do or die; his attention is eres alive to the moft minute details, that can contribute, in any way, to his purpofe. In this manner, like all other profeffonalifts, he acquires more perfect practical fill in the bufinefs of his profeffion; his plans are laid down with judgement, conducted with accuracy, and with the moft minute attention to אeconomy in expence. Subjected to almoft no public duties, his attention is not difracted from the peculiar bufinefs of his profeffion; he can perfonally overfee every operation, and attend to the whole detail of practical oconomy. Jike as with all thofe who live upon profit, his income is unknown; and no particular rate of living is exacted of him, by cuftom and faflion: If his rent, then, is fufficiently modirate, and his cucouragement to induf- 
try otherwife proper, his annual favings may amount to much more in proportion to the produce of his farm, than thofe of the independent country gentleman in proportion to the rents of his eftate. And as his habits are formed, not to enjoyment, but to acquifition, thefe favings are neither dexoted to ornament, nor other expence of living, but are added to his farming capital; which he would certainly rather employ himfelf, in the way of his profeffion, to the fuperior or more extended cultivation of the foil, that he might reap farmer's proft, than lend it to other profeflionalifts, who could afford him only comsmon intereft. From the duft thefe favings arofe, and to the duft they have a natural tendency to return. Unlike to the independent proprietor, he can even, with fafety, borrow money for the purpofes of agricultural improvement; as, under his ceconomical application, capital may reach to double extent of eflicacy *.

The

* A prejudice feems generally prevalent againt the expediency of a tenant farming upon a borrowed capital. In the reafon of the thing, were this fubject placed upon a proper footing, there feems no fufficient caufe, why the borrowing of money hould be more inconfiftent with this profefion, than with that of other gainful profeffions, requiring the outlay of capitat.

Indeed, the ridiculous abfurdity of the retention of the delctuls perfone, a right fo highly faroured by the feudal confruction of Scotilh law, together with equally abfurd articles voluntarily covenanted-all tending to prevent the tesant's intereft in the foil, by his leafe, from being an article in commercio; muft neceffarily preclude the tenant from obtaining money to brrow, by difabling him to offer any proper fecurity to his creditors; muft even, in many cafes, difcourage him from the frec outlay of his own capital; and muft operate to the difouragement of his credit and exertions, as entails do to thofe of the landed proprietor. There is a general complaint of deficiency of capital invefted in agriculture: This deficiency feems not, however, to originate in any thing peculiar to agriculture, making it an object of particular antipathy to credit; bet to fuch abfurd obftructions to agricultural credit, as arife from artificial regulation; which tẹd to banif capital from agriculture, into other kinds of irveftiture, under which it remains more fecurcly in the power of its proprietor; reftrictiug the extent of inveltment of capital in agriculture to that of thofe who have been trained to agriculture as their peculiar profeftion, an 1 who follow it out from habit as much as in view of intercft.

Farmers are, at all events, difadiantageonfly fituated as to borrowing morey. Wonied men generally prefer, for their fat of refidence, the fociety of great towns. 
The gencmal improvement of the productive value of the lands, nutt, for thefe reafons, depend much more upon the exertions of profeffonal farmers, than upon thofe of independent landed proprietors.

But thefe exertions will necefiarily depend upon the encouragement given to exertion, from the fecurity of reaping its fruits. And as, in Scotland, no indirect fecurity is poffeffed by the tenant, in the way of his political influence; his fecurity muft directly arife from the legal or conventional conditions of tis tenure of poffefion *. This leads to the confideration of

$$
\text { Leafes. }
$$

This tentire of the farmer's poffefion may be confidered wnder three points of view, viz. Its duration: The cxtcnt of the right of property in it, during its continuance: And the extent of the ufe of the foil, communicated by it.

in, Duration of the Leafe.-The thorteft poffible period of duration, to which the cultivator of the foil can be circumfcrib. ed, even though he is retained as a mere tenant at will, mult llow him at leat the fecurity of one year's poffefion; elfe he could have no fuficicnt inducement, to lead him to make preparation, cven for a fingie crep, by merely tilling and fowing the land $f$.

The

the naturat refidence of merchants and manufacurers: They, of cistere, get acfirainted with perfons of thefe clafics, and flace coufulence in them: 'They can have lets interccurfe with farners, who necefiarily live ciliferfd. Why then, arrificially, increare this natural difw\}ranage as to credit?

The farmer vipon Neidpath eftate, who, in the lean iime, has exccuted ti.e, greaten quantity of permanent improvement tipon his furm, Legan his fartsing

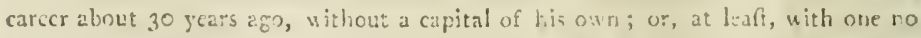
way arlcquate to the cxtent of his undertaking. LIis leates, indect, have cver been of that long duration, which, cven in the cye of law, implies the dereliction of the proprirtn!'s inhcrest right of dublus perfone: His cr.dit thcrefore was good; he could pledge hicleafe in ficurity; and his creditors covid fell, to the higheft hidder, the suverion of his right in the foril, enriched by the fixture of their capital.

- Sec fubfequent note $\mathrm{F}$.

I Fy 1 cmpriers we are informed, that, in Morocen, the lands all belong to

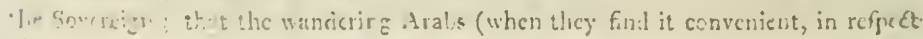


The mof important agricultural improrements are of flow return; the capital, meanwhile advanced in effecting them, muft be fairly fixed in the foil; whence it cannot be withdrawn at once, but gradually, in the profits of each fucceeding ycar; and not entirely, till the expiration of that period which had been held in contemplation when they were made. If we attend to the complicated farming operations, neceffary to bring the lands to their higheft itate of production, but which yield no immediate adrantage adequate to the expence of their execution-fuch as, breaking up of wafte lands, with fallowing and liming-reducing the farm into a connected fyftem of fubferviency, by regular rotation of pafture and tillage-improvement of breeds of cattle, \&c. particularly if we take into the account, the expenfive operations of draining, enclofure, and accommodation of houfes-then fome idea may be formed of the extent of Seare neceffary to give the tenant a fulficient intereft in the execution of fuch pemanent improvements.

Let the tenant poffers at a rent not over racked; and let his leafe be of fuch extent of duration, that the advance of his capital, and of his farings, and of what capital he has credit to borrow, in executing impro:ements of the moft permanent duration, fhall afford a profpect of be:ter return, than under any other mode of their application; and fuch improvements will immediately be fecured, much more effectually, than by any fyltem of compulfatory regulations*. Under his frugal management,

of pafturing their cattle, to pitch their terts in any particular diffich, for fuciz length of time, as to allow thom to wait for the return of a crop) plough and fow what quantity they plcafe; the officers of ihe Crown go through the country, after harvef, and collect the tenth of the produce, in name of the Emperor's rent. It were to be wifhed, that our travcllers, inficad of conining their obfervations to the manners of cities, and the revolutions of political power, wonld attend to the moral excitements held out to agricultural industry, in the various tenures of poffirfion beftowed upon the actual culrivators of the foil:--the fuhjen is, at teaft, cqually interefting.

* Witnefs the improvements on the Nicidpath entate $\{$. IOf, et feguentia, of the Report). 
managcmont, too, annual favings would foon accumulate into a new capital; which, in his judicious and œeconomical mode of application, will go much farther in improving the productive value of the lands, than a much larger capital under the more lavifh expenditure of the independent proprietor; where alfo the application fo often tends to deviate from ufe to ornament.

The advantage of improving quickly, with a large capital, and the whole farm at once, rather than flowly, gradually, and partially, as ftock thall accumulate by degrees in the hands of the improver, is exceedingly obvious. But, where are fuch capitals to be found, as would at once reach to the extent of the improvement of a whole unimproved diftrict? Capital can alone be created from favings: according to the Scots proverb, the ground muf build the dike. Proprietors might, no doubt, pledge their lands, in fecurity of fuch capital as they might borrow; but capital is not to be had, to ferve all the purpofes for which it might be wanted. Upon proper encouragement of farming induftry, it would gradually accumulate in the hands of the tenantry, to ferve every agricultural purpofe.

The interef of the tenant, the proprietor, and the public, if well underfood, are ultimately the fame: viz. that the te= nant, under every proper encouragement, frould be exciled to the inprovement of the producive value of the lands. But, in regard to the duration of the leafe, the intereft of the tenant and the proprietor are, in appearance, immediately at variance.

It is, without doubt, the immediate interef of the propriftoi, to let his lands at the higheft poffible rent-to have them brought, during the leafe, to their higheft poltible cultivation, by the exertions of the tenant's incluftry, and the outlay of his capital-and to feize upon thefe advantages as fpeedily as may

be,

In an age of awakened induftry, enlightened, too, by more intcrchange of com. murication, nothing feems awanting, but proper moral excitement. The torpor that prevailed in Scotland till within thefe 50 years, may be, in part, afcribed to it. aencral ignorance; but partly alfo, no doubt, to the debufid ftate of the the i.r.rity, in refoect of their tenurcs. 
te, by granting the fhortent leafe that a tenant can be found to accept of ; and even that expofed to various chances of forfeiture. Such fhort-fighted avarice muft, however, overreach itfelf, and neceflarily defeat its own end; as advantages, that can only be reaped through the voluntary co-operation of others, cannot, in reafon, be expected, where the advantage is not mutual. If the rent is too much racked, or the duration of the leafe too fhort to encourage induftry or outlay, no fuch advantages can arife; and the tenant's folly or obitinacy may be very abfurdly blamed, when he merely refrains from doing what he has no intereft to do; where, with more juftice, the blame might be imputed to the narrow-minded and illiberal policy of the proprietor. The proprietor has it more in his power to let his lands in what manner he will; the tenant is more under neceffity of receiving them upon fuch conditions as can be obtained.

To think of fupplying the tenant's want of intereft, by compulfion in his leafe, is as idle, as to think of extorting, by the whip, from flaves, the fame ftrenuous exertions as may be excited in free men, when paid in proportion to the work they perform. All compulfory regulations enforcing improvements, in which the tenant enjoys not his equal thare of advantage, will neceffarily by him be evaded, or reftrided within the moft confined fenfe of the letter-a difinterefted regard to the public good, being as little to be expected in this clafs, or lefs fo, than in that of their fuperiors. But, fuppofing that fuperior cultivation could thus be enforced by regulation, without imparting to the tenant a proper mare of the advantage, and that the inmediate advantage refted all with the proprietor; the advantage accruing to the latter would, ultimately, prove to have been more apparent than real: For, if the tenant had been admitted to his proper fhare of the immediate profit, it would not have been diffipated; but would have accumulated, in his oconomical hands, into an addition of capital; enabling him, in proportion to his increafe of ftock, to afford mort rent for land, upon which it might be profitably occurpieci.

It is not eafy to determine what is the proper duration of a leafe. It may, with propriety, be fhorter upon a farn nirea- 
dy improved, where immediate profit is reaped by the tenant, without much expence of outlay. It feens probable, that, with few exceptions, the error through Scotland has lain, hitherto, in too flort duration. There is certainly, however, a juft medium of endurance, if it could be hit upon, neceflary to preferve the tenant in his proper ufeful character. Upon a leafe of exceffive length, though the original leffee night retain the profeffional habits in which he had been trained, even after he had accumulated confiderable wealth; yet his fucceffors might be tempted, however awkwardly at firft, to affume the mamners of thofe born to independence; to commence gentlemen; and, of courfe, to degenerate in their farming capacity. When fuch revolution of character does take place, public utility, as well as the intereft of all concern$\mathrm{ed}$, requires, that the farm were in better hands. It would pafs into better hands, if there is no claufe debarring affignation or fubfet; as a farmer of the true breed, poffefling the true profeffional character, could afford to give him more rent for his farm, than, with his new aflumed character, he could make of it by farming it himfelf. The grudge at feeing a profit thus made of his lands, in which he does not fhare, is, with fome proprietors, a reafon for preventing the power of fubfet; but the lands could never have become worth fo much, had they not been fo held by the tenant, that a profit could be made from them, in which the proprietor could not Share.

After all, though long leafes can alone, without doubt, Lead to improvements of permanent duration; and to the greater quantity of fuch improvements, in proportion as capital, under the adminiftration of the tenant, will go much farther than in any other hands: yet, neverthelefs, towards the clofe of crery leafe, there munt be an unimproving interval, during which, all attempts at melioration on the part of the tenant muft ceafe; and where the compulfion of regulation, under penalty, nutt be fubfituted to the fpur of felf-intereft in the tenant, to enfurce melionation, or to prevent deteriora-

tion. 
tion, - A weak and ineficient fuccedwem, whofe effect will ever be attempted to be declined and evaded.

'To remedy this defect, Lord Kaimes (probably the firft who has conficlerci farming in the view of its proper moral excitements) has fuggefted the indefinite, or perpetual leafe. He propofes, that the tenant fhould pofiers the farm at a rent certain, and for a term of years certain (fuppofe 20 years); after the expiry of this firft term of years, that the tenant fhould continue to poffers for a fecond term of 20 years, the rent for this fecond period to be advanced in a fpecified proportion (for example, to one third part more than for the fint 20 ); and fo to continue, from 20 years to 20 years, upon proportional rifes of rent, ad infinitum - with fuccefion, undoubtedly, to heirs, and liberty of alienation; without whicl, even this leafe could prove no proper inducement to induftry. As, however, at the end of any of thefe 20 years periods, it may fo happen, that the tenant thall judge the fpecified rife of rent too much for him to pay; or the landlord fhall judge it too little for him to accept of : It is therefore farther propofed, that it Mall be optional to either party to vacate the leafe at that period, upon giving twelve months notice to the other; when the farm fhall be laid open to the competition of bidders; with this provifion, in favour of the prefent tenant, "thit he thall be at full liberty to bid for the farm; and that either his offer hall be accepted, or otherwife he fhall receive from the proprietor fo many years (iuppofe i 5 years) purchafe of the advance of rent ofiered by him ; " it bcing left optional to the proprietor to do either, left the tenant hould offer advance merely with a view to the purchafe-money.

In this manner, the proprietor would be certain, at moderate intervals, of receiving a rent adequate to the improved value of his fubject (at leaft, if proper provifion in the rifes could be made to correfpond, not merely to the nowey price of the improvement at the time of fixing the provifion, but making allowance for the cventual variation in the value of money*); whilt the tenant, meanwhite, would be encouragr'T t ed

" Perhaps, this could nut be dose, but making the rest in erain. (Ses p. 86. of the Report.) 
ed to go on improving to the very end of his leafe, under the certainty of either receiving back the farm at fuch a rent as he could readily afford, or of obtaining an adequate compen- fation, if another were preferret to the leafe.

Befides the difficulty of fixing the rifes of rent at the end of each of the 20 year periods, fo as to keep (in a money rent) due proportion to the eventual value of money, other difficulties prefent themfelves, as to this effurt of Lord Kaimes at the idea of a perfect fyftem of continual moral excitement to the tenant's induftry.

I mo, As, under this fyftem, the farm is locked up, ad in finitum, again alteration; it muft have been fo perfectly conItructed, as to its fize, for the moft profitable occupation, as to seed no alteration in this refpect; otherwife, this advantage can never afterward's be obtained. But how is this to be perfedly forefeen?

2do, All improvements of the eftate at large, to which is might very probably be neceffary to facrifice the particular intereft of this fingle farm, are precluded, from the unalterable nature of its conftiturion.

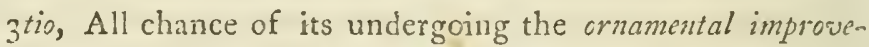
ments, at the leaft, which fuit an abfolute and perpetual proprietor, are excluded; as it can never fall out of leafe.

The cxtent of the right of property in bis leafe, which is communicated to the tenant, falls next to be confidered.

The univerfal prejudice in regard to the propriety of cramping, flackling, and circumfcribing the extent of the tenant's right of property in his leafe, through the proprietor's retention of the right of deleztus perfona in the tenant, by which the latter is deprived of the power of alienation of his right of leafe, has been alreariy akiverteci to in Note B. It hath originated in that particular caft of thinking, which has been impreffed upon us, throngh familiarization with the ufages of the feudal law; which would lead us to force into an unnatural analogy with thefe ufarges, a fubject, which bears no fort of reference to feudalifm, and which ought to be regulated upon principles dianctrically oppofite. 
Had there been any propriety in enforcing, in regard to cuiwivating tenantry, the fame perfect dependence upon the proprietor, as, in times of turbulence, was necefiarily enforced in snilitary tenaniry, upon their military chief; then, the cultivating tenant ought never to have obtained the fmalleft degree of emancipation-he ought to have been rctained as a mere tenant at will: 'The cultivating tenant of one property-chieftain ought never to have been forced upon the acceptance of another property-chieftain ; and the act 144,6 was an iniquitous encroachment upon the inherent, inalienable rights of delectus perfone of heirs and of fingular fucceffors: The cultivating ufufructuary tenant ought, like the military tenant, to have been ever confidered as identified with his mafter; and ouglit to have continued anfwerable for his debts, as the other for his depredations: And the act i 466, relieving him from fuch refponfibility, mut alfo be confidered as a violent and iniquitous interference, diffeyering a connexion which ufage had imprefted with the character of nature.

The principles applicable to a niilitary tenant, are as oppo. fite to thofe applicable to a cultivating tenant, as the principles which regulate fighting, are to thofe which regulate induftry. $\Lambda$ bfolute defpotic rule is alone fuited to the foldier; but induItry is extinguined by its touch. When the cultivator of the foil was fitted to become a farmer, properly fo called, (cultivating the foil, at his own rifk, by the outlay of his own ftock, and paying rent to the proprietor for the ufe of his foil), it was found indifpenfably neceffary to depart from nilitary maxims, under which the tenant's induftry could not pofibly thive; and accordingly, the fecurin of the acts 1446 and 1466 were extended to him.

Still, however, the fecurity of the cultivating tenant is, through the ridiculous adhercice to the jus delectus, very far from being fo full, as what is found necefliry to encourage induftry in other profeffions, requiring, like his, the induftrions outlay of a capital.

Suppofe a tenant holding a leafe, which is not of that long duration, which, ipfo facto, implies the relinquifhment of the jus delectus; and fupnofing he has no children; and fuppofing 
that his heirs are perfons whom he does not love, or whom he hates: If he iball fix his capital in improvenients of the foil, he cannot devife it to whon he will, as he has no power of alienating his leafe to whon he pleafes; but the right of leare to the farm, together with the capital he had fixed in it, is thus carried, by a fort of entail, to heirs for whom he has no regard. Is it fuppofeable, under fuch circumfances, that the tenant will ever fo fix his capital? Will he not rather retain it under his immediate pofieffion, and fubject to his own devifiment? He will be equally barren of improvement, as an heir of an cntailed eftate, fimilarly fituated in point of connexion; having, like him, but a mere liferent interelt in the fubjeot. (See page 35, and foot note, page 105.)

Or, fuppofing a tenant upon a leale, fubject to the embargo of the jus delectus, has no fanily but a daughter: What rational inducement can he have to fint money upon the improvement of his farm; when, after his death, his daughter mult either remain fingle; or, if fhe marries, muf incur a forfeiture of the leafe, through the abfurd fyfem adopted in Scotith law, of forcing the incongruous fubjects of tenures for the purpofes of fighting and of induftry, into analogy? (See page 297.)

Or, fuppofing a tenant to have a family of fons; as we are not yet arrived at the high civilization of being afforted by law or cultom into cafts (iee foot-note, page 254 ), it is very probable nune of the fons may chonfe to follow their father's profetion; but may have all fettled themfelves in more lucrative employments, which they could not relinquin, without great lofs, in order to take up the occupancy of the father's leafe, by facceflion after his dcath. Would any father, poffefled of common fonfe, or common affection, in fuch circumfances, launch out nore upon his farm, than what he liaci a profpect of reaping full advantage from during his own J:fe-when he know's, that, upon the event of his death, his fons are debarred, by the jus diectus, from reaping the profits of a liberal ontliy, by clifpofing of the reverfion of the leafe to the ben bidder; and that they nut either difpofe of it, by selineplining it to the groprietor for nothing, or for any thing 
he pieales to allow; or otherwife continue thenfelves the pofieftion, under the unprofitable management of an overfeer, acting at their rifk, and without any intereft of his own at nake*?

In all thefe infances, whatever may be the fecurity of duration, nominally ppecified in the terms of the tack, the real intereft of the tenant amounts, in efied, to no more, through the operation of the jus delefus, than a mere liferent intereft.

Through the operation of the jus delectus, the tenant is, in a manner, an adforiptus gletie; he cannot id himfelf of his leafe to the beft bidder, fo as to recover the capital he had fixed in the foil, when a more lucrative profelfion opens to him; or when he might have the opportunity of transferring his fuperior fkill, and indutry, and capital, with the greateft. advantage to himfelf, and alfo to the public at large, to fome other farm, in fome lefs improved diftrict; where fuperior profits might be made, from the incapacity of inferior improvers to compete with him in offers of rent, and where his example might be of general bentit.

In other profeflions, it would certainly be confidered as a moft prepoiterous mode of improvement, to force capitals to remain where they were once fixed, or induftry to continue to be employed about the identical fuliject to which it was firft applied. What could we judge of regulations of trade, which fhould bind the trader to the continued occupation of the fume herring-bufs, or Woft Indiamain; or the mercliant to the fame flop; or the marufacturer to the perfonal occlipation of his cotton-mill?

Induftry retains univerfally the fame character: its proper excitement, to whatever fubject applicd, is fecurity and frecdont.

- A cafe of this kind eccurred lately in tlie farm of Blythbank, in Linton parith. A fpinted farmer, who had laid ont great expence in melioration, died at an carly freriod of his leafs. His heirs, oitcrwife engaged, could not take up the cccupancy; and lhe proprictor, had he ufed the powers of his jus dellofus, might have had she leafe given up for an old fong: He gencroully allowed them to difpofe of it to the bet bidder. Where, however, is the encouragement to improve: ment, when the rilis of forfeiture is only avoided theregh forbearance of the land. lord? 
dom. If there is a reluctance againft the inveftiure of capital in agriculture; if capital more freely directs itfelf to inveftiture in manufactures or trade, the reafon I fhould conceive to be extremely obvious. Capital will ever more readily be directed to thofe employments where it enjoys moft freedom and fecurity, where it remains molt at the free difporal of its proprietor, and where it incurs leaft rik of forfeiture.

In the acts 4416 \& $1_{4} 66$, the Scotifh Parliament broke through the analogy of fcudalifm, in favour of the fecurity of capital invefted in agriculture: Nor would it appear a very great ftretcin of power, in the Imperial Parliament, to break through the analogy of the military deletus, by deciaring an unaffignable, inalienable leafe (excepting, perhaps, in a very few fpecified cafes) to be a frocluin illicitum-that crery encouragcment might be held out to the invefting of capital in agriculture, by rendering it cqualiy unfettered, as to ufe and transference, when fo invefted, and equally fecure againt rith of forfeiture, as when invefted in any other induftrious occupation.

For obvions reafons, Parliament will ever be reluctant againt interfering with the free ufe, or even abufe, to a certain extent, of property. And every reftraint of this kind upon agricultural induftry might be removed, by the terms of bargain, by landed proprietors; who might exprefsly renounce the jus delectus, confidered as inherent in them, in the eye of law; - unlefs, indecd, pofiefing heirs of entril night be confidered, in fo doing, as acting ultra vires, in thus trenching upon the inherent prerogative of the heirs of provifion of the cntail.

In many cafes, the jus delectus muft operate, in the ftrongeft manner, in reftraining the tenant from ever fixing his own capital in the foil: in all cales, it mult militate againf agricultural credit. Where the leafe is crickable at law by creditors, this entitles them, not to difpore of it by fale to the lighteft bicider, but merely to adminiftrate for the tenant. Farmers night do fo, though witl confilcrable inconvenience: monied men, not profcffional farmers, might ruin themfelves by fuch adminiftation. But where the proprietor debars all affignation, whether legal or voluntiry (a folly, of which, it feems, they are fupnofed capable, as the law miakes provifion for the cafc); 
caie); even this recourfe, for the money lent to the farmer, is denied. Under the reftraints of the delectus, a monied man would juft be as fcrupulous of lending money to a farmer, upon fecurity of his lcafe, as to a poffefting heir of entail upon fecurity of his eftate. (See foot-note, page 315.)-The latter will, in gencral, more cafily obtain credit, from his real or fuppofed political influence; through the delufive influence of which upon expectation, the lender may fwindle himfelf out of his money, relying upon a fecurity of repayment, whicls has no exiftence but in his own imagination.

The reafons why leafes fhould ever be completely alienable, like every other fpecies of property unon which capital is launched out, are abundantly obvious. The reafons why the alienation of leafes fhould be ciogged by the proprictor's jus delectus, have never appeared to me to be of any weight : Some fuch reafons as the following, I have heard fuggefted.

The delectus lias fometimes been defended, upon the fuppofition that it gave a tie upon the tenant's political principles, in preventing the fubsitution to one with whofe principles the proprietor was originally fatisfied; of another, whofe principles he might have caufe to dillike. Were it a matter of fuch importance, that landed proprietors fhould have the regulation of the tenant's principles; and were it proper and expedient, for this purpofe, that fecurity hould be withdrawn from agricultural induftry; the beft regulation would be, that the whole cultivators of the foil fhould be kept as tenants at will. This, howerer, would be to attempt to preferve a country, after reducing it to a ftate not worth preferving; like to the policy of extirpating the inhabitants, to prevent their rifing in rebellion. To communicate a falie worth defending, I fhould appreinend to be a preferable mode of fecuring attachment to any cxiting orcier of things. In regard to the late danirer of the infurrection of the poor againt the rich, for the divifion of their funds, upon Roufeau and Godwin's fyftems of favage liberty and equality, I think it will not be cienied, that the eflential intereft at falke, in the farming clafs, had the moft powerful efeet in preferving the country from revolutionary madnefs. Much was certainly eilected by the fpirited and heartily affected fervices of the: 
Ycomany : Nor would the zeal have been lefs, in proportion to the largenefs of the capital invefted in agricultural induftry. And though, perhaps from miftaken principle, or perhaps from mifcalculation of confequences, and the defire of being of the fide of what was apprehended would become uppermoft, there night be exceptions among the Yeomanry; yet, from fimilar caufes, were not exceptions equally to be found among landed proprietors, and even titled nobility * ?

The delectus has been defended upon the principle, that if alienation was allowed, the proprietor would be fubjected to the rifk of getting a worfe farmer to his farm. But, upon the common principles by which other matters are regulated, the proprietor may be aflured, that, upon the fyftem of free alienation, the farm will always fall into the hands of the higheft bidder; and the man who gives noft, can do it in no other way, than from the raifing of moft produce at leaft expence, through fuperior kiil, or induftry, or capital.

Deraftations, it is faid, might be committed, in allowing a tenant's creditors, or aflignees, to enter upon his leafe. Such devafutions of an cftate, no doubt, inevitably enfue upon the creditors of the proprietor entering into his place, woith full conmand of the fubject : Nothing of this kind could happen from thofe fubftituted in the original tenant's limited right; as they can do nothing but what he could do-will do nothing for their intereft, but what he would have donc for his-and are obliged to perform cvery thing to which he was bound.

'The retention of the chance of forfeiture of the leafe, after the farm has been improved, by fixing in it the tenant's capital-if ever fuch an iciea was entertained by any pretending to the namic of gentleman-is unworthy of refutation. Under rifk of forieiture, who would rilk lis capital, when, in other profeffions,

* A ludisrous incilent happened in this county. -1 proprietor, through miftake of names, though, 110 dubut, in confequence of his having offered mott rent, let a farm to the ringleader of the county militia mob. The matter is of $n o$ confequence, however much fuch things may be maguified into importanee: Ally other he lad jitched upon might, in the courfe of a nincteen years leafe, lave become a militia mob leader; and might have necded a Tranent military exciution to enlighten him, and to kecp him correct. 
prefefions, it may be outlayed without fuch rifk? In an unaffignable leafe, tenants, no doubt, lay out their capitals under more or lefs ritk of erentual forfeiture; their fecurity lies in the faitls they repore in the honourable character of landed gentlemen; and I belicve there have been few inftances in which that faith hath been fruftrated. But of what ufe is it to retain a chance of forfeiture, when therc is no purpofe of exacting it when it occurs? An independent fecurity is furely $a$ more encouraging footing, for the liberal unreftrained outlay of capital, than the more precarious one, founded in dependence upon another's character. In the latter fituation, there is a degradation, which, other things being equal, would lead men of capital to prefer other fituations of greater refpectability *

The manners of the tenant have been confidered as a reafon for retaining the delectus f. Upon the general principle on which

* In the pattern county of Berwick fhire, improvements, feemingiy originating among proprietors, were completed, over the county, by tenants holding by leafes of from thirty to fifty-feven years endurance. In the fpecimens of leafes, exhibited in the Repont of that county, the tack is more or lefs ftrietly confined to heirs and fucceffors. And the exclufion of aftignees, of affignees legal or voluntary, and of executors and fobtenants, are found more and more explicitly exprefied, as we approach the prefent times. Were the proprietors become more and more anxious of retaining the chances of forfeiture, in proportion as land became more inl more improved through the rinore habitually liberal outlay of the tenant's capitals? Did the tenants ever apprehend, through preconccption, or from experience, that advantage would be taken of thefe excluding clanfes, when opportunity offered?

Thefe probabilities of sirtual forfeiture, which may oceur through the des lecius, as alrcady ftated, reducing the tenant's real intereft to that of a mere liferent, make it not unforeign to relate what has been fated to me, by Mr Alexander J)alziel, formcrly factor on 1.ord Glencairn's eftate of Kilmarnock, " that the very uorftmanaged farms upon that cftate (yielding, by far, the leaft produce, and probably, alfo, the leaft profit to the occupiers) wcre two, which had beer let, in liferent leafe, at a mere quit-rent, to two favourites of the family.' Here, thrungh the injudicious mode of its adminiftration, we fee an inftance of liberality, at once, moft expenfive to the donor, mont unprofitable to the receivers, and moft detrimental to tlie public, in condemning a proportion of the lands to a Atate of comparatirc fterility !

f A kind of morbid fenfibility is excited upon this fubject, from a grotefque ilentificstion of the preprister with his property, as if it, liturally, contituted his 
which lands are let, of preferring the higheft bidder who feerns to have fufficient ftock, I fhould apprehend, that little refpect is paid by proprietors to the companionable qualities of their future tenant; nor that they inrereft themfelves much in his being a man of wit or agreeable converfation, or whether his complexion is fair or black, or that he anfwers to the name of Hugh, rather than to that of Peter. If a regard to neighbourhood had influenced the mode of thinking, in law or practice, as to the delectus, it would particularly have appeared in urban tenements. But all leafes of thefe are, by law, affignable. The mere apery of feudalifm, is the origin of the delectus in the perfon of the farmer.

A more ferious objection to the granting a power of alienation, in whole or in part, feems to found itfelf in actual experience. From the miferable ftate of the actual cultivators, in the Highlands of Scotland, and in Ireland, under fubtacks held by them from the original general tackfmen of farms, an apprehenfion feems to be entertained, that if power of alienation, by affignment or fubtack, were granted in leafes, the cultivation of the lands would be, in a fimilar manner, devolved upon a parcel of mere beggars. In this objection, it appears clearly, in my opinion, that the effect is mifapprehended to be the caufe. It is the deficiency of farming capital, and the beggary of the cultivators of the foil, that give rife to the middlemen, or tackfmen; not the tackfmen that caufe the beggary of the cultivators. The mifapprehenfion, however, is readily fallen. into: It is not unprecedented in other fmilar inftances : It is like the prejudice which would lead us to conceive, that the retail hopkeeper enhances, inftead of cheapening, to the confumers, the articles got by him, at firf hand, from the farmer,

or

froper fuifance; and from a frained analogy, thence derived, betwixt the drefing of his land and the drefing of his perfon. It would indeed be an unjuntifiable piece of arrogance, in a valet, were he to delcgate the fhaving or fich-bruhing of his mafter to other hands, without confidering him as having a jus delectur in the matter, or afking his confent. It would, however, be a very fanciful fenfibility, that wonld lead a perfon to fcel as jealous of the handling of his coat, as of his natural pidermis; and to object to the tailor, whom he had entrufted with its repair, for ievolving the exccution upon his journeyman or apprentice. The tailor is paid; ilie farmor pays. 
or the manufacturer. In fact, the middle tack fman is only factor for the proprietor, who, rather than collect his rents from fuch a beggarly tenantry, choofes to let his lands a little cheaper to one who will be at the trouble of collecting, and who will thus alfo fubject himfelf to become bound for the whole rent *. No South-country farmer, who has gone to farm in the Highlands of Scotland, has ever yet been found to parcel out his lands among fuch minute beggarly cultivators, equally deftitute of both capital and ikill: He has ever found it more advantageous, to cultivate upon the ftrength of his own capital, under the direction of his own filll, than to accept of the ligheft rent which fuch tenantry could pretend to offer; and to give them more in vages, as fervants, than they could ever make for themfelves as occupiers of the foil. In confequence, is it not evident, that, even under the newly introduced occupancy of fhecp, Highland diftricts have become more populous? Without pretending to preternatural forefight, i flall, without hefitation, rilk the character of my fkill, in predicting, that, fo foon as effedive military force flall have reftored quiet, and fecurity of property, in Ireland, the fyftem of middle tackfmen, and beggarly cultivators, fhall inftantly difappear; whenever capitaled and fkilful farmers, from the improved diftricts of Britain, fhall, as no doubt they will, find it convenient to fettle in that country; and that there thall be, there, no more of minute occupancy of land, than what receffarily takes phace, spon the principles explained in the preceding Note C.

I ofier no kind of apolozy for dwelling, at fuch leigth, upon this part of the fubject. I know, that, in the opinion of various perfons, Agricultural Reports ought to be confined (as to general obfervation, over and above the mere report of facts) to practical directions to the farmer as to modes of farming. If proper encouragement is given to atiract capital to farming, eq:ally

\footnotetext{
* A cicrgyman of my acquaintance obtained, through fucceffon, fome old howfes, at Edinburgh Welt-port; they were occupied as low bawdy-houfes; and he gave a houfe to a crook-backed barber, for collecting the other rents. It was not the intermediation of the barber that made the other occupicrs whores; it was their being whores that occafioned the iutermediation of the barber, as tack fman of, or factor upon, the whole.
} 
equally as to other proferfions; by eftablining it in equal iecurity, as to poffeffion, and tranfmifion, and alienation; the farmer would need no more inftruction from byftanders, than any other profeffionalift, whom it would be confidered $a .3$ impertinence to inftruct: In an age of general knowledge and communication, he would find no difficulty in inftructing himfelf. It would be incongruous to attempt to inftruct a galley-1lave in the art of navigation, or a Weft Indian negro in the proper management of a plantation of fugar canes. Give men iufficient intereft in the praclice, and they will find out inftruction. The encouragement for capitaled men, to betake themfelves to farming, is good: it might be made better. If it is not equal to what is found in other profeffions, no capital will remain in it, but what has been addicted to it, through habit; and, of that, even a part may deviate into other employment. There can be no harm in bringing fuch an interenting fubject under difpaffionate difcuflion-though, unhappily, the prefs is oftener applied to the infamous purpore of inflaming the mob, than to that of enlightening the public.

The Extent of the Ufe of the Ssil, communicated by: the Leafe, is the newt circunifance to be confidered.

Though the independent proprietor cannot farm his own lands to advantage; but finds it ncceflary to his intereft to Ict them in leafe to the profeftional farmer; yet, it feens to be with reluelance, that he confents to part with the comniand and management of his fubject; and he parts with as little of it as poffibie. I doubt not but that the monied man might fect the fime reluctance, in relinquilhing the command of the money he lends at intereft. Je muft confent, however, to loie fight of his fubject entirely: He underftands not, nor pictencis to underfand, the fecrets of trade and manuficture; and his confidence mut be entircly placed in the men, and not the meafures. 'There can, on the contrary, be no fecrets in the cut-nf-doors profeftion of hufbandry; and every one affects to judige co what he thinlis he fees paling daily under his nofe. The proprictor, therefore, frequently affects to direct the wholc of the farning orcrations, duing the whole cowfe of 
the leafe. A refident proprietor, who has paid fome attention to farming, may, indeed, afume fuch direction, without aмy great degree of abfurdity: It is not a little ridiculous, to fee fuch direction affumed by a bufinefs man, of the profeffion of the law, very commonly a refident Edinburgh cit; and provided, probably, with one univerfal model, like the bed of Procruftes, to which all practice mut, equally everywhere, be adapted: With equal propriety might he, in general, prefume to regulate the practice of manufacture, or of trade, in thofe proferfionalifts who rent the houfes belonging to his employer, or who borrow his money at intereft.

Even when moft judicioufly planned, according to the exifting rate of agricultural fkill, refricted management, through the whole courfe of the leafe, is but of very ambiguous tenoiency. It may prevent the beft prefently known fyftem from retrogradation; an event little to be dreaded, as its fuperior production, if it is really an improvement, would infallibly infure its continuance-fo long, at leaft, as tenants, like orher prople, are fuppofed to be guided by a fenfe of felf-intereft: But, on the other hand, they as effectually prevent the trial, or even the adoption, of all new improvements, however fuperior. Perhaps, an improved mode of management may thus, fonctines, be forcibly introduced, a little fooner than it would have been roluntarily adopted *. The fubtitution of enforcement, unde: penalty,

- At the lar leafing of Count Lockhart's eftate in Clydestale, a mode of management was preferibed, $f \circ$ judicioufly planned, in reference to the foil, climate, and local circumftances; and fo confiderately atteative to the tenant's intereft and arcommorlation; and with fuch latitude $n$ f diferctional managcment, to fuit fuch crentual circumftances, as could not be forefecn or provided for-that, not only did the refrieted tenants fet about the prefcribed managcment, with unreluctant alacrity, from convietion of its tendency to freure their own advantase; but those alfo, who poffefed upon unexpired lesfer, liaile to no fuch refricione, immediatcly adopied the preferibed node of management.

In the inftance of the refricticd tenants, reftriation would appear to liave procucced the bef effects: In the infance of thofe not reftrictal, mere inilruetion had cqually good effects. So that this experiment is, as to infereuce, juit fo broad and fo long.- The reftrictions of management were planned by Mr Lowe, a profeffional farmer of long-tricd ability, experience, and integrity.-Stich men may gretend to preforibe rules to profofional farmars. 
penalty, to a fenfe of intereft in the tenaint, is, however, at beft, but an awkward, unikindly, and up-hill fort of introduction.

Let men of capital be attracted to the profefion of farming, by rendering the fituation of tenants as fecure and independent, and confequently as refpectable, as that of perions launching out their capitals in any other gainful profeffion, and no prefcription of management would be at all neceflary, during the currency of the leafe, in an age of awakened indurtry, arid of prompt and univeral communication. The tenant's intereft would lead him to wifh for, and'his means to procure, the very beft information; and he would infallibly be led to adopt that mode of culture, which infured the larget production. If $\mathrm{ca}-$ pital is banifhed from agriculture, by fuch refraints as beggars only would fubmit to, beggars alone can we have for tenants; and it is in vain to think of enforcing management, which they have not capital to execute, under the fanction of penalties, which they are unable to pay.

But though, during the currency, no preferibed form of management feems neceffary; though the matter may be, then, left to the tenant's fenfe of lis own intereft; yet, during a few years near to the expiry of the leafc, regulations would feem indifpenfably neceffary. For a few years, it is evidently the tenant's intereft, unlefs indeed he has aiready contracted for a new leafe, to draw from the land cvery thing it can produce, without being at any expence in recruiting its power of production, as he is not to fuffer by its enfuing fterility: Or, if it chance that the farm has been taken by another tenant, the connexion of long pofieffion (probably the only original right of appropriation of land) may mike lim entertain a fort of feeling of injury, upon lris ejection; and may lead him to adopt deteriorating practices, enuloufly, and to his cwn hurt, merely to gratify his refentment againft his fucceflor, who (as he half conceives) has ufurped his place. Refrictions, as to the laft three years of poffefion, would feem fufficient to fecure the intereft of the proprietor; whilft they prevent not (in a lcafe of 20 or 30 years endurance) the adoption of improvements during the currency; which, if evidentiy advantagcous, might, by mutual confent, fuggent alterations as to the reftricted years. 
In 57 years leafes, leading to fuch permanent improvements as thofe which, in Tweeddale, are carrying on upon the eftate of Neidpath, no reftrictions whatever would feem at all neceffary; as no farming pracice, towards the clofe, could undo what had been done at the begimning of the leafe.-(See p. 104, \&c.)

Reftrictions, in Twreeddalc, are but of late introduction.

In regard to hill fheep pafture, it feems generally underftood, that the outgoing tenant fhall not plough fuch land as had not formerly been in ufe of tillage. In regard to the arable croft land of theep farms, there feems no reftriction to have been in ufe; excepting, merely, that no dung fhall be carried off the farm, but thall be either applied to raife crops, or be ieft to the intrant tenant, at a fair valuation. As to the outfield arable land of theep farms, the practice feems not at all accurately defined. Attempts have been lately made by proprietors, to have it afcertained, that no fuch land fhall be broken up from grafs, without previous lining, teathing by folded cattle, or other manuring. As the meafure of the execution muft, however, be referred to arbitration, arbiters (who can have no equitable rule but the cuftom of the country) will fuftain a very lax execution, when melioration is enforced beyond the extent of cuftom: It would be, indeed, iniquitous, to enforce melioration upon the tenant who came to a fcourged farm, and of courfe expected, from cuftom, the fame advantage at his removal. Where there is pofitive law, or exprefs ftipulation, there can be no injury in being compelled to perform what was forefeen and affented to: It is iniquitous, to deprive any one of advantages he was reafonably induced to expect, by any ex poft facto law, regulation, or adopted interpretation.

The regulations, formerly, as to arable farms, extended no farther than what has been ftated as to the croft lands of theep farms.

In regard to the reftriction proper for the laft three years in arable farms, and the rotation land of theep farms, the following reftrictions would feem proper, and at fame time all that are neceffary. For the proper underftanding of their propriety, it will, however, be proper previoufly to ftate, That the term of entry to all Tweeddale farms is at Whitfunday, as to 
the pafture grafs and houfes; and to the arable land, at tile fë paration of the crop from the ground; the crop being the way going crop of the outgoing tenant * : That the poffefing tenant fhall, in his laft crop but one, fow out, with clover and ryegrafs in fpecified proportion, one fpecified portion of his rotation land, anfwering to one of its divifions in the courfe of rotation; the faid portion, the year before, having been under green crop fallow, with all the farm houfe-dung applied to it: That he thall, in his laft crop, allow the incoming tenant, or the proprietor, to fow grafs feeds, along with his crop, upon a fimilar portion of his rotation land; faid portion having, the preceding year, been under green crop fallow, with all the dung applied to it: That the Martinmas before the Whitfunday of his renoval, he thall plough a fimilar portion, which he fhall leave to the intrant to fallow; and that he thall lay no dung upon his wayzoing crop, but leave his dunghill to the intrant tenant, that he may apply it to his fallow green crop: That the intrant tenant fhall purchafe the hay crop at a fair conjectural valuation at Whitfunday, fown as per firft mentioned reftriction: That he fhall pay the outgoing tenant, per valuation, for the eftimated damage that may be fuppofed to accrue to his crop by fowing grafis feeds, per fecond mentioned reftriction, in taking nourifhment from faid crop, as wreeds: That he fhall pay for the third portion, left ploughed at Martinmas, for him to fallow, per third reftriction, at the rate of the eftimated profit which the outgoing tenant might have derived from cropping it: And alfo, that he fhall pay for the year's dung left, at fair valuation of its worth; or elfe, that the outgoing tenant fhail be at liberty to difpofe of it by open auction; in which cafc, the intrant tenant has, at leaft, the prefcrable advantage, of being excufed carriage.

Pcrhaps, it might alfo be cligible, that the intrant fhould have privilege of fowing grafs, to produce an carlier fward over

all

* 'I he cuftom in Tweeddalc is fo well underfood, that, inftead of the tack exprefing that the removal from the grafs is to be at Whitfunday, and from the alabic, it the feparation of the enfuing crop; mont of the tacks mercly bear, that the entry is at Whithindiy, and the removal at Whitfunday: The reft is underSterd. 
ail the crop; paying, as already fpecified, for the eftimated damage that might accrue to the outgoer's crop, by abftracting nourifhment.

The incomer wrould thus, at once, be fet a-going in the beft rotation fyftem prefently known; having fown grafs, for green houfe-feeding, the firft feafon; graffes fown, to come in the next feaion; fallow, for green Winter feeding the firft year, \&c. So that, at once, he would be in proper rotation, which he need not be again thrown cut of.

\section{Size of Farmis.}

IN regard to the fize of farms, as in regard to every other condition of their tenure, it is my opinion, that this fhould be left to regulate itfelf, by the effectual demand of the market; upon the fimple principle of zulo bids more?

More rent cannot be offered for a farm, under one condition of tenure, as to fize, duration, or other circumitances, than under any different condition of tenure; but folely from this caufe, that, under the former, it can be made to yield more produce, at lefs expence, than under the latter t. So foon, then, as there exifts in any country, a fufficiency of agricultural fkill and ftock, to occupg the whole lands in the mof profitabie, becaufe the moft productive manner, the intereft of the proprietor, and of the farmer, will both concur to reduce, in time, the whole under this moft productive mode of occupation. The farmer follows this mode for his own intereft and he who does fo, can offer molt rent for the farm. This is an irrefiftible tendency, which artificial regulation may foolinly attempt to counterad; but which will infallibly counteract every oppofing regulation. (See pages 202, 203, as a! fo the fubfequent note $F$.) *.

WhilR

I Morc produce at lefs expence, is a fyftem declaimed againft as inimical to population. The fame clamour might, with equal reafon, be raifed again máninery, in manufactures.

* The maxim of the Latin poet can no where be better appliedNoturam expelias furca, tumen ufgue reiwret. 
Whilf agricultural hill and ftock are deficient, farms may be either too large, or too fmall. They may be too large, when a farmer gets upon his hands a tract of defert wafte, which he has neither fufficiency of ftock to improve by furface culture, or even to plenifh up with cattle to confume the natural pafture; becaufe, through deficiency of agricultural ftock, the landlord found no competitors for a divifion, and wifhed, nevertheleis, to have the farm taken off his hands. They may be too little, when, from want of the proper eftablifhment of the fubdivifion of labour and employment, (towards which, too, there exifts an irrefiftible tendency, through the mutual intereft of all concerned-See preceding Note $C$, and page 48.), and of outlet to more profitable bufinefs, a farmer's family continue to occupy his farm in the unprofitable modes of minute fubdivifion, or of conjunct counterthwarting management; inftead of lending their ftock at intereft to one of the individuals, which would be more profitable, the reft betaking themfelves to other profeflions; and no relief being to be obtained by fpreading fuch minute capitals into the occupation of a greater extent of lands, as fuch farms would be too large.

Till fufficiency of capital has accumulated out of favings, we muft reft fatisfied with the beft practicable, inftead of the beft conceivable, mode of occupation. As ftock and fkill increafe, the intereft of all concerned begets an invariable tendency to the mott productive and moft profitable occupancy, independent of any artificial regulation to that effect, and in defiance of any regulation to the contrary. Our tribe of difinterefted politicians, who are continually torturing their brains in devifing fchemes for the public good, may reft fatisfied, that, if they are good for any thing, they will take place without any interference; if they are good for nothing, though the public good may be embarrafied, it will not altogether be defeated, by regulations attempting to enforce them. This natural tendency to arrangement, under the mode of moft profitable occupancy, is obftructed, through the reftraining in1luence of the proprietors' dilectus perfona, which prevents the alienation 
alienation of leafes, or commodious interchanges of lands held under leafe, on the part of the tenants; and by the cramping influence of entails, which obftruct fimilar profitable arrangements among proprietors.

The fubject being an interefting one, it may not be improper to enter into a more minute difculfion; and to endeavour to inveftigate the circumfances that conftitute the moft profitable mode of occupancy of farmis; together with the principles that lead to their dilatation to their proper fize, and to their circumfcription within their proper bounds; upon the fuppofition that there exilts a fufficiency of agricultural fkill and capital for the beft poffible occupation of the whole lands.

In every particular inftance, the fkilful and experienced profefficnal farmer is the only competent judge of the arrangement of any particular ditrict into farms, fo as to render each farm of the moft commodious conftruction for the moft productive and the moft profitable occupation. There are, however, cercain obvious general principles relative to farming; from whence any perfon of reflection, though but moderately fkilled in the practical details of farming, (as I confefs myfelf to be), may deduce fome decided general conclufrons as to the moft profitable mode of occupation.

Every perfon, in the flighteft degree acquainted with the fubject, muft know, that, in farming, every fcheme of management comprehends under it a long detail of practice, which muft be gone over within the feafon; as alfo, that there is a particular period of each feafon exclufively adapted to each particular part of the practice, which, if neglected, cannot again be recalled. This takes place, to a confiderable degree, even in a mere pafture farm, where the neceffary operations are comparatively few and fimple. It takes place, to a very great tegree, in an arable farm, where the operations are more numerous and complex: There, every variation of of the feafon; every clange of the weather, varying often, in our uncertain climate, many times in a fingle day; every variation in the ftate of preparation of the foil, or of the ftate and fituation of the crop; all conftitute emergencies, call- 
ing for inftant decifion as to meafures, and as prompt and vigorous execution.

In the fimilar fituation of war, to the opcrations of which thofe of agriculture bear, in this refpect, the moft ftriking analogy, every nation of the earth have ever perceived the neceflity of fubmitting the management entirely to the conduct of a fingle rvill:-from the fubject of the defpot, accuftomed to unreafoning, implicit, and inftantaneous fubmifion; to the fubject of the moft anarchical democracy of ancient or of modern times, where temporary will is the only law, and where the bufinefs of government might often be at a ftand, till the prevailing party could rid themfelves of the oppofition of their antagonifts, by the affafination or banifhment of their majority. In the like fituation of agriculture, the jarring of counfel and contention for preference of ichemes, are equally incompatible with that promptitude of execution, which, in both cafes, is alike indifpenfable: The inftant of execution muft, in either fituation, be feized, left opportunity evaporate during protracted deliberation: The republican adminiftration can only fuit finuations, where there either is no bufinefs, or a ôteat fuperfuity of time.

It would appear, then, one indifputable maxim, in regard to fuccelsful farming, "that, other things being equal, a farm can be occupied to much greater advantage, by a fingle farmer, where the management is directed by a fingle will, than conjunctly, by more than one, in conjund poltefrion.' Under fuch fingle nnembarrafied direction, a moderate proportion of intellect and of energy will go much farther towards profitable farming, than a much greater propottion of both, in a conjunct farm under conjunct management; where the time of action muft often be confumed in jangling contention about preference of counfel. Our Scotilh proverb is here moft ftrictly applicable, 'A mogen pot never played quall.'

Small farms, of fuch diminutive extent as not to do their own turns, that is, of fucls fmall dimenfions as to be infuficient to maintain upon them fuch an abundance of labourers and working cattle as fliall fuffice for cvery different work, which mut 
often be carried on at once in each period of the feafon, without being idle for want of employment for a great part of erery feafon; and where, of courle, neighbouring farmers are $\mathrm{cb}$ liged to join in mutual co-operation; implying, necefrarily, concurrence of wills; or otherwife to keep, each, an expenfive fuperfluity of labour in conftant preparation: Such farms may juftly be confidered as a fpecies of conjunct farms, and as liable to the fame defects, in point of productive conftruction.

So far as we have proceeded, it feems indifputably effential to the mont profitable occupancy, "that the farm fhould be held by a fingle farmer; and that it fhould be able, in point of fize, to afford conftant employment, at all times, to fuch a number of labourers and working cattle, as fhall fufice to exe. cute every neceflary operation, at crery time, without neceflity of co-operation.'

It is the evident intereft of every farmer, to afpire after the occupation of as great a quantity of land, as the extent of his capital can enable him to manage, in this plenitude of occupation; where every part of the farm is kept in its moft productive ftate, by fufficiency of labour; and where no preparation of labour is kept in readinefs for emergencies, but idle for the molt part; but where the whole capacity of labour is in conftant productive employment. And this appears to be the principle of intereft, which will uniformly cperate in dilating farms to their proper fize.

But what then are the principles which will confine farms within their proper bounds? And how are we to be fecured againft the fo much dreaded danger of farming monopoly? Will the circumfcription of farms enfue of itfelf, when matters are left to take their natural courfe, to be dircoled by thic fenfe of felf-intereft in thofe immediately concerned? Or muit we apply to the cuning mon to devife for us a fet of proper artificial regulations to counterad all natural tondencics in the fubject?

'To me, it appears clear, that this mattcr will, alf, aringe itfelf, in the beft poffible manncr; when things are left, with- 
out difturbance of intermeddling interference of regulation, to take their natural courfe.

For, perfonal undelegated managenent feems juit as effentially neceflary to productive profitable farming, as fingle direction. To conduct a farm by means of an overfeer, is the pitiful refource of an independent gentlenan farmer; when, with the habits of his fation, he commences practical farmer in detail; and the fuccefs is anfwerable to the fyitem. An intelligent, induftrious, and œconomical farmer, can outbid all bis farming profit, in his offer of rent. To what elfe, indeed, do farmers paying rent, owe their exiftence as a difinct clafs? Compared to the active, fharp, and interefted fuperintendence of an acute farmer, acting at his own rifk, and for his own fole benefit, the fuperintendence of an overfeer, without rik, and without profpect of proportional gain, is like the turning of ferious bufinefs into farce *.

Although the farmer's overfeeing of his own overfeer, is conducted in a much more accurately fifting manner, than the gentleman's overfight of his overfeer; yet, as the farmer can outbid, in rent, the gentleman's whóle profits in acting by an overfeer, it feems readily to follow, that an equally intelligent, active, and rich farmer, can readily carry ofl any farm from another farmer, who is obliged to commit the management of it to an overfeer; by being able to afford more rent for it, in proportion to the fuperiority of perfonal to delegated management.

Where, then, fkill and capital have arifen, fufficient for the mof profitable occupation of the whole lands, the bounds of the capacity of accurate perfonal fuperintendence, will limit the bounds of the lize of farm: The competition of equal capital, together

- Thicre are exccptions to all rules; there are cxceptions in this county : But our prefent bufinefs is with general rules, and not exceptions. The keen fenfe of f,erfonal interef muft aver be acknowledged a more powerful fpur to energetic induftry, than the gencrally more languid feufe of mere oblization of duty.

All overfeer, coming from a more improved diftrikt to one where improvements are lefs underftood, nuy, fur a while, excel the farmerz of the latter difrid, who farm at thcir own rilk, 
together with the fuperiority of accurate perfonal fuperintendence above that which is either too much diftracted, or under neceflity of being delegated, will neceffarily hom every farmer in within thofe bounds where he can occupy with moft advantage.

The limits of the capacity of perfonal fuperintendence, will, no doubt, vary with the different degrees of ftrength of intellect or of energy to be found in individuals; and the boundaries, within which farms will be circunfcribed, will keep pace with fuch variations. In farming, however, as in other profeffions, eminence is confined to a few; the generality are nearly upon a par; and even eminence is finite-and the monopoly of farms is a bug-bear.

The limits of perfonal fuperintendence will be lefs confined, in a pafture diftrict, in proportion to the paucity and fimplicity of the operations. It will, for the oppofite reafon, be more narrowed, in an arable diftrict. Even a fuperior ftyle of more accurate cultiration of each particular acre, will more and more circumfribe the limits of fuperintendence, as to the extent of land occupied; though not as to the extent of capital laid out, or of rent yearly paid. The beft arrangement of extent will neceffarily find its own way.

When Laputa projectors come gravely forward, the one with his fcheme of 100 acre farms, the other with his of 50 , and a third with a fort of agrarian cottage fyftem, it is dificult to determine, whether our fpleen or our laughter ought to be moved. So long as they fhall confine themfelves to the pragmatical pointing out of their proper interefts to the parties concerned, but who, it feems, have not fenfe to perceive their own advantage; in fo far they can do no ham, and the parties will judge for themfelves. When, however, they would attempt to enforce their fpecific nofmums by leginative authority, their interference is of a more ferious nature than mere pragmatical impertinence.

The Parliament of Great Britain has not been in the labit of carrying meafures by acclamation: A fort of prevalent, philofophic, native plilegm, feems unfufceptible of enthufiaftic admiration of the brilliant fchemes of projectors. The filent operation of the writings of the profound and ingenious Doctor 
Adam Snith, fecms to have given a check to the intermeddling fpirit of regulation.

In all difquifitions of this nature, ptiblic utility is the point of reference upon which all reafonings muft bear. In many inftances, however, privite duty ftands, in part, oppofed to public utility. It is moft conducive to public utility, that he who can pay the higheft rent, fhould be preferred to the farm, as he can only afford to pay it from fuperior production; yet there may be a call upon the landholder's generofity to prefer his old tenant, though, fron: inferior kill in rendering the foil producive, he fhould be unable to afford quite fo much rent. But, even here, the principles explained will have their operation : For if generofity is a duty, on the one hand, there is furely a degree of nodefty incumbent upon the expectant from liberality : And where, in confequence of more profitable occupancy, more rent can be afforded, an old tenant cannot have the face to afk from his landlord the facrifice of the whole advantage in lis favour: He will find himfelf therefore obliged to alter his accuitomed fyftem of occupancy to that fuperior one, upon the credit of which, more rent has been offered; that he may offer nore rent alfo, although he expects a preference without giving the mof. Productive occupancy, when adopted, enables high rents to be given; and high rents offered, enforce the adoption of the moft produdive occupancy.

In thofc violent changes, enfuing upon fudden and unforefeen rcvolutions, it may be impoffible to devife new methods of family fubfintence, upon difpoffefion: In thofe that take place gralually, through the progrefs of the demand for them, as they may more readily be difcerned at a difance, it is more cafy to provide for them: Yet, in an infulated fituation, like the Iighlands of Scotland, where there may be lefs information as to the various different modes of employment that may be reforted to, it might be cruel to introduce fuch changes, fo foon as the demand flould require, or as even public utility flould dictate.

In regard to the principles regulating the fize of farms, $x$ have been much indebted to a chapter, intended for part of a large work by the Board of Agriculture, which was circulated; 
Tnd whicin was drawn up by my refpected friend the late Rev. Dr Thomas Robertion, minifter of Dalmeny.

\section{NOTE E.}

Although this opinion is finctioned by the authrity of the late $\operatorname{Dr} \Lambda$ dam Smith, it feems admifible only to a certain extent.

Many facts are brought to light in the Englifh Reports, from which it appears (contrary to the commonly received notions in Scotland), that, in point of improvement, England in general falls far fhort of thofe parts of Scotiand where improvements have been of any length of ftanding. In particular, it appears, that the great bulk of Englifh farmers are kept in a mifcrable ftate of dependence, preventing all exertion on their part-from their poffeffing as tenants at will, without any teafe; or upon mere liferent leafes; or leafes of very fhort duration: under which unpermanent tenures, too, the whole mode of management is in general fpecifically preferibed, in regulations fanctioned by heary penalties; enforcing ofttimes a practice of hubandry the moft prepofterous and unproductive *.

If conjectures may be allowed, till a fufinciency of facts are eftablifhed to form foundations for certain conclufions; may it not be prefumable, 'that the extenfion of the right of franchife among the farming intereft, as adopted in England in the fruggle of Monarchy againft Arifocracy, has both given origin to nitre early improvements in that country; and has allo, fubfequenily, proved the caufe of their retardment?' In England, the poffeition of a farm by liferent leafe, from which the potfeffor can inftruct that he derives a profit of forty fhillings Sterling yearly, without deducting parliamentary or parochial

$$
\text { Y y }
$$

taxes,

- I am indebterl, for thefe views of the fituation of Englifh farmers, to Dr Robet:fon's agricultural chapter upon the fize of farms, and character of farmers. 
taxes, confers the right of voting in the election of a county reprefentative; a qualification fuppofed cqual, at the time of enactment in the beginning of the fifteenth century, to what 20l. would be now; from the difference of the denomination and value of money. As the moft urual mode of holding land in farm, for any length of endurance, known at the time of this enactment, was that of liferent leafe, it feems extremely probable, that the political iniportance, thus generally conferred upon the clafs of farmers, would procure for them the advantages of fecurity and refpect for their interefts, as an encouragement to their induftry, more early and more completely, than they were obtained, in Scotland, from mere views of indifpenfable utility, or enlightened felf-intereft. As, however, in procers of time, the poffeffion, entitling to the privilege, came, in courfe of the gradual depreciation of money, to be an object of trifling importance to both landholler and farmer; is it not equally probable, that the landholder would create, upon every farm, little liferent holdings to the extent of the qualification, merely for the purpofe of creating a voter to fupport his own political confequence; and (as the poffeffors of fuch fmall holdings could not live upon them, independent of a larger extent of farm) that, in regard to this larger extent, he thould retain them as tenants at will, or upon very thort leafes, in order to fecure their votes in abfolute dependence?

In this county, the inhabitants of the Royal burgh of Peebles held a fmall farm, for grazing thcir milk cows, from the Noblenzan who managed the political intereft of that burgh. They however poffefled it, as is prefumably the cafe in all fimilar fituations, only from year to year.

It would be worth inquiring into, whether the generality of Englifh tenants at will, or upon very thort leafes, are not alfo voters at elections? No improvements of importance can be expected from farmers having fuch unpermanent intereft. It is no wonder proprietors thould place little confidence in their management, and find reftrictions neceffary.

An injudicious extenfion of the right of franchife, may thus readily be conceived as a mearure which might reduce the enfranchifed 
enfranchifed to the moft abject ftate of dependent fervility, deftructive of all exertion. The extenfion of complete fecurity to every clafs, in regard to perfonal liberty, life, and property, is the vary life and foul of induftry; and this, in all probability, depends more upon the enlightening eflicacy of the prefs, under a form of government infuring publicity to all public meafures, than upon any precife diftribution or arrangement of political power, whether in the direct ratio of wealth or population, or the compound ratio of both.

\section{NOTL F.}

Do not the laws againft ufury fall exactly under the foregoing defcription?

It is without doubt proper that a legal rate of interef thould be fixed, at difierent periods, as near to the exifling market rate as can be guefed - to take place in all fuch cafes as afford no opportunity of making an optional bargain. Where, however, there is an opportunity of voluntary agreement, there feems juft as little need of legiflative interference, in fettling the terms as to the price of the ufe of money, as in regard to that of any other article in commerce. In all fuch cafes, the terms may be left, with equal fafety, to be fettled at the difcretion of the parties concerned.

Where capital, properly employed, yields a profit; it is certainly equitable that this profit flould be fhared betwixt the advancer of the capital, and the perfon who profitably employed it ; being the joint product of the one's capital, and the other's induftry. Even if borsowed merely to pend it, it is juft that its owner fhoukl receive, for its ufe, what he would have received from one who thould have employed it, fo as to replace itfelf with a profit; in the fame manner as it would be equitable in the proprietor of an horfe to exact the fame fare from one who hires him for a pleafure ride, as from another who hires him to wrork in his plough.-W What is given in chanity, or lent in friendihip, is out of the quention.--In the cale 
of money lent for hire, for mutual accommadation, upon mere principles of equity, it feems perfectly juft, that the hire, or intereft, fhould not be determined in an invariable fpecific proportion to the capital advanced, or at fo much per cent. ; but that the lender fhould receive more or lefs, in proportion to the profit which the ufe of money can afford. Nor can any ftandard be devifed for apportionating the refpedive fhares of profit betwixt the borrower and lender, but the exifing rate of the money market. Where capital is fearce in proportion to induftry, and its profits confequently high; an higher ratc of intereft will be afforded by the induftrious for the rife of capital: Where the reverfe takes place, the rate of interent muft be beat down, by the competition of capital for employment. Nor does there appear to be any iniquity in demanding more, or offering lefs, for the ufe of money, according as the market will allow, than for any other article in commerce. All laws, counteracting thefe natural tenclencies, will themfelves be counteraded. Laws fixing the maximum of intereft, and condemning an highcr rate under the name of ufury, are evaded, in difguifing the intereft received, under the names of preinizins for the rifk, copartneries, \&rc.; devices to which the conveniency of traders will give rife, and which the laws will, afterwards, recognife and fanction, as exceptions to the general rule.

Laws, in regard to the markets of grain, originating in mobbifh infligation, have fometimes fixed a maximun price, but never a minimum. In the fame mamer, laws in regard to the ufe of money, have, in cvery country where they exit, Hhown an anxiety merely to fix a maximum rate of intereft, and to braind all excess with the imputation of criminality; and probably, in almoft eviry linguage, there is a term equivalene to the term ufury, and, like it, implying blane. It feems pro. bable, that laws againft ufury have generally been enacted when legiflators were money-borrowera and fpendthrifts.

'llie legal rate of intereft is different in every different nation; it has varied in every particular nation, at different: periods: The criminalisy of ufury cannot, when, confit in exading five, ten, or twenty per cont. for the ufe of money; but in exacting more than the ufual sate of the markt. In all op. 
tional tranfactions, the rate of interent might certainly be left to the difcretion of parties, as well as the rate of any other marketable commodity: Nor does there appear any call for the ftatutory conftuction of fraud, in the exaction of more bire for the ule of msney, than the malket rate, into a fpecific crime; more than in that of exacting more than market rate for the ufe of an borfe', or the day's labour of a man. There feems even lefs neceflity for Legiflative interference to guard againf impofition in bargains about money, than in bargains about almoft any other fpecies of commodity: For whereas the quality of every other commodity may vary ad infinitum, under one and the fame denomination; the denominated money, fpecified in the bargain, is aiwajs of an afcertained value at the time: The horfe I hire or buy, may be, in any degree, ferviceable or unferviceable; and the workman I hire, may perform a good or a bad day's work: but the number of guineas or thillings, for the ufe of which I contract, mut prove, upon delivery, exactly what I contracted for.

Art may no doubt take advantage of ignorance and fimplicity, in exacting more than market value for the ufe of money, as well as in other things: There feems, however, no affignable reafon why fuch frauds might not be left to be profecuted at common law, as well as other frauds.

Doctor Adam Smith, however inimical, in general, to the presention of fufering matters to take their natural courfe, feems to approve of the regulation of intereft of money, as preventing the lending, at high interent, under rifk of itatutory infany, to enthuliafic projectors. I thouid, however, doubt, if progrefs, in any thing, is to be expected from mere dull plodders, confraing themfelves entirely to beaten tracks.

If heirs in reverfion borrow money, cither neceftarily or unneceflarily, (which is certainly is not the bufnefs of the lender to intermedlle with, haring no right of tutory controul), they.ought to bind themfelves to higher intereft, in proportion to the rilk of their fucceltion, and future capacity of repaying. Upon eventual fuccefion, if poffelled of honour, fuch heirs will undoubsedly fulfil their engagement. If they take adrantage of laws agninlt ufury, and rcfufe to fulfil 
it, the law will fanction fuch breach of faith: But, in fo doing, does not the law, at beft, only betray its partiality to one clafs of fwindlers, in preference to another?

The ftatutory infany annexed to ufury, throws the bufinefs of adventurous loan, upon high intereft, entirely into the hands of perfons regardlefs of character, who are thus put in poffeffeffion of an exclufive monopoly; and the projector, with dubious profpect of fuccefs, together with the heir apparent, with dubious profpect of fuccefion, are precluded from obtaining money upon the mont reafonable terms, from the prevention of free competition among thofe who have money to lend.

\section{Nore G.}

IN civilized fociety there will neceffarily arife two clafies of perfons, who may be confidered as unproductive: Firfin thofe who do not labour at all, becaufe their circumftances exempt them from the necenity of labouring: Second, thofe whofe labours themfelves are umproductive.

The firft confifts of thofe born to indepencient fortunes, who do not follow the bufinces of any particular profefion; who may be faid to be trained up to the erijoyment, and not to the acquifition of a fortune; and whofe fyftem of enjoyment may be, in any degree, dignified and rational, or irrational and mean: This clals comprehends the landed and the monied interefts. It was the clafs which, in the late feafuns of political ferment, was particularly fingled out by the Jacobinical levellers, as a public nuifance, and its funds held out to the poor as the fair fubject of divifion. Perfons of this clafs were reprefented as the lilies of the field, wobo neitleer toil nor fpin; as the drones in the bive, wubich confume, but do not muke the boney.

'This very fimple, and moft obvious truth, feemed to have becn either overlooked, through incapacity, or fupprefled, in malice-that the allowed exifence, with the perfect protection and security of this clafs, is indifpenfably necefary to the formation and exiftence of the clafs of the productively induftrious. 'The abfurdity of its having been ever called in queftion, is the only a- 
pology that can be offered for endeavouring to confirm a maxim,. whofe truth is fo obvioufly apparent. For induftry, unquentionably, is not at all a primary pafion; it is only a fecondary one: Its object is not ultinate, but refers to a farther end. Nobody is capable of the abfurdity of fetting about acquiring, merely for acquifition's fake; but for the purpofe, and in the view of future ufe and enjoyment: Take away the profpect of enjoyment, and the paftion of acquiring immediately becomes extinet. The paffion of acquifition keeps, indeed, exact meafure with the profpect of enjoyment-grows ruith its growth, and frengthens with its frength. Contract the profpect of enjoyment to the term of mere liferent poffeflion, and the pafion of acquifition will form itfelf into a confonn. ance with this limited profpect: Enlarge it to the fucceffion of heirs, or other natural objects of affection, and the fecondary paffon will undergo a fimilar enlargement. Thus, in countries where there is no fecurity of the tranfmiffion of poffellions after death, he who has acquired what he thinks will fuffice, according to his plan of enjoyment, for his own life, ceafes, we are told, to be any farther induftrious.-Hence, alfo, the high veneration for old trees; becaufe few plant-as the planter cannot expect, himfelf, to be benefited by the fhade, and has no direction as to the perfons who may enjoy it.Hence, in fhort, every indultrious exertion limited to the view of almoft prefent ufe; excluding the poffibility of the accumulation of extenfive capitals *.

In this inftance, as in others, the fecondary paffion, no doubt, will frequently ufurp the place of the primary; and attachment to the means, though originating folely in attachment to the end, will take fuch entire poflefition of the nind, as abfolutely to banith the original purpofe out of view; and the man, become thoroughly avaricious, will expofe himfelf to fuffer all the hardfhips of extreme poverty, from his original anxiety to avoid them; much in the fame manner as, in former times, the ftudy of the antient languages, undertaken originally as the only key to knowledge, came ofttimes to be con-

fidered 
friered as a primary object; to the total negled of its ufe. Eur the queftion is not, as to the modifications which the prinary paftion may undergo; but, as to the origin and the poltibility of the formation of the fecondary pafion: In which view, there can be no doubt whatever, but that the protection and fecurity of the enjoyers of fortune are perfectly indinpenfable to the original exiftence and formation of induftrious niquirers.

In this clafs of men of independent fortune, we expect to find an extent of intellectual range, in tafte and literature, fuited to their greater leifure-more of generofity, liberality, and difintereftednefs, though, generally, fomewhat lefs of enterprize and artivity, than what are to be found in thofe whofe habitual bent is directed towards acquifition-more of public fpirit, with more enlarged viev's of public utility, than in thofe whofe minds are narrowed to the continual purfuit of private interef. Their fituation, and the habits confonant to their fituation, poine them out as proper to manage matters of public concern. Our expectations may, too often indeed, be belied: and, without doubt, no clafs of men is exactly what it ought to be. Mrany of this clais may be confidered as mere fruges confumere nati-nere cunbercrs of the ground. Worthlefs, however, as they may chance to prove, their protection and fecurity is, neverthelefs, indifpenfable to the exiftence of the clafs of the induftrious-in a moral riew, juft as generally wortllefs *.

The fecond clafs of tire unproductive, are thofe whofe labours themfelycs are urprofuctive. To this clafs may be referred, inwyers, phyficians, and divines; together with the profefiors of the liberul arts; and thofe who cultivate the mere abfract

* In cvery ling by neture progrefisc, our entimation is formed by compar rifon. The general rate of attuinnent confitute; the findart of medincrity; within which, the great bulk wiil ever be comprehended. Lixtraorlinaly excefs or defiency, are alone comlidered as riferving of high fraife or cenfure. During Vie lute war, for exampic, fuch was the high rate of attainment in the Erition navy, in regard both to ilaring cnterprizt, and to lkilful, fpirited, and fuccefsful ex.cution; that the feaman conld expiet no more than mere jufification, ulio dit not Lot! undertake and exceutc what, it would, formerly, liave becn accounted ra.anisis cven incicly to huve attempted. 
abitract fciences of quantity and number. None of thefe, at leaft immediately, reproduce their confumption by their labours.

In a ranner more circuitous, a number of thefe labourers are, neverthelefs, by far the moft productive of all; tending to increafe, often in an almoit incalculable ratio, the effect of inmediately productive labours, by the difcovery and application of the mechanical and other natural powers. All of them have the common tendency of awakening the powers of intellect; without which, mere brute force muft remain pitifully circumfcribed in its operations. They all tend to enlarge the fphere of human knowledge--to aroufe, into energy, the nobler faculties of the human foul-to vindicate the fuperiority of the man over the brute. They may not, at all times, either immediately or ultimately, tend to produce wealth: But of what ufe is acquifition, but for the purpofes of enjoyment? And they hold out the means of dignified enjoyment, in which there is no debafement or degradation.

Mendicant idlers, who contribute nothing either to the ufe or to the ornament of fociety, by the labour of the body, or of the intellect, fall under neither of thefe claffes-are, abiolutely, good for no valuable purpofe-and deferve no toleration,

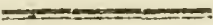

NOTE H.

IN a correfpondence with the late Doctor Robertfon of $\mathrm{D}_{21}$ meny, upon the proper fize of farms, I found, that the only advantage fuggented by him, in favour of fmall farms, was, the prevention of the too great, or the too early heightening of the market price of grain; in confequence of the necellity fuch fruall pofieffors laboured under, of felling immediately, to procure money, from deficiency of ftock to enable them to keep up their grain for a high price: not, however, that fuch advantages were either fo certain, or of fuch importance, as to call for either public or patriotic individual interference, in order to 
force the lands into fuch fmall divifions, to a greater extent than what would naturally take place in courfe of the demand for them.

In this view of the matter, the queftion as to the utility of fmall farms, naturally refolves itfelf into the queftion, as to the good or bad effects upon the market of grain, of a deficiency or fuperabindance of capital ftock in the hands of farmers, or other merchants of grain.

In the firft place, then, we fhall attempt to trace the natural and neceffary effects of a deficiency of capital.

Were we, thenl, to fuppofe a large proportion of the crop vefted annually in the hands of fmall farmers, who, from deficiency of ftock, are obliged immediately to bring their grain to market; and were this not remedied, by the intervention of a fufficiency of corn-merchants poffeffing ftock to enable them to buy it from them, and to abftract it from the confumpt-market, by ftoring it up; the confequence would be, an over-cheapnefs at the beginning of the feafon, which would caufe a rate of confumpt be entered upon, that would infallibly terminate in abfolute famine in the end of the feafon, were it to continue at the fame rate till all was exhaufted. Luckily, however, the remaining few of the holders of grain, who had capital fuffcient to keep it up (fo long as the market was glutted by the fales of thofe deficient in capital), would be enabled to overenhance their price nowv, in proportion to the over-cheapnefs that had prevailed before; proportionally to the over-fcarcity noqu taking place in the market, in confequence of the overplenty in which it was before fupplied: And this comparative dearth, which would of courfe take place, would alfo be indifpenfably neceffary, in the view of public utility, in order to reduce the confumpt from its former extravagant rate, to fuch a rate as thould enable the remainder of the fupply to laft till the return of another crop.-To the confumer, the confequence wou'd be, a furfeit, fullowed by a fhort allowance, inftead of moderate, equal feeding; a cheapnefs, followed by a proportional dearth, inftead of a moderate, cqual average price of the feafon; the dearti and farcity, too, aggravated probably 
by that abfolute wafte occafioned by the over-plenty and cheapnefs in the commencement of the feafon, which would not have taken place under the average price. - The advantage, it is evident, could never accrue to the confumer; it would remain entirely with the few furmers or corn-merchants poffeffed of large capitals: What takes place in every bufinefs requiring. capital to carry it on, would take place here-where copital is fcarce, its profits are bigh.

In the fecond place, let us attempt to trace the effects of a fuperabundance of capital.

Upon this fuppofition, as none of the holders of grain would be under the neceffity of felling it immediately, it might be withheld from market till an over-dearth of price took place, from mifcalculation, in the holders of it, as to the exifting fupply of grain in the country; a fubject fufceptible only of a rough guefs, even by thofe who have the ftrongeft perfonal intereft in afcertaining it, and far lefs afcertainable with precifion by Magiftrates, or by the Legiflature. In proportion, however, as the victual-holders felt a flacknefs in the demand at the exifting prices, which made it feem probable that a furplus would remain undifpofed of in their hands, they would certainly endeavour to avoid this, by lowering the price, as every other dealer would do in like circumftances, efpecially with a commodity of fo perifhable a nature. Upon fuppofition, then, of the wort effects to be dreaded from a fuperabundance of $\mathrm{ca}-$ pital, the confequence would juft prove the reverfing of that ftate of the market which has been noticed as the effect of at deficiency: The confumer might firft experience a temporary dearth and fhort allowance, to be followed by a fucceeding proportional cheapnefs, and full allowance.

In judging betwixt the worft effects to be dreaded, as to the rate of the market, from a deficiency on the one hand, or, on the other, from a fuperabundance of capital in the poffeffion of farmers, or other merchants of grain; the two alternatives are left to the confumer to decide upon, viz. (to ufe an homely phrafe) whether he would prefer, firft a burft, and then a hunger; or, firft a bunger, and then a bur $f$. 
The effects of deficiency are, however, necenfary and unavoidable. From the necefitous fituation of fuch dealers, their conduct is not with them a matter of choice. In regard to the capitaled corn-holder, his conduct is optional, and no way forced upon him by the neceflities of his fituation. It is in his power to alleviate the dearth which enfues, upon witlholding too much his fupplies, from mifcalculation of the crop; and it is as evidently his intereft fo to do, by then bringing forward his fupplies more liberally, left they fhould reft undifpofed of upon his hands. Where there is univerfally a fufficiency of ftock among the dealers in grain, none of them are then obliged to fell in glutted markets; none of them can withhold from market, in any reafonable expectation that others are obliged to fell in glutted markets-to the increafe of confumpt from cheapnefs, and the enhancing of the price of the remaining fupply, through the thus occafioned fcarcity. As every one is equally ready to fupply the demand as it arifes, and as each is equally enabled to withhold from glutted markets; the tendency of thefe univerfal efforts of the whole dealers is, to keep the fupply and the price at an equal rate through the feafon. Nune can form a reafonable expectation of felling at a price above the average price, proportioned to the plenty or farcity of the crop; and it is the intereft of each to fell, fo foon as he can obtain what, to his beft calculation, is the average price. Where capital abounds, its profits would thus be reduced, fron competition.

Jurging of the deficiency or abundance of flock in the hands of farmers and other corn-dealers, by the fluctuation or fteadinefs of the price of grain, we flould feem in moft danger of fuffering inconvenience from its deficiency; for though the certain profpect of a very plentiful crop will fometimes produce a fall, in price, of the remainder of the preceding crop upon hand, yet, in general, the price is higher towards the termination, than the commenccment of each crop. Lefs variation, in this refpect, takes place now, it is believed, than what took place twenty or thirty years ago; which is a favourable fymptom of the increafe of agricultural ftock. 
The fluctuation or fteadinefs of the market price of grain, through a fingle feafon, feems greatly to depend upon the deficiency or abundance of capital ftock in the hands of farmers and other dealers in grain; except in fo far as the immediate profpect of more than ordinary plenty or fcarcity in the fucceeding crop, has an effect in lowering or heightening the price of the remainder then upon hand. The enormous variations in price, which take place from feafon to feafon, depend, however, upon the variations of the crop as to plenty or fcarcity; and the prices muft, of neceffity, follow thefe variations of the crop, till fuch time as fome method be invented of preferving grain for a continuation of years, fo as to enable the merchant of grain to embrace, in his calculation, a feries of feafons, inftead of confining them, as he does now, to the exifting fupply from the crop of fingle feafons.

Could a method be devifed, of preferving grain through a continuation of feafons, fo as to render it poflible (not merely, as at prefent, to transfer a fmali quantity of the furplus of one feafon of plenty, to the relief of one fucceeding year of fcarcity, but) to carry on the fuperabundance of feveral fucceeding years of plenty, to cover the deficiency of feveral fucceeding years of fcarcity, as was done by the Patriarch Jofeph, with the thoroughly ripened grain of Egypt, in the cafe of the feven years of plenty, fucceeded by feven years of barrennefs; and, were there abundance of capital in the hands of farmers and corn merchants to fuffice for fo extenfive an undertaking: In that cafe, the calculations of the market would no longer be confined to the mere exifting fupply of fingle feafons, but (through mere ftrength of natural fagacity, tracing the ufual run of feafons, though unaflitted by the revelation of dreams) might be extended to embrace confiderable periods of time; and night thus give a fteadinefs to the markct prices of grain, fuited to the average of years, inftead of that of fingle feafons ; reducing the variations of price to differences of five, ten, or fifteen per cent., inftesd of the prefent ufual fluctuation, from feafon to feafon, to the enormous differcuces of fifty, an 
hundred, or two hundred per cent.-In thort, the price of grain might then be kept to fomewhat of the fame unvarying fteadinefs as the price of broad cloth; and though a furfeiting excefs of plenty would thus be prevented, a dearth or a famine could never poffibly occur.

Till fome method is devifed, of preferving grain for a confiderable number of years, each ycar muft continue to depend, for its fupply, chiefly upon its own crop; and, in cafe of deficiency of the crop, as it is not in the porver of man to create grain out of notbing, fhort allowance becomes riecefiary, to prevent famine; unlefs the deficiency can be fupplied by importation from other countries. Suppofing the ufual annual confumpt of a country to be equal to the crop of an year of ufual plenty; and fuppofing, in a bad feafon, the crop to amount oniy to three fourths of that of an year of ufual plenty; it is evident, that if this crop is confumed at the fame rate as in an year of ufual plenty, it will laft only for nine months, and leave no provifion for the other three. It is fhort allowance, alone, that can then prevent a farcity from ending in abfolute famine.

Dearth is the natural means of producing diminution of confumpt, fo as to prevent famine; it is an harfh renedy, but a fure one; and one that wiil occur of itfelf, exactly in the proportion neceffary for that purpofe, if things are left to their natural courfe. Every farmer, or other dealer in grain, (whatever they may pretend to the contrary, to avoid popular odium), will, for their own intereit, endeavour to obtain the highef pricc that can be afforded; proportioning the price in fuch manner to the power of purcbafing, as that the awhole exiffing funply may be difpsed of at that rate, withont leciving on band any remainder andifpofed of. If the price is either over or under-calculated for that purnofe, the interent of the dealers will lead them to refify the mintake. If the price is orcr-calculated, it will foon be found, from the diminution of the demand, that the whole cannot be purchafed at that rate of price, and that a furplus mudifpofed of muft remain on hasd. 'To avoid, then, the diminution 
minution of price that muft take place upon that fuppofition, and to obtain, if pollible, the exinting price; more fupplics will be brought forward, and the greater influx to the market will, of courfe, reduce the prices. If on the cther hand, the price is undercalculated, it will as foon be found that the demand is fo great in proportion to the fupply, that, in a fhort time, there muft be a very great farcity; and that thofe who kecp up their grain, will then be enabled greatly to increafe their price. Thefe views will lead the dealers to withhold their grain, and to fupply the market in lefs profufion; till the increafe of price decreafes the confumpt, fo as to beget a probability of the alternative before mentioned. Under, or over-calculation of the price, or (what is in effect the fame thing) the too liberal or too fonty fupply of the market, will thus, of courfe, redrefs itfelf, from the views of the dealers to their own intereft. The intereft of the dealers and of the public, however feemingly at variance, would thus appear cxactly to coincide in the fame thing; viz. that the fitpplies foould be brought forzuard in that pro. portion, and (rubich is in end the fame) that tlic price foonld be fo proportioned to the powver of purclaafing, as that the cxiffing fupply frould laft throngh the webole feafon, without either a deficiency or a remainder. If, towards the end of the feafon, the appearance of the fucceding crop affords a certain profpect of plenty, it will then be the intereft of the dealers to get off what remains fpeedily, while a good price is obtainable; and the competition for fale in the market will lower the price. If, on the contrary, the fucceeding crop is more deficient than the one before, the certainty of a fill higher price, will lead the dealers to be more fparing in their fupply of the market: The price will, of courfe, rife; the confumpt will be diminifhed; and a part of the prefent crop will remain, to cover the deficiency of a ftill more feanty fucceeding one. It feems not eafily conceivable how thefe operations of grain-dealers upon the market, can ever be productive of any thing but the advantage of the public, fo long as they are directed by their own private intereft; a principle, for whofe conftant operation they may cer- 
tainly be trufted, till a more fteady principle of action thall be found to exift in human nature.

Men pinched with ftraits, are, however, unwilling to afcribe them to neceffity, becaufe againft neceflity they know there is no refource. They would therefore fondly wifh to attribute them to voluntary caufes; againft which they can, with more feafibility, utter their complaints; and from which they may flatter themfelves to obtain redrefs, by regulation. Hence, the invention of the imaginary crimes (as they appear to be) of foreftalling, regrating, and monopolizing; the call upon Government to interfere, by internal regulation of the market; and the inept affumption of this power, even by enlightened governments, from the impulfe of popular clamour; together with all thofe deftructive outrages fo often perpetrated by meal mobs. Had, however, thefe evil genii, the corn-dealers (who, like phantoms, haunt and difturb the imaginations of to many honeft people, in times of dearth) any interefted, or rather difinterefled defign in the death of the people, they certainly go very awkwardly about their bufinefs: Their defign might be moft rcadily, and with perfect certainty, effected, if, inftead of raifing the price, fo as to enforce diminution of confumpt, they fhould bring forward the fupply in the fame profufion, and reduce the price, fo as to communicate, to all, the fame power of purchafing, as in years of ordinary plenty. The exifting fupply, if juft equal to a nine months fupply of an ordinary year, would then moft certainly be confumed in nine months; and abfolute irremediable famine would be enfured for the other three.

1f, Monopoly. Of all imaginary evils, that of a monopoly of grain feems the leaft to be dreaded in a free country, or in any country. Stocks, perhaps, may be found, amaffed in fuch a fmall number of hands as renders combination poffible, which may purchafe up the whole of an article, exifting only in very limited quantity, fuch as fugar or fpiceries; but, in regard to an article of univerfal confumpt, and raifed in quantity to anFwer an univerfal, a conftant, and a daily confumpt, it is impoftible 
pollible to fund ftock fufficient, in fuch a number of hands as are capable of combination, to command any perceptible quantity of that article. With all the advantages for combination potieffed by manufacturers, and with all the exclufive privileges which they have generally had the addrefs to procure from every government; was there ever any apprehenfion entertained of a monopoly of the general clothing of a country? How much lefs reafon, then, is there to apprehend a monopoly of the article of general food; which certainly would require an extent of ftock three or four times greater to command it; where thofe who firft raife it, and in whom the property of it is firft vefted, are, from their difperfed fituation, utterly unfit for combination *; and in regard to which, every government (fo far from beftowing cxclufive privileges) have univerfally fhown an anxiety to prevent an imaginary combination, which, in fact, feems impoffible in the nature of the thing? In the anxious fituation of a dearth, it is not, however, furprifing that the minds of the people fhould give way to the terror of imaginary evils and imaginary crimes; particularly, fince their belief in their exiftence, receives fanction from ftatutes, gravely cnacted with a view to their prevention or their punifhment + . When dearth occurs, the ftatutory crimes of monopoly and foreftalling immediately prefent themfelves to the terrified imagination; the alarm is given, and the cry raifed, that the dearth is artificial, that the criminals fhould be punifhed, and their wicked machinations counteracted. If by artificial is meant, wobatever takes place through buman conduct, in confequence of foretbought; moft undoubtedly; every dearth is artificial; being the refult of the $3 A$ conduct

- The impoffibility of a monopoly of farms, feems abundantly evident, from the principles which neceffarily lead to the circumfcription of farms within theit proper bounò; already explained in note $D$.

f Since the repeal of the peral ftatutes againft witcheraft, the belief in it hath ceafec? :-an horfe can now be guietly feen to die of the botts, without having his death imputed to the incantations of an old woman. Wore the natutes aguisst jureftalling, regrating, and monopoly, repealed, it is prefumeable alio, ilat a e'arth rould quic:ly be aferibed to the natural caule of fearcity. 
conduct of the dealers in grain, upon their calculation of the exifting fupply. If, however, the foregoing ftatements and reafonings are juft, it will be found, that, fo long as the dealers continue to act with a view to their own intereft, (which is furely the beft fecurity for their conduct that can be wifhed), their interefts, and that of the public, mutt exactly coincide, in fo proportioning the fupply and the price to the porser of purctafing, as, that the exifting fupply may laft tbrough the feafon, quithout deficiency, and leaving no remainder. The more extenfive the ftock, the dealings, and the information of the grain merchants; fo, in proportion, will their continued efforts to buy where cheapeft, in order to fell where deareft, tend to make the greater plenty of one diftrict contribute to the relief of the greater fcarcity of the reft ; equalizing, everywhere, the fupply and the price.

2. Forefalling. The hue and cry, in regard to monopoly of grain, feems to have greatly fubfided. What is called the crime of Foreftalling or Regrating, feems to be the crime of the day ; and, to judge of it by the newfpaper accounts of the exorbitant fines impofed in various inftances, it would feem to be confidered as a crime of a deep clye. So far as it is poffible to collect the meaning affixed to the term foreftalling or regrating, the effence of the crime would feem to confitt in the practice of buying, upon a markst day, aricles of food of any kind, already upon their road to market, or arrived at the market; with the in tention, manifefed by the overt act, of felling them over again, with a profit, in that market-place, and upon that fame day. There is furely, however, no crime in fimply dealing in victuals, with a view to profit, more than in drink, or clothing, or furniture; or any other fpecies of merchandize. The criminality, if there is any, muft originate in the circumftances under which they are bought and fold. It appears difficult, however, to conceive wherein lies the criminality of buying, to fell over again, with a profit, upon the market day, more than upon the day preceding, or upon the road; or in the market-place, more than in an houfe, or in a field. To attempt to impute criminality from fuch circumntances, feems about equally confiftent with the 
gravity and good fenfe of magiftracy, as to attempt attaching witchcraft to an old woman, by pricking her for the devil's mark.

An imperious public neceffity nay caufe an innocent action be conftrued into a crime; like that of the fentinel, who is thot for involuntary fleeping upon his polt: In thefe caies, however we may regret the imocent fufferer, the necefity of the regulation reconciles us to his fate. But, before we can confider the fines hitherto impofed, as any thing elfe than oppreflive; or the interference in any thape, as any thing elfe than impertinent; it would be neceffary to point out the neceflity of confruing into a crime, an ation, in itfelf confidered, which is neither cenfurable nor meritorious; to point out, as in the cafe of the fentinel, the harm that would enfue, from the toleration of a practice indifferent in its own nature.

There are only three interefts, to which the practices of the foreftaller can bear any conceivable relation, or can in any way affect: That of the foreftaller himfelf; that of the farmer or original producer; and that of the confumer.

In regard to the intereft of the foreftaller, it is evident that no interent has been, or is taken in it, either by the law, or by the magiftrate; it is left entirely to his own difcretion, though generally the moft in hazard of any of the three.

In regard to the farmer, in no country do the laws, relative to this fubject, feem to have originated in any view to his intereft; but to liave been obtained from another quarter. Every dealer, who fits in a work-fhop or behind a counter, within the precincts of a Royal burgh, feems to grudge that the farmer or victual-merchant thould obtain any profit from their refpective profeffions; and has the anturance to condemn, in them, the maxims by which his own whole condnct is regulated, of taking all the profit upon his commodity that the market will afford him; unfairly narrowed, too, as is the competition againft him in his own market, by the exclufive privileges with which his little corporation is invefted; enabling him to reap fo much over-proportion of profit upon the drink, or clothing, or furniture of his cuftomers, as lcaves 
them lefs than in due proportion to lay out upon their victuals. In every view of utility, the profefion of the farmer or the victual-dealer feems, at leaft, equally entitled to protection and encouragement, as that of any producer or merchant. Stunned, however, by the inceffant clamour with which his ears are continually affailed, and which is fo ready so overfet the firment conclufions of reafon; the magiftrate of a burgh, too, generally confiders it as effential to his official character, to fet himfelf in a ftate of direct hoftility againft the farmer and vidual-dealer. The contagion of fuch fentiments feems, alfo, more or lefs to have infected every legiflature; leading to the adoption of the mobbilh idea, of forcing every farmer to become alfo retailer; in the filly conception of thus faving the retailer's profit to the confumer; though, in contradiction to that beft eftablinhed of all political axioms, that, in proportion to the fubdivifion of labour and cmployment, more bufinefs is performed, in lefs time, and in better manner, and at a cheaper rate.

'The intereft of the foreftaller and farmer being out of the queftion, and, in fact, never attended to in the difcuffion; the only other intereft that can polfibly be affected, is that of the confumer; and the only conceivable manner, in which his intereft can be hurt, is, by the enhancing of the price of the commodity.

The confumer may, perhaps, in his great wiflom, conceive, " that, as the original holder of the commodity did, in fact, fell it to the foreftaller at a certain price; it was from thence evident, that faid holder was willing to have parted with it at that price: that, confequently, if the foreftaller had not ftept between, but allowed it to come to markct, the original holder reould bave fold it at that price: but, now that the foreftaller has paid that price, he avill not part with it without a profit; which profit, therefore, the confuncr muft pay.' 'This ftatement certainly contains every hadow of a reafon that can be adduced, to fubftantiate the hurt which can accruc to the conlumer. If the fallacy of his argument, however, does not appear from the italics in the printing, it will be abundantly evident from the following conficlerations. 
The price in the market depends, not upon any fingle intereft, or view, or will ; but upon the general combination of all the views, interefts, and wills, of the whole buyers and fellers in cumulo; when (after higgling and mutual explanations of views, with their reafons on both fides of the queftion, as to the prefent ftate and future profpects), the prices fettle in a rate conformable to what is generally conceived to be the proportion betwixt the actual or prefumeable fupply to the demand. To this alone, both fellers and buyers refer, in endeavouring to fix their ideas of what the market price fhould be ; and nothing elfe is by either taken into confideration. If the foreftaller has, or thinks he has, a clearer preconception of what will turn out to be the market price, than thofe upon their way to the market; and finds, upon trial, that they expect lefs than he imagines the market will afford; in that cafe he buys: If, on the contrary, he finds that their expectation exceeds his ideas of what the market will afford; he does not buy: well knowing that he can have no expectation of profit from the tranfaction, but upon the firft fuppofition; as the market price muft determine his profit, and not his profit the narket price. Had lis will to obtain profit, the power of regulating the market price, he would buy equally upon either fuppofition. He pretends not, however, to be poffefled of the withing cap of Fortunatus. Had fellers, inceed, the power of realizing their wifhes, bankruptcy would be unheard of among morchants.

The confumer buys in the narket at the market price: If the foreftaller has given more for commodities upen the road to market, he muft be contented to fuftain lofs; and it would be ridiculoufly fimple in him to think, that the confuner will conceive himfelf under any obligation to pay him more than market price, to prevent him from fuftaining lofs, or from going without, a profit. It would be an equally fimple conception in the confumer, or foreftaller-hunter, to imagine, that tire farmer (whole conceptions of the market price, while upon his way to market, fell fhort of what turns out, in filet, the price) fhould conceive himfelf as under any obligation to reft fatisfied with wubat be would then have been reiling to bave aciepted, when, upon arriving at the market, he finds he can obtain move: If 
he is conceived to be under any obligation to that purpofe, he thould be put to his oath as to the price he had expected, and be compelled to accept of that price.

The profit or lofs, then, from the previous operations betwixt the foreftaller and farmer, reft entirely between themfelves, according as either has formed the more juft preconception of the market price. Thefe operations can, in no thape whatever, affect the confumer, whofe price is uniformly the market price *

The foreftaller can hardly expect to obtain profit, by buying in a market, and felling over again in that fame market; as, after the market is feen, every one's ideas are more up to the market price. If, indeed, a knowledge of fcarcity has recently occurred (from failure of crop, for infance, elfewhere), which is, as yet, only in pofieftion of a few; he may, in that care, buy up with a profpect of profit; if not in that market, at leaft in a fucceeding one, by the time fuch knowledge fhall have become general; when, if his information turns out wellfounded, he will obtain profit; and his practice, inftead of proving hurtful, will only contribute to the more timely production of that dearth, which alone can infure that diminution of confumpt which is neceffary to prevent fcarcity from ending in famine: If his information turns out ill-founded, he will obtain no profit, but may fuftain lors.

Were we to fuppofe a chartered company, invefted with the exclufive privilege of purchafing all the grain and butcher meat of a country, at fuch a price as thcy chofe to give, and of compelling all the confumers to purchafe it from them, at a price fixed by the company: Or rather, to make the fuppofition bear fome faint refemblance of poflibility, were a government to aflume this privilege over a conquered country, and to enforce it by all the power of the military eftablifhment: In that cafe, it is at leaft a pofible fuppofition, that (in order to fave warehoufe room) the one half of the provifions might be deftroyed, and that the price of the remainder might be raifed fo ligh, as to force out, in the purchafe, the whole fubttance

* The market price is that to which evcry bargain tends, but which none attains: In cvery market, almon every particular bargain is made a litcle higher or lowcr than the average of the wliok, which is the markit price. 
of the inhabitants who did not die of want in the interim. Here would be, not an artificial dearth (which is ever neceflary to prevent famine, in real licarcity), but an artificial fcarcity with a vengeance; though, certainly, it would be a much more eafy and lefs circuitous mosle of obtaining the wealth of the inhabitants, at once to murder and to rob them. If one fcourging crop were thus taken off a country, it would be idle to expect a fecond.-It is probable, however, that fome monftrous chimæra of this nature haunts the inagination of foreftallerhunters; infpiring terrors, fimilar to, and equally reafonable, as thofe of children for hobgoblins in the dark *.

Mr Burke juftly obferves, in treating of the power of language to excite the paftions, that the effect is not produced in confequence of ideas conveyed, but merely through the power of fympathy. When, from infancy, we have been accuftom-

- Though the deftruction of provifions is a thing not unufual in meal mobs, I have heard of no infance of the deftruction of vivres by dealers, which feemed in the fmalleft degree probable; cxcept in regard to Edinburgh butchers, who, it is faid, fometimes bury their meat remaining upon hand after a glutted market, when beginning to grow tainted. 'Tis pity, any thing fhould be thus deftroyed, which can afford fuftenance to man: It were better fold, at a low price, to poor people. The fault, however, does not lye with the butcher, but muft be afcribed to the interference of regulation. The magiftrates are conccived officially bound to infpect the markets, and to take care that no damaged provifions are expofed to fale; a delinquency which they are empowered to correct, by forfeiture of the commodity, and the impofition of fines: To be catched in this mere fatutory dclinquency, expofes the perfon to a fort of ignominy, attached to it by rote. The magifrate, upon infpeeting the market, condemns, at difcretion, the fiefh meat which he confiders as damaged by taint, or even what he conceives merely to be too lean; and, $1 \mathrm{am}$ told, fends it to the poor's houfe. Rather than lofe his incat in this fort of ignominious manner, the butcher may be expected to buty it out of the way, fo foon as he apprehends rifk of its being condemned by the arbitrary power of a magittrate. As nobody, however, can be compclled by the butcher to purchafe his meat when it is tainted, or lean : it does not appear, that any harm could enfue from lcaving this matter cutirely to the difcretion of the purchafer. It feems liard, to deprive the poorer clafies of the option of having meat of inferior quality, at a low price, rather than no meat at all. Flefi mcat, lean from fcanty feeding, or too much exercife, is cren more wholefome than pampered, ftall-fed, fat meat. Even after it hath acquired a conliderable taint from keeping, fleft meat fecms no way noxious to the confitutions of thofe whofe Aomachs can re- 
ed to hear certain words always pronounced in the tone of indignation, we are, from fympathy, fired with the fame indignacion; the word and the paffion get affociated from habit; to that, when one is prefented, the other is exeited. This accounts for numberlefs prejudices of education, and might be illuftrated in the powerful effects produced by many words ending in ian or $i f m$. If we would with to rife fuperior to mere prejudice, we mutt analyze the fubject of our prejudice, to difcover, by its proper teit, whether it is weil-founded. I have known a perfon entertain a moft violent antipathy to fwine's fleh, though he had never tafted it in his life; and who, of courfe, could not know, by the proper telt, whether he really liked or difliked it. When we hear the cry raifed a. gainft foreftallers, regraters, and monopolizers; inftead of allowing curfelves to be hurried away by an inflinctive terror and anxicty for their extirpation, we would do wifely to inquire into the nature of the objects of our terror, that we may know whether there is real danger, or whether we ourfelves only are panic-ftruck.

Griin is a property diffufed neceffarily through fo many hands, that, unlefs an univerfal combination, fuch as never did, nor can happen, were to take place, the deftruction of any part could only redound to the advantage of thofe who preferved it, and to the lofs of the deftroyer.

Were

crive it. In country places, at a diftance from market, it is well known to be necurfy, cven in gented families, to keep fleth meat, for chance of ftrangers, till it bath often contracted a confiderable degree of taint; fo that moft of it is ufed in this ftate, and withert any fenfible inconvenience. In fhesp countries, the herdfmen live very much upon the Ach of fheep, deal of the ficknefs or iliac paftion, the very fmell of which is intolerable to thofe unaccuftomed to it; and they are a clafs of people who are certainly upon a par with any clafs inhabiting great towns, in point of forength, or agility, or foundnefs of conftitution. If fuch meat can be digefted by the aged and infirm in an alms-houfe, it could furely do no damage to the ftronger organs of a ftret-porter, or other day-labourer. It would be alffurd to fuppofe, that poifonous aliments are knowingly fent to the poor's houfe, in older to get rid of the penfioners! or, that the butcher is fraudulently made to incur a forfciture of his meat, that they may be fupported at his expence, withont charge to the funds. A zeal, without difcretion, may, however, betray the ben-iutentioned into inconfiftencies; or rather, an abfurd imputation of duty may force men ujon alfurdities, which they fee and lanent, but cannot avoid. 
Were the laws againt thefe imaginary crimes repealed, the welief in them might cerre, as in the cafe of witchcraft; and the magintrate might be faved much difagreeable embarrafineit.Innovation, however, is langerous; and it is, perlaps, better that they fhould die their natural death, by becoming obfolete. Meanwhile, it might probably be expedicnt to renit the cognizance of all fuch caufes to juries; who, as they juclge both of law and fact, might gradually caufe the whole to fall into nenexecution, in proportion as good fenfe began to prevail.

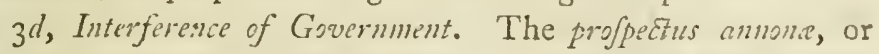
care of the annual fupplies, is a duty which every people have imputed to their governments, in the idle conception, that their governors, and not their own induftry, can, or ought to provide their bread; an imputation which frequently impels Government to interfere; fometimes, perhaps, in the conviction, though, furely, more often without any conviction, of their ability to effect the purpofe.

It might be an eafy matter, for the elder, or chieftain, of a tribe of American favages, to take an account of the whole annual crop of maize, raifed in common by the labour of the women, and all collected into one fpace round the Indian town; and to divide the whole in equal proportions among the different families of the tribe. In an extenfive, well-cultivated European ftate, where cultivation goes on, not in the languid manner of a general concern, but under the keen animation of a fenfe of feparate intereft, it is impolfible any government can either afcertain the extent of the fupply, or the proportion to every individual upon a divificn; or that it can attempt the violent feizure, and arbitrary difpofal of private property, without giving a check to induftry; the ruinous confequences of which would infinitely more than counterbalance any temporary advantage that might be conceived to refult from any fuch interference. The only proper interference of fuch governments, in order to infure plenty, is, not by temporary intermeddling, but, by general laws, protecting the cultirator of the foil, and infuring him of reaping the profits of his own induftry, both againft the oppreffion of his fuperiors, and the outrage of popular ferments. 
In years of ordinary plenty and cheapnefs, matiers are allowed to go on quietly in their natural courfe: In dearth, however, clanour rifes high; governments are loudly called upon to interfere, and are fometimes forced to interfere, or, at leaft, to affect a bufling fhow of interference, merely to prevent popular infurrections; though under conviction, that fuch interference, inftead of doing good, often tends to increafe the very cvil it was intended to remedy. It would certainly be a matter of much advantage, were the people at large duly apprifed of the effects to be expected from the interference of government; that it may neither be impelled, from clamour, into ruinous meafures, nor blamed for declining interference, where it might be productive of harm, and could do no good.

As it is not in luman power to creale grain, it is evident, that, in cafes of fcarcity, neither government, nor the richer claffes of the community, can do any thing to alleviate the fcarcity, or to procure greater plenty; but, by diminithing their own confumpt of grain, to produce a faving; or by contributing funds for the purpofe of importing grain ; or enticing adventurers, by a bounty, to import it, at their owil rin, from other countries - a meafure, which the partial range, to which man's benevolence muft be confined, to be adequate to his power, will juftify in a nation, though at the expence of other nations; but which will hardly be equally juftifiable in the adminiftrators of a burgh, in attempting to relieve the town, at the expence of the provinces; or in the inhabitants of a pro. vince, in attempting to interrupt the free circulation of grain for the relief of the town.-Even this interference, the only one that can really angment the quantity of grain, and really relieve the farcity, ought to be gone about with great difcretion; left the very idea of government interference flould augment the alarm of fcarcity, and, in confequence, lead to mifcalculation of the fupply, and increafe (for a tinse at leaft) the dearth $\%$.

In

* In the farcity of $1795-6$, the Pulliumentary hue and cry about dearth and fcarcity (when, from vulgar conception; or the defpicable attempts at popularity, 
In the way of internal regulation, Governments may, and do fometimes interfere, in times of fcarcity and dearth; though this mode of interference, efpecially of that kind to which governments are impelled by popular clamour, is always hazardous in the extreme.

In all modes of internal govermment interference with the fupplies and the price of the market, there is one principle which can never be departed from, without expofing the people at large to the moft imminent danger of perifining through famine, viz. that the price fould be fo proportioned to the powver of purchafing, as that a rate of confumpt firall be fecured, which foall infure the laft of the exifing fupply, till the return of another. If the price is fixed at an higher rate, the people are pinched more than what is neceffary; if fixed at a lower rate, famine muf neceftarily enfue.

Were governments never to interfere, but from decicied views of public utility; in that cafe, we would often fee anxiety difcovered to fix a minimum price, lefs than which fhould never be accepted, under fevere penalties, in order to infure that moderate rate of confumpt, which would prevent the crop from being eaten up before the return of another, the confequence of which would be irremediable famine. .As, how. ever, 110 government ever did, in the annals of liftory, nor ever will interfere, to fix a minimum price; it feems pretty erident, that views of public utility never did, nor ever will, fuggeft the propriety of any interference at al!.

'The

on the eve of a general clection, many frecches were delivered, which might have fuited the ringleaders of meal molss) moft certainly led to great mifealculation of the fupply; to confequent withholding from market, in a greater proportion than the due one : Of courfe, the dearth rapidly increafed, till Farliament were impalled to entice adventurers to import, at a moft extravagant bounty. The dearth, lowever, proved, in cricl, to have heen fo egregionfly mifcalculated, that it was found, that dearer victual was imported, to compete with cheaper in the home. rarket. The adventurers funained great lofs; and though application was made to Parliament for relief, none was afforded; which, all things conficered, ning ather a hard neafurc. 
The cnly interference of Government, of which we have, or thall etcr lave an account, is, in the fixing of a maximum price *.

The fixing of a maximum price can only be done (if public good is confulted) to prevent the dearth from being orer-calculated. Wherever there is dearth, however, it is orer-calculated in the imagination of the people at large. If Government ever is implled, therefore, to the fixing of a moximum price, it may be eftecmed certuin, that this price will be fixed at a lower rate than the exifting one; and (if it were in the powcr of any Government, which fortunately it is not, perfedly to enforce the regulation) the confequences to be spprehended are obvious.

It inay be alleged, that if a maximum price were fixed in deartin, even fo low as to be fo proportioned to the univerfat power of purchafing, as to allow every one to purchafe as much as he could do in an ufual year of plenty; that the effect would only be, to place the fhort allowance, necefliry in order to prevent a famine, upon the footing of option, inftead of that of necefity; and that every one, from conviction of the neceflity of the meafure, would roluntorily betakc himfelf to that fhort allowance, neceflary to make the exifting fupply laft till the return of another. Such a fcheme would appear, howcver, perfectly Utopian. Unlefs cvery one werc fuppofed to know, what it is impofible for him to know, the proportion of the exilting fupply to that of an ordinary year, fo as to know the proportion of abfinence that fell to his fhare, in proportion to the deficiency of the exifting fupply; and un-

lefs

- When the French Convention (apparently under the infuence of the Paris moal nob in the gallerics) cltablifhed the law of the rasimum, a fanine was confidered as the inevitable confiquence, by every pufou of reftation. Luckily for that people, there are meafures which the moft ferutinizing ty ramy cannot carry into full sfict.

With all the means of infurnation, and ability of cool inventiration, ponfleded ty a Britilh Lecifuture, no mealies of effective intcrnal interference were hazarded in $1795-6$ : Luckily they were not fo ovrawed. 
lefs the good faith of every one could be depended upon, for his voluntarily practifing that meafure of felf-denial which was neceffary, a famine would be the neceffary refult. How little optional felf-denial can be depended on, will, it is apprehended, be fufficiently evident to thofe who have a family of fervants that eat in the mafter's houfe. It is believed, no mafter, fo circumfanced, crer found his fervants willing to be contented with lefs victuals in an year of fearcity, than in an year of plenty. Such a propofal was probably never made by a mafter, from the certainty that it would not be liftened to *.

That

* Were the practice more prevalent, of giving fervants a certain allowance of mea! and money in their own houfes, in licu of viduals in the houfe of the mafter, the temptation of difpofing of the favings, at an high price, would uaiformly infure a confiderable degree of faving, in an year of fcarcity and dearth. Sclfinteren is an energetic principle, is excry fituation. In fituations of cofcurity, where the motives of ostaining credit and celebrity are not prefented, it is not to be expected that views of public utility fhould have fuch infuence. In the farcity of wheat in $1795-6$, it was eafier for our Sorereign to bring himfelf to the fe!f-denial of fubfituting the mcal of barley to the four of wheat in the Royal houfelold, than to perfuade the mcaneft of his fuljects in parih work-houfes to follow the cxamp!e. - In fcarcity, the dearth of price places the felf-denisl of the generality upon the certain fecurity of necer $y$, iuftead of the precarious one of Hion. Among thofe, however, who are fo 1 ich, as that the dcarth does not neccflarily enforce a change in their mode of living, fhort allowance muft remain

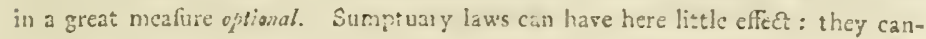
rot be fnfored, except at the expence of retaining a foy or excifeman in exery ioufe. As they adnit, thercfore, of no fanction, they amount merely to reconmendations. Pufors, howercr, in fuch fituations, are few in rumler; and as they live lefs on bread (everywhere the great article of fost among the genejality) and more upon butcher meat, though thicir hort allowance cannot be enforced by necefity, it is of the !efs corfenuence, as all their farings of bread conld have but an imperceptible effect in probicing moce plenty to the generality. Inconfiderable, howerer, as the amount may be, to which fuch favings could arife, it is certairly the daty of all, in fuch ftuations, to pratife faving; fro, as grain cannot be created, the only. Iting remuining to be done in fexicity, is to fare, that the fupply nay lant out the feafon. In fuch confpictous fiturtions, the credit to he ohtaned, by fetinz a Eood cxamph, will always infere a confiderable degrce of faving; paticularly, fo: inflance, ia tixe pamjuring of parade lories, where their greate!? Eanin cori.mp: lies. 
That a Legilature may fix a maximum price in fuch a manner as to incur no rifk of producing an ablolute famine in an year of fcarcity, it would be indifpenfably neceflary that it thould be perfectly apprifed of three things, neither of which can probably be afcertained by any Legiflature in a manner in the leaft degree approaching to precifion: Fir $l$, The rate of confumption of grain in an year of ordinary plenty: Secondly, The proportion which the exifting crop bears to that of an year of ordinary plenty: Tlirdly, The extent of the power of purchafing, in poffeffion of the whole confumers of grain. A maximum cannot, with any degree of fafety, be fixed, unlefs founded upon a perfect knowledge of all thefe data; fo that the price may proportion the power of purchafing fo exactly to the exifting fupply, as that a rate of confumpt may be enfured, which fhall enable it to laft till the return of another.

The Britith Legillature, in $1795-6$, however Atrongly impelled, and notwithftanding of its fuperior means and ability of information, durft not hazard a meafure fo evidently fraught with the moft imminent danger.

If matters are left to their orlinary courfe, the intereft of dealers in grain would appear evidently to have the effect of producing, with certainty, and without danger or violence, precifely what any enlightened Legiflature would propofe by internal interference of regulation, viz. the fixing of the price at fuch a rate, as fiall fo proportion the porver of purchufing to the cxiffing fupply, that it fisall laft out the feafon ruithout remainder or deficiency *.

- In the Anti-Jacobin Review, for February $180 \mathrm{r}$, it is obferved-' that a former is a diftinct being from every other fpecies of trader, who have all an alfolube properly in the articles in which they deal; while be can only have a qualified and conditional property in the fruits of the earth, which are neceffary to the exifence of man, and were exprefsly given by the Crcator for his lupport.' Then follows a dutuctio ad abfurdum, if it was allowed that his right was a complete property - as, that he might ftarve his cuftomers by refuing to fell, or by deftroying his commodity, \&zc. \&:c. 
In regard to individual patriotic interference, for the alleviation of fcarcity, it has been already obferved, that, as grain camnot poffibly be created, the only thing remaining to make the fupply fuflice, is to fave it, or to import it from other countries. In regard to interference, as to the power of purchafing; either by diftribution of money to increafe the power; or by reducing the prices, fo as to render the fame moneypower adequate to a greater extent of purchafe; it may be obferved, that this ought always to be attempted by the rich, in regard to thofe, who, from age, from ficknefs and infirmity, or from families more than orlinarily numerous, are unable to compete in the fcramble of the market with thofe who are not weighed down by fuch incumbrances: To increafe indifcriminately the money-power of purchafing to a few in a particular diftrict, would only give relief to thofe few, at the expence of the generality. An univerfal difribution of noney, would only bring more money into the grain market; but, as it could not augnent the fupply of grain, the effect of the competition

I wonld juft obferve, that, in fimilar fubjets, it is the general sule that ought to be inculcated; - the general tendency is to create exceptions, even long before we have arrived at that condition of neefity, wbicb bath no law. Thefe genlenen, very properly, inculcate the jus divinum of Menarchy, with the general propriety of paffive obedience and non-rcfiftance; and they would certainly reprojate the conduct of fuch as thonld manifeft a propentity to dwell upon the exceptions. Property in the fuhject to which induttry is attached, is the only proner excitement to induftry, in agriculture, as in every thing befide.

I take the opportunity of ftating, here, a fad relative to the operations of the foreftaller and producer, refing betzixt tisemfolves, as Atated pages $36,5,366$. In confeguence of (what I wonld conceive) an abfurd decifion, through which tho wholefale trade in hay had been condemncd uncer the head of foreftalling; a f irmer near Edinburgh refufed to deliver his hay to his merchant who had purchafed it, affecting a fertple of confeicnce, in encouraging the crime of foreftalling. The hav, it muft he obferved, had rifen in price from $I \mathrm{~s}, 6 \mathrm{~d}$. to $22 \mathrm{~d}$. from the date of the fale till the term of delivery. The morchant, intimidated by the recort decifiun, was afraid to have recourfe to legal modes of ensorcing the bargain. What was the confequence? The horrid guilt of foreftalling was, to be fure, not incure !: hut the farmer limfelf, inftead of lis merchant, fold the hay at $2=3$. 
competition would only be, to increafe its moncy-price; but the quantity which each perfon could carry home, would be exactly what it was before. Such a meafure would, indeed, in fome degree, counteract this direct effect; for, as fuch diftribution muft be at the expence, and tend to the diminution, of the funds deftined to fupport ufeful labour, the demand for fuch labour muft flacken in proportion; and, of courfe, the money-power of purchafing muft be diminihed in the one way, in the fame ratio in which it is increafed in the other.

This note was written immediately after the dearth $1795-6$. I thought it needlefs to alter it, in alluding to more recent examples; as the general principles, laid down, are of univerfal application.

N. B. - In explaining the mode in which the market of grain is affected, I have always taken notice, merely, of the operations of the merchant. The effect is, however, equally the joint refult of the competition of purchafers: To have continually noticed both, would have led to unfufferable tedioufnefsthough, affuredly, a merchant cannot fell, without finding others willing to purchafe. 


\section{APPENDIX, $\mathbb{N}^{\circ}$.}

Accoent of Whm, the Seat of Sir James Montgomert, Bart. of Stanbope, Late Lord Chief Baron of his Majefty's Court of Exchequer: With fome OBservations upon the Culture of Flow-Moss, and of Ploughable Moss, from Information communicated by bin.

Tre lands of Whim were purchafed about the year $173^{\circ}$, whilf in a ftate of nature, without cultivation or inhabitant, other than perhaps a fingle herdfman, by the Earl of Illay, afterwards Duke of Argyle; who built a fmall houfe, with offices (enlarged, fince, by the prefent proprietor), at the eaft end of a large flozu-moss, confifting of about an hundred acres of extent*; the depth of the mofs foil, before it had fublided in confequence of draining, being from twelve to twenty feet, and in feveral places more. The houfe ftands nearly upon a level with the top of the hill of Artbur's Seat, in the neighbourhood of Edinburgh. The object, it is faid, which the Earl had chiefly in view, in the choice of this fituation, was, the cultivation and improvement of the flowmofs; and the amufement which he promifed himfelf, in dif-

* Mufs foil, which hath formed itfelf upon a flat, or in a hollow, is generally the mon deep: from the almoft total itagnation of the water, it is kest perpetually in a ftate of 'femi-fludity, and remains level in the furface, like ariy Aurin fub-

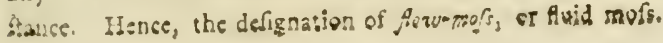


playing the triumph of the creative power of art, in newmodelling the nature of a fubject feemingly fo untoward and unpromifing: Hence the name, by which he defigned his place, The Whin.

Till his death in $176 \mathrm{~F}$, he kept a great number of workmen continualiy employed in draining, planting, and otherwife improving: Even after he became Duke of Argyle, he was, annually, in ufe of fpending feveral weeks at the Whim, in going and returning betwixt London and Inveraray.

Great expence was incurred by the Duke, in originally cutting the main drains through the mofs foil, down to the till-bottom, for a paffage to the waters collected in the lefier interfecting drains; as, in molt places, from the great depth of the mors foil, it was neceffary to ufe a wooden ftage, or fcaffolding, upon which the mofs was thrown from the bottom of the drain, and from thence to the furface. As the mofs, from this drain, was always fpread upon its fides, the weight of it caufed the fides to crumble down, and fall into the drain, each Winter, in much greater quantity than would otherwife have happened: So that every fucceeding Wintes created a neceffity for a repetition of the fame laborious and expenfive work, through the enfuing Summer.

The Duke's plantations upon the dry land, to the fouth and eaft, have fucceeded middling well; they have, in genesal, failed upon the flow-mois, excepting upon that part of it, which lies in the immediate vicinity of the houfe, where the mofs was effectually drained, and cultivated to a confiderable depth, previous to planting. Trees of different kinds had been planted, in ftripes, through the flow-mofs, along the fides of the main drains: 'Thefe lave not, however, fucceeded, excepting upon thofe places where the original foil (or till below the mofs) had been thrown up from the bottom of the drains, and been depofited, to a confiderable thicknefs, upon the' mofs furface; or where the mofs foil had, in its natural ftate, been of a more folid confiftence; in which ftate it is found, when lying above banks, or knolls, which had exifted 
ifted in the fubjacent original foil, previous to the formation of the fuperincumbent mols foil *.

The prefent proprietor has greatly reduced the expence of forming, and keeping in repair, the main drains through the flow-mofs, by working at them only in the Summer feafon, during the continuance of rainy weather; when the increafed quantity of water, from the fide cuts, occafions a confiderable current in the main drains; of which advantage is taken, in flooding away the mofs from the bottom of the drain, and thus faving the expence of throwing it out to the furface, by the help of fcaffolding: An operation the more eafily executed, as the foil of mofs, being of nearly equal fpecific gravity with water, is eafily floated in a very inconfiderable current. The trees he has planted upon the flow-mofs appear to thrive; care having al ways been taken to drain the land, by fide-drains communicating with the main ones; and to meliorate the foil, by repeated culture of potato crops in lazy-beds, witl lime, dung, or afhes, before planting the trees.

The

* In cutting the main drains entirely through the mofs foil to its bottom, it is afceitained, that the original furface of the ground (now covered by the flowmofs) is unequal-rifing, in difierent places, into knolls or banks. It feems probable, that the flow-mofs foil (confifting of decaycd regetable fublances) had originated in the pools of flagnant water, lodged in the hollows betwixt thefe knolls or banks; from the faccefive growth and decay of their aquatic productions, aided, too, in part, by the acumulation of fallen leaves and branches from the trees or thrubs which may be fuppofed to have grown upon the more elevated and dry parts of the original foil. As the mofs foil continued to accumulate from thefe caufes, it would gradnally fwell over the rifings in the original foil: chilling the roots of the trees and thrubs, with which thefe rifings might be covered, and at lat killing them; when, in courfe of decay, or by the force of the wind, they would fall down, broken orer or torn up by the roots, and be gradually fmothered up, and fmoothel over by the gradually increafing and feni-fluid mofs foil. 'Trees are, accordingly, found under the flow-mofs, lying along, with the torn-up roots attached to them; or broken over, with the root and ftump fill ftanding in the fubfuil. Previous to draining, flow-nofs produces only thofe aquatics, called provincially fog, which are of no ufe as panure: When fomewliat drained, heath fnrings up fpontancoully. 
The Duke's plantations (originally extenfive) have been improved and enlarged, fince the property came into poffersion of the Lord Chief Baron; and he has, alfo, greatly enlarged the houfe; adding a court of offices, upon a large fcale, and ornamented in front; extending alfo the lawn.-The place has, upon the whole, an air of magnificence.

In the plearure grounds, there are feveral artificial pieces of water. Eaft of the houfe (where the foil is dry, and covered with fweet graffes), the furface is agreeably diverfified by genthe fwells, tufted with trees. A wild wildernefs walk, through a fmall wood, lands you upon the banks of an artificial lake, with iflands, covering an extent of fix or feven acres of furface.

What chiefly frikes the vifitor at Whim, is the ftrong marked contraft betwixt the improvements of human art, and nature in her wildeft form, here found in immediate contact: Your ears are, at once, faluted with the warblings of the blackbird and thrum, from the plantations; and the wild notes of the plover, the curlew, the groufe, and other mofs birdes from the flow-mors.

Befides the improvement upon the flow-mors, by wood plantations (whicl effectually thut out its haggard appearance from the houfe and the approaches), it has alfo received a furface improvement, converting it into grafs pafture, to the cxtent of a confiderable number of acres, in the immediate vicinity of the place; and that, chiefly, by the prefent proprietor.

The firft thing neceffary to this fpecies of culture, is the. formation of roads of communication to the places intended to be cultivated, for the conveyance of manure, \&c.

The road is formed by a ditch, of no great depth upon each of its fides, to convey the water to fome of the main drains; the ituff from the ditches, forming the plane of the road into a convex Anape; fo that water may defcend from the middle of itg to the ditches on each fide: Then, in winter frofts, (when, 
the flow will bear the weight of carriages), binding materials are laid upon the road, and covered with gravel. The land is now ready to receive its culture, on both fides of the roadthough at no great difance from it on each fide, from the difficulty of tranfporting manure from the carriages, over a foil fo deep, and of fuch foft confiftence.

The mode of cultivating this flow-mofs foil, which Sir James (after repeated experience) has found to be the moft fuccefsful, and, at famc ime, the moft economical, is the following:

The main drains being made effectual for difcharging the water (as already defcribed), the portion intended for cultivation, is furrounded and properly interfected by open drains, of perhaps 3 feet in depth, communicating with the main ones: it is then nivided into ridges of 20 feet in breadth, by ftill more thallow drains of from 12 to 18 inches in deptl, communicating with thofe of 3 feet in depth: Ten feet in breadth (all along the middle of the 20 feet broad ridge) then receives the following furface preparation. All the little prominences, from little hillocks of fog, \&c. are parcd off, and thrown into the hollows; and the foil, from the two lait mentioned kinds of drains, is alfo fpread over it, fo as to make its furface level: A good coat of lime is then fpread above all. If this operation can be effected early in Summer, fo much the better-that the furface foil, with the roots of the mofs plants, may have time to rot and digett with the lime, aided by the fermentation occafioned by the Summer's heat; and may alfo receive the benefit of the Wiuser's froft. In Spring, the 10 feet in the middle of the ridge, which has been thus prepared, is covered with dung; when potatoes are planted upon the dung, and are covered up (in the lazy-bed fafhion) from the remaining 5 fect on each fide; a frefl covering being, from thence alfo, given, if necefiary, to earth up the ftems of the potatoes during their growth. When this firft crop of potatoes is raifed, a fufficiency is Icft in the bcds, as feed for the enfuing year's crop; and immediately the ro feet ridge or bed, is made up anew, with a frehl covering of raw mofs 
mors from the 5 feet on each of its fides; care being taken to clear the fmall drains, or to deepen them a little, if needed; it being alfo highly proper to add a frefl liming to the raw mols which has been laid upon the bed. In raifing this fecond crop of potatoes, the 10 feet broad bed is fpread out upon each of the five. feet fides whence the raw mors had been thrown up, fo as to form a ridge of 20 feet, which munt be kept rounded in the middle. The enfuing Spring, it may be cropped with oats, and laid down with grafs feeds; or, if it is judged proper to take two crops of oats, it is dug over, immediately after the feparation of the firt crop of oats.

Stable-loft grafs feeds, with a mixture of white clover, are spprehended to be the beft fuited to this fpecies of foil.

Dung, lime, the athes of mofs, either burnt with an open or fmothered fire, feem all of great efficacy in rotting and digefting the vegetable matter of mors foil.

Flow-mofs, in its natural, undrained, and undigefted ftate, remains dilated with water, like a wetted fponge: when properly drained and digetted by culture, its dimenfions contract in a very great proportion. His Lordhip is of opinion, that every yard in depth of his flow-mors might, by there means, be confolidated into perhaps one inch, in depth, of real made mould.

It would appear, then, phyfically pofrible, though by no means advifedly practicable, by a continued repetition of the above mentioned culture, (deepening always the drain as the mofs foil fubficed), to reduce, at length, the mors foil of our deepent flows, to a foil of very moderate thicknefs lying upon the futfoil *.

In enlarging his lawn, the Lord Chief Baron found it ne. ceffary to remove the Duke's gardens, which were too near to the houfe; and he adventured to pitch upon a fpot for that purpofe

- Sir Jamcs's mode of culture, of which this account was drawn up in $179^{6}$, fasms to correfpond, in principle, with that latcly fallen upon in AyrRire. 
purpofe (otherwife lying the moft convenient) upon the eaftern extremity of the flow-mofs already mentioned. He was thus, in fome meafure, neceffitated to attempt a culture of flow-mofs, that thould reduce it to a garden mould. About 8 Scots acres are enclofed, by a wall of ftone and lime, from 9 to so feet in height; it having been, previoufly, neceffary to cut a trench or lane through the mofs (which, on the weft fide, was from 8 to ro feet dcep), down to the till bottom, of fufficient width to admit of cart accefs for the materials of building, as well as to obtain a firm foundation for the wall.

A contrivance, in the original formation of the wall, faves, in a good meafure, the expence, and prevents the damage to the wall, from the repeated nailing up of the fruit trees. Slates are built into it, at regular diftances, with one eisd projecting about five or fix inches from it: thefe ends are perforated, fo as to admit rods, of a finger's thicknefs, for fupporting the branches.

The foil of the garden hath been made in the following manner :

Finh ponds have been dug in different places, fo fituated that every part of the garden may be drained into one or other of them, with proper outlets for difcharging the furplus water, when it rifes above a certain level. The mofs foil is carted away, or part of it is prepared and burnt, till it is taken off to within a foot or eighteen inches of the fubfoil ; which laft is of various qualities, though generally inclined to clay; when the afhes from the burnt mors, with lime and dung, are fpread upon the mols foil left remaining. The whole of the left foil, with the manure upon it, and as much of the fubfoil as can be turned up by the plough, are then well mixed and incorporated, by repeated ploughings (in the courfe of cropping with turnip or potato) till the foil is perfectly made fo deep as the plough can reach.

Subfequent to this plough culture, the land is trenched by the fpade, fo as to double the ftaple of the foil. The made foil is, by this procefs, placed undermoft; whilt an equal quantity of unmade fubfoil, from the bottom of the trenches, 
is laid above it, to be afterwards made in its turn. Care is taken, in forming the trenches, to keep the fubfoil (left untouched by the fpade) in fuch a declivity, that the water, finking through the cultivated foil, may have a clear defcent, under $i t$, upon the fubfoil. A covered drain of loofe ftones is alfo formed, all along the lower fide of the declining fubfoil, into which this water falls, and by which it is conveyed into one of the ponds. 'The furface is alfo formed, at fame time, to a flope correfponding to that given to the fubjacent fubfoil; that fo there may, in every fhape, be a proper defcent for the water into the covered drain, whether it runs upon the furface, or finks through the made foil to the till bottom.

In the trenching procefs, each particular break, into which the garden is divided, is thus formed to one equal flope, both in upper furface and fubfoil: the different kinds of foils, where they vary in quality in the fame field, are alfo fometimes now mixed together. The new foil, turned up in the trenching, is treated with raw mors, mors afhes, lime and dung; till, by tillage with fallow crops, it is alfo made: fo that, at length, a foil is formed of from eighteen inches to two feet in depth, upon the whole; producing garden ftuffs, and fmall fruits, in abundance.

The garden is furnifhed with a vinery and a peach-houfe, the produce of which have hitherto been very great.

As one encouragement to the cultivation of Flow.Morfes, and inhabitation of their vicinity, it may not be improper to obferve, that few families in the kingdom have enjoyed more uninterrupted health than Sir James's. So falubrious is the air of Whim, that (though very many working people, from all quarters of the country, have been confantly employed in the improvements there, for now upwards of fixty-five years) I am affured by Sir James, that the ague is a difeafe unknown. -(See article Climate, in the Report.)

Befides the flow-mors, his Lordhip has had long experience in the cultivation of moss foil cultivateable by the plough; as obferved, under the article Soil, in the Report. 
This kind of mors foil is generally found upon the declivities of hills. Though, from this fituation, it is more difficult to account for its original formation, it is, neverthelefs, a foil, in every agricultural view, of the fame compofition as flowmofs, only more confolidated, from the more ready paffage of the water from it: like flow-mofs, however, it abforbs, retains, and is dilated by water, as a fponge, while it remains in its natural ftate, unrotted and undigefted.

This foil is, very commonly, more thin at the top of the declivity, deeper about the middle of the defcent, (from a dip that there often takes place in the fubfoil), and again more fhallow at the bottom; extending, at deepeft, frequently to the depth of near four feet.

His Lordhip diftinguifhes this foil, as it has occurred to him in practice, into two kinds; as characterized by their natural appearance, previous to culture, indicative of their different ftates, as to drynefs, and confequent folidity. The one kind is covered with bent, and other green herbage, being generally full of fprings; the other, more dry and folid, is covered with heath.

As lime is almoft the only attainable manure, for rotting fuch foils, and converting the vegetable matter of which they are compofed into mould; and as lime is found to have little effect upon land foaked with wet; it would appear neceffary to begin the procefs of culture, in the firft of thefe foils, by draining with open ditches and covered drains. The potato culture, in lazy-beds, might be ufed, as far as can be accomplifhed, in the fame manner as in flow-mors, mutatis mutandis; which, at the fame time, effects both purpores of draining and of digefting the foil. As this expenfive culture, however, cannot, with profit, be carried on upon a large fcale, unlefs in the neighbourhood of towns, (where the inhabitants may be induced to undertake the culture, for their own profit, and at their own rifl; or where a fufficiency of hands may be procured, for hire; and, at the fame time, a ready market for the produce, without long carriage, the expence of which its va!ne cannot hear), it would feem neceftary, in other fituations, 
to depend upon the lefs expenfive culture of the plough, wherever the cultivation is attempted upon a large fcale. If the land cannot be laid fufliciently dry, for liming, by drains, without incurring a difproportionate expence, a judicious management of the plough may be made to come in aid of draining. It should be broken up, as foon as it is rendered dry enough to be capable of being ploughed. When, after it has lain a fufficient time for the thorough rotting of the fward, it may, by two or three furrows, in the drought of Summer, be formed into convex ridges, the lime may be then applied; and, in courfe of culture, as the foil digents and confolidates, it will be found more and more eafy to rid it of fuperfluous moifure, from the convexity of the ridges, than while it remained in the fpongy ftate, of raw undigefted mors.

In regard to the fecond more dry and folid fpecies of mofs foil, it would feem proper to apply the lime upon the furface; and to allow the field to lye $t$ wo years in that ftate, previous to ploughing; when it will give an immediate return, in crops, for the culture.

By liming, ploughing, and repeated liming, or otherwife manuring of the frefh mofs foil, as it is turned up (taking crops, to pay for the expence, betwixt the repeated fallowings), the mofs is gradually digefted and compacted; when, after the fubfoil (generally of a clay confiftence) is reached by the plough, and properly mixed, and made to a proper depth of ftaple, this foil is formed into all that perfection of which it is fufceptible. It may thenceforth be treated, in the routine of farming, with the dung bred upon the farm as manure, or with compolt of mofs and lime, \&c.

All mofs foils feem to poffers a frong vegetative power, in the production of grafies, the blade of grains, and the ftems of plants cultivated for the root: They flow themfelves inferior (in their high, fituations in this county, and in our backward climate) in carrying on their productions to maturity. Probably, in lower fituations, and more favourable climates, they might prove the moft productive of all foils. Minrs varies 
in quility, in our climate; the moft folid being the mot fertile, and vice verfa. Its qualities may probably be alfo fufceptible of great variations, from difference of climate.

One comparative advantage is poffefled by the generality of ploughable mofs foils, in this county-that, from their high elevation, they are little liable to be affected by the Harvert frolts, noticed in the Report, article Climate.

Upon the whole, when the expence of cultivation is compared to the return of profit, it would appear, that the cultivation of flow-moss, in this county, is an undertaking unfuitable to a farmer, upon any length of leafe; unfuitable even to a proprietor, except with the indifpenfable view of hiding a nuifance in a policy-unlefs, indeed, a gentleman of fortune (inftead of fpending lis income in thofe enjoyments fuited to his rank, which perifh in the ufe) fhould choofe to employ what he favcs from thefe, in thus eftablifining a permanent value, which may remain, as his mark behind him, when he takes leave of this world. As to floughable mofs foils, their culture may be undertaken, with great propriety, by the landholder, with the probable profpect of being compenfated, in the return, for the expence of outlay: Their culture could fcarcely fuit a farmer, except upon a leafe of confiderable endurance, or in the near vicinity of lime. 


\section{APPENDIX, No. II.}

Essay on the Diseases of Sheep: Drawn up from Communications furnifbed by $\mathrm{Dr}$ Grllespie, Phyjecian in $E_{\text {a }}$ dinburgh; together with Hints by $\mathrm{Dr}$ Coventry, Profefor of Agriculture in the Univerfity. With Notes, fuggefed from Obfervations in Truceddale, छ․

$I^{T}$ is fuppofed by thofe who have beft accefs to information on the fubject, that the ifland of Great Britain contains about thirty millions of theep; and that of thefe, from three to four millions annually die of difeafe. Were we to average the large theep of England, with thofe of lefs value in Scotland, the annual lors, from this caufe, would not be lefs than from two to three millions Sterling: A lofs which is certainly of very ferious concern to the nation at large, as well as to individuals. The mortality of theep, by difeafe, is more than double that of the human race-if we abttract, from the latter, the wafte occafioned by wars, and by the accidents incident to commerce and navigation. It muft therefore appear to be an object of great national importance, to inveftigate the means of preventing, or curing, the difeafes to which theep are expofed.

In the following Effay, we do not pretend to offer a perfect treatife upon the fubject. All we aim at, is to give a fhort catalogue of the various difeafes, and to fuggeft, muder each article, the moft obvious means either of prevention, or of cure. On a fubject which has never been fcientifically inveftigated, 
veftigated, niftakes are unavoidable; and thefe we leave to be corrected by the candour of the reader. Mroft authors who have treated of the difeafes of brute animals, have ftufied their books with a long feries of noftrums and prefcriptions, where the ingredients are exceflively complex, and which either do not mix, or deftroy each other's effect. We thall endeavour to avoid this error; and leave all doubtful cafes to future inveftigation.

Some difeafes are peculiar to lambs, and others to fheep at a more advanced period of life.

Lambs are fubject to

\section{Diarrbcea, or Logfenefs.}

THIs diforder is commonly called, by the fhepherds, pizsning; becaufe, when the purging has advanced a certair length, a glutinous matter flows from the anus, which faftens down the tail to the hips, and prevents any farther paftage. When thepherds obferve this, they commonly feize the lamb, and having wafhed and difengaged the tail, they rub the parts with the earth of a mole-hill, or other powdery matter, to prevent the tail from fticking in future. Hogs lard, or fwee: oil, would anfwer much better for this purpofe. 'The difeafe is caufed by wet and cold in Spring, together with the ewes eating too greedily of foft moift. grafs. Removing them to heathy, or poorer paftures, where aftringent or aromatis plants abound, prevents, or cures the diforder

II. Choli-,

- Among lambs, fcd with their dams, upon the rich improved pafture of Lotiziau parks, pinning never occurs; whence, it is probable that it originates from milk concotted from poorer pafturc, which gives more curd than cream to tlie milk, rendering the excrements of the lamb more vifcid. When the mothers have little milk, the lambs are very rarely pinned. Pinning is therefore confidered as a farourable fympton of the lamb's bcing well nurfed. It is not confidered as a difeafe, in Tweeddale; though, if not redrefled, it would be productire of difeafe It is confidered as an accident to be guarded againft; and which, like other accidents to which theep are liable, requires the Anepherd to be conftatly wikir. through his fock. No Tweeddale farmer would, on this account, temove his ewes and lambs to poorer pafture, where the lambs wasld be worfe giafed; as he 


\section{I. Cholic, or Burfing.}

THIs difeafe is incident to lambs, from furfeiting themfelves with an excefs of milk. Shepherds call the difeafe, burfing; becaufe the milk, apparently, ferments in the ftomach; and, by the difengagement of gafes, the inteftines are burft. It feems perfectiy analogous to the cholic in cows, arifing from an excefive feed of red clover in a wet ftate. The ewes acquire this fatal excefs of milk, by feeding too freely upon foft fucculent grafs in Spring. The evil may be prevented or cured, by removing them, for fome time, to a poorer pafture.

\section{III.-Vermin。}

There are three fpecies of infects which are very hurtful to sheep. I. The fusep-fy, which abounds chiefly in the fouthern parts of the ifland, and is moft troublefome to lambs. Smearing with rancid oil of any kind, feems the moft effectual remedy againft its attacks. 2. Maggots, the offrum ovis. Thefe are flies in their chryfolite ftate, and arife from eggs which flies have depofited, probably in fome fmall boil, or difeafed part of the animal's fkin. They eat into the parts where they

are

knows, that if the pinned lamb is timeoufy noticed, and relieved by pulling up the tail, all danger is removed.

Falling awald, is another accident which muft, in like manner, be guarded againft. When ewes heavy with lamb, or lhiep that are fat, or even merely full fleeced, fall, or lye down upon their backs, in a hollow, or even upon flat ground, they will often lye in this pofition, if not difurbed, or fet upon their legs, till (in confecucnce of the fwelling of the belly, which fpeedily takes place, if the weather is hot, the belly full, and the pofition be with the head down hill) leath enfues: If not raifed, they foon become incapable of raifing themfelves, and will often die in the fpace of half an hour; the contents of the fwelled abdomen probably obftruting the motion of the lungs, or the brain being apopleftically compreffed by the over-diftenfion or rupture of the blood-vefiels of the head. The fell, everwatchful, and far-fceing raven, is always ready to attack them in this helplefs fituation; tearing out, in a few moments, both their cycs and their tongue, even before they are dead. When fet on their legs before the belly has fwoln very nutch, no harm enfies.

C. $F$. 
are faftened, proluce ulcers, teaze, and at laft deftroy the life of the animal. The parts infefted thould be clipped bare, and wafhed repeatedly with black foap and warm water. Laftly, the parts may be covered over with the common fmearing ointment. If this does not operate a perfect cure, recourfe may be had to the means juft now to be mentioned. 3. Ticks, or keds, the bypobofia ovina. The fnearing ointment generally prevents, or kills this infect. But if this hould not happen, or if the theep are not fmeared, infects of every kind may, be effcctually killed, by flightly rubbing the parts affected with mercurial ointment, compofed of three ounces of hogs lard, rubbed up with half a dram of finely-powdered corrofive fublimate. To this ointment, may be added a little of the fpirit of turpencine. Coal-oil is powe:fully de?tructive to infects of every kind; but whether it may not prove injurious to the health or fieece of a theep, has not yet been afcertained by experiment. A decostion or difillation from the gall-plant, which abounds in many mofes and muirs, is known to be very fatal to infeets of every kind; and a theep may be fafely wafhed with this juice. The juice of tobacco is alfo much recommendcd as a poifon for thofe infects which infeft theep.

The two lant fpecies of infects are chiefly hurtful to theep of a year old, or more; and the difeafes which follow, are chiefly confined to theep of this defuription.

$$
\text { IV.- Scrb, or lich. }
$$

This difeafe is incident to ficep in fome particular paftures, fituations, and feafons, more than to others. The predifpofing caufe, feems to be a relaxed habit of body, produced by poverty, or leannefs : though fome fheep are fubject to it that are fat, and otherwife in goot condition. The difeafe feldom feems to originate with fuch theep, but to be conveycd to them by infection. Sheep that are regularly tarred, or fineared, we believe, are fellom infected with this difeafe. If the difeafe be partial, perliaps the beft romedy would be, to clip the affected parts as bare as poffible, and rub them occafonally 
with the common fmearing ointment, to which may be added a little Venice turpentine. They fhould alfo be wathed, once or twice a week, with black foap and water. But if this prove ineffectual, or if the difeafe has gone to a great extremity, the animal fhould firft be wafhed as clean as poftible, in a pond or rill of water, to purge away all the accumulated virus, or infecting matter, from the wool. A little black foap may be of sreat ufe in wahing. Then the whole body may be fmeared with juice of tobacco; and, after the animal becomes dry, may be rubbed with butter mixed with powdered brimftone:-or brimftone, mixed with the fmearing ointment, would anfwer better. A little of the fulphur may, meanwhile, be thrown down its throat. If this treatment, being twice or thrice repeated, after an interval of feveral days, fhould prove ineffectual, recourfe muft be had to the mercurial ointment formerly defcribed, compofed of three ounces of hogs lard, well rubbed in a mortar with half a drachm of finely-powdered corrofive fublimate:-or the fame proportion of corrofive fublimate, well mixed with three ounces of the common fmearing ointment, will anfwer equally well. The animal being fmeared with this ointment, will foon be effectually cured. Meanwhile, the difeafed animal hould bẹ invigorated, by being put upon fubftantial food *,

* Iohn Loch Efq. of Rachan, obfervcs, that it would be proper to add to this account of the fab, that the matter difcharged, mixing with the wool, and ryying, forms a hard, impenctrable cruft, which he has obferved of half an inch is thickncfs; that it is vain to think of curing it by any extcrnal appiication, :Ill this is removed; and that you might as well attempt to cure a man of the itch, by rubbing butter and brimftone upon his coat, inftead of his naked ikin. That the fcurf, thus formed, must be removed, by foaking and walhing it with warm lime-water and foap, und feraping it elean to the quick with a blunt knife. It may then be fuccefsully curcel by the ointment mentioned in this EfTay; or fwhich is a more cicanly and eafier-formed remedy) by diffolving half a drachm of the corrofive fublimate of mercury in a chopin bottle of whilky and water, and xafhing the parts repeatcdly with the folution, which he has always found effectual, upon t wo or three applications. 


\section{V.-Braxy, or Sicknefs.}

This difeafe is of an inflammatory nature; and there are three fpecies of it, which are very different from each other. Thefe are,

1. Inflammation of the bowels, commonly called dry-braxy. This difeafe is moft fatal to young and robuft theep, about fix or feven months old, called, in many parts of the ifland, hogs. It is more deftructive upon fome farms, than others; and, even upon thefe, in one feafon more than another. In a bog-fence, or palture, capable of keeping thirty fcore of hngs, there is, fome years, a lofs of from three to four fcore. This is a very ferious matter, as each of thefe would fell, in the Spring, or beginning of Summer, for half a guinea, or eleven Dhillings. This difeafe begins at thofe times when inflamma-

tory

Except the breabfarw, or dyfentery, (Article VIII. of this Effay), the fcab is the only difeafe from which communication by infection is dreaded in Tweeddale; and here, the danger of general infection of the whole flock is greatly to be feared. It feems not a very deadly difeafe; but, from the conftant difquictude in which it keeps the animal, from the perpetual itching, it effctually prevents its fattening, bcfides making it lofe its wool. When it has thoroughly pervaded a flock, it is very difficultly eradicated. The ground itfesf becomes infected; and it communicates the infection even to a found ftock brought upon it. Every broken piece of ground upon the hill fides, prefenting a perpendicular or overhanging face; againft which the infected animals can rub their backs or fides, becomes charged with the infecting matter, which readily communicates the difafe to the found theep, who delight alfo in rubbing themfelves. Befides curing the infected animals, care fhould alfo be taken to beat lown the infected furface of thefe rubbing places, elfe the animal is only cured to be infected anew If the ground abounds with projecting rocks, the furfaces againft which the fheep rub themfelves, fhould be carefully wathed. After all, the faseft courfe is to fell off the infected ftock to the butcher, and replenish with black cattle for a feafon; when, if the inficting matter confits of aninalcules, as is fupposed of the human itch, a Winter's frofit would probably deftroy them.

A fort of itch, thongh femirigly noway invetcratc, almon always attacks fheep, when firft fet to feed upon turnips. It is eafily cured, by immediately anointing the infected parts with a liquor compofed of turpentine, with decoetion of tobacco; and afoes of tronon, loing that commonly whod in this county.
3 $E$
C F. 
tory diforders are moit apt to prevail, in the months of October and November, and is produced by the common caufes of inflammation, cold, exertion, external injury, \&c. During thefe months, flight frofts fet in; and the ground, in the morning, is often covered with hoar frot, or what is called, in fome parts of Scotland, rlime. It is probable, that eating grafs covered with hoar frof, may be one caufe of the diforder. If $f \circ$, moving the animals about, and preventing then from eating, until the froft is melted by the fun, may tend to prevent the difeafe.

This difeafe runs its courfe very rapidly. When the thepherd leaves his flock at night upon their layers, he fometimes obferves a hog look dull, loitering behind, and reftlefs; fometimes lying down, and fuddenly getting up again: and, in the morning, he will often find it dead, or nearly fo. At other times, he will difcover no apparent ailment among his flock; and, in the morning, he may find one or two dead, or dying. From this it appears, that the difeafe is very acute, and of the inflammatory kind.

This is farther evinced by the appearances after death, when the carcafes are opened. Their bellies are exceffively fwelled, and diftended with a putrid gas: the whole intertines being red and inflamed, gangrenous, and in fome degree mortified. This putrid taint feems to be communicated to the whole carcafe, as all the mufcular parts, and fat, fmell ftrongiy of corruption. The hogs that die of this difeafe, are frequently fat and in good order; which thews that the diforder is of fhort duration *.

we

* John Lack Efq. of Rachan, obferves, in general, in regard to the fheep, that it is an animal of a very coltive habit, difcharges little urine, and that fo acrid, as to burn up grafs like a folution of volatile alkali; it drinks little, and perfpires much of a glecty or greafy nature, as is perhaps the cafe with all fur-bearing animals: Ficnce, all its internal difeafes are highly inflammatory, and run rapidly into a ftate of putrefcence, proving quickly mortal : Hence, its natural œeconomy is cafily difturbed by wet feafons, whiln it gets nothing to eat but wet grafs; its body, meanwhilc, being covered with its wool, drenched like a wet fponge. 
We have already mentioned the eating of grafs, which is covered with hoar froft, as a very probable immediate caufe of this diforder-But is there any predifpofing caufe?

In anfwer to this queftion, we thall adduce a fact, which is well authenticated.- Many parts of the Weftern Hightands of Scotland had been for ages occupied by horfés and licrned. cattle. At the introduction of theep into thofe diftricts, the beft grafs was that which had fprung from the tath and excrements of thefe animals. During many years after thefe diftricts were converted into theep farms, braxy remained unknown. It crept in at laft, and the feverity of the difeare was long, in proportion to the length of time the paftures had been occupied by theep.

From this we would infer, that pafturing upon their own tath is a predifpofing caufe of braxy among theep; and that a frequent alternation of the fpecies of ftock, upon every theep pafture, might ferve to prevent the evil. This idea correfponds with the general laws of the Supreme Being, who certainly never intended, that this earth fhould be monopolized by any particular fpecies of animals; but has fo ordered matters, that the happinefs of individuals fhall refult from the happinefs of the whole family of animated beings.

Hence, it would appear a beneficial practice in ftore farmers, in place of one hog's fence, to keep two or more enclofures of this defcription, and change the frock upon them every feafon. 'This we know to be contrary' to general practice; and that what is called the bog's fence, is carefully guarded againt the intrufion of every ocher animal *.

Lam'ss,

The comparative health of pet-kees, or thofe feeding and houfed with cows, at al! feafons, he attributes more to covered fhelter from the weather, than to fuperiority of feeding; and has therefore refolved to make all his fheep pets, in fo far as to provide them with thades, to retire to in coatfe weather. From the eaturat conftitution of the theep, he is of opinion, that more is to be expected fiom attending to the rotionale of their management, the jusantio and ladertiz, than from medicine, which can rarely be timcoufly adminiftered.

- In regard to the quality of pafture, as a caufe of ficknefo, Tivecddale firncrs feem of opinion, that it arifes from she fouluefs of the grofs at tise rod in ties 
Lambs, immediately after they are weaned, are frequently fent to poor pafture, which is called birning them. Now, this appears to be a very bad practice; for the confequence is, that they fall off confiderably, before they get at the rich grafs in the hog's fence, of which they eat too freely; and thus become difpofed to the difeafe treated of. Children, and all domefticated animals, are carefully fed with nourithing food, for a confiderable time after they are weaned; and yet they fall off for fome time. It would certainly be better to give the lambs the hog's fence at once, and ufe every precaution to prevent them from falling off.

As the difeafe is generally advanced to a dangerous height before it is obferved, we fear that medicine affords but a very faint hope of cure. The difeafe being inflammatory, the thepherd hould attempt to bleed the diftreffed creature as foon as poffible; which he can eafily do, by cutting off part of the tail,

hoz-fences, which are never eaten bare. Some, therefore, take care to have the land, to be faved for the hoz-fence, once eaten as bare as porfible early in Summer, by the black cattle upon the farm, or by old fheep.

It feems afcertained, in Twceddlale, that land wisch has been in ufe to be paftured by older fheep, when converted into a hog-fence, is not liable for fome time to produce ficknefs. Tro accidental experiments occurring, in which this practice took place, in confequence of new arrangements, in the farms of Harehar:p, in Eddlettone parifh, and of Lyne, in Lyne parifh, confirm this conclufion. It is farther confirmed, by an exferiment of Mr Morray, tenant in Flcmington mill - About 20 years ago, he honght in difierent parsels of lambs for logs, and laid them upon the hog-fence, of his hog-farm of Broughtonhaup, in Broughton parish: In one of the parcels, of mucls higher condition ihan the reft, the ficknefs broke out to fuch extent, that they were dying at the rate of two or three daily; fo that the whole parcel feemcr in imminent riik: He transferred this whole pawccl to the farm of Fingland, in Newlands parih, where only old Theep were kept, futting them on fome of the lower pafturc of that farm, which had been hained for feeding the crock ewes, and transferring a proportional quantity of thefe ewes to Broughtonhaup tog-fence; -rot one of the lambs died upon Fingland. To the fame efice?, it deferves attention, that in fmall farms, not admitting of diftinct hirfeling, where, of courfe, old and young fhcep pafture, mixed together, hogs are wery litile liable to fichnefs, thongh perhaps worfe in oiher refpects. Thefe fuets correfpond with Mil Gillcfice of Clenquich's otfervations. (Sce Report, paige 12(1.)

C. F. 
tail, or by nicking it underneath, or by cutting off part of the ears. The animal thould then be removed to a houfe, or thed, and attempts made to produce evacuations. In brute animals, it is difficult to produce thefe by medicines adminiftered by the mouth. The fpeedieft and moft effectual method is, by injections into the rectum, or anus. Such injection may confift of a fmall handful of camomile flowers, Ewo tea-fpoonfuls of anife feeds, and as much carvey feeds; to be boiled flowly in a Scotih mutchkin, or Englifh pint, of milk and water, until the half is evaporated. The liquor fhould then be ftrained off, and two tea-fpoonfuls of caftor oil added: or, if this is not at hand, the fame quantity of good fweet oil may be ufed. This hould be adminitered warm, by an injection bag and pipe; or by an elaftic gum bottle, with a pipe properly fitted. Nothing can be eafier, than to give a fheep a clyfter in this way; and, in all probability, it will have a happy effect, in evacuating the bowels, and procuring relief.

If this does not operate very foon, it may be repeated an hour after, and a large tea-fpoonful of common falt added to the former ingredients. If, after all, the animal does not feem relieved, another clyfter may be given, confifting of a fmall teacupful of warm milk and water, to which are added from twenty to twenty-five drops of laudanum *.

* When phyfician to the army, I found infammation of the bowels a very common complaint. It was attended with coftivenefs, and a large quantity of air was generated in the ftomach and inteftines, which was highly diftreffing to the patient. Each of the following clyfters I found of great ufe :

Warm water, or water gruel, eight or ten ounces; Cantile foap, two or three drachms; Glauber's purging falts, half an eunce; fallad oil, one ounce-Mix, and to be thrown us the rectum.

If this did not procure a fool in the fpace of an hour or two, it was repeated. When the patient had had a ftool (withiu two or three hours after) I ufed the fol-
lowing:

Warm water, or water grnel, ten ocusces; nitrous xther, two drachms; fallad oil, one onnce; and if there was pain ur meafinefs, I added to it forty, fifty, or
fixty drops of laudanum.

Wm. H. Mutberv, M.D.

No. 27, Paxblore Pluse, O.xfort Rout 
As there is a great diftenfion of the ftomach and bowels, arifing from gafes, or elaftic vapours, generated in the inteftines, Mr Walker of Cumberland, in a treatife he wrote upon the difeafes of brute animals, has fuggefted a remedy for this diforder, which has often proved fuccefsful in his diftrict. It confifts in pufhing down their throats a flexible tube, fuch as Dr Monro has recommended, and which has proved fuccefsful in relieving cows that had over-gorged themfelves with red clover early in the feafon. This feems a probable mean of affording temporary relief; and every thepherd that has the care of the hog flock, fhould be furnifhed with one of thefe tubes, adapted to the fize of theep, for trying the experiment upon thofe hogs that labour under the difeafe.

2. Watery Brawy.-This differs from the former refpecting the feat of the diforder, though the effects are nearly the fame. It is analogous to the fupprefion of urine, a difeafe frequent among

\section{(Addition to the preceding Note.)}

From November, at fmearing time, till the Chriftmas (this year-1797), two fafts, in regard to the mode of cure, have been ftated to me, and which, I am difpofel to think authentic.-In the farm of Drummelzier, parifh of Drummelzier, three hogs (out of four upon which the experiment was tried) recovered, upon bleeding, and having poured down their throats a decoction of tobacco-about a finger's length of twilt tobacco boiled in water till the water was diminifhed to a gill, bing the defe for each.- In the farm of Broughton-haup, parifh of Broughton; within the fame fpace of tine, nine or ten (out of fixteen or feventeen upon whom the experiment was made) recovered, upon bleeding, and having an injection of tobacco-fmoke adminiftered from a common tobacco-pipe, by kindling the tobacco, inferting the pipe-flank into the anus, and blowing: the experiment, however, was not fo fuccefsful in fome later inftances. I have, long ago, feen a ewe cured by blecding, and injection of Glauber falts from a common clyfter-bag and pipe.Where braxy breaks out, it might he ufeful, where attainable, to lay the hogs, niglitly, upon dry ground, if the hog-fence is wet; tlic chillircfs of wet ground contributing, no doubt, to the production of inflammation: Clover foggage, or turnip, might be good preventatives, from inducing a lax habit. Mr Gillefpie in Glenquich obferves, that faltpetre has been fuccefsfully ufed in the black fpauld, a difeafe of young black cattlc, fuppofed analogous to braxy in fhetp, both as a preventative and cure. His propofal, of taking the hogs from the hos-fence about the beginning of Auguft, and keeping them, from thence till r 2th September, upon coarfe hill-grafs, as a preventative or cure for fickucfs, would not, it is conceired, anfwer in 'Tuecdale, as thefe grafics are then faded: It might prevent ficknefs, tail wovi. induce foverty.

C. F. 
among females of the human fpecies, and caufed by their fedentary habits. Watery braxy confifts in the bladder being overdiftended with urine, which raifes violent inflammation in that organ, and proluces an incapacity to difcharge the urine that is accumulated. The confequence is, that the urine regurgitates over the fyftem; fetid gafes taint the whole carcafe, as in the former cafe; the bladder becomes gangrenous, burfts, and the animal dies. Young and rigorous fheep are mont liable to this fpecies of braxy, like the former. The immediate caufe of the difeafe, is feeding too freely on fucculent diuretic food, and refting too long in their layers in the morning. It has been frequently obferved, that this fpecies of braxy is moft apt to make its attacks on Sundays; becaufe fhepherds generally fleep longer on Sunday momings, than other days of the week, and, of courfe, allow the hogs to remain too long in their layers.

This difeafe may be prevented by avoiding too free an ufe of fucculent diuretic food, and by moving the animals from their layers early in the morning, making them walk about for fome time, in order to encourage them to pafs their urine and purl.

In attempting a cure, it may be known if the bladder is affected, by a great fulnefs in the lower part of the belly, immediately abore the pubis. The feat of the diforder being difcovered, a female filver catheter, or one of elaftic gum, ought inftantly to be paffed through the urethra into the bladder of females. This will draw of the urine, and afford inftant relief. But this will be more difficult in males, and, if attempted, muft be done witl a long and properly bent catheter, or bougie. In either cafe, when this cannot be effected, a puncture may be made into the bladder with a trocar, immediately above the pubis, taking care not to wound the inteftines. By either of thefe methods the urine may be difcharged, and the animal relieved.

In other refpects, with a view to allay, or prevent inflammation, evacuations thould be procured by clyfters and warm injections into the reclum, as already defcribed. If the feveral ingredients we have nentioned be not at hand, injections 
fhould be attempted, compored of warm milk and water, nearly in equal parts.

3. Cofive Braxy, or Cholic. This is caufed by the fxces hardening in, and adhering to the duodenum or rectum, fo as to obftruct the paffage, and produce inflammation, and confequences fimilar to thofe already defcribed. The cure Thould be attempted by injections and laxative food.

\section{Sturdy, or Water in the Head.}

This difeafe is particularly incident to hogs of a year or 38 months old. It confifts of a collection of water generally formed upon the external furface of the brain, immediately below the cranium; and fometimes, though not often, in the centre, or ventricles of the brain. When the water forms in the laft mentioned parts, we apprehend it is almoft univerfally mortal.

The diforder is firf difcovered, by the animal not keeping up with the reft of the flock, and, by its appearing dull and ftupid. It is afterwards obferved to go round in a giddy manner; and, at laft, it appears blind, and the pupil of the eye feems wide and relaxed. It may continue a long time in this way before it dies; and, we believe, theep fometimes recover of this difeafe without any thing being done for them. They are often in good order when they die, as they continue to feed tolerably well, until near the laft period. Though fome recover, with and without means, perhaps it may be molt advifeable to kill them early in the difeafe, provided they be in good order; as this local diftemper does not affect the good. nels of their mutton.

When the collection of water is on the outfide of the brain, it is often cured by thrufting a fharp wire up the animals noftrils, until it reaches the water, and opens a paffage for it to run off. In other cafes, it is cured by an operation which fome hepherds perform very dexteroully. The water is contained in a bladder, or veficle, generally about the fize of a walnut. The part of the kull, immediately above where it is fituated, feels fofter than other parts. This the flepherd 
difcovers, by prefling with his thumb and fingers upon different parts of the fore and upper parts of the flull. The bone here has become thinner, and feels ioft ; from which, he is certain that the watery collection is formed. After the difeafe has gone on a confiderable time, and he judges it is ripe for the operation, he raifes the fcalp, and lays the bone bare to a fufficient breadth, wit's a harp knife; he then difcovers more accurately the extent of the thin foft part of the bone, and with a ftrong and harp-pointed knife he makes a circular incifion in the kull, raifes up, and takes out the part. He then fees the clear thin bladder underneath, which he lays hold of with a fmall hook, or the point of a needle, and gently draws it out; taking all poffible care that it fhould not be broken, or the water fpilled, which would prove unfavourable to recovery. He fiads a confiderable hollow in the brain, where the bag was fituated, over which he brings the flap of thin that was raifed, fo as to cover it as neatly as pofiible. Over the whole he applies a plafter of tar, and leaves the reft to naw ture. This operation often proves fuccefsful *

\section{Patsy, or Thatter-ill, or Trembling.}

This difeafe is feated in the nervous fyftem, and is perfectly fimilar to palify in the human fpecies. It is fometimes produced by eating poifonous and ftupifying plants; and fometimes it arifes from weaknefs, or general debility. Flowers of zinc, adminiftered in fmall dofes in bread pills, or the fame metal converted into a falt, by union with an acid, is the moft powerful known remedy for this diforder.

\section{Diarrbea, or Cing, or Brealfiarav,}

Is a looferefs, or violent purgation, which fometimes feizes theep after a hard winter, when they are too rafhly put $3 \mathrm{~F}$

upon

- The operation by a wire, or by the trepan, which are indifcriminately ufed, may fucceed in Tweeddale, once in tluice at an average. Of lute, a rimlet has been bored twice into the fkull and brain, from the root of the nollill, in a direc: tion to the root of the hirn on the oppofite fide of the bead-apparently with cgutal fuccefs, howerer fenmiugly mortal the wounds.

C. F. 
upon young fucculent grafs. The cure fhould be attempred by making them feed upon aftringent plants, fuch as tormentil, bark and leaves of oak and willow, or bruifed twirs of thefe plants. If thefe do not foon check the diforder, opiates and laudanum may be adminiftered: From 15 to 20 or 25 drops of laudanum, thrown upon a piece of wheaten bread; which the animal is made to fwallow, will foon clieck the diforder; and it thould be repeated, if it returns with violence. Or, the laudanum may be dropped among a little warm milk, and poured down its throat*.

Another fpecies of diarrhcea frequently occurs in the laft ftage of chronic diforders, and is only to be cured by promoting the ftrength of the animal.

$$
\text { IX.-Rot. }
$$

The general difcriminating character of this difeafe is, that its feat is in the glandular fyftem; though many different. diforders are confounded under this name. The diforder is either partial, and confined to particular glands; or general, and affecting the whole fyltem.

I. Pul-

- John Loch, Efquire, takes notice of what is called breakjarv, or breadfara, in Tweeddale, as a difeafe analogous to dyfentery in the human fpecies, occurring in the end of wet Summers. The difcharge is thin and greenith coloured, (he fuppolis from the wet grafs becoming acid in the ftomach, and turning the gall grcen); it is more or lefs mixed with blood, fometimes florid, fometines grumous and black; the animal pines for a week or two, and dies; though fometimes it recovers: Warm milk pourcd down the throat, is the cure ufed by his herd: He propofes, when it occurs, to try, in addition, nitre in half-dram dofes, with chalk or other abforbent powder, and 20 or 30 drops of laudanum, once or tuice a-day, witis freq̨uent injections of warm milk and water.

This difeafe (in conformity to Mr Gillcfpie of Glenquich's obfervations upon Cling) is often occafioncd by overhcating, when hunted by dogs, in folding them, \&e. or when otherwife feared and terrificd. It is confiderably infectious; and, probably, the method mentioned by Mr Gilleftice, of tarriug part of the flock, that the fmell of the tar may prevent the infection, may be of gieat advantage.

C. $E$. 
1. Pulinonit Rot, or confumption, moft frequently attacks young fheep, cfpecially of the more delicate breeds, in unfavourable fituations and feafons. The moft general caufe is cold and wet, efpecially at the end of Winter, or beginning of Spring, joined to damp fituations, and fcanty fubfiftence. 'The lungs are found to be tuberculous; the animal coughs; and, in the progrefs of weaknefs, an œdematous fwelling, called in Scotland the pock, or poak, is formed under the jaw. 'This fwelling is of a dropfical nature, and is merely a fymptom of weakuefs common to many diforders. It may be pitrced, and the water it contains.drawn out. In this kind of rot, the liver is found.

2. Hepatic Rot has its feat in the liver, and there are feveral varieties of it. I. Sometimes it appenrs in the form of fibirrus, the liver being hardened and fwoln. This occurs in wethers, during a dry year, when their provifions are fcanty, and they labour under an over-coftive habit. It may be prevented by more abuindant, and perhaps more fucculent food. 2. Difordered liver from the fluke-worm, or fafiola bepatica, occurring in the biliary ducts; and fometimes, in confequence of ulceration, appearing even on the furface of the liver. This fpecies of difeafe prevails in fome low, moift grounds, more than others; and, even there, in fome particular animals more than others. Its origin is obfcure, and no cure has yet been attempted. Mercury is the only remedy that promites to be iuccefsful; and it may be occafionally adminiftered in fmall dofes, in bread pills : or mercurial ointment, fuch as we have defiribed, may be rubbed upon the infide of the animal's thigh, previoully laid bare, until the body feems faturated. But, when this difeale is difcovered to be frequent in a fiock, the whole hould be difpored of as foon as pofithle. 3. Sometimes the liver is, in fome parts, fllicd with watery reficles; and fometimes there is a flight thickening, and apparent inflammation, in particular portions of it. But whether thele should be conflered as indications of a primary affesion of that organ, or only confequences of another diforder, is uncertain. 
3. General, or true Rot.-This is by far the moft important, becaufe the moft deftructive, and, in fome fituations, the mont common malady to which theep are expofed. It arifes from deficient, or bad aliment; whether the food itfelf be bad and fcanty, or the animal be incapable of digefting it properly. It is mof: common from the former caufe, want of food; and the difeafe is much the fame with fcurvy among the human race. In addition to thefe caufes; whatever tends to deprefs the fpirits, frequently excites, or at leaft exafperates the malady. It is faid, that foldiers in a garrifon have been known to be feized with the fcurvy on hearing bad news: and I doubt not but terrifying theep with dogs, or other means, may produce, or aggravate, this difeafe. We may hence fee what mifchief a fox-chafe, or any exhibition of that fort, is calculated to bring upon a flock of theep. The difeafe is alfo faid to be produced by feeding upon watered grafs: and hence Ahepherds, in many parts of Scotland, are careful to keep off their fheep from the tender grafs, produced by the occafional overflowing of rivulets. Feeding, alfo, in marfhy and damp paftures, is known to be a powerful caufe of the rot.

The only means of cure, are a fupply of good and whole. fome food, and invigorating the fomach, by permitting the animal to feed on thofe ftimulating and aromatic herbs which are agreeable to its tafte. It is believed, that, on dry fweet paftures, where there is a fufficient quantity of furze and broom, juniper, and other fhrubs that are palatable to theep, the rot is feltom heard of. When ground is fown down for theep pafture, parfley, thyme, peppermint, and other aromatic herbs, thould be fown with the grafs feeds, as thefe plants ferve both to prevent and to cure the rot. In addition to thefe means of cure, every thing that tends to annoy or deprefs the animal, in its wealily fate, ought to be avoided *.

$\mathrm{X}$.

* Sheplierds in Tweeddale are generally unable to diftinguifh thefe three kinds of Rots (as they are unable alfo to dintinguifh the three diferent kinds of Braxy)

from 


\section{Foot Rot,}

Is a fuppuration in the glands between and above the hoofs, and is precifely the fame with chilbiains in the human fpecies. The remote caufe of the difeafe is weaknefs, and the immediate caure is cold and wet. Standing, in cold weather, with the feet perpetually foaked in water upon wet paftures, produces this difeafe; and it can only be removed, by procuring for the animal warmth and drynefs, while its borly is invigorated by proper food.

\section{CONCLUSION.}

IT is evident, from what has been ftated, that it is much eafier to prevent, than to cure, the difeafes of fheep. With a view to prevent difeafes, it is unnecefiary here to recapitulate what has been fo largely detailed in other works, about draining their paftures, and removing its dampnefs: about fweetening the herbage that grows upon thefe paftures: about providing proper fhelter, by trees, fod dikes, fowing or planting whins, broom, juniper, and other thrubs: about providing a proper fupply of wholefome food during Winter, and efpecially in the beginning of Spring, from turnips, and other roots; or from bruifed twigs, where the others cannot be procured.

We

from external fymptoms in the live animal. The pouch gives great fufpicion, but is not an infallible fymptom of rot. The old breeding ewcs are annually examined atout Micliaelnas. They are judged of as rotten or frefh, by handling; the flefh of the rotien being more loofe and flably: The principal mark is taken from the appearance of the eye, in the corner next the nofe, when the eycball is turned to lonk away from the nofe: in a found fhcep, the flefh adhering, in this corner, to the cyeball, under the eyelids, is of a florid red colour; in the rotten, this fle $\mathrm{h}$ is of a dull appearance, and a yellowin red, fomewliat like the culour of a rotten egg when the yolk and white are confonded together. The rotter are always fold of among the crocks, no cure being attempted. $\quad$ C. F. 
We have only one obfervation more to add. In addition to the conveniences already exifting upon laige fore farms, we conceive it would be an improvement to have what may be cailed an hefpital park, or enclofure. This fhould be fituated upon the ofryeft and kindlieft foil in the farm, and fhould be fown with all the graffes and aromatic plants which are known to be moft friendly to heep. It may alfo have a convenient affortment of thore fhrubs which are known to be moft palatable to them. It fhould alfo be provided with a dry fhed, where certain individuals may be confined when neceffary. To this afylum the difeafed may be removed; and, while proper means are employed to effect their cure, the infection will be prevented from fpreading among the reft of the flock. 


\section{SUBSCRIBERS NAMES.}

$A$

Reverend Mir Aitkin, Scone

Mr William Aitchion, Newmains

Mr Willian Anderfon, Drumbain

Mr Douglas Ainflie, Cairubank

Jonn Anfruther Efq. advoçate

Thomas Adair Efq. W. S. Edinisurgh

Ir Adam Anderfon, Traquair

Mr John Ainfle, landfirveyor, Edinburgh

John Aiken Efq. Callends

Mr John Anderfon, Henderland

Mr Charles Alexander, Eafter Happraw

Mir Alexander Ainflie

Samuel Anderfon Efq. banker

Mir Alexander, furzcon, Dunfermline

\section{B}

Johr Bax Efq. Wecpingcrofs, Stafford

William Brakenbury Efq. Yorkhire

Robert Brown Efq. Markle, 2 copies

Mír Alexander Brown, merchant, Linton

Mr Robert Brown, tenant, Spot

Mr Hugh Burn, North Berwick

Captain Robert Burn, do.

Gecrge Bogg Efq. of Broompark, at Bolton

Mr George Begbie, Queenfone

Mr Charles Barclay, Mill of Knockleith, Aberdeenhire

Mr John Bertram, Montrich, Rofshire

John Bailey Efq. Chillingham, 2 copies

James Buck Efq. York thire

Jonathan Binns Efq. M. D. York Thire

Mr Robert Burton, Haddinzton

Wm. Elair Efq. Collinfarm, Perth, 3 cop.

Mir H. Ballingall, Ledenurquhart

Mr Patrick Begbie, Craigindinnis

Mr Adam Bogg, Linplum

Mr Andrew Begbie, Barneymains
Mr Andrew Blair, Tranent

Mir 'eter Brodie, Garvald

Mr John Brodie, Auldhame

John Brander Efq. Elgin

l'rovoft Geurge Brown, Linkwood, Elgin

D. M. Binning Efq. advocate

David Boyle Efq. aćvocate

C. Brown Efq. of Colfton, adrocate

John Brown Eiq. Cultermains

Mir Darid Brown, Symington

Andrew Blane Efq. W. S.

Mr David Brewfer

Niel Ballingall Efq. near Balbirnic

John Boyle Efq. Wellhall

Mr David Brown, writer, Edinburgh

Thomas Bell Efq. Nether Holfeburgh

Mr George Blackie, Langhaugh

Mr Robert Barclay, Haddington

Mrr James Ballantyne, Woodhoufe

Colonel William Tertram of Carfewell

Mr James Bertram, writer, Edinburgh

Mr Robert Bertram, Wa!don

Mr Robert Brown, Mofleiburgh

Mr John Brodie, farmer, Torcraik

Mr Adam Brydon, do. Ilicrons

Mir A. Miuray Bertram, lecebles

\section{C}

Hon. and Rev. James Athole Coclirare

Mr Alexander Crawford, Rhodes

Duncan Campbell Efø. Ardgour-houfe

Mr James Cunningham, Luffnefs-Muir

William Clutter Efq. Ncward to Lord

Gwydir, Lincolnfire

Mr John Campbell

Mr Richard Collins

Mr Robert Corry, Erander

Bcnjamin Colley Efq. Iork lhire

Mr Clar!es Clask, Statord Green 
Rev. Mir Joreph Cook, Chat ton

IIr Andrew Cutlibertfon, Painfon

Mr James Craig, Traprain

Mr Thomas Craig, Burmuckety, Moray

Reverend Dr Carfrae, Durbar

Thomas Cranfoun Efq W. S.

Archibald Campleli Efq advocate

John Clerk Elu advocate

Archibald Crawi rd Efq. writer, Edin.

David Cathcart E.fq. advecate

Ceorge Chalmer: Efq. Office for Trade,

Whitehall, Lon on

Thomas Currie Efq Bruommuir

R. N. Camphell Efq. of Kilzie

John Carmichael Efq. of Shirlinz, 2 copies

Captain Andrew Carmichatl, Weftraw

Mr James Chalmers, Edinburgh

General Fletcher Campoell

Mr James Cunningham, Drem

Mr John Carnegie, Drylawhill

Major Spencer Cochrane

Inr Peter Chalmers, farmer, Redhangh

Dr Coventry, Profotior of Agriculcure, Edinburgh

Mr James Cairns, Peebles

\section{D}

Rev. Mr William Donaldfon, Ballantrae Mr William Dudigeon, Primrofe-hill Mr Genrge Dickinfon, Harriotfield Mr William Dickinion, Linton Mr Peter Didciep, Hacidington Mr Alexander Duderen, Nowmains

IVr Alexander Dodds, Grapton IrIr Thomas Dodds. Wentiall

Rolscrt Dundas Efq. B'a

James Dedzeon Efiq. merchant, London Herry Davidfon Efq. Hadding:on

Right Honourahle the Cunters Dowager of Dundonald, 3 copics

Mr James Duncan, Morrifton MIr Thomas Duncan, Midlar nir Cormo Dawfon, Cromlic
Mr Thomas Dickfon, Miouferald

Colonel William Dickfon, Kilbucho, M.P.

Colonel Alexander Dickfon, Hartie

John Dickfon Lị́ Culter

Reverend David Dickfon, Pcrfiland

John Douglas Efq. W. S.

Mr Alexander Dudgeon, farmer, Humbie

William Dalgliefh, D. D. Peebles

Cuptain Dickfon, Pcebles

In Alexander Daizel, Bardrainey, I'ort.

Gla.fow

Mr John Darling

Mir Alexander Dick, Rüinburgh

Mr John Dixon, 4 copies

Mr Jacob Dixnn, 2 copies

\section{E}

John Francis Erkine Efq. of Mar, $\hat{3}$ copies

Right Honourable Lord Ellibank

Right Honourable Lord Elcho, 3 copies

James Eliiot Efq. WV. S.

Reverend Mr Johu Ellerton, Stafford

F

Sir William Forbes, Bart. of Pitfigo

Mir James Finlayfou, Marklemains

Dr i urbes, phỵfician, lnvernés

Captain Frazer, Bracklay, Invernefsilhire

Mis John frazer, Inverne's

Mr William Ferme, Haddington

Wilium Forbes Efq.

James Firlay fou D. D. Profeftor of La

gic, Edinbu:gh

Reverend John tleming, Cairnton

James Ferguiton Lfq. arloosate

Louis H Ferricr Ef́q. adrocate

Robert Forrefter lifiq

Reverend Ale ander Forrefer, Linton

Mr Michacl Falcon jun. Largs, Newton-

Duglas

Alevanier Findlater Efq. Edinburgh

Mr David Ioys: 
G

Reverend George Goldie, Atholltonford Marmaduke Gray Efq. Kyloe

Reverend William Gordon, Urquhare Mr John Geddes, Orton, Moray John Grainger Efy. W. S. Mr Thomas Gibfon, Cardrona Alexander Guldie Efq. W. S. Alexander Gardiner Efq. Ladykirk Mr William Gairns in Stevenfon Mr James Grahame, merchant, Edinburgh Mr William Gray, Glen

Dr Andrew Grahame, Dalkeith

Alexander Sinclair Gordon Efq. London

\section{H}

Right Hon. Earl of Haddington, 3 copies Right Hon. Lord Hawke, 3 copies Ifonourab!e Charles Hope, Lord Advocate Honourable Baron Hephurn, Smeaton James Hay Efq. of Hayftown, M. D. Captain James Hay, late of the MacCartney Eaff Indiaman John Hay Eiq. banker, 2 copies Sir John Henderfon of Fordel, Bart. Robert Hay Efq: Drummelzier Robert Hay Ifq. of Spot Dr Hunter, phyfician, York Mr David Hepburn, Pieafince Mr Wriliam Hunter, Knows Mr Robert Hiwden, Chapple Ar Jolin Heplurn, Bearstoord Godfrey Higgins Efq. Yorklhire Mr Micha 1 I iarding, Walton, Stafford Mr Juhn Howden, Cardiff, Wales Mr John Hoge, Dunbar Mr James Howilen, Ealt Fortune Mr Joinn Howden, Congalton-ilains Mr Andrew Huwden, Lawhead William Henderfon Efq. Comlongon Francis Horner Efq. advacate Charles Hay Efy. advocate $\operatorname{Mr}$ A. II:aderion, feediman Alesandar Horfoburgh Efq of Pirn
Andrew Hanilton Efq. Spittlehaugh Misfor Thomas Hart

M. Chartes FIowden, Atholltonford

Mr John Handifide, farmer, Wantinwals Rubert Hamilton Efq. adroca:

Culonel Hutton, Peebles

\section{I}

Mr Jamis Johnftone, Glezhornie John Jamiefon Efq. Alloa

Mr William Jobfon, Turvielaws, Northumberland

Mr Alexander Johnftone jun. Elgin

Alexasder Irving Efq. advocate

Mr James Johnfton, merchant, Dalkeitis Mr William Jamiefon, Alloa

\section{IK}

The Right Honourable Earl of Kellie Sir Alexander Kinloch Bart. Gilmerton Mr Lockart Kinloch, Invernefs Archibald Knox Efq. Sunnyfide Jofeph King Efq. Newmill, Elgin Ir Andres Keir, Newton Reverend George Skene Keith, Keithhall Mr Thomas Kerr, Whitekirk Mrs MIurray Ieith, Miurrayfhall Mrs Ann Keith, George Street, Edinburg't John Kennedy Efq. Underwood Adam Kennedy Elq. Romanu Willism Kerr Efq. Kerfiels

\section{I.}

Right Honourable Larl of Leven James Lefie Elq. of Rotbie Mr Georga Leflie of Badenfwoth Jofeph Leifts Efq. Low Newion Rev. William Lufie, St Andrens, Moray. Mir John Lawfon, Old Mills James Laidlaw Efq. W. S. 2 copics William I.aidlaw Efq. of Alierton Gibstt Laing Efq. E.Jinburgh Mr Charles I.axfon, mafon, Newhanils W::liam Lewfon, Efq. Cairnmu:r, 2 bugiee $3 \mathrm{G}$ 
John Loch Efq. Rachan

William Lnch Efq. younger of Rachan

Mr John Lamb, writer, Lanark

Walter Laidlaw Efq. Hyndhope

Mr John Laing, Btythfoank:

\section{M}

Sir James Montgomery, Bart. Stanhope, 3 copies

Sir Gcorge Montgomery, Bart. of Mag. biehill, 2 copics

James Montgomery Ef . $M$ P.

Angus M'Donald Efy. jeweller, G!afgow,

\section{6 copies}

Iveil M'Gibbon Efq. Inveraray

Alesander M'Donald Efq. Glencoe

Adam M'Donald Efq. Achtrighton

James Maxwell Efq. Aros Mill

Mr John Mein, Hacdington

Mr John Murray, Kirklandhil!

George Mylne Efq. Sydferf

James Mayne Efq. Powis Logie

Mr Alexander MacKenzie, Thomation

Alexander MacKenzic Efqg. Iilton,

Rofsthire

Captain Monro, Teanenich, Rofsfritre

Rev, Mr M'Kenzie, Fodderty, ditto

MIarßhall Efq. York:hire

Mr William Mitton, Batdfworth, ditto

Mr William MacKie, Mackie-Ormifon

Kenneth M'Kenzie Efq. Dunain

Mr John Mathew, Rome

Mr Peier Mathew, Sheriffon

Rev. Mr Macquecn, Prefton

Robert Niacbain Efg. Nairnfide*

William M'Intolh Efg. Balnerkir's

Colin Monro Efq. Invernefs

Mr Maitland of Freugh

Mr Julun M'Chlery, Mount-Pleafant, Galloway

George Mole Efq. Abcrdeen

Mr Robert Alurray, Clerkington

Mr Gcorge Murray, Pinkerton

Rev. Mr Moor, Oldhamfocks
John Meek Efq. Campfield

J. Wolfe Murray Efq. advocate

Hugh Mofman Efq. 2 copies

Thomas if'Knight Efq. Ratho

David Monypenny Efq. adrocate

Donald $M I^{\prime}$ Laughlan of $M \cdot$ Langhlan Efq. advocate

Alexander Macconochie Efq. advocate

William Murray Efq of Henderland

John A. Murray Efq. advocate

Colonel Macdowal of Logan

Archihald Mienzies Efq. Fidinburgh

Eneas Mackay Efq. Scotfown, 2 copies

Kenneth M'Kenzie Efq. Dolphington,

2 copies

Kenneth M'Kenzie Efq. W. S. Edinburgh

Rev. George Mark, Carnwath

Mr James Murray, Flemington Mill

Mr James M'Dougal, Linion

Mr Fohn Murray of Hartfone

Mr William Murray, Kednuuir

Mr James Milne, Whitelaw

Stewart Moodie Efq. advocate

Mr John Mathefon, Skirling

Major Moodie of Melfetter

Hugh Montgomery Efq. Port-Glafizow

Captain Maedowall

Mr Charles Macfarlan

Mr Humplary Macfarlane

Mr Robert Macfarlane

George Menzies Ef.̣. Culter

Mr Duncan Macfarlane, Colnefe

Mr John Mitchell, Arochmore

Mr John MIalcolm

IVr Robert Miller

N

Reverend Francis Nicol, Strathmartin

Reverend James Nichol, Traquair

Mr James Noble

\section{0}

William Ogle Wallis Ogle Efq, Caufey.

Park, Northumberland 
Alexander Ofborn Efq. Solicitor of the Cuftums

\author{
$P$
}

J. Parkinfon Efq. Afgarby, Lincolnhire W. Payne Efq. Frickley, York hire, 6 cop. Richard Parkinfon Efq. Slanes-Caftie, Ireland

Mr Park, Caterick, near Beverly, YorkMire

Mr John Proctor, Calcoats, Murray Mr Peter Philip, Longbridgemuir Reverend William Porteous, Kilbucho Reverend Charles Paton, Ettrick Mr David Pearfon

Mr Henry Park, Inverleithan

$\mathrm{R}$

William Rofs Efq. Stranraer George Rennie Efq. Fantafiie, 2 copies Mr George Rennie, Waughton Mr James Reid, Brownrigg David Roughead Efq. Haddington Mr William Ritchie, ftudent of Divinity Jofeph Richardfon Efq. Newfield, near Annan, 2 copies

James Roughead Efq. Haddington, 3 copics

Dr Robcrtion, phyfician, Invernefs Allan Robertfon Efq. Invernefs Mr Colin Ritchie, Culmore, Galloway Mr Alexander Ruffell, Aikenhead James Rofe Efq. Fewride Mir William Rhiud, Invelachty George Robinfon Efq. W. S. Charles Rofs Efq. adrocate Genge Robertfon Efq. Arbuthnat-mains Colancl Renton of Symington

Dr Henry Roberton, Edinburgh Reverend J. M. Robertfon, Living fon Rcverend Charles Ritchie, Kirk!ifton James Reid Efq. furgeon, Provoft of peebles

II. John Rarnmadge, Whitelaugh
Mr William Rennic, Oxwcllmains, Dunbal Mr Andrew Richardfon

\section{$\mathrm{S}$}

Sir John Sinclair of Ulbfter, Bart. M. P. 3 copies

Lady Sinclair of Ulbfter

Sir James Stewart of Coltnefs, Baronet, 2 copics

Mr Richard Sommera, Townhead

Mr John Shirreff, Mungoswells Mr John Shirreff, Capiainhead Mr Richard Shirreff, Luggate Mr Francis Shirreff, Dumhills Mr James Shirreff, Edinburgh Mr Peter Shirreff, Drem Mr James Shirreff, Greenhead David Shirreff Efq. Kinmylees Reverend Dr Stewart, Newburgh Mr John Salmon, Mordunmills Benjamin Sayle Efq. of Wentbridge, Yorkthire

Mr Jofeph Storrs, Yorkhire

John Smart Efq. Trewhitt, Northumberland

Mathew Sandilands Efq. W. S.

Mr Robert Stevenfon, Cafle-Hadingham, Eflex

Mr Donald Smith, Gerdonftown Cinarles Stewart Efq. M. D. Edinburgh Thomas Smith Efq. W. S.

Mr James Struthers, writer, Edinburgh

Reverend William Strachan, Culter

Robert Stark, Efq.

Dugald Stewart, Efq. Profeffor of Mioral

Philofophy, Edinburgh, 2 copies

Mr Thomas Saundeifon, merchant, $E_{-}$ dinburgh

Henry Shettlewood Eíq.

Mr Wuiter Skirring, merchant, Dalkeith

Mr Walter Simpion, Drummelzier

Mr Johu Scott

Mr Alexander Stewart, Fhicld;

Mr David Skirving, Garleton.

$3 \mathrm{G}=$ 
n. Antiew S:mmervilie

Robert Sommerville E.fq. Haddington

Mir Wilian Symington of Edfone

\section{T}

Rizht Honowrabic the Earl of Traquair John Trotter Efq. Mrtonhall, 2 copics Iir Ardrew Taylur, Linton

Mr Adam Turnbull, Ncwbisging

J. D. Thomfon Efq. Leith

Thotburn, Holliice

Ii Tiiliam Tumbull, Elarkisugh

'I homas 'Tneecic Efq. of Oliver

\section{$\mathrm{V}$}

Fobet Teitch Elq. Fulithornbank

\section{WT}

Mr John Walker, Monkridge

Mr Francis Walker, Tunderlane

Iir leter reir, Farygate

William Wirht Efq. Ed:nburgh

R. R. Wrod Exg. Lincolnthire

Trilliam Wrikie Efq. Haddington

Mr Milliam Waton, North ividulicton,

Norti:um!crlard

Jolin Wilion Efe]. Minpeth

P.rhard Whiteward Ef(quire, Backacre, Staforis

Mir Wathins, Rickerfca!e, Stafford
Mit Clarles Woally, Cardiff Mir Francis Walker, Tinitelaw Mr Wrilliam Walker, Halyards Janes Wrilkie Efq. Harl.lington Mr John Wilfon, Preftun, near Dunfe MIr Mislcolon Wright

David Willamfon Fiq. arluncate IvIr Samul Wond, writer, Jechurgh Ruverend Wiliam Watfon, Eigzar James Walker lifq Ii.s.

Mr Jimes Wright, Haw of Nexlifton Waiter Williumfon Ef(j. Cardrona Ir Matthew Wilkie, Bonrington A. S. Wedder'su:n Efq. of Wedderburn Mir Alexander Wellh, Hartfane Mr Watfon, Whitllade Iur Alex. Williamfon, writer, Puebles Mr Adum Whyte Mr Wrilliam W'allace

\section{i}

\section{$\operatorname{Mr}$ Wrilizm Yule, Giford}

Mr John Young, Invernefs Willian Young Efq. Inchbrcom, Elgin

Mi Rosert Young, Coxtown Mr Alcxander Younz, Elgin Mr Archibald Camphell Younzer Mir Chal les Young, infurance !roker, Edinl,urgh

The Porerend Tialicr Young, Erskine

\section{ADDITIONAL NAMES.}

Nir Jumes Allardyce, Inynes Mi!! Commifinner Bown, Finburgh Mr Wilium brown, loufre Gcorge Cranton Lfr. Hiarrivton Rev. Mir Comeror, Jisknewton licv. Dr I'cuzias, Calalhiels Mir Janes ?)ezus, Conlter-park Jumplory Ucuholm Eff. of Birthwood ixIr Jam.s Grant, IVefscat
II Irngh Gilibert, Walno Mr Alcxander Graham, Lieforrell No Alsander Gray, Lyo Rer. Mr Ilaining, Dunfyre Rov. Mir liondyfirle, Lyue I.Ir Richurd Jamicfon, Wandicmill Mr James lierr, Pecules, 2 copics Mr Robert J aidlaw, Kingleelores, $2 \mathrm{cmp}$ Pev. My Lundic, corkhn 
Gide on Ncedham Efq.

Mr Jolın Nimmo, Newholm

Mr William Newbiggine, Pettynain

Mr Jolin Rofe

Mr David Stodhart, Eafton

Mir Thomas Stodhart, Biggar hiels

Mr James Stodhart, Walftone
Mr James Stodhart, Covington Laurence Tweedie $\mathrm{E} \mathrm{f}_{\mathrm{I}}$ jun. of Oliver Mr Rohert Tweedie, Longhaugh, 2 cop. Mr Thorburn, Hollylee Mr William White, Todholes Mr William White, Howburn $\operatorname{Mr}$ William Watfon, Weftown

Several Subfription Papers not baving reached the Publifser in time for infertion in the above Lifl, will account, be trufts, for fundry Names being omitted; and be is moft carnefily folicitous and bopeful, that cvery miflake, wubetber relative to names or defignations, wuill be excufed by thofe Gentlemen abbofe names may lave been either erroneoufly copied, or altogetber omitted-the former of thefe circumfances being often almolt totally unavoidable, from the ve$r y$ indifinct manner in which many of the names in the Lifs returned avere weritten out.

F T N T S.

Printed by D. Wılıson, Craig's Clofe, Edinbugh. 
Lately Publifbed,

Price One Shilling,

\title{
LIBERTY AND EQUALITY,
}

\section{A SERMON, OR ESSAY :}

BEING THE SUBSTANCE OF WHAT WAS DELIVERED FROM THE PULPIT AT NEWLANDS, UPON THE FAST DAY, 13. MAKCH ISOO.

To which is subjoined,

\section{AN APPENDIX,}

CONTAINING AN ANAYLSIS OF, AND SOME OBSERVATIONS ON, GODWIN'S SYSTEM OF SOCIETY IN HIS POLITICAL JUSTICE.

By THE REv. CHARLES FINDLATER, MINISTER OF NEWLANDS.

Aljo, lacksy Fublifjed,

By ARCHIBALD CONSTABLE, Edingurgh,

In One Vol. Square 12 mo. - Price 5s. neatly Bound,

THE GENTLEMAN AND FARMER'S

\section{POCKET COMPANION AND ASSISTANT;}

\author{
Confifting of \\ T A B L E S
}

TOR FINDING THE CONTENTS OF ANY PIECE OF LAND BY PACING,

OR. BY DIMENSIONS TAKEN ON THE SPOT IN ELLS.

\section{J.ikewife}

VARIOUS OTHER TABLES,

OF GREAT USE TO EVERY GENTLEMAN AND FARMER IN SCOTLAND.

By JOHN A INSLIE,

IANDSURYEYOR, EDINBURGL. 





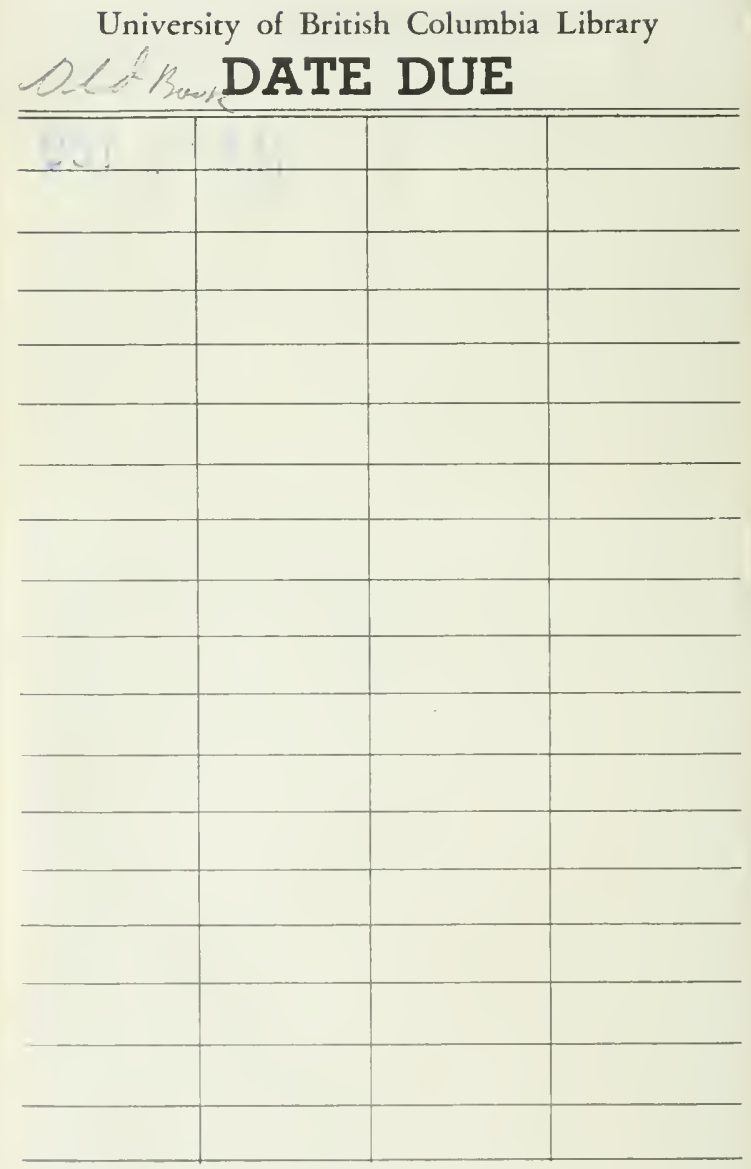

FORM No. 310 


\section{AGRICULTLRE FORESTR' LIB?ARY}

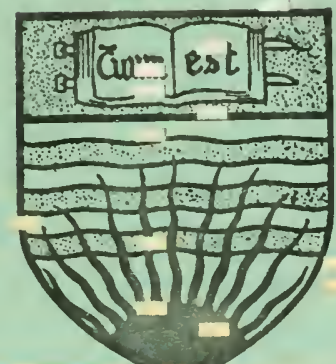




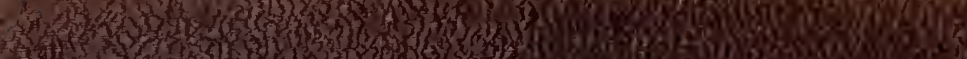

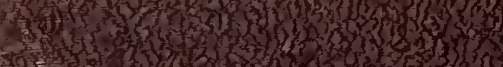

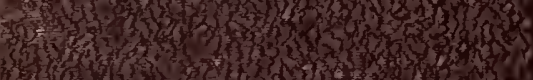

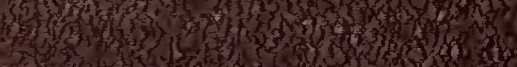

Y.

H.

Sist if

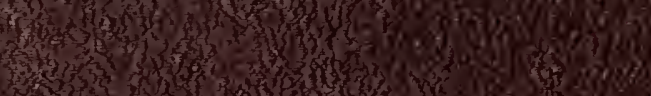

W. 3 , and

(2)

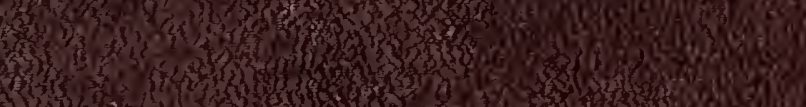

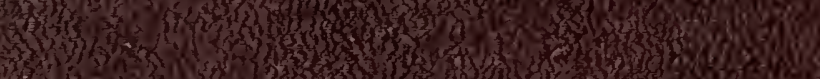

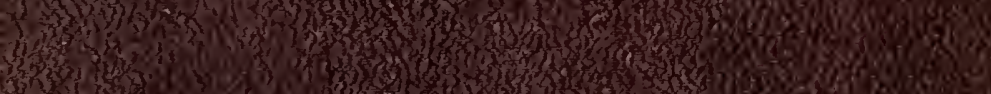

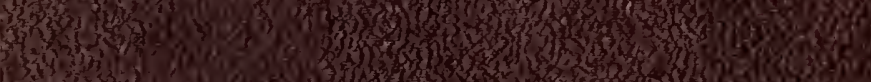

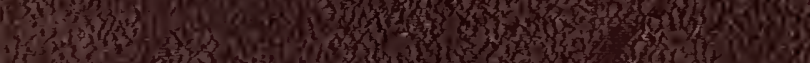

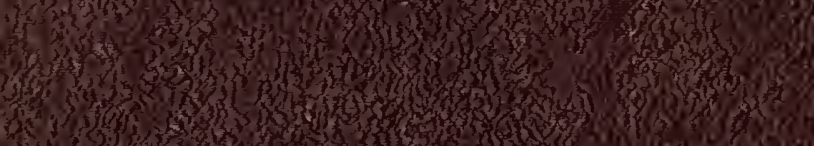

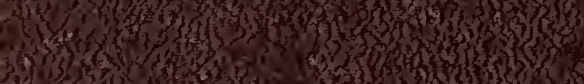

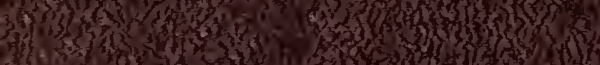

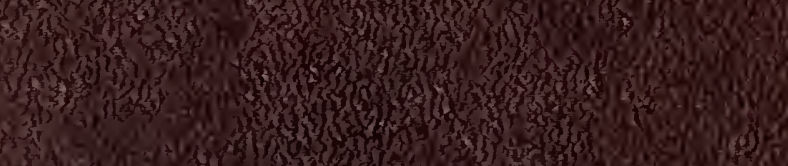

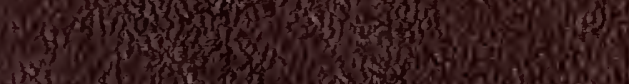

K.

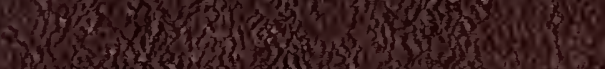

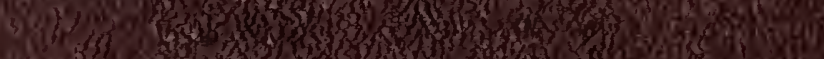

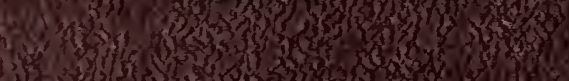

Sin)

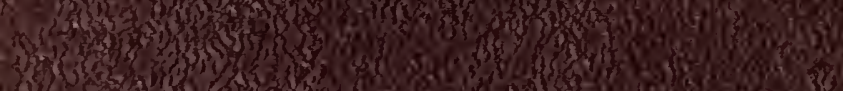

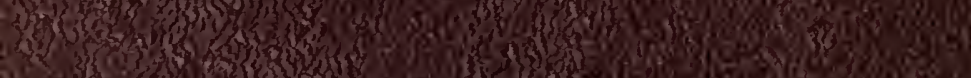

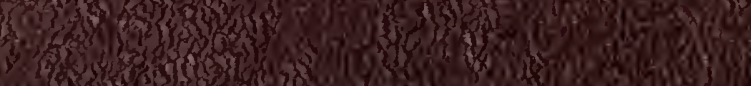

S9.

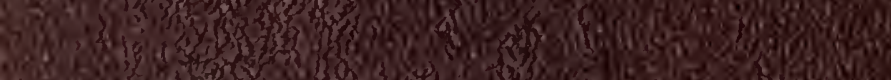

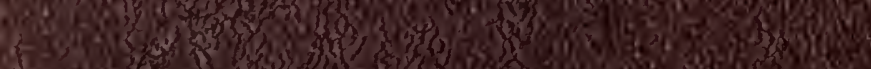

5.7.

a.5.

4 (1)

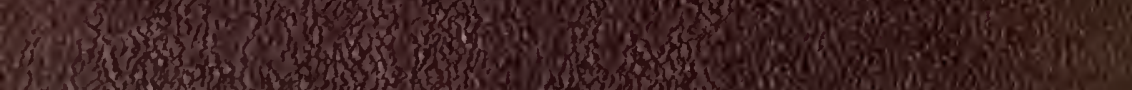

(2) 1 3.

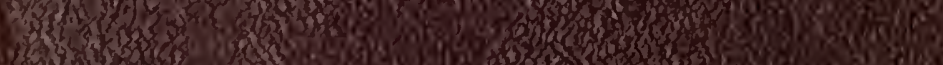
I

3. 